\title{
The Deuteronomistic History Hypothesis: A Reassessment
}

\author{
O'Brien, Mark A
}

\begin{abstract}
This book undertakes a reassessment of the Deuteronomistic History in response to recent developments which raise questions about Martin Noth's understanding of the history as a unified and well planned work. The reassessment is carried out via a literary critical, linguistic and contextual analysis of the text, in particular those passages which are generally regarded as Deuteronomistic compositions. The author argues that the history was indeed a well planned and unified work, but one that ended at 2 Kgs 23:23 with the reign of Josiah. It was principally a story of Israel's leaders and Moses and Joshua (Deuteronomy to Judg 2: 10), the period of Israel from the judges to the monarchy (Judg 2:11 to 1 Sam 11:15), and the period of Israel under the prophets and kings (1 Sam 13:1 to 2 Kgs 23:23). Subsequent redaction was carried out in three main stages. The first was a fairly straightforward updating of the history to stage accounted for the exile by applying the history's critique of the northern kings to the Davidic dynasty. The third stage transferred its attention to the people and sought to transform the history from a story of Israel's leaders into a story of the people's failure to observe the law.
\end{abstract}

Posted at the Zurich Open Repository and Archive, University of Zurich

ZORA URL: https://doi.org/10.5167/uzh-152171

Monograph

Published Version

Originally published at:

O’Brien, Mark A (1989). The Deuteronomistic History Hypothesis: A Reassessment. Freiburg, Switzerland / Göttingen, Germany: Universitätsverlag / Vandenhoeck Ruprecht. 
O'BRIEN - THE DEUTERONOMISTIC HISTORY HYPOTHESIS: A REASSESSMENT 
Published by the Biblical Institute of the University of Fribourg Switzerland

the Seminar für Biblische Zeitgeschichte

of the University of Münster i.W. Federal Republic of Germany

and the Schweizerische Gesellschaft

für orientalische Altertumswissenschaft

Editor: Othmar Keel

Coeditors: Erich Zenger and Albert de Pury

The Author:

Mark O'Brien, born 16th May 1948 in Wagga, N.S.W., Australia; entered the Dominican Order in 1967, studied Theology from 1968-73 in Canberra and Dublin; ordained a priest in 1973. Completed the L.S.S. at the Biblical Institute, Rome in 1976. Lecturer in Old Testament studies at the Yarra Theological Union, Melbourne since 1977. Completed a Doctor of Theology degree at the Melbourne College of Divinity in 1987. 


\author{
MARK A. O'BRIEN
}

\title{
THE DEUTERONOMISTIC
} HISTORY HYPOTHESIS: A REASSESSMENT 


\section{O'Brien, Mark A.:}

The deuteronomistic history hypothesis: a reassessment / Mark A. O'Brien. Freiburg, Schweiz: Univ.-Verl.; Göttingen: Vandenhoeck u. Ruprecht, 1989

(Orbis biblicus et orientalis; 92)

ISBN 3-525-53722-0 (Vandenhoeck u. Ruprecht) Gb.

ISBN 3-7278-0647-8 (Univ.-Verl.) Gb.

NE: GT

Die Textseiten

wurden vom Herausgeber als reprofertige

Dokumente zur Verfügung gestellt

(c) 1989 by Universitätsverlag Freiburg Schweiz

Vandenhoeck \& Ruprecht Göttingen

Paulusdruckerei Freiburg Schweiz

ISBN 3-7278-0647-8 (Universitätsverlag)

ISBN 3-525-53722-0 (Vandenhoeck \& Ruprecht)

Digitalisat erstellt durch Florian Lippke, Departement für Biblische Studien, Universität Freiburg Schweiz 
For My Father

John Thomas O'Brien

1918-1985 



\section{CONTENTS}

$\begin{array}{ll}\text { Acknowledgments } & \text { XI }\end{array}$

Note on Texts and Conventions Used XIII

Part One

Presentation of the Reassessment

Chapter 1: The Need for a Reassessment of the

Deuteronomistic History Hypothesis 3

Martin Noth 3

Developments since Noth 5

The Smend and Cross Schools of Interpretation 6

The Smend School $\quad 7$

The Cross School 10

The Analysis of pre-dtr Redaction $\quad 12$

The Need for a Reassessment 15

Procedure for the Reassessment 22

Chapter 2: The Structure and Conceptual Plan

of the Deuteronomistic History 24

Schematic Presentation 24

Description 27

Israel under Moses and Joshua 28

Israel from the Judges to the Monarchy 30

Israel under the Prophets and Kings 34

Part Two

Justification of the Reassessment

Chapter 3: The Period of Israel under Moses

and Joshua (Deut 1:1-Judg 2:10)

The Book of Deuteronomy 48

Deuteronomy 1-3 49

The Deuteronomic Code and DtrH 56

Josh 1:1-Judg 2:10 67

Joshua 1

Joshua 2-11 68

Joshua 12-22 71

Josh 23:1-Judg 2:10 75

Chapter 4: The Period of Israel from the Judges to the Monarchy (Judg 2:11-1 Sam 11:15) 82

Judg 2:11-3:6 82

Judg 3:7-1 Sam 7:17 88

Judges 13-16 94

Judges 17-21 97 
1 Samuel 1-12 98

1 Samuel 8-12 109

1 Samuel $12 \quad 120$

Chapter 5: The Period of Israel under the Prophets

and Kings [A-1 Sam 13:1-1 Kgs 12:24]

1 Samuel 13-15 129

1 Samuel 16-1 Kings 2

2 Samuel $7 \quad 132$

2 Samuel 8-1 Kings 2

1 Kings 3-12 143

$1 \mathrm{Kgs} \mathrm{3:1-10:29} 143$

1 Kgs 3:1-15 145

1 Kgs 5:15-32 (RSV 5:1-18) 148

1 Kings 8

$1 \mathrm{Kgs} \mathrm{8:14-53} 153$

$1 \mathrm{Kgs} \mathrm{8:54-61} 158$

1 Kgs 9:1-10:29 159

$1 \mathrm{Kgs} \mathrm{11:1-11:39} 160$

1 Kgs 11:29-39 163

1 Kgs 12:1-24 171

Chapter 6: The Period of Israel under the Prophets and Kings [B-1 Kgs 12:25-2 Kgs 20:21] 174

The Regnal Framework $\quad 180$

The Northern Kings from Jeroboam to Hoshea 185

The House of Jeroboam (Jeroboam and Nadab) 186

The House of Baasha (Baasha and Elah) 192

The House of Ahab [Omri, Ahab, Ahaziah, Jehorma) 194

Jehu to Hoshea 204

2 Kings 17

The Davidic Kings from Rehoboam to Hezekiah 212

The Reign of Hezekiah (2 Kings 18-20) 220

Chapter 7: The Period of Israel under the Prophets
and Kings [C-2 Kgs 21:1-23:23]

2 Kgs 21:1-18 (The Reign of Manasseh) 227

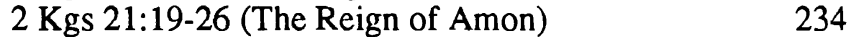

2 Kgs 22:1-23:30 (The Reign of Josiah) 235

2 Kgs 22:3-10 (Discovery of the Book of the Law) 238

2 Kgs 22:12-14 (The Delegation to Huldah) 243

2 Kgs 22:15-20 (The Prophecy of Huldah) 244

$2 \mathrm{Kgs} \mathrm{23:1-23:23}$ (Developments following
Huldah's Prophecy)

2 Kgs 23:1-3 (The Covenant Ceremony) 249

$2 \mathrm{Kgs}$ 23:4-20 (The Reform) 251

2 Kgs 23:21-23 (The Passover Celebration) 265

2 Kgs 23:24-30 266

2 Kgs 23:31-25:30 (The Last Four Kings of Judah) 268 
Chapter 8: The Subsequent Redaction of the

Deuteronomistic History

The First Stage of Subsequent dtr Redaction

272

The Second Stage of Subsequent dtr Redaction 273

Summary of the Second Stage 279

The Third Stage of Subsequent dtr Redaction $\quad 280$

Summary of the Third Stage 282

Further Developments 283

Chapter 9: Conclusion 288

Bibliography of Works Cited 293

Selective Index of Biblical References 311 



\section{ACKNOWLEDGMENTS}

This monograph is a revision of a doctoral thesis submitted to the Melbourne College of Divinity in 1987. The thesis was undertaken on a part-time basis, with a period spent on sabbatical leave at Yale Divinity School as a research fellow, and at the Ecole Biblique in Jerusalem. Throughout the composition of the thesis and its revision I have received much valuable advice and support from a number of people. First and foremost among these I owe a great debt to Dr. Antony Campbell S. J., who agreed to supervise the thesis, inviting me at the same time to join his seminar on Of Prophets and Kings in 1982. I gained immensely from his insights during this seminar, and from his ever patient and helpful supervision of the thesis as it slowly emerged over the years.

Special thanks are due also to Professor Robert Wilson of Yale Divinity School who kindly undertook to act as supervisor during my time there. The Dominican community at St. Mary's Priory, New Haven, contributed much to making my time at Yale a memorable one. My stay in Jerusalem was all too brief, but I am grateful to the community of St. Etienne for their kindness and hospitality.

I am very appreciative of the help I have received from colleagues at the Yarra Theological Union, and other Associated Teaching Institutions within the Melbourne College of Divinity, in particular Dr. Lawrence McIntosh of the Joint Theological Library. The Australian and New Zealand Province of the Order of Preachers helped to fund my study leave, and I am grateful my confrères in the Province for their support throughout the enterprise. Much generous help has also come from my family. I have dedicated this book on behalf of them to my father.

Finally, I would like to express my sincere thanks to Professor Othmar Keel for accepting the manuscript for publication in the series Orbis Biblicus et Orientalis. 



\section{NOTE ON TEXTS AND CONVENTIONS USED}

Texts used in the preparation of this monograph were:

Hebrew

Biblia Hebraica Stuttgartensia. Edited by K. Elliger and W. Rudolph. Stuttgart: Deutsche

Bibelstiftung, 1977.

Greek

Septuaginta. 2 vols. Edited by A. Rahlfs.

Stuttgart: Deutsche Bibelstiftung, 1935.

English

The Revised Standard Version.

The following abbreviations should be noted:

DtrH $=$ The Deuteronomistic History.

DTR $=$ The Deuteronomist, author of DtrH.

Dtr $=$ A subsequent deuteronomistic redactor.

$\mathrm{dtr}=$ deuteronomistic.

Verse halves are indicated by "a" and "b", and follow the major punctuation markers in the Hebrew. Subdivisions within a half verse are indicated by the Greek letters, $\alpha, \beta, \gamma$, etc., and follow the secondary punctuation markers in the Hebrew.

An asterisk $(*)$ is used to indicate that in the verse or passage being referred to, part of the material is not meant to be included in the reference. 



\section{Part One}

Presentation of the Reassessment 



\section{THE NEED FOR A REASSESSMENT OF THE DEUTERONOMISTIC HISTORY HYPOTHESIS}

\section{MARTIN NOTH}

Martin Noth's hypothesis of a Deuteronomistic History (DtrH), which first appeared in 1943, would rank as one of the major achievements of modern OT scholarship.! It received initial support in the independent work of Ivan Engnell in Scandinavia, and Alfred Jepsen in Germany. ${ }^{2}$ Since then it has steadily gained in influence and may now be regarded as a standard feature of scholarly understanding of the composition of the historical books. ${ }^{3}$ True, there have been some dissenting voices, but these are few and they cannot be said to have threatened the general acceptance of the hypothesis. ${ }^{4}$ The real

1Martin Noth, The Deuteronomistic History (JSOTSup 15; Sheffield: JSOT,
1981. German original; Halle 1943).
2Ivan Engnell, "The Pentateuch," in Critical Essays on the Old Testament (London: SPCK, 1970) 50-67. See especially pp. 58-59. Noth's work was unknown to Engnell when he first wrote of a Deuteronomic History in Gamla Testamentet (Stockholm: Svenska Kyrkans Diakonistyrelses Bokförlag, 1945) 210 , n. 3. Alfred Jepsen undertook a literary critical analysis of the books of Kings in Die Quellen des Königsbuches (2d ed.; Halle: Niemeyer, 1956). Jepsen's manuscript was ready in 1939, but publication was delayed by the war. He identified two sources and three layers of redaction. The second of these, a prophetic redaction, he regarded as the equivalent of Noth's DTR.

${ }^{3} \mathrm{Cf}$. for example the studies by Hans Joachim Kraus, "Gesetz und Geschichte. Zum Geschichtsbild des Deuteronomisten," EvT 11(1951-52) 415-28; Enno Janssen, Juda in der Exilszeit (FRLANT 69; Göttingen: Vandenhoeck \& Ruprecht, 1956); Peter R. Ackroyd, Exile and Restoration. A Study of Hebrew Thought of the Sixth Century BC (London: SCM, 1968) 62-83. There have also been a number of valuable articles in Theologische Rundschau which have monitored the acceptance of the hypothesis and developments in the study of it: Emst Jenni, "Zwei Jahrzehnte Forschung an der Büchern Josua bis Könige," TRu 27 (1961) 1-32, 97-146; Amold Nicolaas Radjawane, "Das deuteronomistische Geschichtswerk," TRu 38 (1974) 177-216; and Helga Weippert, "Das deuteronomistische Geschichtswerk. Sein Ziel und Ende in der neueren Forschung," $T R u 50$ (1985) 213-49. Its established position in current OT scholarship is indicated by the way it is given separate treatment in surveys. See for example Ludwig Schmidt, "Deuteronomistisches Geschichtswerk," Altes Testament (Neukirchener Arbeitsbücher; Neukirchen-Vluyn: Neukirchener, 1983) 101-14. It has also been made available to a wider public with such works as Terence E. Fretheim's, Deuteronomic History (Interpreting Biblical Texts; Nashville: Abindgon Press, 1983).

${ }^{4}$ So for example Artur Weiser, Introduction to the Old Testament. The Canon, the Apocrypha and Pseudepigrapha (London: Darton, Longman \& Todd, 
threat to it comes I believe from another and rather unexpected quarter. As with many widely favored hypotheses, DtrH has become the catalyst for a variety of related studies. Nevertheless there have been a number of developments, particularly in more recent studies, which have disturbing implications for the DtrH hypothesis. The foundations on which Noth constructed it have been undermined to such an extent by these developments that-if they are correct-these foundations will need to be relaid or the hypothesis dismantled.

The arguments advanced by Noth to establish the existence of a DtrH are well known. Nevertheless it is well to rehearse them briefly here so that the problems posed by more recent studies can be clearly seen. According to Noth the historical books recorded a different tradition history to that of the Pentateuch. The pre-dtr narratives were not the product of an elaboration of fundamental confessional themes as in the Pentateuch. ${ }^{5}$ Rather they focused on significant periods of Israel's history in the land and the great figures associated with those periods. While some of these narratives were more developed than others, Noth argued that each had quite a limited horizon in view and thereby reflected different stages in the development of Israel's traditions about its life in the land. ${ }^{6}$

At a certain stage in the tradition history of the historical books, namely the Judean exile, these narratives of diverse provenance became sources for the composition of a larger unified work, DtrH. Noth saw evidence of this major project in a number of areas. ${ }^{7}$ The different narratives had been linked via a chronological sequence. They had also been organized to accommodate the insertion of dtr speeches and commentary at appropriate locations (for example, Joshua 23; 1 Samuel 12; 1 Kings 8; 2 Kings 17). Some of the narratives, such as the judges' stories, appeared to owe their present arrangement to a dtr framework. As for the dtr material itself, Noth argued that it exhibited a high degree of linguistic uniformity, and its distribution reached from Deuteronomy to 2 Kings. He found no such unified dtr redaction in Genesis to Numbers.

The unity and scope of the work meant that it could not have been produced by a redactor. ${ }^{8}$ According to Noth DTR was an author who created a completely new piece of literature during the period of the exile. DTR was not of course an author who composed the history out of whole cloth. Nevertheless DTR could be called "authorial" because of the way the sources and redactional comments were molded to produce a unique literary work. Furthermore this new literary work offered a unified interpretation of Israel's history from the occupation of the land to the exile. In effect it portrayed this

1961) 161, 180-82, and Georg Fohrer, Introduction to the Old Testament (London: SPCK, 1976) 193-94.

${ }^{5}$ Noth, A History of Pentateuchal Traditions (Englewood Cliffs: PrenticeHall, 1972. German original; Stuttgart, 1948) 2.

${ }^{6}$ Noth, The Deuteronomistic History, 84-88.

7'Ibid., 4-25.

${ }^{8}$ It is important to remember that Noth accepted the current notion of a redactor. Thus he states "DTR was not a redactor trying to make corrections" (The Deuteronomistic History, 84). More recent studies have considerably expanded this limited notion of a redactor. 
history as one of continued infidelity in the face of God's initiatives on behalf of Israel. The exile was therefore God's just retribution against a faithless people.

\section{DEVELOPMENTS SINCE NOTH}

Gerhard von Rad was one of the first to question Noth's perception of the conceptual plan governing the history. He detected a note of hope in the report of Jehoiachin's rehabilitation in 2 Kgs 25:27-30, and doubted whether Noth had taken sufficient cognizance of Nathan's prophecy of an enduring Davidic dynasty in 2 Samuel 7.9 In addition von Rad had difficulty accommodating the cyclic structure of the book of Judges (cf. the repetition of apostasy, enemy oppression, 1epentance and deliverance) and the more linear structure of the books of Kings, with the hypothesis of a unified and carefully structured history. ${ }^{10}$

Hans Walter Wolff was also of the opinion that Noth's understanding of DtrH was too negative. ${ }^{11}$ Wolff found a number of texts which speak of Israel's return and Yahweh's mercy, texts which he claimed were difficult to incorporate into Noth's understanding of the history. ${ }^{12}$ In addition Wolff argued that Deut 30:1-10 was not, as Noth held, part of the deuteronomic corpus taken over by DTR. Instead it was the work of a later redactor. Wolff proposed that the same later hand was also responsible for Deut 4:29-31. This redactor appeared to have taken the theme of return in DtrH and composed the two passages as a frame around the discourse of Moses. They emphasized the positive outcome of the people's return to Yahweh.

Both von Rad's and Wolff's reflections on DtrH were limited in scope but they opened up some important questions. These concern firstly, the nature of the conceptual plan of DtrH as perceived by Noth and way its various parts function in relation to this plan; secondly, the significance of later redaction and its relationship to DtrH. The presence of multiple dtr redaction in Deuteronomy and the historical books had long been recognized. ${ }^{13}$ Noth

${ }^{9}$ Gerhard von Rad, Studies in Deuteronomy (SBT 9; London: SCM, 1953, 74-91. German original 1948).

${ }^{10} \mathrm{Von}$ Rad, "The Deuteronomist's Theology of History (The Books of Kings)," Old Testament Theology (2 vols.; Edinburgh: Oliver and Boyd, 1962. German original 1957) I. 334-47. See especially pp. 346-47.

${ }^{11}$ Hans Walter Wolff, "The Kerygma of the Deuteronomic Historical Work," The Vitality of Old Testament Traditions (ed. W. Brueggemann \& H. W. Wolff; 2d ed.; Atlanta: J. Knox, 1982) 83-100. German original in ZAW 73 (1961) 171-86. Others besides von Rad and Wolff who detected a positive note in DtrH were Walter Brueggemann ("The Kerygma of the Deuteronomistic Historian," Int 22 [1968] 387-402), and J. Alberto Soggin ("Deuteronomistische Geschichtsauslegung während des babylonischen Exils," Oikonomia: Oscar Cullmann zum 65. Geburtstag gewidmet [ed. Felix Christ; Hamburg-Bergstadt: Reich, 1967] 11-17).

${ }^{12}$ Cf. Judg 2:11-19; 1 Sam 7:3-4; 12:19-22; 1 Kgs 8:46-51; 2 Kgs 17:13; 23:25.

${ }^{13}$ For a survey of the literature on Deuteronomy see Horst Dietrich Preuss, Deuteronomium (Erträge der Forschung 164; Darmstadt: Wissenschaftliche 
himself acknowledged there was later dtr editing of the history, but he did not attribute much signifiance to it and generally relegated his comments on the texts identified to his footnotes. What was challenging about Wolff's study in particular was the potential significance of later redaction and how a more precise understanding of this might force a revision of the conceptual plan and unity of the history. ${ }^{14}$

\section{THE SMEND AND CROSS SCHOOLS OF INTERPRETATION}

In relation to the observations of Wolff it is interesting to observe that a significant amount of subsequent analysis of DtrH has been taken up with the question of later redaction and its significance. ${ }^{15}$ Interest in this question was no doubt facilitated by the development of a redaction history approach to OT texts, and the way this drew attention to the literary and theological contribution of redactors. To date the most important studies of the redaction history of DtrH have come from two distinct schools of thought; one based on the work of Rudolf Smend, ${ }^{16}$ the other on that of Frank Moore Cross. ${ }^{17}$

Buchgesellschaft, 1982). For a survey of the historical books see the articles by Jenni, Radjawane and Weippert cited in $n$. 4.

${ }^{14}$ One should also mention in this context Jepsen's, Die Quellen des Königsbuches. While his study was carried out independently of Noth, his detection of multiple redaction must be reckoned as significant for later developments in DtrH analysis.

${ }^{15}$ Before considering developments in this area it is worth noting another less important revision of Noth's hypothesis which has been proposed. This concerns his position that the history was composed in Palestine. J. Alberto Soggin has however argued for a Babylonian provenance ("Der Entstehungsort des Deuteronomistischen Geschichtswerkes. Ein Beitrag zur Geschichte desselben," TLZ 100 [1975] 3-8), a position also favored by E. W. Nicholson, Preaching to the Exiles (Oxford: Blackwell, 1970).

${ }^{16}$ Smend's seminal study was "Das Gesetz und die Völker: Ein Beitrag zur deuteronomistischen Redaktionsgeschichte," Probleme biblischer Theologie (ed. H. W. Wolff; Munich: Kaiser, 1971) 494-509. See also, Die Entstehung des Alten Testaments (Stuttgart: Kohlhammer, 1978) 69-81, 110-39. The principal contributions since Smend have come from Walter Dietrich, Prophetie und Geschichte (FRLANT 108; Göttingen: Vandenhoeck \& Ruprecht, 1972); and Timo Veijola, Die ewige Dynastie. David und die Entstehung seiner Dynastie nach der deuteronomistischen Darstellung (Annales Academiae Scientiarum Fennicae, B 193; Helsinki: Suomalainen Tiedeakatemia, 1975), also Das Königtum in der Beurteilung der deuteronomistischen Historiographie. Eine redaktionsgeschichtliche Untersuchung (Annales Academiae Scientiarum Fennicae, B 198; Helsinki: Suomalainen Tiedeakatemia, 1977).

${ }^{17}$ Frank Moore Cross, Canaanite Myth and Hebrew Epic (Cambridge: Harvard University, 1973) 274-89. An earlier version appeared as "The Structure of the Deuteronomic History," Perspectives in Jewish Learning (Annual of the College of Jewish Studies, 3; Chicago, 1968) 9-24. Major contributions since Cross's work have come from Richard D. Nelson, The Double Redaction of the Deuteronomistic History (JSOTSup 18; Sheffield: JSOT, 1981), also "Josiah in the Book of Joshua," JBL 100 (1981) 531-40; Richard Elliott Friedman, The Exile and Biblical Narrative. The Formation of the Deuteronomistic and Priestly 


\section{THE SMEND SCHOOL}

The Smend school proposes three exilic dtr redactors in place of Noth's one exilic author. The basic history was compiled by a historian (DtrH) during the early exile. ${ }^{18}$ It was later reworked by a prophetic redactor (DtrP), and then a nomistic redactor (DtrN). What is significant in this revision of Noth is the contribution attributed to these subsequent redactors. According to Walter Dietrich DtrP not only added comments of a prophetic type to DtrH but a substantial number of the traditional prophetic narratives in the books of Kings as well. ${ }^{19}$ Likewise, DtrN was responsible for a significant number of contributions which, he claims, exhibit a marked interest in the law. ${ }^{20}$ For Timo Veijola, DtrH was not, as Noth supposed, anti-monarchical. The antimonarchical strain in the history was the result of reworking by DtrP. DtrN in turn effected a certain compromise. This redactor was critical of the monarchy in the spirit of DtrP, but nevertheless maintained DtrH's positive attitude to it by expressing hope in a Davidic dynasty which would endure if, like David, it was obedient to the law. ${ }^{21}$ The Smend school of interpretation has exerted considerable influence on subsequent studies and commentaries on the historical books. ${ }^{22}$

Works (HSM 22; Chico: Scholars, 1981) 1- 43, also "From Egypt to Egypt: Dtr 1 and Dtr2," Traditions in Transformation: Turning Points in Biblical Faith (ed. B. Halpern and J. D. Levenson; Winona Lake: Eisenbrauns, 1981) 16792; Jon D. Levenson, "From Temple to Synagogue: 1 Kings 8," Traditions in Transformation: Turning Points in Biblical Faith (ed. B. Halpern and J. D. Levenson; Winona Lake: Eisenbrauns, 1981) 121-66, also "Who Inserted The Book of The Torah?" HTR 68 (1975) 203-33. In this article Levenson argues that Deut 4:44-28:68 was inserted by a later exilic redaction of DtrH.

${ }^{18}$ Smend originally described the historian as DtrG (Geschichte). This was followed by Dietrich and Veijola in their respective studies. However in a later review article ("David in Uberlieferung und Geschichte," VF 22 [1977] 44-64) Dietrich adopted the more international terminology of DtrH. This has since been followed by Smend in his book Die Entstehung des Alten Testaments, and will be used therefore in any references to the hypothesis of this school.

${ }^{19}$ Dietrich, Prophetie und Geschichte, 133-34.

${ }^{20}$ Smend (Die Entstehung, 73) raises the possibility that Deuteronomy 4-30 may have been inserted into DtrH by this nomistic redaction. He notes however that one would need to show that there is no redaction by DTR in these chapters.

${ }^{21}$ Veijola, Die ewige Dynastie, 127-42; Das Königtum, 115-22.

${ }^{22}$ Studies which follow the Smend school are: A. Graeme Auld, Joshua, Moses and the Land. Tetrateuch-Pentateuch-Hexateuch in a Generation since 1938 (Edinburgh: T \& T Clark, 1980); Rainer Bickert, "Die Geschichte und das Handeln Jahwes: Zur Eigenart einer deuteronomistischen Offenbarungsauffassung in den Samuelbüchern," Textgemäss: Aufsätze und Beiträge zur Hermeneutik des Alten Testaments (Festschrift E. Würthwein; eds. A. H. J. Gunneweg and O. Kaiser; Göttingen: Vandenhoeck \& Ruprecht, 1979) 9-27; Fabrizio Foresti, The Rejection of Saul in the Perspective of the Deuteronomistic School. A Study of $1 \mathrm{Sm} 15$ and Related Texts (Studia Theologica-Teresianum 5; Rome: Edizioni del Teresianum , 1984); Leslie J. Hoppe, "The Meaning of Deuteronomy," BTB 10 (1980) 111-17; Christoph Levin, Der Sturz der Königin 
Although the Smend school accepts Noth's proposal of an exilic DtrH its analysis of the nature and extent of subsequent DtrP and DtrN redaction considerably alters the shape of Noth's history. One would expect a reassessment of the nature and extent of DtrH as a result, but so far this has not been been carried out by the Smend school. Without such a reassessment however it is difficult to see how the school can be certain about the nature and extent of subsequent redaction.

It is for example surprising that in Dietrich's examination of the extent of DtrP redaction he does not include an analysis of 2 Samuel 7.23 There are two key elements in this prophecy, the promise of an everlasting dynasty for David and the promise of a temple for Yahweh's name. Both are important themes in the subsequent development of the history and it is difficult to see how they could be excluded from DtrH. Dietrich does not comment on their relationship to DtrH or to the prophecy/fulfillment schema which he regards as a characteristic of DtrP. In fact the report of their fulfillment in $1 \mathrm{Kgs} 8: 20$ is assigned to DtrN.

It is equally surprising that Dietrich does not carry out any examination of the relationship between the judgment formulas and the dtr redaction of prophetic passages in the books of Kings. Yet a significant factor in these two components of dtr redaction is the attention they give to the dynasties of

Atalja. Ein Kapitel zur Geschichte Judas im 9. Jahrhundert v. Chr. (SBS 105; Stuttgart: Verlag Katholischen Bibelwerk, 1982); Wolfgang Roth, "The Deuteronomic Rest-Theology: A Redaction-critical Study," BR 21 (1976) 5-14; Hubert Spieckermann, Juda unter Assur in der Sargonidenzeit (FRLANT 129; Göttingen: Vandenhoeck \& Ruprecht, 1982); Rainer Stahl, "Aspekte der Geschichte deuteronomistischer Theologie. Zur Traditionsgeschichte der Terminologie und zur Redaktionsgeschichte der Redekompositionen." (Ph.D. diss.; Jena, 1982), see also TLZ 108 (1983) 74-76. Commentaries which follow the Smend school are: Georg Hentschel, 1-2 Könige (Die Neue Echter Bibel Altes Testament 10-11; Wurzburg: Echter Verlag, 1984); Gwilym H. Jones 1 and 2 Kings (NCB; Grand Rapids: Eerdmans, 1984); Ralph W. Klein, 1 Samuel (Word Biblical Commentary 10; Waco: Word Books, 1983); Soggin, Judges. A Commentary (OTL; London: SCM, 1981); Ernst Würthwein, Die Bücher der Könige. 1. Könige 1-16 (ATD 11/1; Göttingen: Vandenhoeck \& Ruprecht, 1977), and Die Bücher der Könige. 1. Kön. 17-2 Kön. 25 (ATD 11/2; Göttingen: Vandenhoeck \& Ruprecht, 1984).

${ }^{23}$ It is mentioned once in a footnote (cf. Dietrich, Prophetie und Geschichte, 142, n. 129). In his later article, "David in Uberlieferung und Geschichte," 61, Dietrich identifies 2 Sam 7:8-10,11b,13,15b, 16 as DtrH redaction. According to Veijola DtrH redaction occurs in vv $1 \mathrm{~b}, 11 \mathrm{~b}, 13,16$, and DtrN redaction in vv 6, 11a (Die ewige Dynastie, 68-79). Bickert however assigns the oracle on the temple to DtrN, and the oracle on David's dynasty to DtrP ("Die Geschichte und das Handeln Yahwes," 17-18). This variation within the school is due at least in part to lack of a sure DtrH basis. In another study Bickert appears to part company to some extent with the Smend school ("Die List Joabs und der Sinneswandel Davids; Eine dtr bearbeitete Einschaltung in die Thronfolgeerzählung: 2 Sam xiv 2-22," in Studies in the Historical Books of the Old Testament [VTSup 30; Leiden: Brill, 1979] 30-51). Here he dates DirH after DtrN and another redaction DtrM (= Midrasch). 
both kingdoms. ${ }^{24} \mathrm{~A}$ careful examination of the judgment formulas and their relationship to the prophecies would seem to be a necessary pre-requisite before the existence of an independent dtr prophetic redaction could be proposed. In relation to the actual texts attributed to DtrP Dietrich's claim that they form a unified layer of dtr reworking is not compelling. ${ }^{25}$

Another questionable area of Dietrich's analysis is his employment of Smend's DtrN hypothesis. Smend had uncovered some secondary dtr passages in Joshua and Judges which he described as nomistic (DtrN). While his study was an important one, only a limited number of texts were surveyed. Dietrich considerably enlarges the extent of this DtrN redaction. He notes there are some dtr additions to prophetic speeches in Kings, besides those identified as DtrP. Because they show a concern for obedience to the law Dietrich concludes they must be from DtrN. As his investigation proceeds an extensive and quite varied list of texts is assigned to DtrN but without adequate evaluation. These are then used as an aid in identifying DtrP's additions. However a number of the alleged nomistic additions exhibit little or no nomistic concern. ${ }^{26}$

Because of these shortcomings in Dietrich's hypothesis of three stages of dtr redaction, Veijola's application of it to the books of Samuel and Judges must be viewed with caution. To be sure Veijola does undertake an investigation of the nature and extent of DtrH redaction in the books of Samuel. The recognition of the need to do this is welcome, but because Veijola's study covers only the books of Samuel and selected material in the book of Judges (Judg 8:22-23; Judges 17-21) it does not resolve the problems confronting the Smend school. Moreover, in my judgment a number of areas of Veijola's analysis of DtrH are unsatisfactory.

For example, Veijola argues that DtrH was responsible for introducing the theme of divine legitimation of the Davidic dynasty. A key text in his argument is $1 \mathrm{Kgs} 2: 2,4 a a b{ }^{27}$ But this speech by David is concerned with the security of the united kingdom, not with the divine legimation of his dynasty. The future of the united kingdom is dependent on Solomon's conduct, as the introductory particle lema ${ }^{\mathrm{c}} \mathrm{a}$ in $1 \mathrm{Kgs}$ 2:4a

${ }^{24}$ For the northern dynasties see for example the prophecy against the house

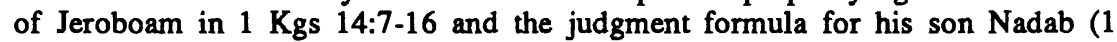
Kgs 15:26); also the prophecy against the house of Ahab (Omri) in $1 \mathrm{Kgs}$ 21:20-24 and the judgment formulas for Ahab (1 Kgs 16:30-33), Ahaziah (1 Kgs 22:53-54 [RSV 22:52-53]), and Jehoram (2 Kgs 3:2-3). For the Davidic dynasty see Ahijah's prophecy in $1 \mathrm{Kgs} 11: 34-36$, the repeated reference to the dynastic predecessor or David in the judgment formulas, and the recall of the

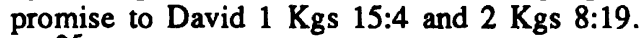

${ }^{25}$ This criticism will be taken up in detail at appropriate places in the discussion of the text.

${ }^{26}$ Dietrich assigns the following texts to DtrN: $1 \mathrm{Kgs} 2: 4$; $8: 14-26,28$ $30 \mathrm{a}, 53-61 ; \quad 9: 1-9 ; \quad 11: 9-13 ; \quad 11: 32,33 \mathrm{~b}, 34 \mathrm{~b}, 35 \mathrm{~b} \beta, 36,37 \mathrm{aa}, 38 \mathrm{aba}$; $14: 8 \mathrm{~b}-9 \mathrm{a}, 15-16 ; 15: 30 ; 16: 13 ; 2$ Kgs $8: 19 ; \quad 9: 36 \mathrm{~b}-37$; 10:10, 30-31a; $13: 4-6,23 ; 14: 15-16,26-27 ; 15: 12 ; 17: 12-19 ; 18: 6-7 \mathrm{a}, 12 ; 21: 4,7 \mathrm{~b}-9$, $15-16,21 ; 22: 17 a \beta, 19 b ; 23: 26-27 ; 24: 3-4,20 a ; 25: 22-30$.

${ }^{27}$ Veijola, Die ewige Dynastie, 23-33. 
The other texts where this theme occurs are $2 \mathrm{Sam} 7: 11 \mathrm{~b}$ and 16. However an examination of Nathan's prophecy does not confirm Veijola's claim that the verses in question were the work of the DtrH redactor. ${ }^{28}$

An important aim of Veijola's study is to test the widely accepted position of Noth that dtr redactional activity in the books of Samuel and 1 Kings 1-2 was quite limited. At times this leads him to identify dtr redaction in a text where the evidence is at best slender. The identification is then used to claim other examples of the same redaction, and so on. The redactional layer recovered via such a procedure is however really only as secure as the first item of evidence. ${ }^{29}$

In short then the major repesentatives of the Smend school have not satisfactorily addressed the question of the nature and extent of the history (DtrH) that remains once the layers of later redaction are removed. ${ }^{30}$ Until this is done, an important component of the validation of their theories of later redaction is missing, and the theories themselves must therefore be regarded as doubtful.

\section{THE CROSS SCHOOL}

According to the Cross school DtrH was compiled by a redactor (Dtr1) during the reign of Josiah and ended at $2 \mathrm{Kgs} 23: 25$. It was subsequently expanded by a dtr editor (Dtr2) around $550 \mathrm{BC}$ to accommodate the disaster of the exile. This editor also carried out a revision of the first edition. ${ }^{31}$ Cross's chapter length study limited him to outlining only the main arguments in favor of a Josianic DtrH. Richard D. Nelson provided further evidence to support Cross's hypothesis by examining the dynastic promises for the

${ }^{28}$ The details of this analysis are given below in part 2 , chapter 5 .

${ }^{29}$ To give one example; Veijola identifies the reference to the succession of Solomon in $1 \mathrm{Kgs} 1: 48 \mathrm{~b}$ as dtr on the basis of the dtr occurrence in $1 \mathrm{Kgs}$ $3: 6 \mathrm{~b} \beta$. David's remark about seeing Solomon's succession with his own eyes in $1: 48 \mathrm{~b}$ is also identified as dtr on the basis of similar phrases about seeing in Deut 28:32; 2 Sam 24:3; Jer 20:4 (Die ewige Dynastie, 27). This hardly seems sufficient evidence to justify Veijola's claim that these texts represent a formulaic dtr phrase, whereas a similar occurrence in Gen 45:12 does not. All the more so when later on he appeals to $1 \mathrm{Kgs} 1: 48 \mathrm{~b}$ to claim dtr provenance for 2 Sam 24:3 (p. 111).

${ }^{30}$ The other studies associated with this school are more limited in scope. Auld (Joshua, Moses and the Land) is mainly interested in Smend's analysis of Josh 13:1-7 and 23:1-16. Foresti (The Rejection of Saul) focuses principally on 1 Samuel 15. Levin (Der Sturz der Königin Atalja) examines 2 Kings 11. Spieckermann (Juda unter Assur) examines dtr redactional layers in 1 Kings 11; 2 Kings 18; 21-23. Stahl (“Aspekte der Geschichte deuteronomistischer Theologie,") examines Deuteronomy 4 and Deut 30:1-10; Joshua 23; 1 Samuel 12; $1 \mathrm{Kgs} 8: 14-61$ and $2 \mathrm{Kgs}$ 17:7-41. Both Spieckermann and Stahl propose additional redactional layers.

${ }^{31}$ Cross identified the revision in Deut 4:27-31; 28:36-37, 63-68; 29:27; 30:1-10; Josh 23:11-13, 15-16; 1 Sam 12:25; 1 Kgs 2:4; 6:11-13; 8:25b, 46-53; 9:4-9; 2 Kgs 17:19; 20:17-18; 21:2-15; (Canaanite Myth and Hebrew Epic, 285-87). The revision amounted to a second edition of DtrH. 
Davidic dynasty and the judgment formulas for the last four kings of Judah, but the bulk of his study was devoted to clarifying the extent and distinctive linguistic features of the exilic edition. ${ }^{32}$ Richard Elliott Friedman and Jon D. Levenson have both tended to accept the Cross hypothesis and focus on the significance of the exilic revision in select areas of the history. Like the Smend school, the Cross school has had considerable impact on studies and commentaries in the area. ${ }^{33}$

The contrast between Noth and Cross's understanding of DtrH goes far deeper than the difference in date of composition. Whereas Noth saw DtrH as a document of judgment and condemnation, Cross sees a call to conversion and the hope of a new era under Josiah. It was the disaster of the exile that prompted the second edition of DtrH with its negative assessment of Israel's history.

There are a number of attractive features about the Cross hypothesis in contrast to the Smend school. First of all, it is able to account for the amount

32Nelson, The Double Redaction, 43-98.

${ }^{33}$ Studies which follow the Cross school of interpretation are: Baruch Halpern, The Constitution of the Monarchy in Israel (HSM 25; Chico: Scholars, 1981); Steven L. McKenzie, The Chronicler's Use of the Deuteronomistic History (HSM 33; Atlanta: Scholars, 1984); Jonathan Rosenbaum, "Hezekiah's Reform and the Deuteronomistic Tradition," HTR 72 (1979) 23-44. Although they cannot be classed as members of the Cross school, a number of others also accept a Josianic history: Mordechai Cogan, "Israel in Exile-The View of a Josianic Historian," JBL 97 (1978) 40-44; A. D. H. Mayes, The Story of Israel between Settlement and Exile. A Redactional Study of the Deuteronomistic History (London: SCM, 1983); Gottfried Vanoni, "Beobachtungen zur deuteronomistischen Terminologie in 2 Kön 23,25-25,30," Das Deuteronomium: Entstehung, Gestalt und Botschaft (BETL 68; ed. N. Lohfink; Leuven: University Press, 1985) 357-62. One may also cite here Norbert Lohfink, "Kerygmata des Deuteronomistischen Geschichtswerks," Die Botschaft und die Boten. Festschrift H. W. Wolff (ed. J. Jeremias \& L. Perlitt; Neukirchen-Vluyn: Neukirchener Verlag, 1981) 87-100. In this study Lohfink proposed a Josianic redaction (DtrL = deuteronomistische Landeroberungserzählung) from Deuteronomy 1 to Joshua 22, and a Josianic edition of the books of Kings. He was however cautious about a Josianic DtrH in Cross's sense, a caution maintained in two more recent studies; "Zur neueren Diskussion über 2 Kön 22-23," Das Deuteronomium: Entstehung, Gestalt und Botschaft (BETL 68; ed. N. Lohfink; Leuven: University Press, 1985) 24-48, especially p. 34, n. 53; and Rückblick im Zorn auf den Staat. Vorlesungen zu ausgewählten Schlüsseltexten der Bücher Samuel und Könige (Frankfurt am Main: Hochschule Sankt Georgen, 1984) 40. I am grateful to Professor Lohfink for his permission to use these printed class notes. Commentaries which follow the Cross school are: Robert G. Boling and G. Ernest Wright, Joshua, A New Translation with Introduction and Commentary (AB 6; Garden City: Doubleday, 1982); Boling, Judges. A New Translation with Introduction and Commentary (AB 6a; Garden City: Doubleday, 1975); P. Kyle McCarter, I-II Samuel (AB 89; Garden City: Doubleday, 1980, 1984); Simon J. DeVries, 1 Kings (Word Biblical Commentary 12; Waco: Word Books, 1985). John Gray (I \& II Kings [OTL; 3d ed.; London: SCM, 1977]) also advocates a pre-exilic edition of DtrH but dates it during the reign of Jehoiakim. 
of attention given in the text to Josiah's reform. This issue is not really addressed satisfactorily by either Noth or the Smend school. Second, it is able to accommodate the promise to David in 2 Samuel 7. According to Cross an important structural component of DtrH is the juxtaposition of the promise to David and the sin of Jeroboam. The hypothesis is thus better equipped to

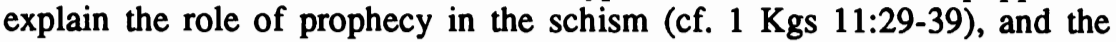
survival of the Davidic dynasty and Judah in contrast to the disastrous end of the northern kingdom.

What is missing in the work of this school however is a thoroughgoing analysis of the Josianic history from beginning to end, and a convincing formulation of its unity and conceptual plan. The school has shown the importance of prophecy in DtrH but has not explored the full significance of its prophecy-fulfillment schema. Similarly, Nelson has noted the distinctive nature of the judgment formulas for the last four kings of Judah and how they function as part of the exilic revision. ${ }^{34}$ However he has not examined in sufficient detail the judgment formulas in the Josianic DtrH and how they function as part of the redactor's conceptual plan. As well as these shortcomings there are other important areas of the text which have not been adequately examined by the school in terms of their function within the history. These are Josh 13:1-Judg 2:10, the dtr redaction and organization of the judges material, 1 Samuel 7-12, and 2 Kings 18-20.

The failure to accurately identify the text, structure and conceptual plan of the Josianic history leads in turn to a number of problems with the Cross school's identification of subsequent redaction. It will suffice here to point out some of the more important texts. They will be discussed in detail in the body of the study. First there is Levenson's proposal that Deut 4:44-28:68 was added to the Josianic history by the exilic revision. Next, there is Nelson's identification of $2 \mathrm{Kgs} \mathrm{17:21-23a}$ as a late addition to the history, in contrast to $2 \mathrm{Kgs} \mathrm{18:12}$ which he includes in it. Third, there is Cross and Nelson's identification of the exilic edition of $2 \mathrm{Kgs} \mathrm{21:1-18.}$

\section{THE ANALYSIS OF PRE-DTR REDACTION}

Before reviewing developments in this area it is worth pointing out that Noth himself had recognized that a series of old etiological stories in the book of Joshua had been combined "into a well-rounded whole" at the pre-dtr level..$^{35}$ But he did not identify extensive pre-dtr redaction in other areas of the history. Subsequent investigation of these areas has however considerably altered the picture. Although the investigations have been carried out over a number of years and the results have been varied, one can discern the emergence of two main groups; those who identify a pre-dtr layer of redaction in particular

\footnotetext{
${ }^{34} \mathrm{Nelson}$ made use of the study of these formulas by Helga Weippert, "Die 'deuteronomistischen' Beurteilungen der Könige von Israel und Juda und das Problem der Redaktion der Königsbücher," Bib 53 (1972) 301-39.

${ }^{35}$ Noth, The Deuteronomistic History, 36. The hypothesis of a ninth century document by a compiler ("Sammler") was first proposed by Noth in Das Buch Josua (HAT 1; 2d ed.; Tübingen: J. C. B. Mohr, 1953. Original edition, 1938).
} 
books (Judges, Samuel, Kings), and those who identify a more extensive layer of pre-dtr redaction.

In 1964 Wolfgang Richter published an exhaustive examination of the book of Judges which proposed that the framework of these stories was not, as Noth supposed, from an exilic DTR, but from a two stage deuteronomic reworking around the time of Josiah. ${ }^{36}$ In the books of Samuel Bruce C. Birch has recently proposed a late eighth century prophetic edition of 1 Samuel 7-15 which includes a number of texts assigned by Noth to DTR. ${ }^{37}$ In his two volume commentary on the books of Samuel, P. Kyle McCarter has expanded Birch's hypothesis by proposing that the prophetic edition also included the story of Samuel (1 Samuel 1-7), the story of David's rise (1 Samuel 16-2 Samuel 5), an edition of 2 Samuel 7, and 2 Samuel 9-20. ${ }^{38}$

For the books of Kings there is the already mentioned study by Jepsen. $\mathrm{He}$ proposed that prior to the dit redaction, a priestly redactor (RI), around $580 \mathrm{BC}$, had combined an account of Solomon's reign and a synchronistic chronicle of the kings of Israel and Judah, with an annalistic work recording the history of the Jerusalem temple and cult. ${ }^{39}$ This pre-dtr redaction covered the story of the monarchy from Solomon to Hezekiah. In a more recent study based on the identification of patterns in the judgment formulas for the kings of Israel and Judah, Helga Weippert formulated a hypothesis of three layers of redaction in the books of Kings. ${ }^{40}$ The first (R I) dealt with the kings from Jehoshaphat of Judah (1 Kgs 22:43) and Jehoram of Israel (2 Kgs 3:2a, 3) to Ahaz of Judah (2

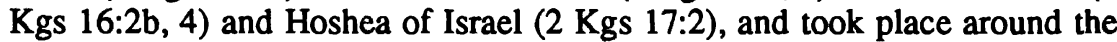
time of the northern exile. Hence it was pre-dtr. The second (R II) effectively formed a frame around the initial redaction. It dealt with the kings from Rehoboam of Judah (1 Kgs 14:22) and Jeroboam of Israel to Asa of Judah (1 Kgs 15:11) and Ahaziah of Israel (1 Kgs 22:53 [RSV 22:52]), and from

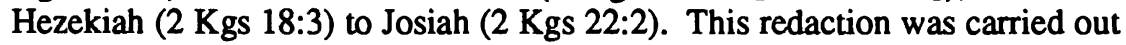
during the reign of Josiah and may be termed dtr. The third layer of redaction (R III), which was carried out during the exile, provided the judgment formulas for the last four kings of Judah. Unfortunately Weippert did not contextualize

${ }^{36}$ Wolfgang Richter, Die Bearbeitung des "Retterbuches" in der deuteronomischen Epoche (BBB 21; Bonn: Hanstein, 1964). See also "Die Uberlieferungen um Jephtah. Ri 10, 17-12, 6," Bib 47 (1966) 485-556. These studies by Richter followed his earlier traditio-historical analysis of the Judges material in Traditionsgschichtliche Untersuchungen zum Richterbuch (BBB 18; Bonn: Hanstein, 1963).

${ }^{37}$ Bruce C. Birch, The Rise of the Israelite Monarchy: the Growth and Development of 1 Samuel 7-15 (SBLDS 27; Missoula: Scholars, 1976). One may cite here also the earlier study of H. -U. Nübel, Davids Aufstieg in der Frühe israelitischer Geschichtsschreibung (Bonn: Rheinische Friedrich-WilhelmsUniversität, 1959)

${ }^{38} \mathrm{P}$. Kyle McCarter, I Samuel, 18-23; II Samuel, 7-8.

39 Jepsen, Die Quellen des Königsbuches, 10, 22-23, 106.

${ }^{40}$ Weippert, "Die 'deuteronomistischen' Beurteilungen". 
her redactional analysis by identifying the text belonging to each layer of redaction. ${ }^{41}$

The first to propose a more extensive pre-dtr redaction was Joachim Schüpphaus who, in a 1967 dissertation in Bonn, argued for a pre-dtr history from Joshua 24 to the reign of Hezekiah. ${ }^{42}$ The postulated date for this work was sometime between the last years of Hezekiah and the early years of Manasseh. In 1979 Giovanni Garbini proposed the existence of a pre-dtr narrative from Judges 9 to 2 Kings 10.43 According to Garbini, this narrative was composed in the early years of the reign of Jehu by prophetic circles opposed to the monarchy. Garbini employed the criterion of distinctive literary types or motifs to identify passages that belonged to the narrative. More recently Steven $\mathrm{L}$. McKenzie has explored the continuation of McCarter's late eighth century Prophetic History in the books of Kings. He proposes that it ran from 1 Samuel 1 to 2 Kings 13.44

The most comprehensive examination so far of pre-dtr composition in the books of Samuel and Kings has been carried out by Antony F. Campbell who proposes the existence of a late ninth century Prophetic Record from 1 Sam 1:1 to $2 \mathrm{Kgs} \mathrm{10:28.45}$ His hypothesis is based on the presence of recurring patterns and characteristic pre-dtr expressions in three groups of texts: those which recount the anointing of Saul, David, and Jehu; those which recount the designation and/or rejection of Jeroboam, Ahab, and Jehu; those pointing to interrelationships between the first two groups and to their links with the larger context of the intervening narrative.

Campbell also proposes two additional hypotheses. The first is that the Prophetic Record was supplemented by a northern expansion which continued

${ }^{41}$ Weippert's proposal has been adopted with modifications by W. B. Barrick, "On the Removal of the 'High Places' in 1-2 Kings," Bib 55 (1974) 257-59, and Andre Lemaire, "Vers L'histoire de la Rédaction des Livres des Rois," ZAW 98 (1986) 221-36. Barrick extends the contribution of Weippert's R I to include Hezekiah. Lemaire seeks to overcome the problem of having $R$ I begin with Jehoshaphat. He argues that $R I$ is in fact a later redaction from the time of Hezekiah, and that the earliest layer is present in the first part of Weippert's R II (the judgment formulas for Judean kings from Rehoboam to Jehoshaphat, and Israelite kings from Nadab to Ahaziah). The second part of $R$ II (formulas from Manasseh to Josiah) stems from a Josian Dtr. Overall then there are four redactions in Kings. The first in the ninth century went as far as Jehoshaphat and Ahaziah. The second went as far as Hezekiah; the third to Josiah (dtr), and the fourth to the exile.

${ }^{42}$ Joachim Schüpphaus, Richter- und Prophetengeschichten als Glieder der Geschichtsdarstellung der Richter- und Königszeit (Bonn: Rheinische FriedrichWilhelms-Universität, 1967).

${ }^{43}$ Giovanni Garbini, "Narrativa della Successione' o 'Storia dei Rei'?" Henoch 1 (1979) 19-41.

${ }^{44}$ Steven L. McKenzie, "The Prophetic History and the Redaction of Kings," Biblical and Other Studies in Memory of S. D. Goitein. Hebrew Annual Review 9 (1985) 203-220.

${ }^{45}$ Antony F. Campbell, Of Prophets and Kings. A late Ninth-Century Document (1Samuel 1-2 Kings 10) (CBQMS 17; Washington: The Catholic Biblical Association of America, 1986). 
the story of the northern kings from Jehu ( $2 \mathrm{Kgs} \mathrm{10:29)}$ to the exile of 721 BC (2 Kgs 17:23). The second is that the Prophetic Record and northern expansion was paralleled by a later Southern Document which told the story of the kingdom of Judah from the schism (1 Kings 12) to its deliverance from the Assyrian threat in the time of Hezekiah (2 Kings 19). This was an independent compilation and probably came from circles opposed to the policies of Manasseh and Amon. The evidence for these additional hypotheses comes from an examination of patterns in the judgment formulas for the kings of Israel and Judah. ${ }^{46}$ Campbell's analysis amounts to a thorough revision of Weippert's earlier study of these patterns. The expanded Prophetic Record and the Southern Document subsequently became sources for the composition of DtrH.

These studies of the pre-dtr redaction history of the historical books clearly have important implications for the hypothesis of a DtrH. Each of the them has claimed for pre-dtr redaction a number of texts which Noth had attributed to DTR. However a thoroughgoing and satisfactory assessment of these studies and their impact on Noth's hypothesis has not yet been carried out.

\section{THE NEED FOR A REASSESSMENT OF THE DTRH HYPOTHESIS}

It is clear from the preceding discussion that the hypothesis is in need of reassessment. The developments which have taken place indicate that the very existence of DtrH and its status as a new and unique piece of literature in Israelite tradition needs to be reexamined. In conjunction with this there is a need to reassess the nature and extent of characteristic dtr language, the nature and extent of pre-dtr sources, and DTR's creativity in assembling these sources to forge a new and unified work. Either there is a carefully planned and unified history in which the parts can be shown to have an integral relationship to the whole, or our understanding of the historical boks has to be drastically revised.

This study cannot claim to be the first to undertake such a reassessment. The reason for doing so comes in part from a dissatisfaction with the studies that have been carried out so far. In my judgment none of them has taken sufficient account of the literary evidence or responded satisfactorily to the problems facing the hypothesis.

Hans Detlef Hoffmann has attempted to reclaim the ground taken from DTR in recent studies by proposing that DtrH was the product of a sophisticated author of the early post-exilic period. ${ }^{47}$ This author composed a unified and carefully structured work centered on the theme of cultic reform. The author's intention was to tell the story of Israel's cultic infidelity and its disastrous consequences in order to promote reform in the post-exilic period. Hoffmann employs a traditio-historical analysis, but his understanding of the tradition history of DtrH is far more radical than that of Noth. He would admit that DTR made use of earlier material, but does not believe that one can

\footnotetext{
${ }^{46}$ For the different patterns identified by Campbell, and their distinctive elements, see ibid., 144-51.

${ }^{47}$ Hans-Detlef Hoffmann, Reform und Reformen (ATANT 66; Zürich: Theologischer Verlag, 1980).
} 
separate this material out as one or more pre-dtr sources. It has been thoroughly integrated. All that can be said is that DTR drew on Israel's tradition in the composition of the history. ${ }^{48}$ Wherever there were lacunae in the tradition DTR supplied what was judged to be an appropriate piece of information, one which would serve the history's purpose. This is particularly evident in the area of major concern, cultic reform.

My difficulties with Hoffmann's study are these. The theme of cultic reform does not adequately explain the relationship of the various parts of the history to the larger whole. It works well in the books of Kings up to Josiah's reform, but is quite unsatisfactory in explaining the dtr assessment of the last four kings of Judah. In fact Hoffmann does not consider these kings in any detail. Morever an examination of the judgment formulas for each one raises questions about a key component of Hoffmann's understanding of DTR as an author. This was DTR's ability to mingle general and specific terminology as part of a rhetorical technique aimed at promoting the importance of cultic reform. In $2 \mathrm{Kgs}$ 23:31-25:30 this alleged characteristic feature of DTR's writing virtually disappears. 49 The difficulty of maintaining cultic reform as the principal and unifying theme of $\mathrm{DtrH}$ is further exacerbated when one turns to the earlier section of the history. Hoffmann is hard put to convince the reader that it is the dominant theme of Deuteronomy, Joshua, Judges and Samuel.

Secondly, Hoffmann's traditio-historical approach does not account satisfactorily for the complexity of the literary evidence. It is significant that he is himself obliged to acknowledge the existence of secondary redaction in 2 Kgs 17:34-41.50 The reason given for this is the tension between the cultic reform described in this passage and cultic reform in the rest of Kings. A question arises however as to why this tension is explained in terms of different authorship, whereas other equally obvious tensions are not.

A third difficulty is that Hoffmann frequently has recourse to the structure of a text to defend unity of authorship. Structural observations are of course important for discerning the conceptual plan of the history and for showing how the parts stand in relationship to the whole. But structural similarities between various passages do not guarantee unity of authorship. Additional evidence from a literary critical, linguisic and contextual analysis is required.

John Van Seters has also argued for DTR as the author of a unified history, a position he arrived at as a result of his study of ANE and Greek historiography. ${ }^{51}$ According to Van Seters DtrH exhibits a number of literary

${ }^{48}$ Ibid., 316-17. His approach is somewhat similar to that of R. A. Carlson (David, the chosen King. A Traditio-Historical Approach to the Second Book of Samuel [Stockholm: Almqvist \& Wiksell, 1964]). Instead of one author however, Carlson spoke of a "D school".

${ }^{49}$ For a list of general and specific cultic terminology, see Reform und Reformen, 325-66. This criticism has has also been made by Vanoni, "Beobachtungen," 358.

${ }^{50}$ Hoffmann, Reform und Reformen, 137-39.

${ }^{51} \mathrm{John}$ Van Seters, In Search of History: Historiography in the Ancient World and the Origins of Biblical Historiography (New Haven: Yale University, 1983). See also "Histories and Historians of the Ancient Near East: The Is- 
characteristics which are similar to those found, in particular, in the work of the Greek historian Herodotus. ${ }^{52}$ Because recent analysis of the histories of Herodotus has come to doubt the validity of applying the traditional distinction between source and redaction to his work, Van Seters proposes that it is also of doubtful value for the analysis of DtrH. His own reassessment of the history leads him to conclude that, although there are some areas where it is evident that DTR made use of older material, this material has been so thoroughly incorporated into DTR's composition that there are generally insufficient grounds to construct a redaction history of the text.

Although there is much of value in Van Seter's research into the historiography of the ancient world, his description of DtrH still fails to do justice to the various parts of the text and how they stand in relationship to the whole. On the more specific level of exegetical procedure the ability of his comparative method to provide a satisfactory account of the composition of DtrH must also be seriously questioned. The recognition of certain shared literary characteristics between DtrH, Herodotus, and to a lesser extent the historiography of the ANE, does not enable one to say that DTR was an author like Herodotus. It simply means that the OT historical books contain some of these characteristics. The Pentateuch, Chronicles, Ezra and Nehemiah share a number of these characteristics as well. Whether DTR was responsible for them as they appear in the historical books needs to be established on other grounds. Van Seters does recognize this need, but as will be pointed out in the course of this study I do not believe his additional arguments are sufficient to meet it.

Brian Peckham shares Hoffmann and Van Seter's antipathy towards the source-redaction model for the composition of DtrH. ${ }^{53}$ Nevertheless his own

raelites," Or 50 (1981) 137-85. Van Seters approach has been followed by Burke $O$. Long in his recent commentary on 1 Kings $(1$ Kings with an Introduction to Historical Literature [The Forms of the Old Testament Literature 9; Grand Rapids: Eerdmans, 1984] 14-22).

${ }^{52}$ Van Seters, In Search of History 358. He states: "These include parataxis (the repetition of a set formula or pattern as a connective) within a particular unit or logos; the use of speeches by major figures or the insertion of editorial comment to introduce or sum up the theme of a unit, or to provide a transition to the next unit; the periodization of history with the dovetailing of eras, themes, and logoi; the association of themes with principal figures-the law of Moses, the promise of David, the Temple of Solomon and its centralization by Josiah, the apostasy of Jeroboam; the pattern of prophecy and fulfillment, which may be used as two poles within a logos or as a link for quite widely separated units; and the use of analogies between figures of history."

${ }^{53}$ Brian Peckham, "The Composition of Deuteronomy 9:1-10:11," Word and Spirit. Essays in Honor of David Michael Stanley, S.J. on his 60th Birthday. (Regis College Press, 1975) 3-59; "The Composition of Deuteronomy 5-11," The Word of the Lord Shall Go Forth. Essays in Honor of David Noel Freedman in Celebration of His Sixtieth Birthday (ed C. L. Meyers and M. O'Connor; Winona Lake: Eisenbrauns, 1983) 217-40; "The Composition of Joshua 3-4," $C B Q 46$ (1984) 413-31; "The Deuteronomistic History of Saul," $Z A W 97$ (1985) 189-209; The Composition of the Deuteronomistic History (HSM 35; Atlanta: Scholars, 1985). 
understanding of the compositional process and the shape of DtrH is quite novel and requires some detailed consideration. Peckham moves away from the hitherto accepted basis of dtr analysis - the presence of characteristic dtr language in the service of a distinctive theological point of view-to a consideration of comparative, stylistic and structural criteria as a more valid basis for determining the nature and extent of DtrH.

He concludes that there were in fact two dtr histories. The first was a fairly straightforward narrative composed by an author (Dtrl) in the pre-exilic period, and extended from Deuteronomy to Hezekiah. A second author (Dtr2) used this as a basis for a larger history extending from Genesis to 2 Kings $25 .^{54}$ According to Peckham this author made use of other ycomplete literary works for the composition of the Genesis to Numbers section of the history. ${ }^{55}$ The earliest of these was a J narrative, then a P document which had been composed as an interpretation of $\mathrm{J}$ and to provide an alternative to Dtr 1 . A third version of the story of Israel's beginnings was $E$, which like $P$ had been composed with Dtr1 in mind. These works, along with the Dtrl history, were then "combined with each other by a system of cross-reference and harmonization and were distributed in the new version of the Pentateuch and the history composed and written by Dtr2".56 The basic relationship between the earlier literary works and the Dtr 2 history is characterized by Peckham as one of narrative to commentary.

It hardly needs to be said that Peckham's analysis amounts to a radical reinterpretation of the DtrH hypothesis. Nevertheless I do not believe he is successful in his endeavor to replace the source-redaction model for understanding the genesis of $\mathrm{DtrH}$ with his narrative-commentary model.

To begin with there are some basic problems concerning the nature and extent of Peckham's Dtrl history. The narrative sequence moves immediately from Josh 11:23aab to 1 Sam 1:1-3a, 4-9aa, 11aba, 18b, 19aßb, 20aba, 21-

${ }^{54}$ Rolf Rendtorff has also proposed the inclusion of Genesis-Numbers in DtrH, but without elaborating on the nature of his revision of Noth (Das Alte Testament. Eine Einleitung [Neukirchen-Vluyn: Neukirchener Verlag, 1983] 197). Smend sees later dtr redaction as responsible for the inclusion of Genesis-Numbers (Die Enstehung, 63). Martin Rose (Deuteronomist und Yahwist. Untersuchungen $z u$ den Berührungspunkten beider Literaturwerke [ATANT 67; Zürich: Theologischer Verlag, 1981]) proposes that a later Yahwist redactor extended DtrH to include Genesis-Numbers. These studies follow up earlier investigation of dtr redaction in Genesis-Numbers, using the traditional criteria of characteristic dtr language. See for example; C. H. W. Brekelmans, "Die sogenannten deuteronomistischen Elemente in Genesis bis Numeri. Ein Beitrag zur Vorgeschichte des Deuteronomiums," Volume du Congrès Genève 1965, VTSup 15 (1966) 90-96; Werner Fuss, Die deuteronomistische Pentateuchredaktion in Exodus 3.17 (BZAW 126; Berlin: de Gruyter, 1972; Peter Weimar, Untersuchungen zur Redaktionsgeschichte des Pentateuch (BZAW 146; Berlin: de Gruyter, 1977). Peckham's analysis goes well beyond the criteria employed in these studies.

${ }^{55}$ For Peckham's version of the J, P, E narratives see The Composition of the Deuteronomistic History, 3-6, 11-19.

${ }^{56}$ Ibid., 1. 
22aba, 23aab, 24aß. Peckham justifies this sequence by arguing that the pilgrimages to Shiloh in 1 Samuel 1 show the law of centralization in place after the completion of the conquest, in accord with Deut 11:22-25a; 12:13-14, 20 , 26. Furthermore the feast celebrated at Shiloh follows the ritual calendar of the $\mathrm{J}$ narrative in Exodus 34. ${ }^{57}$

There is of course a similarity between 1 Sam 1:22ba and Exod 34:24ba, due to the use in each text of the phrase $n r^{2 h}+$ pny yhwh (to present oneself before Yahweh). But this similarity cannot be employed to establish that 1 Sam 1:22ba was referring to the ritual calendar of Exodus 34. The Samuel text refers only to a yearly feast, whereas Exod 34:24ba instructs the people to appear before Yahweh three times in the year. The other examples cited by Peckham are too general to establish that Dtrl was referring to Exodus 34 or Deut 12: 13-14, 20, 26. The proposed linguistic associations are simply not there. ${ }^{58}$ What is even more damaging for Peckham's postulated Dtr 1 history is that 1 Samuel 1 clearly makes use of the pilgrimage to Shiloh as a setting for the dominant theme of the birth and subsequent dedication of Samuel. Even Peckham's minimal text has to preserve this emphasis. 1 Samuel 1 is the beginning of a new narrative about the career of Samuel. It makes no reference to Deuteronomy 12 or Exodus 34.

The conclusion of the Dtr 1 history in 2 Kings $18-19$ is equally problematic. ${ }^{59}$ First of all, although $2 \mathrm{Kgs} 18: 12 \mathrm{aab}$ does contain language which appears in the Dtrl version of Deuteronomy, $2 \mathrm{Kgs} 18: 18-27 \mathrm{aba}, 28-30$ does not. The verb bth (to trust) does not occur in the Dtrl version of Deuteronomy, or anywhere else in the Dtr1 history. Yet it occurs several times in

${ }^{57}$ Ibid., 8; "Saul and David," 203. According to Peckham the J narrative was composed before the Dtr1 history.

${ }^{58}$ See "Saul and David," 203. Thus the chronological notice in 1 Sam 1:20a does not refer to the liturgical calendar of Exod $34: 22 \mathrm{~b}$, but to the time of Samuel's birth. The use of the verb 'th (to go up) in reference to worship is too widely distributed to provide useful evidence here. The same can be said for the presence of the verbs $h w h$ (in hishtaphel, to worship), and $z b h$ (to sacrifice) in 1 Sam 1:3a, 4a, 21b. With hwh note that the form histahāwăh was formerly taken as a hithpalel form of the root $s h h$. For a recent confirmation of the revised etymology see Siegfried Kreuzer, "Zur Bedeutung und Etymologie von hištahāwăh/ysthwy," VT 35 (1985) 39-60. The alleged dependence of Hannah's vow in 1 Sam $1: 11$ on Exod $34: 19 a$ is incorrect. If the law of the first born was actually in Dtrl's mind here, then there was no point in emphasizing that Hannah made a special vow. Peckham has effectively destroyed his argument that the reference to paying vows in $1 \mathrm{Sam} 1: 21 \mathrm{~b}$ is dependent on Deut 12:17ba by eliminating this verse from the Dtr1 history in his monograph (cf. The Composition of the Deuteronomistic History, fig. 2). The same goes for Deut $12: 17 \mathrm{aba}, 18 \mathrm{aa}$. His point about the use of కănâ bešañâ in 1 Sam 1:7a does not make it a reference to the legislation of Deut 15:20. 1 Sam 1:3 also describes the habitual nature of the pilgrimage but uses $y \delta \mathrm{m} / y \overline{\mathrm{m}} \mathrm{m} \mathrm{m}$.

${ }^{59}$ The text of the proposed Dtr1 history is, $2 \mathrm{Kgs} 18: 2,7 \mathrm{~b}, 9 \mathrm{aab}, 10 \mathrm{a} \beta \mathrm{b} \beta$, $11 \mathrm{a}, 12 \mathrm{aab}, 13,17 \mathrm{aba}, 18-27 \mathrm{aba}, 28-30,36 \mathrm{a}$; 19:8-9a, 36aßb, 37 (The Composition of the Deuteronomistic History, fig. 2). 
the text of 2 Kings 18 claimed by Peckham. ${ }^{60}$ Nor does the term for altar occur in the Dtrl version of Deuteronomy. The references are always to the place which Yahweh will choose. It seems extremely unlikely that an author who wished to conclude a history with a strong affirmation of the law of centralization in Deuteronomy, and the importance of obedience to the deuteronomic covenant, would deliberately alter the terminology and so lessen the impact of the intended reference. Peckham offers no reason for the difference in terminology. It appears the reader is expected to accept the interpretation proposed on the strength of Peckham's conviction. On a more general level it is odd that a history written from the perspective of Judah and David has no reference to David's prophetic anointing, and no reference to the construction and dedication of the temple. ${ }^{61}$ In short the Dtrl history looks to be an extremely unlikely hypothesis.

The flaws in Peckham's hypothesis of a Dtr1 history have damaging implications also for the Dtr 2 history. If a continuous Dtr1 narrative cannot be maintained, then one must revise Peckham's thesis by recourse to a theory of discrete sources which were assembled by a redactor, or eliminate the base narrative altogether. Either solution spells problems for the Dtr 2 history. The first solution would require a complete revision of the relationship between the Dtr 1 and Dtr2 histories as narrative and commentary. It would require also a complete revision of what Peckham regards as the characteristic literary features of Dtr2. The second solution would remove the role of the base narrative in Peckham's hypothesis as a foil for the identification of the nature and extent of Dtr2's contribution.

In addition to these difficulties Peckham's failure to incorporate into his analysis the undeniable presence of characteristic dtr language in the historical books is a major omission. ${ }^{62}$ Even if other criteria are adduced as valuable for analyzing aspects of the text, it is difficult to see how these can replace the central importance of dtr language and its distinctive theology for a proper understanding of the nature and extent of DtrH. Peckham's reassessment of the DtrH hypothesis must therefore be judged as unsatisfactory.

In contrast to Hoffmann, Van Seters and Peckham the reassessment carried out by A. D. H. Mayes employs.the source-redaction model for the composition of DtrH. ${ }^{63}$ Mayes's contribution is valuable in that he attempts a rapprochement between the Smend and Cross schools of interpretation. Until his study appeared there had been little comparison of the relative merits and

${ }^{60} \mathrm{Cf} .2 \mathrm{Kgs} 18: 19,20,21,22,24,30$.

${ }^{61}$ See The Composition of the Deuteronomistic History, 8. The same problem of narrative continuity occurs in the postulated $J$ narrative. Peckham notes that "it is often abrupt, tends to insinuate and suggest, seems to presume familiarity with its material and leaves many things unexplained" (ibid., 5). However, it is these very features of the narrative which he does not adequately explain.

${ }^{62}$ Peckham recognizes the distinctive nature of dtr language and intentionality, accepts "that they are the most obvious features of the commentary", but then goes on to add "they are incidental to its historical interpretation" ("Saul and David," 209).

${ }^{63}$ Mayes, The Story of Israel. 
weaknesses of these quite different interpretations of DtrH. Mayes himself favors the Cross theory of a Josianic edition of DtrH, but recognizes that the later exilic revision, as noted by the Smend school, was marked by a strong nomistic interest.

Nevertheless, while Mayes provides quite a detailed breakdown of source and redaction, and offers insightful comments on certain texts, his study is mainly concerned with a review and discussion of the literature on DtrH. At the end of his book the reader is still left unsatisfied about the precise nature of the Josianic DtrH, and how its parts go to make a well planned and unified interpretation of Israel's life in the land from the occupation to the reign of Josiah. This in turn raises questions about his identification of secondary redaction; for example, his assignation to the exilic revision of the discovery of the bnok of the law and Josiah's consultation of Huldah the prophetess. ${ }^{64}$ As stated earlier, if there is a planned and unified DtrH which can be recovered from the present text one would expect that a detailed formulation of its conceptual plan was a necessary pre-requisite for any description of subsequent redaction. Only in this way can an accurate picture of the subsequent redaction history of the text be obtained.

The study by Ian W. Provan is more limited in scope and involves mainly a reassessment of the judgment formulas for the kings of Israel and Judah. ${ }^{65}$ Provan takes issue with the studies cited earlier which argue for pre-dtr authorship for a number of these formulas. He concludes that there were two editions of DtrH. The first began with 1 Samuel 1, or possibly Judges 17-21, and concluded with the reign of Hezekiah. According to Provan this edition was principally a story of the fortunes of the monarchy and sought to portray Hezekiah as a second David. It was most likely composed in the time of Josiah. The second edition was composed in the exilic period. It brought the history up to date with an account of the kings from Manasseh to Jehoiachin. It also sought to counter the earlier edition's positive view of the Judean kings by claiming that it was the disobedience of these kings which led to the exile.

The attention given by Provan to the account of Hezekiah is to be welcomed, as is his recognition of the importance of the judgment formulas for the kings of Israel and Judah. ${ }^{66}$ Nevertheless his arguments in support of dtr authorship for the formulas up to Hezekiah are, to my mind, unsatisfactory. Furthermore his assignation of the bulk of 2 Kings 21-25 to an exilic dtr redaction fails to take sufficient account of the literary complexity of these chapters, or the importance of the reform of Josiah. This is a continuing weakness with all hypotheses which propose that the account of Josiah was

${ }^{64}$ This is surprising in view of Mayes's remark that Josiah was "the one who above all led Israel in obedience to the law of Moses" (ibid., 131).

${ }^{65}$ Ian W. Provan, Hezekiah and the Books of Kings. A Contribution to the Debate about the Composition of the Deuteronomistic History (BZAW 172; Berlin: de Gruyter, 1988).

${ }^{66}$ The focus on Hezekiah is of course not new. Cf. the studies of Jepsen, Schüpphaus, Weippert, Lemaire, Campbell, and Peckham. Provan shares with Peckham the notion that the first edition of DtrH ended with the account of Hezekiah. 
composed during the exile. They are unable to give a satisfactory reason for the obvious importance of this account. ${ }^{67}$

\section{PROCEDURE FOR THE REASSESSMENT}

The reassessment carried out here aims to surmount the shortcomings of these studies. ${ }^{68}$ In order to establish the existence and nature of DtrH it has been necessary to examine all relevant texts from Deuteronomy to 2 Kings 25 . The examination has convinced me that an explanation of the composition of the text in terms of a redaction history offers the best account of the complexity of the literary evidence. The preceding discussion confirms the wisdom of this method, despite the questions it has raised about Noth's understanding of DtrH.

The redaction history of the historical books which I propose is based on a literary critical, linguistic, and contextual analysis of the text. Literary critical analysis is essential for distinguishing source and redaction, and for indicating the way sources have been organized by the redaction. Attention to the specific characteristics of dtr language and theology is necessary in order to pinpoint the contribution of dtr redaction, and whether there was one or more redactors. It is also of course part of the argument to distinguish source and redaction. Contextual analysis in its turn enables one to see how source and redaction function in relation to each other, and how DTR constructed the history according to an overall conceptual plan. To carry out this aspect of the analysis satisfactorily attention must be paid to both the immediate context and its relationship to the larger context of the history. While each component of the methodology has a particular focus, it is important to stress that they are not employed in isolation from each other. Each functions in concert with the other components to construct a redaction history of the text which

${ }^{67}$ For example, Provan overlooks the close parallel between the judgment formulas for Hezekiah (2 Kgs 18:3) and Josiah (2 Kgs 22:2). These kings are alone in being compared favorably with David without qualification.

${ }^{68}$ The study by Robert Polzin (Moses and the Deuteronomist. A Literary Study of the Deuteronomic History [New York: Seabury, 1980]) should also be mentioned in this context. Polzin's study is not a reassessment of the hypothesis in the same sense as other works surveyed here, for he assumes from the outset the existence of DtrH as a unified literary work (ibid., 18). However he does attempt to gain a new perspective on the meaning of the work by avoiding a historical critical analysis of the text and carrying out instead a synchronic literary analysis. According to Polzin the key to the understanding of DtrH lies in the interaction between the words of the narrator (reporting speech) and the words of God found in the narrative (reported speech). The book covers DtrH from Deuteronomy to Judges and so his findings must be judged as provisional, a point which Polzin himself emphasizes. His study is valuable for drawing attention to the importance of contextual analysis at strategic points in the history, although I doubt whether one can extend it as Polzin does without first engaging in the debate over dtr language and theology. It is difficult to see how Polzin can avoid some historical critical consideration of an hypothesis which is based on this type of analysis. 
accounts for the question of sources, and the nature and extent of each layer of dtr redaction.

An additional component of the methodology is the use of structure analysis. This is dependent on the results of literary critical, linguistic, and contextual analysis, but it does provide confirmation of the existence of a well planned and unified history by showing how the various parts go to make up the larger whole. In addition it enables one to condense the detail of exegetical analysis into the manageable form of a schematic presentation.

The reassessment has been organized in two parts. The second chapter of part 1 outlines the structure and conceptual plan of DtrH via a schematic presentation and accompanying description. Even though this reverses the order of exegetical procedure it was judged to be appropriate for the purposes of the reassessment. The schematic presentation of the structure of DtrH enables the reader to see immediately the results of the more detailed exegetical argument, and how the various parts of the history stand in relation to the whole. This form of presentation does however impose certain limits. In order to gain a fuller appreciation of the conceptual plan which guided DTR's composition of the history therefore the schematic presenation is followed by a detailed description of its various parts. This description will also draw attention to those areas of the history where I believe my analysis has provided fresh insight.

In part 2 of the study chapters 3-7 will supply the necessary literary critical, linguistic and contextual arguments to justify the text of the history, its conceptual plan and structure. They will also justify the texts omitted from DtrH as later redaction. Chapter 8 will draw together the varied texts identified as later redaction so as to provide a picture of the subsequent redaction history of DtrH. From this the reader will be able to see how DTR's structure and conceptual plan influenced the course of later redaction. Chapter 9 provides a concluding summary of the principal findings of the reassessment. 


\section{THE STRUCTURE AND CONCEPTUAL PLAN OF THE DEUTERONOMISTIC HISTORY}

\section{SCHEMATIC PRESENTATION}

I. ISRAEL UNDER MOSES AND JOSHUA Deuteronomy; Joshua; Judg 1:1-2:10

A. Israel under Moses as leader

Deuteronomy 1-3*

1. Review of rebellious exodus generation $1: 1 \mathrm{a}, 4,6-8,19-45^{*} ; 2: 1-13^{*}$

2. Death of the exodus generation

2:14-16

3. Review of the conquest generation in Transjordan

2:17-3:20*

B. Transition: to Joshua 3:23-28:46; 31:1, 7-8, 9aa, 24-26a; 34:1-6*

1. Divine command to install Joshua

$3: 23-28$

2. Program for realization of the ideal state (deut code)

$5: 1-28: 46^{*}$

3. Installation of Joshua/writing down of the law 31:1, 7-8, 9aa, 24-26a

4. Death of Moses

C. Israel under Joshua as leader

1. Story of completion of conquest

a. Joshua as Moses' successor

$34: 1-6^{*}$

Josh1:1-Judg 2:10*

1) Divine command to Joshua

2) Joshua commands the people

Josh 1:1-12:24*, 21:43-45

b. Account of conquest of Cisjordan

$1: 1-18$

$1: 1-6$

$1: 10-18$

c. Account of allotment of land for occupation

1) Summary statement

2) Survey of land allotted for occupation

a) in Transjordan

b) in Cisjordan

2:1-11:23aa*

$11: 23 \mathrm{a \beta b} ; 12: 1-24^{*}$

$11: 23 \mathrm{a} \beta \mathrm{b}$

$12: 1-24^{*}$

$12: 1-6^{*}$

$12: 7-24^{*}$

d. Conclusion

1) Review of conquest and occupation

2) Dismissal of Transjordan tribes

2. Transition: change of generations

a. The death of Joshua

$21: 43-22: 1-4,6$
$21: 43-45$
$22: 1-4,6$
$29-31$ Judg $2: 10$

$21: 43-22: 1-4,6$
$21: 43-45$
$22: 1-4,6$
$29-31$ Judg $2: 10$

$21: 43-22: 1-4,6$
$21: 43-45$
$22: 1-4,6$
$29-31$ Judg $2: 10$

Josh 24:29-31; Judg 2:10
Josh 24:29-30

b. Review of conquest generation

$24: 31$

c. Death of conquest generation/new generation

II. ISRAEL FROM THE JUDGES TO THE MONARCHY Judg 2:11-1 Sam 11:15*

A. Story of Israel in the period of the judges Judg 2:11-1 Sam 7:17*

1. Introduction to the period Judg $2: 11,14,15 a a b, 16,18 a \beta b, 19 a a b$

$\begin{array}{ll}\text { 2. First stage } & 3: 7-10: 5 \\ & \end{array}$

a. Cycle of apostasy and deliverance 3:7-8:35

b. Story of failure of leadership: the Abimelech episode 9:1-57

1) Abimelech is made king 9:1-22

2) Consequent crisis in Israel 9:23-57

c. Order restored by return to the judges 10:1-5

3. Second stage Judg 10:6aa, 7-8*, 9b, 17-13:1; 1 Sam 1:1-7:17*

a. Cycle of apostasy and deliverance Judg 10:6aa, 7-8*,9b, 17-13:1

b. Story of failure of leadership: the Elide priests 1 Sam 1:1-2:34

1) Birth of Samuel/failure of the sons of Eli 1:1-2:26

2) Condemnation of the Elides

2:27-34 
c. Emergence of Samuel as a new leader in Israel

$3: 1-7: 17$

1) Samuel established as a prophet

$3: 1-4: 1 \mathrm{a}$

2) Crisis in Israel: the Ark episode

$4: 1 b-7: 2$

a) The war with the Philistines

$4: 1 b-2$

b) Loss of the Ark/end of the Elides

4:3-22

c) Ark returns to Kiriath-jearim

$5: 1-7: 2$

3) Order restored by Samuel

$7: 5-17$

$7: 5-6$

a) Samuel assembles the people at Mizpah

$7: 7-14$

b) Samuel gains deliverance for Israel

c) Samuel as judge of Israel

$7: 15-17$

B. Transition: from the judges to the monarchy

1. Failure of leadership: Samuel's sons as judges

2. Assembly at Ramah
a. The people assemble and demand a king
b. Samuel's diatribe against unacceptable monarchy
c. Stubbomess of the people
d. Samuel instructed to establish acceptable monarchy

3. Prophetic designation of Saul by Samuel

4. Assembly at Mizpah
a. Samuel assembles the people
b. The choice of Saul
c. Acceptance by the people
d. Threat of division: "worthless fellows" reject Saul

1 Sam 8:1-11:15*

$8: 1-3$

$8: 4-6 a, 11-17,19-22$

8:4-6a

8:11-17

8:19-20

8:21-22

9:1-10:16

$10: 17,20-27$

$10: 17$

$10: 20-24$ a

$10: 24 b-26$

$10: 27$

$11: 1-13$

$11: 1-11$

$11: 12-13$

$11: 14-15$

$11: 14$

$11: 15 \mathrm{aa}$

$11: 15 \mathrm{a} \beta \mathrm{b}$

1 Sam 13:1-2 Kgs 23:23*

1 Sam 13:1-1 Kgs 10:29*

1 Sam 13:1-15:35

1 Sam 16:1-1 Kgs 10:29*

1 Sam 16:1-2 Sam 5:25

1 Sam 16:1-13

1 Sam 16:14-2 Sam 5:5

2) Story of David's rise to kingship

3) Account of David's success as king

2 Sam 5:6-25

b. Transition: promise to David of an enduring dynasty 6:1-8:18

1) Critical event: Ark enters Jerusalem 6:1-23

2) Prophetic consultation (Naihan) 7:1-3

3) Nathan's prophecy of dynasty and temple 7:4-17, 18-21, 25-29

4) Prelude to realization: security of David's kingship 8:1-18

c. Realization of the ideal state 2 Sam 9:1-1 Kgs 10:29*

1) Dynasty established with Solomon 2 Sam 9:1-1 Kgs 2:46*

2) Realization of the ideal state under Solomon 1 Kgs 3:1-10:29*

a) The wise king rules Israel at peace $3: 1-5: 14$ (RSV $3: 1-4: 34$ )*

b) Construction of the temple

5:15-8:63 (RSV 5:1-8:63)*

(1) Account of construction

$5: 15-7: 51$

(2) Dedication of the temple

8:1-63*

(a) Assembly: procession with Ark and dedication 8:1-13*

(b) Solomon's prayer

$8: 14-29 a^{*}, 55-56$

(c) Celebration

$8: 62,63 b$ 
d) Account of Solomon's rule

3. Transition: Solomon's infidelity and prophetic intervention

11:1-12:20*

a. Account of Solomon's infidelity

b. Prophetic intervention (Ahijah)

1) Provision for Davidic dynasty

2) Provision for Jeroboam

c. Account of breakdown of the ideal state

1) End of the reign of Solomon

2) Assembly at Shechem: schism

B. Story of the divided kingdom

1. The failure of the northern kingdom

a. Failure of the Jeroboam dynasty

1) The infidelity of Jeroboam

$1: 1,2 b-4,6-7$ $11: 26-31,34-38$ *

$11: 34^{*}, 36$

11: $35 \mathrm{aba}, 38$

11:40-12:20

$11: 40-43$

12:1-20

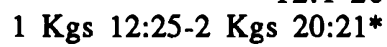

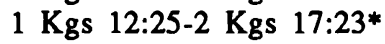

1 Kgs 12:25-15:32*

2) Prophetic intervention (Ahijah)

$12: 25-29,30 \mathrm{~b}, 32 \mathrm{a} ; 13: 33 \mathrm{~b}-34$

3) Realization in history: end of the dynasty

c. Failure of the Baasha dynasty

$14: 1-13^{*}, 16$

$14: 17-15: 32 *$

d. Failure of the Ahab (Omri) dynasty

15:33-16:14*

e. Continuation of Jeroboam's sin in the northem kingdom

16:15-2 Kgs 10:28*

f. End of the northern kingdom: exile by Assyrians

2 Kgs 10:29-15:31*

2. Continuity of Davidic dynasty/Judah

a. Account of incomplete fidelity to centralized worship by Davidic kings

1) Failure to remove high places

2) Crisis under Ahaz

$17: 1-6,20-23$

a) The infidelity of Ahaz

b) The alliance with Assyria

b. Resolution under Hezekiah

$1 \mathrm{Kgs}$ 14:21-2 Kgs 16:20*

$1 \mathrm{Kgs}$ 14:21-2 Kgs 15:38*

2 Kgs 16:1-20*

16:1-3a, 4aa

$16: 5-9,19-20$

1) Reform of Hezekiah: removal of high places

2) Resolution of the Assyrian crisis

a) Critical event: Assyrian threat

b) Prophetic consultation (Isaiah)

c) Prophecy of Isaiah

d) Realization in history

$13,17-20: 21^{*}$

3) Epilogue: healing of Hezekiah

$18: 1-5,7-8$

$18: 9-11,13,17-19: 37 *$

$18: 9-11,13,17-37$

19:1-2

19:5-7

19:8-37*

C. Transition: prelude to a new era

$20: 1-11,20-21$

21:1-23:23*

21:1-26*

a. Apostasy and high places

b. Continuity of Manasseh's policy by Amon

2. Resolution of the crisis under Josiah

$21: 1-2 a, 3 a b a, 5,7,17-18$

a. Critical event: discovery of the book of the law

b. Prophetic consultation (Huldah)

c. Prophecy of Huldah

d. Successful implementation of the reform

1) Assembly and commitment to the book

$21: 19-20,23-26$

22:1-23:23*

22:1-10

22:12-13a*

22:15aab, 18b, 20aa

23:1-23:23*

23:1-3*

2) Reform of Josiah 23:4aba, 5aab, 6-7, 8a, 9, 11-12*

3) Celebration of Passover

23:21-23 


\section{DESCRIPTION ${ }^{1}$}

What is immediately striking about the schematic presentation of the structure of DtrH is the way DTR organized the history into three different periods, each marked by a different form of leadership. When this basic structural feature of the history is taken in conjunction with the opening address by the great leader Moses, and the reform of king Josiah which concludes the history, then a clear impression is gained that DtrH was composed principally as a history of Israel's leaders. This feature has not been fully appreciated in previous studies.

Another immediately recognizable component of the structure is what I haved termed the Transition. An accurate structural presentation should highlight those areas of the text which mark significant developments in the history, areas which one would expect are also important in terms of DTR's conceptual plan. The transition texts enable the reader to identify these areas and their relationship to preceding and following material. Thus there are important transition texts marking the change between the different periods of leadership in Israel's history (cf. Josh 24:29-31; Judg 2:10 and 1 Samuel 8$11^{*}$ ). Transition texts also serve to mark important changes within the first and third periods of leadership. Deut 3:23-28:46*; 31:1,7-8; 34:1-6* records Moses' timely proclamation of the deuteronomic code or program, and the installation of his successor Joshua. 2 Samuel 6-8* records the promise of an everlasting Davidic dynasty and a temple for Yahweh's name. $1 \mathrm{Kgs} \mathrm{11:1-}$ $12: 20^{*}$ deals with the schism in the united kingdom and the emergence of Israel and Judah. Finally, 2 Kgs 21:1-23:23* records the providential discovery of the book of the law, an event which leads to Josiah's definitive establishment of centralized worship and the elimination of the cult of foreign deities.

The transition texts are also significant for tracing the course of Israel's history in relation to the realization of the deuteronomic program. This is indicated by the central position of the Mosaic discourse in the first transition text (Deut 3:23-28:46*; 31:1, 7-8; 34:1-6*), and by Solomon's proclamation in 1 Kgs 8:56 that "not one word has failed of all his good promise, which he uttered by Moses his servant". The history then concludes with Josiah's reform, the purpose of which was to set Judah on the road to regaining what had been lost through the infidelity of Solomon.

The structure also shows how other parts of the history stand in relationship to the transition texts and contribute to the sense of a unified work. However the schematic form of the presentation does impose certain limits on its ability to illustrate the various interconnections. One immediately obvious limitation is the necessity of setting the story of the two kingdoms in sequence. The following description will therefore supply what cannot be included in the schematic presentation of the structure. It will deal

${ }^{1}$ This description is not concerned with the question of source and redaction, which will be taken up in part 2. Nor does it set out the details of later redaction of DtrH. This will also be taken up in part 2. Bibliographical references will be kept to a necessary minimum. 
with each of the periods of leadership in turn, at the same time keeping the overall structure of DtrH in mind.

\section{ISRAEL UNDER MOSES AND JOSHUA}

Within the period of Israel under Moses and Joshua the principal leader for DTR was of course Moses. Indeed Moses is the paradigmatic leader for the whole of the history. The structural outline for this first period indicates the nature and importance of his leadership in three ways. First, he was the one who had authority to interpret the course of Israel's history, as his review in Deuteronomy 1-3* shows. Second, he was the one who, at Yahweh's command, installed Joshua and commissioned him to complete what he had begun (Deut 3:23-28; 31:1, 7-8). Third, he was the one authorized by Yahweh to present the deuteronomic program for Israel's life in the land (Deut 5:128:46*). Each aspect of Moses' leadership was important, not only for the first period but for the history as a whole.

The presentation of Moses as the one authorized to interpret Israel's history occurs in DTR's review of the rebellious exodus generation and the Transjordanian successes of the emergent conquest generation (Deut 1:1-3:17*). The exodus generation had entered into a covenant with Yahweh at Horeb and had received there the promise of conquest of the land (Deut 1:6-8, 21). However, because of their disobedience (Deut 1:22-45*) Yahweh swore that they would not see the land (Deut 1:35). ${ }^{2}$ They were condemned to die in the wilderness (Deut 2:14-16).

There are two things to note about this section of the review. The first is the way the demise of the exodus generation is accounted for within a schema of promise (Yahweh's word in Deut 1:35) and fulfillment (the report in Deut 2:14). The second is the use of the deuteronomic schema of reward and retribution. The exodus generation perished in retribution for their disobedience. Hence at the very outset of the history DTR integrated the promise-fulfillment schema with the reward-retribution schema. This alliance of inter-pretative criteria was important for the larger structure and conceptual plan of DtrH, particularly for the period of Israel under the prophets and kings. Moses' explanation of the demise of the exodus generation thus set the basic agenda for the remainder of the history.

The review of Israel's history by Moses includes an account of the successes of the conquest generation in Transjordan (Deut 2:17-3:17*). Even though it is not explicitly stated, one may infer from the context that this success was a reward for their fidelity to Yahweh. The repeated use of the first person plural in this section-in contrast to the review of the exodus generation-is suggestive of the harmony between the people and their appointed leader Moses. The successes of the conquest generation had shown that they were worthy heirs of the promise which their fathers had forfeited. Hence in Deut 5:2-3 Moses transfers to them the privileges and responsibilities of the

${ }^{2}$ As the exegetical discussion of the review will show, the reference to Caleb in Deut $1: 36$ is a most likely a later addition. 
Horeb covenant. ${ }^{3}$ In terms of the structural organization of the introduction to the history one can see how DTR used the review of past events, the passage of generations, the cross references to Horeb in Deut 1:6 and 5:2-3, and the sense of the transfer of the covenant, to link the introductory section of the history with the important transition text containing the proclamation of the deuteronomic program.

Moses' installation of Joshua likewise has important structural and thematic links with his review in Deuteronomy 1-3* and the proclamation of the deuteronomic program in Deut 5:1-28:46*. The most obvious link is created by Yahweh's refusal to let Moses lead Israel across the Jordan. His death is imminent and a successor is therefore required to complete the conquest (Deut 3:23-28). In this context Moses' proclamation of the deuteronomic program functions as the traditional farewell address by the great leader. At its conclusion Joshua is installed as successor (Deut 31:1,7-8), and Moses then dies (Deut 34:1-6*). There are however some other important structural and thematic links to which attention needs to be drawn.

Although Joshua is installed as Moses' successor, he does not take over all the functions of Mosaic leadership. His commission is limited to completing the conquest and distribution of the land which Moses had begun. This gives a strong sense of unity to the whole conquest theme, making the conquest of Transjordan as well as Cisjordan an integral component of the conquest of the land. ${ }^{4}$ The sense of unity and the notion that Joshua continued and completed what Moses had begun is brought out by two further points. The conquest was completed by the one generation. Futhermore, the type of leadership exercised by Joshua was concerned exclusively with the conquest and distribution of the land. Upon the completion of this task Joshua dies, with no provision for any successor (Josh 24:29-30).

This portrait of Joshua enables one to discern two additional important factors in DTR's presentation of the history at this point. The first concerns the unique status of Moses as lawgiver and authoritative interpreter of the course of Israel's history. Joshua does not function in either of these capacities. This reinforces DTR's presentation of Moses in Deuteronomy 1-3* as the paradigmatic leader. It also indicates that the interpretative criteria employed by Moses govern not just the review of Israel under his leadership, but the subsequent periods as well. The second factor is a clear distinction between the leadership of Joshua and that of the judges. As already noted there is no provision for a successor to Joshua. This serves to emphasize the difference between the two periods. Unlike Joshua, the judges were raised up

${ }^{3}$ It is possible that Deut $5: 3$ is a later addition. Nevertheless the interpretation proposed enables one to incorporate it within the structure of the history. The interpretation is also able to accommodate the point noted by $G$. von Rad (Deuteronomy [OTL; London: SCM, 1966] 55) that the writer's purpose in this verse was to actualize a past event. See also Pierre Buis, Le Deutéronome (VS; Ancien Testament 4; Paris: Beauchesne, 1969) 5.

${ }^{4}$ This notion is continued in Joshua 12 , which sums up the conquest by surveying the land conquered and allotted both by Moses (Transjordan) and Joshua (Cisjordan). 
to deliver Israel from situations of apostasy and oppression. At the same time however, the sense of continuity in the history is maintained by the notice of the change of generations (Josh 24:31; Judg 2:10). The sense of continuity within a larger trajectory of change and development is a feature which, as will be seen, marks DTR's presentation of the transition to the monarchy and other important developments within the history.

The third aspect of Moses' leadership is his authority to proclaim the deuteronomic program for Israel's life in the land. The importance of this program emerges of course as the history unfolds. It would have been virtually impossible for DTR to construct a history which monitored Israel's obedience or disobedience to every law of the deuteronomic code. DtrH was therefore constructed in such a way as to focus on three areas which DTR regarded as the essence of the code. These were, fidelity to the exclusive worship of Yaweh, fidelity to centralized worship at the place chosen by Yahweh, and fidelity to the leaders appointed by Yahweh. During the period of the monarchy the leaders who were entrusted with a Mosaic like authority to interpret the course of Israel's history were the prophets.

As one would expect the three criteria were applied in a way that would verify DTR's overall conceptual plan. An important component of this plan was to show how the ideal life in the land envisaged by Moses in Deut 12:1011 was realized in the time of Solomon and then lost. The elements of this ideal were conquest of the land, rest from enemies, security, and the choice by Yahweh of a place for his name. The following presentation will outline how DTR applied these criteria to show the realization of the ideal under Solomon, its loss through Solomon's infidelity, and the opportunity provided by the reform of Josiah to achieve the ideal once again.

The remainder of the period of Israel under Moses and Joshua records Joshua's completion of the conquest of the land and its allotment (Joshua 2$\left.12^{*}\right)$. There is no need to dwell at length on this section of the history. Its position and function within the first period is evident enough. Attention needs to be drawn however to DTR's statement in Josh 24:31 that the conquest generation was completely faithful to Yahweh. The implication to be drawn from this is that the successful conquest was a reward for their fidelity. So, by the time of the death of Joshua, Israel had seen the completion of an important initial step in the realization of the deuteronomic ideal (Josh 21:43-45; 24:2930).

\section{ISRAEL FROM THE JUDGES TO THE MONARCHY}

The introduction to the period of Israel from the judges to the monarchy shows that the movement towards the realization of the ideal society was stalled by the continued apostasy of the post-conquest generations (Judg 2:10b, $\left.11-19^{*}\right)$. As one reads the introduction and the subequent stories of the judges the repeated pattern of Israelite apostasy, oppression by enemies, and deliverance by a judge, appears to be the dominant feature. In fact it has generally been accepted that this cyclic structure is the organizing principle of the whole section on the judges. As von Rad noted however, this creates 
problems with the larger linear structure of DtrH..$^{5}$ The two stage development of Israel's history proposed in the structure for the times of the judges is, I believe, a more accurate representation of how DTR organized the material. ${ }^{6}$ It is able to incorporate the cyclic structure into a larger linear sequence and so resolve the sort of problem which von Rad had raised.

The identification of a two stage structuring of the judges' material by DTR emerges from a number of considerations. First of all, it needs to be recognized that the introduction in Judg $2: 10 \mathrm{~b}-19 *$ is meant to balance DTR's concluding comment on the faithful conquest generation in Josh 24:31 and Judg 2:10a. Hence it serves to emphasize the contrast between the postconquest generations and the conquest generation. Moreover its location as an introduction indicates that it was not intended to function as DTR's final comment on Israel's history under the judges. If it were, then one would have expected it to be located, like Josh 24:29-31, at the conclusion of the section on judges. The second consideration is the repeated rescue of Israel by deliverers whom Yahweh raised up, a feature brought out strongly in both the introduction and the cycle of stories. Given the direction of the history to this point the repeated intervention by Yahweh pointed to some definitive resolution of the troubled period. Ultimately his saving purpose could not be contained within the confines of such a cycle.

The third consideration is the story of Abimelech's abortive attempt to establish a monarchy in Judg 9:1-57. The story itself constitutes a certain break with the preceding cycle of stories. There is no oppression by enemies. Instead, severe internal dissent results from Abimelech's actions (cf. Judg 9:2255). In addition, Judg 10:1 states that after Abimelech, Israel was "delivered" by the judge Tola. Within the context, this can only mean that order was restored, after the strife caused by Abimelech, via a return to the leadership of the judges. One may also argue from the context of the judges' stories that the use of the term "deliver" implies the hand of Yahweh.?

When one takes these observations into account it is clear that the story of Abimelech and its aftermath provides a climax to the cycle of judges' stories begun in Judg 3:7. The story of Abimelech tells of an attempt to change the leadership of Israel from that of judges raised up by Yahweh, to that of a king. The attempt causes strife in Israel and order is mercifully restored by Yahweh through a return to the judges (Judg 10:1-5). Within the larger sweep of the period of Israel from the judges to the monarchy, this first stage serves to introduce the question of monarchical rule. Nevertheless, Abimelech's failure and the return to the judges suggests that it can only be established on Yahweh's terms and in his good time. It should be noted that kingship itself is not condemned in the story, only the way Abimelech set out to become king.

${ }^{5}$ Von Rad, Old Testament Theology, 1. 346-47.

6This is particularly so when one accepts Richter's proposal that the cyclic structure was a pre-dtr creation (Bearbeitungen, 113-15).

${ }^{7}$ Cf. Judg $2: 16,18 ; 3: 9,31 ; 6: 14,15 ; 13: 5$. This point, and DTR's location of the list of the so-called minor judges, will be discussed in part 2 . 
The presence of the second stage (Judg 10:6aa, 7-8*, 9b, 17-13:1; 1 Sam $\left.1: 1-7: 17^{*}\right)$ is recognizable by the fact that it exhibits the same basic structure as the first stage. It begins with a cycle of apostasy and deliverance (Judg $\left.10: 6 a a, 7-8^{*}, 9 b, 17-13: 1\right)$. It then climaxes with the story of the failure of Eli's sons as leaders (1 Sam 1:1-2:36*), and the emergence of another leader in Samuel (1 Sam 3:1-7:17). This second stage does however contain a number of differences which are important for the development of the history, in particular the transition to the monarchy.

First, the failure and condemnation of the Elide priests is not resolved, as in the case of Abimelech, by a return to the judges. Instead a new leader-the prophet-emerges under the initiative of Yahweh. This indicates that the time for a definitive resolution of the troubles of the judges' period is imminent. Second, as the schematic presentation of the structure shows, the end of the Elides is concomitant with the loss of the ark in the war with the Philistines (1Sam 4:1b-22). The fortunes of the ark are therefore highly significant in relation to the question of leadership in Israel. Its return to Israel and sojourn at Kiriath-jearim (1Sam 5:1-7:17) serves to create the expectation of a new divine initiative in Israel's history.

The second stage of DTR's structural organization of the judges' material functions then in two ways. On the one hand it maintains continuity with the first stage in the way it commences and in its basic structure. On the other hand it contains differences that are essential for the following transition to the monarchy.

The sense of being on the threshold of a new era is particularly evident in the assembly at Mizpah in 1 Sam 7:5-17. This passage belongs with the preceding stories of the second stage because it describes Samuel as a judge (1 Sam 7:6b, 15) who delivers Israel from the Philistines (vv 7-11). But, unlike the heroes of the judges' period Samuel does not lead troops in a holy war. Israel's deliverance in this case comes as a response to Samuel's offering and intercession (vv 9-11). Furthermore, his role of judge is exercised in the context of a national assembly which he calls, and in which he mediates a reconciliation of Israel with Yahweh (vv 5-6). No other judge functions in such an authoritative manner. When we combine these observations with the establishment of Samuel as a prophet in 1 Sam 3:1-4:1a, then it is clear that, although Samuel possesses charisms akin to those of deliverer and judge, he is a new leader in Israel with a new authority.

The section of DtrH which presents the transition to the monarchy is to be found in 1 Sam 8:1-6a, 11-17, 19-22; 9:1-10:16, 17, 20-26; 11:1-15. The precise nature of the divine intervention heralded by the emergence of Samuel and the return of the ark unfolds in the wake of the failure of Samuel's sons as judges (1 Sam 8:1-3), and the crisis this provokes among the people (1 Sam 8:4-6a, 11-17, 19-20). A proper appreciation of the significance of the failure of Samuel's sons is therefore crucial for a correct understanding of how DTR saw the emergence of the monarchy.

To begin with, the report of the failure of Samuel's sons as leaders, the resulting crisis among the people, and the resolution of the crisis via the establishment of the monarchy, clearly reflects the sequence observed in the two stage structure of the period of the judges. Each stage climaxed with a 
failure of leadership, a crisis, and its resolution via a form of leadership established by Yahweh. This structural similarity once again manifests a key component of DTR's organization of the history of Israel; namely, continuity with the past within a larger trajectory of change and development.

The sense of continuity is most clearly discernible in the way the failure of Samuel's sons parallels the earlier failure of the sons of Eli. Continuity is of course also maintained by the figure of Samuel. Nevertheless the failure of Samuel's sons and its consequences is also an integral part of the transition to the monarchy, for it is at this point that the issue of monarchy emerges. In addition it is the strife caused by their failure which brings divine intervention in the form of an instruction to establish a king for the people (1 Sam 8:22a).

The internal organization of 1 Samuel 8 is highly significant for appreciating the structure of this section of the history, and for DTR's understanding of the monarchy. Within the chapter there are a number of elements which form a sharp contrast to 1 Samuel 7, where Samuel takes the initiative and is firmly in control. In 1 Samuel 8 the people take the initiative by sending a delegation to Samuel at Ramah (1 Sam 8:4). They demand a king "like all the nations" ( $v$ 5), and are adamant in their demand despite Samuel's diatribe against the way of such a king (vv 11-17, 19-20).

The people's assembly and delegation, their demand and stubborness, are a product of the strife cause by the failure of Samuel's sons. But these elements also have an important function in relation to the subsequent account of the emergence of the monarchy. As the rest of the transition unfolds, each element of the people's attitude to Samuel is reversed or corrected in favor of the authority of Samuel as Yahweh's prophet. There is first of all the story of Samuel's anointing of Saul in 1 Sam 9:1-10:16. This is in response to Yahweh's command (1 Sam 8:22), and under his guidance (1 Sam 9:16). As Yahweh's anointed therefore, Saul is anything but a king like all the nations. Next, Samuel reasserts his authority over the people by calling a national assembly at Mizpah (1 Sam 10:17, 20-27). Far from being demanding and stubborn, the people on this occasion obediently follow Samuel's directives and accept Saul as Yahweh's chosen one and therefore their king (1 Sam 10:24). Samuel's discourse on monarchical rule reported in 1 Sam 10:25 functions within the larger context as a contrast to his diatribe against the way of a king in 1 Sam 8:11-17.8 The sort of kingship demanded by the people was unacceptable. Instead of resolving their difficulties it would lead to oppression. The only form of acceptable kingship therefore was the one established through the agency of Yahweh's prophet and under his authority.

The success of the assembly at Mizpah is however threatened by a division among the people. Some "worthless fellows" reject Saul, claiming that he cannot deliver them (1 Sam 10:27). This crisis provides the occasion for the final stage of DTR's account of the transition to the monarchy. Saul's victory over Nahash demonstrates that he is in possession of the charism of deliverer (1 Sam 11:1-11). His pardon of the worthless fellows demonstrates that he

${ }^{8}$ Note the use of the term mispat in 1 Sam $8: 11 ; 10: 25$ to describe the rule of the king. 
also has the charism of judge (1 Sam 11:12-13). As with Samuel however, one should note the differences between Saul and the judges of the old order.

First of all, the charisms he exercises have been received via his prophetic anointing. Secondly, he exercises them in concert with the prophet (1 Sam $11: 7,12-13) .{ }^{9}$ Thirdly, his pardon of the worthless fellows is in effect an exercise of the royal prerogative to dispense justice. ${ }^{10}$ The successful resolution of the Ammonite crisis thus serves to verify Yahweh's choice of Saul as king and confirm Samuel's prophetic authority. The authority of the prophet in relation to both king and people is sealed in the assembly at Gilgal, summoned by Samuel (1 Sam 11:14). There the unity of the new monarchical state is secured in a ceremony in which Saul is made king by all the people (1 Sam 11:15).

In sum, 1 Samuel $8-11^{*}$ is a carefully structured transition text which demonstrates continuity with preceding sections of the history within a larger trajectory directed towards the establishment of the monarchical state. Within the transition text DTR clearly indicated the sort of monarchy which alone was acceptable for Israel. It is contained in the contrast between the diatribe of 1 Sam 8:11-17 and the inauguration of a king by the prophet and under the authority of the prophet. DTR's positive attitude to such a monarchy, and the conviction that it was a divine initiative, is brought out also by the way Yahweh's purpose triumphs over the crises and contradictions of Israel's history. According to DTR's understanding of Israel's history, it was the prophet/king form of leadership which enabled Israel to regain the momentum lost after the death of the conquest generation and finally realize the ideal enshrined in the deuteronomic program (cf. Deut 12:10-11).

\section{ISRAEL UNDER THE PROPHETS AND KINGS}

The authority of the prophet as leader and the importance of the prophet/king relationship has not received sufficient attention in the study of DtrH. ${ }^{11}$ A glance over the structure for the period of Israel under the prophets and kings shows just how important the relationship was to DTR's interpretation of this period. One can see how the structure highlights the relationship between key figures such as David and Nathan, Hezekiah and

${ }^{9}$ It was because Saul attempted to act independently of Samuel that he was condemned and eventually lost the kingdom to David. Cf. 1 Sam 13:8-15; $15: 4-31 ; 16: 1$.

${ }^{10}$ Note that David also demonstrates the charisms of deliverer (2 Sam 5:1725 ) and judge ( $2 \mathrm{Sam} 8: 15$ ). However the difference between judges and kings is marked here by the use of the noun pair, justice (mispat, cf. 1 Sam 10:25) and righteousness (șẽãâa). These do not occur in the judges' material. For his part, Solomon was given wisdom in order to govern ( $S p t)$ Yahweh's people $(1 \mathrm{Kgs}$ 3:9).

${ }^{11}$ This is evident in the recent study by Gerald Eddie Gerbrandt, Kingship According to the Deuteronomistic History (SBLDS 87; Atlanta: Scholars, 1986). Gerbrandt recognizes that DTR was not opposed to monarchy (p. 146) but fails to perceive the essential nature of the prophet/king relationship for DTR. 
Isaiah, Josiah and Huldah. The prophecy by Ahijah of Shiloh (1 Kgs 11:29$38^{*}$ ) is not only a key factor for the story of the schism and the emergence of Jeroboam as the first king of northern Israel, but also for the whole subsequent history of the divided kingdom. In addition one may discern in each of the stories of the relationship between prophets and kings a concern on the part of DTR to record the realization in history, or the fulfillment, of the prophetic word. ${ }^{12}$ The schema of prophecy and fulfillment is in fact a basic organizational and interpretative component in DTR's construction of this period of the history. The full significance of this cannot of course be brought out in a schematic presentation. The following comments will therefore supply the necessary detail. As well as illustrating the unified nature of DTR's interpretation at each significant point of this third period of Israel's history, the comments will also point out its relationship with the preceding periods.

The period begins with Saul's disobedience and his rejection by Samuel (cf. 1 Sam 13:7b-15a; 15:1-35). Although this was a crisis for the new monarchical state and the realization of the deuteronomic ideal, it did serve to demonstrate the prophet's authority to reject kings as well as designate them. This same prophetic authority is invoked later in the history against the northern dynasties of Jeroboam, Baasha, and Ahab. Despite the disappointment of Saul, the opportunity to finally realize the ideal came with the anointing of David (1 Sam 16:1-13). David was able to bring Israel within reach of it with such developments as the united kingdom (2 Sam 2:1-4; 5:15 ), the defeat of Israel's enemies (2 Sam 5:17-25; 8:1-14), the entry of the ark into the new capital Jerusalem (2 Samuel 6), and the establishment of a dynasty with the succession of Solomon (1 Kings 1-2*). According to DTR's understanding of Israel's history Solomon's construction and dedication of the temple marked the final step in the realization of the ideal Israelite society.

It is important at this stage to point out in some detail how DTR integrated the reign of David into a unified interpretation of Israel's history. This was effected by explaining the success of David as a reward for his fidelity to the three criteria mentioned earlier. These were; fidelity to the exclusive worship of Yahweh, fidelity to centralized worship, and-with particular reference to the period of the monarchy-fidelity to the prophet/king relationship. According to DTR these three criteria captured the essence of the deuteronomic program. The whole of Moses' address is permeated by the call to be faithful to the exclusive worship of Yahweh. Centralized worship is an essential element of deuteronomic fidelity to Yahweh because it recognizes the divine prerogative to choose the place where Israel may honor him. The authority of the prophet was necessary in order to justify DTR's use of the deuteronomic schema of reward and retribution in the story of the monarchy. Kings who were faithful to Yahweh according to the three criteria were rewarded by success; those who were not met trouble or disaster. The reward or retribution was announced by a prophet, and its realization in history

${ }^{12}$ The importance of this schema was noted by von Rad, Studies in Deuteronomy, 78-81. However von Rad did not explore the structural significance of the schema, nor has it been adequately investigated by subsequent studies. 
marked by a fulfillment notice or other appropriate reference. The prophecyfulfillment schema was thus allied with the reward-retribution schema in much the same way as observed earlier in Deuteronomy 1-3*.

For DTR David was exemplary according to all three criteria. The stories about him in the books of Samuel, and comments by DTR such as $1 \mathrm{Kgs}$ $8: 25 ; 9: 4$, showed that he was a loyal Yahwist throughout his career. There was of course no centralized worship in the temple during his time. Nevertheless David is recorded as requesting permission to build a house for Yahweh in 2 Sam 7:2. Although the request was not granted, David's commitment to centralizing the worship of Yahweh is commended in $1 \mathrm{Kgs} \mathrm{8:18.}$ Moreover, the capture of Jerusalem and the entry of the ark into the city were important steps towards the realization of this key aspect of the deuteronomic ideal. The third criterion, fidelity to the prophet/king relationship, was a particularly important one, not only in relation to David, but also in relation to the subsequent kings of Israel and Judah.

DTR's presentation of David as a model king in his relationship to the prophet was achieved principally by the construction of a four-part sequence, centered on the prophecy of Nathan in 2 Samuel 7. The structure analysis gives the basic outline and text of the sequence. First, there is the critical event of the entry of the ark into Jerusalem in 2 Samuel 6. Second, in response to this event David consults the prophet Nathan (2 Sam 7:1-3). Third, Nathan responds with the prophecy of an everlasting dynasty for David and the construction of the temple by his son (2 Sam 7:14-17). Fourth, the course of history is shown to demonstrate the realization of the prophecy (2 Samuel 8-1 Kings 8$)^{13}$

This four-part sequence or pattern portrayed David as faithful to the prophet/king relationship and thus enabled DTR to present the promises of 2 Samuel 7 as a reward for this fidelity. It also meant that the story of his reign could be used to justify the deuteronomic schema of reward and retribution. Furthermore the notion of a reward for David was able to be invoked by DTR at a later stage in the history in order to explain the schism in the kingdom. One may note here too that whereas David's fidelity to the prophet/king relationship was rewarded by a successful reign, his predecessor Saul suffered divine retribution because of his infidelity to this relationship. ${ }^{14}$

${ }^{13}$ The four-part pattem is not exclusive to DTR. Robert L. Cohn has for example identified a four-part pattem involving prophetic consultation in the accounts of Jeroboam (1 Kings 14), Ahaziah (2 Kings 1), Ben-hadad (2 Kings 8 ), and Hezekiah (2 Kgs 20:1-11). See "Convention and Creativity in the Book of Kings: The Case of the Dying Monarch," CBQ 47 (1985) 603-16. These deal with the theme of threat of death from illness and were not constructed by DTR. What is being claimed here, and will be argued in the exegetical analysis, is that DTR constructed the four-part pattern for the reign of David, and also for Hezekiah and Josiah.

${ }^{14}$ There is no cogent reason to exclude the story of David and Bathsheba in 2 Samuel 11-12 from DtrH. David's sin was not apostasy and did not sever his relationship with Yahweh. Also, David remained faithful to the prophet/king relationship. This is shown by his acceptance of Nathan's judgment in a con- 
Once DTR had demonstrated that David fulfilled the three criteria in an exemplary way he was then used as a model or standard to measure the conduct of subsequent kings. This is evident in a number of the prophetic speeches and judgment formulas in the books of Kings. ${ }^{15}$ It is also evident in the way the four-part pattern was applied to Hezekiah and Josiah, the only two kings who, according to their respective judgment formulas, were like David in all that they did. ${ }^{16}$ In the case of Hezekiah the critical event is the Assyrian threat

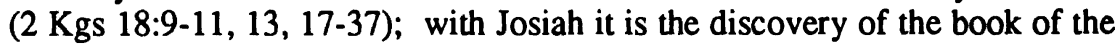
law (2 Kgs 22:3-10). In response to the critical event Hezekiah sends a delegation to consult the prophet Isaiah (2 Kgs 19:1-4). Josiah likewise sends a delegation to Huldah the prophetess (2 Kgs 22:11-13a). Each king receives in return a positive prophecy. For Hezekiah it is contained in $2 \mathrm{Kgs} \mathrm{19:5-7,}$

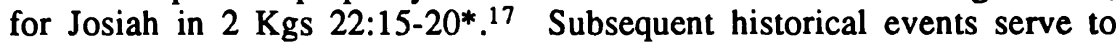
demonstrate the realization of the prophecies. In the case of Hezekiah it is the withdrawal of the Assyrians and subsequent death of Sennacherib (2 Kgs 19:8$9 a, 36-37)$. The fact that DTR wrote during the reign of Josiah meant a full account of the realization of Huldah's prophecy could not be given. Nevertheless it is reasonable to propose that DTR regarded the successful implementation of the reform ( $\left.2 \mathrm{Kgs} 23: 1-23^{*}\right)$ as a sure indication of the validity of the prophecy.

The parallels created by DTR between David, Hezekiah, and Josiah can be summarized as follows. Hezekiah and Josiah were, like David, completely faithful to Yahweh and the policy of centralized worship. Like David, they acknowledged the authority of the prophets and sought the word of Yahweh from them. Their reigns were therefore, like David's, marked throughout by success. These parallels, and the high profile given to Hezekiah and Josiah in the structure of DtrH, invite some further exploration. Before doing this however it is necessary to complete the account of how DTR portrayed the realization of the ideal state under Solomon, its breakdown, and the story of the kingdoms of Israel and Judah.

The construction and dedication of the temple was for DTR the final step in the realization of the deuteronomic ideal. What is important in terms of the structure and conceptual plan of DtrH is the way DTR composed Solomon's dedication speech to forge a link between the realization of the ideal and the prophecy-fulfillment schema. In $1 \mathrm{Kgs}$ 8:56 Solomon identifies the dedication as the fulfillment of Yahweh's good word "which he uttered by Moses his

fession of guilt (2 Sam 12:13a), and Nathan's announcement of forgiveness (v $13 b)$.

${ }^{15}$ For the prophetic speeches, cf. $1 \mathrm{Kgs}$ 11:29-39 (with respect to Solomon and Jeroboam); 14:7-11 (against Jeroboam). For the judgment formulas cf.1 Kgs 3:3 (Solomon); 15:3 (Abijam), 11 (Asa); 2 Kgs 14:3 (Amaziah); 18:3 (Hezekiah); 22:2 (Josiah).

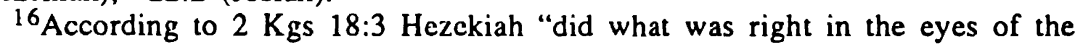
Lord according to all that David his father had done". According to $2 \mathrm{Kgs} 22: 2$ Josiah "walked in all the way of David his father".

${ }^{17}$ The original prophecy of Huldah was extensively rewritten by later redactors. A full discussion will be given in my examination of the reign of Josiah. 
servant". The similarity between this phrase and DTR's notices of prophetic fulfillment clearly shows a concern to link Moses' address (cf. Deut 12:10-11) with the prophecy-fulfillment schema. ${ }^{18}$ In addition to this Solomon also identifies the dedication at an earlier stage in his speech (1 Kgs 8:15-20) as the fulfillment of Nathan's prophecy to David in 2 Samuel 7.

The breakdown of the ideal state was attributed by DTR to Solomon's infidelity to the exclusive centralized worship of Yahweh (1 Kgs 11:1-7*). Solomon was promised the continuity of the ideal state in return for the same fidelity which his father David had shown (1 Kgs 9:1-5). His failure to meet this test led to the withdrawal of the promise and its attendant blessings. Hence the schism in the kingdom. This much could be readily explained in terms of DTR's criteria and incorporated within a general schema of prophecy and fulfillment (cf. $1 \mathrm{Kgs} 11: 29-38^{*} ; 12: 15$ ).

What was more difficult to explain was the fact that the schism did not take place during Solomon's reign. This was rather awkward for the deuteronomic schema of reward and retribution. In addition DTR had to account for the survival of the Davidic dynasty ruling over Judah, and the emergence of the northern kingdom under Jeroboam. The explanation of these events is to be found in the programatic prophecy of Ahijah of Shiloh in 1 Kgs 11:29-38*, in particular vv 34-38. It is worth examining DTR's argument here in some detail, because not only is Ahijah's prophecy an important transition text in the history, it is also a key text for demonstrating how DTR explained events in a way that would preserve an overall conceptual plan and unified interpretation.

The fact that Solomon escaped the punishment of the schism was explained by DTR in $1 \mathrm{Kgs}$ 11:34 in terms of the reward which had been promised to David for his fidelity (cf. 2 Samuel 7). In themselves the promises in 2 Samuel 7 of a dynasty, secure throne, and temple do not appear as rewards for service rendered by David. It is only when they are read in the context of DTR's four-part pattern, and the larger context of the history, that they take on this meaning. In $1 \mathrm{Kgs} 11: 29-38^{*}$ the element of reward was emphasized by DTR because of a concern to account for the events surrounding the schism within the deuteronomic schema of reward and retribution. The authority of the prophetic word justified the interpretation given.

This interpretation of Nathan's promise was employed also in DTR's explanation of the survival of the Davidic dynasty in the wake of the schism, and the emergence of the northern kingdom. According to DTR the survival of the Davidic dynasty was evidence that the reward of an enduring dynasty

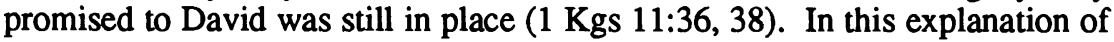
events the deuteronomic requirement of retribution for infidelity was satisfied by the schism and the dynasty's loss of the northern tribes (1 Kgs 11:35). The balance between the notions of reward and retribution was justified on the authority of the prophetic word. The justification gains in authority when Ahijah's prophecy is read in the light of the chastisement clause in 2 Sam

${ }^{18} \mathrm{~A}$ more literal rendering of the hebrew reads "which he spoke by the hand of Moses his servant". Cf. the following prophetic fulfillment notices in DtrH; 1 Kgs 12:15; 14:18; 15:29; 16:12; 2 Kgs 10:10; 17:23. 
7:14-15. This text states that, although punishment would be meted out for sin, the promise of an enduring dynasty would not be revoked. In a real sense

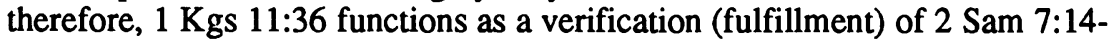
15.

Another aspect of DTR's interpretation of the survival of the Davidic dynasty must also be pointed out in this prophecy. The statement in $1 \mathrm{Kgs}$ 11:36 that "David my servant may always have a lamp before me in Jerusalem, the city where I have chosen to put my name" clearly links the dynasty's continued rule over Judah with the centralization of worship. ${ }^{19}$ The dynasty was therefore meant to be the guardian of the Jerusalem temple's exclusive status as the only legitimate place for worship. In other words, it was commissioned to preserve that key element of the deuteronomic program which David and Solomon had been responsible for implementing. $1 \mathrm{Kgs}$ 11:36 therefore supplies an important criterion for DTR's assessment of the subsequent history of the Davidic dynasty.

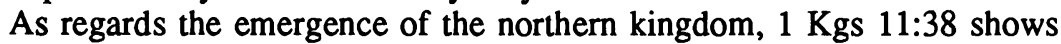
that its first king Jeroboam was offered the same opportunity as David to gain the promise of an enduring dynasty as a reward for fidelity to Yahweh. However, as the following chapters of the history show, Jeroboam failed to heed the prophetic word, was unfaithful to the exclusive centralized worship of Yahweh (1 Kgs 12:25-33*), and therefore did not gain his reward. His establishment of the golden calves at Bethel and Dan was condemned by Ahijah, and the promise of an enduring dynasty revoked (1 Kgs 14:7-13*). A fulfillment notice in $1 \mathrm{Kgs} 15: 29$ marks the end of his dynasty. Thus DTR

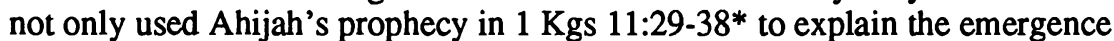
of the northern kingdom, but also to set the agenda for the interpretation of its subsequent history.

Before examining the subsequent history of the monarchy some concluding remarks on DTR's interpretation of the schism are in order. The examination of Ahijah's prophecy has shown that it is a key transition text. As with other transition texts in DtrH it serves to maintain continuity with the preceding material but within a larger trajectory of change and development in the history. The examination also enables one to discern three key elements in DTR's interpretation of the events of the schism which could be legitimately incorporated into the overall conceptual plan. These are: an explanation of the event in terms of the deuteronomic schema of reward and retribution; location of the explanation in a prophecy in order to give it the requisite authority; use of fulfillment notices and other appropriate texts to verify the explanation. The prophecy of Ahijah in $1 \mathrm{Kgs} 11: 29-38^{*}$ is somewhat cumbersome but, as will be demonstrated in the later exegetical discussion, this is due to a

${ }^{19} \mathrm{RSV}$ translates the hebrew term nir in $1 \mathrm{Kgs} 11: 36$ as lamp, identifying it with nēr, from the root nwr. However, Paul Hanson's identification of the root of nir as nyr (yoke) is more acceptable. From this he proposes that the meaning of the term in $1 \mathrm{Kgs} 11: 36 ; 15: 4 ; 2 \mathrm{Kgs} 8: 19$ is dominion. Cf. "The Song of Heshbon and David's Nir," HTR 61 (1968) 304-16; and the confirmation by Manfred Görg, "Ein 'Machtzeichen' Davids 1 Könige XI:36," VT 35 (1985) 363-67. 
combination of multiple redaction and the necessity of compressing what is a complex interpretation into a few verses.

As stated above, the prophecy of Ahijah set the agenda for DTR's account of the divided kingdom. Hence one would expect DTR's interpretation of the story of the two kingdoms to verify the prophecy at each significant step. The fact that the history of the two kingdoms is closely interwoven makes it difficult for a schematic presentation such as the structure to illustrate DTR's organization of the material as it stands. For this reason the accounts have been placed in sequence in the structure. My comments will follow the structural sequence, dealing with northem Israel first and then Judah.

In northern Israel, the short lived dynasty of Jeroboam was followed by those of Baasha and Ahab (Omri). According to DTR these dynasties also failed to endure because their founders walked in the way of Jeroboam. That is, they persisted in disobeying the call to exclusive centralized worship of Yahweh. Like Jeroboam therefore, each founder was condemned by a prophet and his dynasty was ultimately destroyed. ${ }^{20}$ An appropriate fulfillment notice marks the demise of each dynasty. ${ }^{21}$ The pervasive nature of the sin of Jeroboam gives a strong sense of unity to the story of these dynasties. The prophetic rejection of the dynasties clearly enabled DTR to establish a suitable contrast with the enduring Davidic dynasty in Judah.

The destruction of these dynasties because of the pervasive influence of the infidelity of Jeroboam also provided the paradigm for DTR's interpretation of the remaining kings of northern Israel, and the event of the northern exile in 721 BC. By employing judgment formulas for each king's reign, DTR showed that the sin of Jeroboam, which spelt doom for each of the dynasties, in fact pervaded the whole line of northern kings. ${ }^{22}$ The ultimate fate of the

${ }^{20}$ For Baasha the prophecy is that of Jehu ben Hanani in $1 \mathrm{Kgs} 16: 1-4$. For DTR the dynasty of Omri was identified with his son Ahab. This is probably due to stories in DTR's sources of the encourters between Elijah and Ahab, and the accusation that Ahab introduced Baal worship into the northern kingdom (1

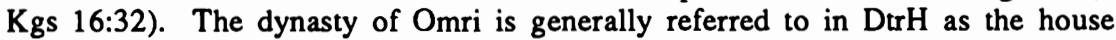
of Ahab (1 Kgs 21:22, 29; $2 \mathrm{Kgs} 8: 18,27 ; 9: 7,9)$. The only reference to the house of Omri occurs in $1 \mathrm{Kgs}$ 18:18. Elijah's condemnation of Ahab occurs in 1 Kgs 21:20-24*.

${ }^{21}$ For the dynasty of Baasha, the fulfillment notice is $1 \mathrm{Kgs} 16: 12$. For the dynasty of Ahab (Omri), $2 \mathrm{Kgs} \mathrm{10:10,17.}$

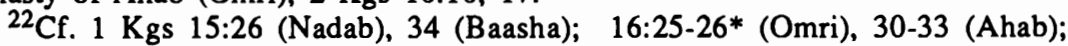
22:53-54 (RSV 22:52-53 [Ahaziah]); 2 Kgs 3:2-3 (Jehoram); 2 Kgs 10:29 (Jehu); 13:2 (Jehoahaz), 11 (Joash); 14:24 (Jeroboam II); 15:9 (Zechariah), 14 (Shallum), 18 (Menahem), 24 (Pekahiah), 28 (Pekah); 17:2 (Hoshea). Elah (1 Kgs 16:6) does not have a judgment formula. Zimri is condemned in $1 \mathrm{Kgs}$ 16:19, which I would judge to be a later addition. The expected judgment formula should come after v 15a. The absence of formulas in $\mathrm{DtrH}$ for these two kings may have been due to their short reigns. It is intriguing that the dynasty of Jehu is not singled out for comment by DTR. On my analysis $2 \mathrm{Kgs}$ 10:30 (promise) and 15:12 (fulfillment notice) are later additions to the history. The omission of a prophecy-fulfillment schema may have been due to the difficulty of constructing a prophecy of condemnation after the prophecy of $2 \mathrm{Kgs} \mathrm{9:6-10,}$ and Jehu's subsequent elimination of Baal worship from Israel. At any rate the 
northern kingdom therefore had to be the same as that of the three dynasties which had been condemned by the prophets. Hence the report of the northern

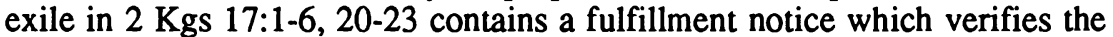
condemnation of "all his servants the prophets", and at the same time extends it to cover the fate of northern Israel itself.

As with the northern kings, the story of the Davidic dynasty after the schism is interpreted according to the criteria introduced in the prophecy of Ahijah in $1 \mathrm{Kgs}$ 11:29-38*. These were that the dynasty's preservation by Yahweh was a reward for David's fidelity and that its principal task henceforth was to ensure the exclusive, centralized worship of Yahweh in Jerusalem. As with the northern kings, DTR employed a series of judgment formulas, and a comment on cultic practice where appropriate, to measure the fidelity of each Davidic king to the policy of exclusive, centralized worship. ${ }^{23}$ The troubled times which Judah experienced for much of its history were attributed, as the structure indicates, to the dynasty's failure to eliminate the threat to the temple's exclusive status posed by the people's continued worship at the high places. ${ }^{24}$

No Davidic king during the period of the divided kingdom is censured for building high places like Jeroboam. ${ }^{25}$ Nevertheless their failure to eliminate worship at them meant that Judah could not enjoy the reward of Yahweh's blessing. They were eventually removed by Hezekiah in $2 \mathrm{Kgs} \mathrm{18:4}$. Significantly, his reign was marked throughout by success (cf. $2 \mathrm{Kgs} \mathrm{18:3-9*).}$ This account of the fortunes of the Davidic dynasty during the period of the divided kingdom served then to validate DTR's position that the exclusive, centralized worship of Yahweh was the only way to ensure divine protection and prosperity for Judah.

DTR demonstrated the validity of the other criterion-preservation of the dynasty as a reward for David's fidelity-by paying particular attention to those Davidic kings who not only, like the others, neglected to remove the high places, but also themselves did what was evil in the eyes of Yahweh. ${ }^{26}$ This was an additional threat to the stability of the Davidic dynasty. Nevertheless the continuation of the dynasty and the kingdom of Judah, despite these kings, was testimony that the reward promised to David by Nathan was still in

judgment formulas were sufficient to include the dynasty within DTR's unified interpretation of the northern kingdom.

${ }^{23}$ The judgment formula is followed by a report of the king's cultic policy. Cf. $1 \mathrm{Kgs}$ 15:3-5* (Abijam), 11-15* (Asa); 22:43 (Jehoshaphat); $2 \mathrm{Kgs} \mathrm{8:18}$ (Jehoram), 27 (Ahaziah); 12:3-4 (RSV 12:2-3) (Jehoash); 14:3-4 (Amaziah); 15:3-4 (Azariah); 15:34-35a (Jotham); 16:2b-4* (Ahaz); 18:3-7* (Hezekiah); 21:2-9* (Manasseh), 20-22* (Amon); 22:2-23:23* (Josiah).

${ }^{24}$ The people (following the hebrew of $B H S$ ) are accused of building high places and worshipping at them in $1 \mathrm{Kgs}$ 14:23. A complaint about the failure of the kings to eliminate this practice is registered against Asa in $1 \mathrm{Kgs}$ 15:14, and continued thereafter for each Davidic king until Hezekiah.

${ }^{25}$ Apart from Solomon, the only one so accused is Manasseh in $2 \mathrm{Kgs}$ 21:3aba.

${ }^{26}$ These kings were Rehoboam (1 Kgs 15:3); Abijam (1 Kgs 15:3); Jehoram (2 Kgs 8:18); Ahaziah (2 Kgs 8:27); Ahaz (2 Kgs 16:2b-4). 
place. This was pointed out by DTR in strategically located comments which were clearly designed to verify the interpretation outlined in Ahijah's prophecy

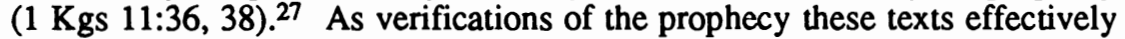
function in the same way as the fulfillment notices.

The story of the Davidic dynasty during the period of the divided kingdom reaches a crisis with king Ahaz ( $2 \mathrm{Kgs} \mathrm{16:1-3a,} \mathrm{4aa).} \mathrm{Not} \mathrm{only} \mathrm{did} \mathrm{he} \mathrm{"not} \mathrm{do}$ what was right in the eyes of the Lord his God" but he himself also "sacrificed and burned incense on the high places". ${ }^{28}$ In addition, he made Judah a vassal of the Assyrians (2 Kgs 16:5-9), who had already begun the deportation of northern Israel (2 Kgs 15:29). This polemical presentation of the reign of Ahaz served an important function within the larger structure of DtrH and the story of the Davidic dynasty. It provided an appropriate contrast for introducing the important reign of Hezekiah. Not only was he completely faithful

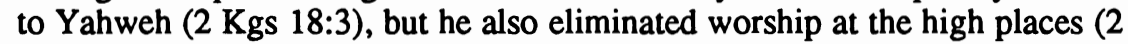
$\mathrm{Kgs} \mathrm{18:4)}$ and rebelled against Assyrian vassalage (2 Kgs 18:7).

As noted beforehand, only Hezekiah and Josiah are compared favorably with the model king David without qualification. This is evident in the judg-

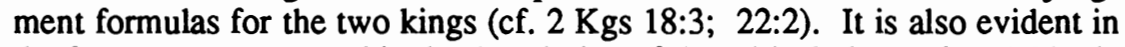
the four-part pattern used in the description of the critical phase of each king's reign. As pointed out in the discussion of David, this pattern was employed by DTR to illustrate the prophet/king form of leadership. These kings recognized the prophets' authority to interpret the course of Israel's history, submitted to their authority, and consulted them at the critical moments of their respective reigns.

In the case of Hezekiah, the recognition of the four-part pattern, in conjunction with the judgment formula in $2 \mathrm{Kgs} \mathrm{18:3}$ and the account of his reforms, shows just how important he was for DTR's overall structure and conceptual plan. This is something which previous studies of DtrH have not appreciated. Hezekiah was the king who, by removing the high places, proved himself the model guardian of the temple's exclusive status as the only legitimate center of Yahweh worship. Also, for his David-like conduct in consulting the prophet Isaiah during the Assyrian crisis, he was rewarded with the retreat of the very invader who had destroyed northern Israel. The reign of Hezekiah thus maintained DTR's unified interpretation of the Davidic dynasty for the period of the divided kingdom, and verified the deuteronomic schema of reward and retribution. Within the larger context of the history it also provided further verification of DTR's understanding of the correct relationship between prophet and king. In relation to the remainder of the history, the period of

${ }^{27}$ For Rehoboam, the first ruler of Judah, the appropriate comment occurs in

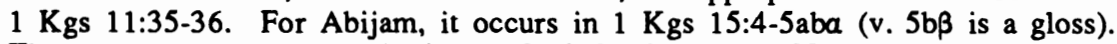
The next comment occurs in $2 \mathrm{Kgs} 8: 19$ for Jehoram. No additional comment was required for Ahaziah and Ahaz who, like Jehoram, walked in the way of the kings of Israel. Ahaz's additional sin of worshipping at the high places provided the immediate prelude to Hezekiah's reform (see below).

${ }^{28} \mathrm{Ahaz}$ is the only Davidic king accused of worshipping at the high places between Solomon (1 Kgs 11:8) and Manasseh (2 Kgs 21:3). 
Judah alone, it provided an appropriate prelude to the account of the reign of Josiah.

The history of the monarchy to this point had clearly shown that the kings' fidelity to Yahweh in terms of DTR's three criteria was the only way to secure divine blessings and a prosperous life in the land. Hezekiah had demonstrated the sort of fidelity required. Nevertheless the reign of Manasseh showed that the kingdom was not yet secure from apostasy and the threat of the high places. Moreover, within the larger sweep of the history the sequence of kings from Ahaz to Hezekiah to Manasseh (and his son Amon) warned that the Davidic dynasty was in danger of sliding into a dangerous cycle somewhat akin to that of the judges' period. That is, a period of apostasy under Ahaz was followed by reform under Hezekiah, which was undone by a return to apostasy under Manasseh and Amon. For DTR it was the providential discovery of the book of the law, coupled with Josiah's fidelity to the three criteria, which would enable Judah to break out of such a cycle.

In order to integrate this understanding of the reign of Josiah into the overall conceptual plan of the history DTR employed the same technique as observed earlier, namely, continuity within a larger trajectory of change and development. Thus there is continuity in the portrayal of the evil kings Ahaz and Manasseh. There is also continuity in the portayal of Hezekiah and Josiah. This is particularly evident in the judgment formulas for these two kings and the way the four-part pattern was used by DTR to construct the account of Josiah. Josiah was therefore a model king like David and Hezekiah.

At the same time however DTR was careful to portray the last portion of the history as a transition to a new era under Josiah. First of all Manasseh was cast as an even more dangerous advocate of cultic abuses than Ahaz (cf. 2 Kgs 21:1-2a, 3aba, 5, 7 with $2 \mathrm{Kgs} 16: 2-3 \mathrm{a}, 4 \mathrm{aa}$ ). This set the scene for the definitive elimination of these abuses by Josiah and the inauguration of a new era of undefiled centralized worship. Events in the account of Josiah which heralded the new era were the discovery of the book, and the actions which this discovery and the accompanying consultation of the prophetess Huldah set in motion. These were; the commitment to the book in the covenant ceremony in the temple ( $\left.2 \mathrm{Kgs} 23: 1-3^{*}\right)$, the reform (23:4-12*), and the celebration of Passover (23:21-23). Moreover, in terms of the overall structure and plan of the history, the discovery of the book of the law, and its proclamation in the temple as a book of the covenant, recalled the occasion of Moses' original proclamation. The time of Josiah was portrayed by DTR as analogous to that of Moses and the conquest generation, a maneuver no doubt designed to enhance the sense of being on the threshold of a new era.

One can see from this presentation that DTR advanced a comprehensive and unified interpretation of the period of Israel under the prophets and kings. The interpretation was verified by the judicious use of the prophecy-fulfillment schema. Where the context precluded the direct use of a formulaic fulfillment notice, DTR employed some other appropriate reference to the relevant prophecy to call the reader's attention to its verfication (cf. $1 \mathrm{Kgs} 15: 4 ; 2 \mathrm{Kgs}$ $8: 19)$. With Josiah of course, the whole thrust of the presentation of his reign indicates that DTR saw the successful implementation of the reform as an initial realization of Huldah's prophecy. 
The description of the conceptual plan of DtrH also enables one to gain a clear idea of DTR's purpose in composing such a history. Simply put, DTR wanted to promote the deuteronomic reform being implemented by king Josiah. In order to provide a reasoned justification for this promotion DTR compiled a history of Israel's life in the land which verified the deuteronomic program. Because DTR supported the royal policy, the success of DtrH depended very much on how well the account of the monarchy, particularly that of the Davidic dynasty, was incorporated into the overall interpretation of Israel's history. Hence DtrH was also a legitimation of the monarchy, and in particular of the Davidic dynasty. One can see from this why DtrH is essentially a story of Israel's leaders. DTR was able to enhance the promotion of the reform under Josiah by showing how the ideal of the deuteronomic program had in fact been realized during the reign of Solomon. It had been Yahweh's reward for the fidelity of David, the founder of the dynasty. Judah could begin to recapture this ideal by a wholehearted commitment to the reform. 
Part Two

Justification of the Reassessment 



\section{THE PERIOD OF ISRAEL UNDER MOSES AND JOSHUA Deut 1:1-Judg 2:10}

The task of this part of the study is to provide the necessary arguments to validate the hypothesis outlined in the preceding chapter. Before proceeding to the task however some comment is in order about the criteria employed for the determination of dtr redaction. The principal criterion is of course the presence of a text which unmistakably exhibits the characteristics of dtr language and thought. In employing this criterion one can make judicious use of the studies of dtr language and thought that have been carried out over the years. ${ }^{1}$ There are however some texts which do not clearly exhibit dtr language but which nevertheless form an integral part of larger passages which are unmistakaby dtr compositions. These can with good reason also be identified as dtr. In addition to these two criteria one must consider the possibility that a phrase or a passage which does not exhibit dtr language, and which is not embedded in a dtr text, may nevertheless be dtr. This can be the case if the theology of the phrase or passage is similar to dtr theology and the particular context does not lend itself to the use of characteristic dtr language. ${ }^{2}$ It hardly needs to be said that this criterion should be employed with due caution.

The above criteria are concerned with the determination of dtr redaction as such. However an important concern of this study is to distinguish as accurately as possible between the work of DTR and later dtr redaction. This will be done by employing the following criteria. First of all, dtr phrases and passages may be identified as secondary where they can be shown on literary critical grounds to be additions to DTR's passages. Secondly, dtr texts may be identified as secondary which exhibit a significantly different vocabulary and theology to DTR. At times this may of course be difficult, particularly where the textual evidence is limited. In such cases one should be cautious about assigning texts too hastily to a multiplicity of later redactors. Thirdly, it needs to be remembered that an accurate appreciation of the nature and extent of secondary redaction can only be gained when it has been weighed against a thorough analysis of the work of DTR. It should then be possible to show how the later redaction stands in relation to the conceptual plan and structure of the history. These three criteria will also be employed to check the complexity and interrelationship of later dtr redaction of $\mathrm{DtrH}$.

A significant amount of the later redaction of DtrH will be described in the course of the analysis as nomistic, because of its focus on obedience to the law,

${ }^{1}$ Two important contributions in this area are Moshe Weinfeld, Deuteronomy and the Deuteronomic School (Oxford: Clarendon Press, 1972) 320-65; and H. D. Hoffmann, Reform und Reformen, 327-66.

${ }^{2}$ For a similar set of criteria see A. F. Campbell, Of Prophets and Kings, 5. 
in particular the people's obedience to the law. While the term is borrowed from the Smend school, it needs to be stated at the outset that it is not to be identified with the school's nomistic redactor (DtrN). As will become clear throughout the analysis the texts which are assigned to the nomistic redaction differ at a number of points from the Smend school's DtrN. In addition I would see the nomistic redaction as an important stage in the development of a deuteronomic school of thought rather than the work of a single redactor, as seems to be the case with the Smend school. ${ }^{3}$ Although obedience to the law was a principal concern of the redaction, and one which is reflected in its use of nomistic language, it had a considerably broader theological perspective. As well as this a number of the larger passages from this stage of redaction show the sort of compositional skills that are consonant with the work of sophisticated authors. This will be demonstrated in the analysis of Joshua $23 ; 1$ Samuel 12; 2 Kgs 17:7-19.

An additional point to note is that there is no need to examine every text in the same detail. Legitimate use can be made of the results of previous scholarship, particularly where there is a general consensus. For example, there is a general consensus that Joshua 23 is a dtr composition, even though there is debate about whether it came from DTR or a subsequent Dtr. In addition, not all texts are equally significant for the conceptual plan and structure of the history. The reassessment will therefore focus on those areas of the history which are critical for the hypothesis proposed, as well as those areas where there is significant dispute over the interpretation of a particular text.

The course of the reassessment will follow the structural outline of the three periods of Israel's history. This chapter is therefore concerned with relevant texts in the first period, that of Israel under Moses and Joshua.

\section{THE BOOK OF DEUTERONOMY}

Within the book of Deuteronomy the text of DtrH needs to be validated in a number of areas. Siegfried Mittmann has argued in a recent literary critical and traditio-historical study that Deuteronomy 1-3 does not contain DTR's introduction to the history as Noth proposed. ${ }^{4}$ This is a serious challenge to the hypothesis of a DtrH and must be examined. Second, there is the question of the inclusion of the deuteronomic code in DtrH. The position that the code is an integral part of the history has been generally accepted since Noth. Some recent studies have proposed however that it was inserted at a later time. ${ }^{5}$ This

${ }^{3}$ I would note however that in his more recent study (Entstehung, 123) Smend refers to DtrN as a redactional layer.

${ }^{4}$ Siegfried Mittmann, Deuteronomium 1:1-6:3 literarkritisch und traditionsgeschichtlich untersucht (BZAW 139; Bcrlin: W. de Gruyter, 1975). B. Peckham (The Composition of the Deuteronomistic History, 7-9 and Fig 2) eliminates Deut 1:1b-3:29 from his Dtr1 history, assigning it to the author of his Dtr 2 history (ibid., Fig 5). However he offers no detailed analysis of the text.

${ }^{5}$ From the Cross school there is J. Levenson, "Who Inserted the Book of the Torah?". The proposal is also made by Richard Clifford, Deuteronomy (Old Testament Message; Wilmington: M. Glazier, 1982) 1-3; Preuss, Deuteronomium, 22, 84. Cf. also G. von Rad, Deuteronomy, 45. 
proposed revision must also be tested. Third, there is the question of later dtr additions to Deuteronomy. Noth himself recognized some subsequent additions had been made. ${ }^{6}$ However the analysis given here differs from his at several points, and these differences need to be justified.

\section{DEUTERONOMY 1-3}

Mittmann proposes a quite complex picture of the growth of these chapters. The earliest stage was a pre-dtr "primary layer" which functioned as an introduction to the original deuteronomic law. The text identified by Mittmann maintains the plural form of address throughout, except for the decalogue in Deut 5:6-21. ${ }^{7}$ The primary layer was subsequently expanded by an address in the plural form (PL1) designed to incorporate the deuteronomic law into the Pentateuch, as well as to forge a link with the account of the conquest in Joshua. A second expansion in the plural form (PL2) then sought to strengthen the links with the Pentateuch and Joshua. Mittmann finds evidence that by the time of this second redaction the extended corpus of Deuteronomy-2 Kings was in existence. Mittmann also detects an additional major redactional layer which employed the singular form of address $(\mathrm{Sg})$, but which was preceded and followed by smaller contributions. Finally, there are a number of expansions which are difficult to classify.

Although there can be no doubting the industry and detail of Mittmann's study, his literary critical arguments in support of the primary layer create more problems than they solve. He aims to recover a text in Deut 1:1-6:3 which is free of the literary tensions created by later additions. But the text recovered in fact creates a new tension by having Deut 5:1a immediately follow Deut 2:1-3, $8 \mathrm{~b}$. There is no evident connection between the divine command in Deut 2:1-3 to leave Mt. Seir and journey in the direction of the wilderness of Moab (cf. Deut 2:8b), and Moses' sudden summons to the people in Deut 5:1a to listen to his discourse on the law. ${ }^{8}$ Mittmann justifies the proposed textual sequence by claiming that the primary layer in Deuteronomy 5 records the renewal of the Horeb covenant which had been breached by Israel in the spy episode of Deut

${ }^{6}$ Noth identified portions of Deuteronomy 4 and the bulk of 31-34 as later additions. In Deuteronomy 4 the later verses are Deut $4: 3-4,9,15-21,24 \mathrm{~b}, 29$ 43. In 31-34 the later additions are to be found in Deut $31: 3-6,9 a \beta, 11 a a, 14-$ 23, 26b-30; 32:1-33:29; 34:1 aab $\beta-3,7-9$ (for Deuteronomy 31-33 see The Deuteronomistic History, 33-35; for Deuteronomy 34 see Überlieferungsgeschichtliche Studien: Die sammelnden und bearbeitenden Geschichtswerke im Alten Testament [Darmstadt: Wissenschaftliche Buchgesellschaft, 1963] 21213).

${ }^{7}$ Thus, Deut 1:ab*, 2a , 6, 7*, 19aa*, 20, 22aba, 23-24a, 25-27, 34-35aab, $39 *, 40-45 ; 2: 1-3,8 b ; 5: 1 a a^{*}, 2,4,5 *, 6-12 a, 13-15 a a, 16 a a b *, 17-21$, $23 \mathrm{ba}, 24 \mathrm{a} * 25 \mathrm{~b}-28,30-31$. This text and those of the subsequent redactions are given in Mittmann, Deuteronomium 1:1-6:3, 180-84.

${ }^{8}$ Mittmann has also been criticized on this point by Lothar Perlitt, "Deuteronomium 1-3 im Streit der Exegetischen Mcthoden," Das Deuteronomium: Entstehung, Gestalt und Botschaft (BETL 68; ed. N. Lohfink; Leuven: University Press, 1985) 149-63. See pp. 154-55. See also H. D. Preuss, Deuteronomium, 78-79. 
1:19-39*. The renewal is proclaimed by Moses in the wilderness of Moab (cf. Deut $2: 8 \mathrm{~b}$ ) before the people cross the Jordan to possess the land (Deut 5:30$31)^{9}$

However Mittmann's primary layer in Deuteronomy 5 makes no reference to Israel's rebellion in the spy episode. ${ }^{10}$ Furthermore, his text of the spy episode includes the promise that the rebellious generation would not enter the land (cf. Deut 1:34-35aab). It is difficult to accept that this same generation is the addressee in Deut 5:1ff and the recipient of the promise of possession of the land in Deut 5:31. The difficulty would be eased by the inclusion of the report of the death of the Exodus generation (Deut 2:14-16), a passage which Mittmann assigns to later redaction. But once this inclusion is made it becomes difficult to exclude Deut 2:13b,17,24aa, which supplies the necessary context for the report. This in turn would make it difficult to exclude a basic account of the successful conquest of Transjordan by the next generation, to whom the promise of conquest of the land had been transferred (cf. Deut 1:39*).

There are therefore some serious problems with Mittmann's analysis. Nevertheless he does raise the question of the literary unity of Deuteronomy 13 , and its identification as the introduction to DtrH. If the introduction is to be found in these chapters it is important that the text be accurately identified. A re-examination of the nature and extent of the basic textual sequence in these chapters is therefore in order. In the light of Mittmann's analysis the crucial question in Deuteronomy 1-3 is the literary relationship between the wilderness journey and conquest sections of the text.

In Deuteronomy 1 the primary layer of text can be identified in Deut 1:1a, $4,6-8,19-20,22-33,34-35,39$ (omit "Moreover your little ones, who you said would become a prey"), 40-45. Deut $1: 1 \mathrm{~b}-3,5$ is an addition which sought to add precision to a number of elements which are treated in a more general fashion in the basic text. These are the geographical location of Moses' address (Deut 1:1b-2; cf. v la with its general reference to "beyond the Jordan") and the date of Moses' address (Deut 1:3; cf. $v 4$ which simply places the address after the defeat of Sihon and $\mathrm{Og}$ ). Deut 1:5 is a reformulation of $v 1$ to make the opening chapters part of Moses' discourse on the law. ${ }^{11}$

${ }^{9}$ Mittmann, Deuteronomium 1:1-6:3, 168-69.

${ }^{10} \mathrm{~N}$. Lohfink ("Darstellungskunst und Theologie in Dt 1,6-3,29," Bib 42 [1960] 105-34) argued on the basis of language, style and structure that the spy story of Deut 1:19-46 forms an integral part of Deuteronomy 1-3 (cf. pp. 11416, 127-31). Mittmann criticizes Lohfink in his introduction for failing to take adequate account of the literary critical evidence in the text. However my own literary critical reassessment of the text leads to a confirmation of Lohfink's position, even though there are some small differences in the distribution of verses.

${ }^{11}$ Cf. von Rad, Deuteronomy, 36-37. Preuss (Deuteronomium, 46) assigns Deut 1:1a, 6-8 to DTR, with Deut $1: 1 \mathrm{~b}, 2,3-4,5$ as later additions. Mittmann's text is Deut 1:ab*, 2a, 6, 7a (to 'Amorites') (Deuteronomium 1:1-6:3, 8-24, 180). The differences in vv 1-2 are not critical for the textual sequence. His omission of the remainder of $\mathbf{v} 7$ is possible, since only the Amorites are referred to in $v v 19,44$. His omission of $v 8$ however depends on his sep- 
Deut 1:9-18 anticipates the later legislative role of Moses in Deuteronomy. It also interrupts the account of the journey from Horeb to the hill country of the Amorites, and is therefore best taken as a later addition. ${ }^{12}$ Deut 1:21 is formulated in the second person singular and is also in effect a doublet of Deut $1: 8$. The use of the alternation between singular and plural form of address in Deuteronomy as a literary critical criterion is a debated issue. ${ }^{13}$ Although it must be taken into account in the identification of texts the unresolved nature of the debate cautions one against using it without supportive evidence. Such evidence is supplied in this case by the recognition that all the verses in Deuteronomy 1-3 which are essential for the basic sequence of Moses' address are formulated in the second person plural. Hence Deut 1:21 may, with some certainty, be identified as a later addition. ${ }^{14}$

In agreement with Mittmann Deut 1:36-39aa is later material. ${ }^{15}$ The promise to Caleb in Deut 1:36 prepares for the special allotment of land given to him in Josh 14:6-15. This passage is part of the distribution of land in Joshua 13-21, which will be shown in due course to be a later addition to DtrH. Deut 1:37-38 anticipates Yahweh's command to Moses in Deut 3:23-28. Along with Deut 1:36, these verses also break into the sequence between 1:35

aration of the wilderness journey from the conquest. The analysis of the relevant texts in Deuteronomy 2 will show that this is not justified.

${ }^{12}$ So Lohfink, "Darstellungskunst und Theologie," 123, n. 1. Against Preuss, Deuteronomium 80. Mittmann proposes a complex distribution of this passage among later redactions (cf. table in Deuteronomium 1:1-6:3, 183-84).

${ }^{13} \mathrm{Cf}$. Christopher T. Begg's review of the literature in "The Significance of the Numeruswechsel in Deuteronomy. The 'Pre-history' of the Question," ETL 55 (1979) 116-24. G. Minette de Tillesse ("Sections 'tu' et sections 'vous' dans le Deutéronome," VT 12 [1962] 29-87) argued that the plural form of address was later than the singular, and was a dtr characteristic. Henri Cazelles followed his lead and used the distinction to assign most of the verses in Deuteronomy 1-3 with the singular form of address to an earlier "introduction to the Decalogue and to the rest of the first edition of Deuteronomy" ("Passages in the Singular within Discourses in the Plural of Dt 1-4," $C B Q 29$ [1967] 207-19. See especially pp. 208-13, 217-18). It is difficult to accept the text recovered by Cazelles as a continuous and unified address. Furthermore, debate since Minette de Tillesse indicates that he has not resolved the question of the provenance of these two types of formulation. The use of the "Numeruswechsel" as a literary critical criterion needs to be carried out with due caution therefore, and each occurrence cross checked against additional criteria where possible. On this see A. D. H. Mayes, Deuteronomy (NCB; Grand Rapids: Eerdmans, 1981) 35-36. See also the discussion by Begg. "The Literary Criticism of Deut 4,1-40. Contributions to a Continuing Discussion," ETL 66 (1980) 10-55; especially pp. 12-23.

${ }^{14}$ Also Mittmann, Deuteronomium $1: 1-6: 3,35$. Other texts in the singular form in Deuteronomy $1-3$ are 2:7, 9, 18-19, 24aßb-25, 30b-31, 37; 3:2. An inspection of these will show that they are not essential for the sequence of Moses' address.

${ }^{15}$ Mittmann (Deuteronomium 1:-6:3, 39). His text from $v 20$ to $v 35$ omits some material which is not critical for the textual sequence (vv 22b $3,24 \mathrm{~b}, 28$ $33,35 \mathrm{a} \beta$ ). His reasons for these omissions are questionable. For example, there is no contradiction between $v 25$ and $v 28$ (p. 36). The first text deals with the land and its fruit, the second with the inhabitants. 
and 1:39 (omitting the phrase "Moreover your little ones, who you said would become a prey" which has no reference point in the preceding verses). This sequence is concerned with contrasting Yahweh's condemnation of the rebellious Exodus generation (Deut 1:35) with his promise to the emerging generation (Deut 1:39*). ${ }^{16}$ Finally, Deut 1:46 is unusual after the command of v 40 and appears to be a later attempt to harmonize Deuteronomy with Num $20: 1,14-20 .^{17}$

In Deuteronomy 2 the basic text is to be found in 2:1-6, 8, 13b, 14-16, 17, 24aa, 26-28, 29*, 30a, 32-36. Deut 2:1 reports the execution of the command given in 1:40. The next command to journey comes in 2:2-3 with the accompanying report of its execution in $2: 8,13 \mathrm{~b}$. This suggests initially that the instruction which comes between, in vv 4-7, may be an addition. ${ }^{18}$ However vv 4-6 are formulated in the second person plural, in accord with the text idendified so far. Moreover they serve to emphasize Yahweh's authority over other nations and lands, something that had been been doubted by Israel (cf. Deut 1:32). They may be included therefore in the basic textual sequence. Deut 2:7 however is in the singular form of address. It also adopts a perspective of the end of the wilderness wandering with its reference to 40 years, whereas the journey is still under way in Deut 2:1-6, 8, 13b. It is most likely then a later appendage to the instruction regarding the sons of Esau.

Mittmann's primary layer includes Deut 2:8b but nothing more in Deuteronomy 2. His omission of the remainder of the chapter is due I believe to a failure to recognize a basic pattern operating in the wilderness journey section of the text. The components of this pattern, of which there are three occurrences, are a command followed by a report of its execution. The divine command in each occurrence is always to "turn" and "journey" in a certain direction (cf. Deut 1:7, 40; 2:3 [turn only]). Each command is then followed by a report of Israel journeying in the designated direction-with derek in each case-and arriving at a point (cf. Deut 1:19 [for 1:7]; 2:1 [for 1:40], 8b, 13b [for 2:3]). Deut 2:13b therefore completes the report of the execution of the command in 2:3.

Mittmann also fails to observe that Deut 2:24aa-with its introduction in $\mathbf{v}$ 17 -contains the same command to "journey" (sse $\hat{e} \hat{u})$ as in the first component of the pattern (cf. Deut 1:7 and 1:40). However the second component of the pattern, the report of the journey, is replaced by the report of victory over Sihon in Deut 2:26ff. Deut 2:24aa therefore maintains continuity with the preceding commands - the verb to journey - but within a context of transition to the

${ }^{16}$ The contrast between Deut 1:39* and the preceding $v 35$ is best captured by translating ûbēnêkem as "but your children . . .".

${ }^{17} \mathrm{Cf}$. Mayes, Deuteronomy, 133.

${ }^{18}$ So Mittmann, Deuteronomium 1:1-6:3, 64-66. However there is a similar textual distance between the command in Deut $1: 40$ and its execution in $2: 1-3$. I would agree with Mittmann that me'et in the MT of Deut 2:8a is to be corrected to 'et, as in the LXX. Cf. also Mayes, Deuteronomy, 136. 
theme of conquest. ${ }^{19}$ A literary critical separation of the wilderness journey and conquest themes is therefore not justified.

Once the link between Deut 2:1-6, 8,13b and 2:17, 24aa is recognized it is clear that the report of the demise of the Exodus generation in 2:14-16 must also be included. In terms of the basic textual sequence it reports the fulfillment of the first part of Yahweh's promise in 1:35, 39*. After this has occurred the fulfillment of the second part of the promise can be reported, namely the conquest of the land by the children who, in the 38 years since leaving Kadesh-barnea, have emerged as the new generation of Israel.20 Within the more immediate context the introductory wayeh $+k^{2}$ 'asser in Deut 2:16 appears to be formulated with vv 17,24aa in mind. ${ }^{21}$

One can now see that Deut 2:13a disrupts the pattern of the wilderness journey suction by giving a command before Israel has arrived at the next stage of the journey. It also contains the commands "rise up" and "cross over" found in 2:24aa rather than, as one would expect, the command to journey found in the pattern. This indicates that Deut 2:13a-with its introduction in $v 9 \mathrm{aa}$-is a later addition and was modelled on 2:24aa. The effect of the addition was to create another stage in the wildemess journey, and to a certain extent to blur the distinction in the basic text between the end of the wilderness journey and the commencement of the conquest. This effect was carried a step further by the

${ }^{19}$ The sense of continuity and transition is also suggested by the verb "to cross over". Israel's crossing over the brook Zered in Deut 2:13b completes the report of the execution of the command in $2: 3$. The same verb occurs in Deut 2:24aa but now in the context of the conquest. The command to "rise up" suggests a new stage in Israel's joumey to the land after the death of the Exodus generation (see below on the inclusion of Deut 2:14-16).

${ }^{20}$ Mittmann distributes Deut 2:14-16 among a variety of later redactions (Deuteronomium 1:1-6:3, 68-79). He claims the chronological notice in $v 14 a$ follows P (cf. Exod 16:1; 19:1; 40:17; Num 1:1; 9:1; 10:11) in allowing 2 years from the Exodus to the end of Sinai and 38 years for the wilderness journey from Sinai, thus giving 40 years from Exodus to journey's end (Deut 1:3). But Deut 2:14a estimates 38 years from Kadesh-barnea, not Sinai (Horeb). Also, in Num 14:33 P reckons 40 years for the period of Israel's punishment, not 38 as in Deut 2:14a. The author of $v 14 \mathrm{a}$ presumably allowed 2 years from Exodus to Kadesh-barnea. $P$ and the author of $v 14 a$ share the round figure 40 , but arrive at it in different ways. Mittmann notes that Deut 2:14b and 16 refer to "the men of war" whereas 1:35 has simply "these men". However, he overlooks $1: 41$ in his primary layer, which clearly portrays these men as men of war (cf. milhama). Finally, there is no compelling reason to assign Deut 2:15 to another hand. The function of Deut 2:14-16 in Deuteronomy 1-3 has been explored by W. L. Moran in relation to the theme of the holy war ("The End of the Unholy War and the Anti-Exodus," Bib 44 (1963) 333-42.

${ }^{21}$ Mittmann himself accepts that Deut $2: 16,17,24 \mathrm{aa}$ belong together, although he assigns them to PL1 (Deuteronomium 1:1-6:3,69, 183). He omits Deut 2:24a a from the primary layer because it does not contain lakem as in Deut 1:7; 2:3, 13 (pp. 71-72). Two observations argue against Mittmann here. First, lakem is associated with the verb to journey in 1:7 but with the verb to turn in 1:40 and $2: 3$. Secondly, it occurs in association with the verb to cross over in 2:13a which Mittmann himself assigns to a different hand. 
addition of Deut 2:9aßyb, an instruction not to molest Moab, and 2:18-19, an instruction not to molest the sons of Ammon. These instructions are formulated in the second person singular and unlike Deut 2:4-6, deal only with the question of conflict. The outcome of the additions was the creation of two additional stages in the journey, each with its set of instructions about avoiding conflict with foreign nations. ${ }^{22}$ In conjunction with these considerations it is significant that Deut 2:9aßyb and 2:18-19 are formulated in the second person singular, in contrast to the plural in 2:13a.

Given the identification of the basic text in Deut 2:1-6, 8, 13b, 14-17, 24aa, one can trace its continuation through the remainder of Deuteronomy 2 in vv 26-28, 29*, 30a, 32-36. These verses report the negotiations with Sihon followed by the subsequent battle and victory. Deut 2:24aß-25 stands in some conflict with the negotiations and the subsequent aggressive response of Sihon in vv $30 \mathrm{a}, 32$. Also, in contrast to $\mathrm{v} 24 \mathrm{aa}$ it is formulated in the second person singular. Hence it is most likely a later addition. ${ }^{23}$ Deut 2:31 for its part is also formulated in the second person singular, and recalls $v 24 \mathrm{a} \beta$. It may therefore be assigned to the same stage of later redaction. The evidence for Deut $2: 30 \mathrm{~b}$ is not so clear, but it does share the second person singular form of the above texts. Deut 2:37 may be omitted as later redaction because it too contains the second person singular form of address, and appends a prohibition against invading the territory of the Ammonites. In terms of form and content then, it is similar to Deut $2: 9 \mathrm{a} \beta \gamma \mathrm{b}$ and $2: 18-19 .{ }^{24}$

In Deuteronomy 3 the basic text is to be found in $3: 1,3-8,10,12,13 \mathrm{a}, 18$ 20,23-28. As with the wilderness journey and conquest sections of the text Mittmann argues for a literary critical separation of the conquest of $\mathrm{Og}$ from the conquest of Sihon. ${ }^{25}$ Once again however he fails to balance literary critical considerations against contextual considerations. Thus the absence of a command in Deut 3:1 is due to the fact that the author intended to present the victory over Og as an integral part of the one conquest of Transjordan. ${ }^{26}$ This is brought out by the use of gam (also) in Deut 3:3, by the mention of Sihon in $v 6$, and the inclusive summary in $v 8$. The concern to link the victory over Og with that over Sihon also explains the different formulation of Deut 3:3 in

${ }^{22}$ Deut 2:10-12 and 2:20-23, along with $3: 9,11,13 \mathrm{~b}-14$, are generally accepted as late parenthetical additions.

${ }^{23}$ Against Mittmann (Deuteronomium 1:1-6:3) this argument cannot be used to exclude Deut 2:26-28. The first and second person singular here is appropriate to the negotiations between Moses and Sihon. In v 29 the reference to the Moabites appears to have been inserted. Whereas the description of what the sons of Esau did finds a reference point in 2:4-6 none exists for the Moabites in 2:9aß $\gamma \mathrm{b}$.

${ }^{24}$ In agreement with Mayes, Deuteronomy, 140-42.

${ }^{25}$ Mittmann, Deuteronomium 1:1-6:3, 82-85, 88-91, 183. The text given is Deut 3:1, 3-4ab* (to 9r), 5-8, 10a (omitting "and Edrei"). This is assigned to the PL2 redaction, whereas the conquest of Sihon $(2: 30 \mathrm{a}, 32-35)$ is assigned to the $P L 1$ redaction.

${ }^{26}$ Israel had to make the journey from one kingdom to another of course. Hence the report in Deut 3:1. Note there is no mention of wilderness here (cf. Deut 1:19, 40; 2:1, 8b). 
relation to Deut 2:33. ${ }^{27}$ The same concern was responsible for the relocation of the references to the ban in the Og account (Deut 3:3b,6). The two principal elements of the ban in Deut 2:34-destruction of the cities with their men, women and children ( $v$ 34a), and the elimination of any survivors ( $v 34 b)$-are here arranged in reverse order as a frame around the details of the conquest (vv 45). ${ }^{28}$

To this account of the conquest of Sihon and Og one may reasonably add the report of the distribution of land in Deut 3:12-13a. ${ }^{29}$ The unified nature of the account of the conquest of Sihon and $\mathrm{Og}$ is enhanced by the way this text reports the distribution of the territory of both kings. Deut 3:9 and 11 are parenthetical additions like 2:10-12, 20-23. Deut 3:13b-14 is another parenthetical comment. Deut 3:15-17 is a somewhat different version of the distribution of the land, brought in probably because of Machir, who is not mentioned in the version in Deut 3:12-13a. It also provides some additional territorial information.

Now that the conquest and distribution of land in Transjordan has been established as an integral part of the basic text one can see that it must also include material in Deuteronomy 3:18-28, which looks forward to the conquest of Cisjordan. This is the principal component of the theme of conquest of the land, and without some reference to it Moses' address would be incomplete. ${ }^{30}$ The verses to be included are Deut 3:18-20, 23-28. Deut 3:21-22 is judged to be an addition because it anticipates the execution of God's instruction to Moses in v 28 to "charge" Joshua (cf. the verb șâvâ in 3:21 and 28). In this sense it is similar to Deut 1:38 which also anticipates $3: 28$, and may well have been added by the same hand. Deut 3:29 is also a later verse because, together

${ }^{27}$ That is, the phrase gam 'et ‘̂g melek Habbð̌săn in Deut 3:3 was formulated to emphasize that the fate of $\mathrm{Og}$ paralleled that of Sihon. The difference between lēpãnênû (Deut 2:33) and bēyãdēnû (Deut 3:3) may be a stylistic variation. It is doubtful that it betrays different authorship.

${ }^{28}$ Mittmann also argues for their separation on the basis of Numbers 21 (Deuteronomium 1:1-6:3, 86-90). He claims Deut 2:30a, 32-33 was based on Num 21:21-32, whereas Num 21:33-35 is an independent composition based on Deut 3:1-10a*. Num 21:21-32 and 33-35 may indeed be from different hands but it does not mean the accounts in Deuteronomy were. It is quite probable the stories about Sihon and $\mathrm{Og}$ were originally independent in Israelite tradition (cf. Judg 11:19-23), but there is strong evidence that their combination occurred first in dtr circles; cf. Deut 1:4; 3:1-11*; 4:46-47; 29:6 (RSV 29:7); 31:4; Josh $2: 10 ; 9: 10 ; 12: 2-4 ; 1 \mathrm{Kgs} 4: 19 \mathrm{ba}$. On this see Noth, The Deuteronomistic History, 31. The other occurrences can be dated as later; Num 21:33-35 (following Mittmann); Josh 13:10-12, 21, 30-31; Ps 135:11; 136:19-20; Neh 9:22.

${ }^{29} \mathrm{Mittmann}$ includes these verses-minus the reference to $\mathrm{Og}$ in $v 13 \mathrm{a}$-in the PL2 redaction, which for him supplied the account of the conquest of $\mathrm{Og}$ (Deuteronomium 1:1-6:3, 82-86, 183).

${ }^{30}$ Mittmann (ibid., p. 183) recognizes this and assigns Deut 3:23-29 as the continuation of the PL1 layer in Deut 2:24aa, 30a, 32-35, and Deut 3:18-22 as the continuation of the PL2 layer in Deut 3:1, 3-4ab*, 5-8, 10a*,12,13a*. 
with Deut 4:46, it forms a frame around Deut 4:1-40 and serves to locate Moses' speech at Beth-peor. ${ }^{31}$

The reassessment of Deuteronomy 1-3 has established therefore that Mittmann's literary critical separation of the wilderness journey section of the text from the conquest section is unjustified. The basic textual sequence identified in the analysis includes both components-Deut 1:1a, 4, 6-8, 19-20, $22-33,34-35,39 *, 40-45$; 2:1-6, 8, 13b, 14-16, 17, 24aa, 26-28, 29*, 30a, $32-36 ; 3: 1,3-8,10,12,13 a, 18-20,23-28$. The transition from the exodus generation to the conquest generation, the account of the conquest of Transjordan, the preparations for the commissioning of Joshua to replace Moses as leader, and the promise of the conquest of Cisjordan, all point to the text identifed as the introduction to a more extensive account of Israel's conquest of the land and settlement there. Although a number of additions were identified in the course of the reassessment Noth's proposal that the introduction to DtrH is to be found in Deuteronomy 1-3 remains firmly in possession.

The provenance of the later additions is difficult to identify clearly. At first sight this may appear unsatisfactory. Nevertheless it is to be expected that an important text such as DTR's introduction to the history would attract attention from a variety of later scribes. Despite this difficulty three main types of later redaction can be discerned: those which supply more precise information about aspects of the existing text (cf. Deut 1:1b-3, 5; 2:10-12, 20-23; 3:9, 11, 13b14); those which emphasize Yahweh's sovereignty over the nations, either in terms of conquest (cf. Deut 2:24aßb-25, 30b-31; 3:2, [15-17]), or in terms of their allottment of land (cf. Deut 2:9aß $\gamma \mathrm{b}, 18-19,37$ ); those which are concerned to strengthen contextual links, either within Deuteronomy 1-3 (cf. Deut 1:37-38; 3:21-22), or with the larger context of Deuteronomy, the Pentateuch and the historical books (cf. Deut 1:9-18, 36; 2:7). ${ }^{32}$

\section{THE DEUTERONOMIC CODE AND DTRH}

The other issues in Deuteronomy which need to be discussed are, the relationship of the deuteronomic code to the history, and the identification of later redaction. The two issues are closely related because, if the code was not part of DtrH then it was presumably inserted by a later redactor. On the first issue I have, in agreement with Noth, included the code in the text of DtrH. ${ }^{33}$ This is in conflict with some recent studies which propose that the code was inserted by a later redactor. ${ }^{34}$

${ }^{31}$ The place name occurs in both verses, and was probably chosen in view of the reference to Baal-peor in Deut 4:3. The secondary nature of Deut 4:1-49 wil be commented on below.

${ }^{32}$ The classification of the principal areas of concern of later redaction does not however imply three different redactors. The redaction identified in Deut $2: 9 a a, 13 a$ cannot be easily included in the classification. It may well have been one of the earliest modifications of DTR's text.

${ }^{33}$ Noth identified Deut $4: 44-30: 20$ as the extent of the deuteronomic code (The Deuteronomic History, 16). The text proposed here is Deut 5:1-28:46.

${ }^{34} \mathrm{Cf}$. the studies by Levenson, Clifford, Preuss, and von Rad cited in n. 5. 
Before examining the arguments for omitting the code from DtrH it needs to be stated that the inclusion or omission of the code does not substantially alter the proposed conceptual plan and structure of the history. It is not essential to have the code in the text of DtrH in order to demonstrate that DTR clearly had it in mind, and that a key concern was to interpret Israel's history in relation to it. This is evident from DTR's language and theology. Nevertheless, the case for the inclusion of the code in DtrH is definitely more convincing than the case for its omission.

The main argument in favor of omitting the code from DtrH is the literary critical observation that Deut 3:23-28 finds its natural continuation in the account of the installation of Joshua as leader in Deuteronomy 31.35 The code disrupts this sequence. An additional argument is that Deuteronomy 1-3 does not appear to prepare for Moses' discourse on the law code. It is certainly true that the code interrupts the commissioning of Joshua. Nevertheless, A. D. H. Mayes has made two important observations which make it difficult to deny that the code was part of DtrH. ${ }^{36}$

His first observation concerns the references to Horeb in Deut 1:6 and 5:2. It is surely significant that DTR does not begin by referring to the Patriarchs or the Exodus but to Horeb (Deut 1:6). This initial reference to Horeb finds its point and explanation in Deut 5:2. It was in the covenant at Horeb that the program for Israel's future was laid down. Mayes's second observation concerns the presentation of Israel's history in Deuteronomy 1-3 as a first person account of Moses. According to Mayes this can only be satisfactorily explained in relation to the deuteronomic code. If DTR did not intend to include the code it is difficult to explain why the history begins with an address by Moses. Both the introduction and the code are formulated as a first person address by Moses. In Deuteronomy 31-34 and the following books the presentation of the history changes to the third person.

A further observation can be added to those of Mayes. Deuteronomy 1-3, with its account of the emergence of a new generation on the eve of entry and conquest of the promised land, and the impending change of leadership, provides an appropriate context for the inclusion of the deuteronomic code. It functions as a farewell speech by the great leader Moses, and at the same time transfers

${ }^{35}$ Levenson ("Who Inserted the Book of the Torah?" 222-31) argues that there are also five areas of tension between the Josianic DtrH and the code, indicating that it must have been inserted by a later redactor. The alleged areas of tension are the deuteronomic and Davidic covenants, the law of the king (Deut 17:14-20) and the portrayal of the Davidic dynasty, the breaking of the law of centralization by Gideon, Samuel and Elijah, David's marriage to a foreign woman in 2 Sam 3:3, and conflict between Deut 16:6-7 and 2 Kgs 23:9. The force of his argument is however greatly weakened when he cannot produce evidence of reworking by the later redactor to bring the history into line with the now inserted code. The particular areas of alleged tension will be discussed in the course of the analysis.

${ }^{36}$ Mayes, The Story of Israel, 23-24. 
the privileges and responsibilities of the deuteronomic program to the emergent conquest generation and its future leader Joshua. ${ }^{37}$

In terms of the relationship of the code to DtrH the earlier presentation of the history's structure and conceptual plan claimed that a principal concern of DTR was to show the realization of the ideals enshrined in the deuteronomic

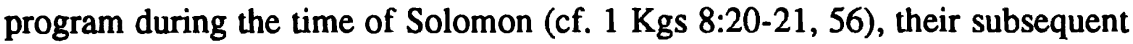

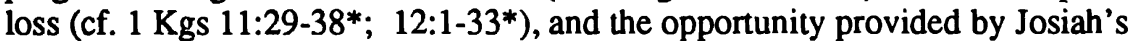
reform to begin to recapture them ( 2 Kings 22-23*). The realization of the ideals was facilitated by the model king David. Their loss was the outcome of Solomon's infidelity to the program's requirement of exclusive centralized worship of Yahweh. The opportunity to recapture them was provided by Josiah's re-establishment of this requirement. The presentation also claimed that the prophecy-fulfillment schema was an essential component of DTR's interpretation of the history of the monarchy according to the deuteronomic program.

There are therefore a number of important aspects of the relationship between the code and DtrH which need to be examined as part of the reassessment. They are; the relationship between the deuteronomic covenant and the promises to David, the nature of the deuteronomic ideal as perceived by DTR, and the relationship between the deuteronomic schema of reward and retribution and the prophetic schema of promise and fulfillment. The question of the relationship between the deuteronomic covenant and the promises to David will be taken up in the analysis of the reigns of David and Solomon. Similarly, the relationship between the deuteronomic schema of reward-retribution and the schema of prophecy-fulfillment is better left until the discussion of the period of Israel under the prophets and kings. It may be pointed out at this stage however that an initial alliance between reward-retribution and promisefulfillment was forged by DTR in Deuteronomy 1 . This can be seen in the announcement of the end of the exodus generation as punishment for their infidelity (Deut 1:34-35), and the report of its fulfillment (Deut 2:14-16).

What can be taken up here is the nature of the deuteronomic ideal as perceived by DTR. The text in the code which in my judgment expresses above all the essence of this ideal is Deut 12:8-12.38 The principal elements in this

${ }^{37}$ The verb $q \bar{a} r \bar{a}^{3}$ in Deut 5:1a does not, as Mittmann observed (Deuteronomium 1:1-6:3,166), denote a new assembly, but a call to attention for the coming discourse.

${ }^{38}$ Deuteronomy 12 has 4 sets of instructions on centralized worship, Deut $12: 4-7,8-12,13-19,20-28$. A number have favored Deut $12: 13-19$ as the earliest legislation and pre-dtr. See Baruch Halpern, "The Centralization Formula in Deuteronomy," VT 31 (1981) 20-38, cf. p. 26; Mayes, Deuteronomy, 222; Preuss, Deuteronomium, 51; M. Rose, Der Ausschliesslichkeitsanspruch Yahwes. Deuteronomische Schultheologie und die Volksfrömmigkeit in der späten Königszeit (BWANT 106; Stuttgart: Kohlhammer, 1975) 76; von Rad, Deuteronomy, 92; Gottfried Seitz, Redaktionsgeschichtliche Studien zum Deuteronomium, (BWANT 93; Stuttgart: W. Kohlhammer, 1971) 206-212. Deut 12:1-12, 20-28 were added subsequently. Mayes assigns Deut 12:8-12 to DTR. Preuss distinguishes dtr levels in Deut 12:2-7 and 12:8-12, with 12:8-12 being earlier, as does Rose. 
passage are; assurance that Yahweh's promise of an inheritance in the land will be realized (vv 9, 10a), assurance that Yahweh will give Israel rest in the land from all its enemies round about (vv 9, 10b), instruction to worship Yahweh at the place which he will choose (vv 11-12). ${ }^{39}$ An important point to note in the instruction is that centralized worship cannot be implemented until Yahweh has chosen the place for it.

The realization of each of these elcments is then commented on at strategic points in the course of Israel's history. ${ }^{40}$ Josh 21:43-45 records the realization of the gift of the land and rest from enemies. ${ }^{41}$ The theme of rest from enemies

${ }^{39}$ There are three different formulas for the law of centralization in Deuteronomy. There is the short form ("in the place which the Lord [your God] will choose") found in Deut 12: 14 (with the addition "in one of your tribes"), 18,$26 ; 14: 25 ; 15: 20 ; 16: 7,15,16 ; 17: 8,10 ; 18: 6 ; 31: 11$. There are two versions of the long form. One has "in the place which the Lord [your God] will choose to make his name dwell [lěsakenn] there", found in Deut 12:11; 14:23; $16: 2,6,11 ; 26: 2,5$. The other has "in the place which the Lord your God will choose to put [lasûm] his name there", found in Deut 12:5, 7, 21; 14:24. For Rose the short form was the earlier, while within the long form he regards the use of lāsûm as later (Der Ausschliesslichkeitsanspruch Yahwes, 84-88). H. Weippert also favors the short form as the older formulation. Deut 16:16 envisaged a temporary centralization of the cult, for the duration of a feast ("Der Ort, den Jahwe erwählen wird, um dort seinen Namen wohnen zu lassen," BZ 24 [1980] 76-94. See p. 79). For B. Halpern the short form is likely an abbreviation of the longer formula ("The Centralization Formula in Deuteronomy," 23). For N. Lohfink the short form was not antecedent. It was simply an abbreviated version of the long form ("Zur deuteronomischen Zentralisationsformel," Bib 65 [1984] 297-329). If Lohfink's understanding is correct the long form in Deut 12:11 may well have been chosen by the Josianic DTR to express a conviction about the definitive and permanent nature of centralized worship (cf. the verb lěsakēn).

${ }^{40}$ The promise of rest occurs in Deut 25:19 in relation to the destruction of Amalek. The realization of this is not reported anywhere in the historical books. The episode in 1 Samuel 15 is not prompted by the realization of rest from all of Israel's enemies. The text is most likely a late addition to Deuteronomy (so Mayes, Deuteronomy, 330).

${ }^{41}$ For a detailed discussion of this and the related texts see Georg Braulik "Zur deuteronomistischen Konzeption von Freiheit und Frieden," Congress Volume Salamanca VTSup 36 (1985) 29-39, and W. Roth, "The Deuteronomic RestTheology," 5-14. Braulik regards them as an integral part of the theology of DtrGW (DtrH). However he suggests there are two levels in Josh 21:43-45. Verses 43, 44b belong to Lohfink's DtrL (Deuteronomy-Joshua 22); vv 44a, 45 mark the incorporation of DtrL into DtrGW (p. 36). Braulik allows that DtrL, a Josian document, could have been incorporated into a larger Josianic or exilic DtrGW. The hypothesis of a DtrL does not require any change in the structure and conceptual plan of DtrH proposed in this study. Braulik shows well the concern in Josh 21:43, 44b to monitor the realization of Deut 12:9-10. But there is a difficulty with a history which ends at Joshua 22, given the importance of centralization (Deut 12:11-12). Roth's analysis relies substantially on the Smend school hypothesis, leading him to assign 2 Sam 7:1b, 11 to DtrN (following Veijola), along with $1 \mathrm{Kgs} \mathrm{5:18a}$ (RSV 5:4a). 
occurs again in the introduction to Nathan's prophecy to David in 2 Sam 7:1b, and is given in $1 \mathrm{Kgs} \mathrm{5:18} \mathrm{(RSV} \mathrm{5:4)} \mathrm{as} \mathrm{the} \mathrm{reason} \mathrm{for} \mathrm{Solomon's} \mathrm{decision} \mathrm{to}$ commence building the temple. The final occurrence of the theme of rest is found in $1 \mathrm{Kgs} 8: 56$, in the context of the inauguration of centralized worship in the temple. This verse marks the inauguration as the fulfillment of all the promises which God had spoken through Moses. ${ }^{42}$ With this fulfillment notice Solomon's speech draws to a close. It is instructive to note therefore that his speech begins in $1 \mathrm{Kgs} 8: 15-20$ by proclaiming the fulifllment of Nathan's prophecy that David's heir would build a temple at the place chosen by God.

Each stage of the realization of the deuteronomic ideal expressed in Deut 12:8-12 is therefore marked by a reference to rest. $1 \mathrm{Kgs} 8: 56$ forms the last member in the series of texts and so records the full realization of the ideal. The close relationship between Deut 12:8-12 and the reports of its stage by stage realization clearly point to DTR as the author of this passage.

The deuteronomic code included in DtrH was identified in the preceding chapter as Deut 5:1-28:46, immediately followed by Deut 31:1, 7-8. While there were later additions to the code a full investigation of them is beyond the scope of this study, which is principally concerned to establish the nature and extent of DtrH. ${ }^{43}$ The remainder of the analysis of the book of Deuteronomy will therefore focus on those passages which were added as a frame around the code (Deut 4:1-49; 28:69-30:20 [RSV 29:1-30:20]. It will then trace the thread of the history through Deuteronomy 31-34.

The identification of Deut 4:1-40 as a later addition to DtrH need not be defended here. It is now generally accepted. ${ }^{44}$ Nor for the purposes of this study does the still debated question of the unity of this pericope need to be engaged. ${ }^{45}$ Two features of the sermon which are significant in relation to the

${ }^{42}$ Thus the law of centralization was not in effect in the time of Gideon and Samuel. The story of the conflict on Mt. Carmel between Elijah and the prophets of Baal comes of course after the establishment of centralized worship. However Elijah does not construct the altar as a place of worship for the people, but as a locus for Yahweh's demonstration of power against Baal. Moreover, the altar is completely consumed by Yahweh's fire in $1 \mathrm{Kgs} 18: 38$ (against Levenson's arguments in, "Who Inserted the Book of the Torah?" 222-31).

${ }^{43} \mathrm{~A}$ number of passages in the code will be identified as secondary in the course of the reasssessment. The question of later redaction of the code is a difficult one, but can only benefit from a clear delineation between the work of DTR and later redaction in the historical narrative.

${ }^{44} \mathrm{Cf}$. Levenson, "Who Inserted the Book of the Torah?" 207, 212; Mayes, The Story of Israel, 24-31; Denis J. McCarthy, Treaty and Covenant. A Study in Form in the Ancient Oriental Documents and in the Old Testament [AnBib 21A; Rome: Biblical Institute, 1978) 189-94; Mittmann, Deuteronomium 1:16:3, 183-84 (distributed across PL1, PL2 and later redaction); L. Schmidt, "Deuteronomistisches Geschichtswerk," 104; Smend, Die Entstehung, 75 (DtrN); R. Stahl, "Aspekte", 128-41 (complex redaction).

${ }^{45}$ For a thorough discussion see Begg, "The Literary Criticism of Deut 4,140," 10-55. Lohfink (Höre, Israel! Auslegung von Texten aus dem Buch Deuteronomium [Die Welt der Bibel; Düsseldorf: Patmos, 1965] 119-20) defends the unity of Deut 4:1-40, and is followed by Braulik (cf. Die Mittel deuteronomischer Rhetorik. Erhoben aus Deuteronomium 4, 1-40 [AnBib 68; 
later redaction of DtrH may however be noted. The first is the focus of the sermon on obedience to the law, and its warnings about the dire consequences of disobedience. ${ }^{46}$ This will be seen in the course of the analysis to be a feature of the later nomistic stage of redaction. The second is the theme of God's mercy and Israel's return (Deut 4:29-31). If the sermon is a unity, this suggests it was composed at a time when the condemnatory tone of the main nomistic redaction was being balanced by the proclamation of restoration and renewal. ${ }^{47}$

As pointed out earlier Deut 3:29, along with Deut 4:44-49, was a late addition to Deuteronomy. Deut 3:29 and 4:46 serve to locate the speech of Deut 4:1-40 at Beth-peor. The location may well have been inspired by the reference to Baal-peor in Deut 4:3. Deut 4:44-49 itself is recognized as a complex text. This is immediately indicated to the reader by the doublet in vv 44-45. It is possible that Deut 4:45 was the original introduction to the deuteronomic code. ${ }^{48}$ If so it was later relocated here as part of a second and more immediate introduction to the code. ${ }^{49}$ This is supported by the general title of law in the introductory $v 44$ and how $v 45$ summarizes the contents of the law as testimonies, statutes and ordinances. The way vv 46-49 draw in summary fashion on the account of the conquest of Sihon and $\mathrm{Og}$ in Deuteronomy 2-3 also points to the text being a later insertion. Although its principal aim is to introduce the law code, it draws on the historical review in order to locate the giving of the law at an appropriate time and place. The provision of cities of refuge in Deut $4: 41-43$ is generally regarded as a very late insertion. 50

The proposal that the code incorporated by DTR ended with an earlier version of Deuteronomy $28\left(28: 1-46^{*}\right)$ is a cautious one. ${ }^{51}$ Nevertheless there are a number of arguments in its favor. First, there is the thesis that Deuteronomy was constructed according to the Ancient Near Eastern treaty pattern, or at least reflects some influence from this pattern. ${ }^{52}$ It is generally accepted

Rome: Biblical Institute, 1978] and "Literarkritik und archäologische Stratigraphie. Zur S. Mittmann's Analyse von Deuteronomium 4, 1-40," Bib 59 [1978] 351-83).

${ }^{46}$ Cf. Deut 4:9, 15, 16, 23, 25-28.

${ }^{47} \mathrm{H}$. W. Wolff argued that Deut 4:29-31 was a later addition to the sermon, by the same hand responsible for 30:1-10 ("The Kerygma," 96-97).

${ }^{48}$ Mayes (Deuteronomy, 48) proposes that the original Deuteronomy began with Deut 4:45. However he thinks that the term "testimonies" may be a later addition to the verse (ibid., 160).

${ }^{49}$ Cf. Buis, Le Deutéronome, 103-4; Mayes, Deuteronomy, 159-60; Preuss, Deuteronomium, 92.

${ }^{50}$ See the review by Preuss, Deuteronomium, 91.

${ }^{51}$ Noth (The Deuteronomistic History, 16) judged that the pre-dtr code ended with Deut 30:20. For Levenson the code ends at Deut 28:68 ("Who Inserted the Book of the Torah?", 203, n.1). For Mayes (Deuteronomy, 330-32) it was Deut 25:16; For McCarthy (Treaty and Covenant, 186) Deut 28:1-46 [69]. Seitz (Redaktionsgeschichtliche Studien zum Deuteronomium, 308-11) includes a core of Deuteronomy 28, but regards Deuteronomy 27; $29 \mathrm{ff}$ as dtr.

${ }^{52}$ On the hypothesis that Deuteronomy was constructed according to the Ancient Near Eastern treaty pattern see McCarthy, Treaty and Covenant, 157-87. See also Klaus Baltzer, The Covenant Formulary in Old Testament, Jewish, and 
that such treaty patterns ended with a series of blessings and curses. Deuteronomy 28 supplies such a series. Deut 26:16-19 would provide an appropriate introductory invocation for their proclamation. Second, there is the occurrence of similar blessings and curses at the end of the law codes in Exod 23:25-31 and Lev 26:3-39.53

Third, within the context of a Josianic DtrH the presence of a version of Deuteronomy 28 in the law book discovered in the temple would provide an appropriate reason for Josiah to rend his clothes in $2 \mathrm{Kgs} 22: 11$. Finally, the presence of a version of Deuteronomy 28 in the code incorporated by DTR would have furnished a suitable matrix for the addition of the later chapters 27 , 29-30. While none of these arguments are particularly cogent in themselves, taken together they do make a reasonable case for including Deut 26:17-19; 28:1-46* in the code..$^{54}$ The arguments against including blessings and curses in the deuteronomic code seem to be less convincing. ${ }^{55}$

After Deut 26:17-19; 28:1-46* the continuation of the text of DtrH is to be found in Deuteronomy 31. Deuteronomy 27;29-30 are later additions. There is no need to enter into a detailed discussion of Deuteronomy 27 here. Even though the series of curses in Deut 27:15-26 may be quite old, the chapter is generally regarded as a late insertion in Deuteronomy. ${ }^{56}$ This must have been done after the compositon of DtrH. It is not in keeping with DTR's presentation of Moses to have the elders (cf. $v$ 1) and Levitical priests (cf. $v$ 9) assist him in the proclamation of law. For DTR this authority was reserved

Early Christian Writings (Philadelphia: Fortress, 1971); Meredith G. Kline, Treaty of the Great King. The Covenant Structure of Deuteronomy (Grand Rapids: Eerdmans, 1963); Weinfeld, Deuteronomy and the Deuteronomic School, 59-146. Because of the variety of Ancient Near Eastem treaty patterns and the difficulty of finding the precise points of correlation in Deuteronomy caution is advised. See the review in Preuss, Deuteronomium, 45, 62-74. Seitz (Redaktionsgeschichtliche Studien zum Deuteronomium, 254-57) gives a cautious response to the hypothesis, but includes a core of Deuteronomy 28 in his pre-dtr text.

${ }^{53}$ Exod 23:25-31 may be part of a dtr addition. Lev 26:3-39 is of course later priestly material, but presumably reflecting an established practice.

${ }^{54}$ One can recognize three major sections in Deuteronomy 28 ; vv $1-46,47$ 57, 58-68. Deut 28:47-57 has been excluded because of the shift from the conditional "if" (cf. $v$ 15) to a declaration of failure. Deut 28:58-68 expresses different concerns to the preceding two sections and is best taken as a later addition. Deut 28:1-46, which was built up from the basic lists of blessings and curses in vv 3-6, 16-19, also underwent some later expansion. One must however be cautious in seeing the change from plural form of address to singular in Deut 26:17-19 and 28:1-46* as a sign of later redaction, given the debate over this phenomenon as a literary critical criterion. For a detailed examination of the chapter see Seitz, Redaktionsgeschichtliche Studien zum Deuteronomium, 257-302.

${ }^{55}$ Against Mayes, Deuteronomy, 348-58. The evidence adduced from his internal study is somewhat ambiguous.

${ }^{56}$ Preuss (Deuteronomium, 149-53) provides a thorough review of the literature. 
exclusively to Moses..$^{57}$ The present location of Deuteronomy 27 was probably facilitated by the theme of blessing and curse in Deuteronomy 28. Deut 27:910 manifests a concern to relate the chapter to Deut 26:17-19 and the beginning of Deuteronomy 28. Two other texts are associated with this insertion; Deut 11:29-32 and Josh 8:30-35. Deut 11:29-32 and 27:1-26 create a frame around Deuteronomy 12-26 in order to make provision for the ceremony described in Josh 8:30-35. Despite the fact that it is Joshua who takes charge of the proceedings in the latter passage, whereas he is not mentioned in Deut 11:29-32 or $27: 1-26$, there is no compelling reason against attributing all three texts to the same hand. .8

Like Deuteronomy 27, Deuteronomy 29-30 is generally recognized as a later addition to Deuteronomy. ${ }^{59}$ In terms of their relationship to DtrH these chapters are to be judged also as a later insertion. Deut 28:69 (RSV 29:1) introduces the subsequent material as Moses' address on the occasion of another covenant made in the land of Moab. ${ }^{60}$ This creates some tension with DTR's introduction in Deuteronomy 1-3, in which it is clearly established that the Horeb covenant is to provide the program for Israel's life in the land. Furthermore the historical review in Deut 29:1-8 (RSV 29:2-9) appears to be a much abbreviated version of DTR's own historical review in Deuteronomy 1-3.

The concern to inculcate obedience to the covenant (Deut 29:9-14 [RSV 29:10-15]), the grim warning to the disobedient (Deut 29:17-27 [RSV 29:18$28]$ ), and the unique use of the term āla (oath, curse) in association with references to the covenant, mark this chapter as distinct from the text of DtrH. ${ }^{61}$

${ }^{57}$ Mayes (The Story of Israel, 33) assigns Deuteronomy 27 to later dtr redaction, although it is doubtful whether the chapter comes from the same hand as that responsible for Deut 4:1-40 and Deuteronomy 29-30, as Mayes indicates.

${ }^{58}$ The most detailed analysis of these texts is that of Jean L'Hour ("L'Alliance de Sichem," $R B \quad 69$ (1962) 5-36, 161-84, 350-68). Even though they reflect old traditions he concludes that their present form and position is due to a post-dtr redactor (cf. p. 182).

${ }^{59}$ For a review of the literature see Preuss, Deuteronomium, 159-62.

${ }^{60}$ Deut 28:69 belongs with Deuteronomy 29 rather than 28, against Levenson who claims that "the covenant at Moab is most likely an original part of Dtn" ("Who Inserted the Book of the Torah?" 212). The verse does of course create a link with the preceding material via its reference to the covenant at Horeb, but its primary function is to provide a new introduction, as shown by Seitz (Redaktionsgeschichtliche Studien zum Deuteronomium, 26). In adddition, as noted by Mayes (Deuteronomy, 360), the term covenant appears five times in Deut 29:8,11, 13, 20, 24. The term is used once in the law corpus (Deut 17:2), a reference which may be a later addition. Lohfink ("Der Bundesschluss im Land Moab," BZ 6 [1962] 32-56) sees in Deut 28:69 the beginning of a new section which extends to $32: 47$.

${ }^{61}$ The term xâ as a description of the type of covenant ("sworn covenant" in RSV) occurs in Deut 29: 11, 13, 18. It is used in Deut 29:20 to describe the curses of the covenant. Presumably the reference is to the curses of Deuteronomy 28, which this later chapter is dependent on. Note that the curses are described in Deut 28:15, 45 as haqqelalot. This term occurs in the singular in Deut 29:26. The variation in terminology between vv 20 and 26 suggests that Deuteronomy 29 is not a unity. Verses $21-27$ (RSV vv 22-28) are probably a 
Its concern for obedience and warning about the consequences of disobedience are similar to Deut 4:1-40. However Deut 29:1-27 (RSV 28:69-29:28) does not contain the note of grace and restoration present in the earlier sermon. The two discourses may not have been composed by the one hand. Nevertheless one can discern a move to frame the deuteronomic code (Deut 5:1-28:46) with appropriate sermons on the law. In my judgment this development is to be associated with a later nomistic stage of redaction. Within this stage the positive note in Deut 4:1-40 suggests it was added after Deut 28:69-29:27 (RSV 29:128).

Deut 29:29 (RSV 29:28) has stronger connections with Deut 30:11-14 than with the preceding sermon. Both texts seek to encourage obedience to the law by emphasizing that it is a special possession of Israel. They appear to have been composed as a frame around a sermon on return and restoration in Deut 30:1-10. Deut 29:28 (RSV 29:29) smooths the transition from the preceding grim sermon to Deut 30:1-10. Deut 30:11-14 for its part provides an appropriate transition to the final statement in 30:15-20.62

The earliest passage in this complex looks to be Deut 30:15-20, a sermon which provides a conclusion to the deuteronomic code. ${ }^{63}$ This text was then supplemented by the addition of Deut 30:1-10, with the accompanying literary seams in Deut 29:28 (RSV 29:29) and 30:11-14. The theme of return and restoration in Deut 30:1-10 recalls Deut 4:29-31, suggesting these two passages may have come from the same stage of redaction, if not from the same hand. ${ }^{64}$ The addition of Deut 29:28 (RSV 29:29); 30:1-14 effected a nice balance in the frame around the deuteronomic code (Deut 4:1-40 and 29-30). Both arms of the frame develop the themes of disobedience to the law and its consequences, but then counter them with the themes of return and restoration.

Now that the arguments justifying the attribution of Deuteronomy 27; 29 30 to later redaction have been set out, we can proceed to a consideration of Deuteronomy 31-34. As outlined in the preceding chapter the proposed text of DtrH in this block of material is Deut 31:1, 7-8, 9aa, 24-26a; 34:1-6*.

separate unit (see Preuss, Deuteronomium, 60). Also v 28 (RSV v 29) belongs more with Deuteronomy 30-on this see below. The only other places where rala occurs in DtrH are Deut 30:7 and $1 \mathrm{Kgs} 8: 31$. The former is part of the section under discussion. The latter will be shown in chapter 6 to be a later addition to DtrH.

${ }^{62}$ On the relationship between Deuteronomy 29 and 30 see Mayes, Deuteronomy, 358; Preuss, Deuteronomium, 159-62; von Rad, Deuteronomy, 178.

${ }^{63}$ Even though the passage functions as a conclusion to the code, it was not originally part of it. The emphasis on obedience to the law, the warning against worshipping foreign gods, and the presentation of the alternatives consequent on obedience or disobedience link the passage with Deuteronomy 4; 29 and Joshua 23, all later additions to DtrH.

${ }^{64}$ Wolff ("The Kerygma," 96-97) holds that Deut 4:29-31 was a later addition to Deut $4: 1-40$ by the same hand responsible for 30:1-10. G. Vanoni ("Der Geist und der Buchstabe: Uberlegungen zum Verhältnis der Testamente und Beobachtungen zu Dtn 30,1-10," $B N 14$ [1981] 65-98) argues that all of Deut 4:1-40 and 30:1-10 stem from the same redaction (cf. p. 89). 
Given the divine command to Moses in Deut 3:23-28 to commission Joshua as his successor, one would expect that the execution of this commission would come immediately after Moses had finished laying down the program for Israel's future life in the land (Deuteronomy 5-28*). There are two texts in Deuteronomy 31 where the actual commissioning of Joshua is reported; Deut 31:7-8, and 31:14-15, 23. Of these the one which follows the text of Deut 3:23-28 most closely is 31:7-8, for it reports Moses' execution of the divine command in 3:28. Deut 31:14-15, 23 on the other hand creates a new schema of command and execution, one which emphasizes the divine initiative in both components of the schema. Furthermore, the reason for Joshua's commission is given in Deut 31:14 as Moses' impending death, rather than Yahweh's anger with Moses on account of the people, as in Deut 3:26. The divine initiative in Joshua's commission is of course present in Deut 3:28. But it may have been the textual distance between this command and its execution in $31: 7-8$ which led to the addition of $31: 14-15,23$, in which the divine initiative is so dominant. 65

Deut 31:7-8 may therefore be taken as DTR's account of the commissioning of Joshua. In relation to DTR's introduction in Deuteronomy 1-3 this text shows that Joshua was commissioned to complete two tasks which Moses had begun, the conquest of the land and its distribution among the people as an inheritance (cf. $v$ 7). ${ }^{66}$ These tasks are confirmed in Josh 1:1-6 immediately prior to the account of the crossing of the Jordan and the conquest and distribution of the land. It is this understanding of Joshua as Moses' successor which leads to the recognition that DTR portrayed the first part of the history as the period of Israel under Moses and Joshua. It should be noted that Joshua's commission does not include the role of lawgiver. For DTR this was exclusive to Moses. The subsequent history of Israel would therefore be concerned with the realization of the deuteronomic program as outlined by Moses. In this way a sense of unity is created, not only for the period of Israel under Moses and Joshua, but also for the history as a whole.

Deut 31:1 can also be included in DtrH if the LXX reading "and Moses finished speaking" is accepted in place of the MT reading "so Moses continued to speak". ${ }^{67}$ This makes good sense in the context, bringing the long Mosaic discourse of Deuteronomy 5-28* to a close. However Deut 31:2-6 is clearly an addition. It begins a new address to the people which gives Moses' advanced age, and not the anger of Yahweh as in Deut 3:26, as the reason why he cannot

\footnotetext{
DtrH.

${ }^{65}$ Against Mayes, (The Story of Israel, 22, 37) who includes both versions in

${ }^{66}$ This was seen by Lohfink, "Die deuteronomistische Darstellung des Ubergangs der Führung Israels von Moses auf Josue. Eine Beitrag zur alttestamentlichen Theologie des Amtes," Scholastik 37 (1962) 32-44.

${ }^{67}$ In the LXX Kal sunetelesen Moyses lalon. This reading is found also in the Qumran texts (cf. Mayes, Deuteronomy, 372). As Mayes notes it is more likely that the MT altered the LXX and Qumran readings because of the addition of further discourses by Moses in Deuteronomy 31-33 than that the alteration went the other way.
} 
enter the land. Furthermore, Moses reports to the people the news that Joshua is to be his successor, as if they had not already heard it (cf. Deut 3:28).

The inclusion of Deut 31:9aa, 24-26a in the text of DtrH follows Noth. ${ }^{68}$ His literary critical analysis makes good sense, and shows how the expansions in Deut 31:9-13 and 26b-29 were incorporated by splitting into two sections the original account of Moses writing down the law. The first expansion is concerned with making provision for the reading of the law at the end of every seven years. The second is concerned with ensuring that the written law continues to function as an authoritative witness against Israel even after Moses' death (Deut 31:26b). Within the larger context of DtrH, Moses' provision of a written copy of the law serves to create a thematic link with the discovery of the book of the law in the temple in $2 \mathrm{Kgs} 22: 3-10$. One might have expected Moses to provide a written copy of the law before his installation of Joshua as his successor in Deut 31:7-8. Nevertheless, because of the importance of the law for the conceptual plan of the history as a whole, it is fitting to have Moses write it in a book and give instructions about its safe keeping as the final gesture before his death (Deut 34:1-6*).

The above remarks show that the text of DtrH in Deuteronomy 31 has been added to substantially. The nature of the additions cannot be fuliy explored here. ${ }^{69}$ However it is instructive to observe how two areas of later redaction, Deut 31:2-6, 14-15, 23 and 31:9aßb-13, 26b-27 (28-29), are expansions of two corresponding elements of DtrH; the commissioning of Joshua, and the provision of a written copy of the law. The expansions concerned with the law may be associated with the nomistic layer of redaction detected in the framing chapters of Deuteronomy 4; 29-30.70 Deut 31:16-22, 30, which functions as an introduction to the song of Deut 32:1-43, may also be related to the concern about disobedience in the nomistic layer of redaction, even if it cannot be identified with it. ${ }^{71}$

In agreement with Noth DTR's account of the death of Moses is to be identified in Deut $34: 1 a^{*} b a, 4-6{ }^{72}$ Deut $34: 1 a^{*} b \beta-3$ contains later geographical expansions, rather like those in Deut 1:1. These, along with Deut 34:7-9 were assigned by Noth to P. Deut 34:10-12 was added later still, after the Pentateuch and the history had been linked together.

${ }^{68}$ Noth, The Deuteronomistic History, 35, 115, n. 64.

${ }^{69}$ For a discussion of the literary critical issues, see Mayes, Deuteronomy, 372-80. Also Preuss, Deuteronomium, 162-65.

${ }^{70}$ Levenson, ("Who Inserted the Book of the Torah?" 212-16) has detected a number of linguistic similarities between Deuteronomy 4; 29-30 and secondary material in 31 .

${ }^{71}$ The introduction to the song in Deut 31:16-22 has been inserted into the account of Joshua's commission in Deut 31:14-15, 23. The song of Deuteronomy 32, with its introduction, and the blessing of Deuteronomy 33 are gencrally regarded as late entries into the book of Deuteronomy. Cf. Buis, Le Deutéronome, 413-49; Mayes, Deuteronomy, 372; Preuss, Deuteronomium, 163-73.

${ }^{72}$ Noth, Überlieferungsgeschichtliche Studien, 213, n.1. In Deut 34:1 a* the text of DtrH reads "and Moses went up to the top of Pisgah". 
JOSH 1:1-JUDG 2:10

For the sake of convenience the analysis of this part of the history may be divided into the following sections: the introduction in Joshua 1; the story of the conquest in Joshua 2-11; the allotment of the conquered land in Joshua 1221 (22); the farewell speeches and death of Joshua in Josh 23:1-Judg 2:10.

\section{JOSHUA 1}

The dtr nature of Joshua 1 is not disputed. Furthermore Noth's observation that Josh 1:7-9 is a later dtr addition to the text has been confirmed by the more recent study of Smend, who assigns these verses to his nomistic redactor (DtrN) ${ }^{73}$ Hence there is no need to rehearse the arguments for assigning Josh 1:1-6 to DTR and vv 7-9 to a later redaction with nomistic interest. As pointed out in the discussion of Deuteronomy 31, DTR's introduction outlines the two tasks with which Joshua was entrusted as Moses' successor: completion of the conquest of the land (Josh 1:3), and the allotment of it as the people's inheritance (Josh 1:6). ${ }^{74}$ DTR recounts Joshua's successful completion of these two tasks in the story of the conquest in Joshua 2-11, and the account of the allotment of the land in Josh 11:23aß; 12:1-24*.

Josh 1:10-11 describes Joshua exercising his authority as Moses' successor by commanding the people to prepare for the crossing of the Jordan. The passage depends on the preceding verses and establishes the relationship between Joshua and the people necessary for the successful completion of the conquest. The address to the Transjordan tribes in Josh 1:12-18 should be included as part of DtrH ${ }^{75}$ The thrust of Joshua's address in vv 12-15, and their reply in vv 1618 , is to stress that the conquest of Cisjordan was the completion of the task begun by Moses, and that Joshua was Moses' authorized successor. This

${ }^{73}$ Noth, The Deuteronomistic History, 116, n.4; Smend, "Das Gesetz," 49497. Mayes (The Story of Israel, 47) judges that Josh 1:9aßb should be included in DtrH. This is possible, although $\vee 9 b$, which repeats the assurance of $v 5$, shifts to the third person. Lohfink ("Kerygmata des Deuteronomistischen Geschichtswerks," 98-99) proposes that Josh 1:3-4 is a later expansion, in the light of comparison with Deut 1:7*; 11:24; Josh 11:15-20; 21:43. For Lohfink, these are expansions to his Josianic DtrL redaction (DeuteronomyJoshua 22).

${ }^{74}$ Note the use of the command to "rise up" in Josh $1: 2$, the same command given to Moses in Deut 2:24aa to begin the conquest of Transjordan.

${ }^{75}$ Against R. G. Boling and G. E. Wright, Joshua, 126, also G. Fohrer, Introduction to the Old Testament, 202. However Boling (who wrote the commentary section of the book) is correct in rejecting the interpretation of J. A. Soggin (Joshua. A Commentary [OTL; London: SCM, 1972] 32-34) who proposes that Josh $1: 12-18$ is an earlier portrayal of the conquest as a military operation. Josh $1: 10-11$ is a later text, which portrays the conquest as a peaceful, cultic like procession. Soggin bases the distinction on the sense of the term provisions (s $\bar{e} d \hat{)}$ ), but as Boling points out, the same term in Judg 20:10 clearly refers to a military campaign. 
recalls the commissioning of Joshua in Deut 3:23-28; $31: 7-8$, and serves to give a unified presentation of the overall conquest of the land. ${ }^{76}$

\section{JOSHUA 2-11}

According to Noth the account of the conquest in Joshua 2-11 was constructed by a ninth century compiler who gathered together and edited a number of older stories. This compiler was also responsible for attributing the conquest to the hero Joshua. ${ }^{77}$ DTR incorporated this account and added only a limited number of redactional comments. These were aimed principally at securing links between the source material and key concerns of DTR in the book of Deuteronomy. ${ }^{78}$ Some recent studies however have sought to greatly enhance the dtr contribution and to even claim that the account is a dtr composition.

R. G. Boling admits there were old stories but holds that they were rewritten by a Josianic redactor (Dtr 1). ${ }^{79}$ What makes Boling's proposal uncertain is that his criteria for identifying the work of Dtr 1 often appear too broad and thematic. This creates uncertainty as to whether he has taken into account sufficiently the well recognized tendency of DTR to use stereotyped language and repeated patterns, in contrast to the considerable variations between the different stories. As well, he does not give adequate attention to the localized

${ }^{76} \mathrm{Cf}$. John Gray, Joshua, Judges and Ruth (NCB; rev. ed.; London: Oliphants, 1977) 48.

${ }^{77}$ This hypothesis was proposed by Noth in his commentary, Das Buch Josua, 11-13. There is no need here to review Noth's dismantling of the classical Hexateuch theory in which the sources J, E were regarded as continuing in the book of Joshua. His position that the conquest stories in Joshua had an independent provenance has gained a strong following, whether one accepts his hypothesis of a ninth century compiler (Sammler) or not. For a thorough review of the debate and confirmation of Noth's separation of Joshua from the Pentateuchal sources, see A. G. Auld, Joshua, Moses and the Land, 1-51. See also M. Rose, Deuteronomist und Yahwist.

${ }^{78}$ There are links with the Transjordan conquest in Josh 2:10b; 9:9b $\beta-10$ (Exodus and conquest), a particular interest in the ark in 3:2-4, 6, 8 (Noth thought the word "priests" was added by DTR in $3: 13,14,15,17 ; 4: 3,9,10$, 18). There is a concern to emphasize that God was with Joshua, as with Moses, in $3: 7 ; 4: 14,24$. There is the interest in the Transjordan tribes in 4:12. An explanation of the circumcision in relation to the change of generations is given in 5:4, 6, 7. Josh 6:26 prepares for DTR's fulfillment notice in $1 \mathrm{Kgs}$ 16:34 (DTR also added the word "priests" in 6:4aa b, 6, 8, 9a, 12b, 13a, 16aß). There are DTR's exhortations in 8:1a; 10:25, and the implementation of Deuteronomy 27 in 8:30-35. Josh 9:27b $\beta$ refers to centralized worship. Josh $11: 15$ and $20 \mathrm{~b}$ note Joshua's scrupulous execution of God's command to Moses, and 11:23 forms a suitable conclusion to the whole. Noth judged that the text on Caleb in 14:6aßb-15a (cf. Deut 1:36) originally came after 11:21-23a (The Deuteronomistic History, 36-39).

${ }^{79}$ Boling, Joshua, 111-317. For Wright's reservations about Noth's position see the introduction pp. 66-72. 
nature of the individual stories, particularly those in the territory of Benjamin (Joshua 2-8).

B. Peckham completely rejects Noth's source and proposes instead that the basic account of the conquest was part of a Dtrl history from Deuteronomy to the reign of Hezekiah. This then became the basis for a thorough reworking by a later Dtr2 history, which reached from Genesis to 2 Kings $25.80 \mathrm{My}$ difficulties with Peckham's revision of the DtrH hypothesis were given in chapter 1 . The particular problems with the Joshua material may be dealt with briefly.

An initial problem lies in the sequence of the basic Dtr1 narrative. The text for Joshua 1-6 is 1:aba, 2, 3, 5abß; 2:1, 3aba, 4-5, 6-9a, 12aba, 13-16, 22$24 a ; 3: 5,10 b, 16 b ; 6: 2,16 b, 20 a a b \beta, 22,23 a a, 25 a a b$. The divine command to Joshua and the people to cross the Jordan in 1:2 is included, but the actual crossing is reported in the bare statement of 3:16b, which does not even mention the Jordan. The prominence given to the command would seem to require more than this. Second, Peckham's distribution of texts often appears arbitrary. ${ }^{81}$ Third, a number of literary critical positions are taken on the basis of alleged quotations or allusions to texts in the Pentateuch. It is doubtful these can be accepted. ${ }^{82}$ Fourth, Peckham fails to consider adequately the question of dtr language and theology. This is evident not only for Dtrl, but also Dtr2. Once the Dtrl text has been identified the remainder of the material is assigned to Dtr2 regardless of its complexity.

In short neither Boling nor Peckham can be said to have established a viable alternative to Noth's source-redaction hypothesis for Joshua 2-11. ${ }^{83}$ For the purposes of this reassessment therefore it will be accepted as the most reasonable explanation of the composition of Joshua 2-11.84 Whether one agrees with Noth or not it is certain that an account of the conquest of the land under Joshua is required as an integral part of DtrH. The extent of dtr redaction

${ }^{80} \mathrm{~B}$. Peckham, "The Composition of Joshua 3-4," 413-31; and The Composition of the Deuteronomistic History, 7-9, 21-68.

${ }^{81}$ For example, Josh 2:1 (the camp at Shittim) is included in Dtr 1 , whereas $3: 1$ is not.

${ }^{82}$ For example Josh 3:5 is included because it allegedly quotes the earlier $\mathbf{J}$ narrative's Exod $34: 10,11 \mathrm{~b}$, and so is an appropriate introduction to Dtrl's conquest. This completely overlooks the much closer text in Josh 7:13 with its call to "sanctify yourselves for tomorrow". Note that Josh 3:5 and 7:13 each prepares the people for a ritual.

${ }^{83} \mathrm{~J}$. Van Seters (In Search of History, 324-31) also holds for dtr authorship of the conquest narrative. His argument rests mainly on Joshua 1. Because this is the introduction to the conquest the subsequent narrative of the conquest depends on it. The author of the introduction (DTR) is therefore the author of the whole (p. 324). This is far too sweeping a conclusion to carry conviction. Rose is more cautious (Deuteronomist und Yahwist, 169). He suggests that the stories appear to be close to deuteronomic-dtr circles in terms of language and thought but are not to be identified as dtr compositions. This may mean that Noth's ninth century date for the compilation is too high.

${ }^{84}$ With Auld, Joshua, Moses and the Land, 6; Soggin, Joshua, 11; Gray, Joshua, Judges and Ruth, 10, 21; E. John Hamlin, Joshua. Inheriting the Land (International Theological Commentary; Grand Rapids: Eerdmans, 1983) xvi. 
identified by Noth may also be accepted, although there is evidence that Josh 9:24-25 should be included. This reply by the Gibeonites refers to the divine charge given to Moses concerning conquest of the land. It also looks to have been inserted between Joshua's announcement of sentence and his execution of it in $v 26.85$

However a number of the texts attributed by Noth to DTR can, in the light of the reassessment, be identified as later redaction. To begin with there is Josh 8:30-35 which, as was pointed out in the discussion of Deuteronomy, most likely came from the same hand responsible for the insertion of Deut 11:29-32; 27:1-26.86 Even if Josh 8:30-35 was originally located in Joshua 24 as part of the Shechem assembly and then moved to its present position, this does not alter its secondary nature in relation to $\mathrm{DtrH} .{ }^{87}$

Other examples of secondary redaction may be detected in Josh $7: 11,15$; $11: 12 b, 15,20$. In Josh $7: 11,15$ the reference to transgressing the covenant seems to be a secondary dtr addition. ${ }^{88}$ The use of cabar (to transgress) in reference to the covenant is not characteristic of DTR. It occurs in Deut 17:2; Josh 23:16; Judg 2:20; $2 \mathrm{Kgs} 18: 12$. Its presence in Deut 17:2 is probably due to an insertion because Deuteronomy consistently uses the verb in its

${ }^{85}$ Rose holds that Joshua 9 is a dtr composition, probably based on an old story which can no longer be recovered (Deuteronomist und Yahwist, 191). Peter J. Kearney sees links between the Gibeonite story and Deuteronomy 29; Joshua 7; 1 Kings 8; 2 Kings 20 ("The Role of the Gibeonites in the Deuteronomic History," $C B Q 35$ [1973] 1-19). The passages reflect "the same redactional level of exilic thought" (p. 18). On inspection however the phrases shared by Deuteronomy 29 and Joshua 9 are few, and the links across the passages appear too slight to support his claim. The function of Joshua 9 may be seen more clearly in the way Joshua $2-11$ is made up of two large blocks, Joshua 2-8 and 9-11. There is evidence of a common pattern in the way each block begins with a story of foreigners who recognize Yahweh's power and accept Israel's taking of the land (Rahab [Josh 2:10] and the Gibeonites [9:9-10, 24-25]), before recounting the conquest of those who resist Israel. Note also how the lives of Rahab and the Gibeonites are spared on oath (Josh 2:12-14; $6: 25 ; 9: 15,19)$. Whether Joshua 9 is a dtr composition, or an older story redacted, there is no reason to omit it from a Josianic DtrH.

${ }^{86} \mathrm{Cf}$. L'Hour, "L'Alliance de Sichem," 178-81; also Mayes, The Story of Israel, 51-52.

${ }^{87}$ Soggin (Joshua, 240-41), and Boling (Joshua, 246) both follow the theory that the pericope was relocated from Joshua 24. LXX locates it after Josh 9:2.

${ }^{88} \mathrm{Begg}$ has recently argued for a more extensive dtr redaction of Joshua 7-8, which he regards as most appropriate in the context of an exilic DtrH ("The Function of Josh 7,1-8,29 in the Deuteronomistic History," Bib 67 [1986] 32033). The extent of proposed dtr redaction is I think questionable, and the links with Deut 1:19-3:11; 9:7-10:11; Judg 10:6-11:33; 20:1-48; 2 Kgs 22:323:25 somewhat overdrawn. Except for the reference to transgressing the covenant in 7:11 the story does not deal with the infidelity of Israel (the verb ma $\mathrm{cal}^{\mathrm{a}}$ in 7:1 is not deuteronomic or dtr, occurring only in Deut 32:51). Nor does the story condemn the people (as in Deut 1:35, and $2 \mathrm{Kgs}$ 23:26) or speak of their repentance (Judg 10:10-16). Once Achan is eliminated the anger of Yahweh subsides. 
normal sense of "to cross over". The other texts will be shown in the course of the analysis to be later additions. Josh $11: 12 \mathrm{~b}, 15,20$ state that the conquest of the land was carried out by Joshua in scrupulous obedience to the divine command communicated to Moses. In contrast DTR's summary in Josh 11:23 sees the conquest as the fulfillment of Yahweh's word to Moses. These texts are more at home in the later nomistic redaction, with its emphasis on obedience to the law. Beyond these texts there are no other clear examples of later dtr redaction. 89

\section{JOSHUA $12-22$}

Noth included Joshua 12 in DtrH, but omitted Joshua 13-22.90 Joshua 12 provides a list of the lands conquered and allotted to Israel on both sides of the Jordan. It has been appended to the basic statement in Josh 11:23 which, in agreement with Noth, is to be assigned to DTR. Josh 11:23 records the completion of the conquest as the fulfillment of Yahweh's promise to Moses and then gives a brief report on the distribution of the land. From this point of view Joshua 12 may look to be an addition.

Nevertheless there are some considerations in favor of Noth's inclusion of Joshua 12. From a contextual point of view the focus on kings in Joshua 12 is in accord with the account of the conquest, which records the defeat of the kings of Transjordan and Cisjordan. Also, by listing the lands conquered and allotted on both sides of the Jordan it serves to emphasize the unified nature of the conquest and settlement. Josh 12:6b, 7b does differ from Josh 11:23a $\beta$ in having "possession" (yěruššâ) instead of "inheritance" (nahălâ). However a similar phrase to Josh 12:6b, 7b occurs in Deut 2:5 (DTR), 9, 12, 19 (later dtr). There is also the occurrence of the verb to posses in Deut 3:20; Josh 1:15 (both DTR). ${ }^{91}$ Hence it is doubtful whether the shift in terminology is

${ }^{89}$ Boling (Joshua, 139-317) claims Josh 2:1-24; 3:17-4:8; 6:25; 7:10-11; $8: 3-11$; 9:15b-27; 10:12-14 are later redaction (Dtr2), but this is unlikely. For example Josh 2:1-24 is held to be in conflict with the ban of Deut 20:10-20 because of the way Rahab is treated by the Israelites (p. 150). But Deut 20:1020 is meant for those who would lead Israel astray (cf. v 20). Clearly Rahab, who professes faith in Yahweh (Josh 2:9) is not in this category. Furthermore, on the basis of her reception of the spies an oath is entered into, which is honored by Joshua (6:25). Boling also argues that the term 'edá (congregation) in Josh 9:15b-27 indicates a later Dtr2 because Dtr1 avoided this term, except for one example in $1 \mathrm{Kgs} 12: 20$ (p. 268). This hardly amounts to convincing evidence.

${ }^{90}$ Noth, The Deuteronomistic History, 39-40.

${ }^{91}$ Lohfink has analysed the verb yarras (to possess) in conjunction with the verb natan (to give) in Deuteronomy and Joshua ("Kerygmata des Deuteronomistischen Geschichtswerks," 89-96; see also "Die Bedeutungen von hebr. JrS qal und hif.," BZ 27 [1981] 14-33). He concludes that they are dtr, and their concentration in Deuteronomy and Joshua leads him to posit a deuteronomistische Landeroberungserzählung (DtrL) redaction in these two books. The absence of these terms in the later books finds a ready explanation in a $\mathrm{DtrH}$ organized into three periods, as proposed here. The concentration of the 
sufficient to justify different authorship. In sum one may accept that DTR appended Joshua 12 as an appropriate summary of the conquest and allotment of the land.92

Smend and a number of others have argued against Noth's omission of Joshua 13-21 from DtrH, but it is doubtful their case for its inclusion can be sustained ${ }^{93}$ Noth argued that Josh 23:1b is earlier than Josh 13:1a because it was more appropriate to have a reference to Joshua's old age as a preface to his farewell address. According to Smend it is more likely that a later redactor repeated the earlier reference in Josh 13:1a, than that he inserted it at an earlier and so less appropriate stage in the text. ${ }^{94}$ While Noth's argument is open to Smend's objection, his own proposal is itself open to the objection that Josh 13:1a may be an example of the resumptive repetition or ring composition technique detected in other OT texts. In this literary technique a redactor utilizes a phrase from the existing text to make an insertion, in this case Joshua 1321.95 The insertion is thus framed by the two references to Joshua's old age in Josh 13:1a and 23:1b.

Furthermore while Smend's literary critical division of Josh 13:1-7 into vv laba, 7 and $v v 1 b \beta-6$ is acceptable, there are problems with his assignation of the first text to DTR.96 First of all, the parallel text in Josh 1:1-6 does not contain a command to conquer the land, but only to cross over the Jordan. The theme of conquest in Josh 1:2-6 is formulated as a promise. Furthermore, the promise includes the assurance to Joshua that he will cause the people to inherit (năhal) cf. v 6) the land. The two promises are fulfilled in the successful conquest of the land (cf. Josh 11:23aa), and its distribution for an inheritance (nahălâ, cf. Josh 11:23aß). Hence, as Noth observed, the command in Josh 13:7 is superfluous after Josh 11:23aß.97

A second problem with Smend's proposal arises when one compares the two commands in Josh 1:2 and 13:7. If these commands were DTR's way of

terms in the first period is appropriate for its concern with the conquest. The realization of the promise of conquest and occupation of the land within this first period is marked by a shift from the use of the two verbs natan and yaras to the verb natan with the noun yërušsa , as is evident in the texts cited. This would also explain Deut 2:5 (occupation realized). The later additions in Deut $2: 9,12,19$ followed suit.

${ }^{92}$ There is evidence of some later expansion in vv $2 b, 3,5,7 a \beta \gamma, 8$ (Cf. Noth, Das Buch Josua, 71).

${ }^{93}$ Smend, "Das Gesetz," 497-500. See also Gordon J. Wenham, "The Deuteronomic Theology of the Book of Joshua," JBL 90 (1971) 140-48; Auld, Joshua, Moses and the Land, 52-71; Mayes, The Story of Israel, 45, 53. Boling (Joshua, 363, 410-11, 469-70) sees Josh 15:1-17:3*; 17:7-19:50 as Dtrl's account of the distribution of the land, following the end of the conquest in Josh 11:23.

${ }^{94}$ Smend, "Das Gesetz," 497-98.

${ }^{95}$ On this see the discussion by C. Kuhl, "Die 'Wiederaufnahme'-ein literarkritisches Prinzip?" $Z A W 64$ (1952) 1-11. The point is not critical for my reassessment which omits both Joshua 13-21 and 23 from DtrH.

${ }^{96}$ The second text is assigned to DtrN (Smend, "Das Gesetz," 498-500).

${ }^{97}$ Noth, The Deuteronomistic History, 40. 
dividing the account of Joshua's execution of his twofold task-conquest and distribution of the land-then one would expect the first command in Josh 1:2 to have been formulated as a command to conquer the land. It would then have anticipated the parallel command to divide the land in Josh 13:7. However the command in Josh 1:2 makes no reference to this, and indeed appears to be only an introduction for the major concern of Yahweh's address, the promise of conquest and inheritance (cf. Josh 1:2-6).

A third problem is that Josh 13:1aba, 7 is not followed by an account of Joshua dividing the land, as one would expect. Even if Josh 13:8-33 is eliminated and the text of DtrH continued with Josh $14: 1$, the sequence is still unsatisfactory. Joshua is presented here as one among several in charge of the distribution of the land, and is named after Eleazar the priest. One could posit an earlier version of Josh $14: 1$ in which only Joshua appeared, but there is no literary critical evidence in the verse to support such a reconstruction. Given the complex nature of Joshua 13-21 and the generally accepted opinion that the chapters were accumulated over a long period of time it seems best therefore to attribute Josh 13:1aba, 7 to a late redactor who wanted to bring some sense of unity into the material by composing a general introduction for it. ${ }^{98}$ Josh $13: 1 b \beta-6$, which addresses the matter of the unfinished conquest, was probably added with, or in view of, a series of notices about the limits of Israel's conquest in Josh 13:13; 15:63; 16:10; 17:11-13; 19:47 (LXX); Judg 1:1636.

Boling includes a basic account of the distribution of the land (Josh 15:117:3*; 17:7-19:50) in DtrH by omitting the introduction in Josh 13:1-7 and attaching the account directly to Josh 11:23.99 A significant element in Boling's argument is that the lists, in particular those in Josh 15:20-63 and $18: 21-28$, reflect the expansionist policies of king Josiah. ${ }^{100}$ However the evidence for this is not at all assured as Boling seems to suppose, and the inclusion of the proposed material in DtrH cannot be justified on this basis. ${ }^{101}$

${ }^{98}$ This may well have been a priestly redactor. Priestly interest can be seen in Josh $14: 1 ; 17: 4 ; 18: 1-10 ; 19: 51 ; 21: 1$. The reference to Joshua only in 13:1 a was appropriate in the context of the larger book of Joshua. As for terminology $P$ uses the term "inheritance" in Num 17:62; 18:21, 24; 26:53-56; 36:3. Von Rad was of the opinion that "the lists in Joshua must be assigned to P" ("The Promised Land and Yahweh's Land in the Hexateuch," The Problem of the Hexateuch and other Essays [London: SCM, 1984] 79-93; p. 80, n. 1).

${ }^{99}$ Boling, Joshua, 363.

${ }^{100}$ Ibid., 393. Boling accepts Cross's hypothesis of a Josianic DtrH.

${ }^{101}$ Albrecht Alt saw evidence of Josiah's expansion into the north and annexation of certain territories in the lists in Joshua ("Judas Gaue unter Josia," Kleine Schriften zur Geschichte des Volkes Israel [Vol 2; Munich: C. H. Beck'sche Verlagsbuchhandlung, 1953] 276-88, especially p. 287). Also Noth, Das Buch Josua, 91. However Peter Welten is much more skeptical about whether Josiah actually expanded his influence into the north (cf. Die KönigsStempel. Ein Beitrag zur Militärpolitik Judas unter Hiskia und Josia [Abhandlungen des Deutschen Palästina-Vereins 1; Wiesbaden: Harrassowitz, 1969] $100-102,163,166)$. H. Darrell Lance ("The Royal Stamps and the Kingdom of Josiah," HTR 64 [1971] 315-32) concludes, against Alt and Noth, that "the 
On a more directly textual basis, the shift in terminology from "divisions" (măhleqoft) in Josh 11:23aß to the unusual term "lot" (górāl) in Josh 15:1 makes it unlikely that these two verses were in immediate sequence. Furthermore, the content of Joshua's speech in Josh 18:3-7 and the subsequent lot casting ceremony does not sit comfortably with the proposal that the short final statement in Josh 11:23a $\beta$ was the introduction to the whole. Overall therefore Boling's arguments are not able to retrieve Joshua 15-19 for inclusion in DtrH. ${ }^{102}$ However, he is correct in identifying Josh 20:1-21:42 as a later addition. ${ }^{103}$

The earlier discussion of Deut 12:8-12 has shown that, in disagreement with Noth, Josh 21:43-45 should be included in the text of DtrH. ${ }^{104}$ The passage records the fulfillment of the promises in Deuteronomy of conquest, occupation, and rest from enemies (cf. Deut 12:10-11). ${ }^{105}$ In terms of DTR's

absence of the stamps at Bethel indicates that that city was not incorporated into Judah and renders impossible the Josianic date long proposed by Alt and Noth for the Judean province in Josh 18:21-28 which includes Bethel and other cities in the environs" (p. 332). Cf. also H. Spieckermann, Judah unter Assur, 113-14, nn 179, 182.

102 Some consideration should be given here to the proposal by Auld (Joshua, Moses and the Land, 56-67). Auld noted the unusual use of the term goral in Josh $14: 2 ; 15: 1 ; 16: 1 ; 17: 1,17$ to describe an allotment rather than a lot cast or drawn, which is its normal meaning (cf. Josh 18:10). On the basis of the LXX he proposes that the MT originally had "territory/border" (gebuul). This was changed to goral when the account of the lot casting ceremony in Josh 18:1-10 was added. According to Auld the lists in Joshua 18-19 originally did not contain their "lot" introductions either. These, like the insertion of the same term in Josh 15:1-17, were added along with Josh 18:1-10 (ibid., 67). Auld, who accepts Smend's analysis of Josh 13:1-7, proposes that Josh 13:1 was followed by Josh 13:7-9*, 11; 15:1-17:10*; 18:11-19:48 (omitting the "lot" terminology). Auld's hypothesis is ingenious, but involves the removal of the seven "lot" introductions in Joshua 18-19, replacing them with a hypothetical earlier introduction for which there seems to be little evidence. Both the MT and LXX have the term goral in Josh 18:11; 19:1, 10, 17, 24, 32, 40. In addition Auld is still left with the problem of the relationship between Josh 13:1, 7 and 1:1-6.

${ }^{103}$ Boling, Joshua, 473, 485, 497. Joshua 20 deals with a legal provision and as such does not belong to the theme of the people's inheritance in the land (against Mayes, The Story of Israel, 53-54). The introductory verses of Josh 21:1-42 show that this text shares the same priestly interests observed in Josh $14: 1 ; 17: 4 ; 18: 1-10 ; 19: 51$. The Levite cities moreover are not distributed by Joshua, but on the command of the Lord, and via a drawing of lots.

${ }^{104}$ Noth, The Deuteronomistic History, 40. The passage is included by Smend ("Das Gesetz," 501) and Mayes (The Story of Israel, 55).

${ }^{105}$ As pointed out in the discussion of Deut 12:8-12 the promise of rest is pronounced in Deut $12: 10$ and its realization in the course of Israel's history monitored by DTR (cf. Josh 21:44; 2 Sam 7:1b, 11; 1 Kgs 5:18 [RSV 5:4]; 8:56). The basic study on this is Braulik, "Zur deuteronomistischen Konzeption von Freiheit und Frieden." 29-39. Note also the presence of the verbs "to give" and "to possess" in Josh 21:43. The reference to "enemies" in Josh 21:44 is in 
conceptual plan and structure therefore the text states that the full realization of the program promised in Deuteronomy was well in sight. All that remained was the centralization of worship at the place Yahweh would choose. It was only the infidelity of the post-conquest generations which delayed it (cf. Judg $\left.2: 10 \mathrm{~b}-19^{*}\right)$. This situation was resolved by the inauguration of the period of the prophets and kings, and centralization of worship finally achieved under Solomon. $1 \mathrm{Kgs}$ 8:56 celebrates the full realization of the promise and so provides an important structural link with Josh 21:43-45.

The final text to be considered in this section is Joshua 22. Josh 22:1-4, 6 forms a satisfactory conclusion to the role played by the Transjordan tribes in the conquest (cf. Deut 3:18-20; Josh 1:12-18). Joshua's address to these tribes serves once again to confirm that his task was the completion of what Moses had begun. The passage contributes to DTR's concern to bind the Transjordan and Cisjordan stages of the conquest together, and so present an overall unified account. It should therefore be included in DtrH. The clear nomistic terminology in Josh 22:5 points to this verse being a later addition. For its part Josh 22:7-34 is generally accepted as a late addition to Joshua, most probably from priestly circles. ${ }^{106}$

\section{JOSH 23:1-JUDG 2:10}

The final section of this first period of the history, the complex conclusion to the book of Joshua (Joshua 23-24) and the beginning of the book of Judges (Judg 1:1-2:10), has proved to be a troublesome one for scholarship. A clear identification of DTR's text has been obscured, I believe, by the conviction that there had to be, as Noth proposed, a dtr speech at this stage of the history. Hence attention tended to focus on Joshua 23 and Josh 24:1-28 as the two candidates for the expected dtr speech. Unfortunately this led to neglect of the surrounding material in Josh 24:29-31 and Judg 2:6-10. Mayes has now pointed a way out of this difficulty by proposing that neither Joshua 23 nor Josh 24:1-28 is to be assigned to DTR. ${ }^{107}$ Nevertheless he does not take the necessary step of satisfactorily accounting for the text of DtrH once the two speeches have been removed. Before supplying this lacuna however the proposal to remove Joshua 23 and Josh 24:1-28 from the text of DtrH needs to be justified.

The principal arguments against the inclusion of Joshua 23 in DtrH are as follows. ${ }^{108}$ First, there is the fact that Joshua 23 speaks throughout of "nations" conquered and yet to be conquered (cf. vv 3,4,7,9,12,13), whereas

accord with DTR's usage elsewhere (cf. Josh 10:25; Judg 2:14, 18; 2 Sam

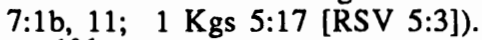

${ }^{106} \mathrm{Cf}$. Noth, Das Buch Josua, 133; and in particular the discussion by John S. Kloppenborg, "Joshua 22: The Priestly Editing of an Ancient Tradition," Bib 62 (1981) $347-71$. Josh $22: 7-8$ is a redactional link to the story of the altar by the Jordan in vv 9-34.

${ }^{107}$ Mayes, The Story of Israel, 48-51.

${ }^{108}$ The arguments here have been developed from those of Smend, "Das Gesetz," 501-3. Cf. also Mayes, The Story of Israel, 48. The dtr nature of the chapter is undisputed. 
in the account of the conquest and occupation of the land DTR consistently refers to "enemies" (cf. Josh 10:25; 11:23; 21:44; cf. also 2 Sam 7:1b, 11; 1 Kgs 5:17 [RSV 5:3]). ${ }^{109}$ Second, there is the evidence of nomistic language in the chapter, particularly in $v 6$. In concert with this, the chapter contains similar warnings against disobedience to those noted in the secondary passages in Deuteronomy $4 ; 29-30$. While this does not mean that the texts came from the same hand, there is a common concern with the threat of disobedience to the law which would be in keeping with a particular school of thought.

The third argument is based on the recognition that, apart from the introduction in Josh 23:1-2aba, Joshua's speech can be readily divided into three sections, vv $2 b \beta-8,9-13,14-16$. A closer inspection of these sections suggests that they have been composed with the three verses of Josh 21:43-45 in mind. The first section deals with the conquest and possession of the land (vv 4-5, cf. Josh 21:43). The second section tells how the nations have not been able to withstand Israel ( $\mathrm{v} 9$, cf. Josh 21:44). The third section takes up the theme of the realization of the promises (v 14-15, cf. Josh 21:45). The initial impression that Joshua 23 was composed on the basis of Josh 21:43-45 is strengthened when one observes that each section modifies the relevant verse in Josh 21:43-45.

Thus Josh 23:2-8 takes up Josh $21: 43$ by acknowledging victory over the nations, but sees the final possession of the land as a future promise, dependent on the people's fidelity to the law of Moses (v 6). Josh 23:9-13 in its turn subtly corrects Josh 21:44 by stating that "no man has been able to withstand you to this day" ( $\mathrm{v} 9 \mathrm{~b}$ ). This modification is more suited to a context of nations remaining to be conquered, the condition of obedience to the law, and the threat of disaster in the event of Israelite infidelity. Finally, Josh 23:14-16 affirms the fulfillment of the promises as in Josh 21:45, but describes them in terms of blessings received (the "good things" of v 15a) in order to warn Israel of the curses (the "evil things" of v 15b) that will follow transgression of the covenant.

F. M. Cross and R. D. Nelson have attempted to retain Joshua 23 within DtrH by carrying out a literary critical division. ${ }^{110}$ But an examination of the compositional technique used in the chapter shows that it is very much a unity and resists literary critical analysis. Each of the sections identified above is introduced by a statement ( $v v 2 b \beta-3,9-10,14$ ) which then provides the basis for a paranesis. Furthermore, there is a carefully structured development in the paraneses over the course of the three sections. Josh 23:6-7 ends the first

${ }^{109}$ Josh 23:1a uses the term "enemies". However the statement conceming rest from enemies in this verse is clearly in conflict with the thrust of Joshua's speech, which addresses a critical stage within an as yet uncompleted campaign of conquest. It is most likely therefore that the verse is an abbreviation of Josh 23:44, and was added to the introduction to Joshua's speech when Josh 21:43-45 and Joshua 23 became further separated by the insertion of Josh 22:7-34.

${ }^{110} \mathrm{~F}$. M. Cross assigns Josh 23:11-13, 15-16 to the exilic Dtr2 (Canaanite Myth and Hebrew Epic, 287), whereas R. D. Nelson opts for vv 4, 7, 12-13 (The Double Redaction, 123). Unfortunately neither outlines his arguments in support of the literary critical division. Boling (Joshua, 526) holds that the chapter originated with Dtr 1, but that it was completely overwritten by Dtr 2 . 
section with an exhortation. In the second section the exhortation in Josh 23:11-13 is coupled with a warning. In the third section Josh $23: 15-16$ is no longer simply a warning, but in effect functions as a prophecy of disaster for Israel's transgression of the covenant. ${ }^{111}$

The chapter is best regarded therefore as a carefully composed whole. If there is a case for any literary critical division, apart from the reference to rest from enemies in Josh 23:1a, it would be in $v 7$. This is a cumbersome sentence and it is introduced asyndetically. Even so, it does serve to prepare for and sharpen the condemnation of mingling with the nations in $v 12$. A reasonable conclusion therefore is to identify Joshua 23 as a composition by a skilled scribe during the later nomistic redaction of DtrH. ${ }^{112}$ The structural and thematic significance of this speech will be commented on once the analysis of the text of the history is complete.

Turning to Josh $24: 1-28$ it is immediately clear that this is a more complex passage than Joshua 23. There is general agreement that the present text is a redaction of an older source, although opinions vary considerably about the nature and date of this source. ${ }^{113}$ As one would expect, this has also led to considerable debate about the redaction history of the text and how much of this

${ }^{11}$ This has been noted also by R. Polzin, Moses and the Deuteronomist, 141. Note that Josh $23: 16$ is introduced by bécobrēkem. The preposition bé is a deliberate change from the normal conditional particle $k \hat{\imath}$ or $1 \mathrm{~m}$. This indicates an exilic perspective. As observed earlier DTR did not use the verb cabar to describe the transgression of the covenant (cf. Deut 17:2; Josh 7:11, 15; Judg

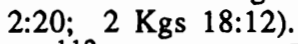

${ }^{112}$ The unity of Joshua 23 is upheld against Cross by Stahl ("Aspekte," 37 39), who assigns it to DtrN.

113 For Noth (Das Buch Josua, 139) it is pre-deuteronomic. L'Hour ("L'Alliance de Sichem," 34-36) holds that the text records an old tradition of a covenant at Shechem. A more precise conclusion is reached by Herbert Mölle (Der sogenannte Landtag zu Sichem [FB 42; Würzburg: Echter, 1980] 252-59) who argues for an original version from between 1200 and 1000 BC. McCarthy (Treaty and Covenant, 283) linked its origins with the revival of Yahwist opposition to syncretism around the time of Elijah. In contrast, Lothar Perlitt (Bundestheologie im Alten Testament [WMANT 36; Neukirchen-Vluyn: Neukirchener Verlag, 1969] 274-79) holds that the basic account should be located in the period between Hezekiah and Josiah, probably during the reign of Manasseh. This is followed by Karl Jaros (Sichem [OBO 11; Göttingen: Vandenhoeck \& Ruprecht, 1976] 139-51). Boling (Joshua, 533) is reluctant to give a date, but affirms the text is old and had a long history of development. Soggin (Joshua, 14) states simply that it is a pre-deuteronomic narrative. Van Seters ("Joshua 24 and the Problem of Tradition in the Old Testament," In the Shelter of Elyon. Essays on Ancient Palestinian Life and Literature in Honor of $G$. W. Ahlström [ed. W. B. Barrick \& J. R. Spencer; JSOTSup 31; Sheffield: JSOT, 1984] 139-58) regards it as a post-dtr composition by the Yahwist. It functioned as a summing up and conclusion of the Yahwist's own history (Genesis to Numbers) which was combined with DtrH. Hoffmann (Reform und Reformen, $300-306$ ) is alone in claiming that it was formulated by DTR (post-exilic). 
redactional activity is attributable to DTR. ${ }^{114}$ Nevertheless, for the purposes of this discussion there is no need to debate the precise distribution of redactional elements in Josh 24:1-28. Whether one considers the present text, or an earlier version, there is convincing evidence that the account of the Shechem assembly was not part of DTR's text.

Within the present text it is clear that Josh 24:14-15 confronts the people with a choice between Yahweh and other gods. ${ }^{115}$ From the context of DtrH examined so far such a choice is unthinkable. ${ }^{116}$ Furthermore, the account of the activities of the conquest generation provides no grounds for a renewal of their commitment to Yahweh. The only misdemeanor reported is the greed of Achan in Joshua 7, which infected Israel and sapped its military strength, but was certainly not a case of apostasy by the people. As well as this the account of Joshua's covenant, and the establishment of a statute and ordinance in Josh $24: 25$, is inconsistent with DTR's understanding of his role as leader. ${ }^{117}$ Joshua was commissioned to complete the conquest initiated by Moses (Deut 31:7-8; cf. Josh 1:1-6), not to establish a new program on his own authority.

A third factor militating against the inclusion of Joshua 24 is the historical review in Josh 24:2-13. It possesses two features which are at odds with comparative passages in DtrH (cf. Deut 6:20-25; 26:5-11; Josh 4:21-24). First, the review is cast as a Yahweh speech introduced by the prophetic messenger formula in $v 2$. Second, it begins with the ancestors who lived

${ }^{114}$ Noth saw dtr redaction in Josh $24: 4^{*}, 8 b, 9 b, 10 a b a, 12 a, 13 a \beta b, 17 *$, 19-24 (Das Buch Josua, 135-46). According to Mölle, the original version underwent an $\mathrm{E}$ reworking shortly before the northern exile, a JE reworking shortly after this exile, and two dtr redactions, one pre-exilic and the other exilic. The first Dtr was not the redactor of DtrH, but a dtr redactor of the JE Hexateuch. The incorporation of Joshua 24 into DtrH was carried out by the second exilic redactor (Der sogenannte Landtag zu Sichem 284-97). McCarthy was cautious about the amount of text that could be attributed to dtr redaction (Treaty and Covenant, 232-34). Perlitt holds that the text was only glossed by dtr redaction (Bundestheologie im Alten Testament, 274); a similar view is expressed by Boling (Joshua, 533). Soggin notes that "the work of the Deuteronomic editor reappears throughout the text" but apart from identifying redaction in vv 25-27 offers little specific comment (Joshua, 226-41). For L'Hour the old source was redacted by a post-dtr redactor ("L'Alliance de Sichem," 35-36, 182).

${ }^{115}$ For a defense of the unified and carefully structured nature of the present text see Charles H. Giblin, "Structural Patterns in Joshua 24,1-25," $C B Q 26$ (1964) 50-69. Giblin recognizes however that the final version was probably the result of considerable scribal effort over a long period of time.

${ }^{116}$ So also McCarthy, Treaty and Covenant, 228, and Johannes Peter Floss, Yahwe Dienen-Göttern Dienen. Terminologische, literarische und semantische Untersuchung einer theologischen Aussage zum Gottesverhältnis im Alten Testament (BBB 45; Bonn: Peter Hanstein, 1975) 370. Against Noth, The Deuteronomistic History, 102, n. 15.

${ }^{117}$ Josh 24:25 states that Joshua "established" (wayyasem) a statute and an ordinance. This is clearly a reference to something new. L'Hour ("L'Alliance de Sichem," 361-64) proposed that the verse originally referred to a law code such as Exodus 20-23, which was subsequently relocated. 
"beyond the river" ( $v 2$ ). In all other such texts the review does not go beyond the sojourn in Egypt and the Exodus. ${ }^{118}$ In addition one may note that Josh 24:11-12 does not square well with the account of the conquest in Joshua 2-11. The story of the capture of Jericho in Joshua 6 does not record any sortie against Israel by the inhabitants of Jericho. The reference to the two kings of the Amorites in Josh 24:12 is also at odds with the account of the conquest, if one accepts the MT reading as a reference to the Transjordan kings Sihon and Og. ${ }^{119}$

If one takes an earlier version of the text it would, in order to provide a coherent account of the assembly at Shechem, have to contain the following elements: a basic version of the historical review, cast as a Yahweh speech and commencing with the ancestors "beyond the river" (Josh 24:2-13*); the choice between Yahweh and the gods "which your fathers served beyond the river" (vv 14-15); a response by the people (vv 16-18*); Joshua's acceptance of their commitment ( $\mathrm{v} 22$ ); and a suitable conclusion, for example, Joshua's erection of the stone of witness and dismissal of the people (26b, 27-28). ${ }^{120}$ In short then, such a text records an exclusive commitment to Yahweh by a people who up to that time had worshipped a number of gods. Moreover, the commitment is made on the authority of Joshua, without any reference to his commission by Moses. Obviously a text of this nature is as much out of context in DtrH as the present text.

A final comment is in order on the well recognized association between Josh 24:1-28 and other "Shechem" texts such as Deut 11:29-32; 27:1-26 and Josh 8:30-35. These texts have all been seen to be later additions to the history. It is tempting therefore to see Josh $24: 1-28$ as part of the same redactional layer. ${ }^{121}$ Nevertheless caution is counselled because Josh $24: 14-15$ creates the same tension with the aforesaid texts as with DtrH. Hence it may be wiser to conclude that the text was inserted in order to provide a model for covenant commitment after the warnings of Joshua 23, in particular the transgression of the covenant in $\mathrm{v} 16 .{ }^{122}$ There was probably also a concern to preserve important Shechem traditions, stimulated by the presence of such passages as Deut 11:29-32; 27:1-26 and Josh 8:30-35. An additional reason for its insertion could have been that of forging a link with the Pentateuch. This is indicated by the nature of the historical review in Josh 24:2-13.123

${ }^{118}$ Deut $26: 5$ begins with a reference to the wandering Aramean, but passes immmediately to the sojourn in Egypt.

${ }^{119}$ The LXX seems to have emended the MT to read twelve kings of the Amorites. For a discussion see Boling, Joshua, 537.

${ }^{120}$ The text of Mölle's original version is Josh $24: 1 a a^{*}, 2 a a b, 3 *, 4 b \beta$, $6 \mathrm{aab}, 7 \mathrm{a} a^{*}, 8 \mathrm{aa} *, 14 \mathrm{a}^{*} \mathrm{~b}^{*}, 15,16 \mathrm{aa}, 18 \mathrm{ba}, 22,26 \mathrm{~b}$ (Der sogenannte Landtag zu Sichem, 284-97).

${ }^{121}$ So L'Hour ("L'Alliance de Sichem," 365-68), who assigns them to a postdtr redactor.

${ }^{122}$ For an analysis of Joshua 24 as an example of the covenant formulary see Baltzer, The Covenant Formulary, 19-27; and the discussion by McCarthy, Treaty and Covenant, 221-42.

${ }^{123}$ Cf. Van Seters ("Joshua 24," 154)-without subscribing to his position that it was composed by an exilic Yahwist. 
We are now in a position to identify DTR's text in this portion of the history. Noth proposed that Judg 2:6-10 was DTR's conclusion to the conquest and occupation. ${ }^{124}$ However Mayes and a number of others propose that Josh 24:29-31 or a combination of verses from both passages was the true conclusion. The one who comes closest to correctly identifying the text of $\mathrm{DtrH}$ is Smend. ${ }^{125}$ His recognition of Josh 24:29-31; Judg 2:10 as DTR's conclusion is marred only by his inclusion of Josh 24:1-28 in the text. Also Smend's article length study seems to have precluded a full examination of the textual evidence in Josh 24:29-31 and Judg 2:6-10. This needs to be carried out.

The secondary nature of Judg 2:6-9 in relation to Josh 24:29-31 and Judg 2:10 may be seen initially from a comparison of the dismissal notice in Judg 2:6 and its parallel in Josh 24:28. There are two expansions in Judg 2:6, indicating it is a later composition which used the other dismissal notice in Josh $24: 28$ as a model. ${ }^{126}$ Next, the differences in vocabulary and sequence of verses between Josh 24:29-31 and Judg 2:7-9 show that the latter verses are the later composition. ${ }^{127}$ In terms of vocabulary Judg 2:7 expands on Josh 24:31 by adding the adjective "great" to the description of Yahweh's work on Israel's behalf. In addition Judg 2:7 contains the verb "to see" ( $\left.r \bar{c}^{3} \hat{a}\right)$ in contrast to Josh 24:31 and Judg 2:10, which contain the verb "to know" (yãda). ${ }^{128}$ This change seems to have been influenced by the occurrence of the verb (rãa) in Josh 23:3 and 24:7. On the question of textual sequence the reversal of the order of Josh 24:29-31 in Judg 2:7-9 is no doubt due to the dismissal notice in Judg 2:6. It

${ }^{124}$ Noth, The Deuteronomistic History, 42. Also Nelson, The Double Redaction, 43, 61; Eamon O'Doherty, "The Literary Problem of Judges 1, 1-3, 6," $C B Q 18$ (1956) 1-7; Van Seters, In Search of History, 342; Weinfeld, "The Period of the Conquest and of the Judges as Seen by the Earlier and the Later Sources," VT 17 (1967) 93-113, see p. 97, n.1.

${ }^{125}$ Smend, "Das Gesetz," 506. Of the others Mayes (The Story of Israel, 59, 161) assigns Josh 24:29-30 to DTR, and Judg 2:6-10; Josh 24:31 to later redaction. Boling (Judges, 30) assigns Judg 2:6-10 to an eighth century collection of the judges stories, and Josh 24:1-28, 31 (following LXX), 29-30 to DTR (Joshua, 541). W. Richter (Bearbeitungen, 46-49) has a complex and unwieldy interpretation. He argues that Judg 2:8-9 originally came after Josh 24:1-27*, 28; DTR added Judg 2:7, 10 to make a link between Joshua and the judges. Judg 2:6 was added along with Joshua 23; Judg 1:1-2:5. Some expansion in Judg 2:7, 10 can be attributed to this redaction also. Josh 24:2930 is a later addition paralleling Judg 2:8-9, with Josh $24: 31$ a late doublet of Judg 2:7. Hartmut N. Rösel ("Die Uberleitungen vom Josua- ins Richterbuch," $V T 30$ [1980] 342-50) sees Josh 24:1-Judg 2:5 as earlier than Joshua 23 and Judg 2:6-10. J. Schüpphaus (Richter- und Prophetengeschichten, 126-30) assigns Josh 24:1-31; Judg 2:10 to his pre-dtr history. Soggin (Judges, 40-41) assigns Josh 24:28-30 to DTR, with Judg 2:6-10 later.

${ }^{126}$ So Rösel, "Die Uberleitungen," 344 . Noted also by Richter (Bearbeitungen, 46-47). The expansions are "the people of Israel went" and "to take possession of the land". Against Rösel however this does not mean that Judg 2:6 can be taken as a displaced dismissal notice for Joshua 23 .

${ }^{127}$ The LXX of Josh $24: 30$ contains a note about the depositing in Joshua's tomb of the knives used for circumcision.

${ }^{128} \mathrm{Cf}$. Rösel, "Die Úberleitungen," 344, and Richter, Bearbeitungen, 47. 
made better sense in this context to have the dismissal notice and the dtr comment contiguous to each other. In DTR's text however there was no assembly and no dismissal. Hence the text followed a simpler sequence: notice of Joshua's death (Josh 24:29); burial (Josh 29:30); DTR's comment (Josh 29:31). 129

Judg 2:10 has no duplicate in Josh 24:29-31. It is significant however that the verse uses the same verb yada as Josh 24:31. Moreover, it follows quite smoothly after this verse. Given that Judg 2:6-9 is dependent on Josh 24:2931 , it is reasonable to propose that Judg 2:10 originally followed Josh 24:2931 . It was relocated as part of a ring composition technique, comprising Judg 2:6-10, in order to incorporate the addition of Judg 1:1-2:5 within the period of the conquest and occupation of the land rather than the period of the judges. ${ }^{130}$

Two further observations support the identification of DTR's text as Josh 24:29-31; Judg 2:10. First, Josh 24:31 and Judg 2:10a form an inclusion with Deut 2:14-16, the notice of the death of the exodus generation which marked the emergence of the conquest generation in its place. Hence the texts serve as an appropriate conclusion to the period of Israel under Moses and Joshua. Second, as DTR's conclusion to the account of this period, Josh 24:29-31 and Judg 2:10a provide a nice balance to the introduction to the period of Israel from the judges to the monarchy in Judg $2: 10 \mathrm{~b}, 11-19^{*}$.

${ }^{129}$ In the LXX Josh 24:31 is located after Josh 24:28. Against Boling (Joshua, 533, 541) this does not justify changing the order of the MT. The LXX relocation was no doubt done on the basis of the sequence in Judg 2:6-7. Also because Josh $24: 29$ did not originally belong with Josh $24: 28$, there is no need to regard the introductory wayehî in $\mathrm{v} 29$ as an indication of a later addition, as does Richter (Bearbeitungen, 48).

${ }^{130} \mathrm{Judg} 1: 1-2: 5$ is accepted as a later addition to the history by Noth, The Deuteronomistic History, 8 and Mayes, the Story of Israel, 60-61). E. Theodore Mullen has carried out a close study of Judg 1:1-36, showing that it is dependent on Joshua 14-19 ("Judges 1:1-36: The Deuteronomistic Reintroduction of the Book of Judges," HTR 77 (1984) 33-54. Rösel however argues for Josh 24:1Judg $2: 5,11 \mathrm{ff}$. as the earlier dtr sequence, with Judg $2: 6-10$ as a later addition along with Joshua 23 ("Die Überleitungen," 342-48). Apart from my difficulty with his inclusion of Joshua 24, the removal of Judg 2:10 creates an unacceptable link between Judg 2:5 and 2:11ff. Boling (Judges, 30) assigns Judg 1:1-36 to a sixth century Dtr, Judg 2:1-5 to the Josianic DtrH and Judg 2:610 to an eighth century "pragmatic collection" (pre-dtr). Prescinding from the question of date the secondary nature of Judg 1:1-36 in relation to DtrH is in agreement with the position argued here. However the inclusion of Judg 2:1-5 in DtrH is problematic. It creates an awkward sequence after Josh $24: 1-28,31$, 29-30, which Boling-following LXX-also includes in DtrH. Without Judg 1:1-36 with its version of the conquest as a mixture of success and failure, and of coexistence with the inhabitants of the land, it is difficult to find a raison d'être for Judg 2:1-5. The clear evidence for Judg 2:6-9 being dependent on Josh 24:29-31 renders untenable Boling's position that it is earlier than DtrH. 


\section{THE PERIOD OF ISRAEL FROM THE JUDGES TO THE MONARCHY Judg 2:11-1 Sam 11:15}

As indicated in the preceding chapter Judg 2:10 is a pivotal text in DtrH. The notice of the passing of the faithful conquest generation in Judg 2:10a concludes DTR's account of the period of Israel under Moses and Joshua. The immediately following information in Judg 2:10b about the emergence of a generation "who did not know the Lord or the work which he had done for Israel" alerts the reader to the beginning of a new and troubled period in Israel's history. The introductory comment in Judg 2:11-19*, which balances Josh $21: 43-45 ; 24: 29-31$, effectively begins DTR's presentation of the second period of the history.

DTR organized the account of this period in the following manner. There is first of all the introduction in Judg 2:11-19*. Second, there is the two stage development of the story of the judges. The first stage extends from Judg 3:710:5; the second stage extends from Judg 10:6-1 Sam 7:17*. Third, there is the important transition from the judges to the monarchy, recounted in 1 Sam $8: 1-11: 15^{*}$. The analysis will concentrate therefore on detailing the nature and extent of DTR's work in each of these sections and how each contributes to the overall structure and conceptual plan of the history. There are however a number of passages whose omission from DtrH needs to be justified. A convenient division of the present text which enables the analysis to treat the text of DtrH in conjunction with these later additions is Judg 2:11-3:6 (introductory material); Judg 3:7-1 Sam 7:17 (the judges); 1 Sam 8:1-12:25 (emergence of the monarchy).

\section{JUDG 2:11-3:6}

The present text of Judg 2:11-3:6 is complex and gives evidence of considerable later expansion. Nevertheless DTR's introduction to the story of the judges can be identified with reasonable certainty in the following text. ${ }^{1}$

${ }^{1} \mathrm{M}$. Noth (The Deuteronomistic History, 7-8) proposed Judg 2:6-11, 14-16, 18-19 as DTR's text. A. D. H. Mayes (The Story of Israel, 68) proposes Judg $2: 11,12 \mathrm{aa}, 13 \mathrm{~b}, 14-16$ (gloss in 15aß), 18aßb, 19aab. W. Richter (Bearbeitungen, 35) has Judg 2:11-12,14, 15aab, 16, 18adb, 19, and J. A. Soggin (Judges, 42) Judg 2:11-12, 14-16, 18-19. R. G. Boling (Judges, 30, 74-76) sees three editions in Judges 2; an eighth century edition in Judg 2:6-10, 11-23; 3:1-6, a seventh century edition from a Deuteronomic History (DtrH) in Judg 2:15 , and finally a sixth century dtr edition in Judg 1:1-36. What is missing in his analysis is a satisfactory treatment of the literary critical and linguistic evidence in vv 11-23. J. Schüpphaus (Richter- und Prophetengeschichten, 131-42) claims a pre-dtr core in Judg $2: 10,13,14 a a b \beta, 15 b, 18$. Schüpphaus does pay 
(2:11) "And the people of Israel did what was evil in the sight of the Lord and served the Baals. (2:14) So the anger of the Lord was kindled against Israel, and he gave them over to plunderers, who plundered them; and he sold them into the power of their enemies round about, so that they could no longer withstand their enemies. (2:15aaßb) Whenever they marched out, the hand of the Lord was against them for evil, as the Lord had warned; and they were in sore straits. (2:16) Then the Lord raised up judges, who saved them out of the power of those who plundered them. (2:18aßb) The Lord was with the judge, and he saved them from the hand of their enemies all the days of the judge; for the Lord was moved to pity by their groaning because of those who afflicted and oppressed them. (2:19aab) But whenever the judge died, they turned back, and behaved worse than their fathers; they did not drop any of their practices or their stubborn ways."

The justification for this text emerges from a number of considerations. First, on the contextual level I would recall the observation made at the conclusion of the preceding chapter that such an introduction to the period of Israel from the judges to the monarchy balances DTR's conclusion to the period under Moses and Joshua in Josh 24:29-31; Judg 2:10. This is particularly so when one observes how Judg $2: 10 \mathrm{~b}$ leads in to Judg 2:11 and the following verses. A second point on the contextual level is the way the proposed text reflects the basic pattern of the framework passages around the subsequent stories of the judges: that is, description of Israel's infidelity ( $v$ 11), Yahweh's reaction and handing over of Israel to oppression by its enemies ( $v$ 14, 15aaßb), the raising up of a judge by Yahweh to deliver Israel ( $v$ 16), subjugation of the enemy during the days of the judge ( $\mathrm{v} 18 \mathrm{aßb})$, Israel's lapse back into infidelity after the death of the judge (v 19aab).

The only elements from the framework passages not present in Judg 2:1119 are Israel's cry to Yahweh for deliverance, and the report that the land enjoyed rest for a number of years after Israel's deliverance. ${ }^{2}$ One can easily see that the notices of rest with their chronological information belong properly to the particular stories and not to a general introduction. ${ }^{3}$ The absence of the cry for deliverance in the introduction is at first glance unusual,

attention to the literary critical evidence in Judg 2:11-19 but fails to note the linguistic and contextual evidence for assigning the bulk of the pericope to DTR.

${ }^{2}$ The framework passages in the judges' stories are as follows. 1)- the accusation of Israelite infidelity (cf. Judg 3:7, 12;4:1; 6:1; 10:6;13:1); 2)Israel's oppression by enemies (cf. Judg $3: 8,12 ; 4: 2 ; 6: 1 ; 10: 7 ; 13: 1$ ); 3)Israel's cry to Yahweh (cf. Judg $3: 9,15 ; 4: 3 ; 6: 6 ; 10: 10 \mathrm{a}) ; 4)-$ Yahweh raises up a deliverer for Israel (cf. Judg 3:9, 15. For the other stories the raising up of a deliverer is an integral part of the narrative and presumably did not require a special statement); 5)- subjugation of the enemy (cf. Judg $3:[10], 30 ; 4: 23$; $8: 28$; 11:33); 6)- rest for the land (cf. Judg $3: 11,30 ; 5: 31$; 8:28); 7)Israel's lapse back into infidelity (cf. Judg $3: 12 ; 4: 1 ; 6: 1 ; 8: 33 ; 10: 6 ; 13: 1$ ).

${ }^{3}$ While the chronological notices belong in the individual stories one may note that the concept is implicit in the statement in $v 18$ that Yahweh saved Israel "all the days of the judge". 
but there is the report in Judg $2: 15 \mathrm{~b}$ that Israel was sorely distressed. ${ }^{4}$ It is worth noting that this report occurs only here and in Judg 10:9b, DTR's introductions to the two stages of the history of the judges.

On a more specific level the text contains references to enemies in vv 14 and 18. This was found in the preceding chapter to be part of DTR's terminology (cf. Deut 1:42; 12:10; Josh 10:25; 11:23; 21:44; —cf. also 2 Sam 7:1b, 11; $1 \mathrm{Kgs} 5: 17$ [RSV 5:3]). ${ }^{5}$ The term does not occur in the framework passages for the stories of the judges, although this may be explained by the fact that each story deals with a particular enemy who is named. In addition to this Judg 2:16 refers to Yahweh raising up judges. This is in contrast to the framework texts of Judg 3:9, 15 which describe Yahweh raising up a deliverer. The shift in terminology in Judg 2:16 is in keeping with DTR's incorporation of the stories of the deliverers into a larger period of Israel from the judges to the monarchy.

Part of DTR's construction of this larger period of the history was the inclusion of the list of minor judges in Judg 10:1-5 and 12:7-15. As noted by Noth, it was the presence of Jephthah in the deliverer story of Judg 11:1-12:6 and the judge list in Judg 12:7 that caused DTR to describe the heroes of the deliverer stories as judges. ${ }^{6}$ The description first appears in Judg 2:16. The language of the rest of the text cannot be claimed as so characteristic of DTR, but is to be included because it forms an integral part of the introduction.?

The text can be further verified as part of DtrH by a literary critical and linguistic evaluation of the verses omitted as later redaction, namely Judg 2:12-13, 15a $, 17,18 \mathrm{a} a, 19 a \beta \gamma$. With Judg 2:12-13 we may note first of all that a literary critical examination shows these verses are an example of the ring composition technique used to insert a redactional addition into the body

${ }^{4}$ Note that the LXX inserts "and they cried (to the Lord)" in $v 15 \mathrm{~b}$. This looks to be an insertion to bring the notice of distress into line with Judg 3:9, $15 ; 6: 6 ; 10: 10$.

${ }^{5}$ The statement in Judg 2:14b that Yahweh sold Israel into the hand of their enemies corresponds closely to Judg $3: 8 ; 4: 2 ; 10: 7$. Judg $6: 1$ and 13:1 however use the verb "to give". The term plunderers in vv 14, 16 occurs elsewhere in the historical books only in $2 \mathrm{Kgs}$ 17:20. While it is somewhat unnecessary given the reference to enemies, the limited number of occurrences cautions against a literary critical separation. I have therefore included the references in DTR's text (cf. the texts of Noth, Mayes, Richter, Soggin in n. 1 above).

${ }^{6}$ Noth, The Deuteronomistic History, 43.

7Thus "to do evil in the sight of the Lord" ( $v$ 11) is an element of the framework passages which will be seen to have been the work of a pre-dtr redaction. The kindling of Yahweh's anger occurs in Judg 10:7 (DTR), but looks to have been taken from Judg 3:8 (pre-dtr). The element in the framework texts which reports that on the death of a judge Israel again did (๕asâ) what was evil is expressed in $v 19 a a$ by the verb $\breve{u} \hat{b} b$ (to return) The reference to Israel's practices and stubborn ways in $v 19 \mathrm{~b}$ is not characteristic of DTR, but neither is it characteristic of later dtr redaction. It emphasizes Israel's habit of repeated apostasy and so has the larger context in mind. 
of the text. In this case the redactor made the join by recalling, in reverse order, that Israel forsook Yahweh and served Baal and the Ashtaroth. ${ }^{8}$

Secondly, Judg 2:12 is a doublet of $v 11$. It expands in a polemical fashion and with different language on the two features of this verse; the evil committed by Israel (changed in v 12aa to the accusation of forsaking Yahweh who had brought them out of Egypt), and their worship of the Baals (changed in v. $12 \mathrm{a} \beta$ to a more general reference to "other gods" and "the gods of the people who were round about them"). 9 Although the statement about Yahweh's anger in $v 12 \mathrm{~b}$ is not in itself a characteristic expression of later redaction it does form a doublet with $\mathrm{v} 14 \mathrm{a}$, which is clearly a more integral component of the textual sequence. It immediately precedes Yahweh's handing over of Israel to enemy oppression, and provides the motivation for it. In addition to these observations it may be pointed out that Judg $2: 12$ is introduced by the verb cazab (to forsake) which, in the sense of forsaking Yahweh, shows clear evidence of being a characteristic term of later dtr redaction. ${ }^{10}$ Judg 2:13 also contains the verb cazab. ${ }^{11}$ This fact, plus the evidence

${ }^{8}$ With Noth (The Deuteronomistic History, 7-8). The omission of vv 12-13 gives a more satisfactory text than that proposed by Mayes (see above n. 1), who fails to note the ring composition. He also includes $v 12 \mathrm{a} a$ which has the verb cazab but omits $\vee 13 a$ where it also appears (cf. also Richter in n. 1). Only the Baals are mentioned in $v 11$, whereas both Baal and the Ashtaroth are mentioned together in $v 13 \mathrm{~b}$. Although this appears at first sight to be closer to Judg 3:7 (with different vocalization for Ashtaroth) and 10:6, the better decision is to accept $v 11$ over $v 13 \mathrm{~b}$. Verse $13 \mathrm{~b}$ refers to Baal in the singular, unlike the other passages which all contain the plural. Also, the governing preposition is $\bar{l} \bar{e}$ rather than 'et as in Judg $2: 11 ; 3: 7 ; 10: 6$. The absence of the expected reference to Ashtaroth in $\mathbf{v} 11$ may be explained by suggesting that the term was originally present in the verse but relocated in the insertion to heighten its more polemical tone. Thus, in $v 11$ Israel is accused of worshipping Baals only. In $v 12$ the accusation is extended to include other gods and the gods of the peoples. Verse 13 then lists as evidence Baal and Ashtaroth.

${ }^{9}$ The wide distribution of the confessional phrase "Yahweh, who brought (yassa $\left.a^{\prime}\right)$ Israel out of the land of Egypt" indicates that it is formulaic and not characteristically dtr. A check on the distribution of the phrase "to serve (go after) other gods" in conjunction with the phrase "to forsake Yahweh" shows that this is a preferred combination in later dtr redaction (cf. J. P. Floss, Yahwe dienen-Göttern dienen, 94-107, and table on p. 97). The verb $h w h$ in the hishtaphel, in the sense of "to worship", and $k \bar{a}^{\mathrm{c}} \mathrm{as}$ in the hiphil in the sense of "to provoke to anger" cannot be claimed as so characteristic of later dtr redaction. The evidence is somewhat better for the phrase "from among the gods of the peoples who were round about them". Deut 6:14; 13:8 (RSV 13:7) contain the same description of foreign gods, but because the reference to Israel (you) is in the plural, in contrast to the surrounding verses which preserve the singular, they look to be later insertions. $2 \mathrm{Kgs} 17: 15$, which will be seen to be a later text, also has the same description of foreign gods, but uses goyim instead of ammim.

${ }^{10}$ The verb occurs in Deut 28:20; 29:24 (forsake Yahweh's covenant); $31: 16$ (forsake Yahweh's covenant); Josh 24:16, 20; Judg 2:13; 10:6b, 10, 13; 1 Sam 8:8; 12:10; 1 Kgs 9:9; 11:33; 2 Kgs 17:16; 21:22; 22:17. The 
that it is part of a ring composition, shows that Judg 2:12 and 13 derive from the same hand. ${ }^{12}$

The next significant addition is Judg 2:17 which portrays the judges as Yahweh's faithful preachers whom the people did not heed. Instead they disobeyed the commandments. This does not square with the portrait of the judges in DtrH..$^{13}$ It is more in line with Joshua 23 where Joshua functions as a preacher of the law who "prophesies" that his warnings will go unheeded by Israel (cf. v 16). Moreover, as will be seen in such texts as 1 Samuel 12 and 2 Kgs 17:7-19, the later nomistic redaction portrayed the prophets as preachers of the law. It makes good sense then to assign Judg 2:17 to this same redaction. The occurrence of the term "other gods" and the use of the verb "to worship" here and in Judg 2:12, plus the mention of Israel's fathers in both texts, suggest that Judg 2:12-13, 17 came from the same nomistic redaction. We can safely attribute Judg 2:18a $a$ to this redaction as well, since it provides the literary seam joining $\mathrm{v} 17$ to DTR's text. ${ }^{14}$ Finally, there is some later expansion in Judg $2: 19 \mathrm{a} \beta \gamma$ which uses similar vocabulary to that of the nomistic additions in the preceding verses. ${ }^{15}$

Judg 2:20-3:6 is also part of the later redaction of DtrH. ${ }^{16}$ The introduction to Judg 2:20 forms a doublet with the introduction to $v$ 14. Yet it lies outside the structure modelled on the framework around the stories of the judges, which DTR drew on to compose the introduction. Moreover, the accusation of transgressing the covenant given to the fathers, and of Israel's failure to listen

secondary nature of the passages in Deuteronomy 29; 31 and Joshua 24 has already been discussed. Most of the other occurrences can be shown to be later because they occur within larger secondary passages (cf. Judg 10:10, 13; $1 \mathrm{Sam}$ $8: 8 ; 12: 10 ; 1 \mathrm{Kgs} 9: 9 ; 2 \mathrm{Kgs} 17: 16 ; 22: 17$ ), or because they function as explanatory additions (cf. $2 \mathrm{Kgs} 21: 22$ ), or appendages attached to an existing statement (cf. Deut 28:20; Judg 10:6b). $1 \mathrm{Kgs} 11: 33$ is a later addition to Ahijah's prophecy to sharpen DTR's rather lenient criticism of Solomon in 1 Kgs 11:1, 2b-4, 6-7 (vv 2a, 5, 8 are additions). Most of these texts will be shown to belong to the nomistic stage of redaction or later.

${ }^{11}$ The presence of the verb c gzab in Judg 2:13 shows that Boling (Judges, 30, 74-76) and Schüpphaus (Richter- und Prophetengeschichten, 134) are mistaken in claiming it as pre-dtr.

${ }^{12}$ Against Richter (Bearbeitungen, 35) who includes $v 12$ but omits v 13.

${ }^{13}$ The verse is also omitted in the texts proposed by Mayes, Noth, Richter, and Soggin (cf. n. 1). R. Smend ("Das Gesetz," 505) assigns it to his DtrN redactor. Judg 2:15aß $\gamma$ contains a doublet. The second member in $v 15 a \gamma$ is the more likely addition, designed to add solemnity to the preceding word of Yahweh. Cf. Noth, The Deuteronomistic History, 7; Richter, Bearbeitungen, 30. Mayes (The Story of Israel, 163, n. 27) omits both.

${ }^{14}$ So also Smend, "Das Gesetz," 505.

${ }^{15}$ Thus the statement about Israel "going after other gods, serving them and bowing down to them" (cf. similar references in vv 12, 17). Cf. also Mayes, The Story of Israel, 67. The accusation that Israel "behaved worse than their fathers" may be included in DtrH as a reference to the rebellious exodus generation.

${ }^{16} \mathrm{Cf}$. Mayes, The Story of Israel, 68; Richter, Bearbeitungen, 44; Soggin, Judges, 42. 
to Yahweh's voice, align Judg 2:20 much more closely with the nomistic material already identified than with DTR. ${ }^{17}$ The formulation of Judg 2:20 points to the continuation of this addition in the following verses, namely $2: 21,23 a ; 3: 5-6 .{ }^{18}$ In Judg 2:21 Yahweh plans to cease driving out the nations that remain, as punishment for Israel's transgression. This clearly recalls the threat enunciated in Josh 23:13. Judg 2:23a reports the implementation of Yahweh's plan, and Judg 3:5-6 forms an appropriate sequel with its information that the Israelites dwelt among the nations, intermarried with them, and served their gods.

The introduction of Judg $2: 20-21,23 a ; 3: 5-6$, with its theme of Israel dwelling among the nations, prompted two other additions. These sought to explain the presence of the nations not as a punishment, but as a test for Israel. The two additions are Judg $2: 22 ; 3: 3-4$, and Judg 3:1-2. Similarity of thought and language reveal that Judg $2: 22 ; 3: 4$ came from the one hand. According to the explanation given in these verses the nations were retained by Yahweh to test Israel's obedience. The plural verb introducing Judg 3:4 indicates that the list of nations in $v 3$ should also be included in this redaction. ${ }^{19}$ Judg 3:1-2 on the other hand has a quite different understanding of testing. Here the nations were retained to sharpen Israel's skill in warfare. The only link between this text and the context is the theme of testing. This suggests that it is a later entry than Judg $2: 22 ; 3: 3-4$ which is more closely linked to the nomistic redaction via the theme of obedience. ${ }^{20}$

Apart from these two later contributions one can see that the major reworking of DTR's introduction in Judg 2:11-19 was carried out by what I have termed the nomistic stage of redaction. This redaction interpreted the failure of the post conquest generations very much in the light of the warnings in Joshua 23 about disobedience and the transgression of the covenant. It is instructive to observe that, as with Deuteronomy 4 and 29-30, Joshua 23 and

${ }^{17}$ The verb cabar to describe transgression of the covenant occurs in Deut 17:2; Josh 7:11, 15; 23:16; $2 \mathrm{Kgs} \mathrm{18:12.} \mathrm{The} \mathrm{texts} \mathrm{in} \mathrm{Deuteronomy} \mathrm{and}$ Joshua have been identified as later dtr redaction with Josh 23:16 in particular a nomistic text. The same will be seen for $2 \mathrm{Kgs} \mathrm{18:12}$. On the accusation that Israel did not listen ( కāmac $^{c}$ ) to the voice of Yahweh see Deut 8:20; 9:23; 28:15, 45, 62; Josh 5:6; Judg 2:2; 6:10; 1 Sam 12:15; 2 Kgs 17:14, 40; 18:12; 21:9. While the occurrences in Deuteronomy are debatable, the remaining ones all belong to texts which are best assigned to nomistic redaction or later. R. D. Nelson (The Double Redaction, 51) has a more restricted application of this accusation as evidence of later redaction.

${ }^{18}$ So also Mayes, The Story of Israel, 76-77; Richter, Bearbeitungen, 44. However I would see Judg $2: 23 \mathrm{~b}$ as an independent and late appendage; it is clearly in conflict with v 21. Smend ("Das Gesetz," 504-6) assigns Judg 2:17, 20-21, 23 to DtrN.

${ }^{19} \mathrm{Cf}$. Mayes, The Story of Israel, 69. Richter (Bearbeitungen, 40, 44) sees Judg 3:3-4 as subsequent to Judg 2:22, but deliberately linked to it.

${ }^{20} \mathrm{Cf}$. Mayes, The Story of Israel, 68. Soggin (Judges, 42) identifies the redaction as Judg 3:1b-2. The provenance of Judg 3:1-2 is difficult to determine. Richter (Bearbeitungen, 44) believes it may be an echo of Josiah's restoration of the holy war. 
the nomistic additions to Judg 2:11-3:6 are strategically positioned around an important transition within DtrH.

\section{JUDG 3:7-1 SAM 7:17}

What needs to be verified in this section is the proposal that DTR structured the stories of the judges in two stages. The first nuns from Judg 3:7 to 10:5; the second from Judg 10:6 to 1 Sam 7:17.21 This proposal differs considerably from Noth's understanding of how DTR organized and redacted the stories of the judges. Before commencing the analysis therefore it is appropriate to outline the reason for this revision of Noth.

There is no need to review all of Noth's arguments for the redaction of the judges material. What is germane to this discussion is his proposal that DTR was responsible for the framework passages of the judges' stories. This led him to conclude that DTR created the sequence of stories from Othniel to Jephthah. ${ }^{22}$ While this enabled Noth to claim a strong thematic unity for DTR's redaction it created problems in relation to the larger linear sequence of DtrH. ${ }^{23}$ This is clearly evident when one proceeds to the Samuel material. Noth traced the period of the judges through to 1 Sam 11:15, but did not demonstrate how the Samuel material was related structurally and thematically to the cyclic pattern created by DTR for the other judges.

Furthermore, even though Noth was right to see that the list of minor judges in Judg 12:7-15 was located after the story of Jephthah because of the occurrence of his name in Judg 12:7, he did not satisfactorily account for the location of the other list of judges in Judg 10:1-5. The two lists do not really form a frame around the story of Jephthah as he claimed. The introduction to Judg 10:1 links it more with the preceding story of Abimelech. Furthermore there is no direct link between Judg 10:5 and the story of Jephthah, as there is between the end of the story of Jephthah in Judg 12:6 and the list of judges in 12:7. The text of Judg 10:6-16 intrudes between them. ${ }^{24}$

A way can be found out of the difficulties created by Noth's understanding of DTR's redactional procedure if one follows through the implications of W. Richter's reassessment of the growth of the judges material, based on a careful analysis of subtle variations of vocabulary. ${ }^{25} \mathrm{He}$ proposes that a redactor compiled a document ("Retterbuch") in the time of Jehu from a number of

${ }^{21}$ Later redaction occurs in Judg 6:7-10; 10:6-9*, 10-16;13:2-16:31; 17:1$21: 25 ; 1$ Sam 2:35-36.

${ }^{22}$ Noth, The Deuteronomistic History, 42-44.

${ }^{23}$ This difficulty was first pointed out by G. von Rad, Old Testament Theology I, 346-47.

${ }^{24}$ Noth (The Deuteronomistic History, 45-46) also included Judg 6:7-10 and all of Judg 10:6-16 in DtrH. A reassessment of these texts shows that all of Judg 6:7-10 and significant portions of 10:10-16 belong to later redaction.

${ }^{25}$ Richter first carried out a traditio-historical analysis of the stories of the judges in Traditionsgeschichtliche Untersuchungen zum Richterbuch. This was then followed by an analysis of the redaction history of the stories in Bearbeitungen. 
traditional stories and other suitable material. ${ }^{26}$ According to Richter the redaction transformed the battles fought by the heroes into holy wars of Yahweh. The purpose in joining this series of stories of charismatic deliverers with the disastrous story of Abimelech's kingship was to mount a polemic against a period of degeneration in the northern kingdom, possibly the turbulent years between Jeroboam I and the Omrides.

Richter next identifies three stages of redaction. The first two were deuteronomic, while the third was the work of Noth's DTR. ${ }^{27}$ It is in his proposal that the two stage deuteronomic redaction was responsible for the construction of the framework passages around the stories of the judges and the story of Othniel in Judg 3:7-11 that Richter parts company with Noth. The first deuteronomic redaction was carried out in northern Israel and was responsible for constructing the framework passages for the stories from Ehud to Gideon.28 This redaction was also responsible for adding Judg 9:16b-19a, 22, 55 to the story of Abimelech. ${ }^{29}$ The second deuteronomic redaction, which was carried out by a Judean redactor, added the brief account of Othniel in Judg 3:7-11, except for the chronological information in Judg 3:8b, 11a, the judging formula in $3: 10$, and the death notice in $3: 11 \mathrm{~b}$. This redaction therefore supplied a southern component to a document completely dominated by northern traditions, and at the same time provided a typical example to introduce the stories of the deliverers.

As for DTR's redaction Richter identifies two major passages; Judg 2:7, 10-12,14, 15aab, 16, 18aßb, 19 and Judg 10:6-16. As well DTR added the chronological information, the lists of minor judges in Judg 10:1-5; 12:7-15, and the Jephthah and Samson stories. Apart from the Samson stories this is in basic agreement with Noth. Also in agreement with Noth, Richter att-

${ }^{26}$ Richter, Traditionsgeschichtliche Untersuchungen zum Richterbuch, 29-343. Richter identified the component elements in Judg 3:15b-26 (Ehud tradition); 4:17a, 18-21 (22) (Jael tradition, already framed at an early stage by a holy war schema in 4:10, 12-16); 6:11a, 18-19, 21-24 (altar tradition); 6:27b-31aba (Baal altar tradition); 7:11b, 13-21 (tradition of Gideon's dream); 8:5-9, 14-21a (Transjordan tradition); 8:21b, 24-27a (Ephod tradition); 8:30, 32 (Gideon grave tradition); 9:8-15 (fable); 9:26-40, 46-54 (Abimelech tradition). The redactor's own contribution is to be found in Judg 3:13, 27-29; 4:4a, 6-9, 11, $17 \mathrm{~b} ; \quad 6: 2 b-5,11 b, 17,25-27 \mathrm{a}, 31 \mathrm{~b} \beta, 32,33-34 ; 7: 1,9-11 \mathrm{a}, 22,23-24,25-$ $8: 3,4,10-13,22-23,29,31 ; 9: 1-7,16 a, 19 b-21,23-24,41-45,56-57$.

${ }^{27}$ Richter, Bearbeitungen, 113-41.

${ }^{28}$ The texts are Judg $3: 12,14,15 a, 30 ; 4: 1 a, 2-3 a, 23-24 ; 5: 31 ; 6: 1,2 a$; 8:28. The chronological information was added by DTR.

${ }^{29}$ This is a more acceptable position than that of T. Veijola, Das Königtum, 112, and Volkmar Fritz, "Abimelech und Sichem in JDC. IX," VT 32 (1982) 12944. Veijola assigns Judg 9:22, 24abaß, 56 to DtrH, and Judg 9:5b, 16b-19a, 24by8, 57 to DtrN. Fritz (pp. 133, 143) assigns Judg 9:5b, 7-16a, 19b-21, 4649 to DtrH, and Judg 9:16b-19a, 24, 57 to DtrN. The texts proposed contain little evidence of dtr language however, and the parallels between Judg 9:16b-19a and 1 Sam 10:18aß $\gamma b-19 a$ claimed by Veijola $(p .111)$ are unconvincing. The Judges' passage is an interpretation of Jotham's fable, whereas the Samuel passage is formulated as the accusation ("Begründung") component a prophetic speech. 
ributes to DTR the description of the deliverers as judges. The relevant texts for Richter are Judg 2:16, 18aßb in DTR's introduction, and the judging formulas in Judg $3: 10 ; 4: 4 b-5$. He also assigns the death notices in Judg $3: 11 ; 4: 16$, and the information on Shamgar in Judg 3:31 to DTR.

There are some elements of Richter's identification of dtr redaction with which I would disagree. ${ }^{30}$ Nevertheless his explanation of the stages of growth of the text does take due account of the literary evidence. It therefore carries more conviction than studies which propose that, even if the stories of the judges are based on old traditions, they have been thoroughly rewritten by DTR. ${ }^{31}$ A measure of the strength of his study is the widespread support it has gained. ${ }^{32}$ Within the context of the DtrH hypothesis what is particularly significant about Richter's study is the way it enables DTR's redactional procedure for the the period of Israel from the judges to the monarchy to be clarified.

The first important clue to discerning DTR's redactional procedure arises from Richter's proposal that the cycle of stories from Judg 3:7-9:57, complete with the framework passages, was pre-dtr. DTR was, according to Richter, responsible for introducing the material from Judges 10 onwards. The presence of a similar cyclic pattern in this material immediately raises the question of whether DTR intended to merely extend the preceding cycle of stories or achieve something more. An examination of the material in Judges 10 and the

${ }^{30} \mathrm{Cf}$. the preceding analysis of Judg 2:11-19. I would also disagree with his assignation of all of Judg 10:6-16 to DTR and his assessment of DTR's chronology (see below).

${ }^{31}$ Cf. J. Van Seters (In Search of History, 342-46) and H. D. Hoffmann (Reform und Reformen, 272-79). Van Scters claims that one cannot recover an original literary stratum for the Ehud story from the framework in Judg 3:12-15 (for him dtr). Richter himself had noted that his "Retterbuch" lacked a suitable introduction (Traditionsgeschichtliche Untersuchungen zum Richterbuch, 323). He proposed that it was deleted by the deuteronomic redaction which supplied the framework. This also affected other introductions within the "Retterbuch", such as the beginning of the Deborah story. While this is a problem for Richter's hypothesis, I believe it is more than offset by the evidence he adduces for the "Retterbuch" in the rest of Judges 3-9. Van Seters does not take up this analysis by Richter which provides the bulk of the evidence for the "Retterbuch". Hoffmann's assessment is based principally on Judges 2 and Judg 10:6-16, identification of the framework passages as dtr, and identification of Judg 6:2532 as DTR's composition because it deals with cultic reform. This is too narrow a basis to claim the whole as a composition by DTR.

${ }^{32}$ Cf. J. Gray, Joshua, Judges and Ruth, 10-11; Mayes, The Story of Israel, 64-65; Nelson, The Double Redaction, 14; Smend, Entstehung, 116; Soggin, Judges, 5-6. Boling (Judges, 29-38) has, like Richter, a basic threefold development of the text: early collection, deuteronomic redaction (DTR), dtr redaction. But he distributes texts differently to Richter. It is regrettable therefore that Boling does not engage in any detailed discussion of Richter's work. Schüpphaus (Richter- und Prophetengeschichten, 125-212) argues for a pre-dtr history of the judges in which he includes nearly all of the passages identified as DTR's contribution by Richter. 
following chapters will show clearly enough that DTR set out in fact to create a two stage history of the judges.

As stated above Richter agrees with Noth that DTR was responsible for the present location of the lists of minor judges in Judg 10:1-5; 12:7-15. But he also provides another important clue to discerning DTR's reason for the location of the lists by drawing attention to the special introduction to Judg $10: 1$, namely, "After Abimelech there arose to deliver Israel Tola the son of Puah." Richter notes that the verb yãsac (hiphil: to deliver) is the same verb used by DTR in the introduction to the judges period. ${ }^{33}$ Unfortunately Richter does not explore the structural and thematic implications of his observation. Nor has this been done by subsequent studies of DtrH which accept his hypothesis of the redaction history of the judges material.

The introduction to the list of minor judges in Judg 10:1-5 clearly links it with the story of Abimelech's abortive attempt to be king, and states that Israel was delivered from the subsequent crisis by the providential rule of Tola and Jair who succeeded him. One gains the impression from this location of the first list of minor judges and its introduction that DTR attached particular significance to the story of Abimelech, and deliberately created a contrast between the strife generated by his leadership of Israel and the re-establishment of order by the judge form of leadership. The resolution of the Abimelech crisis suggests that DTR intended Judg 3:7-10:5 to be read as a structural unit within the larger context of the history. ${ }^{34}$ This is confirmed by the identification of a similar structural unit running from Judg 10:6 to 1 Sam 7:17.

DTR's introduction to this second structural unit or stage in the history of the judges is to be found in Judg 10:6aa, 7-8*, 9b.

(10:6aa) "And the people of Israel again did what was evil in the sight of the Lord, and served the Baals and the Ashtaroth. (10:7*) And the anger of the Lord was kindled against Israel and he sold them into the hands of the Ammonites. (10:8aaba) And they crushed and oppressed

${ }^{33}$ Richter, Bearbeitungen, 118. The text in the introduction is Judg 2:16 (v $18 \mathrm{a} a$ being part of a later literary seam). Cf. also Judg 3:9, 31; 6:14, 15; 13:5. Unlike Judg 2:16 (18) the verse in question does not state that Yahweh raised up Tola. The difference in formulation may be explained by proposing that DTR did not want to equate the work of Tola completely with that of the judges who delivered Israel from enemy oppression. Note also that the verb qûm (to rise up) is common to Judg $2: 16,18 ; 10: 1$.

${ }^{34}$ Richter's identification of DTR's redactional additions in Judg 3:7-10:5 have already been given. Against Noth he believes Judg 6:7-10 was a later addition (Bearbeitungen, 97-109, 142). See also Mayes, The Story of Israel, 163, n. 31; Nelson, The Double Redaction, 47-53; Veijola, Das Königtum, 4348 (DtrN). The passage is not as evidently nomistic in language as those already described in this way. However it does present the prophet as a preacher who warns the people. As will be shown this is in line with the nomistic presentation of the prophet in Samuel and Kings. It also contains the accusation that the people did not listen to Yahweh's voice (cf. the discussion of Judg $2: 20$ ). It may therefore be taken as a nomistic addition. Boling (Judges, 30, $66,125-26$ ) assigns Judg 6:7-10 (and 2:1-5) to his pre-exilic DtrH. 
the children of Israel for eighteen years, (10:9b) so that Israel was sorely distressed." 35

These verses provide the elements of the framework for the story of Jephthah, which follows smoothly in Judg 10:17. Features in the passage which indicate that it was composed by DTR as a parallel introduction to the earlier one in Judg 2:11-19* are the references to the Baals and the Ashtaroth (cf. Judg $2: 11 ; 3: 7$ ), and the description in Judg 10:9b (cf. Judg $2: 15 b$ ) of Israel as sorely distressed (sārar + me'od) by its enemies. These are the only occurrences of such phrases in the story of the judges.

The list of gods in Judg 10:6aßy is out of context, and along with the accusation in $v 6 \mathrm{~b}$ that Israel "forsook the Lord and did not serve him", reflects the heightened polemic evident in later redaction of $\mathrm{DtrH}$, particularly that associated with the nomistic contribution. ${ }^{36}$ In Judg 10:7 the mention of the Philistines is also out of context, and was probably added in front of the reference to Ammonites because of the dominant role the Philistines play in the Samson stories and in 1 Samuel 4-7. In Judg 10:8 the 18 years of oppression has been included but the phrase "in that year", as well as the description of Israelites in Transjordan in v. $8 \mathrm{~b}$, has been omitted. The justification for this will be given below in the discussion of Richter's reconstruction of DTR's chronology. This discussion will also set out the reasons for omitting Judg 10:9a.

As well as these additions there is also Judg 10:10-16.37 The cry to Yahweh in Judg 10:10 introduces a confession of sin by the people. This is different to the cries for help in Judg $3: 9,15 ; 4: 3 ; 6: 6$, where no such confession occurs. ${ }^{38}$ In Judg 10:11 the Ammonites and Philistines, and other nations, are included with the Egyptians and Amorites in a review of Yahweh's past deeds of deliverance. Yet according to the larger narrative sequence these are the oppressors who have still to be overcome. ${ }^{39}$ A third point is that

${ }^{35}$ Mayes (The Story of Israel, 69) identifies DTR's text in Judg 10:6aa, 7-9. Veijola (Das Königtum, 45-48) identifies it in Judg 10:6aa, 7b (omitting the reference to the Philistines), 8a (omitting "the Israelites"), 8b (omitting "18 years").

${ }^{36}$ Cf. Mayes, The Story of Israel 69. The use of the verb "to forsake" as a favored term by later redaction was discussed above in the analysis of Judg 2:113:6. Its position in Judg 10:6b, in conjunction with the verb "to serve", indicates that it was appended to the list of gods to bring the reader back to the main point, Israel's sin of apostasy.

${ }^{37}$ So Mayes, ibid., Veijola, Das Königtum, 46 (DtrN). Against Richter, Bearbeitungen, 13-18; Soggin, Judges, 202-3.

${ }^{38}$ One could propose to include the cry to Yahweh in DtrH by taking Judg $10: 10 \mathrm{a}$ (omitting "to say") and 10:16b as DTR's text. This is possible but the intransitive form of the verb qașar occurs only here and in Judg 16:16 (non-dtr).

${ }^{39}$ This rather free attitude to the context of DtrH occurs also in 1 Samuel 12 where it will be discussed in greater detail. It was deliberately done by the redactor, who sacrificed accuracy of reference for the sake of mounting a unified and broad reaching argument about Yahweh's mercy and Israel's continued infidelity. The MT of Judg 10:11 seems to have suffered the loss of the verb 
Yahweh's indictment of Israel in Judg 10:13-14 is resolved in the following verses (Judg 10:15-16) in such a way that it creates a somewhat awkward link with Judg 10:17ff. Added to this is the recognition that the encounter between Yahweh and Israel in this text is similar in structure to Judg 2:1-5 (an angel condemns Israel) and Judg 6:7-10 (a prophet condemns Israel). Both of these passages have been identified as secondary additions to DtrH. Finally, Judg $10: 10,13$ both contain the verb "to forsake". This verb has already been seen to be a preferred term of the later nomistic stage of redaction. In conjunction with this there are the general references to "other gods" and "foreign gods" in Judg 10:13, 16. The combination of these terms with the verb "to forsake" is also a feature of later nomistic redaction. ${ }^{40}$

The evidence is therefore clearly in favor of taking Judg 10:10-16 as a later insertion. The nomistic vocabulary in the passage is not particularly strong but it does share the highly critical view of Israel evident in other nomistic texts, for example Josh 23:15-16 and additions to Judg 2:11-3:6. Hence it may be assigned to this stage of later redaction.

The second stage of DTR's history of the judges emerges clearly enough when one observes that the sequence of the narrative in Judg 10:6aa, 7-8*, $9 \mathrm{~b}$, $17-13: 1 ; 1$ Sam $1: 1-7: 17^{*}$ is basically the same as that for Judg 3:7-10:5.11 We find there is the same pattern of Israelite infidelity (Judg 10:6aa), oppression (Judg 10:7-8*, 9b) and deliverance (Judg 10:17-12:15), followed by a return to infidelity and renewed oppression (Judg 13:1). As with Judg 3:710:5 this culminates in a crisis of leadership in Israel. In the first stage the crisis occurs with Abimelech's murder of his brothers and the establishment of himself as a king. In the second stage it occurs with the greed of the sons of Eli, the priest of Shiloh (1 Sam 1:1-2:34). In each case the crisis is resolved by the replacement of the failed form of leadership by another form of leadership. With Abimelech this occurs via a return to the judges. With the Elides it occurs via the emergence of Samuel as a prophet (1 Sam 3:1-7:17*).

Although the two stages are structured in the same way their function within the context of DtrH is different. By culminating with the crisis of Abimelech and its resolution via a return to the judges (Judg 10:1-5), the first stage serves to prepare for the development of the second stage and the subsequent transition to the monarchy. The story of Abimelech raises the issue of monarchy, but his failure and the subsequent return to the judges form of leadership suggests that it can only be established in Yahweh's good time and on his terms. The emergence of Samuel as a new type of leader in place of the Elides in the second stage suggests in its turn that the time is imminent. Hence the second stage takes the story of Israel to the threshold of the transition to the monarchy. Before proceeding to an examination of the

yăsac in transmission. This does not hinder an accurate grasp of the sense of the verse. For a discussion see Boling (Judges, 192).

${ }^{40}$ This was pointed out in the discussion of Judg 2:11-3:6. Cf. Floss, Yahwe dienen-Göttern dienen, 94-107.

${ }^{41}$ This is the text of DtrH. The following discussion will present the arguments for omitting the Samson stories and Judges 17-21 from the history. 
Samuel material however the omission of Judges 13-21 from DtrH needs to be justified.

\section{JUDGES 13-16}

Noth inclined against the inclusion of the Samson stories in Judg 13:216:31 for two reasons. ${ }^{42}$ First, they show no sign of having been worked on by DTR. For Noth this meant that they do not contain the elements of the framework which he attributed to DTR. Second, he regarded the judging formulas in Judg 15:20 and 16:31 as secondary additions, along with 1 Sam $4: 18 \mathrm{~b}$. A principal reason for Noth's omission of these formulas was that their chronological information did not fit into his reconstruction of DTR's chronology of 480 years from the Exodus to the building of the temple (1 Kgs 6:1). ${ }^{43}$

In contrast Richter argues for their inclusion in DtrH.44 According to him the judging formulas in Judg 16:31 and 1 Sam $4: 18 \mathrm{~b}$ are closest in form to those in the lists of minor judges in Judg 10:1-5; 12:7-15. These were predtr, but Richter proposes DTR modelled Judg 16:31 and 1 Sam 4:18 on the formulas in the lists of minor judges in order to create a period of the judges reaching from Judg 10:1 to 1 Sam 4:18.45 This period followed that of the deliverers which ran from Judg 3:7 to 9:57.

Richter claims furthermore that the period of the deliverers is characterized by a repeated pattern of chronological information about the years of enemy oppression, followed by the years of rest enjoyed by Israel after the victory of the deliverer. This pattern does not occur for Richter's period of the judges. Instead it is characterized by the repeated notice of the number of years a judge was in office Samson and Eli are part of this period because they are not presented as charismatic heroes. In conjunction with these arguments Richter carries out a reassessment of DTR's chronology. In disagreement with Noth he omits the years of oppression in Judg 10:8; 13:1, but includes instead the 20 years of Samson's judgeship in Judg 16:31, and the 40 years of Eli in 1 Sam $4: 18 b .^{46}$

${ }^{42}$ Noth, The Deuteronomistic History, 52-53.

${ }^{43}$ Ibid., 18-25. Noth's analysis of DTR's chronology may be summarized as follows: a)-from Exodus to conquest [45 years]; b)-from Othniel to Gideon [253 years]; c)-reign of Abimelech [3 years]; d)-minor judges, Tola and Jair [45 years]; e)- oppression by Ammonites [18 years]; f)-minor judges, Jephthah to Abdon [ 31 years]; g)- oppression by Philistines [40 years]; h)-Saul [2 years]; i)-David [40 years]; j)-Solomon, to the building of the temple [4 years]. Overall 481 years, rounded off to 480 by proposing an overlap of David's last year with Solomon's first.

${ }^{44}$ Richter, Bearbeitungen, 128-29, 134. Mayes (The Story of Israel, 73) and Georg Sauer ("Die chronologischen Angaben in den Büchern Deut. bis 2. Kön.," TZ 24 [1968] 1-14) also include the Samson stories.

${ }^{45}$ For Richter Judg 15:20 is a doublet of 16:31 which, because of its location, is to be taken as DTR's (Bearbeitungen, 134, n. 86).

${ }^{46}$ Richter (ibid., 132-41) agrees with Noth that there were 45 years from the Exodus to the end of the conquest, 253 years from Othniel to Gideon, and 46 years for Saul, David, and Solomon up to the building of the temple. However, 
There are however several problems with Richter's revision. To begin with, his claim that the so-called period of the judges from Tola to Eli is dated by the length of each judge in office is valid only if he can provide satisfactory reasons for omitting the chronological notices on Israelite oppression in Judg $10: 8$ and 13:1. Richter eliminates the 18 years oppression from the complex verse Judg 10:8 on literary critical grounds, stating that it is more reasonable to envisage a later attempt to precision what he regards as the vague phrase "in that year" in Judg 10:8a 3 than the addition of such a phrase to an already present notice of 18 years oppression. ${ }^{47}$

Nevertheless this overlooks the fact that the two items of chronological information are for two different groups of Israelites in the verse; one in Judg $10: 8 \mathrm{aa}$, and the other in Judg 10:8b. In other notices of Israelite servitude in Judg $3: 8,14 ; 4: 3 ; 6: 1 ; 13: 1$ the reference is always simply to the "sons of Israel" without further precision. This is the description in Judg 10:8aa. The more precise description of Israelites "that were beyond the Jordan in the land of the Amorites, which is in Gilead" in Judg 10:8b is a later addition, attached rather awkwardly to the chronological notice in Judg 10:8ba. It was added as part of a later move to link the Transjordan Israelites in Gilead (Judg 10:17-18) more closely with all Israel.

I would propose therefore that DTR's text in Judg 10:8 read "and they crushed and oppressed the children of Israel for 18 years". 48 The introduction of the second category of Israelites led in its turn to the insertion of the statement "in that year" in Judg 10:8aß. This enabled the two groups of Israelites to be linked via the following chronological schema. The phrase "in that year" was added to emphasize that oppression followed immediately upon Yahweh's handing over of Israel to its enemies. There then followed 18 years oppression of Israelites in Transjordan. After this the Ammonites crossed the Jordan to attack the rest of Israel, that is, Judah, Benjamin and the house of Ephraim. ${ }^{49}$ The text is a complex one but this explanation of its composition is more satisfactory than the one proposed by Richter.

Richter's revision is also hampered by his failure to take sufficient account of the larger context of DTR's redaction of the judges' material. He acknowledges that the introduction in Judg 2:11-19* shows DTR intended to give a unified presentation which included both deliverers and judges, but does not follow through the implications of this. There seems to be no way of denying

in addition to Judg 10:8 (18 years) and 13:1 (40 years) he omits the 3 years of Abimelech. His estimate for the period of the judges is 136 years (Tola [23], Jair [22], Jephthah [6], Ibzan [7], Elon [10], Abdon [8], Samson [20], Eli [40]). Overall this gives 480 years (1 Kgs 6:1).

${ }^{47}$ Richter proposes that Judg 10:8 originally read "and they crushed and oppressed the children of Israel in that year who [were] in Gilead". The phrase "for 18 years [they oppressed] all the people of Israel that were beyond the Jordan in the land of the Amorites" is a later addition (ibid., p. 17). $4: 3$.

${ }^{48} \mathrm{This}$ is close to the other reports of Israclite oppression, particularly Judg

${ }^{49}$ Thus Judg 10:9a is part of this later editing. Note the phrase "also (gam) Judah". The explanation given for "in that year" provides a reference point for a chronological notice which Richter found vague. 
that Jephthah, like the deliverers in Judg 3:7-8:32, rescued Israel from oppression, subdued the enemy and brought them peace (Judg 11:33; cf. 3:30; $4: 23 ; 8: 28$ ). A chronological notice about a period of rest does not appear after the report of the subjugation of the enemy in Judg 11:33, because a suitable one already existed in Judg 12:7.50 Furthermore, Judg 2:18 states that Yahweh was with each judge and saved Israel from its enemies during his lifetime. Both the deliverers and the minor judges can be accommodated within this overview by DTR. By way of contrast both Samson and Eli experience the oppression of enemies. Hence it is difficult to accept that DTR included Samson or portrayed Eli as one of the judges (cf. 1 Sam 4:18b).

In conclusion therefore Richter's arguments are not sufficiently compelling to justify the chronology he proposes. The literary critical analysis carried out on Judg 10:8 supports Noth's judgment that the 18 years of oppression in this verse should be included in DTR's chronology. In addition one can accept his position that the chronological notice in Judg 13:1 was part of DTR's chronology, whereas those in Judg 16:31 and $1 \mathrm{Sam} 4: 18 \mathrm{~b}$ were later additions. ${ }^{51}$

The case for the omission of Judg 13:2-16:31 has so far been made chiefly on the basis of a consideration of DTR's chronology. One could however excise the secondary chronological notices in 15:20 and 16:31 and argue for the retention of the story of Samson in DtrH. Against this there are a number of considerations which favor its omission. Firstly, although Judg 13:5b states "he shall begin to deliver Israel from the hand of the Philistines" Samson can hardly be placed in the same category as the other deliverers. There is no report that the Philistines were subdued under Samson, and his battles read more like personal vendettas in comparison to those conducted by the deliverers of DtrH.

Secondly, if Samson were part of DTR's sequence of deliverers, one would expect a report of Israelite apostasy and oppression as a sequel to the story. This does not occur. Thirdly, the introduction to the story of Samson has features which parallel the introduction to the story of Samuel: the barren wife; conception of the child as the result of a special intervention by Yahweh; dedication of the child (cf. Judg 13:2-7). This indicates that the story of Samson may have been inserted in its present location because of similarities with the introduction to the story of Samuel. ${ }^{52}$ This would have been before the insertion of Judges 17-21, a section to which we can now turn.

${ }^{50}$ So Noth, The Deuteronomistic History, 43. The chronological notices in the lists of minor judges are pre-dtr.

${ }^{51}$ Richter's suggestion that the 40 years in Judg 13:1 are an indication of the seriousness of the Philistine oppression in contrast to the Ammonite one in Judg 10:8 is unacceptable. The verse is clearly a chronological notice. Sauer ("Die chronologischen Angaben,"1-14) proposes two reconstructions for the period from the Exodus to $1 \mathrm{Kgs} 6: 1$, both of which add up to 480 years. However neither contains the chronology for the minor judges.

${ }^{52}$ The later insertion of the Samson story is accepted in a recent study by Hartmut Gese, "Die ältere Simsonüberlieferung (Richter c. 14-15)," ZTK 82 (1985) 261-80. Sec pp. 261-62. 


\section{JUDGES 17-21}

In contrast to Noth $\mathrm{T}$. Veijola proposes that Judges 17-21 should be included in DtrH. ${ }^{53}$ In favor of this he presents three picces of evidence. First, there is the repeated refrain in Judg 17:6; 18:1 (in part); 19:1 (in part); 21:25 that "in those days there was no king in Israel; every man did what was right in his own eyes". Veijola identifies this as dtr. Second, he claims evidence of dtr redaction in Judg 17:5, $7 \mathrm{~b} \beta, 13 ; 18: 16,19,20,31 \mathrm{~b} ; 19: 1 \mathrm{~b}$, 30: 20:4, 27b-28aa. Third, he argues that Judges 17-21 as a whole functions in the manner of the repeated accusation in Judges that "Israel did what was evil in the sight of the Lord". The chapters therefore continue the negative assessment of the judges' period, and the reference to the absence of a king in the repeated refrain shows that they are intended to foreshadow the emergence of the monarchy.

The identification of the refrain in Judg 17:1;18:1;19:1;21:25 as dtr is likely, although the comparative evidence is limited to the parallel phrase in Deut 12:8 on doing what is right in one's eyes. Josh 9:25 has a simlar phrase but with the addition of $t \delta b$ (good). One needs to be cautious therefore in building a case on what is a fairly limited basis. ${ }^{54}$ Veijola's other dtr redactional additions are more doubtful. They generally comprise a random word or phrase, and none of the texts cited contains clear evidence of characteristic dtr vocabulary. 55

Given the restricted nature of the linguistic evidence the weight of the argument has to be borne by Veijola's assessment of the function of Judges 17-21. But it is doubtful whether Judges 17-21 functions as a continuation of the earlier accusation that Israel "did what was evil in the sight of the Lord", as he claims. The formulation of the refrain in Judges 17-21 is quite different to that of the earlier accusation. One would expect a much closer correlation before accepting Veijola's position. ${ }^{56}$ His structural argument is also de-

${ }^{53}$ Veijola, Das Königtum, 15-29. See also Smend, Die Entstehung, 117; and for a more cautious view Soggin, Judges, 266-305. Noth (The Deuteronomistic History, 121, n. 29) is followed by Gray, Joshua, Judges and Ruth, 185-91 and Mayes, The Story of Israel, 79.

${ }^{54}$ In a recent study Hans-Winfried Jüngling concludes that Judg 21:25 (and Judg 19:1) is not a deuteronomic or dtr formulation (Richter 19-Ein Plädoyer für das Königtum [AnBib 84; Rome: Biblical Institute, 1981] 72). He assigns Judg 19:1-30a, 21:25 to the period of the early monarchy. Judges 20 (which reflects deuteronomic legislation) and Judg 21:1-24 (old material) were added to provide the exilic community with a guideline for dealing with a sinful member. Jüngling discerns a sequence in the arrangement of the material: Judges 19 (sin)-Judges 20 (punishment)_Judges 21 (reconciliation).

${ }^{55}$ Even the reference to the "ark of the covenant of God" in the most substantial text claimed by Veijola (Das Königtum, 22-23), namely Judg 20:27b$28 \mathrm{aa}$, cannot be claimed as dtr. The same description occurs in 1 Sam 4:4; 2 Sam 15:24. Cf. also 1 Chr 16:6. Soggin (Judges, 293) sees it as a "comment of a priestly kind (P)".

${ }^{56}$ In a recent article W. J. Dumbrell proposed a positive meaning for the refrain ("'In those days there was no king in Israel; every man did what was right in his own eyes.' The Purpose of the Book of Judges Reconsidered," JSOT 
pendent on the inclusion of the Samson stories. Judges 17-21 records Israel's return to evil after the judgeship of Samson. The preceding discussion has shown however that it is unlikely the Samson stories were part of DtrH. On balance the evidence on which Veijola bases his case is too ambiguous to really carry conviction. Judges $17-21$ is best regarded as an addition to the history. ${ }^{57}$

\section{SAMUEL 1-12}

The principal task here is to demonstrate how DTR completed the second stage of the story of the judges (1 Samuel 1-7) and constructed the transition to the monarchy (1 Sam 8:1-11:15). An immediately recognizable feature of these chapters is the prominence throughout of Samuel. This surely indicates that their function in DTR's structure and conceptual plan can only be understood by paying proper attention to the way Samuel is portrayed in each part of the story, and weighing the assessment of each portrayal against the larger context. In other words, one should not focus on the texts dealing with the establishment of the monarchy to the neglect of the preceding chapters The surprising thing is that so much modern investigation of the composition of these chapters has tended to do just that. ${ }^{58}$

The tendency of studies to focus on the chapters dealing with the inauguration of the monarchy, to the neglect of the preceding chapters, is due in no small way to the seminal work on this area by Julius Wellhausen. He classified 1 Samuel 7-12 into two sources, one pro-monarchical (1 Sam 9:1-

25 [1983] 23-33). Dumbrell interprets Judges 17-21 as affirming Yahweh's preservation of a united Israel "despite the absence of the sort of human support which might have preserved a human religious or political ideal" (p. 31). In Judg $21: 25$ he sees a recommendation for the post-exilic community. This is interesting but difficult to accept in the light of Phyliss Trible's recent study in Texts of Terror. Literary-Feminist Readings of Biblical Narratives (Overtures to Biblical Theology; Philadelphia: Fortress Press, 1984) 65-91.

${ }^{57}$ An additional piece of evidence in support of Judges $17-21$ as a later addition is the similarity between Judg 20:18 and 1:1-2. Each text reports an enquiry of Yahweh by Israel as to who should be first to wage a campaign. In each case Yahweh names Judah. Judg 1:1-36 was identified earlier as an addition. It is possible then that Judges 1 and $19-21$, or $17-21$, were placed as a frame around Judg 2:11-16:31. This frame would have been in position before Judg 2:6-10, which relocates $1: 1-36$ (and 2:1-5) within the period of the conquest rather than the judges. Boling (Judges, 30-31) includes Judg 2:1-5 and Judges 17-18 in DtrH, with Judg 1:1-36 and Judges 19-21 as the later frame.

${ }^{58} \mathrm{~A}$ full review of the literature is not possible here. See F. Langlamet, "Les récits de l'institution de la royauté (1 Sam., vii-xii). De Wellhausen aux travaux récents," $R B 77$ (1970) 161-200. On more recent literature see Lyle M. Eslinger, Kingship of God in Crisis. A close Reading of 1 Samuel 1-12 (Bible and Literature Series, 10; Shefficld: Almond/JSOT, 1985) 11-40. One exception was Ivar Hylander (Der literarische Samuel-Saul-Komplex (I. Sam 1-15) traditionsgeschichtlich untersucht [Uppsala: Almqvist \& Wiksell, 1932]) who carried out a traditio-historical investigation of the earlier chapters of 1 Samuel (cf. pp. 9-62). 
$10: 16 ; 11: 1-15)$ and the other anti-monarchical (1 Sam 7:2-8:22; 10:17-27)..$^{59}$ Source critics sought to link Wellhausen's sources, or a modified version of them, with the Pentateuchal sources. ${ }^{60}$ Even when Noth parted company with this type of source criticism by formulating the hypothesis of a DtrH, he retained Wellhausen's basic classification and assigned the anti-monarchical material to DTR. ${ }^{61}$

Artur Weiser made a break from the pro- and anti-monarchical classification with his hypothesis of a pre-dtr prophetic edition which included most of the present text of 1 Samuel 7-12.62 This made good sense, given the prominence of Samuel and his prophetic anointing of Saul. ${ }^{63}$ However the limitation of

${ }^{59}$ Julius Wellhausen, Die Composition des Hexateuchs und der historischen Bücher des Alten Testaments (4th ed.; Berlin: de Gruyter, 1963) 240-43. The pro-monarchical source was earlier. The later anti-monarchical source was a retrojection by the exilic or post-exilic community and sought to correct the earlier viewpoint. Wellhausen also postulated that 1 Samuel 11 was appropriated by the anti-monarchical source, which in turn underwent dtr redaction.

${ }^{60}$ This can be most conveniently examined in the work of Otto Eissfeldt. See The Old Testament. An Introduction (Oxford: Blackwell, 1965) 261-81. See also Die Komposition der Samuelisbücher (Leipzig: Heinrichs, 1931).

${ }^{61}$ Noth, The Deuteronomistic History, 48-53. Noth proposed that DTR incorporated 1 Sam 9:1-10:16; 10:27b-11:15, as well as 1 Samuel $1-4$ and $4: 1 \mathrm{~b}$ 7:1 (Ark Narrative). He detected only minor dtr editing in 1 Sam 2:25b, 34-35 and so did not consider 1 Sam 1:1-7:1 particulary significant for the structure and plan of DtrH. Partly as a result of his adoption of Wellhausen's classification Noth saw DTR as anti-monarchical. This created some tension with DTR's positive attitude to David and the Davidic dynasty, a point noted by von Rad (Studies in Deuteronomy, 89-90) and taken up by F. M. Cross (Canaanite Myth and Hebrew Epic, 276-78). Hans Jochen Boecker has attempted to maintain Noth's assessment of DTR's redaction while modifying his understanding of DTR's anti-monarchical attitude (Die Beurteilung der Anfänge des Königtums in den deuteronomistischen Abschnitten des I. Samuelbuches. Ein Beitrag zum Problem des "deuteronomistischen Geschichtswerks" [WMANT 31; NeukirchenVluyn: Neukirchener Verlag, 1969]). Boecker maintains DTR was not against the monarchy as such, only certain aspects of it, for example, when it rejects Yahweh as savior ( 1 Sam $8: 7 ; 10: 17-19)$, or threatens society from within (1 Sam 8:11-17) (p. 30). However he does not take sufficient account of the evidence for later redaction in 1 Samuel 8, 10, 12.

${ }^{62}$ Artur Weiser, Samuel: seine geschichtliche Aufgabe und religiöse Bedeutung. Traditions-geschichtliche Untersuchungen zu 1. Samuel 7-12 (FRLANT 81; Göttingen: Vandenhoeck \& Ruprecht, 1962). The traditions were originally associated with sanctuaries in Israel and reflected different attitudes in Israelite society to the new institution of monarchy

${ }^{63}$ As noted by Mayes (The Story of Israel, 92-93) Weiser also set the antimonarchical view within a credible historical context. A weakness with Noth's attribution of this material to DTR was that it provided no account of how this view developed in Israelite tradition. It is difficult to accept that DTR generated it. The provenance of the anti-monarchical material has now been well explored by Frank Crüsemann, Der Widerstand gegen das Königtum. Die antiköniglichen Texte des Alten Testamentes und der Kampf um den frühen Israelitischen Staat (WMANT 49; Neukirchen-Vluyn: Neukirchener Verlag, 1978). Crüsemann 
his study to 1 Samuel 7-12 showed that he was still operating within the parameters set up by Wellhausen. In addition his assignation of most of the text to a prophetic compiler who was relatively close to the events narrated seems unlikely, given the variation in the material and the evidence of dtr language and theology in 1 Sam 8:1-22;10:17-19;12:1-25.64

The hypothesis of a pre-dtr prophetic edition has been taken up by B. C. Birch, who identifies an eighth century text in 1 Sam 7:5-12, 15-17; 8:1-7, 9; $9: 1-10: 16 ; 10: 17-27 ; 11: 1-15 ; 12: 1-5 ; 13: 2-15: 35$, with dtr redaction in 1 Sam 7:3-4, 13-14; 8:8, 10-22; 12:6-24; 13:1.65 Birch's achievment has been to propose a theory of source and dtr redaction which broke with Wellhausen's neat classification. Unfortunately he is prevented from seeing the true nature and extent of the prophetic edition by commencing his analysis, with Wellhausen, at 1 Samuel 7. The need to consider the earlier chapters as part of this edition has been recognized by P. K. McCarter. However he does not identify its text accurately enough or explore its full significance. ${ }^{66}$ It is for example doubtful whether McCarter is correct in including the Ark Narrative in the prophetic edition when the prophet Samuel makes no appearance in it.

identifies an important anti-monarchical tradition in $1 \mathrm{Sam} 8: 11-17$, which he thinks stemmed from the landed gentry who felt threatened by the monarchy ( $\mathrm{p}$. 73).

${ }^{64}$ One senses that Weiser's interpretation is at times overly influenced by his rejection of Noth's DtrH hypothesis (see Introduction to the Old Testament, 161, 180-82).

${ }^{65} \mathrm{~B}$. C. Birch, The Rise of the Israelite Monarchy. See also "The Development of the Tradition on the Anointing of Saul in I Sam 9:1-10:16," JBL 80 (1971) 55-68. Around the time of Birch's own work a number of studies appeared which explored the hypothesis of a pre-dtr edition in 1 Samuel. In general these were more restricted in scope than Birch's. Crusemann ( $D$ er Widerstand, 58) argues for a pre-dtr edition of 1 Samuel 9-11. See also V. Fritz, "Die Deutungen des Königtums Sauls in den Überlieferungen von seiner Entstehung I Sam 9-11," ZAW 88 (1976) 346-62. Tryggve N. D. Mettinger (King and Messiah. The Civil and Sacral Legitimation of the Israelite Kings [ConBOT 8; Lund: Gleerup, 1976] 85) thinks that 1 Sam 10:17-27 (except for vv 18-19a) and 11:1-15 were connected to each other before the dtr redaction. A more extensive prophetic edition was proposed by Rolf P. Knierim in "The Messianic Concept in The First Book of Samuel," Jesus and the Historian: Written in Honor of Ernest Cadman Colwell (ed. F. T. Trotter; Philadelphia: Westminster, 1968) 20-51. Knierim's text includes 1 Sam 9:1-10:27; 11; 13-31. His interest is principally in the Messianic concept and his study does not contain a detailed justification of the text proposed. But he does recognize the critical role of Samuel in the anointing of Saul and David. There was also the unpublished dissertation on 1 Samuel 9-2 Samuel 7 by F. Mildenberger, "Die vordeuteronomistische Saul-Davidüberlieferung," (Ph. D. diss., Eberhard-KarlsUniversität, Tübingen, 1962).

${ }^{66} \mathrm{McC}$ arter, I Samuel, 18-23. McCarter proposes a prophetic edition covering the two books of Samuel. This was suggested by Birch but not explored (The Rise of the Israelite Monarchy, 153). 
The problem with Wellhausen's theory of pro- and anti-monarchical sources was that it obscured a true perception of the role of the prophet Samuel in the account of the inauguration of the monarchy. ${ }^{67}$ As scholarship broke with the theory it became aware of the significance of the prophet's role and, in terms of the composition of the text, developed the conviction that a prophetic edition lay behind the present text. The survey shows that this conviction is well established. However the true nature and extent of the prophetic edition has not been satisfactorily established because of a tendency to stay within the boundaries marked out by Wellhausen, and a failure to marshal the necessary textual evidence.

In my judgment these shortcomings have now been overcome by the recent study of A. F. Campbell, who proposes the existence of a late ninth century Prophetic Record from 1 Samuel 1-2 Kings $10 .{ }^{68}$ According to Campbell this document was the product of prophetic redactors who worked in the light of Jehu's revolution and purge of Baalism. ${ }^{69}$ In their Record of the history of the monarchy they were vitally concerned to establish the authoritative role of the prophets of northern Israel over the kings, from Saul to Jehu. ${ }^{70}$ According to these redactors monarchy was for Israel a gift bestowed by Yahweh through the agency of his prophets. Hence their Record was devoted principally to demonstrating the God-given authority of prophets to designate and reject kings and their royal houses. The Prophetic Record began with the story of Samuel, the prophet who anointed Saul the first king over Israel. It ended with the climactic events which followed the anointing of Jehu by the disciple of Elisha (cf. 2 Kgs 9:1-10:28).

The evidence on which Campbell bases his hypothesis emerges from a comparison of three sets of texts, all of which deal with an encounter between a king and a prophet. The first set of texts is associated with the prophetic

${ }^{67}$ This is also evident in the recent retum to a two source analysis of 1 Samuel by B. Halpern, The Constitution of the Monarchy in Israel. Halpern eschews the pro- and anti-monarchical schema, but nevertheless divides 1 Samuel 8-31 into two sources A and B (for a listing see p. 171). 1 Samuel 1-7 is eliminated from consideration because there are "no clear indications that more than one source is present" (p. 152). Significantly Halpern underestimates the role of Samuel in the narrative, stating that "as prophet under the monarchy, Samuel would preside over the cultic/theological details of the league war" ( $p$. 157).

${ }^{68}$ A. F. Campbell, Of Prophets and Kings, 17-123.

${ }^{69} \mathrm{On}$ the redactional process itself Campbell states "there is no claim made that the Prophetic Record was the work of one person, rather than a prophetic group. Its unity emerges, not from considerations of personal style, but from its evident unity of vision and concern, of structure and purpose" (ibid., 108). He also accepts that the Record may have been composed over a period of time, and in several stages.

${ }^{70}$ Although the Prophetic Record was principally an account of the monarchy in northern Israel it included David and Solomon, because of the prophetic role in the anointing of David and the prophetic designation of Jeroboam as king during the reign of Solomon. After the schism of 1 Kings 12 however the Record ignored the Davidic dynasty and dealt only with the northern dynasties of Jeroboam, Baasha, and Ahab. 
anointing of Saul (1 Sam 9:1-10:16), David (1 Sam 16:1-13) and Jehu (2 Kgs 9:1-10). ${ }^{71}$ The second set is associated with the prophetic designation and/or rejection of Jeroboam (1 Kgs 11:31-39 [designation]; 14:7-11 [rejection]),

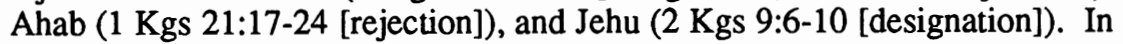
both sets of texts Campbell is able to distinguish the prophetic redaction from later dtr redaction where this occurs. ${ }^{72}$ The third set of texts points to interrelationships between the first two sets, and also establishes links with the intervening narrative.

Interrelationships are evident in the Jehu episode which appears in both sets of texts. They are also evident in the motif of the torn garment in 1 Sam 15:27-28 and $1 \mathrm{Kgs} 11: 29-31$. As well Campbell argues that the prophetic redaction reworked 1 Sam 9:1-10:16 and 1 Samuel 15 in order to draw out their relationship to each other as designation and rejection. ${ }^{73}$ The prophetic anointing of David in 1 Sam 16:1-13, which Campbell attributes entirely to the prophetic redaction, is also related to the foregoing texts and provides another example of Samuel as one empowered by Yahweh to designate and reject kings. 74

Links with the wider context of the intervening narrative occur in the language of Samuel's speech in 1 Sam 28:17-19a, in Nathan's prophecy in 2 Samuel 7, and less certainly, in 2 Sam 12:7b-10.75 Campbell sees further

${ }^{71}$ Campbell identifies 5 features which are shared by the three accounts: 1)anointing by the prophet; 2)- in private, although associated with a special gathering; 3)- on behalf of Yahweh; 4)- to be king or king designate (näg1d); 5)- empowering for action (Of Prophets and Kings, 18, 23).

${ }^{72}$ There is no dtr redaction in 1 Sam $9: 1-10: 16$ or $16: 1-13$. The text of the Record in $1 \mathrm{Kgs} 11: 31-39$ is vv $31,37,38 \mathrm{~b}$, with dtr redaction in vv 32-36, $38 \mathrm{a}, 39$. In $1 \mathrm{Kgs} 14: 7-11$ it is vv $7-8 \mathrm{a}, 9 \mathrm{~b} \beta-11$ with dtr redaction in vv $8 \mathrm{~b}-$ $9 \mathrm{aba}$. In $1 \mathrm{Kgs} 21: 17-24$ it is vv $17-19 \mathrm{a}, 21-22^{*}, 24$, with dtr redaction in vv 20, 22a* (vv 19b, 23 later but not dtr). In $2 \mathrm{Kgs} 9: 6-10$ it is vv 6-7a, 8-9a, $10 \mathrm{~b}$ with dtr redaction in vv 7b,9b-10a. This is in contrast to W. Dietrich (Prophetie und Geschichte) who, in his analysis of the prophetic speeches in Kings, assigns them either to DtrP or DtrN. For Campbell's criticism of Dietrich on this point see pp. 5-14.

${ }^{73}$ The original story in 1 Sam 9:1-10:16 is identified by Campbell (following Ludwig Schmidt) as 1 Sam 9:1-2a, 3-8, 10-13aßb, 14a, 18-19, 22a, 24b-27; $10: 2-4,7,9$. The prophetic redaction occurs in $9: 13 \mathrm{a}, 14 \mathrm{~b}-17,20-21,22 \mathrm{~b}$ $24 a ; 10: 1,13 b-16$. Later additions are found in $9: 2 b, 9 ; 10: 5-6,8,10-13 a$ (Of Prophets and Kings, 18-21). In 1 Samuel 15 the old story is found in 15:1aa, 2$9,13-15,17 \mathrm{a}, 18-22,24-25,31-35 \mathrm{a}$; and the prophetic redaction in 15:1aßb, $10-12,16,17 b, 23 b, 26-30,35 b$ (p. 43).

${ }^{74}$ Ibid., 21, 45.

${ }^{75}$ The evidence for assigning 1 Sam $28: 17-19 a$ to the prophetic redaction is as follows. The statement that "the Lord has turned away from you" in $v 16$ is interpreted in $v 17$ in terms of 1 Samuel 15, and specifically the word spoken by Samuel in 1 Sam 15:26-29. In addition there is the reference to the Amalekite episode ( $v 18$ ) and the tearing away of the kingdom ( $v 17$ ). Finally, the "neighbor" of 1 Sam 15:28 is now named for Saul in 1 Sam 28:17 as David. The mention of David also recalls 1 Sam 16:1-13 (ibid., 46). The text which Campbell assigns to the Prophetic Record in 2 Samuel 7 is 2 Sam 7:1a, 2-5, 7*. 
evidence of the presence of the prophetic redaction in the intervening narrative with the use of the term nagid in the sense of one designated by Yahweh to be king, and the presence of an unusual circumlocution for a male as a mastîn bęqir. ${ }^{76}$ This term occurs only in prophetic speeches which Campbell assigns to the prophetic redaction (cf. $1 \mathrm{Kgs} 14: 10 ; 21: 21 ; 2 \mathrm{Kgs} 9: 8$ ), and in source material of the Prophetic Record (cf. 1 Sam 25:22, 34; $1 \mathrm{Kgs} \mathrm{16:11).} \mathrm{Hence}$ it is exclusive to the Record.

With the hypothesis of a Prophetic Record Campbell is able to locate the prophetic designation of Saul by Samuel in 1 Sam 9:1-10:16 within the larger context of a narrative which, except for the case of Baasha, includes all the examples of prophetic designation and rejection of kings in the books of Samuel and Kings. ${ }^{77}$ Furthermore, he is able to recover the text of this pre-dtr Prophetic Record from DtrH without recourse to textual emendation or speculative reconstruction to fill a gap in the narrative. This would suggest that it was taken over completely by DTR as a major source for the composition of DtrH. The text recovered can be shown to have its own conceptual unity and structure. ${ }^{78}$ It was therefore composed with a definite purpose in mind, and is substantially different to a collection or cycle of prophetic stories. $^{79}$

$10,11 b-12,14-17$ (p. 46, for his arguments in support of this see pp. 72-81). There is some doubt about 2 Sam 12:7b-10. Campbell notes the reference to David's anointing in $v 7$, and how $v 9$ a expresses the same concern as $1 \mathrm{Sam}$ $15: 19$. Verse 9 also exhibits the stylistic trait of throwing the object forward, a phenomenon observed in the prophetic redaction in $1 \mathrm{Sam} \mathrm{15:1a \beta ;1} \mathrm{Kgs}$ $11: 37 ; 14: 9 \mathrm{~b} \beta$. Finally, he observes that the résumé of the Story of David's Rise in 2 Sam 12:7b-8 "is couched in the style of Yahweh's direct involvement which is peculiarly appropriate to the prophetic redaction in this context" (p. 62). Nevertheless Campbell judges that the evidence for assigning this text to the prophetic redaction is not compelling and inclines against its inclusion (and hence also 2 Samuel 11-20) in the Prophetic Record (pp. 62, 83).

${ }^{76}$ For Campbell's analysis of the term nagid see ibid., 47-61. On the circumlocution for a male, see p. 62.

${ }^{77}$ For Campbell (ibid., 39-41) $1 \mathrm{Kgs} 16: 1-4$ is a later dtr imitation of the speeches in the Prophetic Record. The passage does not belong within a prophetic story like the other examples. It refers to Baasha's exaltation out of the dust, but there is no story of his designation. The accusation in $\mathbf{v} 2 b$ is composed of elements which occur mainly in the judgment formulas and not in the Prophetic Record. The threat to cut off every male, bond and free, is absent. Yet this is a characteristic phrase in the Prophetic Record. With the rejections of Jeroboam and Ahab, the introductory "behold" of the announcement is followed by the general phrase "I will bring evil upon ..." before any details are given. In the case of Baasha however it is followed immediately by the details of his rejection ( $v 3$ ). There is also evidence in $1 \mathrm{Kgs} \mathrm{16:1-4}$ of the more pleonastic style of DTR over that of the Prophetic Record.

${ }^{78}$ For the structure of the Prophetic Record see ibid., 101-3.

${ }^{79}$ Noth for example had spoken of the Elijah and Elisha cycle of prophetic stories (The Deuteronomistic History, 68-69). See also A. Jepsen, Die Quellen des Königsbuches, 77-78. Campbell accepts that some of the material for the prophetic redaction could have come from such story cycles (Of Prophets and 
The validity of the Prophetic Record hypothesis is further enhanced by the way it enables one to account for the subsequent growth of the text. ${ }^{80}$ This will be examined in detail in the course of my reassessment. ${ }^{81}$ On a more general level however one can readily see that it provides a very plausible explanation for DTR's interest in the relationship between prophets and kings, and why the third period of the history was organized in a way that would demonstrate the importance of this relationship. It also helps to explain why DTR composed the history as a story of Israel's leaders in which the prophets function in a manner analogous to that of Moses. DTR was able to use the Record's portrayal of prophetic authority to validate the interpretation of the monarchy according to the deuteronomic program laid down by Moses.

Kings, 64, n. 1). G. Garbini (“"Narrativa della Successione' o 'Storia dei Re'?") proposes a prophetic history reaching from the period of the judges (cf. Abimelech) to Jehu. His study is based on the identification of motifs and themes, a method which is useful but which does not facilitate the identification of a continuous narrative. In the end, Garbini does not provide sufficient evidence to clearly distinguish his proposed history from a cycle of stories. According to S. L. McKenzie ("The Prophetic History and the Redaction of Kings,") there was a prophetic history which originally reached from 1 Samuel 1

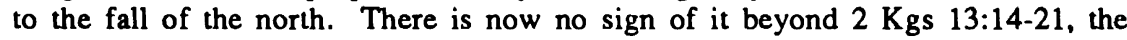
death of Elisha. My difficultics with McKenzie's proposals are these. He includes 1 Samuel 1-12 in the history (p. 204) without adequate discussion of the evidence for dir redaction. His analysis of prophetic speeches in Kings relies on Dietrich, with the result that he identifies dtr elements which Campbell shows are prophetic (pp 205-16). He believes the history's acceptance of David's election could only come from a southern author; hence his belief that the history told of the fall of the north. This overlooks the role of northem prophets as empowered to designate and reject kings, from Saul to Jehu. Schüpphaus (Richter- und Prophetengeschichten, 184-99) includes 1 Sam 4:1$7: 2 \mathrm{aa} ; 9: 1-10: 16 ; 11: 1-11,15$ as part of the judges component of his pre-dtr history from Joshua 24 to 2 Kings 18 . My analysis has shown however that it was DTR who constructed the history of the judges period. 1 Sam 9:1-10:16; $11: 1-11,15$ are an integral part of the transition to the monarchy.

${ }^{80} \mathrm{An}$ examination of the text from a redaction history standpoint provides a more comprehensive explanation of the textual phenomena than the literary reading advocated in the recent study by Eslinger (Kingship of God in Crisis), whose approach is similar to that of Polzin (Moses and the Deuteronomist). Like Polzin, Eslinger's study is valuable for a number of features, such as attention to the context, and awareness of how the narrator creates a sense of expectation in the reader, and at times lets the reader share in the narrator's own omniscient position (cf. p. 74). However his appeal to the various "voices" of the narrative to explain tensions in the text and the function of one text in relation to another is inadequate of itself and needs to be cross-checked against a literary critical analysis. Eslinger appears quite ready to identify tensions and differences between speeches by Samuel, Yahweh, and the narrator's prose as voices in the narrative, but he does not satisfactorily account for the tensions in each one of these elements of the narrative.

${ }^{81}$ The analysis will also test how Campbell's additional hypotheses of a northern expansion to the Prophetic Record, and a parallel Southern Document contribute to an understanding of DTR's redaction 
In relation to the more immediate concern of the first chapters of 1 Samuel, the Prophetic Record enables the significance of the change of leadership wrought by the demise of the Elide priesthood and the emergence of Samuel as a prophet to be clarified. Campbell includes the story of the birth of Samuel and his emergence as a prophet of Israel in the Record. Far from being merely an introduction to the narrative however, the story is also an integral component of the structure and conceptual plan of the history envisaged by the prophetic redaction. According to Campbell 1 Sam 1:1-4:1a "suggests the intention of preparing for a change of epochs in Israel; the change from the old epoch, symbolized in the corrupt Elide priesthood, to the new epoch, expressed in the prophetic guidance, represented first by Samuel". 82 This prophetic guidance of Israel's history is then illustrated by the prophetic redaction in the subsequent stories of the prophets' designation and rejection of kings. 83

It was this change of leadership and its implications, as expressed in the Prophetic Record, which enabled DTR to construct the second stage of the history of the judges and portray it as the immediate prelude to the inauguration of the monarchy. In other words DTR took the basic structural schema of the Prophetic Record at this point, but adapted it to the structure of DtrH. In order to do this DTR first of all brought the second stage of the history of the judges to an end by linking the successful intervention of Samuel in 1 Samuel 7 with the earlier deeds of the judges. ${ }^{84}$ This is evident in DTR's redactional additions, which are to be found in 1 Sam 7:6b, 13-17.

1 Sam 7:6b is to be assigned to DTR on the basis of the analysis of the judges' material. ${ }^{85} 1$ Sam 7:13 for its part recalls similar statements in Judg $3: 30 ; 4: 23 ; 8: 28 ; 11: 33 \mathrm{~b}$. These are not in themselves dtr, but the reference in 1 Sam 7:13 to the subjugation of enemies (Philistines) is evidence that DTR intended to create a definite link between Samuel and the earlier

${ }^{82}$ Campbell, Of Prophets and Kings, 66.

${ }^{83}$ Campbell raises the possibility that the Record may have contained an account of the Philistine war with the loss of the ark and the death of the Elides. A possible text would be 1 Sam 4:1b-2, 4, 10-18a. "If some part of this material is accepted for the Prophetic Record, it is on the assumption that the basic traditions remained in circulation long after they had been incorporated into the Ark Narrative" (ibid, 67, n. 6). Campbell also believes that a version of 1 Samuel 7 could have been part of the Prophetic Record (pp. 67-68). The text he proposes is 1 Sam 7:2b, 5-6a, 7-12. Both of these proposals would make good sense in the Record, although the change of leadership is still visible without it (i.e., reading from 1:1-4:1a to 9:1-10:16). If one includes $1 \mathrm{Sam}$ $4: 1 b-2,4,10-18 a$ and 7:2b, 5-6a, 7-12 the full text of the Record in 1 Samuel 115 is 1 Sam 1:1-3:21*; 4:1a, 1b-2, 4, 10-18a; 7:2b, 5-6a, 7-12; 9:1-10:16*; 11:1-11, 14-15*; 14:52; 15:1-35 (pp. 101-2).

${ }^{84}$ One may accept that DTR found the account of Samuel's intervention in the Record (cf. n. 83), or drew it from another source.

${ }^{85} \mathrm{Cf}$. McCarter, I Samuel 144-45; Hans Joachim Stoebe, Das erste Buch Samuelis (KAT 8/1; Gütersloh: Mohn, 1973) 173. Stoebe bases his conclusion on a comparison with the parallels in the framework passages of the judges stories, which he regards as dtr. 
deliverers. 1 Sam 7:15-17 refers to Samuel's work as judge. It is possible that an old tradition about Samuel is embedded in these verses. Even so it is more than likely DTR adopted and expanded it (cf. also v 6b), as was done with the lists of the minor judges. ${ }^{86} 1$ Sam 7:14 contains some items of information which were probably also traditional elements. Their presence here is best attributed to the author of the surrounding verses, that is, DTR. Although 1 Sam 7:3-4 is a dtr formulation it is best assigned to a later hand than DTR. ${ }^{87}$

The function of DTR's redactional additions can be appreciated better by considering them within the context of the history to this point. DTR not only located Samuel in the overall sequence of deliverer judges, but more specifically he forged a parallel between him and Tola (Judg 10:1-2). Just as Tola delivered (Judg 10:1) Israel from the strife caused by Abimelech's failed attempt at kingship and guided Israel as a judge, so through his intervention Samuel delivered (1 Sam 7:8) Israel from the strife caused by the failure of the Elide priesthood and judged Israel. ${ }^{88}$ When one takes into account the fact that

${ }^{86}$ For a discussion see Richter, Bearbeitungen, 123-29; and " $\mathrm{Zu}$ den 'Richtern Israels'," ZAW 77 (1965) 40-72. In a recent study Horst Seebass claims to recover the text of an old narrative ("der Samuel Utopie") about Samuel the judge (David, Saul und das Wesen des biblischen Glaubens [Neukirchen-Vluyn: Neukirchener Verlag, 1980] 100-111). The text comprises 1 Sam 7:15a, 16a, $2 \mathrm{a} \beta \mathrm{b}, 6-12,14 \mathrm{aab} ; 8: 1,2 \mathrm{~b}, 4-6 \mathrm{a}, 11-16,17 \mathrm{~b}, 19 \mathrm{~b}-22 \mathrm{a} ; 10: 17,25 \mathrm{a}, 19 \mathrm{~b}-24$, 25b-27; 12:1-6a, 16-17a, 18-19a, 20aa, 23a, 24b. According to Seebass DTR combined this text with an old Saul tradition. The value of Seebass's analysis is that it indicates DTR drew on elements of tradition. But the rearrangement of verses in his reconstructed text makes it too hypothetical to be plausible. 1 Samuel 12 is a later dtr composition (see below).

${ }^{87}$ So also Mayes, The Story of Israel, 97-98, and Veijola, Das Königtum, 4448 (DtrN). The two verses form a doublet with 1 Sam 7:5-6, but this only makes them secondary in relation to the Prophetic Record. The evidence which points to a later Dtr is this. First, in DTR's presentation of the period of the judges repentance and return is not a pre-condition for Yahweh's deliverance, as is the case here. Second, the formulation of 1 Sam 7:4 clearly recalls that of Judg $10: 16$, which is itself part of a later addition dealing with the theme of repentance. Third, 1 Sam 7:3 uses the term foreign gods (ēlohe hannekarar) which occurs also in Judg 10:16. This term is found elsewhere in Josh 24:20, 23 (Josh 24:1-28 being a later insertion in DtrH), and Gen 35:2, 4. While the passage does not contain explicit nomistic references, I would judge it to belong to the nomistic stage of later redaction, a dominant concern of which was the people's infidelity. Eslinger (Kingship of God in Crisis, 232-37) does not consider the literary evidence for a doublet here. His claim that Samuel replaces the 'failed ark' in 1 Samuel 7 is unwarranted.

${ }^{88}$ Even though it is not spelt out in terms of the prophecy-fulfillment schema which one finds in DTR's redaction of 1-2 Kings, it is clear from the context that the death of Eli and his sons is the outcome of the prophetic condemnation of 1 Sam 2:27-34. Cf. also 1 Sam 3:13-14. Campbell includes both texts in the Prophetic Record (Of Prophets and Kings, 67, n. 4). Veijola (Die ewige Dynastie, 35-43) assigns 1 Sam 2:27-36 with its fulfillment notice in $1 \mathrm{Kgs}$ 2:27 to DtrH, and 1 Sam 3:11-14 to DtrP, but the evidence is not convincing. 1 Kgs 2:27 contains the verb málè which does not appear in the fulfillment 
Tola and Samuel resolve crises in leadership which emerge after a sequence of stories of Israelite apostasy and deliverance then the two stage structure for DTR's history of the judges becomes quite evident.

DTR however did not see the second stage of the structure (Judg 10:6$13: 1^{*}$; 1 Sam 1:1-7:17*) only in terms of a conclusion to the history of the judges. Nor did DTR see Samuel merely as a parallel to Tola. The text has an additional important function within the larger trajectory of DtrH. There are two items of evidence to support this: first, the emergence of Samuel as a prophet in 1 Sam 3:20-4:1a; second, the narrative of the fortunes of the ark after its capture by the Philistines, in particular its return to the borders of Israel and sojourn in Kiriath-jearim (cf. 1 Sam 7:1-2). Although the emergence of Samuel as a prophet was already present in the Prophetic Record, the story of the fortunes of the ark was inserted by DTR. ${ }^{89}$

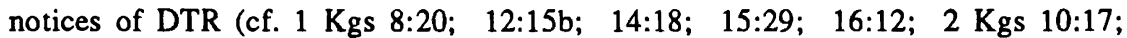
17:23). Veijola's proposal that DtrP replaced an earlier prophecy after 1 Sam 3:10 with his own is highly speculative. Also, as Campbell notes, the term hêqim dābăr in 1 Sam 3:12 is not characteristically dtr (cf. its occurrence in 1 Sam 1:23). In short Campbell's identification of 1 Sam 2:27-34 and 3:11-14 as predtr is to be preferred. 1 Sam 2:35-36 is not from DTR either. The dyarchic form of government envisaged in these verses (priest and king) best suits an early post-exilic date (cf. Jer 33:14-26). Sec R. W. Klein, I Samuel, 28; Stoebe, Das erste Buch Samuelis, 120.

${ }^{89}$ The hypothesis of an independent Ark Narrative (1 Samuel 4-7; 2 Samuel 6) was first proposed by Leonhard Rost, The Succession to the Throne of David (Historic Texts and Interpreters in Biblical Scholarship 1; Sheffield: The Almond Press, 1982) 6-34. Noth (The Deuteronomistic History, 47) accepted Rost's hypothesis but surprisingly attributed only the incorporation of 1 Samuel 4-7 to DTR. 2 Samuel 6 was already in DTR's source (ibid., 55). Recent scholarship has confirmed the basic hypothesis but some disagreement has emerged about the extent of the narrative. Franz Schicklberger (Die Ladeerzählung des ersten Samuel-Buches. Eine literaturwissenschaftliche und theologiegeschichtliche Untersuchung [FB 7; Würzburg: Echter, 1973]) reduces the text to 1 Sam 4:1-6:16. Campbell (The Ark Narrative [1 Sam 4-6; 2 Sam 6]: A Form-critical and Traditio-historical Study [SBLDS 16; Missoula: Scholars, 1975]) agrees substantially with the text proposed by Rost. See also "Yahweh and the Ark: A Case Study in Narrative," JBL 98 (1979) 31-43. Patrick D. Miller and J. M. Roberts (The Hand of the Lord: A Reassessment of the "Ark Narrative" of 1 Samuel [The Johns Hopkins Near Eastern Studies; Baltimore: Johns Hopkins, 1977) argue that the text comprised 1 Sam 2:12-17, 22-25, 27. $36 ; 4: 1 \mathrm{~b}-7: 1$. The disagreements are thus mainly about the beginning and end of the narrative. All agree in 1)-including the block of text which recounts the loss of the ark, its fortunes in Philistine territory, and its retum to Israelite territory; 2)- excluding any mention of Samuel from the Ark Narrative. While a full examination of the issue is clearly beyond the scope of this investigation the following points can be made. First, the absence of Samuel in the Ark Narrative supports the position that it does not belong in a pre-dtr prophetic edition (against McCarter, I Samuel, 26). Second, the Prophetic Record hypothesis provides a better explanation of the presence of anti-Elide material in 1 Sam 2:12-17, 22-25, 27-36 than that of Miller and Roberts. Third, my analysis of 2 Samuel 6 and 1 Kings 8, the two passages which recount the ark's entry 
The emergence of Samuel as a prophet within the context of the history of the judges clearly marks him as a new lcader in Israel, one who cannot be completely contained within the categories of the deliverer judges. ${ }^{90}$ For its part the return of the ark and its lodging at Kiriath-jearim (1 Sam 7:2) on the edge of the land implies that Yahweh has some purpose in mind for Israel, although the execution of the men who looked into the ark (1 Sam 6:19) warns that Israel must wait upon him to reveal his purpose. Yahweh's deliverance of Israel through the agency of Samuel in 1 Samuel 7 is in its turn a clear sign that the divine purpose is favorable.

Nevertheless one could hardly regard the situation achieved in 1 Sam 7:1217, with the ark still at Kiriath-jearim, as the full realization of the divine purpose. Furthermore Samuel has not yet been portrayed exercising his prophetic leadership on behalf of Israel. Something more is therefore expected, an event which will engage Samuel in his role as a prophet who reveals the divine purpose. The reader can reasonably expect that whatever the revelation of the divine purpose, it will include some definitive resolution of the situation of the ark. Within the larger sweep of the history the revelation of the divine purpose comes with the prophetic inauguration of the monarchy. This leads in its turn to the resolution of the situation of the ark when it is successfully brought into Jerusalem in 2 Samuel 6, and eventually placed in the temple by king Solomon in $1 \mathrm{Kgs} 8: 1-11.91$

One can see therefore how DTR constructed the second stage of the history of the judges to maintain a certain continuity with the first stage of that history (Judg 3:7-10:5) but within a larger trajectory of movement towards the monarchy and the realization of the deuteronomic ideal under Solomon. Furthermore, one can also see that this larger trajectory points to a positive interpretation of the institution of the monarchy by DTR. We can now turn to an examination of DTR's redaction of the material dealing with the transition to the monarchy (1 Samuel 8-11*). This will confirm DTR's positive attitude

into Jerusalem and thence into the temple, supports the position that the story of the ark in 1 Samuel 4-7 is an integral component of DTR's conceptual plan for the history. The chronological notice in $1 \mathrm{Sam} 7: 2$ seems to be a later attempt to precision the "long time" by stating that the ark episode took place 20 years before Samuel's victory over the Philistines, hence halfway through the 40 years of Judg 13:1 (cf. Noth, The Deuteronomistic History, 22)

${ }^{90}$ Two additional items of evidence within 1 Samuel 7 serve to illustrate the differences between Samuel and the earlier judges. First, Samuel does not lead troops in a holy war. Rather Yahweh's deliverance comes as a response to his offering and intercession on Israel's behalf. Second, his role as judge is introduced in the context of a national assembly, which he calls, and in which he mediates the reconciliation of Israel with Yahweh (1 Sam 7:5-6). No other judge functions in such an authoritative way.

${ }^{91}$ The function of the ark in DtrH was explored earlier by Hermann Timm, "Die Ladeerzählung (1. Sam. 4-6; 2. Sam. 6) und das Kerygma des deuteronomistischen Geschichtswerks," EvT 26 (1966) 509-26. Timm's asssessment was based on Noth's exilic date for DtrH. My own assessment of the function of the ark would link it much more closely with the monarchy and the realization of the deuteronomic program than Timm's. 
to the monarchy as inaugurated by Yahweh through the agency of his prophet, and under the authority of his prophet. ${ }^{92}$ DTR's understanding of the monarchy is therefore clearly indebted to the doctrine espoused by the redactor(s) of the Prophetic Record. The examination will also provide confirmation of DTR's structure and conceptual plan by demonstrating how the transition to the monarchy is integrally linked to the two stage structure of the history of the judges.

\section{SAMUEL 8-12}

Within these chapters the Prophetic Record is to be found in 1 Sam 9:1$10: 16^{*} ; 11: 1-11,14-15^{*}$. The texts to be examined for dtr redaction are therefore 1 Sam 8:1-22; 10:17-27; 11:12-13; 12:1-25. 1 Samuel 8 divides easily for analysis into 1 Sam 8:1-3 (the report of Samuel's sons as judges), and 1 Sam 8:4-22 (the assembly at Ramah). The report in 1 Sam 8:1-3 is essential to the sequence of the narrative, and is included by all who subscribe to the hypothesis of a DtrH. One may note how the introduction to this report flows smoothly from 1 Sam 7:15-17, giving a strong indication that DTR was responsible for constructing the sequence. There is a real possibility that, as with 1 Sam 7:15-17, DTR drew on traditional material to construct 1 Sam $8: 1-3$. The material that most immediately comes to mind are the names of Samuel's sons and the information that they were judges in Beersheba. ${ }^{93}$ It is more doubtful whether one can claim the report of their failure as judges in 1 Sam 8:3 as a pre-DTR tradition. The accusation that Samuel's sons did not walk in the way of their father calls to mind the judgment formulas in the books of Kings. As will be seen not all of these judgment formulas can be claimed for DTR. Nevertheless DTR did make use of them, and this is most likely the case here as well. The judgment formulas for the kings consistently address the question of right worship. This is not so here of course, but then the context does not call for such a judgment.

The crimes of which the sons are accused concern social justice. The first, that of unjust gain, occurs only here in the historical books. However one finds the second, that of taking a bribe, in Deut 10:17 (God does not take a bribe); 16:19; 27:25 (to slay an innocent person for a bribe). One finds the third crime, perverting justice, also in Deut 16:19, and in 24:17 (for the sojourner, orphaned, widow); $27: 19$ (the same). ${ }^{94}$ Deut 16:19, which occurs

${ }^{92} \mathrm{G}$. E. Gerbrandt's recent study misses this key aspect of DTR's understanding of the monarchy (Kingship According to the Deuteronomistic History, 143-54).

${ }^{93} \mathrm{Cf}$. Noth, The Deuteronomistic History, 122, n. 40. Cf. also Klein, 1 Samuel, 73; McCarter, I Samuel, 156. There is some evidence however that the mention of Beersheba is a later addition (cf. Stoebe, Das erste Buch Samuelis, 182). It comes awkwardly after $v 1$ with its reference to all Israel. The fact that Beersheba is a southern judean town also strikes some as anachronistic (so Van Seters, In Search of History, 251). It may have been added to provide a southern counterpart to the northem towns in 1 Sam 7:15-17.

${ }^{94}$ Justice (mispat) is widely distributed in Deuteronomy and occurs in such dtr texts as $1 \mathrm{Kgs} 2: 3 ; 8: 45,49,58,59 ; 9: 4 ; 11: 33$. The verb "to pervert" (natâ) 
in a section concerning the appointment of judges (Deut 16:18-20), could well have provided the base for the list of the sons' crimes. ${ }^{95}$ Weighing the evidence, there is no compelling reason to deny $v 3$ to DTR. In sum then, 1 Sam 8:1-3 is best described as a composition by DTR in which was included some traditional information about the names of Samuel's sons, and perhaps too, their place of residence..$^{96}$

For the assembly at Ramah, DTR's text as given in the structural presentation is 1 Sam 8:4-6a, 11-17, 19-22.97 The principal omissions are the two instructions to Samuel by Yahweh in vv 7-8 (with $v 6 \mathrm{~b}$ included as Samuel's initial recourse to Yahweh) and vv 9-10. The justification for assigning these verses as secondary comes from a literary critical analysis weighed against what has emerged from the overall reassessment of DTR's theology of kingship. These criteria are more to the fore in the analysis of 1 Samuel 8 because, with the exception of the accusation of apostasy in $v 8$, the chapter does not contain the more characteristic dtr terminology.

The assembly of the people at Ramah and their demand for a king in 1 Sam 8:4-5 is generally accepted as part of DtrH. ${ }^{98}$ The phrase "like all the nations"

occurs in $1 \mathrm{Kgs} 11: 2,3,9$, but the concern is Solomon's apostasy. The phrase "to turn aside after" may have been taken by DTR from source material. It occurs in Judg 9:3 and 1 Kings 2:28 (twice).

${ }^{95}$ The connection between 1 Sam 8:3 and Deut 16:18-20 has been noted by Mayes, The Story of Israel, 97.

${ }_{96}$ Against Weiser, Samuel, 30; Stoebe, Das erste Buch Samuelis, 183.

${ }^{97}$ A possible minimal text would be 1 Sam $8: 1-5,20 \mathrm{~b}-22$. This is the text proposed by N. Lohfink, Rückblick im Zorn, 59. However there is sufficient evidence to warrant the fuller text. The text proposed by Mayes (The Story of Israel, 97-98), 1 Sam 8:1-6a, 11-22, is closest to my own, except for $v 18$. Unfortunately Mayes does not assemble the necessary evidence to justify his proposal. Nor does he account for the discontinuity in vv $6 \mathrm{~b}-10$. Veijola (Das Königtum, 53-72) proposes 1 Sam 8:1-5 (omitting "to govern us like all the nations"), 22b for DtrH, with 1 Sam 8:6-22a assigned to DtrN. The difficulties with Veijola's distribution of text are; first, the location of Samuel's dismissal of the people immediately after $v 5$ is odd in a DtrH which, for Veijola, was promonarchical. One would expect the inclusion of at least vv 20b-22. Second, his claim that "elders" in v 4 and "men of Israel" in v 22b are synonyms whereas "people" in the rest of the chapter is the mark of a different author is unlikely (p. 55). In 1 Samuel 11 the three terms are used interchangeably (cf. vv 1, 3, 7, $8,11,12,14,15)$. Third, he claims that the refusal of the people to listen to the voice of Samuel in $v 19$ is characteristic of later redaction (p. 59 and texts cited). Later redaction did condemn the people for refusing to listen, but it was always with reference to the voice of Yahweh (cf. Josh 5:6; Judg 2:2; 6:10; 1

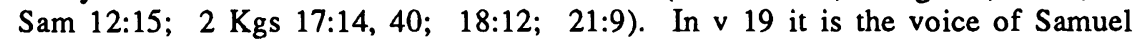
that is rejected. Fourth, his assignation of vv 6-22 to DtrN does not account for the complexity of vv 6-18. This will emerge in the course of the discussion.

${ }^{98}$ Once again, like 1 Sam $7: 15-17$ and $8: 1-3$, DTR may have made use of aspects of the tradition surrounding the emergence of the monarchy in the composition of these verses. Hos 13:10 records a similar demand by the people, "give me a king and princes". Cf. also Jotham's fable in Judg 9:1-21. For a discussion of these texts see Crüsemann, Der Widerstand, 19-42, 91. 
in $v 5 b \beta$ has been proposed as an addition, but this is unnecessary. ${ }^{99}$ The location of the phrase at the end of the sentence was deliberate, designed by DTR to emphasize the sort of government envisaged by the people. It is this sort of government (mİsāt 17. It would provide no solution to the problems brought on by Samuel's sons. The phrase is formulated differently in 1 Sam 8:20 because of the development of the people's argument to include the king's role in battle. What emerges in the course of the narrative is that these two elements of monarchical rule-government and leadership in battle-can only be successfully exercised by a king established through the agency of Yahweh's prophet. In 1 Samuel 11 Saul successfully leads Israel against the Ammonites (vv 1-11) and demonstrates right government (vv 12-13).

The justification for the elimination of the two instructions in 1 Sam 8:6b, 7-8 and 9-10 is based on the following considerations. First of all, they are not essential to the basic sequence of the chapter, as is the one in 1 Sam 8:22a. Second, Yahweh's directive to "make them a king", which follows directly on his instruction in $v 22 \mathrm{a}$ that Samuel hearken to the people, flows smoothly from the people's demand in vv 19-21. This is not the case with the earlier instructions. The instruction in $v 7$ to hearken to the people is followed by the accusation that the people have rejected Yahweh as king. In $v$ 9 it is admittedly followed by another instruction, but its tone is quite negative in comparison to v 22a. ${ }^{100}$ Furthermore, v 10 effectively transforms Samuel's diatribe in vv 11-17 into a report of the "words of the Lord". The common feature in both vv 7-8 and 9-10 is that the initially positive reaction of Yahweh to the people's request for a king is followed by a statement which casts it in a negative light. This is quite different to $1 \mathrm{Sam} 8: 22 \mathrm{a}$ and indicates vv 7-10 are later insertions in the chapter. The redactor or redactors responsible have employed the same technique in each case. They have made use of the element of hearkening to the people in order to introduce a negative statement by Yahweh.

The double occurrence of the divine instruction to hearken to the people in 1 Sam 8:7 and 9, plus the different comment which follows each instruction, points firmly in the direction of multiple redaction. The precise contours of each redactor's contribution are however somewhat elusive. The introduction to Yahweh's speech in $\mathrm{v} 7 \mathrm{a} a$ is of course required for the initial contribution, and one may confidently range $\mathrm{v} 6 \mathrm{~b}$ alongside it. Verse $7 \mathrm{a} a$ provides the divine response to Samuel's prayer in $v 6 \mathrm{~b}$. As for the instructions them-

${ }^{99}$ Against Stoebe, Das erste Buch Samuelis, 184, n. 13, and Veijola, Das Königtum, 68, who includes the preceding verb "to govern us". Even though the use of the term "nations" was an indication of secondary redaction earlier in the history, this was in the context of the conquest. There was the sharp difference between enemies conquered (DTR), and nations remaining to be conquered, or left by Yahweh because of Israel's infidelity (later Dtr). The context of 1 Sam 8:5 does not require the use of the term enemies.

${ }^{100}$ Stoebe (Das erste Buch Samuelis, 184) thinks that the reference to warning the people in 1 Sam 8:9 may be a later addition. This is possible but the evidence is not strong. 
selves, and their accompanying comments, I would judge that 1 Sam 8:7aßb-8 is later than 8:9-10. This is indicated by the way 1 Sam 8:7b claims that in demanding a king the people have rejected Yahweh as king. ${ }^{101}$ It is a more serious reaction to the people's demand than vv 9-10. These effectively turn vv 11-17 into an anti-monarchical statement by Yahweh. But, unlike v 7b, they do not interpret the people's demand as a threat to their relationship with Yahweh. In short, vv 9-10 focus on the monarchy while $v 7 \mathrm{~b}$ focuses more on the people.

1 Sam 8:8 carries this a step further by equating the people's demand for a king with outright apostasy. The independence of $v 8$ from $v 7$ is indicated by the fact that Samuel is here regarded, in contrast to $\vee 7$, as forsaken by the people in the same way as Yahweh. ${ }^{102}$ Nevertheless both 1 Sam 8:7b and 8 share a common interest in the infidelity of the people. It is reasonable to assume that this reflects a later stage in the subsequent redaction of DtrH than vv 9-10. One would expect that a transfer of interest from the monarchy to the people took place after it had become reasonably clear to the survivors of the exile that the restoration of the monarchy was no longer possible.

In sum there is a good case that the devclopment of 1 Sam 8:6b-10 took place in the following manner. 1 Sam 8:6b-7aa, 9-10 was added to DtrH first of all. This was expanded by the insertion of $v 7 \mathrm{a} b \mathrm{~b}$, with $v 8$ a still later insertion. ${ }^{103}$ While there is no nomistic language in these two later additions the focus on the people is in line with the overall thrust of what has been described as the nomistic stage of later dtr redaction. It is likely therefore that $1 \mathrm{Sam} 8: 7 \mathrm{a} \beta \mathrm{b}$ and 8 reflect developments within this broadly conceived stage of redaction.

Once these additions have been identified one can see how DTR's text runs smoothly from the assembly in 1 Sam 8:4-5 to Samuel's reaction in v 6a, and thence to the diatribe in vv 11-17. The diatribe fits in well after the statement

${ }^{101}$ The description of Yahweh as king is itsclf an indication that this verse is later than DtrH. The only other occurrence of this in a dtr passage is $1 \mathrm{Sam}$ 12:12 which, as will be demonstrated below, is a later addition to DtrH. Judg $8: 23$ is pre-dtr and states that "Yahweh will rule (yims $\delta I)$ over you". It is worth noting also that Yahweh's instruction to hearken to the people expands on $v$ $22 a$ with the addition "in all that they say to you". This is somewhat surprising, for it seems to place Samuel under the people. It certainly does not sit well with DTR's view of the prophet. 1 Sam $8: 22 \mathrm{a}$ should not be taken to mean that Samuel is to obey the people. The request of the people will be met, but at Yahweh's command ("make them a king") and on his terms, as the larger context shows.

${ }^{102}$ Against Veijola, Das Königtum, 57-58. Note the use of the verb "to forsake" in concert with the notion of serving other gods. This has already been shown to be a mark of later redaction.

${ }^{103}$ This analysis also requires that the introductory wécatâ in $v 9$ was added by the hand responsible for $v 7 \mathrm{a} \beta \mathrm{b}$. It made for a smoother transition from one instruction to the other. A small point in favor of the proposal is that the instruction šemac béqôlăm in $v 9$ is the same as in $v 22 a$. The instruction in $v$ $7 \mathrm{a} \beta$ has a more elaborate formulation. It also implics that the people's rejection of Yahweh is evident in everything they ask. 
in $\mathbf{v} 6 \mathrm{a}$ that the request for a king displcased Samuel. Admittedly this does not of itself secure the claim that the sequence of 1 Sam 8:6a, 11-17 is DTR's. However it becomes the most reasonable conclusion when one weighs it against the additions outlined above, and the broader context. Before considering the context however the examination of 1 Samuel 8 needs to be completed.

There is no need to go into a detailed analysis of 1 Sam 8:11-17. Although there may be some debate about the precise date of this pericope its pre-dtr character is accepted. ${ }^{104}$ Its author may have had one or more kings of Israel in mind in composing it, but the account of the monarchy does not give us sufficient information to identify the particular king or kings with any certainty. ${ }^{105}$ The reasonable thing to do is read it within the more immediate context, and here one finds a reference point in the people's desire to have a king to govern them like all the nations (1 Sam 8:5). This reading finds support in the way the repeated use of the verb lâqah (to take) in 1 Sam 8:1117 recalls the same verb in 1 Sam 8:3. The message of Samuel's diatribe is clear enough; the 'way' of a king like all the nations would not solve the problems experienced by the people under Samucl's sons, it would only result in a more destructive oppression (cf. $v$ 17).

1 Sam 8:18 is a later addition to the diatribe. The reference to the king "whom you have chosen (behartem) for yourselves" is out of context here. This is not the sense of 1 Sam 8:4-5. Rather, the people ask Samuel to appoint (sim) a king for them. One may add that the choice of a king by the people is not a notion that would have been congenial to DTR. ${ }^{106} \mathrm{~A}$ further indication that this text is a later addition is the threat of Yahweh's refusal to aid the people. This recalls Yahweh's refusal in Judg 10:10-16, also a later text. Apart from this verse however, there is no reason against assigning the remainder of the chapter to DTR. 1 Sam 8:19 follows on as the people's ex-

${ }^{104} \mathrm{~A}$ detailed analysis is given by Crüsemann (Der Widerstand, 66-73) who dates it in the early monarchy. On the pre-dtr character of the pericope see also Birch, The Rise of the Israelite Monarchy, 24-25; Ronald E. Clements, "The Deuteronomic Interpretation of the Founding of the Monarchy in 1 Sam VIII," VT 24 (1974) 398-410; Mayes, The Story of Israel, 94; McCarter, I Samuel, 10, 161; Seebass, David, Saul, 68, 102; Veijola, Das Königtum, 60-66; Weiser, Samuel, 38-41. Some important groundwork on this pericope was done by I. Mendelsohn, "Samuel's Denunciation of Kingship in the Light of Akkadian Documents from Ugarit," BASOR 143 (1956) 17-22. Mendelsohn noticed that the description of the king in 1 Sam 8:11-17 showed knowledge of the Canaanite pattern of royal rule, where the subjects werc regarded as slaves. Thus, this knowledge of the king's 'way' was available to Israel from its earliest days as a monarchy. This lends support to the inclusion of the phrase "like all the nations" in DtrH.

${ }^{105}$ Against for example Clements ("The Founding of the Monarchy," 404), who sees a reference to Solomon.

${ }^{106}$ Note the occurrence of the same verb in 1 Sam 12:13. 
pected response to Samuel's diatribe on the 'way' of the king. ${ }^{107}$ As noted above the repeated request for a king-or given the progress of the chapter, what one may now accurately call a demand-in 1 Sam 8:19-20 is formulated somewhat differently to 1 Sam 8:5. This is because it is in the context of a refusal to listen to Samuel, and contains as well the additional argument that a king would lead Israel in battle.

The preceding literary critical and linguistic analysis finds confirmation from a consideration of 1 Sam 8:1-6a, 11-17, 19-22 within the context of DtrH outlined so far. To begin with there is a similarity between the failure of Samuel's sons as judges and the two previous cases of failure of leadership (Abimelech and the sons of Eli). Thus there is continuity with the period of the judges but within the larger context of transition to the monarchy. ${ }^{108}$ The failure of Samuel's sons is also the occasion for including two other elements which are important for DTR's understanding of Israelite monarchy.

One of these is DTR's inclusion of the pcople in the new dispensation in which Israel is to be ruled by the prophets and kings. Their assembly at Ramah, their demand for a king like all the nations, and their initial rejection of Samuel's authority in 1 Sam 8:19-20 sets the scene for an important contrast in the Mizpah assembly in 1 Sam 10:20-27. In this passage it is Samuel who assembles the people. Furthermore the people on this occasion accept Samuel's authority, the king he presents to them (1 Sam 10:24b), and his proclamation of the royal mišpāt in 1 Sam 10:25 as the new form of government. ${ }^{109}$

The other element concerns the use of this term mišat in 1 Sam 8:3 in relation to the conduct of Samuel's sons as judges (sōptîm), and in the description of the 'way' of the king in 1 Sam 8:11 and in 10:25. The term

${ }^{107}$ Note that the people refuse to listen to Samuel, not Yahweh. It is the addition of vv 9-10 which makes vv 11-17 a word of Yahweh. At this level of redaction therefore $\mathrm{v} 19$ can be read as a refusal to listen to Yahweh.

${ }^{108}$ Hans Wilhelm Hertzberg (I \& II Samuel [OTL; London: SCM, 1964] 71) observes that in each case the failure of leadership involves the question of hereditary succession (cf. also McCarter, I Samuel, 160). However it is difficult to tell whether DTR was making an oblique reference to the Davidic dynasty as the only legitimate form of hereditary succession because it was approved by Yahweh through his prophets.

${ }^{109}$ The recognition of this as DTR's contribution supports Campbell's hypothesis of the Prophetic Record against Birch (The Rise of the Israelite Monarchy, 21-29) and McCarter (I Samuel, 19-20), who include a version of 1 Samuel 8 in their prophetic histories. As Campbell notes, the prophetic redaction saw monarchy as a prophetic gift. The question of monarchy emerging from a demand by the people did not enter consideration (Of Prophets and Kings, $73,117)$. It is instructive therefore to see how DTR integrated the prophetic understanding with the notion of a demand by the people to forge a larger unifed view of the emergence of the monarchy. There may also be some propaganda in the way the people are portrayed here. It was intended to win acceptance for DTR's understanding of the monarchy by showing how it was accepted by Israel at its very inauguration. Nevertheless it is difficult to say how wide a distribution a document such as $\mathrm{DtrH}$ would have had. 
functions as a sort of catchword which links discrete material together to reveal another aspect of DTR's understanding of the monarchy. This is that a king such as the people demanded would not restore justice (cf 1 Sam 8:3) but rather intensify oppression (cf. 1 Sam 8:11-17). The only sort of monarchy which could secure a just society was the one in which the king was established through the agency of Yahweh's prophet, and in which the prophet laid down the mišpat hammelukâ (1 Sam 10:25). ${ }^{110}$ The sense of the term mišpatt here is of course one of a law or code, but the implication is that it is this law which will ensure the recovery of the justice (mišstat) perverted by the crimes of Samuel's sons. A point which emerges from this observation is that, within the context of DtrH, 1 Sam 8:11-17 is not anti-monarchical as such, but only against the sort of king demanded by the people; namely, one like all the nations.

The account of the assembly at Mizpah in 1 Sam 10:17-27 can be divided for analysis into two main sections; Samuel's introductory address in 1 Sam 10:17-19, and the report of the lot-drawing ceremony in 1 Sam 10:20-27. ${ }^{111}$ The proposed text of DtrH omits Samuel's speech in vv 18-19 as a later addition. Given the identification of 1 Samuel 8 as a combination of the work of DTR and subsequent dtr redaction one would also expect this speech, which takes up the theme of the people's demand for a king, to be from DTR or subsequent redaction. ${ }^{112}$ A number of factors militate against attributing it to DTR.

${ }^{110}$ The MT of 1 Sam 10:25 is to be preferred to the LXX, Old Latin and Syriac. The changes were probably made in the light of 1 Sam 8:9, 11 (so McCarter, I Samuel, 191; and Klein, I Samuel, 95; against Stoebe, Das erste Buch Samuelis, 213-14). There is a definite progression in DTR's presentation. The 'way of the kingdom' appears to oblige both king and people in 1 Sam $10: 25$.

$111_{1}$ Sam 9:1-10:16 does not contain any sure evidence of dtr redaction, yet it is clearly an integral component of this section of the history. The integration of the story with its prophetic theology into DtrH can be seen better once the justification of the remainder of DTR's text has been completed (1 Sam $10: 17,20-27 ; 11: 1-15)$.

112 Birch (The Rise of the Israelite Monarchy, 42-54) argues that 1 Sam $10: 17-19,25-27$ a belonged to his prophetic edition. His evidence is based on the assembly being a sequel to 1 Samuel 8 , which he included in the prophetic edition, and on an analysis of the language of the speech (cf. also McCarter, $I$ Samuel, 20). In the light of the analysis of 1 Samuel 8 Birch's first argument cannot be maintained. The argument from language depends on a comparison with Judg 6:7-10, which has been shown to be a secondary dtr passage. The dtr nature of Samuel's speech is acknowledged by Boecker, Die Beurteilung, 34-44; Lohfink, Rückblick im Zorn, 88 (vv 18-19, Dtr II); Mayes, The Story of Israel, 100-101 (vv 18-19a, a later Dtr); Mettinger, King and Messiah, 87 (vv 18-19a); Seebass, David, Saul, 81 (vv 18-19a); Schüpphaus, Richter- und Prophetengeschichten, 194 (vv 18-19); Stoebe, Das erste Buch Samuelis, 216 (v

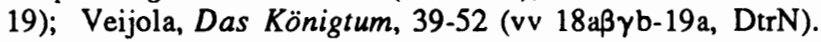


What is immediately striking is the way 1 Sam 10:19 interprets the people's demand for a king as a rejection of Yahweh. ${ }^{113}$ This is more in line with the thought of $1 \mathrm{Sam} 8: 7 \mathrm{a} \mathrm{b}$ than DTR. Moreover if one removes vv 18-19 the remaining text does not contain any element of divine hostility to the people or the notion of kingship. 1 Sam 10:18-19 in effect functions in a similar manner to the additions in 1 Samuel 8 . That is, it qualifies a positive attitude to kingship by prefacing it with a divine speech which censures the people for requesting a king. ${ }^{114}$ The way the expected announcement element of the speech in 1 Sam 10:19 has been replaced by an instruction to assemble before Yahweh is a further indication of how Samuel's speech in vv 18-19 has been inserted into an existing context. ${ }^{115}$

An additional factor emerges from an inspection of the speech's language. While the historical review in $\mathrm{v} 18$ contains two formulaic references to the Exodus which cannot in themselves be used as evidence, the language of $v 19$ is most closely associated with other secondary passages in DtrH. ${ }^{116}$ Thus, the terms "calamities" ( $\left.r a^{c} \delta t\right)$ and "distresses" (sarrot) are found in combination in Deut 31:17, 21. The later redaction in Judg 10:14 has Yahweh say of the foreign gods "let them deliver $\left(y \delta \delta_{\hat{S}}{ }^{\circ} \hat{u}\right)$ you in the time of your distress" (sãratkem). The evidence is limited but nevertheless significant. Taken in conjunction with the preceding observations one can see that 1 Sam 10:18-19 is best regarded as a later addition. Its similarity to $1 \mathrm{Sam} 8: 7 \mathrm{a} \beta \mathrm{b}$ suggests it belongs to the same nomistic stage of later redaction.

With 1 Sam 10:20-27 there is some evidence for identifying two originally independent accounts in 1 Sam 10:20-21b $\alpha$ and 10:21b $\beta-23.117$ These two

${ }^{113}$ The MT reading $(16)$ is preferred to $\left(16^{\jmath}\right)$ by Dominique Barthélemy, Critique textuelle de l'Ancien Testament, vol 1, Josue, Juges, Ruth, Samuel, Rois, Chroniques, Esdras, Néhémie, Esther (OBO 50/1; Fribourg: Éditions Universitaires, 1982) 164.

${ }^{114}$ In 1 Samuel 8 the divine speech occurs in vv 7-9, which we saw was constructed in three stages. The correlation with 1 Sam 10:19 is closest in v $7 \mathrm{a} \beta \mathrm{b}$, which was added after vv 7aa, 9-10. The significant thing is the way both speeches preface DTR's texts which outline a favorable divine initiative; v 22a in 1 Samuel 8, and v 24 in 1 Samuel 10.

${ }^{115}$ The instruction takes up Samuel's original call in $\mathrm{v} 17$ and also provides a literary seam between his accusation in $\mathrm{v} 19 \mathrm{a}$ and the lot-drawing ceremony. Some who accept the secondary nature of the speech nevertheless retain $v 19 \mathrm{~b}$ for DTR (cf. Mayes, The Story of Israel, 100-101; Veijola, Das Königtum, 3952 [vv 18aßyb-19a, DtrN]). This is possible, but it is more likely that the verse is part of the later redaction (Lohfink, Rückblick im Zorn, 88; and Schüpphaus, Richter- und Prophetengeschichten, 88). 1 Sam 10:17 is of course part of DtrH, since it provides the overall introduction to the passage.

${ }^{116}$ Against Stoebe (Das erste Buch Samuelis, 216) there is no compelling reason to make a literary critical separation between the review of $v 18$, with its formulaic references, and the accusation of $v 19$.

${ }^{117}$ Eissfeldt, who first made the proposal (cf. Die Komposition der Samuelisbücher, 7) assigned $1 \mathrm{Sam}$ 10:17-21 ba to his E source, and 10:21b $\beta-27$ to his $\mathrm{L}$ source. The literary critical division was accepted-without subscribing to Eissfeldt's source theory - by Noth, The Deuteronomistic History, 50. Also Birch, The Rise of the Israelite Monarchy, 42-47; Boecker, Die Beurteilung, 45- 
texts reflect different techniques employed for the election of the king. The first is based on the drawing of lots, whereas the second presumes an oracular instruction that the king chosen by Yahweh would be identifiable by his physical stature. The presumed oracle is indicated by the report in 1 Sam $10: 22$ that the people consulted Yahweh "again" ( $\partial d)$. The difficulty of course is that this oracle is not in the present text. Moreover, this version of the election of Saul records an initiative by the people in 1 Sam 10:21b $\beta-23$, but in $v 24 a$ it is Samuel who takes charge.

It seems unlikely therefore that one can recover the complete text of the two versions. The lot-drawing ceremony conducted by Samuel really requires v 24a as its climax, but this verse incorporates a feature of the second account, namely Saul's incomparable stature (1 Sam 10:24aß). The second account (vv $21 \mathrm{~b} 3-23$; appears to have lost its beginning by being thoroughly incorporated into the lot-drawing ceremony, although $v 24 \mathrm{~b}$ - the people's acclamationcould well have been its conclusion. ${ }^{118}$ What is clear is that the combination was designed to subsume the people's initiative under the more authoritative one of Samuel. Given the description so far of the organization and structure of the transition to the monarchy, it is difficult to deny the hand of DTR in the combination. ${ }^{119}$ The present text emphasizes Samuel's authority to act on Yahweh's behalf. It also presents the people responding to Samuel's initiative and accepting the authority of his pronouncement in 1 Sam 10:24a. ${ }^{120}$ The thematic and structural links with 1 Samuel 8 are clear. More needs to be said on the relationship between these two assemblies, but first the analysis of 1 Sam 10:17-27 and 11:12-13 must be completed.

Attention has already been drawn to the relationship between the mispat hammelukâ in 1 Sam 10:25 and the occurrence of mišpatt in 1 Samuel 8. This

46; Cruisemann, Der Widerstand, 55-60; Mayes, The Story of Israel, 100; Veijola, Das Königtum, 51

${ }_{118}$ Noth attributed the composition of the narrative to DTR, who made use of a fragment from the tradition (The Deuteronomistic History, 50). Mayes (The Story of Israel, 100) accepts 1 Sam 10:21b $\beta-24$ as a traditional element, but assigns the rest to DTR. The parallel remark about Saul's stature in 1 Sam 9:2b was probably added in view of 1 Sam 10:24a $\beta$, but it is difficult to tell just when.

${ }^{119}$ Against Birch (The Rise of the Israelite Monarchy, 42-53) and McCarter (I Samuel, 20) who include 1 Sam 10:20-27a in a pre-dtr prophetic edition. Crüsemann has also proposed a pre-dtr text of the selection of Saul ( $D$ er Widerstand, 55-60). 1 Sam 10:21b $\beta-23,24 a \beta b,(26 a), 26 b, 27 a$ was part of a pre-dtr sequence including 1 Sam 9:1-10:16; 11:1-15 (pp. 57-58). There are two difficulties with his proposal. The first concerns $1 \mathrm{Sam}$ 10:22a, which presumes a prior consultation of Yahweh. Crüsemann's reconstruction does not supply this. The second is that his text does not mention Samuel in the selection of Saul and the conclusion to the assembly. It is difficult to see how 1 Samuel 11 can belong to Crüsemann's text therefore, since vv 12-13 seem to presuppose Samuel's knowledge of the rift in 1 Sam 10:26-27a.

${ }^{120}$ It is possible that DTR composed 1 Sam 10:24a. Certainly DTR would have added $\vee 24 a \beta$. However $v 24$ a a may have originally been part of the lotdrawing ceremony of vv 20-21ba. 
relationship, plus the report of a book written and laid up before Yahweh, points to DTR as the author of 1 Sam 10:25. However it is unlikely one can draw a direct reference from this verse to the so-called law of the king in Deut 17:14-20. To begin with, 1 Sam 10:25 refers to the kingdom, not simply to the king as does Deut 17:14-20.121 Nor does Deut 17:14-20 use the term mišat. There is of course a relationship between the terminology used in Deut 17:14-15 to describe the procedure for establishing a king and the terminology of 1 Sam 8:5 and 10:24. The analysis of both these passages has indicated that they came from DTR. They may have been composed with Deut 17:14-20 in mind. ${ }^{122}$ But in the absence of a clear reference to this text in 1 Sam 10:25 it is wiser to interpret the verse within the more immediate context. Thus, as already proposed, it is likely the mišpat hammêlukâ was envisaged as the sort of law which would enable the justice perverted by Samuel's sons to be regained. ${ }^{123}$

With 1 Samuel 11 Campbell assigns the account of the Ammonite war and the assembly at Gilgal (vv 1-11, 14-15) to the Prophetic Record but omits vv $12-13$, the royal pardon for the "worthless fellows" who objected to the election of Saul in 1 Sam 10:27.124 1 Sam 10:26-27 and 11:12-13 can be recognized as DTR's contribution from the way Saul is presented as exercising

${ }^{121}$ Taking the MT in favor of the versions (cf. $n .110$ ).

${ }^{122}$ The so-called law of the king cannot be investigated here. Preuss regards it as dtr (Deuteronomium, 137), whereas others would see an older core with later dtr editing. So G. Seitz, Redaktionsgeschichtliche Studien zum Deuteronomium, 233, 243 (vv 18-19 dtr); Mayes, Deuteronomy, 271 (vv 18-19 to DTR); Felix García Lopez, "Le roi d'Israel: Dt 17, 14-20," Das Deuteronomium: Entstehung, Gestalt und Botschaft (BETL 68; ed. N. Lohfink; Leuven: University Press, 1985) 277-97 (vv 14b $, 15 \mathrm{~b}, 16 \mathrm{a} \beta \gamma, 18-19,20 \mathrm{aa} *$ dtr). Given the validity of these findings DTR could have drawn on Deut 17:14-15. The law would not be out of place in DtrH. It gives divine approval to the establishment of a monarchy, albeit with certain conditions. It also accepts the notion of a dynasty. One factor which suggests it may be a later addition is that the reference in $v 14$ to a king like all the nations does not have the polemical sense of 1 Sam 8:5. This phrase could of course have been added to the law from 1 Sam 8:5, but at a time when monarchy had ceased to be a vital issue for Israel.

${ }^{123} \mathrm{It}$ is tempting to see in this phrase a description of the deuteronomic code as applied to the monarchical state. Faithfulness to what has now become the code of the monarchy would ensure the realization of the deuteronomic ideal. However there is no clear indication that this is what DTR had in mind. It is worth noting that, unlike Joshua in Josh 24:25. Samuel is not described as establishing (cf. sim) a mispst in 1 Sam 10:25.

${ }^{124}$ In a recent article Diana Edelman ("Saul's rescue of Jabesh-Gilead [1Sam 11:1-11]: Sorting Story from History," ZAW 96 [1984] 195-209) suggests that vv 1-2a (or b), 4a, 8a, 9-11 may have been part of an original narrative, while acknowledging that it is probably impossible to accurately recover the text of this narrative (p. 206). On the function of this story in the context I would query her assessment of it as a "testing" between "designation" and "coronation" (p. 198). Also the vassal status of Jabesh-Gilead in 2 Sam 2:4b-7 need not necessarily exclude a previous constitutive membership of Israel as seems to be the case in 1 Samuel 11. 
the function of a judge in 11:12-13, although in a way which is appropriate to the new institution of the monarchy. 125

When Saul's victory over the Ammonites is placed in the context of DtrH it clearly functions in an analogous manner to the stories of the deliverer judges. The association is implied by Saul's statement in v 13 that "the Lord has wrought deliverance in Israel". Nevertheless, one must also take into account the context of 1 Samuel 9-11 which shows that Saul's charism of deliverer has been received through his prophetic anointing. 1 Sam 11:7 emphasizes the essential nature of this prophet/king relationship with its reference to Saul and Samuel.126 While the story itself is therefore quite similar to the deliverer stories, the context rules out classifying Saul among the heroes of the period of the judges. That era is past. Similarly, the pardon granted to the worthless fellows in 1 Sam 11:12-13 shows that Saul possesses an analogous charism to the judges. ${ }^{127}$ But, as with the charism of deliverer this has been received through his prophetic anointing. Moreover Saul is not described as a judge; this term is no longer appropriate. ${ }^{128}$

1 Sam 10:26-27 and 11:12-13 are another example therefore of how DTR took a source (1 Sam 11:1-11,14-15) and reworked it in order to make it an integral component of the larger history. DTR's redactional procedure in 1

${ }^{125}$ Against McCarter (I Samuel, 201) there is no argument for accepting the LXX reading of Samuel in 1 Sam 11:13 in place of the MT, which has Saul. The MT reading is followed by Peter R. Ackroyd, The First Book of Samuel (The Cambridge Bible Commentary; Cambridge: University Press, 1971) 90; Hertzberg, I \& II Samuel, 91; Klein, 1 Samuel, 102; John Mauchline, 1 and 2 Samuel (NCB; London: Oliphants, 1971) 105; Stoebe, Das erste Buch Samuelis, 220.

${ }^{126}$ The mention of Samuel in this verse is redactional (so Stoebe (Das erste Buch Samuelis, 221-22), but there are no compelling reasons to exclude it from DtrH. Campbell attributes it to the prophetic redaction (Of Prophets and Kings, $128-29$, n. 4). I would disagree with Stoebe's opinion that the addition does not give any indication Saul relied on Samuel for his authority. Hertzberg ( 1 \& II Samuel, 90 , n. b) simply notes that the presence of the name shows the source knew Saul's beginnings had something to do with Samuel.

${ }^{127}$ This correlation is made on the basis of a consideration of the context of DtrH and observations by Knierim, "The Messianic Concept," 33. Knierim points out that the people appeal to Samuel as to "the judge of Israel" against slanderers of Yahweh. The appeal is made to Samuel, but it is Saul who grants the pardon. Knierim also carries out an analysis of the term "worthless fellows" in 1 Sam 10:25 (literally 'sons of Belial'). He finds that in "all Old Testament references $\not \grave{S}$ bellyya'al is a slanderer of God or a breaker of sacral laws, a destroyer of justice, a rebel against the king, or one who destroys life".

${ }^{128}$ In support of this argument it can be pointed out that although David also demonstrates charisms akin to those of deliverer and judge, similar distinctions apply. In 2 Sam 5:17-25 he leads troops as anointed king, and in 2 Sam 8:15 his exercise of the charism of right judgment is described by the use of the noun pair justice and righteousness. These do not occur in the description of the judges. With Solomon of course deliverance from Israel's enemies had already been achieved. However, his charism of right judgment was a component of his

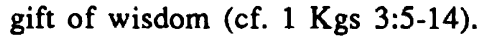


Sam 10:17, 20-27; 11:1-15 also reveals an important aspect of the function of 1 Sam 9:1-10:16 in the transition to the monarchy. Besides affirming the prophetic anointing of Saul, this passage establishes an important link between 1 Samuel 7 and 11. The charisms of deliverer and judge exercised by Samuel in 1 Samuel 7 are bestowed on Saul via his prophetic anointing, and exercised by him as king in 1 Samuel 11. At the risk of laboring a point one may also draw attention to a similar link with 1 Samuel 8. As anointed king, Saul is capable of exercising the sort of judicial authority (1 Sam 11:12-13) that will restore the order disturbed by the failure of Samuel's sons (1 Sam 8:1-3), and meet the demand of the people expressed in 1 Sam 8:4-5. Furthermore Saul is shown to be capable of delivering Israel from its enemies (1 Sam 11:1-11), and so of fulfilling the hopes of the people expressed in 1 Sam 8:20.

As a final comment on DTR's careful organization of the section dealing with the transition to the monarchy we may note how it is bound together by a series of assemblies. ${ }^{129}$ At the end of the story of the judges there is the assembly at Mizpah called by Samuel in 1 Sam 7:5. Samuel takes the initiative at each key step in this assembly and the people are united in their obedience to his directives. By contrast, in 1 Samuel 8 it is the people who assemble at Ramah and take the initiative. Moreover they reject the counsel of Samuel. 1 Sam 10:17, 20-27 resolves this tension. Samuel again assembles the people at Mizpah and this time assumes the authoritative role which had been manifested in 1 Samuel 7. Here too the people obediently follow his directives. The authority of Samuel and the unity of the people is threatened by the worthless fellows in 1 Sam 10:26-27. However, the crisis is resolved in the wake of the victory over the Ammonites, and Samuel summons a final assembly at Gilgal to celebrate the establishment of the kingdom (1 Sam $11: 14) .{ }^{130}$ All the people obey the summons and gather as one for the coronation of Saul (1 Sam 11:15). Thus the sequence of assemblies is an important element in the structure of this section of the history, and provides another example of DTR's technique of continuity within a larger trajectory of change and development.

\section{SAMUEL 12}

The omission of this passage from DtrH is based on a number of criteria which will be developed in the course of the analysis. First there is the

${ }^{129} \mathrm{D}$. J. McCarthy saw the assemblies were a structural element, but did not draw out their significance fully ("The Inauguration of Monarchy in Israel. A Form-Critical Study of I Samuel 8-12*," Int 27 [1973] 401-12).

${ }^{130}$ The verb hadas is translated as "renew" in the RSV. However Paul Dhorme (Les livres de Samuel [EBib; Paris: Gabalda, 1910] 97) translated it as "inaugurate". 1 Sam 11:14-15 may preserve an element of old Israelite tradition (cf. McCarter, 1 Samuel, 205, 207; Stoebe, Das erste Buch Samuelis, 228-30). Campbell (Of Prophets and Kings, 128-29, n. 4) believes the prophetic redactors may have added the mention of Samuel in $v 14$ (cf. also $v 7$ ). On the basis of the analysis given here the proposal by Robert J. Vannoy (Covenant Renewal at Gilgal. A Study of 1 Samuel 11:14-12:25 [New Jersey: Mack, 1978] 68) that the kingdom in 1 Sam 11:15 refers to Yahweh's kingdom is unacceptable. 
recognition of a difference of theology from DTR. In concert with this there is similarity of thought between 1 Samuel 12 and other later passages. There is also what I would term a characteristic compositional technique throughout the chapter. The recognition of this criterion was prompted by the way the chapter adapts aspects of DtrH to serve the dominant concern of the theological argument being developed. Finally there are a number of linguistic features which point to later redaction. These are limited and so cannot be used in themselves as convincing evidence of later redaction. Nevertheless they do become significant when taken in conjunction with the other criteria. ${ }^{131}$

The chapter may be divided into the following sections: 1 Sam 12:1-5 (Samuel's testimony); 12:6-15 (review and stipulation); 12:16-19 (storm sign and confession by the people); 12:20-25 (Samuel's response and exhortation). The division is based on the presence in the text of phrases such as "and Samuel said" and "now therefore", which mark important stages in the unfolding of the chapter. While this division enables the major parts of the chapter to be seen and facilitates analysis of each part, it should not be allowed to obscure one's perception of the whole and how the parts stand in relationship to that whole.

Turning first of all to 1 Sam 12:1-5 the following observations can be made about theology, compositional technique and language. Verse 1 invites an initial comment on language. The statement that "I have hearkened to your voice in all that you have said to me" clearly recalls 1 Sam 8:7. This verse has been shown to be a later expansion of the basic divine instruction in 1 Sam 8:22. Samuel's introductory review also uses the verb mallak to describe the establishment of the king. This term does not occur in any of the preceding parallel passages from DTR (cf. 1 Sam 8:5-6a, 19-20, 22; 10:24). However it does occur in 1 Sam 8:9 and 12:12.132 The point is not a strong one, but indicative of a later hand nevertheless.

${ }^{131}$ Veijola (Das Königtum, 83-99) assigns the chapter to DtrN with later additions in vv $6 \mathrm{~b}, 21$. He is followed by Mayes (The Story of Israel, 101) who in an earlier article included it in DtrH ("The Rise of the Israelite Monarchy," $Z A W 90$ [1978] 1-19). The recognition of later redaction is correct but the arguments are inadequate. Veijola claims the chapter is not located like other speeches in DtrH. However 1 Sam 11:14-15 can function as a locating text (so Vannoy, Covenant Renewal at Gilgal, 127-30; Eslinger, Kingship of God in Crisis, 383-84; Lohfink, Rückblick im Zorn, 94). His second argument that it disrupts the sequence of 1 Sam 11:15; 13:1 is stronger. But one could respond that this is the most appropriate location for such a discourse on the new era of monarchy. Veijola also argues that the chapter displays nomistic language. There is some evidence of this but it is insufficient of itself to secure Veijola's position. The proposal that 1 Samuel 12 was not part of DtrH needs to be placed on a surer footing than that given by Veijola. R. Stahl ("Aspekte," 6164), who follows the Smend school, comes to quite a different conclusion to Veijola. He asssigns 1 Sam 12:1-9, 10*, 11-12,13*, 14*, 15*, 16-17a, 18, $19 a, 20 a a, 23,24 a a b, 25$ to DtrH. DtrN additions are found in 1 Sam 12:17b, $19 \mathrm{~b}, 20 \mathrm{a} \beta \mathrm{b}, 22,24 \mathrm{a} \beta$, with some terminology also in vv $10,13,14,15$.

${ }^{132}$ It occurs also in 1 Sam 8:11, a pre-dtr text. 
In addition to this linguistic evidence an examination of the composition of 1 Sam 12:1-5 shows there is little evidence to claim a pre-dtr source. ${ }^{133}$ Nor can one claim the sort of connection between 1 Samuel 8; 10 and 12 that would establish unity of authorship. ${ }^{134}$ Samuel's sons are mentioned, but only in passing and without any reference to the critical situation described in 1Sam 8:1-3. Samuel's testimony in 1 Sam 12:3 may be based on a traditional element. ${ }^{135}$ The repeated use of the verb laqah (to take) indicates that it is intended principally to allude to the occurrence of the same verb in 1 Sam 8:3 and 8:11-17. But one cannot correlate the contents of 1 Sam 12:3 with either 1 Sam 8:3 or 8:11-17, nor for that matter, with anything about Samuel in the history. ${ }^{136}$ In my judgment this phenomenon is not due to carelessness or dependence on a source. The author who composed 1 Samuel 12 was out to develop an argument which would offer an interpretation of the emergence of the monarchy and locate it within the overall context of Israel's history. The author made enough references to the history to establish a basic contextual relationship with it, but in doing so interpreted or adapted the reference points so that they would better serve the argument being developed. The examination of the rest of the chapter will verify this interpretation.

1 Sam 12:1-5 may be described as a defense of Samuel's faultless conduct in all that had taken place to this point. Without using either term the text would appear to conflate his roles of prophet (vv 1-2) and judge (vv 2-5). In DtrH however there is a clear progression from Samuel's activity as judge to that of prophet. The people's acknowledgement of Samuel's fidelity to his tasks provides a suitable prelude to his defense of Yahweh's fidelity and exposure of the people's guilt in vv 7-12. Samuel's assessment is verified by the divine sign in vv 16-18. This is followed by the people's confession in $v$ 19 and the subsequent instructions for the future in vv 19-25.

Before passing to the rest of the chapter two additional observations can be made about 1 Sam 12:1-5. First, 1 Sam 12:2 indicates that Samuel intends to make a farewell address because of his old age. It is customary for such addresses to make some provision for the future (cf. Moses' discourse in Deuteronomy, Joshua's in Joshua 23, and David's in $1 \mathrm{Kgs} 2: 1-4)$. This observation supports the position that 1 Sam 12:1-5 is an integral part of the whole chapter. Second, 1 Sam 12:1-5 has Samuel in effect submit himself to the judgment of the people. This does not accord with DTR's understanding of

${ }^{133}$ Against McCarthy, Treaty and Covenant, 212, who claims traditional material in 1 Sam 12:2-5. Also Weiser, Samuel, 79ff; Seebass, David, Saul, 103 (vv 1-6a).

${ }^{134}$ Against Birch and McCarter for whom the connection belongs to their proposed pre-dtr prophetic history. While Birch has only 1 Sam 12:1-5 in his prophetic text, McCarter includes 12:16-19a, 20a, 23. Dtr redaction is identified in vv 19b, 20b-22, 24-25 (I Samuel, 216).

${ }^{135} \mathrm{Cf}$. such texts as Num 16:15; Deut 26:13-14; Job 31:16-18. For a discussion see von Rad, "The Early History of the Form-Category of I Corinthians xiii. 4-7," The Problem of the Hexateuch and Other Essays, 301-17, especially pp. 314-17.

${ }^{136}$ The term for bribe in 1 Sam 12:3 (koper) is different to the one in 8:3 (sohad). 
Samuel as the authoritative prophet, and is an additional indication of different authorship. ${ }^{137}$

In order to facilitate the discussion of 1 Sam 12:6-15 the review in vv 6-12 will be examined first and then the stipulations in vv (13) 14-15. Within vv $6-12$, attention needs to be drawn first of all to the addition in $v 6 \mathrm{~b}$. This begins Samuel's review of Yahweh's saving deeds before its formal introduction in v 7 ("now therefore"), and also anticipates the mention of Moses and Aaron in v 8b. ${ }^{138}$ As for 1 Sam 12:7-12 itself, although it is presented in the form of a review of salvation history, its main thrust is to defend the fidelity and mercy of Yahweh throughout that history in contrast to the infidelity of Israel. 139

The argument unfolds as follows. Yahweh's fidelity was demonstrated at the very inception of Israel's history, in his response to the cry of the fathers (v 8). Despite this, Israel forgot Yahweh, who then handed them over to their enemies ( $v$ 9). The recognition that this was an act of their God because of their infidelity led Israel to confess their sin, plead for deliverance, and pledge fidelity $(\mathrm{v} 10)$. In response to this Yahweh delivered them from their enemies (v 11). 1 Sam 12:10-11 contains the key elements of this interpretation of Israel's past. ${ }^{140}$ They are: 1)- recognition by Israel that their oppression is an "accusation" by Yahweh that they have sinned; 2)- the confession of sinfulness; 3)- petition; 4)- pledge of fidelity; 5)- renewal of relationship with Yahweh, signalled by deliverance from enemies and safety. This exposition of Israel's past relationship with Yahweh is then used by the author to interpret the emergence of the monarchy. All the elements are employed, but are applied in a somewhat different way because of the nature of the events being interpreted.

The theological perspective evident in this review is not that of DtrH. DTR's presentation of the cycle of apostasy and deliverance in the period of the judges does not contain elements $1,2,3$, or 4 . However elements 1,2 and 3 are found in the secondary passage Judg 10:10-16. ${ }^{141}$ As well the notion of

${ }^{137}$ The parallel description of the king and Samuel walking before the people in $1 \mathrm{Sam}$ 12:2 suggests that the king is intended to replace Samuel. This does not accord with the theology of DTR either. 1 Sam 12:3, 5 states that Samuel's testimony was also made before Yahweh's "anointed". However this is probably an addition (so McCarter, I Samuel, 213; Veijola, Das Königtum, 94).

${ }^{138}$ The MT of $v 6 \mathrm{~b}$ also appears to have lost a word or phrase after "Yahweh". For a discussion see McCarter, I Samuel, 210; Stoebe, Das erste Buch Samuelis, 233. Noth (The Deuteronomistic History, 123, n. 50) eliminates the reference to Moses and Aaron in vv $6 \mathrm{~b}$ and $8 \mathrm{~b}$, as does Boecker, Die Beurteilung. 71. However, there is no reason to justify elimination of the second one.

${ }^{139}$ An initial indication of this thrust is given by the presence of the verb šăpat in 1 Sam 12:7.

${ }^{140}$ Against Stahl ("Aspckte," 47-50) there is no cogent reason for regarding the details of the sin in $v 10$ as a later expansion. Also Floss, Yahwe DienenGöttern Dienen, 395.

${ }^{141}$ Element 4 is not present as such, but the narrative reports that the people served Yahweh faithfully (Judg 10:16). 
repentance as a pre-condition for divine deliverance is present in the secondary passage 1 Sam 7:3-4. This similarity of thought with other secondary passages is matched by a number of linguistic associations. ${ }^{142}$ On the question of compositional technique there is evidence in the review of $1 \mathrm{Sam}$ 12:7-11, similar to that observed in 1 Sam 12:1-5, to indicate that its author was content to provide only a general link with the context of the history, because the principal concern in these verses was to outline the necessary criteria for interpreting the emergence of the monarchy. The relevant evidence occurs in the list of enemies in v 9, and the list of deliverers in v 11. Each of these recalls the period of the judges, but in a selective manner, sufficient to maintain the necessary basic contact with the course of the history. ${ }^{143}$

In order to review the emergence of the monarchy (1 Sam 12:12) within the parameters of this argument from history, the author once again adapted information from that history. In this case however, the nature of the material did not lend itself as easily to the argument as the judges' material. The Ammonite crisis was the only example of oppression and deliverance which the author could draw on to link up with the schema of the historical review.

${ }^{142}$ The verb "to forsake" in 1 Sam 12:10 has been observed as a feature of later redaction. Note how closely the formulation of $v 10$ follows that of Judg 10:10. Veijola (Das Königtum, 83) offers a number of linguistic parallels between 1 Sam 12:10 and 1 Sam 7:3-4 and 8:8; 10:18b, all of which have been identified as later. It should be noted that the terms used are not exclusive to later redaction. However, they are significant when taken in conjunction with the other criteria. The reference to Aaron in conjunction with Moses in $v 8 b$ is not found anywhere else in DtrH. The combination occurs in Josh 24:5, in $P$ material and in Chronicles.

${ }^{143}$ As with 1 Sam $12: 2-3$ this seems a more reasonable position than that which posits hypothetical source fragments, as did McCarthy, Treaty and Covenant, 208-9. In the end McCarthy was left with a series of fragments which do not really help to explain the text. On the list of enemies Noth suggested that it refers in reverse order to the sequence of judges; Ehud, Shamgar, DeborahBarak (The Deuteronomistic History, 51). His explanation depends on the LXX and Syriac reading of Barak for the MT Bedan. However tempting this may be the "lectio difficilior" of the MT should be preferred (cf. Barthelemy, Critique textuelle de l'Ancien Testament 1, 174). This does not affect my interpretation. On the list of judges Jerubbaal (Gideon), Jephthah and Samuel provide a suitable selection of key figures. The obscure name Bedan has been explained as a corruption of "from Dan" or "son of Dan", and so a reference to Samson. If this is the case it is out of sequence and probably a later gloss. A proposal has also been made that the Gileadite Bedan of 1 Chron 7:17 is another name for the Gileadite Jephthah. Hence he had two names in Israelite tradition. Either Bedan or Jephthah could therefore have been added as a later gloss. For details see McCarter, I Samuel, 211. Surprisingly McCarter accepts Samson (LXXL, Syriac) in place of Samuel (MT, LXXBA) in $v 11$. The weight of evidence and opinion is against this: cf. Barthélemy, p. 174; Hertzberg, I \& II Samuel, 95; Klein, 1 Samuel, 110; Stoebe, Das erste Buch Samuelis, 233. Among earlier commentators cf. Samuel R. Driver, Notes on the Hebrew Text and the Topography of the Books of Samuel, with an Introduction on Hebrew Palaeography and the ancient Versions and Facsimiles of Inscriptions and Maps (2d ed. rev. and enl.; Oxford: Clarendon, 1913) 93. 
In addition, while the people's demand for a king was an element which could be interpreted as a sin of infidelity, the successful establishment of the monarchy ruled out any straightforward application of the schema of the historical review. That is, the author could not identify the demand for a king with the sort of infidelity which in the review was followed with oppression by enemies. In relation to this it is instructive to note how 1 Sam 12:12 refers to Yahweh's kingship, but does not fully endorse the accusation of 1 Sam 8:7b that the people had rejected Yahweh as king. The point of the accusation in 1 Sam 12:12 is that the people's wrong lay in their demand for a king rather than their rejection of Yahweh as king. ${ }^{144}$ This is confirmed by 1 Sam 12:17, 19.

While the association of the demand for a king with the Ammonite crisis is therefore quite artificial in relation to the sequence of $\mathrm{DtrH}$, it nevertheless enabled the author to maintain a continuity of argument. The demand for a king was, like the earlier cases of Israclite infidelity, an affront to a God who had always shown himself ready to deliver Israel from oppression. In order therefore to restore its relationship to Yahweh Israel must acknowledge its fault and pledge itself once again to his service. The confession and pledge are reported respectivcly in the context of the storm scene of 1 Sam 12:16-19, and in an instruction by Samuel in 12: 20-25. Each of these bears a direct relationship to the accusation of 1 Sam 12:12. ${ }^{145}$

Before turning to these last two sections of 1 Samuel 12 however, some comment is required on 1 Sam 12:13-15. 1 Sam 12:13 is a summary statement of the successful establishment of the monarchy, combining the two

${ }^{144}$ It was noted earlier that 1 Sam 8:8 was added as an expansion of $8: 7 a \beta b$ in order to label the rejection of the kingship of Yahweh as apostasy. This may well have been an attempt to do what the author of 1 Samuel 12 had to avoid; that is, to read the rejection of Yahweh's kingship as apostasy and so identify it as exactly the same sin condemned in 12:9, 10.

1451 Sam 12:12 is a difficult verse to interpret, but the explanation derived from within the context of the chapter is more satisfactory than the alternatives. Boecker (Die Beurteilung, 75-76) explains the discrepancies with the larger context by claiming that redactors were not as concerned with the sort of disparity that troubles a modern reader. This may be true, but it does not explain the meaning of the verse or its function within the chapter. The explanation that the verse represents a particular tradition does not really solve the problem either (cf. Hertzberg, I \& II Samuel, 99; McCarthy, Treaty and Covenant, 212; Mayes, "The Rise of the Israelite Monarchy," 15; Stoebe, Das erste Buch Samuelis, 237-38; Weiser, Samuel, 72-74). Vannoy attempts to defend a historical sequence by stating that the context does not contradict the idea that the Ammonite threat lay behind the demand in 1 Samuel 8 (Covenant Renewal at Gilgal, 38-39). Eslinger (Kingship of God in Crisis, 403) accepts the disparity, but his explanation of it in terms of a "voice" in 1 Samuel 1-12 obscures a true perception of the relationship between $v 12$ and the review. He states that "The discrepancy between the request as described in ch. 8 and ch. 12 is a relatively simple matter of a disparity between the way it was, and the way a deeply involved character (Samuel as a 'voice') would like everyone to believe it was". 
elements of Yahweh's initiative and the people's demand. ${ }^{146}$ It is required after 1 Sam 12:12. It also enables one to explain the location of the stipulations in 1 Sam 12:14-15.147 These verses might have been expected to come after Israel's confession of guilt, thus following more closely the schema of 1 Sam 12:10 where Israel pledges to serve (`azzab, cf. v 14) Yahweh after having confessed its guilt. However, this is in the context of enemy oppression which is not the case of course with the emergence of the monarchy. Despite the condemnation of Israel's demand the author had to acknowledge the successful emergence of the monarchy, and Yahweh's initiative in its establishment. Nevertheless, immediately after acknowledging this divine initiative (v 13) the author has Samuel remind the people that the new institution of monarchy in no way absolves them from obedience to their God. ${ }^{148}$ The stipulations which governed Israel's relationship to Yahweh beforehand still stand. The future will be judged by the same criteria as the past.

Two significant theological differences with DTR emerge from this consideration of the author's procedure. First of all 1 Sam 12:14-15 clearly shows that the thrust of the stipulations is directed to the people. The king is mentioned only in the apodoses, because of the requirements of the context. In contrast DTR was concerned principally, as shall be seen in the presentation of the period of the monarchy, with the kings' fidelity to Yahweh, whose will was revealed through the prophets. Secondly, the presentation of Samuel as a preacher of the law in these verses is not in keeping with DTR's understanding of the prophets. For DTR the prophets intervened in Israel's history to interpret the course of that history within a schema of prophecy and fulfillment.

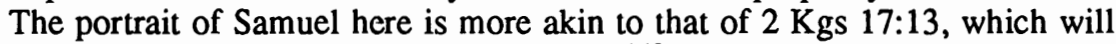
be shown in due course to be a later text. ${ }^{149}$ Also, there are no fulfllment notices in DtrH which relate to 1 Samuel 12.

1 Sam 12:16-19 supplies the element of acknowledgement of guilt which, as stated in the argument of 12:10, is a necessary prerequisite for a renewal of

${ }^{146}$ The verse appears somewhat overloaded and commentators have proposed the omission of the phrase referring to the people's choice (eg. Stoebe, Das erste Buch Samuelis, 233), or the phrase referring to their demand (eg. McCarter, I Samuel, 211; Driver, Notes, 94). LXX omits the latter. However I suspect that it was the former which was added, in the light of 1 Sam 8:18. Either solution does not affect the interpretation proposed here.

${ }^{147} \mathrm{I}$ would accept Boecker's resolution of the aposiopesis problem in $v 14$. 1 Sam 12:14a, 15a are two protases with balancing apodoses in vv 14b, 15b (Die Beurteilung, 77-82; cf. also McCarthy, Treaty and Covenant, 215). There is no need to propose an apodosis for $v 14$ which at some stage dropped out of the text (cf. McCarter, I Samuel, 211-21).

${ }^{148} \mathrm{On}$ the textual difficulty in $v 15$ the occurrence of king in the first apodosis favors the same reading in the second apodosis, as in the LXX, but there are grounds also for retaining the MT. For a full discussion see Barthélemy, Critique textuelle de l'Ancien Testament 1, 174-75. A comprehensive discussion is also provided by Eslinger, Kingship of God in Crisis, 48586.

${ }^{149} \mathrm{Cf}$. also Judg $2: 17$, which was identified as a later addition. It presents the judges as preachers of the law. 
Yahweh's protection. As with the other sections of this chapter it is unlikely that a pre-dtr source lies behind the sign of the storm. ${ }^{150}$ We noted in the argument of 12:10 that the accounts of enemy oppression were interpreted as a sign from Yahweh that Israel had sinned. The author of 1 Samuel 12 had no such account for the emergence of the monarchy. The scene in 12:16-19 was therefore constructed to take its place. In the light of Samuel's introductory speech in 12:16-17 the storm sign functions in the same manner as the oppression element of the argument. ${ }^{151}$ The storm is an appropriate sign from the divinity that Israel had sinned by demanding a king. ${ }^{152}$ It also confirms the veracity of Samuel's indictment of Israel. As in 1 Sam 12:10 this element of the argument is then followed by Israel's confession of sinfulness and petition (v 19). ${ }^{153}$ The petition is made through Samuel, an appropriate gesture which links up with the first section of vv 1-5, in which Samuel's innocence before Yahweh had been acknowledged by the people. It also links up with the final section of the chapter, where an important component of Israel's future relationship with Yahweh is the authoritative position of Samuel as intermediary.

The confession of sinfulness and petition in 1 Sam 12:19 is followed by the final section of the chapter (12:20-25) in which the elements from 12:10, of Yahweh's protection in return for obedience are taken up. The element of obedience recalls the stipulations of 1 Sam 12:14-15. ${ }^{154}$ But it is expressed in the form of an instruction by Samuel, coupled with an assurance of Yahweh's protection, and in conjunction with his own commitment to Israel's welfare (vv 20, 22-25). ${ }^{155}$ The instruction by Samucl rather than a statement by Israel (cf. v 10) is appropriate to the final section of the author's composition. It establishes Samuel as Israel's authorized intermediary and also looks to the

${ }^{150}$ Against McCarter, I Samuel, 216; Seebass, David, Saul, 103. The storm is a sign of Yahweh's power and authority rather than a theophany (so, Boecker, Die Beurteilung, 84; Stoebe, Das erste Buch Samuelis, 238). As my interpretation of the section demonstrates, this fits the context of the chapter.

${ }^{151} \mathrm{~A}$ storm in Israel during the harvest season would be seen as a destructive force. A feature of the Midianite oppression in Judg 6:2-6 was their destruction of Israelite crops.

${ }^{152} \mathrm{~A}$ clear link with the argument of the review section is created by the occurrence of the verb hityassèbû ("stand still") in 12:7 and 12:16. The difference in language between 1 Sam 12:17 and DTR's text in 1 Sam 8:6a should also be noted. 1 Sam 12:17 identifies the demand for a king as a great evil in the eyes of Yahweh. DTR states only that it was evil in the eyes of Samuel.

${ }^{153} \mathrm{~A}$ further link with the review of $1 \mathrm{Sam} 12: 7-11$ is indicated by the way the people acknowledge that they have added to their sins by demanding a king. It makes good sense within the chapter to see this reference to former sins in terms of $12: 10$.

${ }^{154}$ Note the occurrence of the verbs "to fear" and "to serve" in 1 Sam 12:14 and $12: 20,24$. Also, the warning in 12:25 recalls the apodosis in 12:15b.

1551 Sam $12: 21$ is generally agreed to be a later addition with similarities to Second Isaiah. Cf. Boecker, Die Beurteilung, 86; Lohfink, Rückblick im Zorn, 98; McCarter, I Samuel, 217; McCarthy, Treaty and Covenant, 211; Stahl, "Aspekte," 59; Veijola, Das Königtum, 90, n. 46. 
larger context of Israel's history. The alternation of instruction with assurance of Yahweh's protection emphasizes the requirement of obedience as a necessary condition for the continuation of a fruitful relationship with Yahweh. Samuel's own pledge in v 23 comes at the center of this final section, and serves to emphasize his authority to instruct Israel on obedience to the law. It also recalls the theme of his fidelity to and service of the people in 1 Sam 12:4-5. As well as this Samuel's description of his role in v 23 recalls vv 1415 , but it is clearly not in accord with DTR's portrait of the prophet. In 1

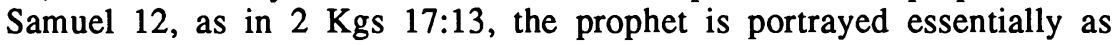
Yahweh's designated preacher of the law.

The combination of theology, compositional technique, and linguistic evidence clearly militates against assigning 1 Samuel 12 to $\mathrm{DtrH}$. The chapter is a composition by a subsequent Dtr, who was principally concerned to demonstrate that the demand for a king was a great evil on the people's part, an infidelity like their previous infidelities, and that it had placed their relationship with Yahweh in jeopardy. In this sense this Dtr was more antipeople than anti-monarchical. The language of the chapter, the focus on obedience to divine stipulations, the emphasis on the sins of the people, and the portrait of the prophet suggest that it shares the viewpoint of the nomistic stage of later dtr redaction. ${ }^{156}$ The unified nature of the chapter and its careful argumentation point however to an individual, highly skilled author.

${ }^{156}$ Baltzer (The Covenant Formulary, 66-68) argues that 1 Samuel 12 was composed as a covenant renewal according to the structural elements of the covenant formulary. See also McCarthy, Treaty and Covenant, 213-21. Care must be taken not to overlook the unique character of a particular text in applying such structures. McCarthy's attempt to incorporate 1 Sam 12:1-5 in the structure as a penance liturgy seems forced (p. 217). One may speak of a covenant renewal in the chapter but, as has been shown, it is within the context of a larger interpretation of Israel's history, in particular the emergence of the monarchy. It is quite probable that in constructing the argument, the author employed aspects of the covenant formulary. Lohfink (Rückblick im Zorn, 104) is more balanced in noting that there are elements of the covenant formulary in a number of secondary dtr passages, namely Deuteronomy 4; 29-30; Joshua 23; 24; 1 Samuel 12. While it is doubtful one can claim the presence of these elements as exclusive to the later redaction, it does indicate a certain preference. It also supports my proposal that such texts came from a recognizable stage of later dtr redaction which I have termed the nomistic stage. 


\section{THE PERIOD OF ISRAEL UNDER THE PROPHETS AND KINGS [A] 1 Sam 13:1-1 Kgs 12:24}

The period of Israel under the prophets and kings is too extensive to treat in one chapter. A convenient division is however indicated by the outline of the structure of DtrH, which has three principal stages for this period. These are: the stage from the reign of Saul to the schism in the kingdom (corresponding to $[\mathrm{A}]$ in the structure); the stage from the schism to the reign of Hezekiah (corresponding to $[\mathrm{B}]$ in the structure); the stage from Manasseh to the successful completion of Josiah's reform (corresponding to $[\mathrm{C}]$ in the structure). This chapter will therefore examine the text within stage A. Chapter 6 will examine stage B, and chapter 7 stage C. Chapter 7 will include an examination of the additions to DtrH in $2 \mathrm{Kgs}$ 23:24-25:30.

The establishment of what one may call the prophet/king form of leadership gave Israel an opportunity to regain the momentum lost at the end of the conquest period, and to finally realize what DTR saw as the ideal of the deuteronomic program laid down by Moses. This was the secure possession of the land, rest from enemies, and worship of Yahweh at the place which he would choose (cf. Deut 12:10-11). According to DTR's interpretation of Israel's history, this occurred during the reign of Solomon. David had conquered Israel's enemies. The secure possession of the land, continually threatened during the period of the judges, had finally been gained (cf. $1 \mathrm{Kgs} \mathrm{5:18}$ [RSV 5:4]). In addition the entry of the ark into Jerusalem had signalled that this was the city of Yahweh's choice. Solomon was therefore able to implement the final component of the deuteronomic program-centralized worship-by constructing the Jerusalem temple. $1 \mathrm{Kgs}$ 8:56 describes this high point in Solomon's reign as the realization or fulifllment of all of Yahweh's promises uttered through his servant Moses.

\section{SAMUEL 13-15}

The failure of Saul was accommodated within the conceptual plan and structure of DTR's history in the following manner. First of all, Samuel's rejection of Saul for his failure to fully implement the ban in the Amalekite campaign (1 Samuel 15) served to illustrate the authority of the prophet in relation to the king, as outlined in the account of the inauguration of the monarchy. Secondly, it provided a suitable prelude to DTR's account of the success of David. David was a king who recognized the authority of the prophet to guide the course of history, followed his word, and was therefore judged a faithful servant of Yahweh. His reign was marked by success and he was rewarded with the promise of an enduring dynasty (2 Samuel 7). Saul, on the other hand, failed to heed the prophetic word and thereby forfeited any 
promise of a dynasty (1 Samuel 13). He was rejected as king (1 Samuel 15) and his reign ended in disaster (1 Samuel 31).

A. F. Campbell includes the brief report of Saul's campaigns in 1 Sam 14:52 and the story of Saul's rejection 1 Samuel 15 in his Prophetic Record. An older story in 1 Samuel 15 was reworked by the prophetic redaction to highlight the authority of prophets to designate and reject kings. ${ }^{1}$ Saul had been designated king by Samuel in 1 Sam 9:1-10:16. In 1 Samuel 15 he is rejected by the same prophetic authority. Campbell finds no evidence of dtr language in the chapter. ${ }^{2}$

The absence of dtr redaction in 1 Samuel 15 can be explained on the basis of two observations. First, as noted above, the prophetic rejection of Saul was able to be accommodated within DTR's conceptual plan and structure without alteration. In fact one can say that the chapter's principal value was the way it verified DTR's understanding of the prophet/king form of leadership. The same can also be said for the prophetic designation of David in 1 Sam 16:1-13. Second, Saul's sin was not one of apostasy. Hence it did not provide an appropriate example for the sort of dtr censure that one encounters with the subsequent kings of Israel and Judah.

Except for 1 Sam 14:52 the remainder of 1 Samuel 13-14 is onitted from the Prophetic Record because it does not show any trace of the Record's prophetic concerns. ${ }^{3}$ However there are no compelling reasons against the

${ }^{1}$ A. F. Campbell, Of Prophets and Kings, 42-45. The redactional additions are $1 \mathrm{Sam} 15: 1 \mathrm{a} \beta \mathrm{b}, 10-12,16,17 \mathrm{~b}, 23 \mathrm{~b}, 26-30,35 \mathrm{~b}$.

${ }^{2} \mathrm{~F}$. Foresti (The Rejection of Saul in the Perspective of the Deuteronomistic School, 70, 89) assigns the bulk of 1 Samuel 15 to DtrP, with DtrN additions in vv 1b, 21a, 22, 23aß, 27-28. T. Veijola (Die ewige Dynastie, 102, n. 156) believes 1 Samuel 15 and 16:1-13 were of prophetic origin, and possibly inserted by DtrP. Apart from the unease created by Foresti's rather uncritical adoption of the Smend school hypothesis there are a number of problems with the evidence he assembles. If $1 \mathrm{Sam}$ 15:2-3 were formulated with Deut 20:[14]15-17 (for Foresti DtrH) in mind one would expect a closer correlation than is evident (pp. 120-30). The ban list in 1 Sam 15:3 is formulated as a series of 4 pairs and all in the singular, whereas Deut 20:14, 16 has general categories which do not appear in 1 Sam 15:3. Also the verb hatram is not exclusive to Deuteronomy and dtr texts; cf. Josh $6: 18,21 ; 8: 26 ; 10: 1 ; 11: 1$. The same goes for the alleged dependence of the ban against the Amalekites (1 Sam 15:2-3) on Deut 25:17-19 (pp. 92-102). 1 Sam 15:2 speaks of Amalek opposing Israel, whereas Deut 15:18 recalls Amalek's attack against a faint and weary Israel. Saul is commanded to strike Amalek, Deut 25:19 commands Israel to blot out the memory of Amalek. Deut 25:17 uses the verb yașă’ to describe the Exodus, whereas 1 Sam 15:2 uses alâ. Finally, 1 Samuel 15 makes no reference to the rest from enemies in Deut 25:19. J. Van Seters also argues from Deut 25:17-19 for the dtr nature of 1 Samuel 15 (In Search of History, 260). A. D. H. Mayes (Deuteronomy, 330-31) assigns Deut 25:17-19 to a late dtr editor.

${ }^{3}$ Campbell believes that the encounter between Samuel and Saul in $1 \mathrm{Sam}$ 13:7b-15a "very probably came from the same circles as the Prophetic Record" (p. 69, n. 11), but omits it as secondary. It is dependent on 1 Sam 10:8, which in its turn is secondary within the context of 1 Sam 9:1-10:16. With the omission of 1 Sam 13:7b-15a the rest of 1 Samuel 13-14 has no prophetic 
inclusion of these chapters in DtrH. 1 Samuel 13 is the passage in which Saul is deprived of a dynasty because of his disobedience, whereas 1 Samuel 15 is the passage in which Saul himself is rejected. ${ }^{4}$ From a thematic point of view the two passages combine to record the rejection of Saul and his house by Samuel. In relation to DTR's fous on the prophet/king form of leadership both passages could therefore be accommodated within the conceptual plan and structure of the history. It is possible that 1 Samuel 13-14 was added at the pre-dtr level, with likely dtr additions discernible in $1 \mathrm{Sam} 13: 13 \mathrm{~b}, 14 \mathrm{~b} 3 .^{5}$

\section{SAMUEL 16-1 KINGS 2}

There is no need to dwell on the story of David's rise in 1 Samuel 16-2 Samuel 5. ${ }^{6}$ This extensive narrative was easily incorporated into DtrH. In ternıs of DTR's conceptual plan and structure the success of David provided a suitable contrast to the failure of Saul. The portrait of David in these chapters also contributed to DTR's presentation of him as the model king.

There are three key features of this portrait of David as a model king: fidelity to the exclusive worship of Yahweh, fidelity to the prophet/king relationship, and fidelity to the policy of centralized worship in the temple.

component. H. W. Hertzberg (1 \& 11 Samuel, 105-7) and P. K. McCarter (I Samuel, 228) also see1 Sam 13:7b-15a as a later addition

${ }^{4}$ Following F. M. Cross (Canaanite Myth and Hebrew Epic, 224, nn. 19, 20) but without embracing his literary critical assumptions. Van Seters (In Search of History, 260-61) denies this difference but the reference in 1 Sam 13:13b to a kingdom that would be for ever seems clear enough.

${ }^{5}$ The term mișâ is well attested in deuteronomic and dtr passages. See, in addition to the occurrences in Deuteronomy, Josh 22:3, 5; Judg $2: 17 ; 3: 4 ; 1$ Kgs $2: 3,43 ; 3: 14 ; 6: 12 ; 8: 58,61 ; 9: 6 ; 11: 34,38 ; 14: 8 ; 18: 18 ; 2 \mathrm{Kgs}$ $17: 13,16,19,37 ; 18: 6 ; 23: 3$. Veijola (Die ewige Dynastie, 55-57) assigns 1 Sam 13:13-14 to DtrN.

${ }^{6}$ Van Seters (In Search of History, 260-64) omits 1 Sam 15:1-16:13; 28:325 from DtrH as later, but includes 1 Samuel 13. Even if one accepts that these passages are additions to the story of David's rise, this does not necessarily mean they are additions to DtrH. Redactional expansion of the story of David's rise could equally well have gone on at the pre-dtr level. Campbell has shown there is no evidence of dtr language in these passages (Of Prophets and Kings, 42-46). Van Seters also argues that DTR used the term năgîd (1 Sam 9:16; 10:1; 13:14; 2 Sam 7:8) whereas in 1 Sam 15:1-16:13 the term melek occurs, a sign of different authorship. Again it is doubtful whether this variation in terminology can be used to distinguish the hand of DTR from a later author. Van Seters does not provide any convincing argument that DTR added nagid to 1 Sam 9:1-10:16 and 13:14 (p. 255, 259). The discussion of 2 Samuel 7 will show there is good evidence $\mathbf{v} 8$ belongs to a pre-dtr level of Nathan's prophecy. The distribution of the terms nāgid (cf. 1 Sam 9:16; 10:1; 13:14;

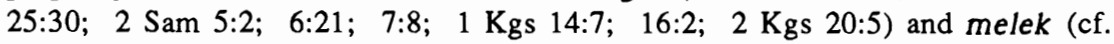
1 Sam 15:1; 16:1-3; 2 Sam 2:4; 5:3; 1 Kgs 1:34, 45; 2 Kgs 9:3, 6) in relation to royal legitimation indicates they cannot be used to separate DtrH passages from later additions. For a thorough examination of the term năgîd see Of Prophets and Kings, 47-61. 
These are more fully developed in DTR's organization of the four-part pattern around 2 Samuel 7 and the subsequent history of the monarchy. Nevertheless one can also see a connection between them and important aspects of 1 Samuel 16-2 Samuel 5. David's fidelity to Yahweh is recorded in a number of texts (cf. 1 Sam 17:45-47; 24:6, 17-21; 25:28; 26:23; 2 Sam 1:14; 3:28). Secondly, David's successful rise to kingship can be taken as the working out of his prophetic designation in 1 Samuel 16 (cf. also 1 Sam 25:30; 2 Sam $3: 9-10,18)$. Finally, an initial step in the establishment of centralized worship is achieved with David's capture of Jerusalem. From DTR's point of view therefore only a few chronological additions were required to complete the integration of 1 Samuel $16-2$ Samuel 5 into the history. ${ }^{7}$

\section{SAMUEL 7}

This is not the place to review in detail the wealth of literature which study of 2 Samuel 7 has generated. ${ }^{8}$ In keeping with the task of reassessing the DtrH hypothesis the goal here is to demonstrate how Nathan's prophecy functions within the conceptual plan and structure of the history. In order to do this, legitimate use can be made of those areas of the analysis of 2 Samuel 7 where a substantial degree of consensus has been reached and which can contribute to the understanding of its function.

The pre-dtr provenance of Nathan's prophecy is now generally accepted, even if considerable differences remain about the nature of the earliest version and the extent and unity of later redaction. ${ }^{9}$ Given this consensus, Campbell's proposal that a pre-dtr version of the prophecy belonged to a larger literary context such as that of the Prophetic Record makes good sense. It also enables a clearer picture to be gained of the contribution of DTR.

The earliest version of Nathan's prophecy-what Campbell terms the Davidic level-began with David's question to Nathan about building a house for the ark of God (2 Sam 7:1a [introduction], 2). The prophecy which followed was constructed around a play on the word house (2 Sam 7:4b-5, 7*

${ }^{7}$ In agreement with M. Noth DTR's additions are the chronological notices in 2 Sam 2:10a, 11 and 5:4-5. 2 Sam 3:2-5 and 5:13-16 were not part of the original tradition, but were inserted prior to DTR (The Deuteronomistic History, 55,125, n. 11).

${ }^{8}$ See McCarter, II Samuel, 210-31, also the literature cited by Campbell, of Prophets and Kings, 72, n. 19.

${ }^{9}$ Cf. McCarter, II Samuel, 215-17; 220-24. "It is difficult to believe, on the other hand, that ideas as theologically central to Israelite thought as those expressed here had no early documentary basis, or that a Deuteronomistic writer passed over such material in fashioning the present account" (p. 221). Van Seters (In Search of History, 271-77) regards 2 Samuel 7 as a unity, composed by DTR. He is correct to deny the two parts of Nathan's oracle (vv 4-7 and 816) can be separated on form critical grounds (p. 273). The questions in vv 5 and 7 expect an answer. But it does not necessarily follow that the present text is a unified composition. As the discussion will show there is good evidence that the present text was built up from a basic oracle constructed on a play around the word "house" in vv 5, 7b (questions) and vv 11b, 16 (answers). 
[omitting to "Israel"], 11b, 16). ${ }^{10}$ The thrust of this original prophecy was that David would not build a house for Yahweh, rather Yahweh would build a sure house (i.e., dynasty) for David. ${ }^{11}$

The next stage in the development of the text was associated with the Prophetic Record. The relevant verses are 2 Sam 7:3-4a, 8-10, 12, 14-15, 17. The addition of 2 Sam 7:3-4a was designed to point out that it was Yahweh's will to deny the temple to David. ${ }^{12}$ Campbell notes further that at the pre-dtr level there is no divine authorization for Solomon to build the temple. Such a prophetic viewpoint would not have been welcome in Judean circles, but it is quite understandable in a northern context. 2 Sam 7:8-10 contains a clear reference to the account of David's prophetic designation in 1 Sam 16:1-13 (cf v 8), as well as a concise summary of the story of his rise (cf. v 9a). 2 Sam $7: 9 \mathrm{~b}-10$ looks to the future and serves also to link up with the prophecy in $7: 11 \mathrm{~b}, 12,14-16 .{ }^{13}$ The prophetic redaction in these verses addressed the issue of Solomon's success (cf. v 12), as well as the prophetic intervention of Ahijah of Shiloh and the subsequent schism in the kingdom (cf. vv 14-15). In this way the reign of Solomon was brought within the compass of prophetic authority claimed by the Record. It is interesting to note that, taken in themselves, these verses do not contain a clear reference to the larger Davidic dynasty. ${ }^{14}$ This is in accord with the text of the Prophetic Record recovered by Campbell. After the schism in the kingdom it focuses exclusively on the story of the northern kings.

The third stage of the text's growth is identified by Campbell with the redaction of DtrH, the relevant verses being 2 Sam 7:1b, 11a, 13.15 These are marked by their dtr language and the way they integrate Nathan's prophecy into the larger trajectory of DtrH. Thus 2 Sam 7:1b, 1 laß refer to rest from enemies, a DTR concern noted earlier in such passages as Deut 12:10-11;

${ }^{10}$ Veijola (Die ewige Dynastie, 68-79) identifies a pre-dtr core in 2 Sam 7:1a, $2-5,7,8 a, 9-10,12,14-15,17$, with DtrH additions in vv $1 b, 11 b, 13,16$, and DtrN in vv 6, 11a. Thus DtrH was responsible for the divine legitimation of the Davidic dynasty. Veijola claims $v 11 \mathrm{~b}$, addressed to David, is an addition in relation to $v 10$, addressed to Israel. But the removal of $v 11 \mathrm{~b}$ only makes $v$ 12 , also addressed to David, immediately contiguous to $v 10$ ( $\mathrm{v} 11 \mathrm{a}$ is $\mathrm{DtrN})$. Rather than advance our understanding of the composition of the text therefore, Veijola's analysis creates a new problem. He also fails to recognize that the play on the word house binds together vv $4 \mathrm{~b}-5$ and vv $11 \mathrm{~b}, 16$.

${ }^{11}$ Campbell (Of Prophets and Kings, 78) is of the opinion that "while the tradition would not have originated with the priests responsible for the ark, it may well have been preserved and made known in association with the Ark Narrative".

${ }^{12} 2$ Sam 7:4 contains an awkward double introduction, giving support to the proposal that it was constructed in two stages (cf. ibid., 79).

${ }^{13}$ Note that the deliverance from affliction promised in 2 Sam 7:10 contains as well a reference to 1 Sam $9: 16$ b.

${ }^{14}$ The use of the term "sced" in 2 Sam 7:12 can of course be taken in a collective sense. However it is the seed which will "come forth from your body". 2 Sam 7:14-15 for its part focuses clearly on Solomon.

${ }^{15}$ Campbell, Of Prophets and Kings, 80-81. 
Josh 21:44, as well as $1 \mathrm{Kgs} \mathrm{5:18} \mathrm{(RSV} \mathrm{5:4);} \mathrm{8:56.16} 2$ Sam 7:11aa also enlarges the horizon of the Prophetic Record's reference in v 10 to include the period of the judges. 2 Sam 7:13 performs a similar function with its incorporation of the construction of the temple within the horizon of Nathan's prophecy. It is identifiable as dtr by the way it describes the temple as a "house for my name".17

Overall Campbell's account of the literary history of 2 Sam 7:1-17 is persuasive. $\mathrm{He}$ is able to identify a coherent text at each stage of the prophecy's growth without recourse to textual emendation. In addition each layer of text finds support within the larger literary context of the books of Samuel. What is particularly valuable is that the text of the Prophetic Record facilitates a clear identification of DTR's additions. The significance of these additions can be more fully appreciated when they are seen within the context of a four-part pattern which DTR constructed around 2 Samuel 7. The component parts of this pattern are: 1)- a critical event in the king's reign; 2)- the king consults a prophet; 3 )- a favorable prophecy is given; 4)- a significant development follows which functions as a fulfillment of the prophecy. ${ }^{18}$ The pattern was used by DTR for the reigns of David, Hezekiah and Josiah in order to draw a close parallel between these three kings.

${ }^{16} \mathrm{McC}$ arter (II Samuel, 191) omits the reference to rest from enemies in 2 Sam 7:1b on the strength of its absence in $1 \mathrm{Chr} 17: 1$. He believes that the phrase creates difficulties in the context of David's continuing wars in 2 Samuel 8 and the statement in $1 \mathrm{Kgs} 5: 17-18$ (RSV 5:3-4) that he was unable to build the temple because of warfare. The point is well made, but given the Chronicler's propensity for omitting unsuitable material in Samuel and Kings it is quite possible that this author omitted the phrase in 1 Chr 17:1. 2 Sam 7:1b can be incorporated within DtrH if one accepts that DTR saw the rest described here as referring to the enemies whom David had thus far eliminated. In 2 Sam 7:11 a 3 - which is a promise-DTR sought to include David's subsequent conquests and establishment of an empire. In $1 \mathrm{Kgs}$ 5:17-18 (RSV 5:3-4) Solomon's enjoyment of rest is interpreted as the fulfillment of this promise. These two stages in the achievement of rest were associated by DTR with two other related divine initiatives. These were the arrival of the ark in Jerusalem, and the lodging of it in the newly constructed temple. This explanation also shows there is no need to assign 2 Sam 7:1b, 11a to later dtr redaction-against Veijola (Die ewige Dynastie, 74) and Roth ("The Deuteronomic Rest-Theology," 9) who assign the verses to DtrN.

${ }^{17}$ The portion of the prophecy which Campbell finds most difficult to assign satisfactorily is 2 Sam 7:6-7aa* (to "Israel"). The complexity of the verses makes precise identification difficult but he considers it likely they were added by an anti-temple group in the northern kingdom (Of Prophets and Kings, 81, n. 37). It does not appear that the verses in question could come from a Dtr. They do not sit comfortably with a policy of centralization of worship. Nor do they contain the sort of terminology that could be confidently described as dtragainst Veijola (Die ewige Dynastie, 77, 80) who assigns 2 Sam 7:6 to DtrN. 2 Sam 7:6-7a* is not critical for an understanding of the function of the prophecy within the context of DtrH.

${ }^{18}$ Noth commented on the structural significance of dtr passages such as Joshua 23; 1 Samuel 12 and 2 Kings 17, but did not explore this aspect of 
An initial indication that DTR intended to draw a close parallel is provided by the judgment formulas for Hezekiah (2 Kgs 18:3) and Josiah (2 Kgs 22:2). Only these two kings are compared favorably with David without qualification. The emphasis in each formula is instructive. Hezekiah "did what was right in the eyes of the Lord according to all that David his father had done". Josiah "walked in all the way of David his father". As with David there are three criteria governing this assessment of Hezekiah and Josiah: fidelity to the exclusive worship of Yahweh; fidelity to the policy of centralized worship; and fidelity to the prophet/king relationship, demonstrated by the way each king consults a prophet at a critical period in his reign.

The four-part pattern provided a suitable structure for DTR's presentation in particular of this third criterion. This was to be expected given that DTR saw the period of the monarchy as one of Israel under the prophets and kings. Nevertheless it was also able to incorporate texts at appropriate points which illustrated the particular king's fidelity to Yahweh, and to centralized worship. There is of course a qualitative difference between David and the two other kings. David is the standard against which Hezekiah, Josiah, and indeed all the other kings are measured. There is also a difference in the matter of centralized worship. David's reign was not the appropriate time for its establishment (cf 2 Sam 7:5-13). Nevertheless 2 Sam 7:2 shows that David desired it and for this he is commended in $1 \mathrm{Kgs} 8: 17-18$. His capture of Jerusalem and the entry of the ark were important initial steps towards its establishment. The difference with Hezekiah and Josiah is that they were faithful in protecting centralized worship against the threat of worship at the high places. Another important function of the four-part pattern was that it enabled DTR to construct the accounts of David, Hezekiah and Josiah according to a prophecyfulfillment schema. One of the results which emerges from the reassessment of $1 \mathrm{Sam} 13: 1-2 \mathrm{Kgs} 23: 23$ is that the prophecy-fulfillment schema in fact embraces the whole period of Israel under the prophets and kings.

In the case of David DTR constructed the four-part pattern by a skilfull combination of source material and redactional comment. The text of the Prophetic Record supplied most of the elements of the pattern: namely, the prophetic consultation (cf. 2 Sam 7:1a, 2-3), the prophecy of Nathan (cf. 2 Sam 7:4-17*), and an account of subsequent historical developments which function within the structure as a fulfillment of the prophecy (cf. 2 Samuel 8-1 Kings 2). DTR contributed the insertion of the second part of the Ark Narrative (2 Samuel 6), made the redactional additions in 2 Sam 7:1b, 11a, 13,

DTR's use of important source material such as Nathan's prophecy. D. J. McCarthy ("II Samuel 7 and the Structure of the Deuteronomic History," JBL 84 [1965] 131-38) did go some way towards rectifying this. He noted that Nathan's prophecy functions within DtrH as a reward for David's fidelity. Hence the Davidic and deuteronomic covenants are not in conflict. McCarthy linked David's reward of a dynasty with his protection of the ark (p. 135). However the entry of the ark was a divine initiative to which David responded by consulting the prophet. The recognition of prophetic authority is an important element in DTR's portrayal of David, a factor overlooked by McCarthy. 
and assembled an account of Solomon's reign with its high point being the construction and dedication of the temple.

At first glance one might object that the story of the ark's entry into Jerusalem in 2 Samuel 6 should belong to the text of the Prophetic Record. After all, David's statement in 2 Sam 7:2 assumes that the ark is in the city. Nevertheless there are a number of factors which militate against this. To begin with there is the evidence from the discussion of 1 Samuel 4-7, where it was shown that the story of the ark was not a concern of the prophetic redaction. Next there is the evidence of 2 Sam 7:13, taken in combination with Solomon's speech in $1 \mathrm{Kgs} 8: 15-21$. 2 Sam 7:13 is clearly a dir formulation and Solomon's speech has likewise long been recognized as a dtr composition. ${ }^{19}$ In $1 \mathrm{Kgs}$ 8:15-21 Solomon clearly identifies the installation of the ark in the temple as an essential part of the fulfillment of Nathan's prophecy in 2 Sam 7:13.

The story of the ark was therefore an integral part of the conceptual plan and structure of DtrH, not of the Prophetic Record. The incorporation of the first part of the Ark Narrative in 1 Samuel 4-7 was designed by DTR to emphasize the divine initiative in Israel's history. The return of the ark to the land and its sojourn at Kiriath-jearim heralded a new era for Israel. The nature of this new era was revealed in the establishment of the prophet/king form of leadership. In a similar way the arrival of the ark in Jerusalem signalled an important development within the new era. The nature of this development was revealed in Nathan's prophecy to David and the subsequent events of Israel's history, culminating in the construction of the temple. Hence the second part of the Ark Narrative (2 Samuel 6) and the prophecy of Nathan enabled DTR to integrate the powerful theological symbol of the ark into a prophecy (2 Sam 7:13)-fulfillment (1 Kgs 8:15-21) schema which embraced the construction of the temple. Within DTR's larger conceptual plan and structure therefore the story of the ark contributed to establishing the temple-under the protection of the Davidic dynasty - as the only legitimate place of worship.

In short, the Prophetic Record can stand without the material on the ark, whereas DtrH cannot. ${ }^{20}$ The reference to the ark in 2 Sam 7:2 is therefore to be taken traditio-historically at the level of the Prophetic Record. It did not

${ }^{19}$ Among earlier studies see for example J. Wellhausen, Die Composition des Hexateuchs, 270; C. F. Burney, Notes on the Hebrew Text of the Book of Kings (Oxford: Clarendon Press, 1903) 112 (RD - pre-exilic redaction); Carl Heinrich Cornill, Einleitung in die kanonischen Bücher des Alten Testaments (Tübingen: J. C. B. Mohr-Paul Siebeck, 1908) 125. More recent studies are J. Gray, I \& II Kings, 214; M. Noth, Könige I, 1-16 (BKAT 9/1. NeukirchenVluyn: Neukirchener Verlag, 1968) 182-84; Roland de Vaux, Les Livres des Rois (SBJ; Paris: Cerf, 1958) 17. Among the most recent studies see S. J. DeVries, I Kings, 121, 125; G. H. Jones, 1 and 2 Kings I; 198-99; B. O. Long, 1 Kings, 94, 99-101; R. D. Nelson, First and Second Kings (Interpretation; Atlanta: John Knox, 1987) 52.

${ }^{20} \mathrm{~A}$ useful discussion of the theological significance of the ark in DtrH is given by H. Timm ("Die Ladeerzählung," 509-26) although I would not subscribe to his acceptance of an exilic DtrH. However the story of the ark could also have generated hope of return for a people in exile. 
have the text of 2 Samuel 6 in mind. ${ }^{21}$ Once one accepts the insertion of 2 Samuel 6 as DTR's contribution its role in the construction of the first part of the pattern becomes clear. It functions as the important divine initiative which signalls a new stage in the career of David. The sense of impending change and development is also brought out by the way DTR states in 2 Sam 7:1b that the entry of the ark took place at a time when Yahweh had given David rest from his enemies. The insertion of Samuel 6 and the comment in 2 Sam $7: 1 \mathrm{~b}$ also serve to make David's consultation of Nathan a genuine response to the divine initiative. This was necessary for DTR's portrait of him as the model king. Without 2 Samuel 6 and 2 Sam 7:1b David's question to Nathan appears to portray himself, rather than Yahweh, as the one taking the initiative. ${ }^{22}$

The promise of rest from enemies in 2 Sam 7:11aß integrates the subsequent victories of David in 2 Samuel 8 firmly into the prophecy-fulfillment schema. The trajectory of this verse also embraces the reign of Solomon. In $1 \mathrm{Kgs}$ 5:17 (RSV 5:3) Solomon refers to the wars which occupied David "until the Lord put them under the soles of his feet". ${ }^{23}$ As a result of David's victories Solomon can justifiably claim there is no threat to his kingdom. Finally, as noted above, 2 Sam 7:13 also extends the reach of Nathan's prophecy to incorporate the construction of the temple within the prophecyfulfillment schema. Solomon announces its fulfillment in $1 \mathrm{Kgs}$ 8:20.

Nathan's prophecy then is an integral part of the four-part pattern for David, and a pivotal text within the larger structure of DtrH. It also serves to emphasize David's model conduct in terms of the criteria outlined earlier: fidelity to the prophet/king relationship; and fidelity to the policy of centralized worship. In relation to the second criterion DTR made sure that David's desire to build a temple (cf. 2 Sam 7:2) was commended by Yahweh in $1 \mathrm{Kgs} 8: 17-18$. Also the promise in 2 Sam 7:12-13 of a successor who would build a temple showed that David was a key figure in the movement towards centralized worship. There is no explicit statement in Nathan's prophecy of David's fidelity to the exclusive worship of Yahweh. A number of texts on this theme were however noted earlier in the story of David's rise. There is also David's submission to the divine will in 2 Sam 16:11-12, and his acknowledgment of Yahweh's hand in the succession of Solomon in $1 \mathrm{Kgs}$ $1: 48$. One may even say that within DTR's terms of reference David's very success was testimony enough to his fidelity to Yahweh. Once one moves to Solomon and the subsequent kings, David is continually referred to as a model of fidelity.

${ }^{21}$ Cf. Campbell, of Prophets and Kings, 71, n. 18.

${ }^{22}$ At the pre-dtr level, one can see that David's initiative would have provided a motive for Yahweh's refusal to allow him to build a temple.

${ }^{23}$ The RSV follows the MT Ketib and the LXX, rather than the MT Qere, which has "my feet". There is no record in the text of Solomon waging war however. The correction may have been provoked by the following statement of Solomon, "But now the Lord has given me rest on every side." This phrase is intended in the context to acknowledge the fulfillment of the divine promise of rest rather than to record victories by Solomon. 
Before leaving 2 Samuel 7 some comment is required on David's prayer in 2 Sam 7:18-29. ${ }^{24}$ L. Rost proposed that the prayer had a pre-dtr provenance and that it belonged to the earliest recoverable edition of 2 Samuel 7, namely vv $1-7,11 \mathrm{~b}, 16,18-21,25-29$. A Dtr added 2 Sam 7:22-24 to the prayer. ${ }^{25}$ The hypothesis of an original pre-dtr prayer expanded by later dtr redaction was followed by Noth and a number of others. ${ }^{26}$ But it has also been argued that the prayer is a dtr composition, or that the original version was so thoroughly rewritten by DTR that one can no longer recover it. ${ }^{27}$

The corrupt nature of the text makes a satisfactory resolution of the authorship of the prayer somewhat difficult. ${ }^{28}$ However, what makes one hesitate to identify the whole prayer as dtr is the repeated reference to the "Lord Yahweh". The combination is found elsewhere in DtrH only in $1 \mathrm{Kgs} 2: 26$ (non-dtr) and 8:53 (late Dtr). This suggests it is more likely the prayer had a pre-dtr provenance, although the similarity between 2 Sam 7:22-24 and Deut 4:7-8, 34-39 points to dtr authorship at least for these verses. ${ }^{29}$ The similarity also shows that 2 Sam 7:22-24 did not come from DTR but from later redaction. The shift of attention from king to people can be observed in a number of other additions to $\mathrm{DtrH}$, such as the prayers in $1 \mathrm{Kgs} 8: 31-53$, the warning against apostasy in $1 \mathrm{Kgs} 9: 6-9$, and the reflection on the northern exile in $2 \mathrm{Kgs}$ 17:7-19.

${ }^{24}$ Campbell (Of Prophets and Kings, 81, n. 38) does not include the prayer in the Prophetic Record because it "would not have served the purposes of the prophetic redactors". He acknowledges it may have originated at the pre-dtr level.

${ }^{25}$ L. Rost, The Succession to the Throne of David, 37.

${ }^{26}$ For Noth (The Deuteronomistic History, 55) DTR added 2 Sam 7:22-24. For a more cautious view see "David and Israel in II Samuel VII," The Laws in the Pentateuch and Other Essays (Edinburgh: Oliver \& Boyd, 1966) 250-59, especially pp. 252-53. M. Görg (Gott-König Reden in Israel und Ägypten [BWANT 105; Stuttgart: W. Kohlhammer, 1975] 205) assigns 2 Sam 7:18-22a, 25-29 as the original prayer, with vv $22 \mathrm{~b}-24$ as dir expansion. T. N. D. Mettinger (King and Messiah, 51) argues that 2 Sam 7:18-22a, 27-29 is pre-dtr, with vv 22b-26 the dtr addition. McCarter (II Samuel, 240) follows Mettinger, except for identifying some pre-dtr prophetic redaction in vv 20-21. M. Weinfeld (Deuteronomy and the Deuteronomic School, 37-38) identifies deuteronomic language only in vv 22b-24. Two regard the prayer as completely pre-dtr: Otto Plöger, "Reden und Gebete im deuteronomischen und chronistischen Geschichtswerke," Festschrift für Günter Dehn zum 75. Geburtstag (ed. W. Schneemelcher; Neukirchen Kreis Moers: Verlag der Buchhandlung des Erziehungsvereins, 1957) 35-49, see p. 36; and C. S. Labuschagne, "Some Remarks on The Prayer of David in II Sam. 7," Studies on the Books of Samuel (Papers read at 3rd Mecting of Die O. T. Werkgemeenskap in Suid-Afrika, University of Stellenbosch, 1960) 28-35.

${ }^{27}$ R. A. Carlson, David, the chosen King, 128; Cross, Canaanite Myth and Hebrew Epic, 247; Mayes, The Story of Israel, 104; Van Seters, In Search of History, 273. Veijola (Die ewige Dynastie, 74-80) assigns 2 Sam 7:18-21, 2529 to DtrH, and vv 22-24 to DtrN.

${ }^{28}$ For a discussion of the text see McCarter, II Samuel, 233-39.

${ }^{29}$ In basic agreement with Noth, Görg, Weinfeld (cf. n. 26), 
The question of whether the pre-dtr version of the prayer belonged to the earliest stage of 2 Samuel 7, as proposed by Rost, cannot be resolved here. ${ }^{30}$ The texture of the Prophetic Record would not appear to be significantly altered if it was included. Certainly there is no compelling reason to omit it from DtrH. Whether the prayer was included by DTR or was already in place, it is quite in harmony with the portrait of David given in the history.

\section{SAMUEL 8-1 KINGS 2}

The text of Campbell's Prophetic Record after 2 Samuel 7 includes 2 Samuel 8, but omits 2 Samuel 9-10. He also inclines against the inclusion of 2 Samuel 11-20, judging that it was unlikely the prophetic redactors would have included such an extensive block of material which was not essential for the narrative sequence of the Record, nor directly related to their principal concerns. The account of the succession of Solomon in 1 Kings 1-2 is however included, since it is essential for the narrative thread of the Record. ${ }^{31}$

Campbell's assessment of what was most likely part of the Prophetic Record is made within the context of recent reassessment of Rost's original hypothesis of a Succession Narrative from 2 Samuel 9-1 Kings 2.32 There is a considerable body of opinion that the narrative is not a unified composition as Rost thought. It may well have been built up from an earlier story centered around the revolt of Absalom. ${ }^{33}$ It cannot be the task of this investigation to enter into a discussion of the composition of the Succession Narrative. Nevertheless, given that 2 Samuel 9-20 was probably not part of the Prophetic Record, the question does arise as to whether it was part of DtrH, particularly in view of Nathan's prophetic condemnation of David over the Bathsheba affair.

${ }^{30}$ Matitiahu Tsevat proposed that the prayer must have been in place prior to 2 Sam 7:13-16 at least, because he judges it improper to have David pray for what he has already been promised ("The House of David in Nathan's Prophecy," Bib 46 [1965] 353-56; cf. p. 35). One may ask however why a later redactor should have introduced such an impropriety into the text.

${ }^{31}$ Campbell, Of Prophets and Kings, 81-4. He also accepts the possibility that the Record may only have included the summary in 2 Sam 8:15. 2 Samuel 9 is not directly concerned with the theme of succession and the Davidic dynasty. Also the prophetic redaction would not have been interested in tracing the fortunes of Saul's family once David had received prophetic approval. 2 Samuel 10 provides the historical context for the story of David and Bathsheba in 2 Samuel 11-12. In 1 Kings 1-2 the text of the Record comprises $1 \mathrm{Kgs}$ 1:1a, 5-15a, 16-48; 2:1a, 10, 12.

${ }^{32}$ Rost, The Succession to the Throne of David. The German original was published in 1926. Rost thought the beginning of the narrative originally reached further back, but had been interwoven with 2 Samuel 6-7.

${ }^{33}$ Cf. for example J. W. Flanagan, "Court History or Succession Document? A Study of 2 Samuel 9-20 and 1 Kings 1-2," JBL 91 (1972) 172-81, and Charles Conroy, Absalom Absalom! Narrative and Language in 2 Sam 13-20 (AnBib 81; Rome: Biblical Institute, 1978) 97-105. See also the discussion by McCarter, II Samuel, 13-16. 
J. Van Seters argues that the whole of the Succession Narrative should be omitted from DtrH. It is a post-DTR addition from the post-exilic period, "the product of an antimessianic tendency in certain Jewish circles at this time". ${ }^{34}$ However it is questionable whether this is an accurate characterization of the Succession Narrative. The detailed literary critical study by F. Langlament concludes that an earlier anti-David and Solomon narrative was reworked by later redactors to portray these two kings in a more positive light. ${ }^{35}$ This is supported by more recent studies which see the Succession Narrative as a piece of court apologetic, attempting to defend David and Solomon against accusation from hostile quarters. ${ }^{36}$ As well as this studies which analyze the Succession Narrative more from a literary point of view claim that it is an artfully constructed and subtle composition which resists simple classification. ${ }^{37}$ On the basis of these investigations it would be fair to say that while there are aspects of the narrative which are critical of David it is quite inaccurate to characterize it simply as anti-David or antimessianic.

The most negative portrayal of David in the whole Succession Narrative occurs of course in the Bathsheba episode in 2 Samuel 11-12. Nevertheless David's immediate acceptance of Nathan's judgment in 2 Sam 12:13a demonstrated his acknowledgement of the authority of the prophet. In contrast to Saul therefore he had not ruptured the prophet/king relationship. This is shown by Nathan's announcement of Yahweh's forgiveness in 2 Sam 12:13b. In addition David's sin was not apostasy and did not sever his relationship with Yahweh. The prophecy delivered on the birth of Solomon in 2 Sam 12:25 is a sign that David has regained favor with Yahweh. It also provides an early hint that Solomon is the one who will succeed to the throne.

Although the structure and conceptual plan of DtrH proposed in this reassessment requires the succession of Solomon in 1 Kings 1-2 it is not dependent on the inclusion of 2 Samuel 9-20. However on the strength of the

${ }^{34}$ Van Seters (In Search of History, 290) draws on the work of Lienhard Delekat ("Tendenz und Theologie der David-Solomon-Erzählung," Das ferne und nahe Wort [BZAW 105; Berlin: W. de Gruyter, 1967] 26-36) and E. Würthwein (Die Erzählung von der Thronfolge Davids-theologische oder politische Geschichtsschreibung? [Theologische Studien 115; Zürich: Theologischer Verlag, 1974]). Delekat's study was however designed to counter a too one sided interpretation of the Succession Narrative by Rost and others as pro-David and Solomon. Würthwein proposed that an earlier story hostile to David and Solomon was redacted in a pro-David and Solomon direction. Van Seters does not find Wurthwein's redactional arguments convincing (cf. p. 287, n. 171).

${ }^{35} \mathrm{~F}$. Langlamet, "Pour ou contre Salomon? La rédaction prosalomonienne de I Rois, I-II," RB 83 (1976) 321-79, 481-529. Langlamet developed the redactional proposals of Würthwein and the literary critical analysis of Veijola, without subscribing to Veijola's position that the redactional layers were chiefly the work of different Dtr's.

${ }^{36}$ See for example Keith W. Whitelam, "The Defense of David," JSOT 29 (1984) 61-87; also the discussion in McCarter, II Samuel, 11-13.

${ }^{37}$ David M. Gunn (The Story of King David. Genre and Interpretation [JSOTSup 6; Sheffield: JSOT, 1978]) proposes that it was composed as a work of art principally for entertainment. 
observations made there seems to be no compelling reason to omit it. The chapters do not betray any dtr redaction, but it is difficult to imagine that DTR would have omitted what was no doubt a well known account of a critical period in David's reign. ${ }^{38}$ One may reasonably suggest that DTR judged they could be comfortably included in the history without creating undue tension with its portrait of David. ${ }^{39}$

Within 1 Kings 1-2 the text of the Prophetic Record is traced in $1 \mathrm{Kgs}$ $1: 1 a, 5-15 a, 16-48 ; 2: 1 a, 10,12$. Deuteronomistic language is clearly present in David's farewell speech to Solomon in $1 \mathrm{Kgs} 2: 2-4$. Not all of it however can be attributed to DTR. It is most likely that DTR's contribution is to be

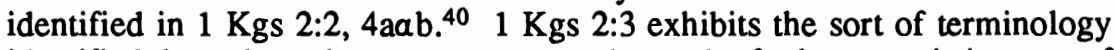
identified throughout the reassessment as the work of a later nomistic stage of dtr redaction. ${ }^{41} 1 \mathrm{Kgs} 2: 4 a \beta$ is more difficult to assess, but the conditional clause may have crept into the text from $1 \mathrm{Kgs} 8: 25 ; 9: 4$. The double occurrence of lemor supports this. It does not appear in the LXX (Lucian) and

${ }^{38}$ It is possible of course that 2 Samuel 9-20 was added at a pre-dtr stage, and in more than one stage.

${ }^{39}$ Some comment is required at this point on 2 Samuel 21-24. Veijola (Die ewige Dynastie, 106-26) includes 2 Sam 21:1-22; 23:8-39; 24:1-25 in DtrH, with 22:1-23:7 and some other redactional additions assigned to DtrN and DtrP. The application of the threefold redactional schema seems forced here. There is little distinctive linguistic or other evidence that one can appeal to in favor of a particular Dtr. In spite of this Veijola has a point. It is possible that all or a substantial portion of 2 Samuel 21-24 was part of DtrH. From a thematic point of view it could be accommodated within DTR's portrait of David. In terms of location there was no other suitable one for a redactor, DTR or another, who wanted to incorporate this material. A number of factors do however caution against including it. 2 Samuel 21-24 appears to be a rather heterogeneous collection inserted into the story of David just before the account of his death. A similar phenomenon is observable in Deuteronomy 31-33 and Joshua 23-24 where material was added prior to the accounts of the death of Moses and Joshua. The presence of the psalm in 2 Samuel 22 parallels Moses' song in Deuteronomy 32, a late addition. Furthermore 2 Samuel 21-24 is organized according to a concentric structure which sets it apart to some extent from the surrounding context: 2 Sam 21:1-14 (A); 21:15-22 (B); 22:1-51 (C); 23:1-7 $\left(C^{\prime}\right)$; 23:8-39 (B'); 24:1-25 (A'). For a discussion of this structure see McCarter, II Samuel, 18-19. In sum, while the evidence is not conclusive either way, my preference is to regard 2 Samuel 21-24 as a later addition (with McCarter, p. 17, cf. also Noth, The Deuteronomistic History, 124-25, n. 3).

${ }^{40}$ Veijola assigns $1 \mathrm{Kgs} 2: 2,4 \mathrm{aab}$ to $\mathrm{DtrH}$, and 2:3, 4aß to DtrN (Die Ewige Dynastie, 29). W. Dictrich (Prophetie und Geschichte, 73, n. 35) assigns 1 Kgs $2: 4$ to DtrN. However Veijola greatly overtstates the extent of dtr redaction in 1 Kings 1-2, claiming DtrH was responsible for $1 \mathrm{Kgs} 1: 30 *$, 35-37, 46-48; 2:5$11,15 b \gamma, 24,26 b, 27,31 b-33,35 b, 37 b$.

${ }^{41}$ One could be tempted to carry out a literary critical division within this

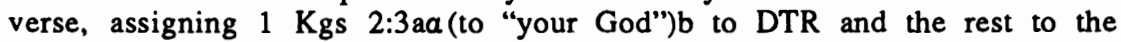
nomistic stage. However the phrase "keep the charge of the Lord your God" seems to be a late expression, occurring in Numbers in cultic texts, in Nehemiah and 1-2 Chronicles (cf. De Vries, 1 Kings, 34). 
the Vulgate. Apart from this exhortation to Solomon by the dying David the only other clear evidence of the hand of DTR occurs in the chronological notice in $1 \mathrm{Kgs} 2: 11$.

It is more than likely the remainder of 1 Kings 2 , namely vv $1 \mathrm{~b}, 5-9,13-$ 46, came from a pre-dtr reworking of the Succession Narrative, what Langlamet has termed a pro-Solomonic redaction. ${ }^{42}$ This redaction sought to justify a series of executions carried out by Solomon. According to the Succession Narrative Joab and Shimei had offended David. Hence it was appropriate to insert a speech by the dying David in $1 \mathrm{Kgs} 2: 5-9$, charging Solomon to avenge the offenses and thereby giving his actions legitimacy. ${ }^{43}$ The executions are recounted in $1 \mathrm{Kgs} 2: 28-46$. There was no such offense by Adonijah and Abiathar. The score to be settled in their case concerned Solomon more directly than David. Therefore they do not appear in David's

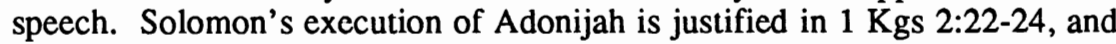
his exile of Abiathar in 2:26.

It is possible that the stories of the fate of these men were added in stages. If this were the case it is likely that the story of Adonijah was the earliest, because of its close relationship to the story of Solomon's succession.44 The account of Abiathar's exile would have followed. The stories of Joab and Shimei, along with David's speech in $1 \mathrm{Kgs}$ 2:5-9, were added subsequently but prior to the composition of DtrH. ${ }^{45}$ It should be noted however that the LXX version contains the MT conclusion of $1 \mathrm{Kgs} 2: 46 \mathrm{~b}$ in $v 35$. There is a possibility then that $1 \mathrm{Kgs} 2: 36-46$ may be a late, independent addition. ${ }^{46}$ If this is so it would indicate that $1 \mathrm{Kgs} 2: 8-9$ was also a late addition. ${ }^{47}$

${ }^{42}$ Langlamet, "Pour ou contre Salomon?" 502-5, 523-25.

${ }^{43} \mathrm{DTR}$ would have added the introductory (wégam) in $1 \mathrm{Kgs} 2: 5$ in order to

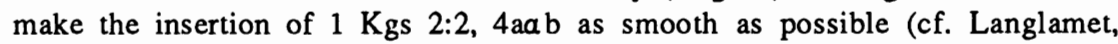
"Pour ou contre Salomon?" 525)

${ }^{44}$ It could have been part of the Prophetic Record. Campbell omits $1 \mathrm{Kgs}$ 1:49-53 and the story of Adonijah's death without detailed discussion, but implies that its inclusion would not substantially alter the Record (Of Prophets and Kings, 84, n. 44). For Rost the Succession Narrative ended in $1 \mathrm{Kgs}$ 2:46. For Noth however it was quite possible for the narrative to have ended with 1 $\mathrm{Kgs}$ 2:12. $1 \mathrm{Kgs}$ 1:49-53 provides a suitable resolution of Adonijah's situation and does not necessarily have to be followed by $1 \mathrm{Kgs}$ 2:13-35 (Könige, 11).

${ }^{45}$ Noth (Könige, 11) reckoned that $1 \mathrm{Kgs}$ 2:5-9 was added after the narratives in $2: 13-46$.

${ }^{46}$ On this see Langlamet, "Pour ou contre Salomon?" 518-19. For a detailed discussion see Julio C. Trebolle Barrera, "Testamento y muerte de David. Estudio de historia de la Recensión y Redacción de I Rey., II," $R B \quad 87$ (1980) 87 103, especially 98-103; also Salomón y Jeroboán. Historia de la recensión y redacción de 1 Reyes, 2-12, 14 (Instituto Español Bíblico y Arqueológico de Jerusalén; Jerusalén-Valencia: Casa de Santiago, 1980) 244-83. This second work includes a discussion of the relationship between the MT and LXX 3 Reigns 2:35a-o, and 2:46a-1.

${ }^{47} \mathrm{~A}$ final point to consider is Trebolle Barrera's proposal that the LXXL records the original order of $1 \mathrm{Kgs} 2: 1-12$ in contrast to the MT ("Testamento y muerte de David," 89-98; also Salomón y Jeroboán, 244-50). In the LXXL a notice of David's death is followed immediately by the statement that he slept 


\section{KINGS 3-12}

For the purpose of analyzing the nature and extent of dtr redaction this block of material can be conveniently divided into three sections: the period of Solomon's fidelity (1 Kgs 3:1-10:29); his infidelity and condemnation by Ahijah the prophet (1 Kgs 11:1-43); the resulting schism in the kingdom (1 Kgs :12:1-24). $1 \mathrm{Kgs} 12: 25$ and the following verses report Jeroboam's implementation of a number of policies for northern Israel and so belong more properly to the period of the divided kingdom.

\section{KGS 3:1-10:29}

According to Campbell it is unlikely the prophetic redaction with its northern focus would have included an extensive account of the reign of Solomon. In fact, as the Prophetic Record's version of Ahijah's prophecy shows, it was quite hostile to him. Nevertheless one would expect some basic information as part of the narrative thread of the Record. For Campbell this is supplied by $1 \mathrm{Kgs} 3: 1 ; 9: 15-24 * .48$ The account of Solomon's building program in $1 \mathrm{Kgs} 9: 15-24^{*}$ and the extensive service industry it required could provide a context for the complaints voiced in the assembly of 1 Kings 12.49 An additional point in favor of the proposed text as an early report of Solomon's reign is the way $1 \mathrm{Kgs} 3: 1$ forms a chiastic structure in conjunction with 9:15-24*. That is: Pharaoh's daughter (3:1); Solomon's building program (3:1); Solomon's building program (9:15-23); Pharaoh's daughter $(9: 24) .^{50}$ This chiastic structure was broken up by DTR to provide a framework for a much more extensive account of the reign of Solomon.

In addition to these observations by Campbell it is significant that the order of Solomon's building program is reversed in 1 Kings 5-7. In this section, in contrast to $1 \mathrm{Kgs} 3: 1$, the construction of the temple is described before the royal palace. This gives further support to the independent provenance of $1 \mathrm{Kgs} \mathrm{3:1.} \mathrm{A} \mathrm{further} \mathrm{point} \mathrm{to} \mathrm{note} \mathrm{is} \mathrm{that} \mathrm{the} \mathrm{report} \mathrm{of} \mathrm{Solomon's}$

with his fathers, thus: kai egeneto meta tauta kai apethane David kai ekoimethe meta ton paterón autou. The dtr exhortation then follows with the introduction "and he commanded his son Solomon before his death . . .". Trebolle notes that in other reports of the deaths of kings the notice that the king slept with his fathers is never preceded by a statement that he died. The juxtaposition in the LXXL is therefore unusual (lectio difficilior) and he would propose that the MT overcame it by altering the formulation of $1 \mathrm{Kgs} 2: 1 \mathrm{a}$. This was probably done with a view to relocating $1 \mathrm{Kgs} 2: 1 \mathrm{~b}-9$, from which the phrase "before his death" was omitted. This seems a plausible explanation for the unusual LXXL reading. For the sake of convenience however I have followed the MT order in the above presentation. Trebolle's explanation does not alter my distribution of dtr redaction. With the Prophetic Record the only change made if the LXXL is followed is that $1 \mathrm{Kgs} 2: 1$ becomes a simple report of David's death.

${ }^{48}$ Campbell, Of Prophets and Kings, 85-87, 102.

${ }^{49}$ As Campbell notes (ibid., 86, n. 49) the language of the complaints in 1 Kings 12 is symbolic rather than specific. Nevertheless the association is suggestive.

${ }^{50}$ Ibid., 85, n. 46. 
marriage to Pharaoh's daughter in $1 \mathrm{Kgs} 3: 1 ; 9: 24$ does not receive any dtr

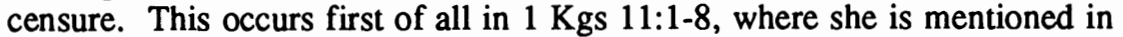
company with many other foreign women. Overall therefore the assignation

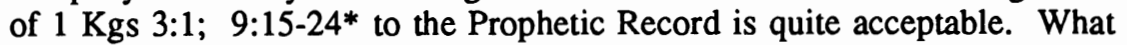
must now be identified is the nature and extent of DTR's redaction in relation to the Record.

Noth claimed to have recovered a pre-dtr Solomonic history in $1 \mathrm{Kgs} 3: 4-$ 28*; 5:9-14 (RSV 4:29-34); 6:2-38*; 7:1-51; 8:1-13*; 9:10-10:29*.51 However there are some important considerations which militate against the acceptance of such a pre-dtr history. First of all, one would expect an independent pre-dtr Solomonic History to have an introduction. Given that 1 Kings 1-2 now functions as the conclusion to the Succession Narrative, the only candidates for such an introduction are $1 \mathrm{Kgs} 3: 1$ or 3:4-15*, 3:2-3 being dtr. Neither is however acceptable. $1 \mathrm{Kgs}$ 3:1 is hardly an appropriate introduction for a history which, according to the text proposed by Noth, dealt with Solomon's wisdom, wealth, and wise rule, as well as his foreign alliances and building program. $.^{52} 1 \mathrm{Kgs} 3: 4-15^{*}$ is also unsuitable because $\mathrm{v}$ 4 does not contain Solomon's name. This indicates the verse presupposes the occurrence of his name in a preceding verse, either $1 \mathrm{Kgs} 3: 1$, or $3: j$. As well, the dialog between Solomon and Yahweh in $1 \mathrm{Kgs}$ 3:5-14 does not refer to Solomon's building program.

Secondly, according to Noth's text the principal achievements of Solomon's reign were, on the one hand his wisdom, riches and wise rule (cf. 1 Kgs 3:4-28*; 5:9-14 [RSV 4:29-34], cf. also 1 Kgs 10:1-29), and on the other hand his building program, culminating in the construction and dedication of the temple (cf. $1 \mathrm{Kgs} 6: 2-8: 13^{*}$ ). For the hypothesis of a pre-dtr Solomonic History to be acceptable one would expect its author to have linked these parts together in order to forge the larger whole. The only place where this occurs is in $1 \mathrm{Kgs} \mathrm{5:15-26} \mathrm{(RSV} \mathrm{5:1-12).} \mathrm{But} \mathrm{as} \mathrm{will} \mathrm{be} \mathrm{seen} \mathrm{shortly,}$ this link was forged by DTR. ${ }^{53}$

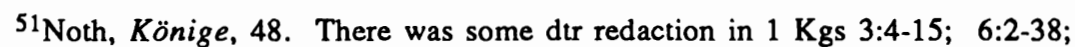
8:1-13 (with some priestly additions) and 9:10-10:29 (dtr touches). This was a change from his earlier position in The Deuteronomistic History, 57-8, where he attributed the history of Solomon to DTR. Others who have proposed a pre-dtr history are I. Benzinger, Die Bücher der Könige, ix-x; R. Kittel, Die Bücher der Könige, ix; J. Liver, "The Book of the Acts of Solomon," Bib 48 (1967) 75101; J. Schüpphaus, Richter- und Prophetengeschichten, 110-11.

${ }^{52}$ Noth himself recognized that $1 \mathrm{Kgs} 3: 1$ could not be an introduction to a larger narrative (Könige, 48). He assigned it as a later addition, a position accepted also by Würthwein (1. Könige 1-16, 28-9) and Gray (I \& II Kings, 117 18).

${ }^{53}$ This is a serious weakness in Noth's position, because he also attributes 1

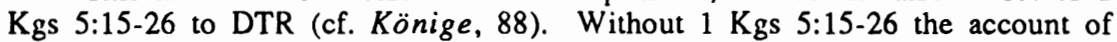
the construction of the temple in 1 Kings 6 bears no clear relationship to the preceding material in $1 \mathrm{Kgs} 3: 4-5: 14^{*}$. Note that $1 \mathrm{Kgs} 6: 1$ is DTR's chronological notice. Liver's study is flawed by his failure to carry out any critical analysis of dtr redaction in the story of Solomon. Likewise Schüpphaus does not provide any literary critical analysis of the text to support his proposal. 
Noth held that the book of the Acts of Solomon cited in $1 \mathrm{Kgs}$ 11:41 was to be identified with the pre-dtr Solomonic History. ${ }^{54}$ However, the very formulation of $1 \mathrm{Kgs} 11: 41$ makes this unlikely. It refers the reader to the "rest of the acts of Solomon", indicating that there was more information available than what was given in the text of Kings. Even if one were to argue that the pre-dtr history was a portion of the Acts, the formulation of the reference to "the book of the acts of Solomon, and all that he did, and all his wisdom" does not give any indication that the material in the Acts was organized in the same way as the text of Kings.

In contrast to these problems a convincing case can be made that DTR constructed the first part of Solomon's reign in order to portray his wise and peaceful rule, and the centralization of worship, as the completion of the deuteronomic program. Within this larger horizon the construction of the temple is also identified as the fulfillment of Nathan's prophecy in 2 Sam 7:13a. Two texts play an important function in DTR's organization of Solomon's reign, namely $1 \mathrm{Kgs} 3: 1-15$ and 5:15-26 (RSV 5:1-12). These texts first of all testify to Solomon's fidelity to Yahweh throughout this period of his reign. Secondly, they emphasize the divine initiative and approval of Solomon at key stages in the movement towards the realization of the deuteronomic ideal. This divine initiative is identified especially in

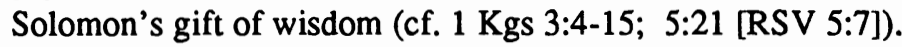

\section{KGS 3:1-15}

This text can be conveniently divided into two sections: vv 1-3 and vv 415. Within the first section $v 1$ has already been identified as part of the Prophetic Record. $1 \mathrm{Kgs}$ 3:2-3 is clearly dtr material although not all of it can be attributed to DTR. The introductory raq in $1 \mathrm{Kgs} \mathrm{3:2}$ is abrupt after $1 \mathrm{Kgs}$ 3:1. Moreover the interest in the conduct of the people is out of context in a section devoted to Solomon. $1 \mathrm{Kgs} \mathrm{3:2}$ is therefore best taken as a later dtr addition.55

$1 \mathrm{Kgs} \mathrm{3:3} \mathrm{is} \mathrm{a} \mathrm{more} \mathrm{complex} \mathrm{verse.} \mathrm{It} \mathrm{functions} \mathrm{as} \mathrm{a} \mathrm{judgment} \mathrm{formula} \mathrm{for}$ Solomon, like the judgment formulas for subsequent kings of Israel and Judah.

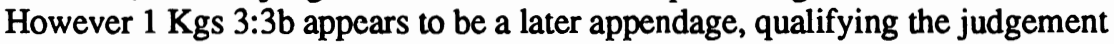

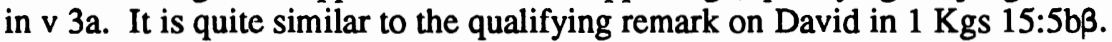
Moreover, it has already been pointed out that centralized worship became the norm for DTR only after Yahweh had chosen the place for his name. $1 \mathrm{Kgs}$

${ }^{54}$ Noth, Könige, 263.

${ }^{55}$ The late addition of the verse has long been recognized: cf. Benzinger, Die Bücher der Könige, 14-15; Burney, Notes, 28; Kittel, Die Bücher der Könige, 24; Sanda, Die Bücher der Könige 1, 63 (v 2a a gloss, v 2b dtr); James A. Montgomery and Henry Snyder Gehman, A Critical Exegetical Commentary on the Books of Kings (ICC; Edinburgh: T. \& T. Clark, 1951) 103 (hereafter only Montgomery cited). Among more recent works cf. De Vries, 1 Kings, 50; Gray, I \& II Kings, 120; G. Hentschel, I Könige, 33; Jones, 1 and 2 Kings I, 124; Long, 1 Kings, 61; Noth, Könige, 45-46; Martin Rehm, Das erste Buch der Könige: ein Kommentar (Würzburg: Echter Verlag, 1979) 42; Würthwein, 1. Könige 1-16, 28, n.1. 
$3: 3 \mathrm{~b}$ is also in some tension with the positive portrait of Solomon in the Gibeon scene (1 Kgs 3:4-15).

$1 \mathrm{Kgs} \mathrm{3:3a}$ is unique in that it is the only judgment formula which describes a king as loving ('ähab) Yahweh. DTR selected this verb precisely in order to contrast Solomon's initial fidelity to Yahweh with his infidelity in 1 Kings 11 , where it is stated that he loved many foreign women ( $v 1)$, and that he clung to them in love (v 2b). ${ }^{56}$ It was this love of foreign women which led to Solomon's infidelity to Yahweh (cf. v 4). The two uses of the term love are appropriate therefore for the special role of Solomon in DTR's conceptual plan and structure. Solomon's love of Yahweh was an important factor in the realization of the deuteronomic program. His failure to persevere in that love was an equally important factor in its breakdown. ${ }^{57}$

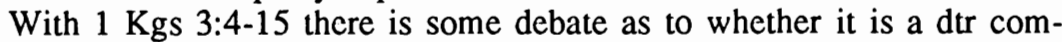
position or a redaction of an older source..$^{58}$ It is not essential for the reassessment to enter fully into this debate. Despite the difference of opinion all who accept the hypothesis of a DtrH are agreed that the pericope is to be included in the text. The proponents of a source-redaction interpretation do appear however to have the better of the argument. ${ }^{59}$ It provides a more reasonable explanation of a number of linguistic features in the dialog between

${ }^{56}$ Noted also by Nelson, First and Second Kings, 34. It should be born in mind of course that DTR used the term in its deuteronomic sense of complete fidelity to Yahweh. On this see Weinfcld, Deuteronomy and the Deuteronomic School, 81-82.

${ }^{57}$ One might be tempted to regard the reference to walking in the statutes of David in $1 \mathrm{Kg} \mathrm{3:3a}$ as secondary also. Certainly this is the only case where such a reference is made. A unique phrase however does not automatically mean a later one. Except for its uniqueness there does not seem to be any compelling reason to exclude it. I would therefore retain it for DTR.

${ }^{58}$ In favor of dtr composition are Helen Kenik, Design for Kingship. The Deuteronomistic Narrative Technique in 1 Kings 3:4-15 (SBLDS 69; Chico: Scholars, 1983) and Van Seters, In Search of History, 308. R. B. Y. Scott ("Solomon and the Beginnings of Wisdom in Israel," VTS up 3 [1955] 262-79, cf. p. 271) retains the framework as pre-dtr. Those who argue for a sourceredaction interpretation are De Vries, 1 Kings, 48-50; Görg, Gott-König Reden, 31; Gray, I \& II Kings, 120-27; Hentschel, 1 Könige, 32-34; Jones, 1 and 2 Kings I, 120-23; Mettinger, King and Messiah, 239; Rehm, 1 Könige, 42; Würthwein, 1. Könige 1-16,32-34. Some recognize a pre-dtr provenance, but are cautious about being able to clearly distinguish pre-dir and dtr elements (cf. Long, 1 Kings, 63; Noth, Könige, 45).

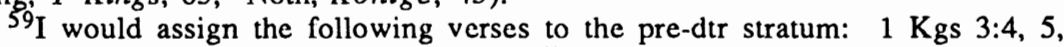
$6 \mathrm{a} a *$ (ie. "and Solomon said"), 7 (omit wēcattâ), 9a, (10), $11 \mathrm{aa}$ (i.e., "and God said to him"), 12aba, 13a $15 \mathrm{ab} \beta \gamma$. A full justification of this text would unduly lengthen the discussion. A similar text is proposed by Görg, Gott-König

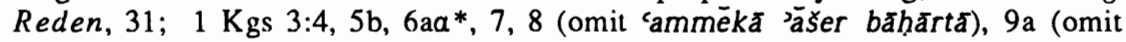
llispot 'et-cammēkã) 11-12, 13 (omit kol-yãmêkā) 14b, 15 (omit wayyābo' yērûsálaim). A somewhat shorter text is proposed by Würthwein, 1 Könige 1-16,

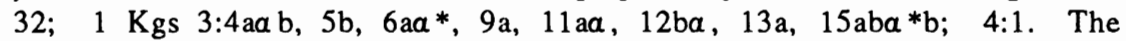
analyses of Kenik and Van Seters are, I believe, deficient in their attention to the literary critical evidence. 
Yahweh and Solomon which are difficult to accept as dtr. ${ }^{60}$ As well, it is quite reasonable to believe there was a story of the source of Solomon's wisdom and wealth circulating in Israelite tradition long before the composition of DtrH. ${ }^{61}$

Given the consensus on the inclusion of $1 \mathrm{Kgs} 3: 4-15$ in DtrH, my comments can be directed to outlining its function within DTR's conceptual plan. ${ }^{62}$ The principal function of the pericope is to bring a number of salient features of Solomon's reign within the compass of the divine initiative guiding Israel's history. While it does not contain the prophecy-fulfillment schema it nevertheless functions in the same way as the schema. Two reasons can be given for the absence of the schema. One emerges out of the sourceredaction interpretation of the text. The pre-dtr version of the story made no mention of a prophet. The other emerges from a consideration of the content of the dialog between Yahweh and Solomon. The different aspects of Solomon's reign dealt with in the dialog were all able to be incorporated within the prophecy-fulfillment trajectory reaching from 2 Samuel 7 to 1 Kings 8. There was no need then for an additional prophecy at this juncture.

In $1 \mathrm{Kgs}$ 3:6b-7 Solomon acknowledges that it is Yahweh who has placed him on the throne of David. Within the larger sweep of DtrH this is in line with the prophecy of 2 Samuel 7.63 The particular contribution of $1 \mathrm{Kgs} \mathrm{3:7}$ is to identify Solomon as the "seed" spoken of in 2 Sam 7:12. Within the

${ }^{60}$ These are: Solomon's description of himself as a little child in $1 \mathrm{Kgs} 3: 7$; the phrase léb šmēac and the expression "to discern between good and evil" in v $9 \mathrm{a}$; the terms riches and honor in $v$ 13. Kenik (Design for Kingship, 141) claims that the phrase "wise and discerning mind" in v 12aba is drawn from Deut $1: 13$, where the same phrase is applied to the leaders chosen by Moses. But in Deut 1:13 the leaders' wisdom and discernment are equated with their readiness to obey the Mosaic law (cf. Deut 1:16-18), whereas in $1 \mathrm{Kgs}$ 3:12aba it is a question of Yahweh's gift.

${ }^{61}$ The pre-dtr form of the story has been linked with Egyptian royal short stories (Königsnovelle) by, for example, Görg, Gott-König Reden, 16-115. This has been criticized by Kenik, Design for Kingship, 29-32, and C. H. W. Brekelmans, "Solomon at Gibeon," Von Kanaan bis Kerala. Festschrift für Prof. Mag. Dr. Dr. J. P. M. van der Ploeg O.P. (AOAT 211; Neukirchen: Neukirchener Verlag, 1982) 53-59. Brekelmans prefers to see parallels between 1 Kgs 3:4-15 and some aspects of the royal Psalms, for example, Psalms 2; 21; 30 . In view of these criticisms one should be cautious about accepting a direct dependence. However a more indirect influence of the Egyptian "Königsnovelle" on the composition of $1 \mathrm{Kgs}$ 3:4-15 seems possible. For further discussion see also Jones, 1 and 2 Kings I, 122-23; and Long, 1 Kings, 64-66.

${ }^{62}$ The passage does show signs of some later expansion. The nomistic language in $1 \mathrm{Kgs} 3: 14$, and the way it is attached to a speech dealing with the bestowal of gifts, indicates that it is a later addition. The return of Solomon to Jerusalem and the ark in $v 15$ may also be a later insertion. But there are no later additions in vv 8-9 (against Würthwein (1. Könige 1-16, 35).

${ }^{63}$ Brekelmans ("Solomon at Gibeon," 56) argues that a function of the pre-dtr version was to provide divine legitimation of Solomon. This may well have been the function of an earlier version. The version in DtrH however functions more as a confirmation that the divine initiative promised in Nathan's prophecy had been realized (cf. also Würthwein, 1.Könige 1-16,31). 
more immediate context $1 \mathrm{Kgs}$ 3:6b recalls David's statement in $1 \mathrm{Kgs} \mathrm{1:48.}$

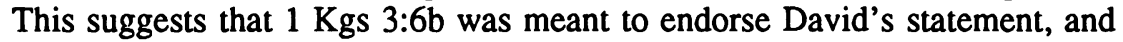
also validate his oath in $1 \mathrm{Kgs} 1: 13,30$ that Solomon was to succeed him. Taken on its own, David's oath could appear to be in some tension with DTR's emphasis on the divine initiative.

The other divine initiatives which $1 \mathrm{Kgs}$ 3:4-15 deals with are the gifts of wisdom, riches and honor (cf. vv 12-13). Even though Solomon requests a "hearing heart" to govern the people in $v 9$, this is within the context of the divine initiative expressed by the invitation in $\mathrm{v} 5 \mathrm{~b}$. The list of gifts brings the following accounts of Solomon's wisdom, wealth and renown within the compass of the divine initiative. The gift of wisdom is however especially significant because it is linked to the building of the temple in $1 \mathrm{Kgs} 5: 21$ (RSV 5:7). In addition, the close association between the gift of wisdom and royal rule (šapat) in $1 \mathrm{Kgs} \mathrm{3:9-12} \mathrm{creates} \mathrm{an} \mathrm{important} \mathrm{link} \mathrm{with} \mathrm{the} \mathrm{earlier} \mathrm{use}$ of this term in relation to Saul and David. Solomon's wise rule marked the full realization of a charism which had been bestowed initially on Saul by Samuel (cf. 1 Sam 11:12-13). After his rejection it was bestowed on his successor David and faithfully exercised by him (cf. 2 Sam 8:15) ${ }^{64}$

In addition to this function $1 \mathrm{Kgs} 3: 4-15$ is also important in relation to the theme of fidelity. In $1 \mathrm{Kgs} \mathrm{3:6}$ we find for the first time, a description by DTR of David as the model king. What is particularly significant about the verse however is the way it portrays the succession of Solomon as a reward for David's fidelity. In conjunction with the four-part pattern for the reign of David outlined earlier, and such texts as $1 \mathrm{Kgs} 8: 25$; 9:4; 11:34, 38, one can see here DTR's progressive integration of the promise of an enduring dynasty with the deuteronomic criteria of reward and retribution. In other words there is the integration of the Davidic covenant with the deuteronomic covenant. ${ }^{65} 1$ Kgs 3:4-15 also portrays Solomon in a way that is in accord with the Davidic model. He acknowledges his complete dependence on Yahweh (cf. vv 7-9). As well, the gifts he receives are presented as Yahweh's reward for his right attitude (cf. vv 11-13).

\section{KGS 5:15-32 (RSV 5:1-18)}

The core of this section is $1 \mathrm{Kgs} 5: 15-26$ (RSV 5:1-12), a passage which reports the diplomatic exchange between Solomon and Hiram on the proposed

${ }^{64}$ With Solomon $1 \mathrm{Kgs} 4: 1-5: 8$ (RSV $4: 1-28$ ) provides a suitable report of the results of his wise rule. The story of the two harlots in $1 \mathrm{Kgs} \mathrm{3:16-28}$ is also clearly designed to illustrate his wisdom, although Solomon is not named in the story itself. However it could be the sort of story which DTR chose to attribute to Solomon. Noth (Könige, 48, 52-53) included it in his pre-dtr Solomonic History. Würthwein however (1 Könige 1-16, 36) regards it as postdtr. Scott ("Solomon and the Beginnings of Wisdom," 271-72) regards $1 \mathrm{Kgs}$ 5:9-14 (RSV 4:29-34) as post-dtr. A close examination of these passages is not possible here.

${ }^{65}$ Against J. Levenson ("Who Inserted the Book of the Torah?" 224-27) who omits the deuteronomic code from DtrH because of alleged conflict between the two covenants. 
building of the temple. An examination of these verses shows that they are a combination of source and dtr redaction. The concern with the temple for Yahweh's name in $1 \mathrm{Kgs}$ 5:17-19 (RSV 5:3-5) is clearly a dtr contribution. The margins of the dtr contribution are less clearly definable, but may be taken to extend from $1 \mathrm{Kgs} 5: 17$ to 5:21 (RSV 5:2 to 5:7). The narrative framework in $1 \mathrm{Kgs} 5: 15-16,24-26$ (RSV 5:1-2, 10-12), as well as Hiram's reply in 1 Kgs 5:22-23 (RSV 5:8-9), is most likely of pre-dtr provenance. DTR may have taken this material from the Acts of Solomon referred to in $1 \mathrm{Kgs}$ $11: 41.66$

The most appropriate way to determine the extent of DTR's contribution is to begin with what is manifestly dtr and work out from there. We can begin therefore with $1 \mathrm{Kgs}$ 5:17-19 which is thoroughly permeated by dtr terminology. ${ }^{67}$ These verses also make two major statements in relation to DTR's conceptual plan and structure. First, Solomon proclaims that with the enjoyment of rest from enemies the time was ripe for the completion of the deuteronomic program as outlined in Deut 12:10-11; that is, worship at the place chosen by Yahweh for his name. Second, Solomon identifies himself as the one through whom the promise of 2 Sam 7:13 would be fulfilled. This attention to Nathan's prophecy was observed also in $1 \mathrm{Kgs} \mathrm{3:7.} \mathrm{Both} \mathrm{texts}$ reveal the progressive integration of Solomon's achievements into DTR's prophecy-fulfillment schema.

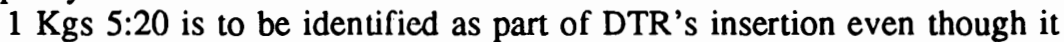
does not contain any dtr language. The nature of the verse does not really lend itself to dtr clichés. However it does require the preceding speech by Solomon to identify the purpose of his request and to justify it. Verse 20 also provides a suitable context for Hiram's reply in the following $v 21$. This too makes an important statement in relation to DTR's theology. It links Yahweh's gift of

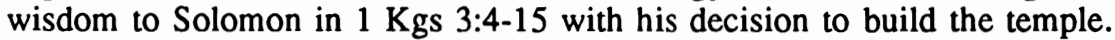
Both of these events were therefore able to be presented by DTR as important steps towards the realization of the deuteronomic ideal.

The logistics of supply and payment as outlined by Hiram in $1 \mathrm{Kgs} 5: 22$ 23 are different to what Solomon has in mind in $1 \mathrm{Kgs} 5: 20$. Solomom speaks only of cedar, whereas Hiram refers to cypress as well. Solomon envisages his servants working side by side with Hiram's from the outset, whereas Hiram speaks only of his own servants. Solomon proposes paying Hiram's servants a wage whereas Hiram proposes payment in the form of food for his household. The differences are significant and point to different authorship for the two texts. Two of the differences support the position that DTR composed $v 20$. One is Solomon's concern that the workmen are paid. This is in kecping with DTR's portrait of Solomon as the wise and just king.

${ }^{66}$ To avoid repetition the following discussion will follow the MT versification.

${ }^{67} \mathrm{Dtr}$ terminology is evident in the repeated reference to the house for the name of the Lord, and in the reference to rest from enemies. The terms "adversary" and "misfortune" do not occur in any other dtr text. This may be an indication that the phrase in $v 18 \mathrm{~b}$ is an addition. However the evidence is too meagre to draw any sure conclusions. 
The same concern is not present in Hiram's reply. The other is Solomon's desire that Israelites ("my servants") be present throughout the operation. This is in keeping with the overall purpose of the operation, the building of

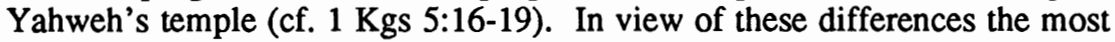
reasonable explanation is to accept that vv 22-23 preserve a portion of the original exchange between the kings. Verse 20 is a modified version of the exchange and one more suited to DTR's concerns. There does not appear to be any secondary dtr redaction in this material.

The narrative in $1 \mathrm{Kgs} 5: 24-25$ (26) contains the terms of the agreement as outlined in vv 22-23. One may presume then that it has the same pre-dtr provenance. ${ }^{68}$ It makes good sense to include $1 \mathrm{Kgs} 5: 15$ as part of this pre-dtr text. ${ }^{69}$ Both this opening verse and $1 \mathrm{Kgs} \mathrm{5:24-25}$ form a narrative frame around the exchange between Solomon and Hiram in 5:16-23. There was probably once a complete pre-dtr version of their exchange, but the present text preserves only the introduction to Solomon's message in v 16 and Hiram's reply in vv 22-23. DTR replaced the remainder with vv 17-21. As a result of this analysis it is difficult to accept there was a pre-dtr Solomonic history which combined an account of Solomon's wise rule with his building program. The two components are only linked in $1 \mathrm{Kgs} 5: 17-21$, a passage which was composed by DTR. ${ }^{70}$

Before passing on to an examination of 1 Kings 8 , a brief comment is in order on dtr redaction in 1 Kings 6-7. The relevant texts are $1 \mathrm{Kgs} \mathrm{6:1} \mathrm{and}$

${ }^{68} 1 \mathrm{Kgs} 5: 26$ is difficult to identify. As a comment on Solomon's wisdom it initially looks like it could be from DTR. Würthwein (1. Könige 1-16, 51, 5556) assigns $\vee 26 \mathrm{~b}$ to DTR, with $\vee 26 \mathrm{a}$ as a later gloss. Cf. also Jepsen, Die Quellen des Königsbuches, 20; Rehm, 1 Könige, 60. However Solomon's wisdom here has to do with international diplomacy (so Noth, Könige, 92), which does not seem to have been a concern of DTR (cf. $1 \mathrm{Kgs}$ 3:4-15). The whole verse may be a later addition.

${ }^{69} \mathrm{~A}$ further clue to the pre-dor provenance of the narrative framework may lie

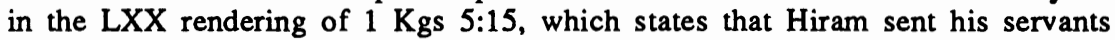
to anoint Solomon in place of his father David. This could preserve evidence of a diplomatic gesture between nations that had an alliance. Such a gesture was likely to be recorded in the Acts of Solomon. But the LXX can also be read as indicating that Solomon was a vassal of Hiram. This may have been found objectionable by later scribes. Alternatively the notion of a foreign king's delegates anointing a Davidic king may have been unacceptable. At any rate the MT appears to have suppressed the reading given in the LXX.

${ }^{70}$ The redactional procedure in $1 \mathrm{Kgs} \mathrm{5:15-26}$ is similar to that in $1 \mathrm{Kgs} \mathrm{3:4-}$ 15. DTR seems to have been content to retain the narrative framework and rework the speech. Other examples of this technique are 1 Kings 8, and the exchanges between prophets and kings (cf. DeVries, 1 Kings, 79). An exception is $1 \mathrm{Kgs}$ 16:1-4 which was composed by DTR. Because of differences between $1 \mathrm{Kgs} 5: 27-32$ and the preceding material it is regarded as a late addition by Noth, Könige, 88-89 (but attributed to DTR in The Deuteronomistic History, 58) and Würthwein, 1. Könige 1-16, 53. DeVries (pp. 80-81) includes it in DtrH. 
6:11-13. $1 \mathrm{Kgs} 6: 1$ is part of DTR's chronology. ${ }^{71} 1 \mathrm{Kgs} 6: 11-13$ however is a later addition to the history. ${ }^{72}$ It intrudes into the account of the temple construction and exhibits the sort of language which has been identified with the nomistic stage of redaction. Furthermore, the content of Yahweh's word to David is not spelt out, as it is in $1 \mathrm{Kgs} 2: 4 ; 8: 25 ; 9: 5$. This indicates an author who was summarizing these fuller expressions. The passage may not be from the one hand. $1 \mathrm{Kgs} 6: 13$ switches the focus from the king to Israel and shows some contact with priestly language in the Pentateuch and postexilic prophecy. ${ }^{73} 1 \mathrm{Kgs} 6: 14$, which duplicates $\mathrm{v} 9$ a, may be a literary seam joining the earlier insertion (1 Kgs 6:11-12) to the existing text. $1 \mathrm{Kgs} 6: 13$ was inserted subsequently.

\section{KINGS 8}

This chapter comprises a narrative frame in $1 \mathrm{Kgs} 8: 1-11,62-66$, with a central section composed almost entirely of direct speech (vv 12-61). The central section can be divided into $1 \mathrm{Kgs}$ 8:12-13 (a short dedication pronouncement), 8:14-21 (review of promises fulfilled), 8:22-30 (prayer), 8:31-53 (collection of 7 prayers), 8:54-61 (further review and exhortation). Although there is general consensus that an account of the dedication of the temple was part of DtrH there is considerable disagreement about just how much of 1 Kings 8 belonged to it, and how much is later elaboration. As one might expect, the main area of disagreement is the long and complex speech by Solomon in $1 \mathrm{Kgs} 8: 14-61$, the dtr nature of which has long been recognized. ${ }^{74}$ The major portion of the reassessment will therefore be

${ }^{71}$ Some have argued against Noth on this (Gray, I \& II Kings, 159; Rehm, 1 Könige, 66; de Vaux, Rois, 45). They propose that the number of years from 1 $\mathrm{Kgs}$ 6:1 to the Judean exile may be taken for a round figure as 430. If one adds 50 years for the exile we have the same total of 480 years as for the period from the Exodus to the construction of the temple. Hence $1 \mathrm{Kgs}$ 6:1 was a late chronological addition to locate the construction of the temple at the mid-point of Israel's history from the Exodus to the the end of the exile. But as Noth pointed out, there is no textual evidence in the books of Kings for including the 50 years of exile in this calculation (Könige, 110).

${ }^{72} \mathrm{Cf}$. Noth, Könige, 118; also Dietrich, Prophetie und Geschichte, 71, n. 23 (DtrN); Hentschel, 1 Könige, 45 (DtrN); Jones, 1 and 2 Kings I, 160; ; Rehm, 1 Könige, 65; Würthwein, 1. Könige 1-16, 65. It is assigned to DTR by DeVries, I Kings, 93; Gray, I \& II Kings, 167; Jepsen, Die Quellen des Königsbuches, (cf. Ubersicht); Long, 1 Kings, 85.

${ }_{73}$ I refer to the notion of Yahweh dwelling among the people; cf. Exod 29:45, 46; Num 5:3; 35:34; Zech 2:14, 15; 8:3, 8; Ezek 43:9.

${ }^{74} \mathrm{Cf}$. Benzinger, Die Bücher der Könige, 65-66; Bumey, Notes, 112; Cornill, Einleitung, 125; Gustav Hölscher, "Das Buch der Könige, seine Quellen und seine Redaktion," Eucharisterion: Studien zur Religion und Literatur des Alten und Neuen Testaments. Hermann Gunkel zum 60. Geburtstag (ed. H. Schmidt; FRLANT 36/1; Göttingen: Vandenhoeck \& Ruprecht, 1923) 158 213; Kittel, Die Bücher der Könige, 78-79; Sanda, Die Bücher der Könige 1, 245-46; Wellhausen, Die Composition des Hexateuch, 270. Sanda, among others, did hold that some of the prayers in $1 \mathrm{Kgs}$ 8:31-53 may be old. 
concerned with the composition of this speech. But before this is undertaken some comment is required on the narrative framework.

The analysis so far has shown that DTR constructed the Solomonic history by arranging and redacting source material. It is reasonable to expect that this source material also supplied a basic account of the dedication of the temple, one which described the assembly and procession to the temple (cf. vv 1-11), recorded the dedication by Solomon (cf. vv 12-13) and reported details of the accompanying liturgical celebration (cf. vv 62-66). ${ }^{75}$

An accurate identification of such a text is hampered somewhat by two factors. The account has undergone elaboration, particularly in $1 \mathrm{Kgs} 8: 1-11$. This was to be expected given the significance of the event. In addition there is considerable variation between the MT and the LXX, once again in vv 1-11. However, upon weighing the evidence, the following verses may be taken as the probable pre-dtr narrative framework: $1 \mathrm{Kgs} \mathrm{8:2a}, 3 \mathrm{a}, 4 \mathrm{aa}, 5,6,62,63 \mathrm{~b}$. This text provides a concise and coherent account without recourse to any textual surgery. ${ }^{76}$ The assembly described in $v 1$ is best taken as a later elaboration and not the work of DTR. ${ }^{77}$ The expansions in $1 \mathrm{Kgs} 8: 2 \mathrm{~b}, 3 \mathrm{~b}$, $4 \mathrm{a} \beta \mathrm{b}$ reflect priestly concerns, as do $v v 7-8$ and vv $10-11 .{ }^{78}$ The reference to Horeb in $1 \mathrm{Kgs} \mathrm{8:9}$ suggests that it is dtr, but not necessarily from DTR. ${ }^{79}$ In

${ }^{75}$ The existence of such an account has found widespread support. Cf. DeVries, I Kings, 122; Gray, I \& II Kings, 203-4; Hentschel, 1 Könige, 55; Jepsen, Die Quellen des Königsbuches, 22; Jones, 1 and 2 Kings I, 191; Long, 1 Kings, 96; Noth, Könige, 174-75; Würthwein, 1. Könige 1-16, 84-88.

${ }^{76}$ The text follows the MT. The LXX has been favored by some because it gives a smoother sequence, without the accretions in the MT (so Burney, Notes, 104; Montgomery, Kings, 186; Rehm, I Könige, 90). Rehm has conveniently bracketed the sections of the text which do not appear in the LXX. However the very complexity of the MT in relation to the LXX is an indication that it preserves an older text which was redacted. The LXX has gone a step further in smoothing out the sequence. Also, one cannot recover the elders as bearers of the ark from the LXX, as can be done from the MT. In the text given here the priests took the ark only to put it in its place (v 6). The one deletion I would suggest from the MT is sadat in $\vee 5 a$, following the LXXL.

${ }^{77}$ Against Noth, Könige, 89, and Würthwein, 1. Könige 1-16, 88. The verb qahal (assemble) in the hiphil form is attested elsewhere only in late dtr passages (Deut 4:10; 31:12, 28) and other late texts (Exod 35:1; Lev 8:3; Num 1:18;

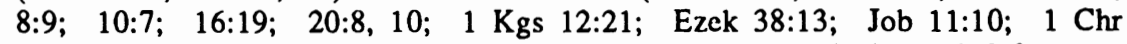
$13: 5 ; 15: 3 ; 28: 1 ; 2 \operatorname{Chr} 5: 2 ; 11: 1$ ). Note however that in its niphal form, as

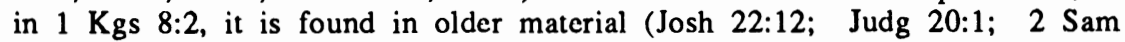
20:14) as well as in later material (Exod 32:1; Lev 8:4; Num 16:3; 17:7; 20:2; Ezek 38:7).

${ }^{78}$ For a similar assessment see Jones, 1 and 2 Kings I, 191-96, and with some variation, Noth, Könige, 174-81. Würthwein (1. Könige 1-16, 84-88) has a different assessment which I do not find convincing. The omission of any reference to Solomon in the original text is unduly influenced by his conviction that Solomon had no interest in the ark. According to Würthwein, his favored cult object was the cherub throne.

${ }^{79}$ Würthwein for example, regards it as late (ibid., p. 88). 
fact there is no clear evidence that DTR altered the old account of $1 \mathrm{Kgs} 8: 1$ 11.

$1 \mathrm{Kgs} 8: 62,63 \mathrm{~b}$ provides an appropriate conclusion to the dedication. ${ }^{80}$ The precise numbers in $\mathrm{v} 63 \mathrm{a}$ create some tension with the general description in v 5. $1 \mathrm{Kgs} 8: 64$ looks to be an appendage concerned with consecration rather than dedication, as is the case in $v 63 \mathrm{~b}$. $1 \mathrm{Kgs}$ 8:65-66 is rather loosely attached to the preceding by the phrase "at that time". In addition the intrusion of the writer in $1 \mathrm{Kgs} \mathrm{8:65} \mathrm{(cf.} \mathrm{"our} \mathrm{God")} \mathrm{is} \mathrm{unusual.} \mathrm{It} \mathrm{would} \mathrm{appear} \mathrm{these}$ two verses were added by an editor who felt that the older ending at $v 63 \mathrm{~b}$ was not appropriate enough, or who wanted to link the temple dedication to the feast of Booths. ${ }^{81}$ It seems that, as with $1 \mathrm{Kgs} 8: 1-11$, DTR made no additions to this section of the framework.

The short dedication pronouncement in $1 \mathrm{Kgs} 8: 12-13$ is generally accepted as ancient, perhaps a quotation from a longer poem. ${ }^{82}$ Even though it may have had an independent origin its presence in the text is best attributed to the author(s) responsible for the pre-dtr account of the dedication of the temple. ${ }^{83}$ The notion of Yahweh dwelling in the temple would not have been particularly conducive to the dtr name theology. It appears to be challenged by the rhetorical question in $v 27$ of Solomon's speech.

\section{KGS 8:14-53}

Solomon's speech divides easily for analysis into the following sections: $1 \mathrm{Kgs} 8: 14-21,22-30,31-53,54-61$. DTR's text is to be found in $1 \mathrm{Kgs}$ 8:14-21, 22, 23aa (introductory invocation only), 24 (omit 'ăšer) 25-26, 28-

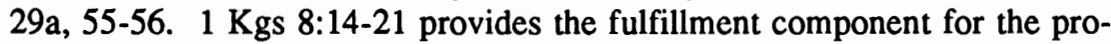
phecy of 2 Samuel 7, a factor to which attention has already been drawn. However there are a number of features in the passage which merit consideration because of what they reveal about DTR's redactional technique. ${ }^{84}$

${ }^{80}$ Surprisingly Noth (Könige, 190-92) assigns all of $1 \mathrm{Kgs} 8: 62-66$ to DTR. However there is no evidence of dtr language in these verses, except perhaps for the reference to David in $v 66$. In 2 Samuel 6 (pre-dtr provenance) David sacrifices during the procession with the ark, and after its installation in the tent. Jepsen (Die Quellen des Königsbuches, 102 and Ubersicht) assigns vv 62 66 to a post-dtr levitical redaction.

${ }^{81}$ Cf. Deut 16:13-15. Noted by Noth, Könige, 192; Rehm, 1 Könige, 99; Würthwein, 1. Könige 1-16,102. This editor may have been dtr, and the verses added before the insertion of $v 64$.

${ }^{82}$ The first stich in the RSV is supplied from the LXX. A. Van Den Born ("Zum Tempelweihspruch [I Kgs viii 12f]," OTS 14 [1965] 235-44) proposes that the verses are a fragment of an old creation epic (p. 243). Cf. also the study by $O$. Loretz, "Der Torso eines Kanaanaisch-israelitischen Tempelweihspruches in I Kg 8, 12-13," UF 6 (1974) 478-80.

${ }^{83}$ Its independent provenance is indicated by the statement in the LXX "At the dedication. Is it not written in the Book of the Song?". Its insertion in the narrative is indicated by the introductory "then" (so Jones, 1 and 2 Kings I, 196). The poem appears after $1 \mathrm{Kgs} 8: 53$ in the LXX.

${ }^{84}$ Dietrich (Prophetie und Geschichte, 74, n. 39) assigns $1 \mathrm{Kgs} 8: 14-26,28$ 30a, 53-61 to the later DirN, and is followed by Hentschel (1 Könige, 57-58). 
What is initially striking about these verses is that they quote the prophecy as part of the fulfillment citation. A closer inspection reveals however that the quotation is in fact a summary and a rephrasing of Nathan's prophecy. In my judgment this rephrasing was done deliberately by DTR to integrate the key events of Solomon's reign into the prophecy-fulfillment schema. Thus in 1 Kgs 8:16a the prophecy of a house for Yahweh's name (2 Sam 7:13a) was rephrased in order to show that it had been fulfilled by the construction of the temple in Jerusalem. The rephrasing of the prophecy in $1 \mathrm{Kgs} 8: 16 \mathrm{~b}-19$ is equally deliberate. On the one hand it directly associates Yahweh's choice of David with that of Jerusalem. ${ }^{85}$ This was a key stage in the progressive realization of the divine purpose. ${ }^{86}$ On the other hand it was designed to remove any sense of impropriety in David's remark in 2 Sam 7:2. David is commended in $1 \mathrm{Kgs}$ 8:18 for wanting to build a temple, even though his reign was not the appropriate time to do so. ${ }^{87}$

Within $1 \mathrm{Kgs}$ 8:22-30 DTR's text can be traced in vv 22, 23aa (introductory invocation only), 24 (omit 'äser), 25-26, 28-29a. ${ }^{88}$ The description of Yahweh's incomparibility in $1 \mathrm{Kgs} \mathrm{8:23} \mathrm{expresses} \mathrm{sentiments}$ similar to those found in Deut $4: 35,39$. The general reference to "thy servants", and the theme of reward for obedience is also somewhat out of con-

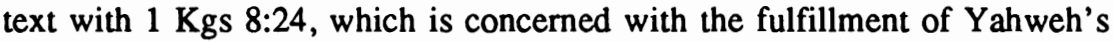
promise in relation to David. However the invocation to Yahweh in $1 \mathrm{Kgs}$ 8:23aa should be retained as the introduction to $v 24$. The expansion in $1 \mathrm{Kgs}$ 8:23 required the insertion of the introductory ašer at the head of $v 24$. It is more than likely that $1 \mathrm{Kgs} 8: 27$ too is a later addition. ${ }^{89}$ The rhetorical

Stahl ("Aspekte," 107) assigns vv 14-26, 28, 54-58, 61 to DtrN1. What is missing in these studies is any convincing evidence of nomistic language in 1 Kgs 8:14-21. Dietrich's analysis is confined to a footnote. Stahl does carry out a detailed analysis, but even here there is difficulty distinguishing his DtrN1 redactor from DtrH or DtrP. This is a serious problem given that he claims to identify up to $9 \mathrm{dtr}$ redactions.

${ }^{85}$ In 2 Chr 6:5-6 and LXX 3 Reigns 8:16 the formulation has been altered to spell out the allusion to Jerusalem. For DTR, the context made this unnecessary. A similar example is provided by $1 \mathrm{Kgs} 11: 36$, where DTR referred to the one tribe retained for the Davidic dynasty. The context made it clear enough that the tribe was Judah.

${ }^{86}$ Note how the use of the verb bāhar (to choose) occurs in $1 \mathrm{Kgs} 8: 16$ in

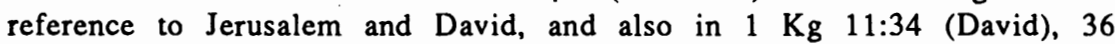

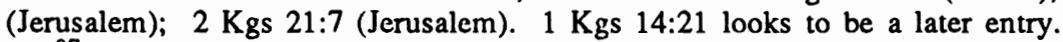

${ }^{87} \mathrm{~A}$ similar concern to preserve David from any impropriety was observed in the four-part pattern constructed around 2 Samuel 7. DTR contrived to make David's remark to Nathan a response to a divine initiative, signalled by the entry of the ark (2 Samuel 6) and the enjoyment of rest from enemies (2 Sam $7: 1 \mathrm{~b})$.

${ }^{88}$ Levenson ("From Temple to Synagogue," 143-66) assigns $1 \mathrm{Kgs} 8: 23-53$ to an exilic Dtr. The prayers in vv $31-53$ are certainly later, but it is difficult to accept vv 23-26, 28-29a express "the possibility of return, both literal and metaphorical, in spite of Israel's sorry history of sin" (p. 162).

${ }^{89}$ Dietrich (Prophetie und Geschichte, 74, n. 39) assigns $1 \mathrm{Kgs} 8: 27$ to a later hand than DtrN, along with vv 30b-43. For Hentschel $(1$ Könige, 58) it 
question interrupts the overall sequence of petitions. Yet one can see why it was inserted. It is located at the beginning of the series of petitions which have the temple as their focus. Hence it provides a corrective to the sentiments expressed in the dedication pronouncement in $1 \mathrm{Kgs} 8: 12-13$.

$1 \mathrm{Kgs} 8: 24-26$ and 28-29a contain two petitions concerning dynasty and temple which are closely linked to $1 \mathrm{Kgs} \mathrm{8:14-21}$. Each recalls the relevant fulfillment notice for dynasty and temple in $1 \mathrm{Kgs} 8: 14-21$ as a motivation for Yahweh to grant the petition. The two petitions are granted by Yahweh in 1 Kgs 9:1-5, after which they function as normative criteria for DTR's interpretation of the subsequent history of the Davidic dynasty.

Thus $1 \mathrm{Kgs} \mathrm{8:24}$ recalls Nathan's promise to David of a dynasty - which is

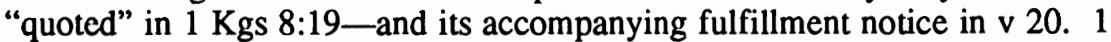
Kgs 8:25 opens as a petition but immediately brings into consideration another element which was necessary for the interpretation of the rest of the reign of Solomon, and indeed the whole subsequent history of the monarchy. The element in question was first introduced in David's death bed speech to Solomon in $1 \mathrm{Kgs} 2: 2$, 4aab. In this speech Solomon was exhorted to conduct himself in such a way that Yahweh would secure his word to David, "there shall not fail you a man on the throne of Israel". The throne referred to here is that of the united kingdom of Israel and Judah. ${ }^{90}$ The inclusion of this conditional promise within the petition of $v 25$ was a necessary preparatory step for DTR's interpretation of Solomon's infidelity and the schism in the kingdom. With Yahweh's approval of the petition in $1 \mathrm{Kgs} \mathrm{9:4-5}$ the conditions contained in it become normative. $1 \mathrm{Kgs} \mathrm{8:26}$ has the effect of unifying the promise to David of a dynasty (cf. v 24), and the conditional promise conveyed to Solomon (cf. v 25), into the one word of Yahweh to David.

One cannot claim that $1 \mathrm{Kgs} 8: 25$ is nomistic simply because it contains a

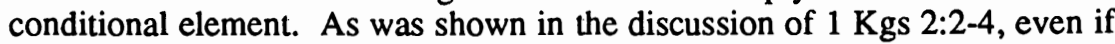
vv $3,4 a \beta$ are removed as later nomistic additions, the conditional element remains with the lemacan of $\mathrm{v} 4 \mathrm{aa} .{ }^{91}$ This introduction, along with $1 \mathrm{Kgs}$ $2: 2,4 \mathrm{~b}$ is part of DtrH. The conditional clause in $1 \mathrm{Kgs} 8: 25$ is therefore required in order to reflect the basic sense of $1 \mathrm{Kgs} 2: 2,4 \mathrm{aab}$. The reference to

belongs to a third level of redaction after DtrN. Stahl (“Aspekte," 104) assigns it to DtrTh4. Others who accept the verse is late are Hölscher ("Könige," 166ff, along with vv 30-43), Jones ( 1 and 2 Kings $I, 201$ ), S anda (Die Bücher der Könige 1, 246, along with vv 29, 44-51, 59-60), Würthwein (1. Könige 1-16, 97, one of a number of additions from different hands).

${ }^{90}$ In agreement with Nelson, The Double Redaction, 99-104. See also his "Dynastic Oracle in Dtr: A Worskshop in Recent Trends," Society of Biblical Literature 1976 Seminar Papers (ed. G. MacRae; Montana: Scholars, 1976) 114 , in particular p. 5 . Nelson notes that the phrase "the throne of Israel" in 2 Kgs 10:30; 15:12 clearly refers to the northern kingdom. This is in contrast to $1 \mathrm{Kgs} 2: 4 ; 8: 20 ; 9: 5 ; 10: 9$ which refer to the united kingdom. The first three are from DTR. $1 \mathrm{Kgs} 10: 9$ is not so sure, but in any case clearly shares DTR's use of the phrase.

${ }^{91}$ This was recognized by Veijola (Die ewige Dynastie, 23), who assigned 1 Kgs 2:2, 4aab to his DtrH. 
"sons" in $1 \mathrm{Kgs} \mathrm{8:25}$ is also required because the petition has the subsequent fortunes of the monarchy in mind. ${ }^{92}$

$1 \mathrm{Kgs} 8: 28-29$ a functions in the same way as vv $24-26$, although the formulation is somewhat different and there is only one promise referred to. The different formulation and terminology is due to the different nature of the petition. Solomon is in effect making a request for the temple to have exclusive and permanent status in the eyes of Yahweh ( $v 29 a){ }^{93}$ This request is approved in $1 \mathrm{Kgs} 9: 3$. As with $1 \mathrm{Kgs}$ 8:25-26 and 9:4-5 DTR used the combination of petition and divine approval to legitimate the temple's exclusive status as the only place of worship, and to provide an authoritative criterion for the subsequent interpretation of the relationship between the Davidic dynasty and the temple (cf. $1 \mathrm{Kgs} 11: 36 ; 2 \mathrm{Kgs} 21: 7$ ).

The divine promise of a temple quoted in $1 \mathrm{Kgs} 8: 16-19$ is recalled in $\mathrm{v}$ 29a. Its position at the end of the petition is the reverse of the order of vv 2426 but is due to DTR's desire to create an inclusion between $v 29$ a and $1 \mathrm{Kgs}$ 8:16a. The evidence for this emerges from the way $1 \mathrm{Kgs} \mathrm{8:29a}$ recalls key elements of $v 16 a$, namely the house (temple), and the presence of Yahweh's name in the house. The sense of an inclusion gains support from the way the formulation of the reference to the name in $1 \mathrm{Kgs} 8: 29 \mathrm{a}$ closely parallels the one in $1 \mathrm{Kgs} \mathrm{8:16a \gamma .}{ }^{94}$ These two points, the reversal of order and the formation of an inclusion, also suggest that DTR brought the prayer of Solomon to an end at this point.

The suggestion is supported by the way $1 \mathrm{Kgs} 8: 29 \mathrm{~b}$ introduces a new request, that Yahweh listen to a prayer Solomon is about to make. The different authorship of this new prayer is indicated by the way Solomon speaks of offering the prayer "toward this place". The implication is that Solomon is

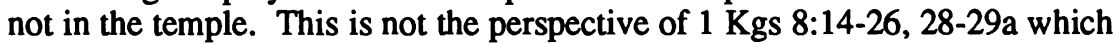
clearly locates Solomon within the temple. Furthermore $1 \mathrm{Kgs} 8: 30$, which also uses the phrase "toward this place" suggesting distance from the temple, makes a request on behalf of the people as well as the king. In short, $1 \mathrm{Kgs}$ 8:29b-30 is a later literary seam between DTR's conclusion in $1 \mathrm{Kgs} \mathrm{8:29a}$ and the seven prayers in $1 \mathrm{Kgs}$ 8:31-53 which are concerned exclusively with the people. ${ }^{95}$ This proposal can be verified by a consideration of some salient features of the collection of seven prayers in $1 \mathrm{Kgs}$ 8:31-53.

${ }^{92}$ Nelson's proposal that the term "sons" in $1 \mathrm{Kgs} 2: 4 ; 8: 25$ refers only to David's immediate family does not seem correct (The Double Redaction, 102-3). The dtr nature of these occurrences, and the fact that later Davidic kings are compared with "David his father" (cf. $1 \mathrm{Kgs} 15: 11 ; 2 \mathrm{Kgs} 14: 3 ; 16: 2$ b; 18:3; $22: 2$ ), indicates that the term was used in the broader dynastic sense.

${ }^{93}$ The solemnity of this moment requires appropriate language. Hence the elaborate preface to the petition in $1 \mathrm{Kgs} 8: 28$.

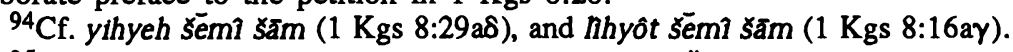

95Jepsen (Die Quellen des Königsbuches, cf. Ubersicht) made a division between $1 \mathrm{Kgs} 8: 29 \mathrm{aa}(\mathrm{RI})$ and 8:29aßb (Dtr) but in general the literary critical evidence in favor of a break at $8: 29 \mathrm{a}$ has been overlooked: cf. Dietrich, Prophetie und Geschichte, 74, n. 39 (between v 30a and v 30b); Hentschel, 1 Könige, 58 (between v 28 and v 29); Hölscher, "Könige," 166 (between v 29 and v 30); Jones, 1 and 2 Kings I, 201 (between $\vee 28$ and v 29); Sanda, Die 
There is no need to enter into a detailed examination of each prayer in order to verify that $1 \mathrm{Kgs} 8: 29 \mathrm{~b}-53$ was a later insertion into the history. The following considerations are sufficient for this purpose. To begin with, there is the already outlined literary critical evidence for distinguishing $1 \mathrm{Kgs} 8: 29 \mathrm{~b}-$ 30 from the preceding text. These verses provide an introduction to the series of prayers, and are required as such even if one claims that one or more of the prayers was composed in a pre-exilic setting. ${ }^{96}$

A second point that necds to be noted is the way $1 \mathrm{Kgs} \mathrm{8:29b-30} \mathrm{and} \mathrm{8:52-}$ 53 frame the series of prayers as introduction and conclusion. The sudden return of the king in $1 \mathrm{Kgs} 8: 52$ as one in need of prayer is an indication that this is a literary scam joining the series of prayers to the larger context. ${ }^{97}$ The technique is the same as that observed in $1 \mathrm{Kgs} 8: 29 \mathrm{~b}-30$. Hence it is reasonable to attribute both texts to the same hand. ${ }^{98}$

Third, there is the fact that all the prayers address situations which confront the people and not the king. ${ }^{99}$ In the analysis so far of the period of Israel under the Prophets and Kings the shift from the king to the people has been seen to be a characteristic of later redaction (cf. 1 Sam 8:7-8; 10:17-19; 12:1-

Bücher der Könige 1, 245-46 (between v 28 and v 29, with v 30 a late gloss); Stahl, "Aspekte," 101 (between v 28 and v 29); Würthwein, 1. Könige 1-16, 97 (between v 28 and $v 29$ ).

${ }^{96}$ It is widely accepted that the prayers do not all come from the one hand. One example that could have been composed in the pre-exilic period is $1 \mathrm{Kgs}$ 8:44-45. It speaks of an expedition against an enemy without any suggestion of defeat, loss of land, city or temple. Its petition is for Yahweh to "maintain their cause". But in the present text it is closely linked to $1 \mathrm{Kgs} 8: 46-51$, to which it provides an introduction. The "they" of v 46 refers back to "thy people" of $v 44$, and the situation of battle in vv $44-45$ provides a suitable context for vv 46-51. The setting of the prayer in vv 46-51 is, as its language shows, clearly exilic. Nelson (First and Second Kings, 53) sees a link between the prayers and the curses of Deuteronomy 28.

${ }^{97}$ Note the close similarity in the petitions of $1 \mathrm{Kgs} \mathrm{8:30}$ and 8:52; "the supplication of thy servant and (to the supplication [v 52]) of thy people Israel".

${ }^{98} \mathrm{G}$. Braulik has proposed that $1 \mathrm{Kgs} 8: 52-53$, along with vv $59-60$ is later than the principal dtr redaction ("Spuren einer Neubearbeitung des deuteronomistischen Geschichtswerkes in I Kön 8: 52-53, 59-60," Bib 52 [1971] 20-33). See also Stahl, "Aspekte," 106.

${ }^{99}$ The prayer for the individual in $1 \mathrm{Kgs} 8: 31-32$ can hardly be taken as a reference to the king. Along with the prayer for the foreigner in vv 41-43 it seems to have been used as a frame around vv 33-40, thus forming a collection. Many recognize this by distinguishing this collection from $1 \mathrm{Kgs} 8: 44-51$, thus Dietrich, Prophetie und Geschichte, 74, n. 39; Gray, I \& II Kings, 214; Jepsen, Die Quellen des Königsbuches, Ubersicht; Jones, 1 and 2 Kings I, 204; Hentschel, 1 Könige, 58; Long, 1 Kings, 102 (with caution); Montgomery, Kings, 193-94; Noth, Könige, 188-89; Rehm, 1 Könige, 91; Stahl, "Aspekte," 105; Würthwein, 1. Könige 1-16, 99.

The unity of $1 \mathrm{Kgs} 8: 31-53$ is defended by Arnold Gamper, "Die heilsgeschichtliche Bedeutung des Salomonischen Tempelweihgebets," ZKT 85 (1963) 55-61. 
25; 2 Sam 7:22-24). This will receive further confirmation in the analysis of the remainder of the history.

Fourth, there is the deep concern in the majority of the prayers with the forgiveness of $\sin$ (cf. $1 \mathrm{Kgs} 8: 34,36,39,46-50$ ). The verb sălah (to forgive) has been found to occur principally in exilic and post-exilic texts. ${ }^{100}$ The verb occurs elsewhere in Deuteronomy-2 Kings in Deut 29:19 (RSV 29:20) and 2 Kgs 5:18; 24:4. Deut 29:19 has already been identified as a later dtr addition. $2 \mathrm{Kgs} \mathrm{5:18}$ is non-dtr. $2 \mathrm{Kgs} 24: 4$, as will be demonstrated in the analysis of 2 Kings 21-25, forms part of a later dtr condemnation of Manasseh.

Finally, the prayers in $1 \mathrm{Kgs} 8: 31-53$ presuppose that the temple's exclusive status has already been approved by Yahweh. This is however somewhat out of step with the surrounding context. Solomon makes his plea in $1 \mathrm{Kgs}$ 8:29a that Yahweh's eyes be open day and night to "the place of which thou hast said, "My name shall be there". The petition is granted by Yahweh in $1 \mathrm{Kgs}$ 9:3, who states that "my eyes and my heart will be there for all time". Hence it is with this authoritative statement, and not before, that the temple gains its exclusive status.

\section{KGS 8:54-61}

This is a rather complex text, but DTR's contribution may be identified with reasonable certainty in $1 \mathrm{Kgs} 8: 55-56$. Verse 55 can follow quite smoothly after $1 \mathrm{Kgs} 8: 29$ a. Three things identify v 56 as DTR's conclusion. First of all, Solomon's blessing forms a neat inclusion with his blessing in v 15. Second, the content of the blessing in $v 56$ proclaims that all the elements of Moses' promise in Deut 12:10-11 had been fulfilled or, as it can also be phrased, the deuteronomic program had been fully realized. Third, the inclusion with v 15 also enabled DTR to integrate the fulfillment of the promises to David proclaimed there into the larger trajectory of $v 56 .^{101}$

$1 \mathrm{Kgs} 8: 54$ is probably a later addition, designed to link the collection of prayers in $1 \mathrm{Kgs}$ 8:31-53 with DTR's conclusion. Solomon is described as having knelt for the prayer, but this is not mentioned in $v 22$. As well, one may note the reference to "all this prayer and supplication" in $v 54$. Even

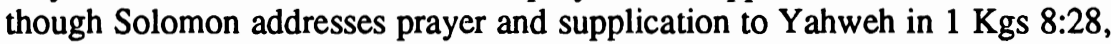
the addition of all in $\mathrm{v} 54$ seems to have the extensive collection of vv 31-53 also in mind. ${ }^{102}$

${ }^{100}$ On this see Klaus Koch, "Sühne und Sündenvergebung um die Wende von der exilischen zur nachexilischen Zeit," EvT 26 (1966) 127-39.

${ }^{101}$ Attention has already been drawn to the importance of $1 \mathrm{Kgs} 8: 56$ in the structure and conceptual plan of DtrH. The use of the noun "rest" may have been intended to add a nuance of solemnity or finality to the proclamation. The other references to rest in DtrH all use the hiphil form of the verb (Deut 3:20; 12:10; Josh $1: 13,15 ; 21: 44 ; 22: 4 ; 2$ Sam 7:1b, 11; 1 Kgs 5:18 (RSV 5:4).

${ }^{102}$ Given that $1 \mathrm{Kgs} 8: 54$ is a later addition the initial verb in $v 55 \mathrm{a}$ (and he stood) may also come from the same hand. Solomon was already standing in DTR's text (cf. $v$ 22). Note that in $1 \mathrm{Kgs} 8: 30$ and 52 supplication (tèhinnâ) alone occurs. A number of manuscripts altered $v 30$ to read prayer (téprllâ). This was probably done to harmonize with the word pair in vv 28 and 54 . 
The provenance of $1 \mathrm{Kgs} \mathrm{8:57}$ is difficult to identify with accuracy, but it does suggest awareness of the dtr interpretation of the exile as Yahweh's rejection of Israel (cf. $2 \mathrm{Kgs} 21: 14$, and also 1 Sam 12:22). $1 \mathrm{Kgs} \mathrm{8:58}$ and 61 exhibit a strong nomistic tone, and so are likely to have come from the nomistic stage of later redaction. $1 \mathrm{Kgs} \mathrm{8:57} \mathrm{may} \mathrm{be} \mathrm{included} \mathrm{in} \mathrm{this} \mathrm{redaction}$ because it forms a recognizable sequence with vv 58 and 61 . The sequence begins with the introductory petition in $v 57$, which is then made more specific in $\vee 58$, where the nomistic terminology becomes apparent. $1 \mathrm{Kgs}$ 8:61 follows as an exhortation, with particular emphasis on obedience to the law. In contrast $1 \mathrm{Kgs} \mathrm{8:59-60} \mathrm{returns} \mathrm{to} \mathrm{the} \mathrm{prayers} \mathrm{of} 1 \mathrm{Kgs} 8: 29 \mathrm{~b}-53$ and petitions that they be near the divinity day and night. $1 \mathrm{Kgs} 8: 60$ provides a motivation for the divinity to accept this petition. $1 \mathrm{Kgs} 8: 59-60$ is therefore to be distinguished from the surrounding nomistic material. ${ }^{103}$

\section{KGS 9:1-10:29}

The principal dtr text in this section is $1 \mathrm{Kgs} 9: 1-9.104$ The function of 1 Kgs 9:1-5 as Yahweh's response to the petitions in $1 \mathrm{Kgs}$ 8:24-26 and 28-29a indicates that these verses are from DTR. Two additional observations support the identification. First, we may note how Yahweh, in response to Solomon's petition in $1 \mathrm{Kgs} 8: 28-29 \mathrm{a}$, consecrates the temple and assures him that his name will be there for ever, and that "my eyes and my heart will be there for all time" (v 3). ${ }^{105}$ On the basis of this statement the temple gains not only an exclusive status, but also an assurance of continuity which is reaffirmed by DTR at critical stages in the history (cf. $1 \mathrm{Kgs} 11: 36 ; 2 \mathrm{Kgs} 21: 7$ ). The second point to note is that $1 \mathrm{Kgs} 9: 4$ refers only to Solomon. The shift from "sons" in $1 \mathrm{Kgs} \mathrm{8:25}$ was deliberately made in order to prepare for the account of Solomon's infidelity in $1 \mathrm{Kgs} 11: 1-8 .{ }^{106}$

${ }^{103}$ Braulik ("Spuren," 22-26) assigns these verses to the same hand as $1 \mathrm{Kgs}$ $8: 52-53$, and identifies this author as the one responsible for Deut $4: 1-40$ (p. 29). Others who note the special nature of $1 \mathrm{Kgs} \mathrm{8:59-60}$ are Jones, 1 and 2 Kings I, 206; Hentschel, 1 Könige, 63; Noth, Könige, 190; Stahl, "Aspekte," 106; Wurthwein, 1. Könige 1-16, 96.

${ }^{104}$ Görg (Gott-König Reden, 175) distinguishes a basic stratum in $1 \mathrm{Kgs}$ $9: 3 \mathrm{a} \beta, 5 \mathrm{a}$, a pre-dtr redaction in vv $1-2,3 \mathrm{aab}$ (which is a continuation of $1 \mathrm{Kgs}$ $8: 28-29$ ), and a dtr redaction in vv $4,5 b, 6-9$. However the evidence for such a distribution of the verses is extremely meagre.

${ }^{105}$ The sense of consecration is also present in the formulation lasum-sêmi sam. This point answers a difficulty Hölscher had with the difference in formulation between $1 \mathrm{Kgs} \mathrm{8:16} \mathrm{and} \mathrm{9:3} \mathrm{("Könige,"} \mathrm{170).}$

${ }^{106} \mathrm{I}$. W. Provan (Hezekiah, 106-11) regards the promises in $1 \mathrm{Kgs} 2: 4 ; 8: 25$ and 9:4-5 as conditional and therefore of exilic provenance. As shown here however the promises are only conditional in relation to the united kingdom. After the schism DTR employed the promise of an everlasting nir for the Davidic dynasty to contrast Judah's security with the condemned north (cf. $1 \mathrm{Kgs}$ 11:36; 15:4; $2 \mathrm{Kgs} \mathrm{8:19).} \mathrm{Provan's} \mathrm{position} \mathrm{depends} \mathrm{to} \mathrm{a} \mathrm{large} \mathrm{extent} \mathrm{on} \mathrm{his}$ perception of $1 \mathrm{Kgs} 9: 1-9$ as a unit. This is not the case. Note that $1 \mathrm{Kgs} 9: 4 \mathrm{~b}$ is attached asyndetically to $v 4 \mathrm{a}$ and may be a later nomistic type retouching of the text. 
$1 \mathrm{Kgs} \mathrm{9:6-9} \mathrm{is} \mathrm{to} \mathrm{be} \mathrm{taken} \mathrm{as} \mathrm{a} \mathrm{later} \mathrm{expansion.}{ }^{107}$ There is the asyndetic attachment of $1 \mathrm{Kgs} \mathrm{9:6} \mathrm{to} \mathrm{9:5,} \mathrm{and} \mathrm{the} \mathrm{awkward} \mathrm{shift} \mathrm{from} \mathrm{the} \mathrm{singular} \mathrm{to} \mathrm{the}$ plural form of address. The accompanying transfer of attention from the king to the people is a phenomenon which has been found elsewhere to be a mark of later redaction. The situation described is also clearly that of the exile. Finally, there are linguistic and stylistic features which are not characteristic of DTR. Their similarity to texts in Jeremiah suggests an association with the dtr redaction of that book. ${ }^{108}$

The intervening material in $1 \mathrm{Kgs} 9: 10-10: 29$ need not be investigated here, although some of it may have been added later to DtrH. As noted earlier $1 \mathrm{Kgs}$ 9:15-24* is assigned by Campbell to the Prophetic Record. This, along with $1 \mathrm{Kgs}$ 9:10-14 and 10:23-29 may have comprised the text of DtrH. However Noth includes all of $1 \mathrm{Kgs} 9: 10-10: 29$ in his pre-dtr Solomonic History, with dtr touches in 10:1, 9.109 A resolution of the matter is not critical for the purposes of this study. ${ }^{110}$

\section{KGS 11:1-39}

The principal areas of dtr redaction in this section of the history are $1 \mathrm{Kgs}$ 11:1-13 and the prophecy of Ahijah in 1 Kgs 11:29-39. The first text falls easily into two sections; the report of Solomon's infidelity in $1 \mathrm{Kgs} 11: 1-8$, and the subsequent condemnation by Yahweh in 11:9-13. In relation to the report of Solomon's infidelity there is general recognition that old source material underlies the present text, which clearly bears a dtr stamp. ${ }^{111}$ An

${ }^{107}$ The secondary nature of $1 \mathrm{Kgs} 9: 6-9$ is recognized by Nelson, The Double Redaction, 73-74. Cross (Canaanite Myth and Hebrew Epic, 287) identifies 1 Kgs 9:4-9 as secondary. Dietrich (Prophetie und Geschichte, p. 72, n. 35) assigns all of $1 \mathrm{Kgs} 9: 1-9$ to DtrN. Noth assigned $1 \mathrm{Kgs} \mathrm{9:1-9}$ to DTR (The Deuteronomistic History, 60); cf. also Gray, I \& II Kings, 236, Jepsen, Die Quellen des Königsbuches, 80, Montgomery, Kings, 204.

${ }^{108}$ These are; "to become a proverb and a byword among all peoples" (v 7), found in Deut 28:37 and Jer 24:9, and the verb to hiss, found in Jer 19:8; $49: 17 ; 50: 13$. There is also the question and answer schema in vv 8-9 which occurs in Deut 29:23-27 (RSV 29:24-28) and Jer 22:8-9. On this schema see D. E. Skweres, "Das Motiv der Strafgrunderfragung in biblischen und neuassyrischen Texten," BZ 14 (1970) 181-97. It is difficult to comment on 'elyón in $\vee 8$, which is corrected to lé ciyyîn (ruins) in the Old Latin, Syriac and Targums. For a discussion see Barthélemy (Critique textuelle de l'Ancien Testament $1,355-57$ ) where the correction is accepted.

${ }^{109}$ Noth, Könige, 208.

${ }^{110}$ Würthwcin (1. Könige $\left.1-16,115,120\right)$ regards the visit of the queen of Sheba as a later addition to DtrH. The interpretation of the theme of Solomon's wisdom given in my analysis of $1 \mathrm{Kgs} 3: 4-15$ and 5:15-26 (RSV 5:1-12) is not dependent on the story of the queen of Sheba, or the other material on his legendary wisdom in $1 \mathrm{Kgs} 3: 16-28$ and 5:9-14 (RSV 4:29-34).

${ }^{111}$ Thus-with the source given in brackets-DeVries, I Kings, 142-43 (v 3); Jones, 1 and 2 Kings $I, 232-33$ (vv 1a, 3a , 7a); Hentschel, $I$ Könige, 7374 (vv 1*, 3a, 7); Long, 1 Kings, 121 (vv 3, 7); Noth, Könige, 244 (vv 3a, 7); Rehm, 1 Könige, 122 (in vv 3, 7); H. Spieckermann, Juda unter Assur, 419 
accurate distinction between source and redaction is hampered to some extent by differences between the MT and the LXX. ${ }^{112}$ Nevertheless the source material can be identified with reasonable certitude in $1 \mathrm{Kgs} 11: 3 \mathrm{a}, 7$. With $\mathrm{v}$ 3a one may point out that it speaks of wives and concubines, yet only the wives are of interest to the dtr redaction. ${ }^{113}$ The comment in $v 3 \mathrm{~b}$ that Solomon's wives turned away his heart is dtr. It is possible that $v 7$ was taken from records of Solomon's building program, although when one considers the nature of the information in relation to the rest of the program this becomes doubtful. A more likely provenance is Campbell's proposal that it was part of the Prophetic Record. ${ }^{114}$

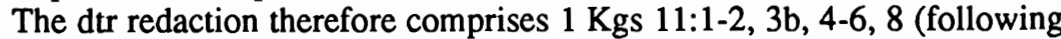
the MT sequence). Of these the verses which are to be identified as DTR's contribution are $1 \mathrm{Kgs} 11: 1,2 \mathrm{~b}, 3 \mathrm{~b}, 4,6$. Attention has already been drawn to the contrast established by DTR between Solomon's love of Yahweh in $1 \mathrm{Kgs}$ $3: 3$ and his love of foreign women in $1 \mathrm{Kgs} 11: 1-2$. Within these verses the "quotation" from Deut 7:3-4 in $v 2 \mathrm{a}$ is a later addition inserted between the list of foreign women in $v 1$ and bahem in $v 2 b$, which obviously refers to them. ${ }^{115} 1 \mathrm{Kgs} 11: 5$ is in some tension with the preceding verses which are more lenient towards Solomon. They claim that it was his wives who led him astray ( $v 3 b$ ) in his old age ( $v 4)$. The censure in $v 4 b$ states that "his heart was not wholly true to the Lord his God". In contrast v 5 makes no attempt to play down the seriousness of Solomon's apostasy. $1 \mathrm{Kgs} \mathrm{11:8} \mathrm{was}$

(vv 1a*, 3a); Gottfried Vanoni, Literarkritik und Grammatik. Untersuchung der Wiederholungen und Spannungen in 1 Kön 11-12 (Arbeiten zu Text und Sprache im Alten Testament 21; St. Ottilien: EOS Verlag, 1984) 254 (vv 4aab, 7aab); Würthwein, 1. Könige 1-16,131 (vv 1a*, 3a, 7aab). Vanoni's identification of $v 4 a a b$ as a source is surprising given the evidence for dtr language in $v 4 b$. While I am appreciative of Vanoni's careful analysis of the text, his results need to be assessed in terms of the larger context and the hypothesis of a DtrH. This is something which Vanoni does not do since he covers only some of the steps in Richter's exegetical method. Hoffmann (Reform und Reformen, 49-53) argues that $1 \mathrm{Kgs} 11: 1-13$ is a dtr composition. His analysis is limited by its focus on Solomon's cultic innovations in vv 5 and 7 . Also his argument that $2 \mathrm{Kgs}$ $23: 13$ is a reference to $1 \mathrm{Kgs} 11: 5,7$ does not rule out a literary critical analysis.

${ }^{112}$ The most important differences in the LXX are: relocation of $v 3 a$ after nasim in $v 1 \mathrm{a}$; inversion of the order of $v 4$; omission of $v 5$; relocation of $v$ 6 after $\vee 8$. The details are given in Burney, Notes, 153; also Montgomery, Kings, 231-32.

113 A point noted by DeVries, 1 Kings, 143. Also, in the Ancient Near East the information in $v 3$ a would have been seen as a sign of Solomon's power and international prestige. In the dtr context it takes on a negative meaning (cf. J. Robinson, The First Book of Kings [Cambridge Bible Commentary; Cambridge: CUP, 1972] 138).

${ }^{114}$ Campbell, Of Prophets and Kings, 87, n. 51.

${ }^{115}$ Note also how $1 \mathrm{Kgs} 11: 2 \mathrm{a}$ focuses on the people. The quotation of Deut $7: 3-4$ is a rather free one. The only other case where a command from

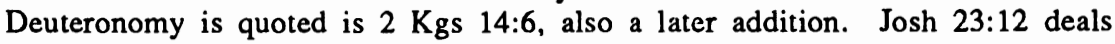
with this issue, without quoting Deuteronomy. 
probably added by a later Dtr who noted that vv 1-7 did not contain any statement about the cultic practices of Solomon's wives. ${ }^{116}$ The identification of this verse as an addition gains further support from a consideration of the way DTR organized the redactional comments in vv $1,2 b, 3 b, 4,6$ and the source material in vv $3 a, 7$.

DTR's account of Solomon as a faithful and successful king in the earlier chapters can be seen to be structured in the following manner. Solomon's love of Yahweh in $1 \mathrm{Kgs}$ 3:3 is followed by an account of his faithful conduct

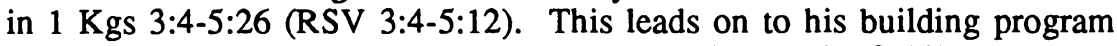
with its climax in the construction of the temple (1 Kgs 6:1-8:56*). In $1 \mathrm{Kgs}$ $11: 1,2 b-4,6-7$ we have the same sequence, but with a telling contrast in content. In place of the love of Yahweh Solomon is drawn to love foreign women (1 Kgs 11:1, 2b, 3). In place of the earlier account of his faithful conduct there is a report of his infidelity to Yahweh in vv 4, 6. ${ }^{117}$ In place of the temple built for Yahweh Solomon's unfaithful conduct leads to a building program on behalf of foreign gods in $\mathbf{v} 7$. The contrast is deliberate and striking and, as illustrated by the structure of $\mathrm{DtrH}$, identifies $1 \mathrm{Kgs} 11: 1,2 \mathrm{~b}$ 4, 6-7 as an important turning point in the history.

$1 \mathrm{Kgs}$ 11:9-13 is clearly a dtr composition and, as an accusation against Solomon, flows smoothly enough from $1 \mathrm{Kgs} 11: 1-7^{*}$. The difficulty is that the passage anticipates $1 \mathrm{Kgs} 11: 29-39$ and appears to be a conscious summarizing of the main points of this latter text. There are also two other features in the passage which advise against attributing it to DTR. First, v 9 shows none of the leniency of DTR's indictment of Solomon in 1 Kgs 11:3-4. It is more in tune with the later addition in $v 5$. Second, $1 \mathrm{Kgs} 11: 11$ has some elements in common with the later nomistic stage of redaction. ${ }^{18} 1$ $\mathrm{Kgs}$ 11:9-13 may have been composed when $1 \mathrm{Kgs}$ 11:14-25 was added to the narrative. ${ }^{119}$ A later redactor felt that the close connection between Solomon's infidelity and his condemnation in Ahijah's prophecy needed to be maintained after the increased textual "distance" created by these additions. Hence the insertion of $1 \mathrm{Kgs} 11: 9-13$. Whatever the case the presence of $1 \mathrm{Kgs} 11: 9-13$

116 For Campbell (Of Prophets and Kings, 87, n. 51) it was a post-dtr addition. In the light of other occurrences already discussed the phrase "after other gods" in $v 4$ may also be an addition.

${ }^{117}$ The formulation of $1 \mathrm{Kgs} 11: 6$ is that of a summary, and it intrudes to a certain extent between $v 4$ and $v 7$. It may originally have come after $v 7$, as in the LXX, and been relocated in the MT by a later editor. The order of the LXX does not affect the point made.

${ }^{118}$ Namely the accusation of breaking the covenant (cf. Josh 23:16) and of disobeying the statutes. There is also the occurrence of "other gods" in $v 10$. This phrase has been found to be a favored term of later dtr redaction.

${ }_{119}$ Jones, 1 and 2 Kings $I, 232,237$ regards this as a post-dtr addition. Cf. also Würthwein, 1. Könige 1-16, 130. Hadad and Rezon, together with Jeroboam, form a trio of rebels against Solomon. The pattern of three highlights the introduction of Jeroboam in $1 \mathrm{Kgs} \mathrm{11:26.}$ 
tends to rob the encounter between Jeroboam and Ahijah of some of its dramatic, one may even say prophetic, impact. ${ }^{120}$

\section{KGS 11:29-39}

$1 \mathrm{Kgs}$ 11:29-39 is a key text for Campbell's hypothesis of a Prophetic Record because it records Ahijah of Shiloh's designation of Jeroboam as king of northern Israel. His examination of the prophecy leads him to identify the text of the Record in $1 \mathrm{Kgs} 11: 29-31,37,38 \mathrm{~b}$. The remaining verses of the prophecy are distributed as follows: DTR's redaction (vv 33aba, 34*, 35*, $36,38 \mathrm{a}, 39$ ); secondary dtr redaction ( $\mathrm{v} 32$, "whole" in v 34 , "ten tribes" in $\mathrm{v}$ 35); later glosses (v 33bß and kî naśi 'ášstennû in v. 34b).121

Campbell's analysis of $1 \mathrm{Kgs} 11: 29-39$ is a convincing one for a number of rcasons. To begin with, the original core of the prophecy which he recovers is free of dtr language. ${ }^{122}$ This is evident in vv 29-31 where the circumstances of the meeting between Ahijah and Jeroboam (in private), and the motif of the torn garment, are characteristics of prophetic rather than dtr composition. ${ }^{123}$ It is evident in v 37 where the phrase "all that your soul desires" cannot be classed as dtr. It occurs with reference to royal rule elsewhere in DtrH only in

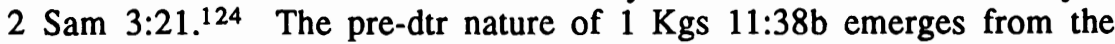
recognition that it bestows on Jeroboam the same promise made to David. This would be surprising in a dtr context, and one can in fact see that $v 38 \mathrm{a}$ has been prefaced to $v 38 \mathrm{~b}$ to supply the appropriate qualifying conditions.

${ }^{120}$ Dietrich (Prophetie und Geschichte, 68-69, n. 7) assigns the passage to DtrN. For Benzinger (Die Bücher der Könige, 78) and Hölscher ("Könige," 175 , n.1) vv 9-10 were later. Sanda (Die Bücher der Könige 1,323) assigned vv 10, 13 to a later redactor.

${ }_{121}$ Campbell, Of Prophets and Kings, 25-32.

${ }^{122}$ Against Dietrich (Prophetie und Geschichte, 15-20) who distributes the prophecy between DtrP ( $1 \mathrm{Kgs} 11: 29-31,33 \mathrm{a}, 34 \mathrm{a}, 35 \mathrm{aba}, 37 \mathrm{a} \beta \gamma \mathrm{b}$ ), DtrN (vv

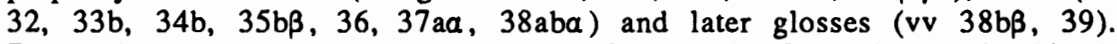
Dietrich's analysis is followed closely by Würthwein, I. Könige 1-16, 139-44. Interestingly S. L. McKenzie proposes in his recent study ("The Prophetic History," 205) that Dietrich's DtrP text actually derived from a pre-dtr prophetic historian. In his Könige commentary (pp. 245-46) Noth proposed that the prophecy was a unified dtr composition apart from some glosses, a contrast to his earlier position in The Deuteronomistic History, 62, 68 where he accepted a pre-dtr tradition in $1 \mathrm{Kgs} 11: 29 \mathrm{a} \beta \mathrm{b}-31,36 \mathrm{aba}, 37$.

${ }^{123}$ See also Nelson, The Double Redaction, 111. Nelson notes too that the detail about the new cloak and the nature of Ahijah's symbolic action would "be alien to the Deuteronomistic historian". Dietrich claims that the torn garment motif was appropriated by DtrP from 1 Sam 15:27-28 (Prophetie und Geschichte, 86-87). But the references to tearing of the kingdom all occur in Prophetic Record passages (1 Sam 15:28; 28:17; $1 \mathrm{Kgs} 11: 31 ; 14: 8$ ), and in $2 \mathrm{Kgs}$ 17:21 which Campbell assigns to the northern expansion.

${ }^{124}$ The phrase occurs in Deut 12:20; $14: 26$ and 1 Sam 2:16 with reference to one's appetite. 
Secondly, the text of Campbell's pre-dtr prophecy is more satisfactory than the alternatives that have been proposed. ${ }^{125}$ In an admittedly complex pericope it provides the most plausible and coherent oracle that can clearly be distinguished from dtr redaction. ${ }^{126}$ Nor does it require any emendation of the present text or recourse to a hypothesis of a lost oracle or portions of one.

Thirdly, he has shown that the proposed text makes good sense in relation to other prophecies dealing with the designation and rejection of kings. The pre-dtr prophecy is principally concerned to claim the emergence of Jeroboam, king of northem Israel, as the outcome of a prophetic intervention. ${ }^{127}$ This is

${ }^{125}$ In addition to Noth (n. 122 above) there are the following proposals: Jörg Debus, Die Sünde Jerobeams. Studien zur Darstellung Jerobeams und der Geschichte des Nordreichs in der deuteronomistischen Geschichtsschreibung (FRLANT 93; Göttingen: Vandenhoeck \& Ruprecht, 1967) 10-11 (vv 29-31); Gray, I \& II Kings, 280, 288 (vv 29-32a); Hentschel, 1 Könige, 79 (vv 29-31, 37); Jones, 1 and 2 Kings I, 241, 244 (vv 29-31); Lohfink, Rückblick im Zorn, 140 (vv 31, 36*, 37); Mayes, The Story of Israel, 118 (vv 29-31, 34a, 35bß, 37a); McKenzie, "The Prophetic History," (vv 29-31, 33a, 34a, 35aba, $37 \mathrm{a} \beta \gamma \mathrm{b}$ ); Nelson, The Double Redaction, 113 (vv 29-31, 34a); Ina Plein, "Erwägungen zur Öberlieferung von I Reg 11: 26-14:20," ZAW 78 (1966) 8-24 (vv 29-31, 34aba, 36aba, 37a, cf. pp. 18-20); Rehm, 1 Könige, 127 (with caution, vv 29-32a, 34a, 36a, 37); Schüpphaus, Richter- und Prophetengeschichten, 15 (vv 31b-32a, 37); H. Seebass, "Zur Teilung der Herrschaft Salomos nach 1 Reg 11:29-39," ZAW 88 (1976) 363-76 (vv 29aßb, 37, 38ba, cf. p. 373); Trebolle Barrera, Salomón y Jeroboán, 147 (vv 29-31a); Vanoni, Literarkritik und Grammatik, 261 (vv 31* [from "behold"], 34aba [or $36 \mathrm{aba}$ - omitting "in Jerusalem"], 37); H. Weippert, "Die Ätiologie des Nordreiches und seines Königshauses (1 Reg 11:29-40)," ZAW 95 (1983) 34475 (vv 29-31, 37, 38baß).

${ }^{126}$ The closest to Campbell's text is Weippert, and to a lesser extent Seebass. The weakness with proposals that include only $1 \mathrm{Kgs}$ 11:29-31 (cf. Jones, Trebolle Barrera) is that they overlook the evidence of pre-dtr language in vv 37, 38b. The inclusion of $v 32 \mathrm{a}$ is unlikely (cf. Gray, Rehm, Schüpphaus). The provision of one tribe "for him" refers to the subject of $v 36$ rather than Solomon (v 31). It has therefore been composed in the light of it. The whole of $v 32$ appears to be a later summary of the redacted oracle. The inclusion of portions of vv 34 and 36 is more difficult to decide (cf. Lohfink, Mayes, McKenzie, Nelson, Plein, Rehm, Vanoni). Certainly one cannot claim characteristic dtr language in vv 34a, 36a. But the concern with the delay until Rehoboam ( $v 34 a)$ and the provision of one tribe for him ( $v$ 36a) seem to reflect later modifications of an earlier oracle. Also, as Campbell notes (Of Prophets and Kings, 27, n. 13), the half verses in hebrew do not provide a satisfactory sequence and are stylistically repetitive. The same reasoning for vv $34 \mathrm{a}$ and $36 \mathrm{a}$ applies to $v 35 \mathrm{aba}$ (cf. McKenzie). The inclusion of $v 35 \mathrm{~b} \beta$ by Mayes creates an awkward sequence after $v 34 \mathrm{a}$. The majority concur in including $v 37$, but only Seebass and Weippert agree with Campbell in seeing the original oracle in v $38 \mathrm{~b}$.

${ }^{127}$ It is conceivable that the story of Jeroboam's encounter with Ahijah was inserted into an older context, supplied by $1 \mathrm{Kgs} 11: 26$ (27-28), 40 (so Debus, Die Sünde Jerobeams, 4-5). But it is difficult to tell whether this older text supplied only a basic report (vv 26-28, 40), or whether material was deleted by 
in keeping with the overall thrust of the prophetic redaction which sought to stake a claim for the importance of prophets in the unfolding of Israel's history. The almost exclusive focus on Jeroboam in the prophecy is also in keeping with the northern perspective of the prophetic redaction. It incorporated David and Solomon as part of the account of the period of the united kingdom. But once the schism in the kingdom had occurred, the prophetic redaction showed no further interest in the story of the Davidic dynasty and Judah.

Fourthly, and most importantly for the reassessment of the DtrH hypothesis, the pre-dtr prophecy recovered by Campbell enables one to gain a more precise understanding of the dit redaction. The distribution of verses between the Prophetic Record, DTR, and later redaction can be most easily seen in the following lay out of Ahijah's speech (1 Kgs 11:31-39). ${ }^{128}$

(31) AND HE SAID TO JEROBOAM, "TAKE FOR YOURSELF TEN PIECES: FOR THUS SAYS THE LORD, THE GOD OF ISRAEL, 'BEHOLD, I AM ABOUT TO TEAR THE KINGDOM FROM THE HAND OF SOLOMON, AND WILL GIVE YOU TEN TRIBES. (32) But he shall have one tribe, for the sake of my servant David and for the sake of Jerusalem, the city which I have chosen out of all the tribes of Israel. (33) Because they have forsaken me, and worshipped Ashtoreth the goddess of the Sidonians. Chemosh the god of Moab. and Milcom the god of the Ammonites, and have not walked in my ways, doing what is right in my sight, and (keeping) my statutes and my ordinances, as David his father did: (34) Nevertheless I will not take the whole kingdom out of his hand but I will make him ruler all the days of his life, for the sake of David my servant whom I chose, who kept my commandments and my statutes; (35) but I will take the kingdom out his son's hand, and will give it to you, ten tribes. (36) Yet to his son I will give one tribe, that David my servant may always have a lamp before me in Jerusalem, the city where I have chosen to put my name. (37) AND I WILL TAKE YOU, AND YOU SHALL REIGN OVER ALL THAT YOUR SOUL DESIRES, AND YOU SHALL BE KING OVER ISRAEL. (38) And if you will hearken to all that I command you, and will walk in my ways, and do what is right in my eyes by keeping my statutes and my commandments, as David my servant did, (AND) I WILL BE WITH

the prophetic redaction in favor of the prophecy. It is also conceivable the redaction's version of the prophecy was taken from an older version such as the prophecy of Shemaiah son of Enlami to Jeroboam in the LXX text 3 Reigns 12:240. The relationship between the LXX and MT texts is discussed by Trebolle Barrera (Salomón y Jeroboán, 143-48). Campbell has shown how the prophetic redactors made use of older prophetic texs in 1 Sam 9:1-10:16; 15:17 35; 2 Sam 7:1-17. It is also likely they constructed the speeches in $1 \mathrm{Kgs}$ $14: 6-13 ; 21: 17-24$ and $2 \mathrm{Kgs} 9: 6-10$ on the basis of older material.

${ }^{128}$ CAPITALS are used for the text of the Record, upper and lower case type for DTR's redaction, underlining for secondary dtr redaction, and italics for glosses. 
YOU, AND WILL BUILD YOU A SURE HOUSE, AS I BUILT FOR DAVID, AND I WILL GIVE ISRAEL TO YOU. (39) And I will for this afflict the descendants of David, but not for ever'."

DTR's reworking of the prophecy is to be found then in $1 \mathrm{Kgs} 11: 34 \mathrm{ab} \beta$, $35 \mathrm{aba}, 36,38 \mathrm{a} .{ }^{129}$ As already observed there is no evidence of dtr terminology in vv $34 \mathrm{a}, 36 \mathrm{a}$. The same can be said also of $v 35$. Nevertheless, it makes better sense to identify these verses as part of DTR's redaction than to locate them in the original prophecy. The verses seek to bring the delay of the rupture of the kingdom until Rehoboam, and his retention of Judah, within the compass of Ahijah's prophecy. This sense of adjustment makes it difficult to accept them as part of the original prophecy. It is possible they were later predtr modifications of the original prophecy, but against this there is Campbell's observation that $1 \mathrm{Kgs} 11: 34 \mathrm{a}, 35 \mathrm{a}, 36 \mathrm{a}$ create a sequence of truncated sentences in which vv $34 \mathrm{a}, 36 \mathrm{a}$ in particular appear stylistically awkward. ${ }^{130}$ This is eased if they are taken as introductions to DTR's comments in vv $34 \mathrm{~b}$, $36 \mathrm{~b}$.

The one tribe referred to in $v 36$ is to be identified as Judah, which is in keeping with DTR's statement about Davidic dominion in $v 36 \mathrm{ba} .{ }^{131}$ Weippert claims that at the pre-dtr level it referred to Benjamin. However the difficulty of establishing a literary relationship between her proposed pre-dtr updating of the original oracle in vv 35a, 36a and the larger narrative in Kings makes this problematic. ${ }^{132}$ On balance therefore it is better to accept $1 \mathrm{Kgs}$

${ }^{129}$ Later dtr redaction is to be found in $1 \mathrm{Kgs} 11: 32-33,39$, and also with the term "whole" in $v 34 \mathrm{a}$ and "ten tribes" in $v 35 \mathrm{~b} \beta$. There is evidence of nomistic additions in $v 34 b \gamma$ and in $v 38 a a$. Later glosses are $v 33 b \beta$ and the phrase $k \hat{I}$ naś ${ }^{2}$ 'āsitennû in $v 34$. Note that the plural is read in $v 33$, following the MT. While the verses identified as dtr are the same as Campbell's my distribution of them between DTR and later dtr redaction is somewhat different.

${ }^{130}$ Campbell, Of Prophets and Kings, 27, n. 13. Schüpphaus (Richter- und Prophetengeschichten, 17) assigns vv 34aba, 35, 36aba to a later pre-dtr redaction. Weippert ("Die Ätiologie," 355-60) identifies a two stage pre-dtr update, the first in vv $34 \mathrm{a}, 40 \mathrm{~b} \beta$, the second in vv $35 \mathrm{a}, 36 \mathrm{a}$.

${ }^{131} \mathrm{P}$. Hanson's proposal that the meaning of the term nir in $1 \mathrm{Kgs} 11: 36$; 15:4; $2 \mathrm{Kgs} \mathrm{8:19}$ is dominion and not lamp is to be preferred. See "The Song of Heshbon and David's Nîr," 304-16; and Görg's confirmation of this in "Ein 'Machtzeichen' Davids," 363-67.

${ }^{132}$ Weippert, "Die Ätiologie," 355, n. 23. See also Noth, The Deuteronomistic History, 130, n. 64. Weippert bases her argument on the reference to the tribe of Benjamin in $1 \mathrm{Kgs} 12: 21$ and the dispute over Benjaminite territory in $1 \mathrm{Kgs} 15: 16-22$. But there is a strong body of opinion that $1 \mathrm{Kgs}$ $12: 21-24$ is a late addition to the text. Moreover she does not really comment on the reference to the tribe of Judah in $v 20.1 \mathrm{Kgs} 15: 16-22$ does appear to deal with the territory of Benjamin (cf. "Geba of Benjamin" in v 22), but there is the question of the literary relationship of this text to $1 \mathrm{Kgs} 11: 36 \mathrm{a}$. For example, Campbell includes it in an independent Southern Document $(O f$ Prophets and Kings, 190-91). Because of its narrow textual basis Weippert is cautious about her proposal for a two stage updating of the original prophecy. For a critique of Noth's argument see Debus, Die Sünde Jerobeams, 14-16. 
$11: 34 \mathrm{ab} \beta, 35 \mathrm{aba}, 36$ as DTR's contribution. ${ }^{133}$ Some observations on the function of these verses within the context of the conceptual plan and structure of the history will help to confirm their identification.

To begin with it is evident that the additions shift the strong northern focus of the oracle in the Prophetic Record firmly in the direction of the Davidic dynasty and the Jerusalem temple. This is in line with the importance of these two elements for DTR's conceptual plan. One can also see that the additions were designed to explain the schism in the kingdom in terms which were acceptable both in relation to the deuteronomic schema of reward and retribution, and in relation to the foundational prophecy on the Davidic dynasty in 2 Samuel 7.

We have seen how DTR interpreted the promises of dynasty, secure throne, and temple in 2 Samuel 7. Within the prophecy itself they do not appear as favors or rewards for David's fidelity. But when read in the context of DTR's four-part pattern constructed around 2 Samuel 7, and within the larger context of the history, the promises take on this meaning. This is so especially in DTR's redaction of Ahijah's prophecy. The fact that the schism did not occur during Solomon's reign is explained as a divine favor for his faithful servant David (cf. $1 \mathrm{Kgs} 11: 34 \mathrm{ab} \beta$ ). ${ }^{134}$ The explanation is not completely satisfactory, but then the fact that Solomon escaped punishment was a difficult one for DTR to incorporate within the schema of reward and retribution. ${ }^{135}$ Nevertheless the explanation does accommodate Solomon in a general way within the schema, and it is given authority by its location in the prophecy.

The survival of the Davidic dynasty in the wake of the schism was able to be explained more easily by DTR in terms of the schema of reward and retribution. Rehoboam's limited dominion over "one tribe" (Judah) is accounted for in $1 \mathrm{Kgs}$ 11:36, like the delay of the schism, as a divine favor

${ }^{133}$ The shift from hammamlākâ in v 34 to hammélûkâ in v 35 is regarded by Weippert as a sign of the second update ("Die Ätiologie," 358). Vanoni (Literarkritik und Grammatik, 262) assigns it to the same late layer as v 32. The evidence seems too limited to warrant a literary critical division. I do not see that the understanding of the prophecy is enhanced by singling this verse out. Against Vanoni it is difficult to accept that $1 \mathrm{Kgs} 11: 32$ and 35 can be attributed to the same hand just because they are not in tension. $1 \mathrm{Kgs} 11: 32$ provides a later summary of the provision for the Davidic dynasty in vv 34-36, whereas $\mathbf{v} 35$ is part of the sequence of these verses.

${ }^{134} \mathrm{The}$ assignation of the reference to commandments and statutes in $1 \mathrm{Kgs}$ $11: 34 \mathrm{by}$ to a later hand does not affect this interpretation. David is described as "David my servant", whereas in the Prophetic Record text he is simply "David" (cf. $\vee 38 \mathrm{~b}$ ). The nomistic reference in $\mathrm{v} 34 \mathrm{by}$ is similar to the one in $1 \mathrm{Kgs}$ 9:4b. Besides, $v 34 \mathrm{by}$ is somewhat superfluous, since DTR spelt out the nature of David's fidelity clearly enough in $\mathbf{v} 38 \mathrm{a}$. While due caution needs to be exercised in assigning nomistic references to later redaction $1 \mathrm{Kgs} 9: 4 \mathrm{~b}$ and 11:34by do appear to have been appended to their respective verses.

${ }^{135}$ This may explain the later introduction of $1 \mathrm{Kgs} 11: 14-22$ and 23-25, both of which begin with a statement that "the Lord (God) raised up an adversary against Solomon". These two passages clearly convey the sense of divine retribution for Solomon's infidelity in $1 \mathrm{Kgs}$ 11:1-8. 
because of David "my servant". The prophecy that the Davidic dynasty and its dominion will last "all the days" looks to the larger history of the divided kingdom. The continuation of the dynasty and Judah after the collapse of the north is foreshadowed here as a further assurance that the reward of an everlasting dynasty promised to David (cf. 2 Sam 7:16) was still in place. The loss of the northern tribes was for its part used by DTR in v 35 to satisfy the requirement of retribution for Solomon's infidelity.

As with the explanation of the delay of the schism DTR's distribution of reward and retribution was justified on the authority of the prophetic word. We

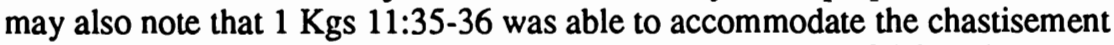

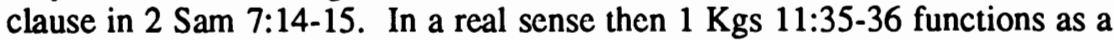
verification or fulfillment of the Samuel text. Within the more immediate context $1 \mathrm{Kgs}$ 11:35-36 also takes up the conditional promise made to Solomon in $1 \mathrm{Kgs} 2: 2,4 \mathrm{aab} ; 8: 25 ; 9: 5$. When they are taken in sequence these texts provide another example of DTR's technique of progressively incorporating an important event-in this case the loss of the "throne of Israel"-into an overall conceptual plan.

An additional important component of $1 \mathrm{Kgs} 11: 36$ is Yahweh's statement that Jerusalem is "the city where I have chosen to put my name". The formulation of the verse shows that this confirmation of the exclusive status of the temple is also covered by the preceding phrase "all the days". The dynasty's lasting rule in Jerusalem is therefore integrally bound up with Yahweh's definitive choice of the Jerusalem temple. ${ }^{136}$ Furthermore, within the context of DTR's concern over fidelity to the policy of centralized worship, this close association of the Davidic dynasty with the temple clearly implies that the dynasty was henceforrth to be the guardian of the temple's exclusive status as the only legitimate place of worship. Within the account of the divided kingdom, an important component of the judgment formulas is the Davidic kings' fidelity to the policy of centralized worship. In a skillful way therefore DTR was able to combine the exclusive status of the temple with the preservation of the Davidic dynasty (cf. $1 \mathrm{Kgs} 9: 1-5$ ), and set the agenda for the subsequent history of the dynasty.

We can now turn to DTR's comment in $1 \mathrm{Kgs} 11: 38 \mathrm{a}$ on the emergence of the northern kingdom. It is instructive to observe that the same criteria were applied to the northern kings as to David and the Davidic dynasty. The first king Jeroboam was offered the same opportunity as David to gain the promise of an enduring dynasty as a reward for fidelity to Yahweh. However, as the subsequent chapters of the history show, he failed to heed the prophetic word,

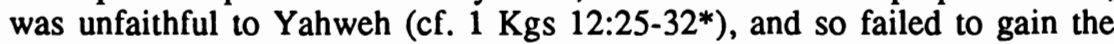

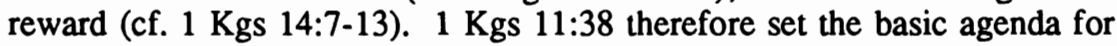
DTR's interpretation of the history of the northern kingdom in much the same way as $1 \mathrm{Kgs} 11: 36$ set the agenda for the Davidic dynasty. The prophecy of Ahijah is clearly a pivotal text for DTR's presentation of the period of Israel under the prophets and kings.

${ }^{136}$ The reference to the city in $1 \mathrm{Kgs} 11: 36$ rather than the temple was required by the fact that DTR was combining a comment on the dynasty, which ruled in Jerusalem, with a comment on the Jerusalem temple. 
With respect to later redaction of the prophecy the principal additions are to be found in $1 \mathrm{Kgs} 11: 32,33,39.1 \mathrm{Kgs} 11: 32$ is a later addition for a number of reasons. First, the phrases "one tribe" and "to him" presuppose the reference to Rehoboam in $v 36 .{ }^{137}$ Verse 32 does not sit easily therefore with the reference to Solomon in $v 31$. Second, the verse betrays some changes in formulation from DTR's own contributions. David is referred to as "my servant David" instead of "David my servant" in vv 34b, 36b, 38a. As well, the verse does not contain any reference to "all the days" of $v 36 \mathrm{~b}$. This indicates an exilic perspective. Third, the verse anticipates DTR's comments

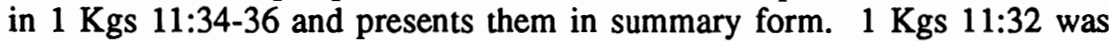
probably added therefore as a late summary of what had become a complex prophecy. ${ }^{138}$

Campbell assigns $1 \mathrm{Kgs} \mathrm{11:33} \mathrm{to} \mathrm{DTR,} \mathrm{but} \mathrm{there} \mathrm{are} \mathrm{a} \mathrm{number} \mathrm{of} \mathrm{factors}$ which argue against this. First, the plural verbs in the MT, which are to be preferred to the LXX singular reading, show that the verse intended to indict the people as well as the king. ${ }^{139}$ This shift in focus was observed earlier between $1 \mathrm{Kgs}$ 9:1-5 and 9:6-9, with the latter being identified as an addition to DtrH. Next, the verse contains the verb cazab (to forsake) which has been seen to be a mark of the later nomistic stage of redaction. Third, although the verse functions as an accusation for the prophetic announcement in the following verses its polemical tone is not really in harmony with the thrust of DTR's comment in vv 34-36. In sum then, $1 \mathrm{Kgs} 11: 33$ is most likely a later dtr addition, and would seem to have some association with the nomistic stage of later redaction. ${ }^{140}$ It supplied an accusation for the prophecy, but one which reflects a more hostile attitude to Solomon (and the people) than is evident in DTR. ${ }^{141}$

${ }^{137}$ Noted by Campbell, Of Prophets and Kings, 29, n. 17.

${ }^{138}$ Against Weippert ("Die Ätiologie," 362) who assigns it to R II (dtr). Vanoni (Literarkritik und Grammatik, 262) assigns it to his fourth and last layer of text, prior to some later glosses.

${ }^{139}$ The plural form is accepted by Barthélemy, Critique textuelle de l'Ancien Testament 1, 363; Benzinger, Die Bücher der Könige, 84; Campbell, Of Prophets and Kings, 28-29; DeVries, 1 Kings, 146; Noth, Könige, 243; Rehm, 1 Könige, 121; Vanoni, Literarkritik und Grammatik, 50; Weippert, "Die Ätiologie," 373. The singular reading is adopted by Bumey, Notes, 171; Debus, Die Sünde Jerobeams, 11; Gray, I \& II Kings, 291; Hentschel, I Könige, 79; Kittel, Die Bücher der Könige, 100; Sanda, Die Bücher der Könige 1, 319; Würthwein, 1. Könige 1-16, 139. Despite the lack of consensus the lectio difficilior (MT) is to be preferred.

${ }^{140} \mathrm{Cf}$. DeVries, 1 Kings, 149; Hentschel, 1 Könige, 79; Mayes, The Story of Israel, 118; Vanoni, Literarkritik und Grammatik, 261-62; Weippert, "Die Âtiologie," 373. Dietrich (Prophetie und Geschichte, 18-19) assigns v 33a to DtrP, v 33b to DtrN, as does Würthwein, 1. Könige 1-16, 139.

${ }^{141}$ See my earlier remarks on $1 \mathrm{Kgs} 11: 1-8$, and the evidence in support of 1 Kgs 11:5 being a later polemical addition to a text which seems to be somewhat lenient on Solomon. The reference to David in $v 33$ is probably a later gloss, and perhaps too the preceding nomistic reference (so Campbell, Of Prophets and Kings, 29; Noth, Könige, 260-61). 
$1 \mathrm{Kgs} \mathrm{11:39}$ is regarded by Cross and Nelson as a clear indication of a Josianic history. ${ }^{142}$ However there are a number of factors which advise against accepting their view. To begin with the morphology of waxanneh in $v$ 39 is unusual; one would expect a waw with the perfect following on from wenatati in $\mathrm{v} 38 \mathrm{~b} .{ }^{143}$ Furthermore the phrase lema ${ }^{\complement} a n z \delta^{2} t$ is vague. In conjunction with the introductory verb this does not give a very satisfactory link with the preceding verses. ${ }^{144}$ The rather vague phrase in $v 39$ a could refer back to $v 33$. If so, this would make it a later appendage, an assurance that the dynasty would not be punished forever for the sins of Solomon. Alternatively, it could refer to the dynasty's limited hegemony due to the schism. However the interpretation of this as an affliction is in some tension with $\mathbf{v} 36$, where the preservation of Judah was seen by DTR as a divine favor for the sake of David. A final point against attributing the verse to a Josianic Dtr is that there is no indication given in 2 Kings 22-23 of a restoration of the northern state to the dynasty. The evidence indicates therefore that this verse was appended after the completion of DtrH. ${ }^{145}$

The remaining areas of later redaction are not so critical and may be dealt with briefly. ${ }^{146}$ The phrase $k i$ naśj 'ásitennû in $1 \mathrm{Kgs} 11: 34$ is unusual in the context and seems to give Solomon a more subordinate function than that of a king. ${ }^{147}$ It is more in line with Ezekiel's description of the king in Ezek 34:24. In agreement with Campbell it is best taken as a gloss. ${ }^{148}$ Finally, the reference to the "whole" kingdom in $1 \mathrm{Kgs} 11: 34 \mathrm{a}$ and the "ten tribes" in v

${ }^{142}$ Cross, Canaanite Myth and Hebrew Epic, 279, 283; Nelson, The Double Redaction, 115.

${ }^{143}$ Burney (Notes, 171) regards it as indicative of a later hand. Noth (Könige, 244) suggests that the verb should be read as an imperfect, that is wa'sa ${ }^{2}$ anneh. In agreement with Nelson however (The Double Redaction, 115) this would introduce an unacceptable shift from future aspect to past aspect.

${ }^{144}$ Nelson's attempt to overcome the awkward syntactical link between $v 38 \mathrm{~b}$ and $v 39$ is not resolved by the rendering "I am going to give you Israel, that I might humble the seed of David" (ibid., 116). This completely overlooks lemaran zơt

${ }^{145} 1 \mathrm{Kgs} 11: 39$ is regarded as late by DeVries, 1 Kings, 149; Dietrich, Prophetie und Geschichte, 19, n. 14 (with v 38by); Hentschel, 1 Könige, 79 (with v 38by); Noth, Könige, 262 (with v 38by); Rehm, I Könige, 128; Vanoni, Literarkritik und Grammatik, 262 (with v 38by); Weippert, "Die Ätiologie," 374 (with v 38by); Würthwein, 1. Könige 1-16, 140 (with v 38by).

${ }^{146} \mathrm{The}$ nomistic appendage in $1 \mathrm{Kgs} 11: 34 \mathrm{by}$, and the additions to $v 33 \mathrm{~b}$ have already been considered. It is also likely the reference to keeping commandments and statutes in $\vee 38 \mathrm{a}$ reveals some nomistic retouching (so Mayes, The Story of Israel, 118, 172. n. 32).

${ }^{147} \mathrm{An}$ alternative reading has been proposed, nåsó 'eśśă' lô ("I will forbear with him")-cf. Gray, I \& II Kings, 291; Noth, Könige, 243, 261. This reading, based on the LXX, is possible but looks to be a later attempt to smooth out the verse.

${ }^{148} \mathrm{Cf}$. also Jones, 1 and 2 Kings I, 245; Würthwein, 1 . Könige 1-16, 140. 
$35 \mathrm{~b} \beta$ seem to be later clarifications, probably added in conjunction with $\mathbf{v}$ $32 .{ }^{149}$

\section{KGS 12:1-24}

Campbell proposes the following distribution of material in this account: $1 \mathrm{Kgs}$ 12:1, 3b-15a, 16-18, 20 to the Prophetic Record; 12:2-3a, 12 (the mention of Jeroboam), $15 \mathrm{ba}, 19$ to an originally independent Southern Document; $12: 15 \mathrm{~b} \beta$ to dtr redaction; $12: 17$ as a later precision; $12: 21-24$ to a post-exilic addition. ${ }^{150}$ The account of the assembly at Shechem and the schism probably circulated in two versions, one reflecting the northern interpretation of this critical event, the other the southern interpretation. What we have in the present text is substantially the northern version, which was incorporated into the Prophetic Record. The southern version differed from the northern one chiefly in the role it gave Jeroboam in the assembly, and its interpretation of the schism as a northern rebellion. When DTR combined the Prophetic Record and Southern Document these elements were worked into the account. Hence the insertion of vv 2-3a, the mention of Jeroboam in v 12, and the rather pejorative statement in $v 19.151$

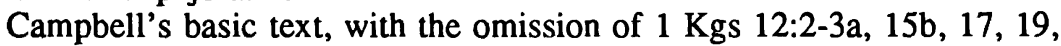
is close to the findings of a number of recent studies. ${ }^{152}$ The conflict between vv 2-3a and v 20 is evident. In the former Jeroboam is summoned by the northern party and takes part in the assembly. In the latter he is only summoned after the breakdown of negotiations with Rehoboam. However even though vv 2-3a give a different version of Jeroboam's whereabouts to $v 20$ it is questionable whether they can be identified as the residue of an independent account of the assembly and schism, as Campbell proposes.

${ }^{149} \mathrm{Cf}$. Campbell, Of Prophets and Kings, 27, n. 13. See also Gray, I \& II Kings, 297-98; Noth, Könige, 261; Würthwein, 1. Könige 1-16, 140.

${ }^{150}$ Campbell, Of Prophets and Kings, 89, 187-89.

${ }^{151}$ Campbell observes that $1 \mathrm{Kgs} 12: 15 \mathrm{ba}$ "might be considered the work of the prophetic redactors" (ibid., 89, n. 55). However he discerns little evidence that the redactors were concerned to note the fulfillment of their prophecies. He therefore favors the view that the verse records a brief allusion to Ahijah's prophecy from the Southern Document.

${ }^{152}$ Cf. for example E. Lipinski, "Le Récit de 1 Rois XII 1-19 à la Lumière de L'Ancien Usage de l'Hébreu et de Nouveaux Textes de Mari," VT 24 (1974) 430 37, cf. pp. 436-47 (vv 1, 3b-14, 16, 18-19); Noth, Könige, 269 (vv 1, 3b-14, 16, 18-20); Plein, "Erwägungen," 13 (vv 1, 3b-15a, 16, 18-19); Trebolle Barrera, Salomón y Jeroboán, 140 (vv 1*, 3b-14*, 16*, 18b*, 20*, 21*); Vanoni, Literarkritik und Grammatik, 51-53 (vv 1, 3b-15a, 16, 18-19). Somewhat different is the text proposed by Würthwein, 1. Könige 1-16, 150 (vv 1, 3b-19). Cf. also Debus, Die Sünde Jerobeams, 22 (vv 1, 3b-16, 18-19). Debus, Noth, Trebolle Barrera, Vanoni and Würthwein all omit Jeroboam from $v$ 12 in their proposed texts. A much more truncated text was proposed by Hannelis Schulte, Die Entstehung der Geschichtsschreibung im Alten Israel (BZAW 128; Berlin: de Gruyter, 1972) 217, n. 54 (vv 1, 3b, 4aba, 13a, 15a, $16,18,19)$. For a detailed critique of this see Trebolle Barrera, pp. 126-31. 


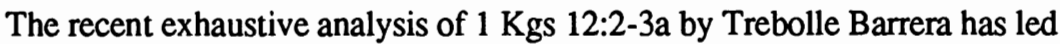
him to conclude that these verses are a later redactional composition made up

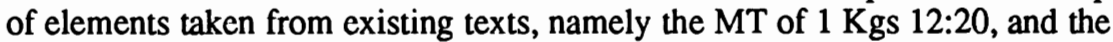
LXX versions in 3 Reigns 11:43 and 12:24d, f, p. ${ }^{153}$ Trebolle Barrera is particularly concerned to integrate text criticism with a literary critical and redactional analysis. His text critical examination leads him to accept the MT of wayyěseb ("and he dwelt") in v $2 b$, against the LXX rendering of wayyāsob ("and he returned") which to date has enjoyed favor as the majority position. ${ }^{154}$

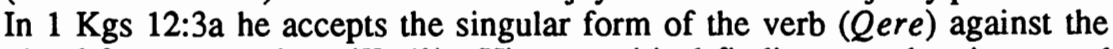
plural form wayyābo'î (Ketib). His text critical findings are then integrated

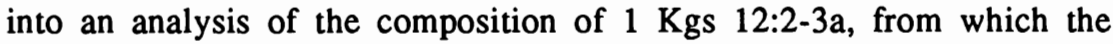
following results emerge.

According to Trebolle Barrera a significant feature of $1 \mathrm{Kgs} \mathrm{12:2-3a}$ is the presence of the phrases "and when Jeroboam the son of Nebat heard of it" in $v$ $2 \mathrm{a}$, and "and he returned" in $\mathrm{v} 3 \mathrm{a}$. Similar phrases are also found in 3 Reigns 11:43 and 12:24:d, $f$, where they refer to Jeroboam hearing of Solomon's death and then returning to Ephraim. Trebolle Barrera proposes that these two phrases were part of an original more extensive report. They show that the report was constructed as a protasis with apodosis. It was replaced by later redactional activity which retained the two phrases in question in order to construct the report now preserved in $1 \mathrm{Kgs} 12: 2-3 \mathrm{a}$. It needs to be remembered that for Trebolle Barrera this report bore the readings proposed in his text criticism.

The redaction followed the original structure of protasis and apodosis. In $\mathbf{v}$ 2a the first phrase formed the protasis of a long sentence, with its apodosis in $v 3 a$. The protasis is followed by a parenthesis in $v 2 b$ which was constructed on the basis of such texts as $1 \mathrm{Kgs} 11: 40$ and 3 Reigns 11:40, 43. The statement that Jeroboam lived in Egypt (MT wayyeseb) belongs to the parenthesis. The LXX reading wayyašob changed it to become part of the apodosis of $v 3 \mathrm{a}$. The second phrase was incorporated into a report in $v 3 \mathrm{a}$ about Jeroboam being summoned to the assembly. This part of the redaction

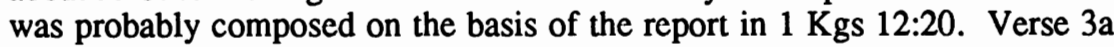
shows some complexity. A desire to integrate Jeroboam more firmly into the assembly may have prompted a later scribe to change the singular "and he came" to the plural. The phrase "and all the assembly of Israel" may have been added for the same reason. ${ }^{155}$

${ }^{153}$ Trebolle Barrera, "Jeroboán y la Asamblea de Siquén (1 Rey. TM 12, 2 3a; LXX 11, 43; 12, 24d.f.p.)," EstBib 38 (1979-1980) 189-220; also Salomón y Jeroboán, 47-83.

${ }^{154}$ See the review of the literature in "Jeroboan y la Asamblea," 190-200. The details of his own analysis cannot be gone into here. The MT reading wayyeseb in $\mathrm{v} 2 \mathrm{~b}$ is favored in Barthélemy, Critique textuelle de l'Ancien Testament 1, 363-64.

${ }^{155}$ Trebolle Barrera does not accept the theory of D. W. Gooding ("The Septuagint's Rival Versions of Jeroboam's Rise to Power," VT 17 [1967] 17389) that there were three independent versions of the assembly; the MT, LXXA (parallel version), and LXX-B (version in 3 Reigns 12:24a-z). Trebolle 
On the basis of this analysis it is difficult to see how $1 \mathrm{Kgs} 12: 2-3 \mathrm{a}$ can be attributed to an independent Southern Document. The concern of this insertion to have Jeroboam at the Shechem assembly suggests in turn that the mention of Jeroboam in v 12 is part of the same process. He is not mentioned in the LXX. However the recognition of $1 \mathrm{Kgs} 12: 2-3 \mathrm{a}$ as a redactional insertion does not of itself rule out the existence of a Southern Document. It may be that the Southern Document's version of the assembly can no longer be recovered. ${ }^{156}$ It may also be the case that its version is to be found in 3 Reigns 12:240-u. The suggestion can only be made here, but it is significant that Jeroboam is credited with calling the assembly in this account (cf. 3 Reigns 12:240). Despite claims that it is more midrash than history, Trebolle Barrera has argued that 3 Reigns 12:240-u is a reliable and early account of the schism, if not in fact the earliest. ${ }^{157}$

There is little evidence of dtr redaction in $1 \mathrm{Kgs} 12: 1-24$. However the fulfillment notice in $1 \mathrm{Kgs} 12: 15 \mathrm{~b} \beta$ may be assigned to DTR. It is formulated in a manner which is similar to other such notices of DTR (cf. $1 \mathrm{Kgs} \mathrm{14:18;}$ $15: 29 ; 16: 12 ; 2 \mathrm{Kgs} 9: 36 ; 10: 10 ; 17: 23) .1 \mathrm{Kgs} 12: 21-24$ on the other hand gives clear indication of being an independent and late addition. ${ }^{158} 1 \mathrm{Kgs}$ 12:21 refers to the house of Judah instead of the tribe of Judah ( $v 20$ ), and introduces the tribe of Benjamin. The verse also repeats the information about Rehoboam's return to Jerusalem in $v 18 \mathrm{~b}$. Furthermore, $1 \mathrm{Kgs} 12: 24 \mathrm{~b} \beta$ does not contain the characteristic DTR reference to the fulfillment of prophecy. The passage is also in conflict with the information in $1 \mathrm{Kgs} \mathrm{15:6} \mathrm{(cf.} \mathrm{14:30)}$ that there was continual war between Rehoboam and Jeroboam.

Barrera accepts only two versions: one preserved in the MT and LXX-A; the other in the LXX-B. The differences between the MT and LXX-A are not an indication of originally independent versions but of the process of redaction (Salomón y Jeroboán, 195-200). Trebolle Barrera's position indicates that LXX 3 Reigns 11:43 should be part of the Prophetic Record. This would not change the nature of the Record.

${ }^{156}$ Except perhaps for the other verses identified by Campbell, namely $1 \mathrm{Kgs}$ 12:15ba and 19 .

${ }^{157}$ Trebolle Barrera, Salomón y Jeroboán, 143, 185. Seebass ("Zur Königserhebung Jerobeams I," VT 17 [1967] 325-33) used this version in an attempt at historical reconstruction. On the negative side Debus (Die Sünde Jerobeams, 91) concluded that the version "represents a developed and corrupted type of text". See also Gooding, "The Septuagint's Rival Versions," 173-89, and R. P. Gordon, "The Second Septuagint Account of Jeroboam: History or Midrash?" VT 25 (1975) 368-93.

${ }^{158} \mathrm{Cf}$. Debus, Die Sünde Jerobeams, 34; Gray, I \& II Kings, 308-9; Hentschel, 1 Könige, 83; Jepsen, Die Quellen des Königsbuches, 102; Jones, 1 and 2 Kings I, 248; Noth, Könige, 279-80; Vanoni, Literarkritik und Grammatik, 53; Würthwein, 1. Könige 1-16, 160-61. 


\section{THE PERIOD OF ISRAEL UNDER THE PROPHETS AND KINGS [B] 1 Kgs 12:25-2 Kgs 20:21}

The analysis of $1 \mathrm{Kgs} 12: 25-2 \mathrm{Kgs} 20: 21$ will continue the reassessment of dtr redaction against the background of the Prophetic Record. It will also consider two further proposals which Campbell made in the light of the Prophetic Record hypothesis. These are, the existence of a northern expansion of the Record which chronicled the story of the northern kings from Jehu to the northern exile, and a later independent Southern Document which chronicled the story of the Davidic kings from the schism to Hezekiah. These hypotheses are based on a close analysis of the judgment formulas for the kings of Israel and Judah. ${ }^{1}$ Campbell's examination of the component elements of these judgment formulas and their distribution uncovers three distinctive types or patterns of formula. ${ }^{2}$ Two of these are identified as pre-dtr, while the third is dtr. ${ }^{3}$

The earliest pre-dtr pattern (A) occurs in the series of judgment formulas for northern kings from Jehu (2 Kgs 10:29) to Hoshea (2 Kgs 17:2). ${ }^{4}$ This

${ }^{1}$ A. F. Campbell, Of Prophets and Kings, 139-52. See especially the results of his analysis in the tables on pp. 144-51.

${ }^{2}$ Campbell (ibid., 144-45) identifies 9 component elements in the formulas: 1)- He (king) did what was evil/right in the sight of the Lord; 2)- which he made Israel to sin; 3)- comparison of king with a]- his father, b]- some other king, c]- comparison of degree (i.e., more than $X\}$; 4)- the sins of $X ; 5$ )- he walked in the way of X [or 5a]- he walked in the sins of X]; 6)- he did not depart from; 7)- which he sinned/and in his sin; 8)- to provoke to anger; 9)the high places were not taken away.

${ }^{3}$ Campbell's analysis of the judgment formulas is a development and revision of $\mathrm{H}$. Weippert's earlier study, "Die 'deuteronomistischen' Beurteilungen," 30139. A problem with Weippert's study was the difficulty of correlating the patterns identified with a workable hypothesis of the redaction of the text of Kings. The first redaction in particular begins at an odd place, with the formulas for Joram (north) and Jehoshaphat (south). Campbell proposes that the hypotheses of a Prophetic Record, northern expansion, and Southern Document enable one to interpret the patterns noticed by Weippert more accurately, and to provide a satisfactory explanation of their variation in terms of the redaction history of the text. Campbell's revision is more compelling than A. Lemaire's ("Vers L'histoire de la Rédaction des Livres des Rois," 22136), and provides a convincing response to Enzo Cortese's criticisms of Weippert ("Lo schema deuteronomistico per i re di Giuda e d'Israele," Bib 56 [1975] 37-52, cf. pp. 43-48).

${ }^{4} 2 \mathrm{Kgs} \mathrm{10:29}$ (Jehu); 13:2 (Jehoahaz); 13:11 (Jehoash); 14:24 (Jeroboam); 15:9 (Zechariah); 15:18 (Menahem); 15:24 (Pekahiah); 15:28 (Pekah); 17:2 (Hoshea). 
pattern is characterized by its simplicity and inner consistency. ${ }^{5}$ It also contains two elements which are practically exclusive to it. ${ }^{6}$ The distinctive nature of this pattern points to the work of a particular author. When one notes that the first judgment formula in the series, the one for Jehu, comes immediately after the conclusion of the Prophetic Record (cf. $2 \mathrm{Kgs} \mathrm{10:28),} \mathrm{it}$ is difficult to avoid the impression that the author's intention was to extend the Record's unfavorable portrayal of northern kings from Jeroboam to Joram by a negative assessment of their successors from Jehu to Hoshea. Campbell judges that it is most likely such a series of judgment formulas was associated with the composition of an account of the northern kings which took up from where the Prophetic Record concluded. He recovers the thread of this narrative account from the present text by claiming for it those passages which harmonize best with the horizon of the series of judgment formulas. ${ }^{7}$ The recovered text begins with $2 \mathrm{Kgs} \mathrm{10:29}$ and ends with a report of the exile (2 Kgs 17:1-6) and a final comment (cf. $2 \mathrm{Kgs} \mathrm{17:20,21,23b).}$

In $2 \mathrm{Kgs} 17: 21$ there is no explicit reference to Ahijah's prophecy in the Prophetic Record that Yahweh would make Jeroboam king. The verse notes only the component of the prophecy which deals with the tearing away of the

${ }^{5}$ There are some variations in the pattern (for a list see Campbell, of Prophets and Kings, 145) The most significant ones are that element 1 is lacking for Jehu, and elements 2, 4, 6 for Hoshea. The absence of element 1 for Jehu is explained by the nature of the preceding verse $(2 \mathrm{Kgs} 10: 28)$ and indeed the whole account of Jehu. This Yahwist zealot could hardly be summed up as having done evil throughout his reign. The reference to the golden calves in 2 Kgs 10:29 is omitted by Campbell as a later gloss (p. 158, n. 29). With Hoshea (2 Kgs 17:2) the missing elements are replaced by the statement "yet not as the kings of Israel who were before him". The change was probably to "prevent the calamity which occurred early in his reign from being attributed to his sin alone-it is the consequence of cumulative evildoing" (p. 153). The variations therefore are appropriate for the position of the two formulas at the beginning and end of the series.

${ }^{6}$ Pattern A contains elements $1,2,4,6$. Elements 1 and 2 are shared with the other patterns (ibid., 145). The first element is found in all three patterns. The second is shared with the pattern (C) which Campbell identifies as a series of dtr judgment formulas for the northern kings from Jeroboam to Joram, i.e., for those kings within the Prophetic Record. Element 4 in pattern A refers to the "sins of Jeroboam the son of Nebat". While this reference is found also in pattern $\mathrm{C}$, it is only for members of the dynasty of Ahab (Omri). With pattern A however, only the judgment formula for Hoshea in $2 \mathrm{Kgs}$ 17:2 does not contain this reference. It can be taken then as a characteristic feature of the pattern. Element 6 is "he did not depart from". This occurs elsewhere once in

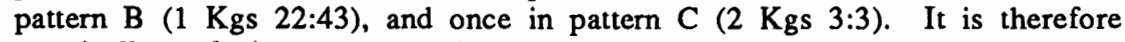
practically exclusive to pattern A.

${ }^{7}$ Because it was a continuation of the northern Prophetic Record the text did not include any information on the southern kingdom or the relationship between it and the northern kingdom. Hence Campbell omits the synchronistic system and follows a simple linear sequence, in line with that for the Record. In support of a linear sequence he notes the one for kings of Edom in Gen 36:31-39. The full text of the expansion is given on pp. 158-61. 
ten tribes. It also emphasizes that the people made Jeroboam king. Both of these elements indicate a different author to the Record. The formulation of 2 $\mathrm{Kgs} 17: 21$, 23b clearly links king and people much more closely than is evident in the Record. This is in line with the thrust of the judgment formulas and points to a common author for the formulas and the final comment.

The northern expansion provides a fitting sequel to the Record, identifying the continuing presence of the sins of Jeroboam as the cancer which infected the northern kingdom and eventually led to its downfall. ${ }^{8}$ The conclusion of the expansion shows it must have been composed after the fall of the northern kingdom. For Campbell the lack of any southern perspective indicates northern authorship. But it is difficult to tell whether it was added to the Record in the north or after refugees had fled south.

Campbell's second proposal is that some time later another document emerged to cover the period of the Davidic dynasty from the establishment of Judah under Rehoboam to the reform of Hezekiah. It was composed in the light of the combined Prophetic Record and northern expansion, and provided a southern parallel to the northern text-hence a Southern Document. ${ }^{9} \mathrm{He}$ believes that it most likely emerged during the reigns of Manasseh and Amon. The document gives some evidence of being a veiled polemic against their dismantling of the reforming policies of Hezekiah.

As with the northern expansion the hypothesis of a Southern Document is based on an examination of judgment formulas, in this case the formulas for Davidic kings from the reign of Rehoboam to that of Hezekiah. An analysis of these judgment formulas reveals a second distinctive pattern which he calls pattern B. ${ }^{10}$ The evidence for this pattern is clearest for the series of formulas from Jehoshaphat to Hezekiah, where two types of judgment formula make up the larger pattern. Each type possesses two principal elements. ${ }^{11}$

One type is characterized by the following two elements: "he (king) did what was right in the eyes of the Lord" (clement 1); "the high places were not taken away, and the people still sacrificed and burned incense on the high places" (element 9). This type of formula occurs for Jehoshaphat (1 Kgs 22:43), Jehoash (2 Kgs 12:3-4), Amaziah (14:3-4), Azariah (15:3-4), Jotham

${ }^{8}$ Campbell (ibid., 173-75) finds that it is likely the northem expansion shared the Prophetic Record's concern about Jeroboam's indiscriminate

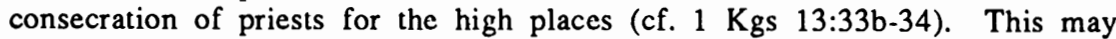
have been seen as a threat to the principal shrines in the north, Bethel and Dan

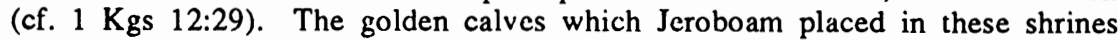
do not appear to have been regarded as a sin by the Prophetic Record, or the subsequent northem expansion. The reference to them in $2 \mathrm{Kgs} 10: 29$ is a later gloss.

${ }^{9}$ Campbell, ibid., 169-202.

${ }^{10}$ Cf. 1 Kgs 14:22a, 23a (Judah [Rehoboam]); 15:3a (Abijam); 15:11-12a, 14a (Asa); 22:43a, 44 (Jehoshaphat); $2 \mathrm{Kgs} \mathrm{8:18} \mathrm{(Jehoram);} \mathrm{8:27} \mathrm{(Ahaziah);}$ 12:3-4 (RSV 12:2-3_Jehoash); 14:3-4 (Amaziah); 15:3-4 (Azariah); 15:3435a (Jotham); 16:2b-3a (Ahaz); 18:3-5 (Hezekiah). In 1 Kgs 14:22a Campbell follows the MT reading (Judah) against the LXX (Rehoboam).

${ }^{11}$ Campbell, Of Prophets and Kings, 146-47 (for evidence in tabular form), 169-71 (for assessment of evidence). 
(15:34-35a), Hezekiah (18:3-5). The complaint about the high places is exclusive to pattern B. It hardly needs to be said that Hezekiah's elimination of high places required the change in formulation in $2 \mathrm{Kgs} \mathrm{18:4.}$

With Jehoshaphat the judgment that he did what was right in the sight of the Lord (1 Kgs 22:43b) is appended rather awkwardly to the statement "he walked in the way of Asa his father; he did not turn aside from it" ( $v$ 43a). One would expect the negative statement-he did not turn aside from it-to be followed by an infinitive clause describing the evil to which he turned. Furthermore this is the only example of element 1 which is formulated as an infinitive clause. It would appear therefore that it was appended by a later editor who wished to bring the judgment formula for Jehoshaphat more into line with the other formulas which approve of Davidic kings. There is

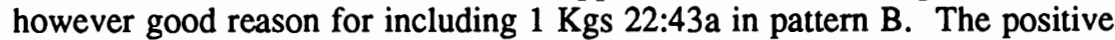
use of the metaphor of walking (hâlak) in this verse was designed to contrast Jehoshaphat with the two subsequent kings Jehoram ( $2 \mathrm{Kgs} 8: 18$ ) and Ahaziah (8:27), who are accused respectively of walking in the way of the kings of Israel and in the way of the house of Ahab. The texts which deal with these two kings belong to the other type of judgment formula. Hence the particular

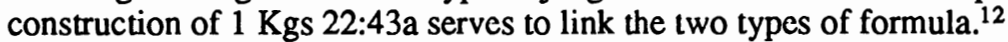

The other type of formula occurs for Jehoram (2 Kgs 8:18), Ahaziah (8:27) and Ahaz (16:2b-3a), and is characterized by the following two elements. There is the accusation (element 1) that Jehoram and Ahaziah "did evil in the sight of the Lord". For Ahaz the accusation is that he "did not do what was right in the eyes of the Lord his God". This gencral accusation is accompanied by the specification that each one walked in the way of the kings of Israel (element 5). ${ }^{13}$ The nature of the specific accusation therefore necessitated the different type of judgment formula. The accusation of walking in the way of the kings of Israel is exclusive to pattern B. On the question of authorship the fact that this type of formula is located within a larger sequence of the other type of formula makes it logical to attribute both types to the same author. This is supported by the already observed link between the formulas for Jehoshaphat and Jehoram.

The clearest evidence for a distinctive pattern $\mathrm{B}$ is found then in the judgment formulas from Jehoshaphat to Hezekiah. However Campbell sees some additional evidence which favors the extension of the pattern to include the formulas for Judah (Rehoboam), Abijam, and Asa. ${ }^{14}$ To begin with there is the repeated complaint about the high places. This complaint is present in a shortened form, without reference to the people's practices, in the judgment formula for Asa (1 Kgs 15:14a). Furthermore in $1 \mathrm{Kgs} \mathrm{14:23a}$ the Judeans are

${ }^{12}$ There is no reason to omit the phrase "he did not turn aside from it" from the formula. The infinitive clause which follows it and the awkward link this clause makes with $v 43 \mathrm{a}$ indicates the phrase was already in place.

${ }^{13}$ There is a slight variation in the formulation of this element between Jehoram and his son Ahaziah. Jehoram "walked in the way of the kings of Israel, as the house of Ahab had done". Ahaziah "walked in the way of the house of Ahab".

${ }^{14}$ Campbell, Of Prophets and Kings, 170-71. 
accused of building high places in the time of Rehoboam. ${ }^{15}$ This is significant and suggests that the repeated complaint about the high places, an element which is exclusive to pattern $B$, is dependent on this initiative by the Judeans. A complaint that these high places were not removed is registered against Asa in $1 \mathrm{Kgs} \mathrm{15:14a.} \mathrm{From} \mathrm{Jehoshaphat} \mathrm{on,} \mathrm{this} \mathrm{complaint} \mathrm{is} \mathrm{accom-}$ panied by a further one about the people's (Judeans) practices there. According to Campbell the complaint could not have occurred for Rehoboam and his son Abijam, because it was under Rehoboam that the high places were constructed. Abijam for his part is accused of walking in his father's sins. It is a consistent feature of pattern B that the complaint over the continued presence of the high places occurs only for those kings who were otherwise judged favorably. ${ }^{16}$

The second piece of evidence is not so significant, but nevertheless worthy of mention. This is the reference to Asa, father of Jehoshaphat, in the judgment formula in $1 \mathrm{Kgs} 22: 43 \mathrm{a}$. It suggests that the sequence of formulas extends further back than Jehoshaphat. A point in favor of such an extension is the way each of the Davidic kings who are judged favorably in the sequence from Jehoshaphat to Hezekiah, is compared with his predecessor or with David. The one exception is the orphaned Jehoash of whom it is stated that he was instructed by the priest Jehoiada. This indicates that Asa, who is compared with David, should also be included. He could not be compared with Abijam, who received a negative judgment.

Campbell also draws attention to the way pattern B differs from pattern A and a third pattern of judgment formulas (pattern $C$ ). This third pattern comprises the series of formulas for northern kings from Jeroboam (cf. $1 \mathrm{Kgs}$ 14:15-16) to Joram (2 Kgs 3:2-3) and is identified with the dtr redaction. ${ }^{17}$ Pattern B has characteristic elements which are not present in either pattern A or $\mathrm{C} .{ }^{18}$ What is striking about the differences between pattern $\mathrm{B}$ and $\mathrm{C}$ is the

\footnotetext{
${ }^{15}$ Following the MT reading (Judah) in $1 \mathrm{Kgs} 14: 22$, not the LXX (Rehoboam).

${ }^{16}$ These observations find support in the independent work of W. B. Barrick, "On the Removal of the 'High-Places' in 1-2 Kings," 257-59. He notes a development in the complaint against the high places. It begins in $1 \mathrm{Kgs}$ 15:14a (Asa) with a short form introduced by the waw copular. $1 \mathrm{Kgs} 22: 44 \mathrm{~b}$ (Jehoshaphat) has the long form introduced by sak. The long form is repeated for Jehoash to Jotham, but with the more forceful raq. Finally Ahaz himself is accused in $2 \mathrm{Kgs} 16: 4 \mathrm{a}$ of worshipping on the high places. Thus there is a definite sequence of texts on the high places. It moves from an initial short report to the fuller more forceful complaints, and thence to a climax with Ahaz's personal involvment. Finally the high places are removed by Hezekiah. Campbell omits $2 \mathrm{Kgs}$ 16:4a from pattern B. Barrick shows however that it fits nicely into the sequence.

${ }^{17}$ Campbell, Of Prophets and Kings, 148-49. The texts for pattern C are: Israel [Jeroboam] (1 Kgs 14:15-16); Nadab (15:26); Baasha (15:34); Elah (16:13); Zimri (16:19); Omri (16:25-26); Ahab (16:30-33); Ahaziah (22:5354 [RSV 22:52-53]); Joram (2 Kgs 3:2-3).

${ }^{18}$ To recall the differences between pattern $A$ and $B$ : elements $2,4,6$ are characteristic of pattern $A$. The one occurrence of element 6 in $1 \mathrm{Kgs} \mathrm{22:43a}$
} 
simplicity of $B$ in relation to $C$. As well as this pattern $C$ contains a number of elements which are not found in B. ${ }^{19}$

These considerations indicate that pattern $B$ is not to be attributed to the author of pattern A or of pattern C. Campbell argues that, as with pattern A, it is reasonable to suppose pattern $B$ was associated with the generation of a text whose horizon corresponded to that of the judgment formulas. The text which he recovers is a more expansive one than its northern counterpart. ${ }^{20}$ This is in line with the more expansive nature of the judgment formulas in pattern B. The Southern Document, as it is called, was most likely constructed according to a linear system like the northern expansion. Hence the synchronistic system was part of the later combination of the parallel northern and southern documents.

On balance the case for a Southern Document is not as compelling as that for the northern expansion. ${ }^{21}$ The strongest evidence for pattern $B$ lies in the sequence from Jehoshaphat to Hezekiah, but it is difficult to find a suitable beginning for a text which might have been constructed on the basis of this sequence. This is eased by extending pattern B's judgment formulas back to include Judah (Rehoboam), Abijam and Asa. Nevertheless these formulas do not show the same consistency as the other ones in pattern B. This is particularly so for Abijam where only the statement that "he walked in all the sins which his father did before him" (1 Kgs 15:3a) is included in the Southern Document. Despite these uncertainties Campbell considers that the hypothesis of a pre-dtr Southern Document reaching from 1 Kings 12 to 2 Kings 19 makes good sense overall and provides a plausible context for the concerns expressed in the judgment formulas. 22

The hypotheses of a Prophetic Record, northern expansion and Southern Document provide a comprehensive explanation of the growth of the books of

(pattern B) is used positively and not negatively, as in A. Elements 5 and 9 are characteristic of pattern B, being totally absent from $A$.

${ }^{19}$ These are, elements 3 (comparison of degree), 4 (the sins of $\mathrm{X}$ ), 7 (the absence of the emphatic usage "which he sinned/ in his sin"), 8 (the notice of provocation to anger). Campbell also notes that while pattern $B$ uses "the way of" as its preferred mode of expression, pattern C uses "the way of" and "the sins of" with equal freedom (cf. ibid., 172-73)

${ }^{20}$ The text is given on pp. 187-97. It began with a version of the schism in the kingdom (1 Kgs 12:1-20) at the time of Rehoboam, and ended with an account of the deliverance of Jerusalem via an oracle of the prophet Isaiah in 2 Kgs 19:20, 32, 34-35.

${ }^{21}$ Campbell observes "The evidence is such as to make it presumptuous to lay claim to any certainty" (ibid., 169).

${ }^{22}$ Campbell (ibid., 186) sees additional support for commencing the Southern Document with the schism in two other texts. The first concerns the statements in $1 \mathrm{Kgs} 12: 27,28 \mathrm{~b}$. These are not dtr, but would fit in well with a critical southern view of Jeroboam's cultic initiatives. Secondly, 1 Kgs 14:21 states "Rehoboam the son of Solomon reigned in Judah". All other reports of accession state that a king reigned over Israel/Judah, or was king of Israel/Judah. This unique statement could have been the Southern Document's conclusion to the assembly at Shechem. 
Samuel-Kings prior to the dtr redaction. ${ }^{23}$ The implications of this for our understanding of the dtr redaction cannot I believe be ignored. My analysis of

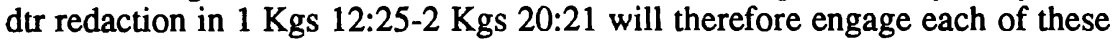
hypotheses. As pre-dtr sources they should facilitate a more precise delineation of the contours of dtr redaction. A satisfactory account of this dtr redaction will in its turn provide some confirmation of Campbell's hypotheses. The danger of circular argument needs to be kept in mind here, because these hypotheses are being employed as an aid in the analysis of dtr redaction. Nevertheless, if such an exercise leads to an understanding of DTR's conceptual plan and structure which is in accord with what has so far been gained, then it is reasonable to conclude that this provides confirmation of Campbell's hypotheses. The understanding of how a text was constructed does not always emerge as the inevitable conclusion of one line of argument, but often from a careful weighing of a number of factors. One of these is the contribution of previous scholarship.

The analysis will first of all consider the effect of Campbell's hypothesis on the authorship of the so-called regnal framework which surrounds the account of each king's reign. According to $M$. Noth this framework was the work of DTR. ${ }^{24}$ Following this the dtr interpretation of the northern kings will be examined, and then the southern or Davidic kings. This will enable the chapter to conclude with an analysis of the importance of Hezekiah for DTR. The focus of the reassessment will be the dtr contribution to the judgment formulas and the schema of prophecy and fulfillment.

\section{THE REGNAL FRAMEWORK}

The regnal framework in the books of Kings is made up of 9 elements. In order of occurrence these are: 1)- synchronism (for the period of the divided monarchy); 2)- age of king at accession (Davidic kings only); 3)- length of reign; 4)-capital city; 5)- name of queen mother (Davidic kings only); 6)judgment formula; 7)- reference notice or source citation; 8)- death and burial

${ }^{23}$ Campbell's identification of pattern $\mathrm{A}$ and $\mathrm{B}$ as pre-dtr is rejected by I. W. Provan (Hezekiah, 44-46, 53-54), who believes the variations in the formulas are better explained as the slight variations in language and style made by a single dtr author, as proposed by $\mathrm{R}$. D. Nelson (The Double Redaction, 31-36) and E. Cortese ("Lo schema deuteronomistico," 43-52). Nelson and Cortese criticised the findings of Weippert. The point is not the variations themselves-these are recognized by all-but their explanation. While Campbell's explanations are hypotheses, as is DtrH itself, they do throw light on the text. The striking distribution of the variations in the formulas finds an illuminating explanation in the hypotheses. As well as the variations already discussed there is the complete absence of any attention to the dynasty of Jehu in pattern $A$. In contrast patterns $B$ and $C$ are careful to monitor the dynastic relationship. If the variations were the work of one author, one would expect either a random distribution of the elements which is not the case, or a much greater consistency throughout, which is also not the case. Unfortunately Provan does not take up the evidence assembled by Campbell in his own analysis of the formulas.

${ }^{24} \mathrm{M}$. Noth, The Deuteronomistic History, 63. 
information; 9)- notice of succession. ${ }^{25}$ According to Campbell's hypotheses the following elements were in place prior to DtrH: 6 (for patterns A and B), 8, 9. This leaves as candidates for dtr authorship elements $1,2,3,4,5,6$ (for pattern $C$ and additions to the other patterns), 7.

The existence of two originally independent linear sequences-Prophetic Record plus northern expansion, and Southern Document-which were later combined via the synchronistic system (element 1 ) is suggested by the presence of a number of needless repetitions of information. These occur in 1 Kgs 16:28-29; 2 Kgs 8:24-25; 13:9-10; 15:22-23; 15:38-16:1. ${ }^{26}$ The most reasonable explanation for this phenomenon is that these texts show where the now dominant synchronistic system found it difficult to incorporate smoothly the older independent linear systems. For the sake of consistency the formulaic pattern of the synchronistic system was maintained, but at the expense of some repetition in the text. ${ }^{27}$ Once the synchronisms cease after the fall of the north, this repetition no longer occurs.

Given that the synchronistic system was constructed to combine the originally independent pre-dtr texts identified by Campbell, it is clear DTR was the one responsible. It is difficult to see how the text of the history could stand without the synchronisms. ${ }^{28}$ In addition to this the chronological component of the synchronisms is best seen as a continuation of the chronology constructed by DTR for the period of Israel from the Exodus to the building of the temple (cf. $1 \mathrm{Kgs} \mathrm{6:1)}{ }^{29}$ Elements 2 (age at accession for

${ }^{25}$ For a similar outline see Nelson, The Double Redaction, 31-32.

${ }^{26} \mathrm{Cf}$. Campbell, Of Prophets and Kings, 139.

${ }^{27}$ This argues against A. Jepsen's hypothesis of a synchronistic chronicle which was incorporated by later redaction (Die Quellen des Königsbuches, 30 36). Jepsen's hypothesis is also weakened by a number of gaps which are unacceptable in such a chronicle. Thus there is no report of the death of Joram of Israel and no report of Jehu becoming king, only his conspiracy $(2 \mathrm{Kgs}$ 9:14). The problems are resolved by Campbell's proposal that the Prophetic Record and Southern Document were combined by DTR.

${ }^{28}$ This is a difficulty with Shoshana R. Bin-Nun's proposal that the synchronisms were added later than the other elements of the regnal framework ("Formulas from Royal Records of Israel and of Judah," VT 18 [1968] 414-32, cf. pp. 419, 424-25). Her complaint (p. 424) about the illogical nature of the combination of synchronism with length of reign is resolved if one accepts these elements were added to an existing document.

${ }^{29} \mathrm{This}$ is so notwithstanding the difficulties encountered in the reconstruction of the chronologies of the kings, due to a combination of factors. There is conflicting chronological information within the MT, as for example the two texts on Jchoram in $2 \mathrm{Kgs} 1: 17$ and $3: 1$, and the two on Ahaziah in 2 Kgs 8:25 and 9:29. The MT and LXX have different chronologies, and in addition there is variation between the LXX recensions. The resolution of these conflicting chronologies is difficult but at least all testify to the existence of an original chronology which can be taken as constructed by DTR. The differences are not critical for our understanding of DTR's conceptual plan and structure. For a discussion of the chronological problem see G. H. Jones, 1 and 2 Kings I, 9-28. See also the recent article by Alberto R. Green ("Regnal Formulas in the 
Davidic kings) and 3 (length of reign) are also to be attributed to DTR, since they form part of the chronology of the kings. It is reasonable to expect that the information contained in these elements was available to DTR from sources such as kings lists compiled in the north and south..$^{30}$ Element 5 (the name of the queen mother) is a feature which is exclusive to the Davidic kings and which always occurs after the mention of Jerusalem. A list of the queen mothers may therefore have been part of the judean king list, but not of the northern one. Given the conjunction of this formula with elements 1,2 , and 3 , it is reasonable to conclude that it was added also by DTR. ${ }^{31}$

Element 6 is the judgment formula, which will be examined in detail in the analysis of the northern and southern kings. Element 7 is the reference notice or source citation which was assigned by Noth to DTR. ${ }^{32}$ According to Noth the chronicles of the kings of Israel and Judah cited in these notices were not official annals, but rather unofficial documents adapted from them. DTR referred to the chronicles for two reasons. First of all they gave the reader the source of information for a king's reign. Second, they provided a reference for the reader who wanted to find further information. As Noth saw it DTR took only a selection from the chronicles, chiefly chronological and political information which was useful for composing the history. For the Davidic

Hebrew and Greek Texts of the Books of Kings," JNES 42 [1983] 167-80) who argues in favor of the MT chronology.

${ }^{30}$ Bin-Nun ("Formulas," 423) claims that the different style of the entries for northern and southem kings shows the author was citing directly from two king lists. Cf. also Van Seters, In Search of History, 298. Cortese ("Lo schema deuteronomistico," 40) argues that the differences are due, not to separate sources, but to DTR's inclusion of the Davidic king's age at accession. This information is lacking for northern kings. The entry required the length of reign for Davidic kings to be placed before the verb in order to separate this information from bémolk $\delta$, the notice of accession (see also the criticism by Nelson, The Double Redaction, 30). Cortese's explanation does not completely rule out Bin-Nun's, since it is possible the southern king list contained the king's accession age whereas the northern one did not. On balance however Cortese's explanation does appear more likely. David, Solomon, Jeroboam and Jehu have their regnal years recorded in a different formulation at the end of their reigns (cf. $1 \mathrm{Kgs} 2: 11 ; 11: 42 ; 14: 20 ; 2 \mathrm{Kgs} 10: 36$ ). The text on David repeats information given in 2 Sam 5:10. This may have been due to the extensive account of his reign. Because the accessions of Solomon, Jeroboam and Jehu occur within the context of a dramatic narrative DTR may have felt reluctant to intrude with the standard element of the framework. Hence the different location. The summary nature of these statements also suggests they were formulated by DTR (against Bin-Nun, p. 422).

${ }^{31}$ It is missing only for Jehoram (2 Kgs 8:17) and Ahaz (2 Kgs 16:2). Stefan Timm (Die Dynastie Omri: Quellen und Untersuchungen zur Geschichte Israels im 9. Jahrhundert vor Christus [FRLANT 124; Göttingen: Vandenhoeck \& Ruprecht, 1982] 20) suggests that DTR may have omitted mention of the queen mother for northern kings to highlight their failure to secure a lasting dynasty.

${ }^{32}$ Noth, The Deuteronomistic History, 63-67. 
kings there was additional information in the chronicle about the temple. The prophetic stories of course did not derive from the chronicles.

Campbell's hypothesis of extensive pre-dtr documents for northern and southern kings would claim most of this material which Noth thought came from the chronicles. ${ }^{33}$ At first glance this may appear problematic. But when one examines the sort of material attributed by Noth to the chronicles it is difficult to imagine that it could have been adapted from official annals. Most of the political events reported for the northern kingdom concern conspiracies which have a distinctly anti-monarchical flavor. This anti-monarchical thrust is not so strong for the southern kingdom. Nevertheless a critical stance is discernible in the stories of the kings' campaigns (cf. 2 Kgs 14:8-14) and in the reporting of coups and conspiracies (cf. 2 Kgs 11:1-20; 12:20-21; 14:5, 19). It is difficult for example to accept that Athaliah's coup in 2 Kings 11 and the counter coup by Jehoiada the priest were part of an official annals. ${ }^{34}$

Likewise it is difficult to believe that the repeated plundering of the temple treasury was recorded in official annals or a temple chronicle (cf. $1 \mathrm{Kgs} \mathrm{14:25-}$ 28; 15:18; 2 Kgs 12:18-19 [RSV 12:17-18]; 14:14; 16:8). One may respond that this material would be acceptable in the sort of unofficial chronicles proposed by Noth. The problem with this is that once one moves away from the notion of official records the identity and provenance of such unofficial chronicles becomes very speculative and uncertain. In contrast to this uncertainty Campbell's hypothesis offers a very plausible provenance for this material.

On the basis of these observations it would seem the most likely reason for the references notices was that they supplied a source for the reader who

${ }^{33}$ In the northern expansion Campbell omits, in addition to the framework and passages which are obviously commentary, $2 \mathrm{Kgs}$ 13:4-5 (petition and response), 13:14-25 (Elisha material); 14:25 (prophetic material); 15:16 (Menahem's brutality).

In the Southern Document he omits $1 \mathrm{Kgs}$ 14:27-28 (replacement of temple shields-possible dtr addition); 15:15 (gifts for temple); 22:48-50 (RSV 22:47-49) (political and economic information-outside the framework); $2 \mathrm{Kgs}$ 12:5-17 (RSV 12:4-16) (temple repairs); 14:22 (a text which seems out of place); 15:35b (temple construction); 16:10-18 (cultic innovations by Ahaz); 18:14-19:9a (longer version of Assyrian invasion of Judah).

${ }^{34}$ The question of the relationship of such material to the chronicles has also been explored by G. Garbini, "Le Fonti Citate nel 'Libro dei $\mathrm{Re}^{\text {' a proposito }}$ degli 'Atti di Salomone', degli 'Annali dei re di Giuda' e degli 'Annali dei re d'Israele'," Henoch 3 (1981) 26-46. For Garbini it is very unlikely the stories of coups, wars, and reports about the temple were part of the archives of the royal court. Once one removes the prophetic narratives as well, very little remains to be derived from the chronicles. He concludes that they were fictitious, invented by DTR to give a sense of unity to the treatment of kings. One can see in this a development of Jepsen's proposal-and earlier that of Wellhausen and Hölscher-that DTR was really using one annals of the kings, even though the impression is given there were two (cf. Die Quellen des Königsbuches, 55). 
sought further information on the deeds of a particular king. ${ }^{35}$ The repeated statement "the rest of the acts of $\mathrm{X}$ and all that he did" does not of itself indicate that the writer had been taking material from the source. In fact the phrase "and all that he did" would seem to suggest otherwise. Nor is there sufficient evidence from the additional remarks in some reference notices to demonstrate that the author was using the particular chronicle to construct the account of a king's reign. ${ }^{36}$

Given this understanding of the reference notices there is no compelling reason against attributing them to DTR. ${ }^{37}$ The two other elements of the

${ }^{35}$ This is close to Noth's second reason. However there are two differences. First, DTR was not referring the reader to a source from which material had already been selected. Second, there is no reason to maintain Noth's hypothesis of unofficial chronicles. DTR was presumably referring to official documents. There is also no need to regard the chronicles referred to as fictitious (against Garbini ("Le Fonti," 43-44). Garbini is led to this by arguing against the position which claimed DTR selected material from chronicles of the kings. Once he had concluded the material in Kings could not come from such a source the source itself had to be fictitious. The explanation outlined here avoids this rather odd picture of DTR constantly citing sources which did not exist.

${ }^{36}$ With the northern kings we have an added reference to "his might" for Baasha (1 Kgs 16:5), Omri (1 Kgs 16:27), Jehu (2 Kgs 10:34), Jehoahaz (13:8), Jehoash (2 Kgs 13:12 [cf.14:15]), Jeroboam II (2 Kgs 14:28). Only the one for Jehoash is specific, as it refers to his might against Amaziah. This campaign is reported in $2 \mathrm{Kgs} 14: 8-14$. The others are too general to identify clearly with any event(s) described in the text. In fact the one for Jehoahaz is in straight contradiction to $2 \mathrm{Kgs} \mathrm{13:7.} \mathrm{With} \mathrm{Jeroboam} \mathrm{there} \mathrm{is} \mathrm{a} \mathrm{reference} \mathrm{to} \mathrm{"how} \mathrm{he}$ warred and reigned" (1 Kgs 14:19). It is difficult to correlate this general statement with anything in the text, except the equally general statements in 1 Kgs 14:30 and 15:7b, each of which comes after a reference notice. The

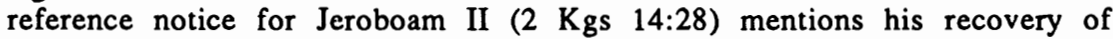
territory. Part of this correlates with the report in $v 25$. There are two examples of correlation between a remark in the reference notice and an event described in the text, namely the conspiracies of Zimri (1 Kgs 16:20) and Shallum (2 Kgs 15:15). With the Davidic kings we find references to "his might" for Asa (1 Kgs 15:23), Jehoshaphat (1 Kgs 22:46 [RSV 22:45]), and Hezekiah ( $2 \mathrm{Kgs} 20: 20$ ). Once again it is difficult to correlate these with any events described in the history, except the general statement of war between Asa and Baasha (1 Kgs 15:16). The reference notice for Jehoshaphat also refers to "how he warred". This could refer to the campaigns in 1 Kings 22 and 2 Kings 3. However, on my analysis of DtrH these chapters are later additions. The reference notice for Hezekiah mentions two features which do not appear in the text, his construction of a pool and tunnel. Only with Asa do we find a direct correlation, in the reference to the cities he built (cf. $1 \mathrm{Kgs} \mathrm{15:22).} \mathrm{In} \mathrm{short}$ there is little to suggest that the chronicles were used to construct the history. I suspect that a number of these remarks were in fact later additions. A fairly clear case is the reference to Manasseh's sin in $2 \mathrm{Kgs} 21: 17$. It is unlikely that this came from an official chronicle.

${ }^{37}$ The notices are missing for Jehoram and Hoshea of Israel, and Ahaziah, Jehoahaz, Jehoiachin, and Zedekiah of Judah. The omission for Hoshea, Jehoahaz, Jehoiachin, and Zedekiah was probably due to the fact they were taken 
framework, 8 (death and burial notice) and 9 (succession notice), have however been claimed by Campbell as part of the linear sequence in his pre-dtr texts. This is supported by the fact that Ahaz is the last Davidic king who is described as "buried with his fathers in the city of David". ${ }^{38}$ According to Campbell the Southern Document ended with the reign of Hezekiah, but did

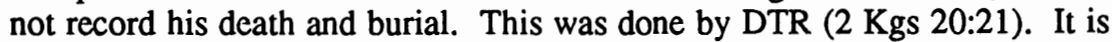
significant therefore that the formulation of his burial notice omits the above phrase. ${ }^{39}$

The component elements of the regnal framework can therefore be distributed between Campbell's pre-dtr documents and DTR without conflict. To restate the distribution briefly: elements 8 and 9 belong to the linear sequence of the pre-dtr documents, while $1,2,3,4$, and 5 form DTR's synchronistic system. Element 7, the reference notice, is a special feature but is best assigned to DTR. The element which still requires examination is the judgment formula, and to this we can now turn. As mentioned earlier, the northern kings will be examined first, followed by the Davidic kings from Rehoboam to Hezekiah.

\section{THE NORTHERN KINGS FROM JEROBOAM TO HOSHEA}

Campbell's analysis was primarily concerned with the nature and function of the pre-dtr judgment formulas. Hence he did not pursue the question of how the dtr formulas function in relationship to DTR's conceptual plan and structure. It will be the business of this section of the reassessment to take up that question. A number of features will emerge in the course of the analysis. First, there is the integration of DTR's judgment formulas with the schema of prophecy and fulfillment. Second, there is DTR's focus on the dynasties of Jeroboam, Baasha and Ahab (Omri), a focus which is marked by distinctive elements in the judgment formulas and in the prophetic speeches for each dynasty. Third, there is the absence of any clear evidence of DTR's hand after the reign of Jehu until the final comment on the northern kingdom in $2 \mathrm{Kgs}$ 17:22-23a (vv 20-21, 23b being the northern expansion's comment). This may seem surprising but it is in keeping with DTR's focus on the dynasties of Jeroboam, Baasha and Ahab, and the concern to incorporate each one within the schema of prophecy and fulfillment. Fourth, there is the evidence of later dtr redaction, which sought to expand aspects of DTR's own work. The analysis will show that while the bulk of pattern C is from DTR, there are some entries which are to be assigned to later redaction.

into exile. The omissions for Jehoram and Ahaziah are unexplained. There is a slight difference in formulation for Jeroboam, Zechariah, Shallum, Pekahiah, and Pekah of Israel (hinnăm instead of the customary hälón-hem).

${ }^{38}$ Noted by Bin-Nun ("Formulas," 430-31) and Provan (Hezekiah, 134-38, 141-43). In disagreement with Provan however the burial formulas up to Ahaz were not the work of the first Dtr.

${ }^{39}$ Manasseh was buried in a garden tomb ( $2 \mathrm{Kgs} 21: 18$ ), as was his son Amon (2 Kgs 21:26). Josiah was buried in his own tomb $(2 \mathrm{Kgs} \mathrm{23:30).} \mathrm{There}$ is no report of where Jehoiakim was buried (cf. $2 \mathrm{Kgs} \mathrm{24:6).}$ 


\section{THE HOUSE OF JEROBOAM (JEROBOAM AND NADAB)}

The story of the northern kingdom opens with the account of Jeroboam's cultic innovations in $1 \mathrm{Kgs}$ 12:25-13:34. Campbell distributes this section of

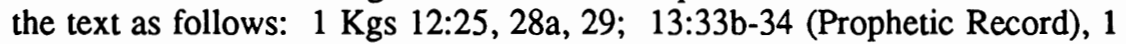
Kgs 12:26-27, 28-29, 30b-32 (Southern Document), $1 \mathrm{Kgs} 12: 30 \mathrm{a}, 33$; 13:133a (dtr redaction). ${ }^{40}$ The Record simply reported the erection of the golden calves in Bethel and Dan, but identified as Jeroboam's sin his indiscriminate

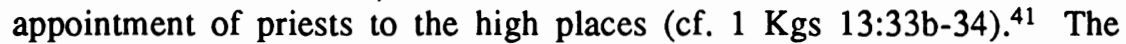
Southern Document took a more polemical line, identifying the cult of the golden calves as apostasy. ${ }^{42}$ It also accused Jeroboam of building high places, of appointing priests who were not Levites, and of arranging a rival festival. The dtr redaction added the story of the man of God in 1 Kings 13 as a further condemnation of Jeroboam, but also to foreshadow Josiah's destruction of

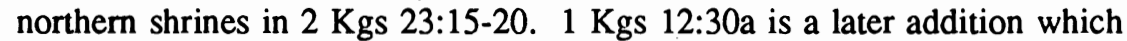
sought to emphasize the effect of Jeroboam's action on the people.

The distribution of texts between the Prophetic Record and The Southern Document does shed light on what is a complex section of 1 Kings. There is nothing evidently dtr about the account of Jeroboam's cultic innovations in 1 Kgs $12: 25,28 a, 29 ; 13: 33 b-34$. The material attributed to the Southern Document in vv $26-27,28 \mathrm{~b}-29,30 \mathrm{~b}-32$ is not so clear. The accusation in these verses of apostasy in the northern kingdom and worship at the high places is a concern of the dir redaction. Nevertheless there is no sure evidence of dtr language..$^{43}$ Furthermore the charge of apostasy is implied in the

${ }^{40}$ Campbell, Of Prophets and Kings, 89-90, 189. Note that wayyasob in 1

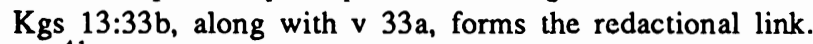

${ }^{41}$ Campbell (ibid., 173-75) observes that the sin of Jeroboam is a complex issue in the present text. It includes the golden calves and the two sanctuaries of Bethel and Dan, the establishment of high places, the appointment of priests

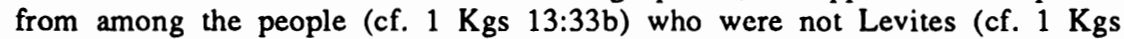
12:31), and the rival festival. Given that the Prophetic Record focuses on the indiscriminate appointment of priests to the high places as his sin $(1 \mathrm{Kgs}$ $13: 33 b-34)$ it is quite possible that the prophetic redactors did not have any problem with the calves. These could have been part of the cult of Yahweh at these shrines. After all Jeroboam's innovation has some similarity to David's with the ark. Nor is it likely the festival was a problem for them. However it suited the purpose of the Southern Document to condemn these aspects of the northern cult, a condemnation which later worked to DTR's advantage.

${ }^{42}$ Note the plural verb he élûka in $1 \mathrm{Kgs} 12: 28$.

43 Against H. D. Hoffmann (Reform und Reformen, 64-69) who sees dtr language in $1 \mathrm{Kgs} 12: 25-31$. He is however incorrect to take vv $26-27$ simply as an expression of the dtr demand for centralization. The main thrust of these verses is the issue of allegiance to the king, not centralization of worship. The account goes on to describe the cultic abuses initiated by Jeroboam to secure the allegiance of the people. The reference to the Exodus in $v 28 \mathrm{~b}$ is formulaic rather than characteristically dtr (cf. Exod 17:3; 32:4, 6, 7, 8, 23; 33:1; Num $20: 5 ; 21: 5$; Deut $20: 1$; Josh $24: 17 ; 2$ Sam 7:6). With $\vee 31$, even though the "sons of Levi" occurs in Deut 21:5; $31: 9$, this hardly seems sufficient to assure dtr authorship. The fact that $v 32$ records an exact date for the feast does not 
northern expansion's judgment formulas for Jehoram (2 Kgs 8:18) and Ahaziah $(8: 27){ }^{44}$ The hostility to worship at the high places is registered elsewhere in the Southern Document, in the repeated complaints of the judgment formulas for Davidic kings.

The lack of dtr language in a text which nevertheless shares concerns of the dtr redaction finds a plausible explanation in the hypothesis of a Southern Document. The likely date of this document in the time of Manasseh or Amon would bring it within the general orbit of the emerging deuteronomic movement. One can see it as foreshadowing the more ambitious project of DTR. Thus when DTR combined the Prophetic Record and Southern Document there was no need to rework the account of Jeroboam's cultic abuses. The Southern Document's version of them was well suited for DTR's purposes. $1 \mathrm{Kgs}$ 12:30a, 33-13:33a was, in my judgment, inserted by later dtr redaction. ${ }^{45}$ Because the fulfillment of the man of God's prophecy in 1 Kings 13 is given in $2 \mathrm{Kgs} \mathrm{23:16-17}$ the justification for this position can be postponed until the analysis of Josiah's reform in the north ( $2 \mathrm{Kgs}$ 23:15-20).

The texts which provide DTR's interpretation of the Jeroboam dynasty are

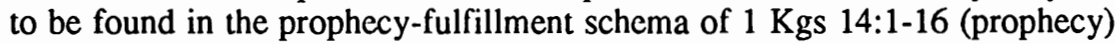
and 14:18; 15:29-30 (fulfillment), and the judgment formula on Nadab in 1 Kgs 15:26. The important function of Ahijah's prophecy (1 Kgs 11:29-38*) in establishing the criteria for DTR's interpretation of the northern monarchy has already been described. One would expect to find them applied in Ahijah's second prophecy to Jeroboam in $1 \mathrm{Kgs} \mathrm{14:1-16.} \mathrm{The} \mathrm{text} \mathrm{of} \mathrm{the} \mathrm{Prophetic}$ Record for this prophecy is $1 \mathrm{Kgs} 14: 1-8 \mathrm{a}, 9 \mathrm{~b} \beta-13 .{ }^{46}$ This leaves vv $8 \mathrm{~b}-9 \mathrm{ba}$, 14-16 to be investigated for dtr redaction.

A close reading of $1 \mathrm{Kgs} 14: 8 \mathrm{~b}-9 \mathrm{ba}$ indicates that it contains a nicely balanced construction which has been disturbed to some extent by overfilling. The balance is created by the way each of the elements of Jeroboam's

necessarily align it with post-exilic legislation (cf. Lev 23:34). Given the link between royal allegiance and worship in vv 26-27 it is quite reasonable to expect that the king would have had a say in the arrangement of the liturgical calendar. Noth (Könige, 272) saw no dtr language in this section.

${ }^{44}$ The claim that these kings walked in the way of the house of Ahab seems to be a reference to Baal worship, introduced in the time of Ahab (cf. $1 \mathrm{Kgs}$ 16:32-Prophetic Record).

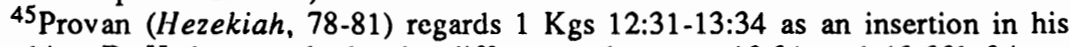
Hezekian DtrH, but overlooks the differences between 12:31 and 13:33b-34, as does Hoffmann, Reform und Reformen, 67-68.

${ }^{46}$ Campbell, Of Prophets and Kings, 103. There is no need to go into an analysis of the version recorded in 3 Reigns $12: 24 \mathrm{~g}-\mathrm{n}$. More recent opinion would tend to see this prophecy as an ancient variant of the consultation of Ahijah by Jeroboam's wife. Sec J. C. Trebolle Barrera, Salomón y Jeroboán, 152-59; H. N. Wallace, "The Oracles Against the Israelite Dynasties in 1 and 2 Kings," Bib 67 (1986) 21-40, cf. p.27. The LXX version contains no dtr redaction. It does contain the Prophetic Record's condemnation of the dynasty, but the way it disturbs the context indicates a later insertion, based on the MT version (cf. Salomón y Jeroboán, 154). It is unlikely then that the LXX version was ever part of the Record. 
unfavorable comparison with David in $v 8 \mathrm{~b}$ is matched in the following series of accusations against Jeroboam in $v 9 \mathrm{aba}$. This can be seen if the matching parts of the construction are highlighted and the overfilling placed within brackets.

“(8b) AND YET YOU HAVE NOT BEEN LIKE MY SERVANT DAVID, (who kept my commandments and) who walked after me with all his heart, doing only that which was right in my eyes, (9aba) but you have done evil ABOVE ALL THAT WERE BEFORE YOU and have walked to make for yourself (other gods and) molten images, provoking me to anger".47

An examination of the text within the context of DtrH, coupled with a careful consideration of its formulation, will establish that the balanced construction is the work of DTR. The material in the brackets is to be identified as later dtr redaction.

On the level of context $1 \mathrm{Kgs} 14: 8 \mathrm{~b}$ can readily be seen to recall the

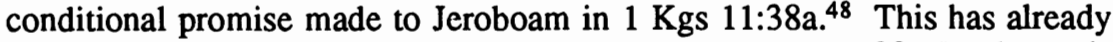
been established as part of DTR's redaction. In $1 \mathrm{Kgs} \mathrm{11:38a} \mathrm{Jeroboam} \mathrm{is}$ promised a sure house like David's, provided he proves as faithful as David. The verdict in $1 \mathrm{Kgs} 14: 8 \mathrm{~b}$ is that he has failed the test. Hence the promised reward is revoked (1 Kgs 14:10-13). One can see from this how the older prophecy of the Prophetic Record was integrated into DTR's larger schemas of prophecy and fulfillment, reward and retribution. The fulfillment notices come in $1 \mathrm{Kgs} 14: 18 \mathrm{~b}$ and $15: 29 \mathrm{~b} .{ }^{49}$

On the level of the formulation of the text the metaphorical statement in $\mathbf{v}$ $8 \mathrm{~b}$ that David walked (hălak) after Yahweh with all his heart is balanced by the accusation in $\mathrm{v} 9 \mathrm{ba}$ that Jeroboam walked (watēlek) to make molten images for himself. The molten images refer to the golden calves of $1 \mathrm{Kgs} 12: 28 .{ }^{50}$

${ }^{47}$ The translation given here is more literal than the RSV in order to draw out the balanced nature of the construction more clearly.

${ }^{48}$ The terminology of $\mathrm{v} 8 \mathrm{~b}$ supports this. It also recalls terminology from other passages by DTR. Thus: "my servant David" (cf. 1 Kgs 3:6; 8:24, 26; $11: 34,36,38$ ); "followed (lit. walked after) me with all his heart" (cf. $1 \mathrm{Kgs}$ $3: 6 ; 8: 25 ; 9: 4 ; 11: 38$ [walk only], cf. also $1 \mathrm{Kgs} 3: 6 ; 9: 4 ; 11: 4$ [heart]); "doing only that which was right in my eyes" (cf. $1 \mathrm{Kgs} \mathrm{11:38).}$

${ }^{49} \mathrm{~A}$ survey of fulfillment notices in Joshua-2 Kings leads Campbell to favor attributing them to dtr redaction (Of Prophets and Kings, 92, n. 61). He notes they do not occur in 1-2 Samuel. One finds them in the Elijah-Elisha stories, but the prophets are not described as 'ebed or nābl'. It is likely then that the prophetic redactors saw the fulfillment of their prophecies as self evident. There was no need to spell it out (p. 89, n. 55).

${ }^{50}$ The term massékot (molten images) occurs in the plural elsewhere only in 2 Chr 34:3. It is found in the singular in Exod 32:4, 8; 34:17; Deut 9:12, 16; 27:15; Judg 17:3, 4; 18:17, 18; $2 \mathrm{Kgs} 17: 16$; Hos 13:2. The rarity of the plural occurrence does not argue against attributing the term to DTR. It belongs in the context as a reference to the two golden calves of $1 \mathrm{Kgs} 12: 28$. All the other occurrences in Deuteronomy and the historical books are in the singular and are most likely later additions to DtrH. This has been seen for Deut 27:15; Judg 17:3, 4; 18:17, 18. $2 \mathrm{Kgs} 17: 16$ will be seen in due course to be part of 
Next, the statement that David did what was right (la ăsót raq hayyašăr) in the eyes of Yahweh is balanced by the accusation in $v 9 \mathrm{a}$ that Jeroboam did evil (watăra' lacásót). ${ }^{51}$ Third, the unfavorable comparison of Jeroboam with David in $\mathrm{v} 8 \mathrm{~b}$ is paralleled by the statement in $\mathrm{v} 9 \mathrm{a}$ that Jeroboam did more evil than all his predecessors.52 The accusation in $v 9 \mathrm{ba}$ that Jeroboam provoked Yahweh to anger follows on from the preceding series of accusations by emphasizing their severity, but also forges a link with the announcement in vv 10-13. These verses are an expression of the divine wrath which has been provoked. ${ }^{53}$ On both the level of context and formulation therefore there is a strong case for assigning the balanced construction in vv 8b-9ba to DTR.

On the basis of these considerations it can be seen that the reference to keeping commandments in $1 \mathrm{Kgs} \mathrm{14:8b}$ disturbs the balanced nature of the construction. Within the larger context the phrase parallels the evidence for later nomistic retouching of passages observed in $1 \mathrm{Kgs} 11: 4,34,38$. It is most likely then an addition from this stage of later dtr redaction. The

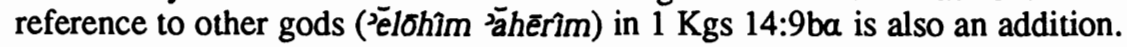
This is the only place where a person is described as making other gods. In all other occurrences the reference is to following, serving or worshipping other

a later dtr reflection on the fall of the north. Deut 9:12, 16 are regarded as later dtr additions by Mayes (Deuteronomy, 195). Furthermore the verb cása (to make) does not occur in any other text with "other gods". This points to "other gods" as an insertion in $v 9 \mathrm{ba}$ (for further comment see below). There is however no reason to regard the verb "to make" as an addition and it is required for the "molten images".

${ }^{51}$ These phrases are not exclusive to DTR, as the patterns in the northern expansion and Southern Document show. The justification for authorship by DTR comes in this case from a consideration of these phrases in the context.

${ }^{52}$ In this comparison the king who springs to mind is Solomon. Jeroboam's

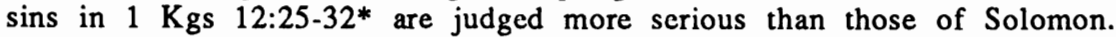
According to DTR's statement in 1 Kgs 11:4 Solomon's heart "was not wholly true to the Lord his God, as was the heart of David his father".

${ }^{53}$ The phrase "to provoke Yahweh to anger" (kascas in the hiphil) occurs in Deut $4: 25 ; 9: 18 ; 31: 29 ; 32: 16,21$; Judg 2:12; 1 Kgs 14:9, 15; 15:30; $16: 2,7,13,26,33 ; 21: 22 ; 22: 54$ (RSV 22:53); 2 Kgs 17:11, 17; 21:6, 15; $22: 17$; 23:19, 26. It is recognized as dtr (cf. M. Weinfeld, Deuteronomy and the Deuteronomic School, 340). The following occur in passages which have been assigned to a later Dtr: Deut 4:25; 31:29; Judg 2:12. Deut 32:16, 21 are part of Moses' song which is a later insertion in Deuteronomy, although its composition may well be pre-dtr. Hence one must be cautious about taking all occurrences as later than DTR. It is significant for example that the phrase occurs in each of the prophecies against the northern dynasties in a way that associates it closely with the announcement of each dynasty's end. Each occurrence needs to be examined in relation to its function in the context. The function of these phrases in $\mathrm{DtrH}$, and other statements on divine wrath, has been examined by D. J. McCarthy, but on the assumption that all are from DTR ("The Wrath of Yahweh and the Structural Unity of the Deuteronomistic History," Essays in Old Testament Ethics [ed. J. L. Crenshaw and J. T. Willis; New York: Ktav, 1974] 97-110). 
gods. Also this phrase has been observed so far principally in later dtr texts. ${ }^{54}$ Once this phrase is identified as a later addition the coherent nature of the underlying text can be seen. It is more than likely that the phrase was added

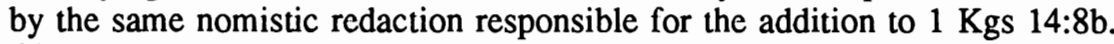
Given this, it follows that this redaction was also responsible for the addition of the waw in v $8 \mathrm{~b}$ (cf. wààser) and in $9 \mathrm{ba}$ (cf. ûmassék6t). ${ }^{55}$

$1 \mathrm{Kgs} 14: 14-16$ is generally regarded as dtr. ${ }^{56} 1 \mathrm{Kgs} 14: 14$ functions as a prophetic designation of Baasha who wiped out the house of Jeroboam. Nevertheless there are a number of factors which advise against attributing the verse to DTR. The subsequent narrative of Baasha's conspiracy against Nadab makes no mention of his prophetic designation. As well as this the form-

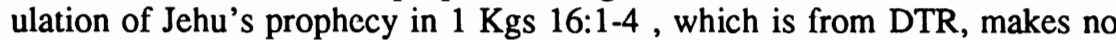
clear reference to this verse with its emphasis on Baasha's 'vocation' to destroy the house of Jeroboam. ${ }^{57}$ Finally, the condemnation of Baasha in Jehu's prophecy contrasts sharply with the tone of $1 \mathrm{Kgs} 14: 14$. In sum the verse appears to be a later attempt to provide Baasha with a prophetic designation. ${ }^{58}$

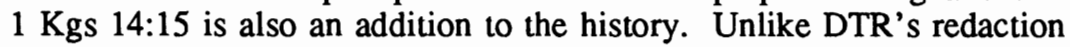
this verse has no clcar relationship to the context. Israel is condemned not because of the sins of Jeroboam but because they made Asherim, an accusation which has no reference point in the text. In addition the three verbs used to

${ }^{54}$ It occurs in the following passages which have been assigned to later redaction: Josh 23:16; 24:2, 16; Judg 2:12,17, 19; 10:13; 1 Sam 8:8; 1 Kgs 9:6, 9; 11:10. This evidence suggested the occurrence in $1 \mathrm{Kgs} 11: 4$ was also an addition. There are occurrences in $2 \mathrm{Kgs} 17: 7,35,37,38 ; 22: 17$ which will in due course be identified also as later additions. However this evidence must be weighed against the wide distribution of the term in Deuteronomy (18 times), and an occurrence in 1 Sam 26:19 (pre-dtr). Hence additional criteria are required before an assessment is made of the provenance of each occurrence.

${ }^{55} \mathrm{This}$ analysis of dtr redaction shows there is no convincing evidence to

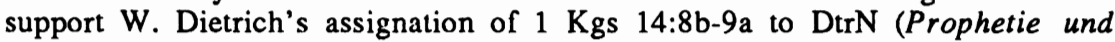
Geschichte, 35).

${ }^{56} 1 \mathrm{Kgs}$ 14:14-16 speaks of Yahweh in the third person. This may have been prompted by the reference to "the Lord, the God of Israel" in v 13. From a literary critical point of view it only makes the verses secondary to the Prophetic Record.

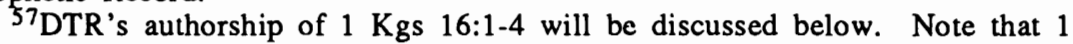
Kgs 14:14 uses the verb qûm in the hiphil. $1 \mathrm{Kgs} \mathrm{16:2}$ uses rûm in the hiphil. If this verse was intended to refer to $1 \mathrm{Kgs} 14: 14$ one would have expected a closer correlation than the vague statement "I exalted you out of the dust".

${ }^{58}$ With J. Gray, I \& II Kings, 333-35; Jones, 1 and 2 Kings I, 273-74; Hentschel, 1 Könige, 93; Noth, Könige, 317 (with some caution); M. Rehm, 1 Könige, 147; Würthwein, 1. Könige 1-16, 174. Surprisingly J. Debus (Die Sünde Jerobeams, 53) and S. L. McKenzie ("The Prophetic History," 209) think that v 14 could belong to the pre-dur layer of the prophecy. If this were the case one would expect it to be formulated in the first person. The troublesome last part of the verse is probably a late gloss (cf. Barthélemy, Critique textuelle de l'Ancien Testament 1, 366-67). 
describe Israel's demise are not part of DTR's vocabulary. ${ }^{59}$ A further clue to the status of this verse can be gained if we anticipate the results of the analysis

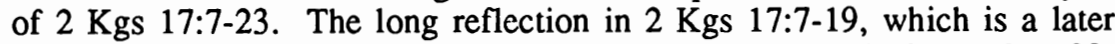
addition that does not mention Jeroboam, has been located in front of vv 2023, which clearly emphasizes the role of Jeroboam in Israel's ultimate downfall. These verses are part of DtrH. In similar fashion $1 \mathrm{Kgs} \mathrm{14:15 \text {has }}$

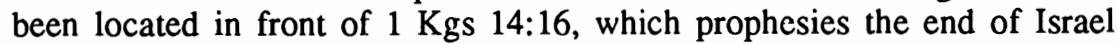

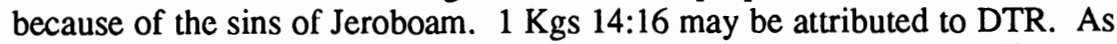
a prophecy it finds an appropriate fulfillment notice in $2 \mathrm{Kgs} \mathrm{17:23a.} \mathrm{Its}$ formulation is close to DTR's judgment formulas, especially those in $1 \mathrm{Kgs}$ $15: 26,34$.

The conclusion which emerges from these considerations is that $1 \mathrm{Kgs}$ 14:16 was probably part of DTR's redaction of Ahijah's prophecy with its fulfillment notice in $2 \mathrm{Kgs} \mathrm{17:23a.1} \mathrm{Kgs} \mathrm{14:15} \mathrm{was} \mathrm{inserted} \mathrm{before} \mathrm{DTR's}$ text in order to foreshadow the similarly positioned reflection in $2 \mathrm{Kgs} \mathrm{17:7-19}$ (note the warnings by prophet and secr in $v 13$ ). The shift of focus from king to people in both these texts is in keeping with later redaction of DtrH. On the basis of this analysis it would appear $1 \mathrm{Kgs} 14: 14$ and 15 were independent

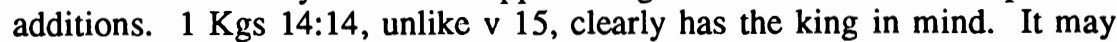
therefore reflect an earlier stage of subsequent dtr redaction, before attention swung towards the people and their sins.

What is significant about the judgment formula for Nadab in $1 \mathrm{Kgs} 15: 26$ is that the accusation he walked (halak) in the way of his father creates a definite connection with DTR's accusation against Jeroboam in $1 \mathrm{Kgs} \mathrm{14:8 \textrm {b } -}$ $9 \mathrm{ba}$. The analysis of this passage showed that the same verb was employed as part of DTR's comparison of Jeroboam with David. This link between judgment formula and prophecy is an important structural element in DTR's interpretation of the northern kings. Hereafter every northern king is accused in the relevant judgment formula of the same infidelity as Jeroboam. All of them therefore come under the same prophetic censure.

The emphatic statement in $1 \mathrm{Kgs}$ 15:26 "and in his sin which he made Israel to sin" has two functions. ${ }^{60}$ On the one hand it recalls the activities of Jeroboam in $1 \mathrm{Kgs} 12: 26-32$. On the other hand it claims that Jeroboam corrupted the north with his sin. This prepares for the final comment by DTR

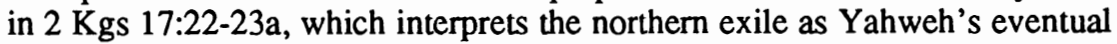

${ }^{59} \mathrm{I}$ refer to nûd (shake), found only here in $\mathrm{DtrH}$; natas (root up), found only in Deut 29:27, a later dtr text; zãrâ (scatter), found only here. All these verbs have a significant number of occurrences in Jcremiah. The verb nákâ (smite) is too widely distributed to be taken into consideration. The accusation of pro-

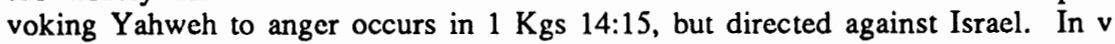
9 the same accusation against Jeroboam is included in DtrH.

${ }^{60}$ Campbell sees the element "which he sinned/and in his sin" as a characteristic feature of pattern $C$ judgment formulas, which he identifies as dtr (Of Prophets and Kings, 149). The reference to walking in the way is shared with pattern B (Southern Document). What is unique about $1 \mathrm{Kgs} 15: 26$ is the way DTR used this phrase to connect the judgment formula with the redaction of Ahijah's prophecy against Jeroboam. 
intervention against a people who failed to turn from Jeroboam's sin. This final comment also notes that Yahweh's intervention was the fulfillment of the prophetic word (cf. $\vee 23 a$ ). The judgment formula in $1 \mathrm{Kgs} \mathrm{15:26} \mathrm{is}$ therefore part of a larger trajectory by DTR, one which is framed by a schema of prophecy (1 Kgs 14:1-16*) and fulfillment ( $2 \mathrm{Kgs} \mathrm{17:23a).} \mathrm{As} \mathrm{will} \mathrm{shortly}$ be seen the judgment formulas for the dynasties of Baasha and Ahab (Omri) are also integrated into DTR's prophecy-fulfillment schema.

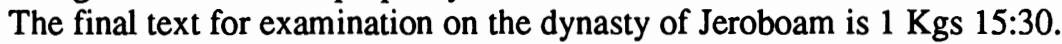
Although this verse is clearly a dtr formulation, its location after the fulfillment notice suggests that it may be a later addition. The link with $1 \mathrm{Kgs}$ 15:29 is abrupt and the statement is also somewhat superfluous in the context. The evidence is however not compelling, and an assignation to DTR or a later redactor is not critical for an understanding of the conceptual plan of DtrH. ${ }^{6 \mathbf{i}}$

\section{THE HOUSE OF BAASHA (BAASHA AND ELAH)}

The texts on this dynasty which require examination are the judgment formula in $1 \mathrm{Kgs} 15: 34$, Jehu's prophecy in $1 \mathrm{Kgs} 16: 1-4$ with its fulfillment notice in 16:12, another report of his prophecy in 16:7, and the final comment in 16:13. DTR's interpretation of this dynasty is constructed in much the same way as for the dynasty of Jeroboam. The centerpiece is a prophecy, in this case Jehu's condemnation of the dynasty in $1 \mathrm{Kgs} 16: 1-4$.

The dtr nature of this prophecy is generally accepted. ${ }^{62}$ What can be pointed out however is the way $1 \mathrm{Kgs} 16: 1-4$ is built up of elements from Ahijah's prophecy against Jeroboam and the intervening judgment formulas. There is the accusation of walking in the way of Jeroboam..$^{63}$ There is the accusation of making Israel sin and of provoking Yahweh to anger. ${ }^{64}$ Finally,

${ }^{61}$ Dietrich (Prophetie und Geschichte, 37) attributes it to DtrN, followed by Hentschel, 1 Könige, 99, Jones, 1 and 2 Kings I, 290, Würthwein, 1 . Könige 1 16, 193 (vv 29b-30).

${ }^{62}$ For Campbell (Of Prophets and Kings, 40-41) this is the only prophecy among those dealing with the designation or rejection of kings which is a dtr composition. He gives six reasons for this. 1)- Unlike the other speeches in the Prophetic Record this one is not part of a prophetic story. 2)- It refers to Baasha's exaltation "out of the dust" when there is no story of his designation by Yahweh. $1 \mathrm{Kgs} 14: 14$ can hardly play this role. 3)- The accusation (v 2b) is made up of elements from the judgment formulas. This is not the case with the prophecies in the Record. 4)- The reference to every male, bond and free, with the description of the male as a mastin bëqir, is absent. This language is a feature of the prophecies in the Record, and occurs in the narrative in v 11. 5)The formulation of the announcement is different to that of the Record's speeches. 6)- Given the absence of a prophecy against Baasha in the Record one could expect that DTR would construct an oracle to bring this dynasty into line with the others.

${ }^{63}$ The term halak was used in $1 \mathrm{Kgs} 14: 9 \mathrm{ba}$ in reference to Jeroboam's sin. The judgment formulas in $1 \mathrm{Kgs} 15: 26,34$ refer to walking in the way of Jeroboam.

${ }^{64}$ The first accusation draws on the judgment formulas in $1 \mathrm{Kgs} 15: 26,34$; the second draws on $1 \mathrm{Kgs} 14: 9 \mathrm{ba}$. 
there is the announcement that the house of Baasha will share the same fate as the one described in $1 \mathrm{Kgs} 14: 10-11$ for the house of Jeroboam. Thus from both a linguistic and contextual point of view the prophecy is an integral part of DTR's interpretation of the northern dynasties. ${ }^{65}$ The fulfillment notice in $1 \mathrm{Kgs} 16: 12 \mathrm{~b}$ may also therefore be attributed to DTR.

The judgment formula in $1 \mathrm{Kgs}$ 15:34 has two functions. On the one hand it forms part of a series which continues through to DTR's final comment on the northern kingdom in $2 \mathrm{Kgs} \mathrm{17:22-23a.} \mathrm{On} \mathrm{the} \mathrm{other} \mathrm{hand,} \mathrm{as} \mathrm{the} \mathrm{preceding}$ observations indicate, it provides the evidence for Jehu's accusation in $1 \mathrm{Kgs}$ 16:2. As with the dynasty of Jeroboam therefore, this judgment formula was constructed with the prophecy in mind.

The location of $1 \mathrm{Kgs} \mathrm{16:7} \mathrm{outside} \mathrm{the} \mathrm{regnal} \mathrm{framework} \mathrm{indicates} \mathrm{it} \mathrm{is} \mathrm{an}$ appendage. Furthermore, the content of the verse shows that it was an attempt to clarify some points of DTR's redaction. Closer inspection reveals that the clarification was undertaken in two stages. $1 \mathrm{Kgs} 16: 7 \mathrm{a}$ was first. It emphasizes that Jehu's prophecy was against Baasha and his house. This is an expansion on $1 \mathrm{Kgs} \mathrm{16:1}$ which does not contain the latter element. ${ }^{66}$ Verse 7 a also claims that Jehu condemned him for "all" the evil he did, and gives a more complex version of the accusation that he provoked Yahweh to anger. This suggests that the redactor in question failed to see the close connection between the judgment formula in $1 \mathrm{Kgs} \mathrm{15:34}$ and Jehu's prophecy. Verse 7b was added in a further attempt to spell out the nature of Baasha's sin. The editor responsible turned to the only specific piece of information available in the text, Baasha's violent destruction of the house of Jeroboam. ${ }^{67}$

A similar procedure is evident in $1 \mathrm{Kgs} \mathrm{16:13.} \mathrm{The} \mathrm{verse} \mathrm{takes} \mathrm{up} \mathrm{el-}$ ements of DTR's redaction but seeks to polemicize the portrait of Baasha with additional "evidence" and to emphasize that his son Elah was equally as bad. The elements from DTR's redaction can be seen in the phrase "which they sinned", in the accusations of having made Israel sin, and of provoking Yahweh to anger. The polemical additions are evident in the reference to "all

${ }^{65}$ For Dietrich $1 \mathrm{Kgs} 16: 1-4$ is the paradigm prophetic speech of DtrP and the one with which he begins his study (Prophetie und Geschichte, 9-10). However its neat formulation is due rather to DTR's imitation of prophecies in the Prophtic Record. The more complex formulation of the other prophecies arose because DTR was obliged to work with an existing text.

${ }^{66}$ This point was noted by Dietrich, Prophetie und Geschichte, 10, n. 22. H. Seebass has argued that $1 \mathrm{Kgs} 16: 7$ was the original report of the prophecy and that the original announcement of disaster can be detected in $v 3 a$ ("Tradition und Interpretation bei Jehu ben Chanani und Ahia von Silo," VT 25 [1975] 17590; see p. 178). Cf. also Jones, 1 and 2 Kings $I, 291$. In view of the explanation given here this is unlikely. Seebass's proposal also involves a hypothetical rearrangement of the text.

${ }^{67} \mathrm{It}$ is difficult to determine the relationship between $1 \mathrm{Kgs} 14: 14$ and 16:7b. Certainly they could not have come from the same hand. Gray (I \& II Kings, 361) tries to ease the tension by translating $\vee 7 \mathrm{~b}$ as a concessive clause. This is rejected by Secbass ("Tradition und Interpretation," 175). 
the sins of Baasha" and to idols. ${ }^{68}$ The concern to emphasize Elah's part in the sins of the dynasty is clear enough. $1 \mathrm{Kgs} 16: 7$ a shows a similar concern in the way it refers to Baasha and his house. It would seem that the redactors responsible for both additions noted that DTR had no judgment formula for Elah. A clear reason for this is difficult to find, but I would suggest that the lacuna is due to DTR's focus on dynasties. ${ }^{69}$ With such a short lived dynasty as Baasha's DTR may have reasoned that Jehu's prophecy sufficed for Elah (cf. $1 \mathrm{Kgs} \mathrm{16:3-4).}$

This explanation receives some support from the absence of a judgment formula in the expected location for Zimri, that is, after $1 \mathrm{Kgs} \mathrm{16:15a}$. This king founded no dynasty. What we find instead is a list of accusations against him in $v 19$, which indicates that a later redactor noted the absence of a judgment formula on Zimri and so supplied one. ${ }^{70}$ The location of the entry after the account of his death, and its polemical tone, parallels the similar entries on the death of Nadab (1 Kgs 15:30) and Elah (1 Kgs 16:13) which have also been proposed as later additions. It is therefore quite possible the three entries were by the same hand. ${ }^{71}$

\section{THE HOUSE OF AHAB (OMRI, AHAB, AHAZIAH, JEHORAM)}

An examination of this dynasty reveals a similar redactional procedure to the one observed for the dynasties of Jeroboam and Baasha. That is, DTR provided a unified interpretation of the dynasty within a larger trajectory of the overall interpretation of the northern kings. As with the earlier dynasties DTR's interpretation is based on the interrelationship between the judgment formulas and prophecy. In this case there are two prophecies, one against Ahab in $1 \mathrm{Kgs} 21: 17-24$, the other to Jehu in $2 \mathrm{Kgs} \mathrm{9:1-10.} \mathrm{The}$

${ }^{68}$ The term "idols" occurs in Deut $32: 21 ; 1 \mathrm{Kgs} 16: 13,26 ; 2 \mathrm{Kgs} 17: 15$ (singular). This distribution in itself makes it difficult to draw conclusions. The assessment here is based on the way $1 \mathrm{Kgs} 16: 13$ shows the same tendency as $\vee 7$ to add detail to DTR's accusation against Baasha.

${ }^{69}$ One could argue that the shortness of Elah's reign-two years-was a factor. This may have been even shorter, since he was killed in the year after his accession (cf. Jones, $I$ and 2 Kings $I, 292$, and Würthwein, 1. Könige 1-16, 195). But Nadab, who also reigned for two years (1 Kgs 15:25), has a judgment formula. Shallum, who reigned for one month, does not have one (cf. $2 \mathrm{Kgs}$ 15:13), whereas Zechariah, who reigned for six months, does (cf. 15:8-9). Jehoahaz and Jehoiachin each had very short reigns but receive judgment formulas $(2 \mathrm{Kgs} 23: 31 ; 24: 8)$. Shallum and Zechariah are part of the northern expansion. Jehoahaz and Jehoiachin are part of the exilic redaction of DtrH. The formula for Nadab is required to begin the series of judgment formulas. The one other king who has no formula is Zimri (see the following comment).

${ }^{70}$ The later addition of the verse is proposed also by Gray, I \& II Kings, 365; Hentschel, 1 Könige, 101; Jones, 1 and 2 Kings I, 294; Noth, Könige, 349-50; Würthwein, 1. Könige 1-16, 197.

${ }^{71}$ This proposal points to some differentiation within Campbell's pattern C (Of Prophets and Kings, 148-49). While all the entries can be identified as dtr the three entries in question were from later dtr redaction which employed elements of DTR's judgment formulas. 
interrelationship can be illustrated best by examining the judgment formulas first and then the prophecies.

The judgment formulas for the four members of this dynasty occur in 1 Kgs 16:25-26 (Omri); 16:30-33 (Ahab); 22:53-54 (RSV 22:52-53 [Ah-

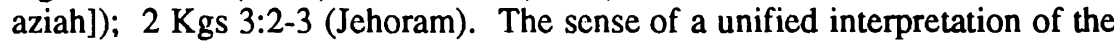
dynasty is immediately evident in the formulas for Ahab and Ahaziah, and to a lesser extent Jehoram. The differences in the formulas for Omri and Jehoram are due to the fact that they link this dynasty with the formulas for the preceding and following kings. Thus $1 \mathrm{Kgs}$ 16:25-26 contains the same elements present in the formulas for Nadab and Baasha (1 Kgs 15:26 and 34): 1)- he did evil, 2)- walked in the way of Jeroboam, 3)- in the sin which he made Israel sin. ${ }^{72}$ Additional elements are the comparison in $\mathrm{v} 25 \mathrm{~b}$ and the provocation of Yahweh to anger in $v 26 \mathrm{~b}$. The formulation of these elements and the contextual comparison with the other formulas indicates they were not from DTR. ${ }^{73}$

The peculiar composition of the judgment formula for Ahab in $1 \mathrm{Kgs}$ $16: 30-33$ is due to its incorporation of two pieces of information from the Prophetic Record in vv 31b-32, his marriage to Jezebel and his worship of Baal. ${ }^{74}$ DTR constructed the formula around this information. The formula begins in $1 \mathrm{Kgs} \mathrm{16:30}$ with the customary accusation of evil, and then adds the

${ }^{72}$ With element 2 note the description of Jeroboam as the son of Nebat. This is common to all the formulas for this dynasty, but did not occur in the formulas for the preceding two dynasties. It contributes to the unified nature of DTR's presentation of the Ahab dynasty. In element 3 the plural "sins" is given in the text (Ketib), with Qere correcting it to the singular in line with the other formulas.

${ }^{73}$ Unlike the comparisons with predecessors in $1 \mathrm{Kgs} 14: 9$ and $16: 30 \mathrm{~b}$ this example begins with the verb racac. The provocation to anger contains the reference to idols, present also in the addition in $1 \mathrm{Kgs} \mathrm{16:13.} \mathrm{The} \mathrm{additions}$ were probably made to the formula for Omri because he was the founder of the dynasty. For DTR however Ahab was the real villain in the dynasty and the one whose actions brought divine retribution upon it. This follows the lead of the Prophetic Record which condemned Ahab and always referred to the dynasty as the house of Ahab.

${ }^{74} \mathrm{Cf}$. Campbell, Of Prophets and Kings, 103. According to the Record Ahab was responsible for institutionalizing Baalism in northern Israel. This ultimately led to the prophetic designation of Jchu as king, who then "wiped out Baal from Israel" (2 Kgs 10:28). Ahab's policy was probably a result of his marriage to Jezebcl who no doubt worshipped the Tyrian Baal (cf. Noth, Könige, 354). One might argue that $v 31 \mathrm{~b} \beta$ was dtr because the verbs "to serve" and "to worship" occur frequently in dtr texts. This would not affect the notice in $\mathbf{v} 32$. Noth (Könige, 354-55) thought $v 31$ ba was from a source, with $v 31 \mathrm{~b} \beta$ as $\mathrm{dtr}$. Verse 32 may also be an item of information drawn from a source (p. 350). Timm (Die Dynastie Omri, 34, 37) believes that vv $31 \mathrm{~b} \beta-32$ cannot have come from official sources, but are a dtr presentation of official information. The analysis of $1 \mathrm{Kgs} 16: 30-33$ given here is in disagreement with Hoffmann's claim of a unified dir composition (Reform und Reformen, 78-82). 
unfavorable comparison with predecessors. ${ }^{75}$ We saw the same comparison in Ahijah's prophecy against Jeroboam in $1 \mathrm{Kgs} \mathrm{14:9a.} \mathrm{Ahab's} \mathrm{initiatives} \mathrm{in}$ institutionalizing the worship of Baal (cf. v 32) and making an Asherah (v 33a) parallel Jeroboam's initiative with the golden calves. Given that vv 32 , 33a can be shown to be part of DtrH one may conclude that the comparison was made by DTR.

There are two reasons for the particular formulation of $v 31 \mathrm{a}$. It is an adaptation of the accusation of walking in the way of Jeroboam because of the presence of the Prophetic Record material (vv 31b-32). It is also designed to link this material with $v 30 \mathrm{~b}$ and so supply evidence to justify the unfavorable comparison given there. ${ }^{76}$ Hence $v 31 a$ is an integral part of DTR's redaction. The report in v 33a that Ahab made an Asherah is not part of the Prophetic Record, and does not seem to have been a concern of the prophetic redactors although there may have been Asherah there at the time (cf. the prophets of Asherah in $1 \mathrm{Kgs} 18: 19 \mathrm{~b} \beta$ ). It is not mentioned in the purge of Jehu. However it is quite likely that it came from DTR. The report supplies another item of evidence to back up the comparison of $v 30 \mathrm{~b}$. Also, within the larger sweep of the history it prepares for DTR's comparison of Manasseh with Ahab in $2 \mathrm{Kgs} 21: 3 \mathrm{~b}$. DTR may have thought that because both prophets of Baal

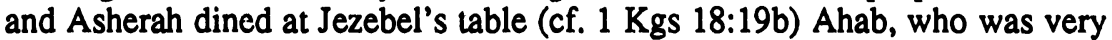
much under his wife's influence, must have worshipped Asherah as well as Baal. ${ }^{77}$

$1 \mathrm{Kgs} \mathrm{16:33b}$ contains a second comparison with predecessors, conflated with an accusation of provoking Yahweh to anger. It is possible this was part of DtrH, because both accusations were used earlier by DTR against Jeroboam (1 Kgs 14:9). Nevertheless two factors argue against it. First, in DTR's redactional additions accusations such as these are given separately, they are never conflated as in v 33b. Secondly, one would expect that, following DTR's treatment of Jeroboam and Baasha, the accusation of provoking Yahweh to anger should occur in a prophetic speech. The expected accusation does appear in $1 \mathrm{Kgs}$ 21:22. The textual distance between the judgment formula for Ahab and Elijah's prophecy may have led a later redactor to add it to the formula. The addition was made by conflating the accusation of provoking Yahweh to anger with the comparison, thus forming an inclusion with $1 \mathrm{Kgs}$ $16: 30 \mathrm{~b} .{ }^{78}$

${ }^{75}$ The reference to Ahab as the son of Omri in $v 30 \mathrm{a}$ may be a later addition, by the same editor who expanded the formula for Omri. It is not in the LXX.

${ }^{76}$ Note the rhetorical question in hañqel in $v 31 \mathrm{a}$, expecting a negative answer (cf. Gray, I \& II Kings, 367-68; Noth, Könige, 325). Against Wurthwein (1. Könige 1-16, 201) who reads it as the definite article.

${ }^{77} 1 \mathrm{Kgs} 18: 19 \mathrm{~b} \beta$ has been identified as part of an anti-Jezebel redaction of the Elijah stories undertaken before the composition of DtrH. This will be commented on in the discussion of the prophecies. There is a reference to an

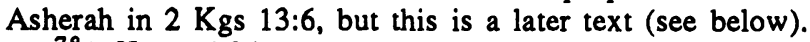

${ }^{78} 1 \mathrm{Kgs} 16: 34$ has only a loose connection with the context and portrays Joshua as a prophet. It is highly unlikely that the verse came from DTR. There is no corresponding prophecy for this fulfillment notice. 
The judgment formula for Ahaziah (1 Kgs 22:53-54 [RSV 22:52-53]) gives clear evidence of the way DTR constructed a unified interpretation of the Ahab dynasty within a larger trajectory. In relation to the larger trajectory there are the following elements: 1)- doing evil, 2)- walking in the way of Jeroboam, 3)- who made Israel sin. In relation to the more specific topic of the Ahab dynasty there are the accusations of walking in the way of his father and mother, and worship of Baal. ${ }^{79}$ Ahaziah is the only other member of the dynasty besides Ahab about whom there was information in DTR's source that he followed Baal. This is provided by the story of his consultation of Baalzebub in 2 Kings 1.80 It is reasonable to see the accusation about Baal worship as an allusion to this story. However the accusation of provoking

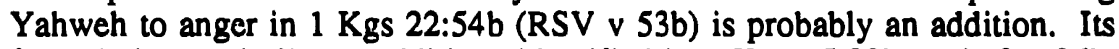

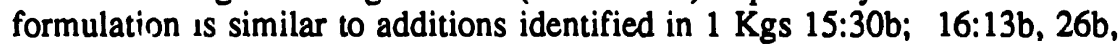
$33 \mathrm{~b}$ (cf. the phrase "the Lord, the God of Isracl" in each occurrence). As with these other additions, it also occurs in a judgment formula, whereas DTR's use of this accusation is confined to prophecies against the founders of the northern dynasties (1 Kgs 14:9b; 16:2; 21:22).

The differences in the judgment formula for Jehoram in $2 \mathrm{Kgs} 3: 2-3$ can be explained in terms of its location between the formulas for the Ahab dynasty and the following ones for northern kings from Jehu to Hoshea. These formulas were composed by the author of the northern expansion. $2 \mathrm{Kgs} \mathrm{3:2-3}$ can be seen first of all to contain the three elements common to all the formulas constructed by DTR. They are; 1)- doing evil, 2)- the sin of Jeroboam, 3)- making Israel sin. The difference in formulation of element 2 is due to DTR's incorporation of an element from the formulas for the northern expansion, namely "he did not depart from it". It served to create a connection with this series of formulas. ${ }^{81}$ Next we may note two elements which recall the formulas for Ahab and Ahaziah. These are; 1)-reference to his father and

${ }^{79}$ It is instructive to note the reference to Jezebel in the formula. As will be seen the condemnation of her here connects with DTR's redaction of the prophecies. The queen mother apparently had a powerful influence on royal policy in both the north and the south. For a discussion see Niels-Erik $A$. Andreasen, "The Role of the Queen Mother in Israelite Society," CBQ 45 (1983) 179-94. For his treatment of Jezebel see pp. 187-88.

${ }^{80}$ This story, except for vv $1,9-16,17 \mathrm{a} b \mathrm{~b}$ is included in the Prophetic Record (Campbell, Of Prophets and Kings, 98-99). The unity of 2 Kgs 1:2-17a is defended by C. T. Begg, "Unifying Factors in 2 Kings 1:2-17a," JSOT 32 (1985) 75-86.

${ }^{81}$ The accusation that "he did not depart from it" is a characteristic of the formulas for the northern expansion (Campbell, Of Prophets and Kings, 145). The explanation offered here is a more satisfactory one than Weippert's assignation of this formula to the same redactor responsible for the series from Jehu to Hoshea ("Dic 'deuteronomistischen' Beurtcilungen," 316, 320). Her proposal does not explain the use of the verb dábaq (to cling) in $2 \mathrm{Kgs} \mathrm{3:3.} \mathrm{The}$ use of this verb elsewhere indicales that it is dir. The closest parallel is $1 \mathrm{Kgs}$ $11: 2 \mathrm{~b}$ (Solomon clung to his forcign women). It occurs in the sense of "cling to Yahweh" in Deut $4: 4 ; 10: 20 ; 11: 22 ; 13: 5 ; 30: 20$; Josh $22: 5 ; 23: 8 ; 2$ Kgs 18:6. 
mother (not like them), 2)- reference to Baal (removed his pillar). The difference in the formulation of these two elements could be due to the fact that DTR found no condemnation of Jchoram for Baal worship in the Prophetic Record source. ${ }^{82}$ In short there is nothing against assigning all of $2 \mathrm{Kgs} \mathrm{3:2-3}$ to DTR. ${ }^{83}$

We can now turn to an investigation of the prophecies which deal with the

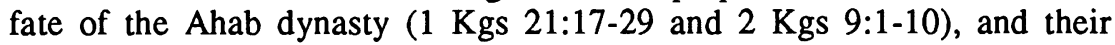
corresponding fulfillment notices (2 Kgs 9:36-37 and 10:10-11). Campbell includes a version of both prophecies in the Prophetic Record. ${ }^{84}$ They formed an integral part of the prophetic redactors' demonstration of the prophets' authority to reject (Ahab and his house) and designate kings (Jehu). The present text of Elijah's prophecy against Ahab is particularly complex. Nevertheless one can gain a reasonably accurate idea of DTR's redaction by considering the additions to the text of the Record in the light of what has emerged so far.

DTR's redaction of Elijah's prophecy against Ahab can be most clearly

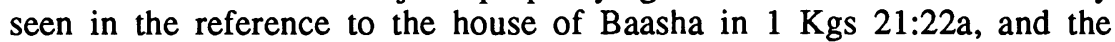
accusation of provocation to anger in $v 22 \mathrm{~b}$. Similarly, in the prophecy of Elisha's disciple to Jehu, DTR's redaction is immediately evident in the reference to the house of Baasha in $2 \mathrm{Kgs} \mathrm{9:9b.} \mathrm{The} \mathrm{assignation} \mathrm{of} \mathrm{these} \mathrm{verses}$ follows from what has been seen so far to be DTR's additions to the Prophetic Record. As well as these there are reasonable grounds for proposing that DTR had a hand in developing the anti-Jezebel component of these prophecies. The

${ }^{82}$ Hence he was not like his father or mother, nor for that matter like his brother Ahaziah. DTR may have based the statement about the removal of the pillar of Baal ( $v 2 b$ ) on information which is not recorded in the text. But the possibility could also be entertained that DTR constructed it on the basis of 2 Kgs 10:25-27 (Prophetic Record), where it is reported that Jehu's men went into the inner room of the Baal temple to bring out the pillar. DTR took this to mean that it was not on display during Jehoram's reign. It suited DTR's purpose to imply that Ahab made it and put it on display. For a similar explanation see A. Sanda, Die Bücher der Könige II, 18, 113.

${ }^{83}$ The doublet in the synchronism for Jehoram cannot be investigated fully here. However I would note that $2 \mathrm{Kgs} 3: 1-3$ could follow on from $2 \mathrm{Kgs}$ $1: 17 \mathrm{aab}$. The repetition created by this sort of sequence occurs elsewhere (cf. 1 Kgs 16:28-29; 2 Kgs 8:24-25; 13:9-10; 15:22-23; 15:38-16:1) and results from the juxtaposition of the linear and synchronistic systems. Alternatively, 2 Kgs 3:2-3 could follow after $2 \mathrm{Kgs} 1: 17$ (including the synchronism in $\mathbf{v} 17 \mathrm{a} \beta$ ). The reference to Ahab and Jezebel as Jehoram's father and mother would fit in well after the notice that Ahaziah had no son. The LXX refers to Jehoram as Ahaziah's brother, but this is missing in the MT.

${ }^{84}$ Campbell, Of Prophets and Kings, 35-38, 96-98, 99-100. The text of the Record for each is as follows: $1 \mathrm{Kgs} 21: 1-7 \mathrm{a}, 8,11,14-19 \mathrm{a}, 21,22 \mathrm{aa}, 24$ and $2 \mathrm{Kgs} \mathrm{9:1-7a,8,9a,10b.} \mathrm{The} \mathrm{text} \mathrm{of} \mathrm{the} \mathrm{narrative} \mathrm{about} \mathrm{Naboth's} \mathrm{vineyard} \mathrm{is}$ considered to be prior to any anti-Jezebel redaction (p. 96, n. 77). Hans Schmoldt's recent study of Elijah's prophecy leads him to propose a pre-dtr text that is close to Campbell's ("Elijas Botschaft an Ahab. Úberlegungen zum Werdegang von 1 Kön 21," $B N 28$ [1985] 39-51). Schmoldt's text is 1 Kgs

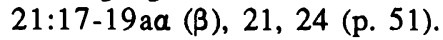




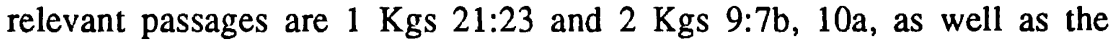
fulfillment notice in $2 \mathrm{Kgs} \mathrm{9:36-37.} \mathrm{It} \mathrm{is} \mathrm{possible} \mathrm{that} \mathrm{these} \mathrm{texts} \mathrm{were} \mathrm{part} \mathrm{of}$ a larger pre-dtr anti-Jezebel redaction. ${ }^{85}$ Certainly it is unlikely one can

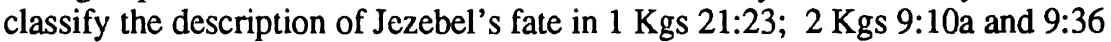
as a typical dtr formulation. This appears to be a traditional saying. ${ }^{86}$ Nevertheless there are a number of factors which favor the hand of DTR, at least in $2 \mathrm{Kgs} 9: 7 \mathrm{~b}, 10 \mathrm{a}$ and 9:36-37.

First, there is the reference to "my servants the prophets" in $2 \mathrm{Kgs} \mathrm{9:7b.}$ This is a dtr phrase. ${ }^{87}$ Furthermore the condemnation of Jezebel for slaughtering the prophets of Yahweh is in keeping with DTR's appreciation of the significance of prophets in Isracl's history. ${ }^{88}$ Second, the fulfillment

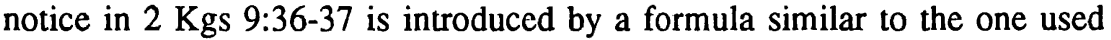
elsewhere by DTR in constructing the prophecy-fulfillment schema. $2 \mathrm{Kgs}$

${ }^{85}$ The precise extent of this redaction is debated, but in the Elijah narratives it has been identified in $1 \mathrm{Kgs} 18: 3 \mathrm{~b}-4,12 \mathrm{~b}-13,19 \mathrm{~b} \beta ; 19: 1-3 \mathrm{aa}$, and in the Naboth story. For a discussion see Georg Hentschel, Die Elijaerzählungen: Zum Verhältnis von historischem Geschehen und geschichtlicher Aufsätze (Erfurter Theologische Studien 33; Leipzig: St. Benno, 1977) 69-72; Odil Hannes Steck, Überlieferung und Zeitgeschichte in den Elia-Erzählungen (WMANT 26; Neukirchen-Vluyn: Neukirchener Verlag, 1968) 30, 40-43, 50-52; Timm, Die Dynastie Omri, 101-2 (on $1 \mathrm{Kgs} 19: 1-3$ ). Steck argues for the inclusion of 1 Kgs 21:23 in the anti-Jezebel redaction, but thinks that its present location is due to dtr redaction (pp. 37,39-40). Hentschel attributes it to the anti-Jezebel "Tendenz" (p. 21) but does not appear to link it with the dtr redaction (pp. 4043).

${ }^{86}$ The traditional saying was, "the dogs shall eat Jezebel in the territory of Jezreel". $1 \mathrm{Kgs} 21: 23$ has hel (rampart) instead of heleq (territory) in the other occurrences. Reinhold Bohlen (Der Fall Nabot: Form, Hintergrund und Werdegang einer alttestamentlichen Erzählung [1 Kön 21] [Trierer Theologische Studien; Trier: Paulinus, 1978] 85, 298-99) argues that this makes $1 \mathrm{Kgs}$ 21:23 closer to $2 \mathrm{Kgs} 9: 30-35$ than 9:36, which he assigns to DtrN (p. 297following Dietrich). On the other hand Hentschel (Elijaerzählungen, 42) argues for 9:36 as the earlier version. The shift provides very limited evidence for either case. The MT of $1 \mathrm{Kgs} 21: 23$ is corrected to "territory" in the Syriac, Targums and Vulgate.

${ }^{87}$ It occurs elsewhere in $2 \mathrm{Kgs} 17: 13 \mathrm{~b}, 23 \mathrm{a} ; 21: 10 ; 24: 2 \mathrm{~b}$. It will be argued below on contextual grounds that the fulfillment notice in $2 \mathrm{Kgs} \mathrm{17:23a}$ is from DTR. The other fulfillment notice in $2 \mathrm{Kgs} 24: 2 \mathrm{~b}$ is part of the exilic

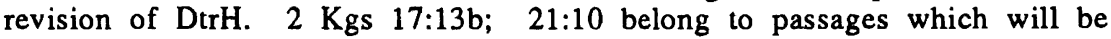
shown in due course to be secondary.

${ }^{88}$ The slaughter referred to occurs in the proposed anti-Jezebel redaction in 1

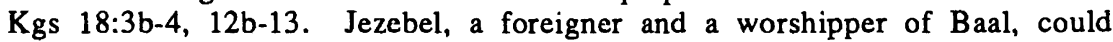
hardly be condemned along with Ahab and his sons of becoming a follower of Baal. It is instructive to note therefore that while Jezebel is integrated into the judgment formulas, there is no accusation in them that she followed Baal. However the killing of Yahweh's prophets was another matter, and for this she

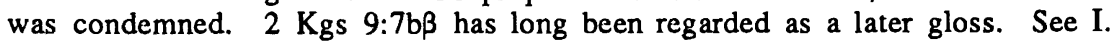
Benzinger, Die Bücher der Könige, 150 (who thought that it was a reference to Naboth and his sons [cf. 2 Kgs 9:26]); Sanda, Die Bücher der Könige II, 94. More recently, see Würthwein, 1. Kön. 17-2. Kön. 25, 325, n. 4. 
9:36-37 also parallels the fulfillment notice for the Ahab dynasty in $2 \mathrm{Kgs}$ 10:10.89 Even though the description of Jezebel's fate in $2 \mathrm{Kgs} \mathrm{9:36-37} \mathrm{is}$ probably made up of traditional sayings, they are dependent on the introductory formula. ${ }^{90}$ Given that DTR was responsible for $2 \mathrm{Kgs} \mathrm{9:36-37} \mathrm{one} \mathrm{may} \mathrm{make}$ the same claim for $2 \mathrm{Kgs} \mathrm{9:10a.} \mathrm{In} \mathrm{this} \mathrm{verse} \mathrm{the} \mathrm{addition} \mathrm{to} \mathrm{the} \mathrm{saying} \mathrm{on}$ Jezebel of the phrase "and none shall bury her" appears to have been deliberately made with $2 \mathrm{Kgs} 9: 37$ in mind.

A fourth argument is supplied by the evidence from the judgment formulas that DTR's assessment of the Ahab dynasty included Jezebel. Attention has been drawn to the way DTR connected judgment formulas with the prophetic speeches for the dynasties of Jeroboam and Baasha. It is reasonable to expect therefore that DTR sought to make a similar connection in this case between

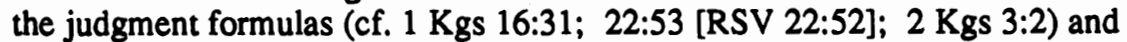
the two prophecies (cf. $1 \mathrm{Kgs} 21: 23 ; 2 \mathrm{Kgs} 9: 7 \mathrm{~b}, 10 \mathrm{a}, 36-37$ ) via the figure of Jezebel.

Each of these items of evidence is limited in itself. But taken together they do make a reasonable case for assigning the material on Jezebel in $2 \mathrm{Kgs}$ 9:7b, 10a, 36-37 to DTR. $1 \mathrm{Kgs} 21: 23$ may also have been part of DTR's redaction. However there is no evidence of DTR's hand here. It could equally well have been part of the earlier anti-Jezebel redaction. If this is the case its presence would have prompted DTR to develop the anti-Jezebel component by incorporating the above texts. ${ }^{91}$

${ }^{89}$ The other fulfillment notices are for the dynasties of Jeroboam and Baasha,

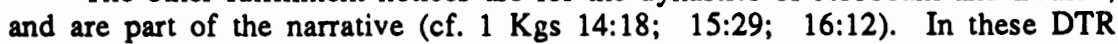
used the formula "according to the word of the Lord which he spoke by his servant X the prophet". 2 Kgs 17:23a does not contain the initial "word of the Lord", presumably because it is a general vindication of all the particular words of the Lord spoken through the prophets. The difference in formulation with 2 Kgs 9:36-37 and 10:10 would be accounted for by the fact these are speeches, not narrative. Both however cite the authority of "his servant X".

${ }^{90} 2 \mathrm{Kgs} \mathrm{9:36b}$ has "In the territory of Jezreel the dogs shall eat the flesh of Jezebel". The reversal of the order of the earlier occurrences of the saying and the addition of "flesh" was done to link it more closely with the narrative context (cf. vv 30-35). Both changes suggest a redactor carefully integrating a traditional saying into the context. $2 \mathrm{Kgs} 9: 37$ is a hapax in DtrH and is probably a traditional saying. In Jeremiah we find the saying "they shall become dung over the face of the ground" (Jer 8:2; 9:21 [uncertain text]; 16:4; 25:33). As Hentschel points out however (Elijaerzählungen, 42, n. 131), one cannot argue that $2 \mathrm{Kgs} \mathrm{9:37} \mathrm{is} \mathrm{dependent} \mathrm{on} \mathrm{these.} \mathrm{It} \mathrm{states} \mathrm{"the} \mathrm{corpse} \mathrm{of}$ Jezebel will be as dung on the face of the field".

${ }^{91}$ It is clear that $1 \mathrm{Kgs} 21: 23$ is an insertion, but the hypothesis of a Prophetic Record only makes it an insertion with respect to the Record. Its location is appropriate, since the threat against Jezebel is thereby able to be incorporated within the larger statement in v 24 ("any one belonging to Ahab .

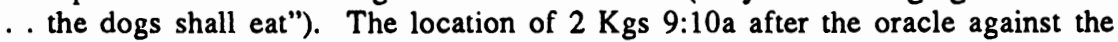
house of Ahab is due to the fact there is no reference to dogs in vv 8-9. Despite some uncertainty about the nature of the anti-Jezebel material the explanation developed here is I believe more satisfactory than Dietrich's (Prophetie und Geschichte, 48-51), who assigns $1 \mathrm{Kgs} 21: 23 ; 2 \mathrm{Kgs} 9: 7-10 \mathrm{a}$ to DtrP, and 
A number of verses in Elijah's prophecy to Ahab remain to be considered, namely $1 \mathrm{Kgs} 21: 19 \mathrm{~b}-20,25-26,27-29$. These comprise a prophecy on Ahab's personal fate in $v 19 \mathrm{~b}, \mathrm{a}$ new introduction with accusation in $v 20, a$ general comment on Ahab in vv 25-26, and an account in vv 27-29 of Ahab's repentance resulting in a further prophecy from Elijah.

The secondary nature of $1 \mathrm{Kgs} 21: 19 \mathrm{~b}$ emerges from the following observations. Yahweh's new command to Elijah in v 19ba, followed by the repetition of the messenger formula of $v 19 a$, indicates that the accompanying oracle has been inserted into an existing context.92 The sequence of verses in $1 \mathrm{Kgs} 21: 19-24$ also shows that $\mathrm{v} 19 \mathrm{~b}$ could only have been added when $v 20$ was already in place. Without it there is an unacceptable sequence between $v 19 \mathrm{~b}$ and $v v 21-24$. Yet, as will be pointed out shortly, there is a good case for taking $v 20$ as a later addition to DtrH.

In addition to these points there are two distinctive features about the oracle in $v 19 \mathrm{~b}$ in relation to the one in $v 24$ (DtrH). Firstly, it is directed against Ahab himself and not those belonging to him, as in v 24. Secondly, it describes the dogs as licking up the blood of the condemned instead of eating him..$^{93}$ These distinctive features find their closest correlation in the des-

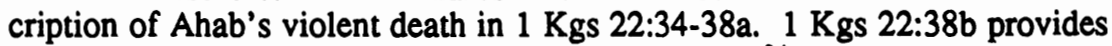
the fulfillment notice for the oracle in $1 \mathrm{Kgs} 21: 19 \mathrm{~b} .{ }^{94}$ Ahab's violent death is in conflict with the report in $1 \mathrm{Kgs} 22: 40$ that he slept with his fathers. This type of report always refers to a king's peaceful death.95 $1 \mathrm{Kgs} 22: 40 \mathrm{can}$

9:36b-37 to DtrN (pp. 37-38). It is also in disagreement with Schupphaus (Richter- und Prophetengeschichten, 66) who includes all the anti-Jezebel material in his pre-dtr history.

${ }^{92}$ As noted earlier Schmoldt ("Elijas Botschaft," 51) identifies $1 \mathrm{Kgs} \mathrm{17-19aa}$ $(\beta), 21,24$ as the original text, with $\vee 19 \mathrm{~b}$ a later insertion (p. 44). This is close to Campbell's Prophetic Record text of $1 \mathrm{Kgs} 21: 17-19 \mathrm{a}, 21,22 \mathrm{a}, 24$. See also the discussion by Bohlen (Der Fall Nabot, 93-94).

${ }^{{ }^{3}} \mathrm{This}$ is not to say that the oracle in $v 19 \mathrm{~b}$ is later than the other. There seems to have been a number of traditional prophetic sayings about Ahab which circulated, and it is difficult to determine which was the earliest (cf. $1 \mathrm{Kgs}$ 21:19b, 24; 2 Kgs 9:26). On this see Hentschel, Elijaerzählungen, 156. The point argued here is that the oracle in $v 19 \mathrm{~b}$ was taken and used to facilitate the incorporation of 1 Kings 20 and 22 (sec below).

${ }^{94}$ This fulfillment notice is not formulated in the same way as DTR's (cf. 1 Kgs $14: 18 ; 15: 29 ; 16: 12 ; 2 \mathrm{Kgs} 9: 36 ; 10: 10)$. It is possible that the reference to dogs licking up blood in $1 \mathrm{Kgs} 22: 38$ was added to bring the narrative into line with $1 \mathrm{Kgs} 21: 19 \mathrm{~b}$. Similarly the phrase "who is in Samaria" in $1 \mathrm{Kgs} 21: 18$ a may have been added with $1 \mathrm{Kgs} 22: 38$ in mind (so J. Maxwell Miller, "The Fall of the House of Ahab," VT 17 [1967] 307-24, see p. 313). The phrase can also be read as a royal title rather than a place of residence (cf. Steck, Elia-Erzählungen, 42, n. 2).

${ }^{95}$ Cf. 1 Kgs $2: 10 ; 11: 43 ; 14: 20,31 ; 15: 8,24 ; 16: 6,28 ; 22: 51$ (RSV 22:50); 2 Kgs 8:24; 13:9, 13; 14:16, 29; 15:7, 22, 38; 16:20; 20:21; 21:18; 24:6. $2 \mathrm{Kgs}$ 14:22 appears to state that Amaziah slept with his fathers, even though he suffered a violent death ( $v 19)$. However the report comes after the accession of the new king Azariah, is appended to a note about the recovery of Elath, and does not refer to Amaziah by name. The location of the verse 
be included in DtrH, because Elijah's prophecy in $1 \mathrm{Kgs} 21: 21-24$ is concerned with the fate of Ahab's dynasty rather than Ahab himself. Both Jeroboam (1 $\mathrm{Kgs} \mathrm{14:20)}$ and Baasha (16:6) are reported as dying peacefully.

$1 \mathrm{Kgs} 21: 19 \mathrm{~b}$ can therefore be identified as part of a later redaction which focused on the personal fate of Ahab rather than his dynasty. The redaction was responsible for the inclusion of the story of the campaign against Syria in

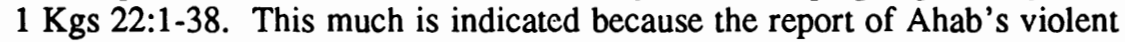
death is an integral part of the narrative. The earlier campaign against Syria in 1 Kings 20 should be included in this redaction as well. The prophecy in 1 Kgs 20:42, which is directed against the king and his people, finds its fulfillment in $1 \mathrm{Kgs} 22: 34-36$. There the king is slain, and the defeated army (people) disperses. ${ }^{96}$ Overall then this later redaction was made up of 1 Kings 20, $1 \mathrm{Kgs} 21: 19 \mathrm{~b}$ and 22:1-38.97

We can now turn to an examination of $1 \mathrm{Kgs} 21: 20$. The accusation in $\mathbf{v}$ $20 \mathrm{~b} \beta$ that Ahab had sold himself to do evil may be classified as dtr but it does not occur in DTR's own accusations against the northern dynasties. ${ }^{98}$ Moreover it supplies an accusation for Elijah's prophecy when one, which is definitely characteristic of DTR, is already present in $v 22 \mathrm{~b}$. A third point to note is that the introduction to the accusation in $v 20$ has the effect of making the word of Yahweh in v 19a a word of Elijah. Given the thrust of DTR's redactional procedure observed so far this is out of character. In short it looks as though $1 \mathrm{Kgs}$ 21:20 was added by a later Dtr who noticed there was no

indicates it is a later appendage. It is possible the king referred to was the king of Edom (cf. B. Alfrink, "L’Expression sakab cim 'abotãyw," Oudtestamentische Studiën 2 [1943] 106-118, in particular p. 112).

${ }^{96} \mathrm{Cf}$. Hans-Christoph Schmitt, Elisa. Traditionsgeschichtliche Untersuchungen zur vorklassischen nordisraelitischen Prophetie (Gütersloh: Mohn, 1972) 50. Schmitt thinks that 1 Kings 20 and 22 were linked before their inclusion in Kings and were part of a collection of War Narratives which included 2 Kgs 3:4-27; 6:24-7:20. Cf. also Schüpphaus, Richter- und Prophetengeschichten, 58. The later insertion of 1 Kings 20 and 22 is also supported by Jones, 1 and 2 Kings II, 339; Miller, "The Fall," 313. The stories originally referred to an unnamed king of Israel, who was identified as Ahab when they were included (cf. $1 \mathrm{Kgs}$ 20:2,13, 14; 22:20). McKenzie ("The Prophetic History," 211-13) includes 1 Kings 20 and 22 in his pre-dtr prophetic history. In view of the analysis given here this is unacceptable.

${ }^{97}$ Dietrich (Prophetie und Geschichte, 48-51, 120-22) assigns $1 \mathrm{Kgs} 21: 19 \mathrm{~b}$, $20 \mathrm{~b} \beta-24 ; \quad 22: 38$ and the insertion of 1 Kings 20 and 22 to DtrP. This overlooks the distinction between the prophecy on the fate of the house of Ahab (vv 21-24) and on his own fate (v 19b). Würthwein (1. Kön. 17-2. Kön. $25,262)$ regards all of $1 \mathrm{Kgs} 17: 1-22: 38$ as a later insertion in DtrH. The LXX has 1 Kings 20 and 22 after 1 Kings 21 . This receives support from the introduction to 1 Kings 22 (cf. Jones, $I$ and 2 Kings II, 360). However the MT order has been defended by D. W. Gooding, "Ahab According to the Septuagint," ZAW 76 (1964) 269-79.

${ }^{98} \mathrm{It}$ occurs in $1 \mathrm{Kgs} 21: 25$ and $2 \mathrm{Kgs} 17: 17$. The first text is fairly obviously a later der comment appended to the prophecy. $2 \mathrm{Kgs} \mathrm{17:17}$ is part of a later dtr reflection on the northem exile (sec below). Deut 28:68 uses the verb to describe Israelites selling themselves as slaves. 
explicit accusation against Ahab of having done evil. The accusation required a new introduction after $v 19 \mathrm{a}$, and one may surmise that the similar encounter between Ahab and Elijah in $1 \mathrm{Kgs}$ 18:17-19 supplied the model for composing the introduction. ${ }^{99}$

There is no need to dwell on $1 \mathrm{Kgs} 21: 25-26$, which is generally accepted as a late summary of Ahab's evils appended to Elijah's prophecy. ${ }^{100}$ With 1 Kgs 21:27-29 opinion ranges from an carly or pre-dtr date through to a late or post-dtr date. ${ }^{101}$ An inspection of the language does not give any clear indication that it is a dir composition. ${ }^{102}$ Nor is there convincing evidence that it is post-dtr. An argument in favor of such a provenance has been that the text shows evidence of the Chronicler's doctrine of individual retribution. ${ }^{103}$ This is inaccurate. The focus of the prophecy is not the advent of evil upon Ahab himself but upon his house. In short there seems nothing against accepting a pre-dtr provenance for the pericope. It is unlikely DTR would have inserted a report of Ahab's humility. By the same token it would not have disturbed the conceptual plan of DtrH or the prophecy-fulfillment schema. The passage is not included by Campbell in the Prophetic Record.

${ }^{99} 1 \mathrm{Kgs} 18: 18 \mathrm{~b}$ looks to be a dtr addition. The accusation of forsaking Yahweh has already been seen to be characteristic of later dtr redaction. Here it is the accusation of forsaking Yahweh's commandments, one which is made against Israel in $2 \mathrm{Kgs} \mathrm{17:16.}$

${ }^{100}$ Cf. Bohlen, Der Fall Nabot, 318-19; Dietrich, Prophetie und Geschichte, 36; Gray, I \& II Kings, 443; Hentschel, 1 Könige, 128; Jones, 1 and 2 Kings II, 351-52; Mayes, The Story of Israel, 114; Montgomery, Kings, 332; Timm, Die Dynastie Omri, 130; Würthwein, 1. Kön. 17-2. Kön., 252.

${ }^{101}$ It is regarded as early by G. Fohrer, Elia (ATANT 53; Zürich: Zwingli, 1957) 28-29; Hentschel, Elijaerzählungen, 20, 36-40; Schüpphaus, Richterund Prophetengeschichten, 63; Steck, Elia-Erzählungen, 43, 45-48. It is regarded as a dtr composition by Hoffmann, Reform und Reformen, 177-78; Schmitt, Elisa, 135. It is regarded as post-dtr by Bohlen, Der Fall Nabot, $304-$ 9; Jepsen, "Ahab's Busse. Ein kleiner Beitrag zur Methode literarhistorischer Einordnung," Archäologie und Altes Testament. Festschrift für K. Galling (ed. A. Kuschke and E. Kutsch; Tübingen: J. C. B. Mohr, 1970) 145-55; Miller, "The Fall," 310; Timm, Die Dynastie Omri, 130-31.

${ }^{102}$ There are two possibilities for dtr composition. In $v 27$ Ahab rends his clothes on hearing the word of the Lord. Josiah does the same in $2 \mathrm{Kgs} 22: 11$. However Ahab's rending of his clothes is only one among a number of dramatic pentitential gestures. His fasting recalls David in 2 Sam 12:15. His sackcloth

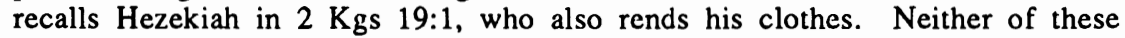
texts are dtr. No doubt such gestures were traditional in Israel and cannot in themselves give an indication of dtr authorship. Secondly, in $v 29$ there is the

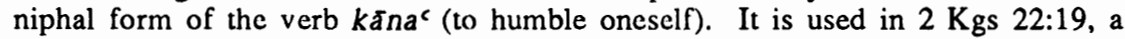
dtr text, to describe Josiah. This could suggest that the portion of the prophecy dealing with Ahab's humility is a dtr addition, but one could also argue that the Josian text was dependent on the (pre-dtr) $1 \mathrm{Kgs} \mathrm{21:27.}$

${ }^{103}$ On this see Jepsen, "Ahab's Busse," 150 . Jepsen's analysis is dominated by the material he takes from Chronicles. 
But it may well have been added at the pre-dtr stage in order to bring the report of Ahab's peaceful death in $1 \mathrm{Kgs} 22: 40$ within the prophetic compass. ${ }^{104}$

\section{JEHU TO HOSHEA}

As outlined earlier the judgment formulas for the northern kings from Jehu (2 Kgs 10:29) to Hoshea (2 Kgs 17:2) contain a number of distinctive features which lead Campbell to propose that they belonged to a subsequent northern expansion of the Prophetic Record. This leaves the following passages as the most likely candidates for dtr commentary: $2 \mathrm{Kgs} \mathrm{10:31;} \mathrm{13:3-6,} \mathrm{23;} \mathrm{14:26-}$ 27. As well as these there is the promise-fulfillment schema embracing the

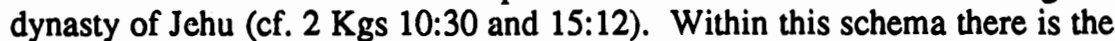

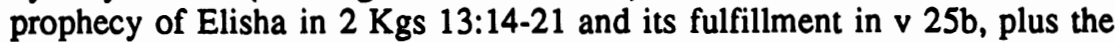

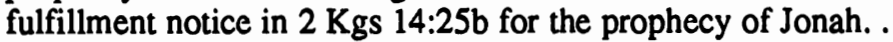

Despite the location of these texts in the account of Jehu's dynasty, there is no convincing evidence that one can assign any of them to DTR. On the broader contextual level the additions do not follow the pattern of DTR's redaction observed so far for the northern kings. There seems to have been no attempt to connect the judgment formulas with the prophecies, as was the case with DTR's treatment of the earlier dynasties. The two components are quite independent of one another. ${ }^{105}$ This initial impression can be confirmed by a closer examination.

To take the promise-fulfillment schema first of all (cf. $2 \mathrm{Kgs} \mathrm{10:30;}$ 15:12), there are a number of features which distinguish it from DTR's own prophecy-fulfillment schema. The introduction to $2 \mathrm{Kgs} \mathrm{10:30} \mathrm{is} \mathrm{not} \mathrm{the}$ same as other prophecies in DtrH. ${ }^{106}$ Nor is the dynasty of Jehu described as a

${ }^{104}$ The whole complex of Elisha traditions cannot be investigated here, but it is quite probable that they were a later addition to $\mathrm{DtrH}$, and in more than one stage. For a concise discussion see Würthwein (1. Kön. 17-2. Kön. 25, 36668) who follows Schmitt. This would mean that the only reference to Elisha in DtrH was in $2 \mathrm{Kgs} \mathrm{9:1.} \mathrm{The} \mathrm{rather} \mathrm{abrupt} \mathrm{introduction} \mathrm{of} \mathrm{Elisha} \mathrm{here} \mathrm{is} \mathrm{not}$ problematic. Indeed it is all the more intelligible if the account of the anointing of Jehu came from the circle of his disciples, who would have thought he needed no such introduction. Note the similar abrupt introduction of Elijah in $1 \mathrm{Kgs} 17: 1$.

${ }^{105}$ This is evident in $2 \mathrm{Kgs} 10: 31$ which was a later attempt to reinforce the judgment formula of $v 29$ against the thrust of the prophecy in $v 30$. One would have expected the prophecy after $v 28$, to be followed by a suitable judgment formula. M. Rehm (Das zweite Buch der Könige: ein Kommentar [Würzburg: Echter, 1982] 110) regards $v 29$ as a later insertion into vv 28-31. However the nomistic language of $v 31$ shows that it is later than $v 29$. J. Robinson (The Second Book of Kings [Cambridge Bible Commentary; Cambridge: CUP, 1976] 103) considers vv 30-31 to be earlier than vv 28-29.

${ }^{106} \mathrm{~A}$ direct address by $\mathrm{Y}$ ahweh rather than via a prophet is unusual but tolerable given Yahweh's address to Solomon in 1 Kings 9. For the house of Baasha DTR introduced the prophet Jehu ben Hanani (1 Kgs 16:1-4), presumably a figure from the tradition. There may have been no such prophet to associate

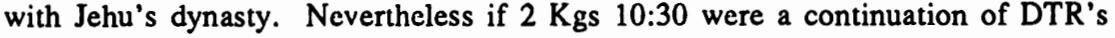


"house", as is the case with the preceding dynasties. Within the promise itself the combination of the verbs "to do well" and "to do right" is not found elsewhere in DtrH. ${ }^{107}$ Finally, the fulfillment notice in $2 \mathrm{Kgs} \mathrm{15:12}$ falls outside the regnal framework and is formulated differently to DTR's own notices. ${ }^{108}$ These differences cannot be explained away by appeal to the fact that, unlike the preceding dynasties, the dynasty of Jehu was not condemned. The concern, like that of DTR, was to accommodate the dynasty of Jehu within a schema of promise-fulfillment. However the differences point to a later redactor who extended DTR's schema to cover this dynasty. The judgment formula in $2 \mathrm{Kgs} \mathrm{10:31} \mathrm{was} \mathrm{added} \mathrm{subsequently} \mathrm{in} \mathrm{order} \mathrm{to} \mathrm{reinforce}$

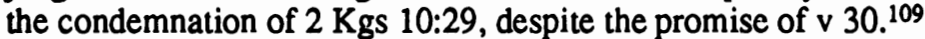

The next addition occurs in $2 \mathrm{Kgs} 13: 3-6 .{ }^{110}$ The tension created with vv 7 and 22 by $v 5$ is an initial indication of a later addition. But what makes it

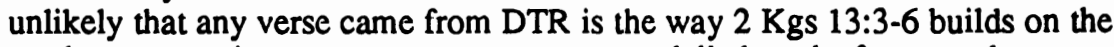
northern expansion to create a commentary modelled on the framework pattern for the judges' period. There is the basic accusation of infidelity from the northern expansion in $v 2$. This is followed by a report of Yahweh's anger ( $v$ $3 a)$, oppression by encmies ( $v 3 b)$, cry to Yahwch ( $v 4)$, appearance of a savior ( $v 5 a)$, period of rest $(v 5 b)$, and further infidelity $(v 6)$. This is quite out of context in terms of the conceptual plan and structure of DtrH.

Attention may also be drawn to a number of other factors. $2 \mathrm{Kgs} \mathrm{13:3} \mathrm{has}$ been attached secondarily to the northern expansion's judgment formula in $\mathbf{v} 2$. The former reports Yahweh's anger against Israel, whereas in $v 2$ Jehoahaz is the guilty party. This shift from king to people has been noted throughout the analysis as a feature of later redaction. Verse 4 uses the verb hălâ to describe

schema one would have expected an introduction such as "The word of the Lord came to Jehu ....".

${ }^{107}$ The verb "to do well" ( $t \sigma b$ in the hiphil) occurs in $1 \mathrm{Kgs} \mathrm{8:18.} \mathrm{The} \mathrm{verb}$ "to do right"occurs in a number of the judgment formulas for Davidic kings. The reference to the house of Ahab is tautological and may be a later addition (so Jones, 1 and 2 Kings $I I, 473$ ).

${ }^{108}$ There is no "according (kidbar) to the word of the Lord" as found in $1 \mathrm{Kgs}$ $14: 18 ; 15: 29 ; 16: 12$. Also none of these notices have the final "and so it came to pass".

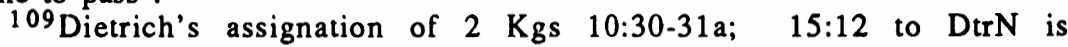
unacceptable (Prophetie und Geschichte, 34). The only nomistic evidence in these verses occurs in the judgment formula of $v 31$.

${ }^{110} 2 \mathrm{Kgs} \mathrm{13:3,7}$ is included by Campbell in the northern expansion (Of Prophets and Kings, 158-59). However the phrase "the anger of the Lord was kindled against Israel" ( $v$ 3) occurs principally in dtr passages: cf. Judg 2:14 and 10:7 (DTR), and in Josh 23:16 and 2 Kgs 23:26 (later dtr). It occurs also in Deut $6: 15 ; 7: 4,11,17 ; 29: 26 ; 31: 17$. There are two pre-dtr occurrences in

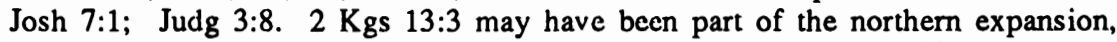
but my examination of vv 3-6 suggests it belongs to the later addition. A more suitable notice of Syrian oppression occurs in $v 22$. This verse, which is now located in a context concerned with Jchoahaz's son Joash, may have originally stood after 13:2 in the northern expansion and been followed by $v 7$. Some further comment on the location of $v 22$ will be given in the discussion of Elisha (2 Kgs 13:14-21). 
Jehoahaz's cry, whereas in the judges' period we find $z \bar{a}{ }^{\varsigma} a q$ (Judg 3:9, 15; 6:6, 7). ${ }^{111}$ Similarly v 5 speaks of Yahweh giving (nātan) a savior, whereas Judg $2: 16,18 ; 3: 9,15$ speak of him raising up (qûm) a savior. ${ }^{112}$ Verse $5 \mathrm{~b}$ also does not use the terminology of rest found in Judg $3: 11,30 ; 4: 31 ; 8: 28$. Verse 6 can be taken in this context as paralleling the judges' pattern where Israel lapses into sin once again. It has borrowed from the judgment formula in $v 2$, but directs the accusation against Israel. ${ }^{113}$

The context suggests a reason for the unusual use of the judges' framework here. It records a steady decline of the northern monarchy after Jehu and a hardening of the kings in the sin of Jeroboam. The reign of Jehoahaz reports the first oppression suffered by the northern monarchy. At this point $2 \mathrm{Kgs}$ 13:3-6 was inserted to provide an example of Yahweh's mercy to those who call on him for help. As in the judges' period Yahweh showed that he would come to the aid of a sinful people when they cried to him, and send them a savior. However Israel failed to heed the moral of the judges' period, or the example of Jehoahaz. The nature of this addition indicates it was made independently of the one in $2 \mathrm{Kgs} \mathrm{10:30-31.}$

The rest of 2 Kings 13 has a number of problem areas. The conclusion of Joash's reign in $2 \mathrm{Kgs} 13: 12-13$ is repeated in 14:15-16. 2 Kgs 13:14-19 (2021) locates the story of Joash's encounter with the dying Elisha after the report

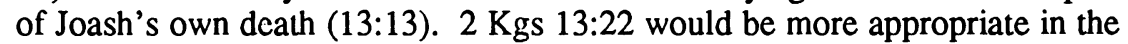
account of Jehoahaz. Finally, $\vee 25$ locates a report of Joash's victories after the report of his death. A detailed discussion of these problems is clearly beyond the scope of this study. The following observations are therefore offered as a tentative explanation of how the present order came about.

The principal cause of the present order was the insertion of the story of Elisha's illness and death in $2 \mathrm{Kgs} 13: 14-21 .{ }^{114}$ This led to the relocation of $v$ 22 , originally positioned after $\mathrm{v} 2$, in order to provide a suitable introduction to vv 24-25. The purpose of vv 24-25 was to illustrate the fulfillment of Elisha's prophecy of three victories ( $v 19, \mathrm{cf} . \mathrm{v} 25 \mathrm{~b}){ }^{115}$ This sequence was

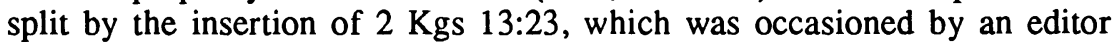
noting the name of Jehoahaz in $\mathrm{v} 22$. This led the editor to reaffirm the message of the already inserted $2 \mathrm{Kgs}$ 13:3-6 which reported Yahweh's mercy

${ }^{111}$ Note too that it is Jehoahaz who cries to Yahweh, whereas in the judges' period it is always Israel.

${ }^{112}$ D. J. McCarthy (" 2 Kings 13:4-6," Bib 54 [1973] 409-10) proposed that the mention of a savior was occasioned by the note about Yahweh's anger in $v$ 3. However he does not explain why the term savior was used. The recognition of the use of the Judges' framework resolves that question. Attempts to identify the savior have not proved successful and there is no point speculating on it here (cf. Jones, 1 and 2 Kings II, 499-500).

${ }^{113}$ The singular halak in $v 6 \mathrm{a}$ is corrected to the plural in accord with the versions (cf. Barthélemy, Critique textuelle de l'Ancien Testament 1, 401-2).

${ }^{114}$ The secondary nature of $2 \mathrm{Kgs} 13: 14-21$ in relation to $\mathrm{DtrH}$ is proposed by Schmitt, Elisa, 132-33. Cf. also Würthwein, 1. Kön. 17-2. Kön. 25, 36668 .

${ }^{115}$ The relocation of $2 \mathrm{Kgs} 13: 22$ was probably carried out before the insertion of $2 \mathrm{Kgs} \mathrm{13:3-6.}$ 
during this king's reign. ${ }^{116}$ The final piece of editing was the addition of elements of the regnal framework in $2 \mathrm{Kgs} \mathrm{13:12-13.117}$

$2 \mathrm{Kgs} 14: 25-27$ can be divided into two sections: v 25 and vv 26-27. 2 Kgs 14:25 is made up of a report of Jeroboam II's success (v 25a) and an interpretation of it as a fulfillment of prophecy ( $v 25 \mathrm{~b}$ ). This notice is formulated in the same way as the ones by DTR. What is missing is the corresponding prophecy, a lacuna which suggests it is an isolated entry rather than part of DTR's prophecy-fulfillment schema. $2 \mathrm{Kgs} 14: 26-27$ is best seen as an attempt to come to grips with the significance of $v 25$. It does so by drawing on the themes in $2 \mathrm{Kgs} \mathrm{13:3-6}$ of God's mercy for an afflicted people and their deliverance via a savior. The savior in this case was Jeroboam II who restored Israelite territory in accord with the word of the Lord. The thematic association between $2 \mathrm{Kgs}$ 13:3-6 and 14:26-27 has long been recognized but it is doubtful whether the two texts can be attributed to the same author. ${ }^{118}$

On the basis of this analysis the later redaction of the Jehu dynasty cannot be attributed to one hand. What does unite the passages however is their common interest in the fortunes of Israel under the dynasty of Jehu. The absence of any redactional contribution by DTR may be explained in terms of the conceptual plan and structure of DtrH. The judgment formulas of the northern expansion linked the kings from Jehu to Hoshea with DTR's overall condemnation of the northern kings. This is evident in the repeated accusation that these later kings did not depart from the sin of Jeroboam. Hence they

${ }^{116} \mathrm{Cf}$. Jones, 1 and 2 Kings II, 505. The editor reaffirmed the earlier report, but in terms of Yahweh's covenant with the patriarchs. This shift may have been due to an inability to identify the savior of $2 \mathrm{Kgs} 13: 3-6$. Rehm (2 Könige, 135) sees Priestly influence in $2 \mathrm{Kgs} \mathrm{13:23} \mathrm{(cf.} \mathrm{Exod} \mathrm{2:24;} \mathrm{6:4;} \mathrm{Lev}$ 26:42). Dietrich (Prophetie und Geschichte, 34-35, n. 51) assigns it to DtrN.

${ }^{117}$ Hence $2 \mathrm{Kgs} 14: 15-16$ was the original notice. This is the weakest part of the explanation proposed. It is difficult to see why an editor should have closed the account of Joash with $2 \mathrm{Kgs} 13: 12-13$, unless it was to associate the

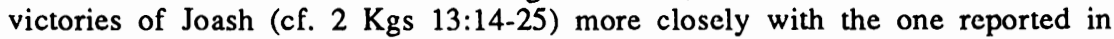

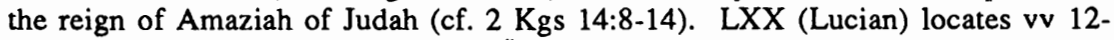
13 at the end of 2 Kings 13 (cf. Sanda, Die Bücher der Könige II, 154).

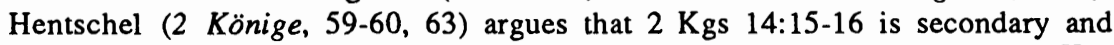
arose out of a desire to relocate $2 \mathrm{Kgs} 14: 8-14$, which originally preceded $2 \mathrm{Kgs}$ $13: 12-13$. A difficulty with this is that one must posit some editing in the relocation process, namely the reference to Edom in $v 10$. This is necessary because of $2 \mathrm{Kgs} 14: 7$. It also does not account for the location of $2 \mathrm{Kgs}$

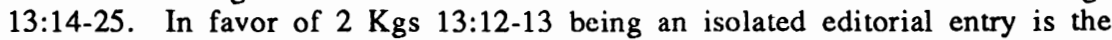
unique statement that Jeroboam II "sat upon his throne". This does not occur in any other accession formula.

${ }^{118} 2 \mathrm{Kgs} 14: 26-27$ uses different terminology to $2 \mathrm{Kgs} 13: 3-6$ and appears to come too late for the author of $2 \mathrm{Kgs} 13: 3-6$. But it does look to be an attempt to identify Jeroboam II as the anonymous savior in the earlier text. Those who accept unity of authorship are for example, Sanda, Die Bücher der Könige 1I, 173; and more recently Rehm, 2 Könige, 144, Dietrich, Prophetie und Geschichte, 34-35, n. 51 (DtrN), Jaques Briend, "Jéroboam II, saveur d'Israel," Mélanges bibliques et orientaux en l'honneur de M. Henri Cazelles (AOAT 212; Neukirchen-Vluyn: Neukirchener Verlag, 1981) 41-49. 
were able to be accommodated within the fulfillment of prophecy in $2 \mathrm{Kgs}$ $17: 23$. DTR may also have refrained from encasing the Jehu dynasty in a prophecy-fulfillment schema because there was no record in the Prophetic Record or northern expansion of the climination of the house of Jehu. ${ }^{119}$

\section{KINGS 17}

This chapter is made up of a report of the northern exile in vv 1-6, a long reflection in vv 7-23 on why the exile happened, a report in vv 24-34a on the post-exilic situation in the north, and a concluding comment in vv $34 \mathrm{~b}-41$. The most important section in relation to the dtr redaction is vv 7-23. This is a complex passaage which has generated a variety of explanations. However the hypothesis of a northern expansion which concluded with $2 \mathrm{Kgs} \mathrm{17:1-6,}$ $20-21,23 \mathrm{~b}$ enables a clearer perception to be gained of the way this section was put together. 120

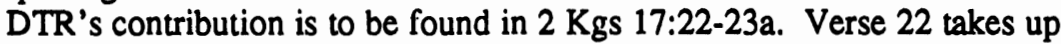
the accusation of the northern expansion in $v 21$ but with recognizable differences. In $\vee 22 a$ the peoplc arc accused of walking in the sins of Jeroboam. This metaphor was used consistently by DTR in the judgment formulas for the northern kings, but only once by the northern expansion. ${ }^{121}$

$1192 \mathrm{Kgs} 15: 10$ records only the assassination of Zechariah. The Prophetic Record records the destruction of the houses of Jeroboam (1 Kgs 15:29a), Baasha (16:11), and Ahab (2 Kgs 10:11, 17).

${ }^{120} \mathrm{Cf}$. Campbell, Of Prophets and Kings, 161. $2 \mathrm{Kgs} \mathrm{17:1-6}$ is the report of the exile, with $v 2$ the judgment formula for Hoshea. Verse 20 is a doublet of $\mathbf{v}$ 18a which is the conclusion to the later dtr reflection beginning in $v 7$ (see below). In v 20 the verb ma'as (reject) occurs in the Prophetic Record (1 Sam $15: 23,26 ; 16: 1,7)$, while the phrase zera' yiśra'el (descendants of Israel) occurs only here in Samuel-Kings. The term "spoilers" (sossim) occurs in Judg 2:14, 16 (dtr) and $1 \mathrm{Sam}$ 14:48 (non-dtr), but such limited distribution contributes little in itself to the identification of authorship. Verse 21 recalls the schism in the kingdom recounted in the Record, and the northern expansion's conviction that it was the pervasive influence of the sin of Jeroboam which brought Israel down (cf. the judgment formulas). The concluding statement in $\vee 23 \mathrm{~b}$ contains no dtr terminology. The evidence of pre-dtr material in $2 \mathrm{Kgs} \mathrm{17:7-23} \mathrm{has} \mathrm{been}$ little explored. One exception is Gustavo Bacna, "El vocabulario de II Reyes 17, 7-23," EstBib 32 (1973) $357-84$ and "Caracter literario de II Reyes 17, 7. 23," EstBib 33 (1974) 5-29. For Baena vv 7-23 were composed in a period when Deuteronomy was emerging, but pre-dtr. He would see some dtr terminology in vv 18-20, 23a ("El vocabulario," 378; "Caracter," 9). Unfortunately Baena relies too much on Jepsen's redaction history schema (cf. Die Quellen des Königsbuches) and on Eissfeldt's source analysis of the Pentateuch. Campbell's northem expansion plus dtr redaction provides a more satisfactory account of the literary evidence.

${ }^{121}$ In the judgment formula for Jchoahaz in $2 \mathrm{Kgs} \mathrm{13:2.} \mathrm{Even} \mathrm{here} \mathrm{the}$ expression is different, using 'ahar (after) rather than be (in) as in DTR's formulas. There is a shift from "great $\sin$ " in v 21 to "all the sins" in v 22. DTR's use of the term "sin" instead of "way" was occasioned by the reference to "great $\sin$ " in the northern expansion. 
It emphasizes the complicity of the people in perpetuating the sin of Jeroboam. They were as guilty as each of the kings condemned in the judgment formulas. ${ }^{122}$ The accusation in $v 22$ justifies Yahweh's response in v 23a, which is then followed by the fulfillment notice. ${ }^{123}$ This notice is an integral part of DTR's conceptual plan and structure. Because of the sin of Jeroboam the ultimate fate of the northern kingdom had to be the same as that of the northern dynasties which had been condemned by the prophets. This was in fact spelt out in the prophecy of $1 \mathrm{Kgs} 14: 16$. Hence $2 \mathrm{Kgs} 17: 23$ contains a fulfillment noticc vindicating the condemnation of "all his servants the prophets" and extending it to cover the fate of the kingdom itself.

The northern expansion's conclusion has the basic sequence of verdict $(v$ 21 ) followed by the sentence of exile ( $v 23 b)$. DTR's sequence is the same but it sharpens the guilty verdict against the people ( $v 22$ ) and states that the sentence was executed by Yahweh himself ( $v 23 a)$. This element is not explicit in the northern expansion's $v 23 b .124$

$2 \mathrm{Kgs} \mathrm{17:7-19}$ was not part of DtrH. First of all, it does not mention the sin of Jeroboam at all as the cause of Israel's demise. Second, even though the pericope sets out to review Israel's sinfulness from the Exodus on (cf. v 7) it focuses exclusively on the people's evils with no reference to the influence of the kings. ${ }^{125}$ A similar shift from king to people has been observed previously in a number of passages identified as later redaction (cf. 1 Samuel

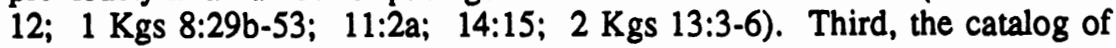

${ }^{122}$ This is brought out also by the way DTR has taken the phrase "he did not depart from it" from the northem expansion's judgment formulas on the kings and applied it to Israel-_"they did not depart from it".

${ }^{123}$ Note that $v 23$ a speaks of removal from Yahweh's sight, whereas v 20 speaks of casting off. DTR's expression was taken up by later dtr redaction in 2 Kgs 17:18; 23:27; 24:3.

${ }^{124}$ This analysis is in disagreement with Noth (The Deuteronomistic History, 136, n. 60) who assigned vv 7-20 to DTR and 21-23 as later, and Nelson (The Double Redaction, 55-63) who assigns vv 7-20, 23b to an exilic redactor, and vv $21-23 a$ to a still later editor. For Nelson DTR's comment on the northern exile is found in $2 \mathrm{Kgs} 18: 12$. The problem with $2 \mathrm{Kgs} 18: 12$ is that it contains the accusation that the people "did not listen", a phrase which Nelson assigns elsewhere to the exilic redactor (cf. p. 51). It also refers to transgressing the covenant, the same phrase found in Josh 23:16, which has been shown to be later than DTR. The analysis here is also in disagreement with Dietrich (Prophetie und Geschichte, 45-46, 138) who assigns 2 Kgs 17:711, 20 to DtrH, 12-19 to DtrN, and 21-23 to DtrP. Pauline A. Viviano ("2 Kings 17: A Rhetorical and Form-Critical Analysis," CBQ 49 [1987] 548-59) argues that the chapter is a unified literary whole from DTR. Her observations on the organization of vv $7-19$ are helpful, but she overlooks the differences between these verses and vv 21-23 (pp. 553-54).

${ }^{125}$ The reference to kings in $v 8 \mathrm{~b}$ is a later gloss. Cf. Burney, Notes, 332; also Gray, I \& II Kings, 646; Hentschel, 2 Könige, 79; Jones, 1 and 2 Kings II, 549; Wurthwein, 1. Kön. 17-2. Kön. 25. 392. The phrase, which is somewhat obscure, was probably added by an editor who noted the absence of any reference to kings. 
Israel's sins is taken as much from the story of Judah as that of Israel. ${ }^{126}$ Only Judah is accused of setting up pillars and Asherim on the high places and burning incense there (vv 9-11, cf. 1 Kgs 14:23; 22:43; 2 Kgs 12:4 [RSV $12: 3] ; 14: 4 ; 15: 4,35 \mathrm{a})$. Only Davidic kings and Judeans are accused of worshipping the host of heaven, of passing sons through fire and of using divination and sorcery (vv 16-17, cf. $2 \mathrm{Kgs} \mathrm{16:3;21:6;23:10} \mathrm{[any} \mathrm{Judean]).}$ The free mingling of northern and southern abuses in a reflection on the fall of the northem kingdom places the pericope somewhat at odds with the context of $\mathrm{DtrH}$. Fourth, the role of the prophet in vv 13-14 is that of a preacher of the law. This is not the understanding of DTR, who cast the prophets as figures who intervened to authoritatively interpret the course of Israel's history within a schema of prophecy and fulfillment. ${ }^{127}$ Fifth, the passage contains nomistic language in vv 13 and $15 .{ }^{128}$

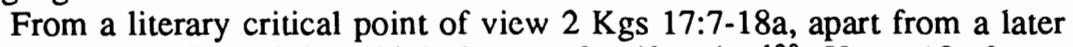
insertion in $v 12$, exhibits a high degree of uniformity. ${ }^{129}$ Verse $18 \mathrm{a}$ forms the apodosis of a long sentence whose protasis is in $v 7 .{ }^{130}$ The argument develops in the following manner: catalog of sins (vv 9-12); divine intervention via prophetic warning ( $v$ 13); rejection of warning (vv 14-15a); second catalog of sins ( $v v 15 \mathrm{~b}-17)$; divine intervention ( $\mathrm{v} 18 \mathrm{a})$. The second catalog gives the impression of being more polemical, building to a climax in $v 17$. Yahweh's reaction, which follows immediately in $v 18 \mathrm{a}$, is therefore completely justified. ${ }^{131}$ In the light of this the comment on Judah in v 19 is clearly a later appendage. This in turn indicates the mention of Judah in vv 13 and $18 \mathrm{~b}$ are also additions. ${ }^{132}$ All three additions were made by an editor who noted the presence of Judean sins in the catalog of vv 7-11 and 15b-17, and sought to make the passage address the story of Judah more explicitly.

${ }^{126}$ This was observed by Benzinger, Die Bücher der Könige, 174. Cf. also Burney, Notes, 331, and more recently Viviano ("2 Kings 17," 552).

${ }^{127}$ Dietrich (Prophetie und Geschichte, 42, n. 80) sees this as evidence of DtrN. O. H. Steck sees a connection between the portrait of the prophet as rejected preacher in these verses and the development of the theme of Israel's rejection and persecution of Yahwch's prophets in later Israelite tradition (cf. Neh 9:26). The tradition focused on Jeremiah as a prime example of such a prophet (cf. Israel und das gewaltsame Geschick der Propheten. Untersuchungen zur Überlieferung des deuteronomistischen Geschichtsbildes im Alten Testament, spät Judentum und Urchristentum [WMANT 23; Neukirchen-Vluyn: Neukirchener Verlag, 1967] 70).

${ }^{128}$ There is also the presence of the verb "to forsake" in $v 16$, which has been shown to be a preferred term of later redaction.

${ }^{129}$ Verse $12 \mathrm{~b}$, like $\mathrm{v} 13$, contains a divine warning, but it refers only to the idols of $v 12 \mathrm{a}$. The more general thrust of $v 13$ suits the context better. Verse 12 may therefore have been added later to introduce the theme of idol worship.

${ }^{130}$ This was noted by Sanda, Die Bücher der Könige II, 220. Cf. also Montgomery, Kings, 468, Nelson, The Double Redaction, 55, Provan, Hezekiah, 71.

${ }^{131}$ Note that each divine intervention in $v v 13$ and $18 \mathrm{a}$ is preceded by the accusation of provoking Yahweh to anger (cf. vv 11 and 17). On the organization of the argument in vv 7-18 see Viviano, "2 Kings 17," 550-52.

${ }^{132}$ The mention of two calves in $v 16 \mathrm{a}$ is a later gloss (cf. Würthwein, 1 . Kön. 17-2. Kön. 25, 392). 
These observations on $2 \mathrm{Kgs}$ 17:7-19 indicate that it came from the nomistic stage of later redaction. Furthermore the carefully constructed argument of vv 7-11,13-18a matches the sort of compositional skill that was observed earlier in Joshua 23 and 1 Samuel 12. Like these passages $2 \mathrm{Kgs}$ 17:7-11, 13-18a looks to be the product of a highly skilled author working within the later nomistic stage of redaction. ${ }^{133}$ This is supported by the presence of a number of terms and phrases that are unique in Deuteronomy-2 Kings. ${ }^{134}$

$2 \mathrm{Kgs} \mathrm{17:24-41} \mathrm{is} \mathrm{also} \mathrm{a} \mathrm{later} \mathrm{addition,} \mathrm{but} \mathrm{independent} \mathrm{of} \mathrm{vv} \mathrm{7-19.} \mathrm{It} \mathrm{was}$

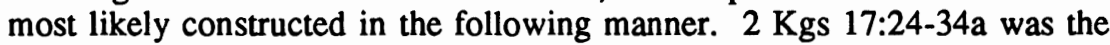
initial addition. The terminology and narrative style of this account shows that it is by a different author to the preceding material. ${ }^{135}$ Verses $24-28$ give

${ }^{133}$ Shemaryahu Talmon has argued that one should not make too sharp a distinction between authors, redactors and copyists in the composition of the OT ("The Textual Study of the Bible-A New Outlook," Qumran and the History of the Biblical Text [ed. F. M. Cross and S. Talmon; Cambridge: Harvard University, 1975] 321-400; see especially p. 336). According to Talmon an author could also function as a redactor, editor or copyist when the need arose. It is quite probable that Joshua 23; 1 Samuel 12; and $2 \mathrm{Kgs} \mathrm{17:7-11,13-18a}$ are examples of redactors from the nomistic stage of redaction composing more extensive texts.

${ }^{134}$ The phrase "to fear other gods" in $v 7$ is unique. The phrase "to fear Yahweh" is a feature of $2 \mathrm{Kgs}$ 17:24-41, which is a later addition (see below). In $v \vee 8,19$ the negative sense of "customs" is unique. In $\vee 9$ hapa (do secretly) is unique. In $v 11$ the verb gâla to describe the removal of nations is unique; the normal dtr verb is yaras. In v 13 the reference to "every prophet and seer" is unique. We may note also the verb ûd (warn-hiphil) occurs in 1 Sam 8:9, a secondary passage (cf. Jer $6: 10 ; 11: 7 ; 42: 19$ and Neh 9:26, 29, 30, 34). In v 14 "stiffen the neck" is unique as an accusation. It occurs as part of an exhortation in Deut 10:16. Cf. Jer 7:26; 17:23; 19:15; Neh 9:16, 17, 29. In v 15 the use of the verb "to reject" in relation to the covenant is unique, as is the verb habal (to be vain or false). The phrase in $v 15$ ba is an exact parallel to Jer 2:5.

${ }^{135}$ Mayes (The Story of Israel, 125-27) sees vv 24-34a as DTR's continuation of the report of the exile in vv 1-6. Verses $34 \mathrm{~b}-41$ are a later commentary by the same redactor responsible for vv 7-23. It is clear that $2 \mathrm{Kgs}$ 17:24 provides a narrative link with $\vee 6$, but this is insufficient to establish that vv 24-34a are from DTR. The phrase "to fear the Lord" is not found in other texts by DTR. It is peculiar to this passage (cf. vv $25,28,32,33$ ). It is used in combination with the command not to fear other gods throughout vv $34 \mathrm{~b}-41$. The "shrines of the high places" in $v 32$ does not occur in DtrH either (see chapter 7). John MacDonald ("The Structure of II Kings XVII," Glascow University Oriental Society Transactions 23 [1969-1970] 29-41) has pointed to a definite preference in vv 24-41 for the participial form of the verb. Narrative sequence is introduced by wayèhî or wayyihyú with the participle. This construction is not found elsewhere in DtrH, but is a feature of later hebrew narrative style with probable aramaic influence. He also notes the use of hem with the participle in vv 29,34,40,41, again a feature of later hebrew style. Mayes's assignation of vv 7-23 to later redaction obliges him, like Nelson, to 
an account of the return of an exiled priest in order to teach immigrants how to fear the Lord ( $v$ 28). Verses 29-34a report on the syncretism that developed in Samaria as a result of the priest's instruction. This looks like a thinly veiled attack on the northern priesthood. Indeed vv 32-33 suggest the situation in post-exilic Samaria was more disastrous for Yahwism than the one described in $1 \mathrm{Kgs} 12: 30-32$. $2 \mathrm{Kgs}$ 17:24-34a could therefore be the product of a hostile Jerusalem priesthood in the post-exilic period. However it is difficult to say whether it was directed against the Samaritan sect. ${ }^{136}$

$2 \mathrm{Kgs} 17: 34 \mathrm{~b}-40(41)$ is a subsequent addition, clearly dependent on vv 29 $34 \mathrm{a} .{ }^{137}$ This is evident in the way $\mathrm{v} 34 \mathrm{~b}$ links up with the preceding passage which was concerned with the practices of the immigrants, but also introduces a sermon on the covenant with Israel in vv 35-39. It is also evident in v 40b which forms a resumptive repetition with $\mathrm{v} 34 \mathrm{a}$. The main feature of the passage is the sermon on the covenant. However it contains a different assessment of the immigrant population to the preceding passage. In vv 29-34a they are described as syncretistic. In $v 34 \mathrm{~b}$ they are accused, along with Israel, of

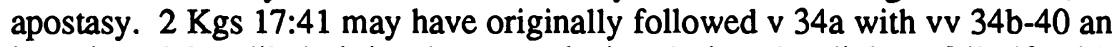
insertion. More likely it is a later conclusion designed to link vv $34 \mathrm{~b}-40$ with the preceding portrait of the syncretistic immigrant population. ${ }^{138}$

\section{THE DAVIDIC KINGS FROM REHOBOAM TO HEZEKIAH}

As with the analysis of the northern kings the task here is to distinguish DTR's contribution from pre-dtr material (Southern Document), and from later dtr additions. One would expect DTR's treatment of the Davidic kings to follow the same pattern as for the northern kings. That is, the judgment for-

take $2 \mathrm{Kgs} 18: 12$ as DTR's comment on the fall of the north. But this makes no reference to the sin of Jeroboam, and contains the accusation of not listening to Yahweh, a characteristic not of DTR but of later redaction (cf. Judg $2: 2,17 ; 6: 10 ; 1 \mathrm{Sam} 12: 15 ; 2 \mathrm{Kgs} 17: 14)$. Mayes identifies all of these other passages as later redaction.

${ }^{136}$ This was suggested by Burney, Notes, 333. However J. Purvis (The Samaritan Pentateuch and the Origin of the Samaritan Sect [Cambridge: Harvard U. P., 1968] 96) inclines against this view.

${ }^{137}$ This literary critical division goes back to Bernhard Stade, "Anmerkungen zu 2 Kö. 15-21," ZAW 6 (1886) 156-89; cf. pp. 167-70. In view of the analysis developed here $\mathrm{M}$. Cogan's proposal that $2 \mathrm{Kgs} 17: 34 \mathrm{~b}-40$ was an address by a Josianic Dtr is untenable ("Israel in Exile-The View of a Josianic Historian," 40-44). Viviano's observation on the structural similarities between $2 \mathrm{Kgs} \mathrm{17:1-6} \mathrm{(historical} \mathrm{notice),} \mathrm{vv} \mathrm{7-23} \mathrm{(comment)-vv} \mathrm{24-33} \mathrm{(historical}$ notice), vv $34-41$ (comment) is insufficient to establish unity of authorship ("2 Kings 17," 556).

${ }^{38}$ Noth regarded $2 \mathrm{Kgs} 17: 34 \mathrm{~b}-40$ as a later addition to $\mathrm{DtrH}$ (The Deuteronomistic History, 73, 137). Nelson (The Double Redaction, 63-64)

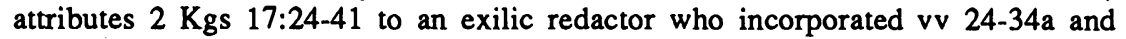
added the comment in vv 34b-40. Verse 41 was by a still later hand.

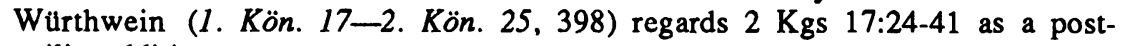
exilic addition. 
mulas for the Davidic kings from Rehoboam to Hezekiah should be integrated into the schema of prophecy and fulfillment.

With the first judgment formula in $1 \mathrm{Kgs} 14: 22-24$, Campbell assigns vv 22a, 23a to the Southern Document. ${ }^{139}$ This leaves vv 22b, 23b-24 as possible dtr redaction. $1 \mathrm{Kgs} 14: 22 \mathrm{~b}$ is unlikely to have come from DTR. It was observed in the discussion of the northern kings that DTR always formulated the accusation of provoking the divinity to anger with the verb $k \bar{a}^{\prime} a s$ rather than $q \bar{a} n \bar{a}^{\top}$ as here. ${ }^{140}$ The element of comparison with predecessors was used by DTR in $1 \mathrm{Kgs} \mathrm{14:9a} \mathrm{(Jeroboam);} \mathrm{16:30,} 33$ (Ahab); 22:54 (RSV 22:53 [Ahaziah]); 2 Kgs 3:2 (Jehoram). But the statement "in the sins which he/they sinned" never immediately followed the comparison

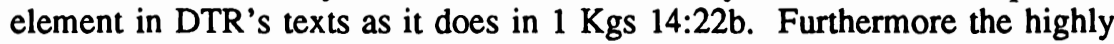
polemical atitude to the people's failings in $v 22 \mathrm{~b}$ is in keeping with other texts which have been found to belong to the nomistic stage of later redaction (cf. Josh 23:16; Judg 2:12-13, 17; 1 Sam 8:8; 12:1-25; 1 Kgs 14:15; 2 $\mathrm{Kgs}$ 17:7-19). Although the linguistic evidence is somewhat limited I would nevertheless judge there are sufficient grounds for including $v 22 \mathrm{~b}$ in this same stage of later redaction. ${ }^{141}$

${ }^{139}$ Campbell, Of Prophets and Kings, 179-80. Campbell notes there is nothing characteristically dtr about the triad, high places, pillars and Asherim (p. 179, n. 29). Cf. Deut 7:5; 12:3 (no mention of high places); 16:21-22. 1 Kgs 14:15 mentions only Asherim. $2 \mathrm{Kgs}$ 18:4a reports Hezekiah's removal of

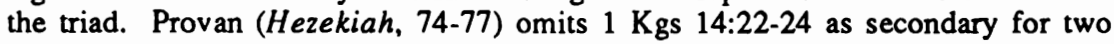
reasons. First, DtrH (ended at Hezekiah) was concerned with Yahweh worship at the high places, not worship of other gods (cf. also pp. 60-65). 1 Kgs 14:2224 describes the worship of other gods and so is unlikely to have been part of DtrH. Second, the present judgment formula replaced an original one which was directed against Rehoboam The first argument depends on the unity of authorship of the northern and southem judgment formulas. The special nature of the southern formulas between 1 Kings 22 and 2 Kings 15 shows that the author regarded worship of Yahweh on the high places as illegitimate. Against this unity of authorship there is the evidence assembled by Campbell. Furthermore, in order to maintain the interpretation of Yahweh worship at the high places Provan proposes some questionable literary critical excisions in 2 Kgs 16:2-4 and 18:4. It is possible the southern judgment formulas were concerned only with Yahweh worship at the high places, but to my mind the texts are such as to rule out a sure conclusion one way or the other. What makes Provan's omission of $v 23$ difficult to accept is that it is dependent on his reading of Rehoboam as the subject of $v 22$, following the LXX. This puts the plural of $v 23$ in conflict with $v 22$. To make such a judgment on the basis of a reconstructed original reading which is itsclf debatable is hazardous. Provan's omission of $v 23$ also leaves him without a reference point for the complaints against the people's worship at the high places.

${ }^{140}$ It does not occur in any other texts which can be claimed as DTR's. It occurs with káas as a word pair in Deut 32:16, 21; Ps 78:58. It occurs alone in $1 \mathrm{Kgs} \mathrm{19:10,14}$ in the sense of zeal for Yahweh.

${ }^{141}$ The accusation against the people is of course required by the context. The point being made here is that the polemical nature of the dtr additions is in keeping with the focus of later nomistic redaction. 
The phrase "on every high hill and under every green tree" in $1 \mathrm{Kgs} \mathrm{14:23b}$ can be taken as dtr. ${ }^{142}$ But it is possible the phrase is dependent on Jer 2:20, in which case it is difficult to attribute it to a Josianic Dtr. It is more likely to be from an exilic hand. ${ }^{143}$ Verse 24 , the final component of the judgment formula, consists of two elements. The first in v 24a claims there were cultic prostitutes in the land. ${ }^{144}$ It clearly prepares for the report of Asa's removal of them in $1 \mathrm{Kgs} 15: 12 \mathrm{a}$. Given that this report was part of the Southern Document, $1 \mathrm{Kgs} 14: 24 \mathrm{a}$ could have been inserted by DTR. ${ }^{145}$ It is a more matter of fact statement than the polemical $\vee 22 \mathrm{~b} .1461 \mathrm{Kgs} 14: 24 \mathrm{~b}$ matches the polemical anti-people attitude observed in $v 22 \mathrm{~b}$, and for this reason may also be assigned to a later Dtr. ${ }^{147}$

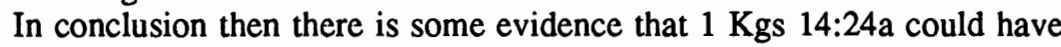
come from DTR. However contextual, and to a lesser extent linguistic, considerations indicate there is no compelling evidence that vv $22 \mathrm{~b}, 23 \mathrm{~b}, 24 \mathrm{~b}$ came from DTR. Certainly the general and polemical anti-people statements in vv 22b, (23b), 24b are not in keeping with what has been seen so far of DTR. These are more in tune with the work of later nomistic redaction. ${ }^{148}$

${ }^{142} \mathrm{Cf}$. Weinfeld, Deuteronomy and the Deuteronomic School, 322.

${ }^{143}$ William L. Holladay ("On Every High Hill and Under Every Green Tree," VT 11 [1961] 170-76) proposes that the saying originated with Hos 4:13, and was then taken up in Deut 12:2. Jer 2:20 represents the standardized form of the saying, with $1 \mathrm{Kgs} 14: 23$ and $2 \mathrm{Kgs} 17: 10$ identical to it in wording. $2 \mathrm{Kgs}$ 17:10 has already been established as later than DTR. $2 \mathrm{Kgs} 16: 4$ has a slightly different formulation, which Holladay sees as dependent on Deut 12:2, not Jer 2:20.

${ }^{144}$ Noth (Könige, 330) takes the singular qãdēs as a collective for both male and female cultic prostitution. Cf. also Jones, 1 and 2 Kings I, 277; Würthwein, 1. Könige 1-16, 182-83.

${ }^{145} \mathrm{On}$ the inclusion of $1 \mathrm{Kgs} 15: 12$ in the Southern Document see Campbell, Of Prophets and Kings, 181. The verb 'abar to describe Asa's reforming action in $1 \mathrm{Kgs} 15: 12 \mathrm{a}$ is not characteristically dtr. It is used in dtr texts to describe the rite of passing a child through fire (cf. $2 \mathrm{Kgs} 16: 3 ; 21: 6 ; 23: 10$. Cf. also Deut 18:10). Noth (Könige, 336) regarded v $12 \mathrm{a}$ as a source used by DTR.

${ }^{146}$ The introductory wegam is at times indicative of an addition, although not always. Its presence here in conjunction with the other evidence lends support to the verse being an addition. Taken on its own however the wëgam would only indicate something added to the Southern Document. A point against including $1 \mathrm{Kgs} 14: 24 \mathrm{a}$ in $\mathrm{DtrH}$ is that one might have expected DTR to integrate the entry more carefully into the judgment formula.

${ }^{147}$ The occurrences of the term "abominations" do not give a clear indication of provenance. It is found in Deut 18:9, 12;20:18; $2 \mathrm{Kgs} \mathrm{16:3b \beta ;21:11.2}$ $\mathrm{Kgs} 16: 3 \mathrm{~b} \beta$ is almost identical to $1 \mathrm{Kgs} 14: 24 \mathrm{~b}$. However the attachment of such a general statement to the preceding particular sin of $2 \mathrm{Kgs} \mathrm{16:3ba}$ is unusual. $2 \mathrm{Kgs} 21: 11$ is in a secondary passage, as will be shown in chapter 7 .

${ }^{148}$ There is one other dtr comment on the reign of Rehoboam in $1 \mathrm{Kgs}$ $14: 21 \mathrm{~b}$. Although it takes up an important theme of DtrH it does disturb the regnal framework. It may therefore have been inserted by a later hand (so Jones 1 and 2 Kings I, 276; Noth, Könige, 328; Würthwein, 1. Könige 1-16, 181). 
For the judgment formula on Abijam in $1 \mathrm{Kgs} 15: 3-5$ only $\mathrm{v} 3 \mathrm{a}$ is included in the Southern Document. ${ }^{149} 1 \mathrm{Kgs} 15: 3 \mathrm{~b}-4$ may be assigned to DTR. ${ }^{150}$ In $v 3 b$ the comparison with David as the model king clearly belongs to DTR's conceptual plan. The phrasing of the comparison is almost identical to DTR's comment on Solomon in $1 \mathrm{Kgs} 11: 4 \mathrm{~b}$. Verse 5 repeats this theme of David as model king but in terms which suggest it was a later attempt to spell out in what way David was wholly true to Yahweh. ${ }^{151}$ Verse 4 for its part functions as a verification of the prophecy in $1 \mathrm{Kgs} 11: 36$. The establishment of the dynasty's rule in Jerusalem despite the infidelity of Abijam testified that the promise won by David for his fidelity to Yahweh was still in place. Although it is not explicitly spelt out the reader senses a deliberate contrast with $1 \mathrm{Kgs}$ 14:16 where Ahijah prophesies the end of the northern kingdom because of the sins of Jeroboam.

A similar comment is made in $2 \mathrm{Kgs} 8: 19$. Here the contrast between the two kingdoms is brought out quite explicitly by DTR's use of "Judah", after the occurrence of "Israel" in v 18. Within the larger context one can see that

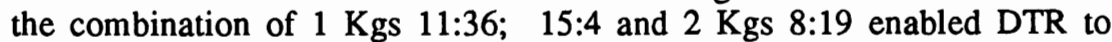
accommodate within a schema of prophecy and fulfillment (or verification) all the Davidic kings from Rehoboam to Hezekiah who are accused of evil. ${ }^{152}$ The son spoken of in $1 \mathrm{Kgs} 11: 36$ is Rehoboam. For Abijam there is $1 \mathrm{Kgs}$ 15:4, and for Jehoram $2 \mathrm{Kgs} 8: 19$. Ahaziah (2 Kgs 8:27) and Ahaz (2 Kgs $16: 2 \mathrm{~b}-4)$ were like Jehoram in that they walked in the way of the kings of Israel. Hence DTR's comment in $2 \mathrm{Kgs} \mathrm{8:19}$ was able to cover them as well. Ahaz's additional sin of worshipping at the high places (2 Kgs 16:4) may also be included within the horizon of the comment in $2 \mathrm{Kgs} \mathrm{8:19}$, since the kings of Israel were guilty of this in their perpetration of the sin of Jeroboam. ${ }^{153}$

${ }^{149}$ Campbell is cautious about including this comment in pattern B. It "is thoroughly uncertain in its attribution, but it is not impossible for it to be predtr" (Of Prophets and Kings, 180).

${ }^{150}$ Against Dietrich (Prophetie und Geschichte, 142), Hentschel (1 Könige, 95-96), Jones ( 1 and 2 Kings $I, 282$ ), Noth (Könige, 334), Würthwein (1. Könige $1-16,185$ ) who assign all of vv $3 b-5$ to a later Dtr.

${ }^{151}$ There is some evidence of nomistic language in the reference to commandments, but it is not strong. The rider about David's murder of Uriah in this verse has consistently been taken as a later gloss. Cf. Benzinger, Die Bücher der Könige, 99; Sanda, Die Bücher der Könige I, 383; Gray, I \& II Kings, 348, n. d; Noth, Könige, 334; Würthwein, 1. Könige 1-16, 184, n. 2. It is not in the LXX.

${ }^{152}$ Noted also by Nelson (The Double Redaction, 116-18) and Provan (Hezekiah, 95). Nelson ( p. 117) has also shown that Noth's proposal to read the $k \hat{1}$ at the beginning of $1 \mathrm{Kgs} 15: 4$ as causal, and therefore as indicative of a later addition, is incorrect (cf. Könige, 334). It was pointed out earlier that the

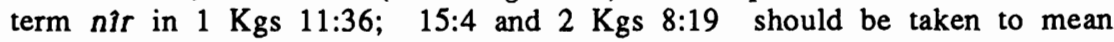
dominion rather than lamp.

${ }^{153}$ The judgment formula for Ahaz begins with the accusation that he did not do right and is then followed by the reference to the kings of Israel. With Jehoram (2 Kgs 8:18) and Ahaziah (8:27) this order is reversed, and the accusation of doing evil is used rather than not doing right. The different order 
Once the northern kingdom fell of course this contrast was no longer required. The trajectory of the prophecy in $1 \mathrm{Kgs} 11: 36$ is traced beyond this stage of the history by DTR in $2 \mathrm{Kgs} 21: 7 \mathrm{~b}$. Here once again the enduring nature of the promises made to David is confirmed, despite the infidelity of Manasseh.

Thus DTR adopted the same sort of procedure as for the northern dynasties. The judgment formulas for the Davidic dynasty are brought within the compass of the interpretative schema which DTR established in the redaction of Ahijah's prophecy. The judgment formulas for both northern and Davidic kings are therefore integrated into DTR's unified presentation of the history by being linked with the prophetic speeches, in particular the programatic speech of Ahijah in $1 \mathrm{Kgs} 11: 29-38^{*}$.

With the judgment formula for king Asa the verses claimed for the Southern Document are $1 \mathrm{Kgs}$ 15:11, 12a, 14a. ${ }^{154}$ This leaves vv 12b, 13, $14 \mathrm{~b}-15$. Verse $12 \mathrm{~b}$ contains the element of comparison with predecessors but it is unlikely to have come from DTR. The term for idols occurs elsewhere in texts which are secondary. ${ }^{155}$ Moreover although the evil "fathers" referred to are probably Abijam, Rehoboam and Solomon, there is no report of them making idols. The verse is best taken then as a later addition. ${ }^{156} 1 \mathrm{Kgs}$ 15:13 is a difficult verse to identify precisely. Its construction is unusual and suggests that a piece of information has been inserted into the text. ${ }^{157}$

of the formula for Ahaz was probably occasioned by the importance of this king in the Southern Document's series of judgment formulas. The principal concern was to contrast him with the reforming Hezekiah who "did what was right" (2 Kgs 18:3). This led to the use of the phrase "he did not do right"and its location at the head of the formula. The other concerns then followed, namely his sin of walking in the way of the kings of Israel (as did Jehorm and Ahaziah), and of worshipping on the high places. The location of the accusation that he did not do what was right was able thereby to include the two specific crimes.

${ }^{154}$ Campbell, Of Prophets and Kings, 180-82. Verses 11, 14a comprise the basic elements of the judgment formula (pattern B). Campbell thinks v 12a could well be pre-dtr and so be part of the Southern Document (cf. n. 145 above). Asa is the only reforming king besides Hezekiah in this sequence of Davidic kings. Given that Campbell includes Hezekiah's removal of the bronze serpent in $2 \mathrm{Kgs} 18: 4$ in the Document it would not be inappropriate to include $\checkmark$ 12a as a parallel report of Asa's reforms.

${ }^{155} \mathrm{Cf}$. Deut 29:16; $1 \mathrm{Kgs} 21: 26 ; 2 \mathrm{Kgs} 17: 12$, all of which have been identified as additions to DtrH. The secondary nature of the other occurrences in

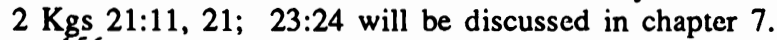

${ }^{156}$ So also $H$. Spieckermann, Juda unter Assur, 185, 412. It may be associated with later morc hostile additions against Solomon in $1 \mathrm{Kgs}$ 9:6-9 (plural); 11:5, 33 (plural).

${ }^{157}$ It is introduced by wègam, which can indicate the verse has been inserted into an existing context. The predicate is introduced by a waw consecutive after a preceding "accusativus pendens" with 'et. Burney (Notes, 139, 197) observed

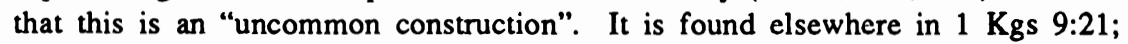
$12: 17 ; 2 \mathrm{Kgs} 16: 14$, none of which are dtr texts. 
Moreover it is not evidently dtr in its formulation. ${ }^{158}$ Hence it could have been added by DTR or a later editor. As a reform report it certainly does not disturb the portrait of Asa. ${ }^{159}$

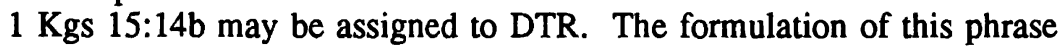
clearly recalls DTR's description of David in $1 \mathrm{Kgs} \mathrm{11:4}$ and 15:3b. Asa could not however be compared with David in the same way as Hezekiah and Josiah because of the complaint about high places in v 14a. Apart from this he was, like them, a king who promoted reform. The report in v 15 that Asa replenished the temple treasury is in keeping with the portrait of him as a

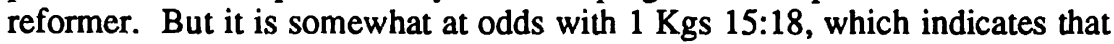
the temple treasury had not been replenished since Shishak's campaign in 1 Kgs 14:26. ${ }^{160}$ This makes distribution of the verse to DTR or a later editor somewhat uncertain.

In sum, the evidence for DTR's hand is strongest in $1 \mathrm{Kgs} 15: 14 \mathrm{~b}$. This addition had the effect of drawing a subtle yet positive comparison between Asa and David the model king. The provenance of vv 13,15 is not so clear, but their concern to enhance the portrait of Asa as a reformer (cf. vv 11-12a), and one who cared for the temple, suggests they could be from DTR. On the other hand it is fairly evident that $1 \mathrm{Kgs} 15: 12 \mathrm{~b}$ is a later addition

The judgment formula for Jehoshaphat in $1 \mathrm{Kgs} 22: 43$ contains no dtr additions to the Southern Document. ${ }^{161}$ There is the reference to his removal of cult prostitutes in $\vee 47$ (RSV $\vee 46$ ) but this occurs outside the regnal framework and is probably a later addition. ${ }^{162}$ DTR's redaction of the judgment formula for Jehoram (2 Kgs 8:18-19) has already been commented on

${ }^{158}$ Campbell surveys the occurrences of Asherah/Asherim and finds that "allowing for the uncertainty of $1 \mathrm{Kgs} 15: 13$, that gives about $50 \%$ of the occurrences to dtr circles" (Of Prophets and Kings, 181, n. 37). In addition to this the term mipleset (abominable image) occurs only here and in the parallel text in 2 Chr 15:16.

${ }^{159}$ It could conceivably have been part of the Southern Document, although the introductory particle suggests it was added to an existing narrative. Campbell allows that $v 13 \mathrm{~b}$ could be a dir precision (ibid.). Noth thought that v 13 came from DTR's source (Könige, 336). Hoffmann, who generally rejects sources, would accept $\mathbf{v} 13$ as the historical basis for DTR's portrait of Asa (Reform und Reformen, 91). For a discussion of the power of the queen mother in Israelite society see Andreasen, "The Role of the Queen Mother," 179-94, and earlier Ihromi, "Die Königinmutter und der "amm ha'arez im Reich Juda," VT 24 (1974) 421-29.

${ }^{160}$ Note that $1 \mathrm{Kgs} 15: 18$ refers to what was left (hannotarim) in the treasury, presumably after Shishak's campaign.

${ }^{161}$ Cf. Campbell, Of Prophets and Kings, 191.

${ }^{162}$ Noth (The Deuteronomistic History, 135, n. 46) thought it was probably from DTR. Campbell (Of Prophets and Kings, 191) regards it as post-dtr, along with vv 48-50 (RSV vv 47-49) which also lie outside the framework. Spieckermann (Juda unter Assur, 188) assigns v 47 to a late Dtr. The account of Jehoshaphat's reign appears in the LXX also in 3 Reigns 16:28a-g, without the notice of peace with the king of Israel (cf. $1 \mathrm{Kgs} 22: 45$ [RSV 22:44]). It would have been out of place in this earlier location. 
in the discussion of Abijam. ${ }^{163}$ The judgment formulas for Ahaziah ( $2 \mathrm{Kgs}$ 8:27) and Jehoash (2 Kgs 12:3-4 [RSV 12:2-3]) do not contain any dtr additions to the text of the Southern Document. ${ }^{164}$ With Amaziah there is the comment in $2 \mathrm{Kgs} \mathrm{14:6}$ on his purge of conspirators (cf. v 5). The emphasis on individual retribution is however not a concern of DTR. The verse is generally accepted as a later addition. ${ }^{165}$ The judgment formula for Azariah in $2 \mathrm{Kgs}$ 15:3-4 has no dtr additions. With Uzziah in $2 \mathrm{Kgs} \mathrm{15:34-35} \mathrm{Campbell}$

${ }^{163} \mathrm{It}$ is found in the comment in $\mathrm{v} 19$. Some have proposed reading (Tepannay) "before me" instead of the MT's (lêbañyw) "to his sons" in this verse. The proposal is based on the occurrence of "before me" in $1 \mathrm{Kgs}$ 11:36. However the MT reading is to be preferred (following Barthélemy, Critique textuelle de l'Ancien Testament 1,391). The MT text has a rather awkward sequence and the parallel verse in $2 \mathrm{Chr} 21: 7$ adds waw to give "and to his sons", thus providing a smoother sequence. A number of the versions have inserted the copular into 2 Kgs 8:19.

${ }^{164}$ Campbell omits the story of temple repairs in $2 \mathrm{Kgs} \mathrm{12:5-17}$ (RSV 12:416) as more likely to have been of interest to DTR. This story will be discussed along with the analysis of Josiah's temple repairs in 2 Kings 22 . He includes 2 Kgs 11:1-20, while recognizing the possibility of an earlier shorter text. Stade (“Anmerkungen zu 2 Ko. 10-14," ZAW 5 [1885] 275-97) proposed two sources for the chapter, vv 1-12, 18b-20 (a political account) and vv 13-18a (a cultic reform account). This was taken up in a number of subsequent studies. The second account looks to have been inserted in the first, and could contain dtr elements in vv 17-18a. C. Levin proposes a quite different and complex account of the text's growth, and assigns vv 14aß, 17aßy, 18a to dtr redaction (Der Sturz der Königin Atalja, cf. pp. 18-19, 95). Hoffmann (Reform und Reformen, 10413) argues that the chapter is a unified construction by DTR (p. 111). Trebolle Barrera ("La coronación de Joás [2 Re 11]. Texto, narración e historia," EstBib 41 [1983] 5-16) also defends the unity of the chapter, but does not attribute it to DTR (see also Jehú y Joás. Texto y composición literaria de 2 Reyes 9-11 [Institución San Jerónimo 17; Valencia: Edilva, 1984] 165-83). A full discussion of the text is not possible here. While I would not agree with every aspect of Levin's analysis, in the light of his study it is difficult to accept the chapter is a literary unity, and even more difficult to accept it was composed by DTR. As noted Levin proposes dtr redaction in vv $17 \mathrm{a} \beta \gamma, 18 \mathrm{a}$. This is possible but, given the Prophetic Record's condemnation of the Ahab dynasty's worship of Baal, it would be quite in keeping for the Southern Document to report its presence in the south through the influence of Athaliah. Hence dtr authorship of $\mathrm{v} 18 \mathrm{a}$ is not assured. For its part $\mathrm{v} 17 \mathrm{a} \beta \gamma$ could be a later summary of the covenant ceremony in $2 \mathrm{Kgs} 23: 1-3$ read back into the basic account of an alliance between king and people ( $v 17 a a b)$.

${ }^{165}$ Cf. Gray, I \& II Kings, 604; Hentschel, 2 Könige, 64 (DtrN); Jones, 1 and 2 Kings II, 508 (separates $\vee 6 \mathrm{a}$ from the later comment in $\vee 6 \mathrm{~b}$ ); Montgomery, Kings, 439 (separates v 6a from v 6b); Rehm, 2 Könige, 137; Wüthwein, 1. Kön. 17-2. Kön. 25, $317(\mathrm{DtrN})$. The quote in $\mathbf{v} 6 \mathrm{~b}$ is from Deut 24:16. Noth (The Deuteronomistic History, 92) attributed it to DTR, cf. also T. R. Hobbs, 2 Kings (Word Biblical Commentary 13; Texas: Waco, 1985) 176. 
judges the report of temple repairs in $v 35 \mathrm{~b}$ would be more likely to come from DTR. ${ }^{166}$ Apart from this the rest of the formula is included in the Southern Document.

With the judgment formula for Ahaz in $2 \mathrm{Kgs} \mathrm{16:2b-4} \mathrm{Campbell} \mathrm{assigns}$ vv $2 b, 3 a$ to the Southern Document. ${ }^{167}$ However there is a good case for including the report in $v 4 a a$ about Ahaz worshipping at the high places. The complaint about the people's worship at the high places recurs throughout the Southern Document like a refrain. Hence the report of Ahaz extending his royal patronage to a practice which until then had been restricted to the people creates a dramatic climax, and in turn provides a suitable prelude to Hezekiah's intervention against the practice. 168

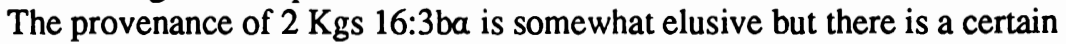
amount of evidence which advises against attributing it to DTR. First, it was pointed out earlier how DTR incorporated the three Davidic kings-Jehoram, Ahaziah and Ahaz-who walked in the way of the kings of Israel into the prophecy-fulfillment schema. The sin of passing one's child through fire

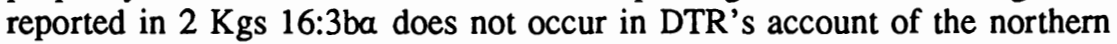
kings. Second, all other references to this sin occur in later additions to the history. ${ }^{169}$ The attachment of the general comparison in $2 \mathrm{Kgs} \mathrm{16:3b \beta}$ to v $3 \mathrm{ba}$ is unusual. The earlier occurrence of this phrase in $1 \mathrm{Kgs} 14: 24 \mathrm{~b}$ pointed to it being part of a later more polemical reassessment of Judah's sins. It is reasonable therefore to draw a parallel conclusion for $2 \mathrm{Kgs} 16: 3 \mathrm{~b} \beta$ even though the polemic in this case is directed against Ahaz. In a similar vein the earlier discussion of the phrase "on every high hill and under every green tree" in $1 \mathrm{Kgs} \mathrm{14:23b}$ suggested it was more likely an exilic borrowing from Jer $2: 20$. If this is the case it is unlikely the similar phrase in $2 \mathrm{Kgs} 16: 4 \mathrm{a} \beta \mathrm{b}$

${ }^{166}$ Campbell, Of Prophets and Kings, 194, n. 87. This would be in keeping

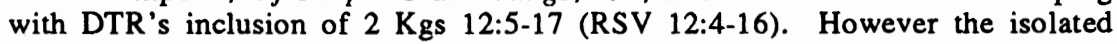
report allows little certainty about its provenance.

${ }^{167}$ Campbell, ibid., 184. The elements included are the basic accusation of not doing right in the eyes of Yahweh ( $v 2 b$ ), and of walking in the way of the kings of Israel (v 3a). This accusation appears also for Jehoram and Ahaziah. In the account of Ahaz's reign Campbell omits $2 \mathrm{Kgs}$ 16:10-18. This could have been included by DTR, but it was more likely to have been of interest to priestly circles (Cf. Hoffmann, Reform und Reformen, 141-45; Levin, Der Sturz der Königin Atalja, 56; Spieckermann, Juda unter Assur, 362-63).

${ }^{168}$ Following Barrick. "The Removal," 258 (cf. also n. 16 above). Although

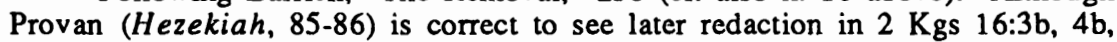
his argument for the omission of $v 4 a$ is unconvincing (p. 86, n. 81). Once the king is accused of worship at the high places, the regular complaint that they were not removed is understood.

${ }^{169}$ There is the late reference in $2 \mathrm{Kgs} \mathrm{17:17}$. There are also $2 \mathrm{Kgs} 21: 6$ and 23:10 which will be shown in chapter 7 to be later additions. On the practice itself Weinfeld ("The Worship of Molech and of the Queen of Heaven and its Background," UF 4 [1972] 133-54) argues that the above passages and similar ones in Jeremiah describe a dedication rather than a child sacrifice. However Klaus Dietrich Fricke (Das zweite Buch von den Königen [Die Botschaft des Alten Testaments, 12/2; Stuttgart: Calwer, 1972] 213) asserts that it is widely accepted such texts refer to child sacrifice. 
came from DTR. Although the evidence is somewhat ambiguous it does look as though DTR may not have made any contribution to the judgment formula for Ahaz. The additions reflect a later more hostile attitude to the Davidic kings, seen elsewhere in $1 \mathrm{Kgs}$ 9:6-9 (plural); 11:5, 33 (plural); 15:12b.

\section{THE REIGN OF HEZEKIAH (2 KINGS 18-20)}

The reign of Hezekiah is best considered in two stages; the account of his

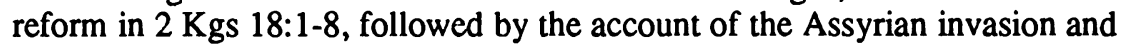

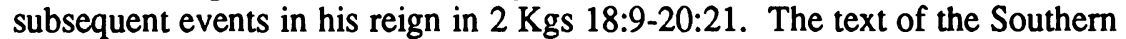
Document for Hezekiah's reform comprises $2 \mathrm{Kgs}$ 18:3-5aba, 7-8. ${ }^{170}$ As has already been pointed out Hezekiah's removal of the high places provides a fitting resolution to the threat against the centrality of the Jerusalem temple, a threat which reached crisis point with Ahaz's adoption of the people's practice.

The judgment formulas of the Southern Document were able to be incorporated easily into DTR's conceptual plan with the minimum of revision. The analysis of DTR's redaction of the judgment formulas has identified two related areas of contribution. There is the linking of the formulas with the prophecy-fulfillment schema, evident in the additions in $1 \mathrm{Kgs} \mathrm{15:4}$ and $2 \mathrm{Kgs}$ 8:19. There is also the comparison with David the model king, evident in 1 $\mathrm{Kgs} 15: 3 \mathrm{~b}$ and to a lesser extent in $v 14 \mathrm{~b}$. As well as this Asa's removal of the Asherah in $1 \mathrm{Kgs} 15: 13$ may be attributed to DTR. Apart from the possibility that $1 \mathrm{Kgs} 14: 24 \mathrm{a}$ and $15: 13$ may be from DTR the remainder of the additions have been found to be more likely the work of later dtr redaction.

DTR's redaction of the judgment formulas is therefore limited, but recognizable as part of the incorporation of the Southern Document into DtrH. One problem in the relationship between the Document and DtrH is the reference to David in the judgment formulas for Asa (1 Kgs 15:11), Amaziah (2 Kgs 14:3), Ahaz (2 Kgs 16:2b), Hezekiah (2 Kgs 18:3). These references hold David up as the model king in much the same way as DTR. This could work against the hypothesis of a Southern Document with its own distinctive

${ }^{170}$ Campbell, Of Prophets and Kings, 195-96. A small but significant piece of information in favor of a pre-dtr Southern Document is Barrick's observation

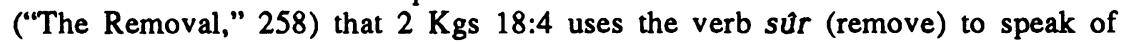
Hezekiah's reform, whereas the dtr text in $2 \mathrm{Kgs} 21: 3$ uses the verb 'abad (destroy). Burney (Notes, 337) and Würthwein (1. Kön. 17-2. Kön. 25, 411) argue that the waw-perfect in $2 \mathrm{Kgs} 18: 4$ is evidence of later aramaizing style (see also Provan, Hezekiah, 86). While this form did become prevalent in later hebrew writing the studies of R. Meyer ("Auffallender Erzählungsstil in einem angeblichen Auszug aus der 'Chronik der Könige von Juda'," Festschrift Friedrich Baumgärtel zum 70. Geburtstag [ed. L. Rost; Erlanger Forschungen A/10; Erlangen: Universitätsbibliothek, 1959] 114-23), and more recently Spieckermann (Juda unter Assur, 120-30) have shown that it was in use at a much earlier date. It cannot therefore be employed as a sure literary critical criterion of late authorship (also Hoffmann, Reform und Reformen, 216, n. 41). Also the evidence in favor of omitting $2 \mathrm{Kgs} 18: 4 \mathrm{a} \beta$ as later dtr is not as clear as Provan claims (cf. such texts as Deut $7: 5 ; 12: 3 ; 16: 21-22$ [singular as in $v$ $4 \mathrm{a} \beta])$. 
series of judgment formulas. On the other hand, there is nothing against the notion that DTR developed a theme already present in the Southern Document. Another posssibility is that DTR added the references to David in the judgment formulas. However the reference to "his father", whether David or the king's actual father, seems to be an integral part of the formulas. ${ }^{171}$ Hence it is a less likely possibility.

Returning to the specific case of Hezekiah and the question of the extent of dtr redaction, one finds it is consistent with what has been observed for the bulk of these formulas. The account of Hezekiah's reform was able to be incorporated into DtrH without modification. The reference to "those who were before him" in $2 \mathrm{Kgs} 18: 5 \mathrm{~b} \beta$ is a late gloss awkwardly appended to the verse. ${ }^{172}$ The remaining addition to the Southern Document in $v 6$ is more in keeping with the later nomistic concern of obedience to the law than with DTR. ${ }^{173}$

For the rest of the story of Hezekiah there are three things which need to be established in relation to the understanding of DtrH. These are: the text of

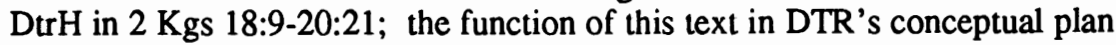
and structure; and the extent and nature of later redaction.

The analysis given here emerges from the recognition in the story of the Assyrian campaign and its outcome of the presence of the same four-part pattern found in the stories of David and Josiah. ${ }^{174}$ As has already been pointed out, only Hezekiah and Josiah were compared favorably with David without qualification. ${ }^{175}$ The discussion of David proposed that there were

${ }^{171}$ The king's own father is referred to for Abijam, Jehoshaphat, Amaziah, Azariah, Jotham. The reference to David occurs when a comparison with the predecessor was inappropriate; so Asa, Ahaz, Hezekiah. The absence of a reference to "X his father" for Jehoram and Ahaziah may be explained by their association with the dynasty of Ahab (Omri). Jehoash also has no such reference, probably because he was an orphan. The notion of David as model is clear in the formula for Amaziah (2 Kgs 14:3-4).

${ }^{172}$ Cf. Campbell, Of Prophets and Kings, 195-96, n. 90; Gray, I \& II Kings, 671; Jones, 1 and 2 Kings II, 562; Würthwein, 1. Kön. 17-2. Kön. 25, 406, n. 1. Campbell considers v 5 ba could belong in the Southern Document as a veiled criticism of the policies of Manasseh, and perhaps also of Amon. The verb batah (to trust) in v $5 \mathrm{a}$ is not dtr. Cf. Deut 28:52; Judg 9:26; 18:7, 10, 27; 20:36; 2 Kgs 18:5, 19, 20, 21, 22, 24, 30; 19:10.

${ }^{173}$ Dietrich (Prophetie und Geschichte, 138, n. 115) assigns vv 6-7a to DtrN. However $v 7 \mathrm{a}$ follows equally well after $v 5 \mathrm{aba}$. The phrase "to cling to Yahweh/him" occurs in the following secondary passages; Deut 4:4; 30:20; Josh 22:5; 23:8. It occurs elsewhere in Deut 10:20; 11:22; 13:4.

${ }^{174}$ To recall briefly the elements of the four-part pattern: 1)- a critical event occurs in the reign of the king; 2)- as a result of the event the king in question consults a prophet; 3)- a favorable prophecy is given; 4)- a significant development follows which functions as a fulfillment of the prophecy.

${ }^{175} \mathrm{Cf}$. the judgment formulas for Hezekiah ( $\mathrm{Kgs} \mathrm{18:3)}$ and Josiah (2 Kgs 22:2). As pointed out earlier a weakness in the recent study of kingship in DtrH by G. E. Gerbrandt (Kingship According to the Deuteronomistic History) is his failure to recognize the importance of the prophet/king relationship. This is particularly evident in his discussion of Hezekiah and Josiah (see pp. 46-89). 
three criteria governing DTR's comparison of Hezekiah and Josiah with David. These were fidelity to Yahweh, fidelity to the policy of centralized worship, and fidelity to the prophet/king form of leadership, demonstrated in the way each king consults a prophet at a critical period of his reign. Hezekiah's fidelity to Yahweh and to the centrality of the temple is contained in the

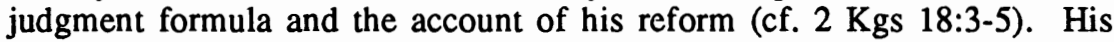
fidelity to the prophet/king form of leadership is demonstrated in his consultation of Isaiah during the Assyrian crisis. It is instructive to observe that the theme of Hezekiah's fidelity to Yahweh expressed in his trust (battah cf. 2

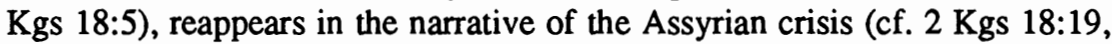
$20,22,30 ; 19: 10)$. Also the theme of his fidelity to the centrality of the

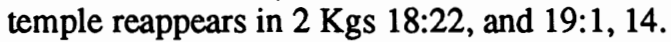

It is generally recognized that the present account of the Assyrian crisis is a compilation of three originally separate accounts. There are the two so-called

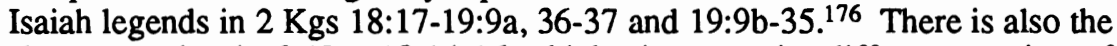
short narrative in $2 \mathrm{Kgs} \mathrm{18:14-16}$ which gives a quite different version of Hezekiah's response to the crisis. ${ }^{177}$ Furthermore, it is generally accepted that these accounts were pre-dtr compositions. ${ }^{178}$ Campbell has included a version

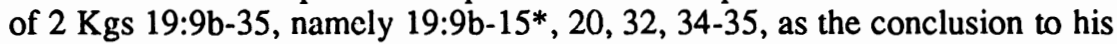
Southern Document. The authors of the Document supplied an introduction for the Isaiah legend in $2 \mathrm{Kgs} 18: 9-11,13 .{ }^{179}$

${ }^{176}$ This literary criticial division goes back to Stade in "Anmerkungen zu 2 Kö. 15-21,"175-83, and has been followed by studies and commentaries. Cf. the studies by; Schüpphaus, Richter- und Prophetengeschichten, 87; Brevard S. Childs, Isaiah and the Assyrian Crisis (SBT 3; London: SCM, 1967) 70-103; Roland E. Clements, Isaiah and the Deliverance of Jerusalem (JSOTSup 13; Sheffield: JSOT, 1980) 53-54. Cf. the commentaries of; Gray, I \& II Kings, 659; Hobbs, 2 Kings, 246; Hentschel, 2 Könige, 87; Jones, 1 and 2 Kings II, 568; Würthwein, 1. Kön. 17-2. Kön. 25, 414. Cf. also Otto Kaiser, Isaiah 13-39 (OTL; London: SCM, 1974) 376-77, 385, 392. For Kaiser the version in Isaiah 36-39 is dependent on the Kings account ( p. 367). For the purposes of this discussion Stade's division at $2 \mathrm{Kgs} \mathrm{19:9a}$ and $9 \mathrm{~b}$, accepted by the majority, will be followed.

${ }^{177}$ It has been widely accepted there was only one Assyrian campaign during Hezekiah's reign and that the three narratives represent different versions of it (see for example Childs, Isaiah and the Assyrian Crisis, 118-27). This position has now been questioned by W. H. Shea, "Sennacherib's Second Palestinian Campaign," JBL104 (1985) 401-18. Because the principal concern in the reassessment is the relationship of $2 \mathrm{Kgs} 18: 14-16$ to $\mathrm{DtrH}$, this problem may be set aside.

${ }^{178}$ Perhaps the closest association between the Isaiah legends and the dtr movement is the one drawn by Clements. He ascribes the present arrangement of the material to a circle of writers who stood close to those who edited Isaiah's prophecies in Josiah's time. He recognizes associations between this circle and an emerging deuteronomic school (Isaiah, 56-57, 61).

${ }^{179}$ Campbell, Of Prophets and Kings, 196-97. The synchronisms in vv 910 are omitted as part of DTR's redaction. The dtr comment in $v 12$ is also omitted. In view of the analysis of $2 \mathrm{Kgs} 17: 21-23$ this is not DTR's comment on the fall of the north (against Nelson, The Double Redaction, 62 and Mayes, 
The identification of the text of the Southern Document leads in its turn to an attractive explanation for the presence of two versions of the Isaiah legend in the present text. The combination of the versions was the work of DTR and was done with a twofold purpose in mind. The first was to encase the Southern Document's version within this section of DtrH by framing it with the Isaiah legend of $2 \mathrm{Kgs} 18: 17-19: 9 \mathrm{a}, 36-37$. The second was to supply an essential component of the four-part pattern, namely the prophetic consultation

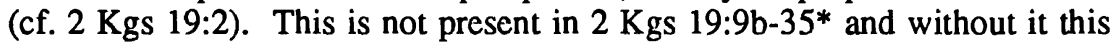
version cannot form the four-part pattern. With $2 \mathrm{Kgs} \mathrm{18:17-9:9a,} \mathrm{36-37}$ however the parts of the pattern can be clearly seen. These are: 1)- critical event in the king's reign (18:17-37, with the introduction from the Southern Document in vv 9-11, 13); 2)- prophetic consultation (19:1-2); 3)- prophecy (19:5-7); 4)- fulfillment of prophecy (19:8-9a, 36-37). ${ }^{180} 2 \mathrm{Kgs} \mathrm{19:1-2,5-7}$ also gives more initiative and authority to the prophet Isaiah than the other version, which portrays him informing Hezekiah that his prayer has been heard. ${ }^{181}$ The former text is clearly more in keeping with the prophet/king relationship expounded by DTR.

It has been proposed that $2 \mathrm{Kgs} 18: 17-19: 9 \mathrm{a}, 36-37^{*}$ and 19:9b-35* were combined before the composition of DtrH. ${ }^{182}$ This is quite possible. There is no clear evidence of dtr language in these stories, and DTR may have found them already combined. The four-part pattern is not exclusive to DTR. ${ }^{183}$ What is claimed in this study is that DTR made use of the pattern to serve the aims of the history. Nevertheless there does not seem to be any compelling reason against attributing the combination to DTR, given the way $2 \mathrm{Kgs}$ 18:17-19:9a, 36-37 creates the four-part pattern. It has also been proposed that

The Story of Israel, 171, n. 18). The well recognized chronological inconsistency between $2 \mathrm{Kgs} 18: 1,9$ on the one hand and $18: 13$ on the other may have arisen because the notices came from different authors. $2 \mathrm{Kgs}$ 18:1416 is omitted by Campbell because it is in conflict with the portrait of Hezekiah

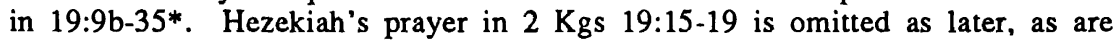
vv 21-31. Verse 33 is also omitted as a later harmonization (for details see pp. 196-97, nn. 94-97).

${ }^{180}$ We may note in anticipation the way Josiah's reaction to hearing the law book read and the description of his delegation to Huldah the prophetess (cf. 2 Kgs 22:11-14*) parallels that of the Hezekiah account.

${ }_{181} 2 \mathrm{Kgs} \mathrm{19:3-4} \mathrm{intrudes}$ between vv 1-2 and 5-7 and is best taken as a later addition (so Würthwein, 1. Kön. 17-2. Kön. 25, 424). It may have been added to bring 19:1-7 into line with the tone of Hezekiah's prayer in 19:15-19, itself a later addition to the Southern Document (following Campbell). Note in particular the similarity between $2 \mathrm{Kgs} 19: 4$ and 16. Weinfeld (Deuteronomy and the Deuteronomic School, 39) sees deuteronomic style in the prayer, but the close similarity between $19: 18$ and Deut 4:28 points to it being later than DTR.

${ }^{182}$ This is the position for example of Clements, Isaiah, 56-57 (cf. above n. 178).

${ }^{183} \mathrm{~A}$ similar pattern has been found by $\mathrm{R}$. L. Cohn in stories of the dying monarch, for example in 2 Kings 1 (Ahaziah); 8 (Ben-hadad) ("Convention and Creativity in the Book of Kings," 603-16). Neither of these is dtr. 


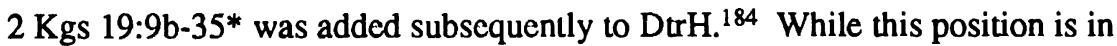
disagreement with Campbell's proposal for the Southern Document it does not disturb the four-part pattern outlined above.

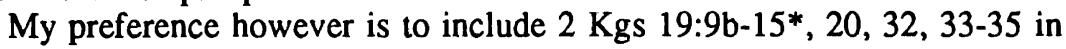
$\mathrm{DtrH}$. This gives the following text as DTR's account of the Assyrian crisis;

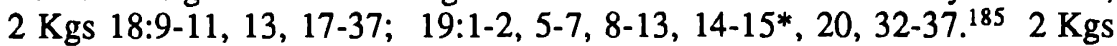
20:1-11 may also be included in DtrH. It continues the positive presentation of Hezekiah which characterizes DtrH, and there is no compelling reason to assign its presence to a later hand. ${ }^{186}$ The two significant texts which have yet to be accounted for are $2 \mathrm{Kgs}$ 18:14-16 and 20:12-19.

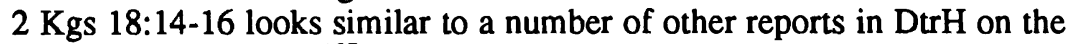
plundering of the temple. ${ }^{187}$ However an examination of these reports shows that they consistently record the plundering of the temple as the price of Judah's freedom from foreign invasion. Thus, an invader may plunder the temple and royal treasury and then withdraw (1 Kgs 14:25). Alternatively, the king of Judah himself plunders the temple in order to buy off an invader (2 $\mathrm{Kgs} \mathrm{12:18-19} \mathrm{[RSV} \mathrm{12:17-18]),} \mathrm{or} \mathrm{to} \mathrm{buy} \mathrm{the} \mathrm{assistance} \mathrm{of} \mathrm{an} \mathrm{ally} \mathrm{against} \mathrm{an}$

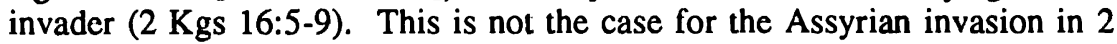
Kings 18-19. According to the present text Hezekiah's attempt to buy off Sennacharib was to no avail (2 Kgs 18:14-17). When one considers the change in this pattern in conjunction with DTR's presentation of Hezekiah it is clear that $2 \mathrm{Kgs}$ 18:14-16 must have been added later as a counter measure to this presentation. $2 \mathrm{Kgs} 18: 13$ was therefore followed in $\mathrm{DtrH}$ by the account of the invasion in 18:17-37. It is much more unlikely that a later redactor would have added this passage to $2 \mathrm{Kgs} 18: 14-16$.

$2 \mathrm{Kgs} 20: 12-19$ is also a later addition. Hezekiah's display of the treasures of his realm to delegates of a foreign power creates a thematic relationship with $2 \mathrm{Kgs} 18: 14-16$. When one takes into account Isaiah's prophecy that treasures would be plundered by the Babylonians ( $2 \mathrm{Kgs} 20: 17$ ) then the thematic relationship appcars to have been deliberately created. It makes good sense therefore to attribute the inscrtion of both passages to a redactor who constructed a frame around the story of the Assyrian crisis in order to counter

${ }^{184}$ This is the position for example of Gray (I \& II Kings, 667) who believes that it is a more mature version than the other and was probably added by an exilic redaction. Gray's assessment is influenced by the developed theology

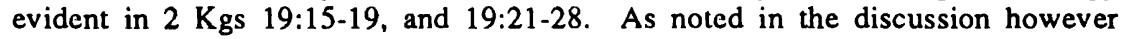

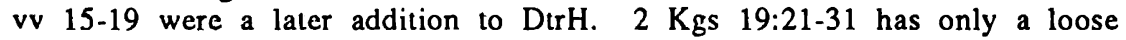
connection with the context and is recognized also as a late inclusion by Hentschel, 2 Könige, 94; Jones, 1 and 2 Kings $I I, 578$; Würthwein, 1 . Kön. 17-2. Kön. 25, 428, 430-32. Provan (Hezekiah, 128-29) omits 2 Kgs 19:9-34 from his first edition of DtrH.

${ }^{185}$ Omitted therefore are $2 \mathrm{Kgs} 18: 12$ (late dtr comment); 18:14-16 (see below); 19:3-4 (intrusion betwen vv 1-2, 5-7), 15-19 (Hezekiah's prayer), 21 31 (later oracles). $2 \mathrm{Kgs} 19: 33$ is a sccondary harmonization based on the combination of the accounts. It may be included in DtrH.

$1862 \mathrm{Kgs} 20: 6 \mathrm{~b}$ may have been added on the basis of 19:34, since it is somewhat out of context in 20:1-11.

${ }^{187}$ Cf. 1 Kgs $14: 25$; 15:16-21; 2 Kgs 12:18-19 (RSV 12:17-18); 16:5-9. 
its positive portrayal of Hezekiah. It can also be pointed out that the interest in Babylonians as Judah's despoilers would fit in with an exilic perspective rather than a Josianic one. Furthermore, $2 \mathrm{Kgs} 24: 13$ seems to be a fulfillment notice for $2 \mathrm{Kgs} \mathrm{20:17}$. The redaction may have come from the same circle as other later passages which exhibit a negative or hostile attitude to Davidic kings (cf. $1 \mathrm{Kgs} \mathrm{9:6-9} \mathrm{[plural];} \mathrm{11:5,} 33$ [plural]; 15:12b; $2 \mathrm{Kgs}$ $16: 3 b a[\beta]) .188$

The analysis of dtr redaction in $1 \mathrm{Kgs} 12: 25-2 \mathrm{Kgs} \mathrm{20:21}$ in general confirms the Campbell hypotheses of a Prophetic Record supplemented by a later northern expansion, and an independent Southern Document. The hypothesis of a northern expansion offers a very plausible explanation of the stereotyped series of judgment formulas from Jehu to Hoshea. The analysis showed how DTR was able to incorporate the expansion into the larger history with a minimum of revision. This revision is evident in DTR's comment on the northern exile in $2 \mathrm{Kgs}$ 17:22-23a. What is particularly significant about the comment is the way it brings the northern expansion within the compass of DTR's prophecy-fulfillment schema (cf. $v$ 23a). The examination of the dtr redaction of the Prophetic Record showed that DTR forged an integral relationship between the overall series of judgment formulas for the northern kings and the prophecy-fulfillment schema. In addition to this it was found that within DTR's overall unified treatment of the northern kings specific attention was devoted to the dynasties of Jeroboam, Baasha, and Ahab (Omri). The evidence for this came once again from an examination of DTR's judgment formulas and the redaction of the prophetic speeches. The focus on these dynasties is in keeping with the importance of the notion of dynasty for DTR's theology, in particular the contrast between the enduring Davidic dynasty and the failed northern dynasties.

As pointed out earlier Campbell considers that the evidence for an independent Southern Document is not as compelling as for the northern expansion. Certainly the analysis found that the distinction between DTR and pre-dtr material is not so striking for the Southern Document. There are aspects of the Document's theology which merge with those of DTR, for example the notion of David as the model king and the concern about centralized worship. This could well be explained by the southern provenance of the Document, and its relatively close historical proximity to the work of DTR. According to Campbell the Southern Document may have been written in the time of Manasseh. The analysis did find however that there is a clear enough distinction between the Southern Document and DTR's prophecyfulfillment schema. This is recognizable in the redaction of the judgment

${ }^{188}$ The assignation of this pericope to exilic redaction is in disagreement with Nelson (The Double Redaction, 129-32) who includes it in his Josianic DtrH. C. T. Begg ("2 Kings 20:12-19 as an Element of the Deuteronomistic History," $C B Q 48$ [1986] 27-38) explores the function of this pericope in the context of an exilic DtrH. I would endorse his observation that $2 \mathrm{Kgs} 20: 12-19$ counters the mood of 18:17-20:11 and prepares for the end of Judah. In my judgment however this was the work of later redaction which was hostile to the Davidic kings. 
formulas, where DTR was careful to point out that despite the infidelity of some Davidic kings the reward promised to David was still in place (cf. $1 \mathrm{Kgs}$ 11:36; 15:4; $2 \mathrm{Kgs} 8: 19$ ). There is also an attractive case for seeing DTR's hand in the organization of the four-part pattern for the reign of Hezekiah. On balance therefore the case for an independent Southern Document which was later incorporated into DtrH by DTR is a reasonable one. ${ }^{189}$

${ }^{189} \mathrm{~B}$. Peckham (The Composition of the Deuteronomistic History) and Provan (Hezekiah) both propose a DtrH which ended with the reign of Hezekiah. While both are right in seeing the significance of Hezekiah, the reassessment carried out here renders their DtrH hypotheses unlikely. My difficulties with Peckham's analysis were outlined in chapter 1. Problems with Provan's analysis have been addressed throughout the treatment of Kings. Two further observations may be made here. First, the concern over centralization of worship cannot in itself be claimed as dtr in origin. This is evident enough in $2 \mathrm{Kgs} \mathrm{18:22}$ which is clearly not a dtr formulation (cf. also Deut 12:13-19). Provan makes the link between $2 \mathrm{Kgs}$ 18:22 and Hezekiah's removal of the high places (p. 85) but does not address the implications this pre-dtr text has for the judgment formulas. Moreover the verb "to trust" in $2 \mathrm{Kgs} 18: 5,19,20-22,24$, 30; 19:10 is not dtr. If the account of Hezekiah were the climax of DtrH one would expect a closer correlation with dtr terminology, particularly in $\mathbf{v} 5$. Second, within the dtr redaction itself Provan fails to see that the trajectory of the prophecy in $1 \mathrm{Kgs}$ 11:36 (DTR) reaches beyond Hezekiah to Manasseh (cf. 2 Kgs 21:7b). Schüpphaus concludes his pre-dtr history with the reign of Hezekiah, but regards the prophetic material in 2 Kings 18-19 as dtr additions (Richter- und Prophetengeschichten, 101-2). 


\section{THE PERIOD OF ISRAEL UNDER THE PROPHETS AND KINGS [C] \\ 2 Kgs 21:1-23:23}

This final section of DtrH is complex and requires careful analysis. There is evidence of considerable later redaction in both the account of the reign of Manasseh and the account of Josiah's reform. At times it is difficult to trace the precise contours of source and redaction, or of the various layers of redaction. Nevertheless one can, via a judicious application of literary critical, linguistic and contextual criteria, follow the course of the history with a reasonable degree of certainty.

The nature of the task undertaken-the reassessment of the DtrH hypothesis-means that a number of interesting areas of investigation must be set aside. These are for example, the well known discrepancies between the account of the reform in 2 Kings $22-23$ and 2 Chronicles 34-35, the reconstruction of the history of Josiah's reform, and the nature of Judean religious and foreign policy in the turbulent period which marked the transition from Assyrian to Babylonian hegemony. The analysis of DtrH can be carried out without the prior resolution of these questions. A satisfactory $\mathrm{DtrH}$ hypothesis will in fact greatly assist their resolution. In order to complete the picture of the relationship between DtrH and later redaction which can be traced through $2 \mathrm{Kgs} 21: 1-23: 23$, the chapter will also include an analysis of $2 \mathrm{Kgs}$ 23:24-25:30.

\section{KGS 21:1-18 (THE REIGN OF MANASSEH)}

The account of Manasseh's reign can be conveniently divided into four sections: vv 1-9 (report of Manasseh's "reform"); vv 10-15 (prophetic condemnation); v 16 (further report); vv 17-18 (conclusion). The text of DtrH is to be found in $2 \mathrm{Kgs} 21: 1-2 \mathrm{a}, 3 \mathrm{aba}, 5,7,17-18$. $^{1}$ The introduction in $\mathrm{v} 1$, the basic judgment formula in $v 2 \mathrm{a}$, and the conclusion in vv 17-18 are essential

\footnotetext{
${ }^{1}$ The text of $2 \mathrm{Kgs} 21: 1-16$ has generated a number of different literary critical assessments over the years. Only the more recent studies are listed here. F. M. Cross, Canaanite Myth and Hebrew Epic, 285-86 (vv 2-6 [Dtr1], 7-15 [Dtr2]); W. Dietrich, Prophetie und Geschichte, 31-34 (vv 2-3, 5-7a [DtrH], 10-14 [DtrP], 4, 7b-9, 15-16 [DtrN])-followed by G. Hentschel and G. H. Jones; J. Gray, I \& II Kings, 705 (vv 1-7, 16 [DTR], 8-15 [exilic compiler]); N. Lohfink, Rückblick im Zorn, 184 (vv 2a, 3-5 [Dtr I], 2b, 6-16 [Dtr II]); R. D. Nelson, The Double Redaction, 66-67 (vv 1-3ba, 16-18 [DTR], 3b $\beta-15$ [exilic redactor]); $H$. Spieckermann, Juda unter Assur, 421-22 (vv 2, 3ab*, 5-6aa, 7a [DtrH], 6aßb, 79, 16 [DtrN], 4, 10-15 [late Dtr]); E. Würthwein, 1. Kön. 17-2. Kön. 25, 440 (vv 2a [DtrH], 10-13 [DtrP], 2b, 3, 5, 7-9, 11*, 14, 15 [various DtrN circles], 4, 6 [later insertions]).
} 
for the narrative thread of the history and are accepted by all as part of DtrH. ${ }^{2}$ They require no further comment here. The analysis will therefore focus on the distribution of the intervening material.

Within the first section there are a number of good reasons for identifying 2 Kgs 21:3aba, 5, 7 as DTR's "evidence" to back up the judgment against Manasseh. ${ }^{3}$ To begin with, these verses are united by the way they specify each cultic object made by Manasseh. ${ }^{4}$ There is the reference to his reconstruction of the high places destroyed by Hezekiah in $v 3 \mathrm{a}$. There are the altars made for Baal and the fashioning of an Asherah in $v 3 \mathrm{ba}$. There are the altars made for the host of heaven in $v 5$. Finally there is the report that Manasseh

${ }^{2}$ I. W. Provan (Hezekiah, 115) rejects a literary critical separation between $\mathbf{v}$ $2 a$ and $v 2 b$ because the latter supplies the expected comparison element of the judgment formula. He notes that the negative formulas for earlier Davidic kings compare them with David (1 Kgs 15:3; $2 \mathrm{Kgs} \mathrm{16:2)}$ or with the house of Ahab (2 Kgs 8:18, 27). I would agree that $v 2 \mathrm{~b}$ reflects an exilic perspective. However the comparison with predecessors is supplied in DTR's text by $v 3 a$ (Hezekiah) and $v 3$ ba (Ahab).

${ }^{3}$ The unity of $2 \mathrm{Kgs} 21: 1-16$ was accepted by Noth who did not go into an analysis of the text (The Deuteronomistic History, 73). It has been defended recently against the findings of literary critical analysis by $H$. D. Hoffmann (Reform und Reformen, 155-62) on the basis of three arguments; the structure of the account, its language and style, and comparison with other accounts of cultic reform in DtrH. In terms of structure Hoffmann sees a heightening polemic culminating in the statement in $v 7$. His assessment of the importance of $v 7$ is correct, but his structure fails to account for $v 4$ (similar to $v 7$ ) or vv 8-9, which make no reference to $v 7$. In terms of language and style, Hoffmann sees evidence in vv 2-9 of DTR's mixing of "general" and "specific" terminology. However this argument is not really integrated with the first one from structure. The analysis here will show there are a number of occasions where changes in language and style are significant for determining the structure of DTR's text, and the structure of later redaction. The third argument also creates problems. If for example $v 6$ is an integral part of DTR's structure in vv 2-9-occurring just before the climax in $v 7-i t$ is surprising to find a parallel to it in Josiah's

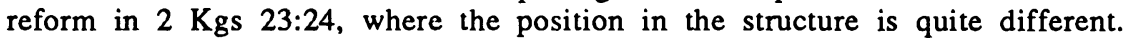
Other studies which defend the unity of the account, but without detailed analysis are T. R. Hobbs, 2 Kings, 300-301, and more cautiously, M. Rehm, 2 Könige, 269.

${ }^{4} \mathrm{C}$. F. Burney (Notes, 352-53) proposed that the redactor's report was derived from annalistic information, recognizable in vv 3, 4a, 5, 6a, 7a. More recently, Nelson (The Double Redaction, 66) says that "certain verses (3a, 4a, 6a, 7a) resemble the annalistic notices in the earlier parts of the history". Spieckermann (Juda unter Assur, 164-67) claims a "Vorlage" in vv 5, 7a (omitting "which he made"). However the carefully organized nature of the report makes recovery of a source difficult. It is possible that DTR composed it from an annals, or a temple source which recorded, for example, the construction of the altars in v 5. But it is equally possible DTR drew on suitable information in the tradition. My analysis of the report leads to the identification of vv 4 and 6 as later additions (against Burney and Nelson). Verse 4 in particular combines elements of DTR's own report in summary form. 
placed the Asherah he made in the temple. This serves to create an inclusion with $\mathbf{v} 3$.

Secondly, the details of Manasseh's program as described in vv 3aba, 5, 7 have a definite function in the development of this section of DtrH. They point to a deliberate move by DTR to draw a parallel between Manasseh and Ahaz. Ahaz sacrificed and burned incense on the high places (2 Kgs 16:4a). Manasseh's first act was to rebuild these high places which Hezekiah had destroyed (21:3a). ${ }^{5}$ Ahaz walked in the way of the kings of Israel (16:3a). In 1 Kgs 16:32-33a Ahab king of Israel was accused of erecting an altar for Baal and of making an Asherah. It is hardly coincidental therefore to find that Manasseh is accused of erecting altars for Baal and of making an Asherah as Ahab had done (2 Kgs 21:3ba). The direct association of Manasseh with Ahab here cautions one against seeing Manasseh simply as a carbon copy of Ahaz. His cultic innovations were viewed by DTR as far more dramatic and threatening for Yahwism than those of Ahaz. The report of the cultic abuses initiated by Manasseh is designed to set the stage for the dramatic and decisive reform of Josiah.

The report of Manasseh's erection of altars for the host of heaven in $2 \mathrm{Kgs}$ $21: 5$ does not find a recognizable parallel in the account of Ahaz. Nevertheless it is the only other verse which specifies a particular cult object. Its inclusion gains some indirect support from the point made in the preceding paragraph, namely that Manassch was portrayed by DTR as a more dangerous apostate than Ahaz in order to enhance the impact of the Josian reform. $2 \mathrm{Kgs}$ 23:12 reports that Josiah dismantled the altars constructed by Manasseh. Other observations to come in the course of the analysis will provide further support for the inclusion of $2 \mathrm{Kgs} 23: 5$ in DtrH.

$2 \mathrm{Kgs} 21: 7$ plays a particularly significant role in relation to DTR's conceptual plan and structure. ${ }^{6}$ This verse not only forms an inclusion with v 3, the report that Manasseh made an Asherah. It also forms the climax of DTR's list of Manasseh's cultic abuses and foreshadows the reform of Josiah. This can be seen in the way the verse is formulated. It states that Manasseh placed (wayyāsem) the graven image (pesel) of Asherah in the "house of which the Lord said to David and to Solomon his son, 'In this house, and in Jerusalem, which I have chosen out of all the tribes of Israel, I will put ('asim)

${ }^{5}$ DTR used the verb "to destroy" in reference to Hezekiah's reform. In the Southem Document's account in $2 \mathrm{Kgs} 18: 4$ the verb used is "to remove".

${ }^{6}$ The special term graven image (pesel) invites some comment. It occurs elsewhere in Deut $4: 16,23,25 ; 5: 8 ; 27: 15$. All of these contain prohibitions against making a graven image of anything, whereas $2 \mathrm{Kgs} \mathrm{21:7}$ refers specifically to the Asherah. Spieckermann (Juda unter Assur, 166-67) regards it as part of the source for DTR's account of Manasseh. This is possible although we may note DTR's use of the special term massekot (molten images) in $1 \mathrm{Kgs}$ 14:9b. The "graven image of Asherah" may have been chosen deliberately by DTR to contrast with "my name" in $v 7 \mathrm{~b}$. The phrase "which he made" looks to be a later explanatory gloss. It is not in the LXX. 


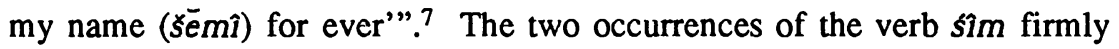
imply that Manasseh's placing of the Asherah in the temple was a gross affront to Yahweh's exclusive claim to the temple. A tension is created in the history which is resolved in $2 \mathrm{Kgs}$ 23:6 when Josiah brings the Asherah out of the temple and destroys it. As well as this the formulation of $v 7 \mathrm{~b}$ is clearly designed to affirm that, despite the infidelity of Manasseh, the promises made to David were still intact. Thus Manasseh is brought within the trajectory of

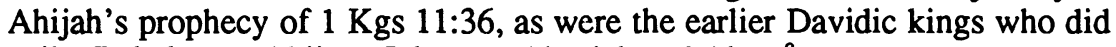
evil-Rehoboam, Abijam, Jehoram, Ahaziah and Ahaz. ${ }^{8}$

A third argument in favor of the proposed text is that each item of Manasseh's program can be accommodated within the pre-exilic setting of DtrH. There is no difficulty accepting the references to high places, the altars for Baal, and the Asherah in this setting. Each has already appeared in the history. The reference to all the host of heaven in $2 \mathrm{Kgs} 21: 5$ is however new. The phrase occurs in Deut 4:19;17:3; $2 \mathrm{Kgs} 17: 16 ; 21: 3 \mathrm{~b} \beta, 5 ; 23: 4,5$. Of these Deut 4:19 and $2 \mathrm{Kgs}$ 17:16 have been shown as post-DTR. Deut 17:3 is rather awkwardly appended to the preceding words and may be a dtr addition. It is difficult to tell whether it came from DTR or a later redactor. 9 The secondary nature of $2 \mathrm{Kgs} 21: 3 \mathrm{bB}$ will be discussed more fully below. One may be tempted to assign the occurrences in $2 \mathrm{Kgs} 21: 5$ and 23:4-5 to a later

${ }^{7}$ Dietrich (Prophetie und Geschichte, 31-33) divides $2 \mathrm{Kgs} \mathrm{21:7} \mathrm{into} \mathrm{7a} \mathrm{and}$ 7b. He considers the phrase "out of all the tribes of Israel" to be secondary because of its occurrence in $1 \mathrm{Kgs} 8: 16$ and 11:32, both of which he assigns to later redaction. $1 \mathrm{Kgs} 11: 32$ is indeed a later summary of Ahijah's prophecy, but the analysis of $1 \mathrm{Kgs} 8: 16$ has shown that it is an integral part of DtrH, as is 1 Kgs 11:36, where the phrase also occurs. My examination of $2 \mathrm{Kgs} \mathrm{21:7}$ shows that a literary critical division is unwarranted (also against Burney, Notes, 352; Hentschel, 2 Könige, 101-2, Nelson, The Double Redaction, 67).

${ }^{8}$ The sequence of texts dealing with the promises to David of an everlasting dynasty and a temple (cf. 2 Samuel 7; 1 Kgs 2:2, 4aab; 8:16-21, 25; 9:3-5; $11: 36 ; 15: 4 ; 2 \mathrm{Kgs} 8: 19$ and $21: 7 \mathrm{~b}$ ) are another example of DTR's progressive interpretation and integration of key themes into the conceptual plan of DtrH. As pointed out in the preceding chapter, the term nir (RSV "lamp") was used to contrast the dynasty's assured dominion over Judah with the northern kingdom (1 Kgs 11:36; 15:4; 2 Kgs 8:19). After the northern exile there was no need to continue this contrast. $2 \mathrm{Kgs} 21: 7$ was formulated to recall $1 \mathrm{Kgs} 8: 16$ (cf. "all the tribes of Israel"); 9:4 (cf. silm with reference to the name, and "for ever"); 11:36 (cf. Jerusalem, and sîm with reference to the name), as well as to draw a contrast between Yahweh's placing of his name in the temple and Manasseh's placing of the Asherah there. Note that "all the days" in $1 \mathrm{Kgs} 11: 36$ and "for ever" in $2 \mathrm{Kgs} 21: 7$ are synonymous, as shown by their presence in $1 \mathrm{Kgs} \mathrm{9:3.}$ The significance of $2 \mathrm{Kgs} \mathrm{21:7}$ has been overlooked by Provan (Hezekiah, 117). Nelson (The Double Redaction, 67) assigns $2 \mathrm{Kgs} 21: 7 \mathrm{~b}$ to his exilic redactor because the verb sim in $v 7 \mathrm{~b}$ is finite, whereas it is in the infinitive mood in 1 Kgs 9:3; 11:36; 14:21. However the finite mood was required in $v 7 \mathrm{~b}$ to balance the same mood in $v 7 \mathrm{a}$. Nelson also overlooks the assurance of "forever" in $v 7 \mathrm{~b}$. This occurs in $1 \mathrm{Kgs} \mathrm{9:3} \mathrm{which} \mathrm{Nelson} \mathrm{correctly} \mathrm{assigns} \mathrm{to}$ DTR (p. 74).

${ }^{9}$ Cf. A. D. H. Mayes, Deuteronomy, 266. 
hand as well. But they are unique in that unlike the other references they do not refer to "worshipping and serving" the host of heaven. ${ }^{10}$ It is conceivable therefore that these two passages record DTR's references to the host of heaven, while the other passages reflect a later more polemical usage.

Two additional observations indicate that the cult of the host of heaven was a concern of the Josianic reform. ${ }^{11}$ First, it seems that Judah's period of Assyrian vassalage led to a serious development of astral cults. One could expect that this was accompanied by the building of altars ( $2 \mathrm{Kgs} 21: 5)$ and fashioning of suitable cult objects (23:4) for the host of heaven.12 Second, there is the reference to the cult of the host of heaven in Zeph 1:5. Recent study of the book of Zephaniah has defended the prophetic provenance of $v 5$ and Zephaniah's association with, or influence on, the Josianic reform. ${ }^{13}$

${ }^{10}$ All use this word pair except $2 \mathrm{Kgs} 17: 16$, which has only the verb to worship. $2 \mathrm{Kgs} 23: 5$ refers to the burning of incense to the host of heaven.

${ }^{11}$ Hoffmann (Reform und Reformen, 249-50) argues that the reference in $2 \mathrm{Kgs}$ 21:5 to the temple's two courts reveals a projection of the plan of the second

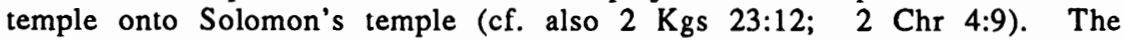
historical accuracy of such descriptions is not easy to establish, but Hoffmann may be over skeptical. Th. A. Busink accepts $2 \mathrm{Chr} 20: 5$ as a reliable reference to the construction of a second court in Jehoshaphat's time (Der Tempel von Jerusalem, von Salomo bis Herodes. Eine archäologisch-historische Studie unter Berücksichtigung des westsemitischen Tempelbaus [2 vols.; Leiden: Brill, 1970] 1. 146). Walther Zimmerli accepts that the ideal temple described in Ezekiel 4044 is probably based on Solomon's temple. Ezek 40:17 and 28 speak of an outer and inner court (Ezekiel 2: A Commentary on the Book of the Prophet Ezekiel, Chapters 25-48 [Hermeneia; Philadelphia: Fortress, 1983] 330-62). See also his comment on Ezek 8:3 in Ezekiel 1. A Commentary on the Book of the Prophet Ezekiel, Chapters 1-24 (Hermeneia; Philadelphia: Fortress, 1979) 237.

${ }^{12}$ There is general agreement that the period of Assyrian vassalage saw an increase of astral cults in Judah, although there is disagreement over whether or not Assyria imposed these cults on vassals. The more traditional view accepted the imposition theory. This has been questioned by John McKay, Religion in Judah under the Assyrians. 732-609 BC (SBT 26; London: SCM, 1973) 67, and Morton Cogan, Imperialism and Religion: Assyria, Judah and Israel in the Eighth and Seventh Centuries B. C. E. (SBLMS 19; Missoula: Scholars, 1974) 111. However the theory of cultic imposition has been reaffirmed by Spieckermann, Juda unter Assur, 369-72. The resolution of this debate is not critical for the point being made. All agree that Assyria's astral cult, whether by imposition or assimilation, influenced the development of astral cults in Judah (cf. McKay, 59; Cogan, 87-88; Spieckermann, 221-25). Note that the point is one of a significant development, not of origin. Astral cults in the Ancient Near East no doubt long predated the emergence of Assyria as a power (so McKay, 59).

${ }^{13}$ On the prophetic rather than dtr provenance of Zeph 1:5 see Guy Langohr "Redaction et composition du livre de Sophonie," Mus 89 (1976) 51-73, and "Le livre de Sophonie et la critique d'authenticité," ETL 52 (1976) 1-27. Langohr also proposes a pre-exilic redaction of the prophecy. In a recent criticism of commentaries on Zephaniah by H. Irsigler and W. Rudolph, Josef Scharbert has supported the association of this prophet with reform circles in the time of Josiah ("Zefania und die Reform des Joschija," Künder des Wortes. Beiträge zur 
The identification of $2 \mathrm{Kgs} 21: 1-2 \mathrm{a}, 3 \mathrm{aba}, 5,7$ as the text of DtrH can be confirmed by a consideration of the verses that have been omitted. $2 \mathrm{Kgs}$ $21: 2 \mathrm{~b}$ makes the same accusation as $1 \mathrm{Kgs} 14: 24 \mathrm{~b}$ and $2 \mathrm{Kgs} 16: 3 \mathrm{~b} \beta$. These two texts were judged to have been appended to DtrH. $2 \mathrm{Kgs} 21: 2 \mathrm{~b}$ was in similar vein appended to the judgment formula in $\mathrm{v} 2 \mathrm{a}$ in order to provide a general and polemical introduction to the extensive list of cultic abuses attributed to Manasseh. ${ }^{14}$ They are all gathered under the category of "the abominable practices of the nations".

With the other additions to $2 \mathrm{Kgs} 21: 2-7$ it is instructive to observe how each one disturbs the sequence of DTR's report in one way or another. Thus $v$ $3 \mathrm{~b} \beta$ accuses Manasseh of worshipping and serving the host of heaven, before the report of his construction of altars for them in $v 5 .{ }^{15}$ Verse 4 for its part anticipates the statement on the exclusive status of the temple in $v 7$. In addition it looks to have been composed from elements of DTR's text, namely the report of Manasseh's construction of altars in $v 5$ and the statement about the temple in $v 7$. The way each of DTR's elements appears in truncated form in this verse points to a later redactor who summarized them. ${ }^{16}$ Verse 6 also interrupts the report of Manasseh's "construction program" with a list of accusations about his conduct. In this it is rather like $v 3 b \beta$, although the tone is more strident. The list of accusations appears to have been made up of a number of elements taken from other locations. ${ }^{17}$ In addition to these points

Theologie der Propheten [ed. L. Perlitt, P. Weimar, E. Zenger; Würzburg: Echter, 1982] 237-53. See p. 248. The worship of the host of heaven is referred to also in Jer 8:2 and 19:13. However Winfried Thiel assigns both texts to the dtr redaction (D) of Jeremiah (Die deuteronomistische Redaktion von Jeremia 1-25 (WMANT 41; Neukirchen-Vluyn: Neukirchener Verlag, 1973] 131, 132, 223-24. This would make them exilic.

${ }^{14}$ The identification of $v 2 b$ as a later addition was recognized by $I$. Benzinger, Die Bücher der Könige, 188; A. Sanda, Die Bücher der Könige II, 324-25; B. Stade, "Anmerkungen zu Kö 15-21," 186-88. More recently by Hentschel, 2 Könige, 101-2; Lohfkink, Rückblick im Zorn, 184; Würthwein, 1 . Kön. 17-2. Kön. 25, 440.

${ }^{15}$ Nelson (The Double Redaction, 65) also identifies this accusation as an addition, claiming that the exilic revision reversed the normal order of the phrase "serve and worship". However $2 \mathrm{Kgs} 21: 21$ is also a later addition, but with the verbs in the accustomed order. Sanda (Die Bücher der Könige II, 324-25) assigned $v 3 \mathrm{~b} \beta$ to a later redactor.

${ }^{16}$ Thus the reference to altars omits their location in the two courts of the temple (cf. v 5), and the statement about the temple omits the phrase "for ever" (cf. $v$ 7). This in particular is an indication of an exilic perspective. Montgomery (Kings, 519) regarded $v 4$ as a secondary duplicate of $v 7$.

${ }^{17}$ The accusation of passing one's son through fire (RSV "burned his son")

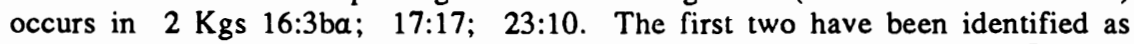
secondary. The third will be seen as more than likely a later addition to Josiah's reform. The accusation of soothsaying, augury, and dealing with mediums and wizards occurs in $2 \mathrm{Kgs} 23: 24$, which is definitely a later addition to Josiah's reform. The accusation of provocation to anger occurs in both DTR and later texts (cf. chapter 6). Nelson finds the verb "to provoke" is used without an object only in $2 \mathrm{Kgs}$ 21:6 and 23:19, a later addition (The Double Redaction, 
there is also the presence of the we-qatal form of the verbs in vv 4 and 6 . One must be cautious in employing this as a literary critical criterion. ${ }^{18}$ Neverthleless its repeated use in $v 6$ in particular is striking.

This intrusion into the sequence of DTR's report was done with a definite purpose in mind. The additions effectively break up the structure of DTR's text to create two similar structures in vv 3-4 and 5-7. Each begins with a report of Manasseh's "construction program" (cf. vv 3aba, 5), progresses to a condemnation of his conduct (cf. vv $3 \mathrm{~b} \beta, 6$ ), and concludes with a second report and statement about the temple (cf. vv 4,7). One can see that DTR's structure was adopted, duplicated, and expanded in the process with the condemnations in vv $3 \mathrm{~b} \beta$ and 6 . This procedure resulted in some uneveness in the text but it had the effect of creating a much more condemnatory portrait of Manasseh.

Given this analysis of $2 \mathrm{Kgs} \mathrm{21:2-7}$ it is evident that vv 8-9 are also a later addition to DtrH. ${ }^{19}$ Verse 8 abruptly shifts the focus from the choice of the temple "forever" to the exile of Israel from the land. The reference to Israel in $v 8$ is out of context in a passage dealing with the cult in Judah. There is also evidence of nomistic language in this verse. Verse 9 is dependent on $v 8$ and may be regarded as coming from the same hand. ${ }^{20}$ The focus on the people and the interest in obedience to the law points firmly to a later nomistic dtr provenance for $2 \mathrm{Kgs} 21: 8-9$.

We can now turn to a consideration of the prophecy in $2 \mathrm{Kgs} 21: 10-15$. It is clear that the announcement of disaster in this prophecy, and the corresponding fulfillment notice in $2 \mathrm{Kgs} 24: 2$ (cf. "his servants the prophets"), has the exile of Judah in mind. It cannot therefore form part of a Josianic DtrH. An examination of the prophecy shows there are grounds for linking it with the later redaction of $2 \mathrm{Kgs} 21: 2-7$. The reference to abominations in $v$ 11 recalls the same term used in $\mathrm{v} 2 \mathrm{~b}$ to describe Manasseh's cultic abuses. Furthermore the reference to idols in the same verse looks to be a general and polemical description of the items listed in vv 3-7.21 The aim of the prophecy was to place the blame for the exile squarely on Manasseh. He is the only Davidic king accused of making Judah sin (cf. v 11).

Whereas $2 \mathrm{Kgs} 21: 11-14$, with its accusation in $\mathrm{v} 11$ and announcement of disaster in vv 12-14, clearly forms a unit, there is evidence in favor of $v 15$ as

68). Also the verb rabah (hiphil) in $v 6$ and $v 16$ is not found in any other judgment formulas for kings.

${ }^{18}$ In view of the work of R. Meyer, "Auffallender Erzählungsstil," 114-23, and Spieckermann, Juda unter Assur, 120-30. Their findings were commented on in the discussion of the reform of Hezekiah.

${ }^{19}$ Against for example, Provan, Hezekiah, 117. The break between $v 7$ and 8 is noted by Gray, I \& II Kings, 705; and R. E. Friedman, "From Egypt to Egypt: Dtr1 and Dtr2," 177.

${ }^{20} 2 \mathrm{Kgs} 21: 9$ contains the general complaint that the people did not listen, noted by Nelson as an exilic dtr comment (The Double Redaction, 51).

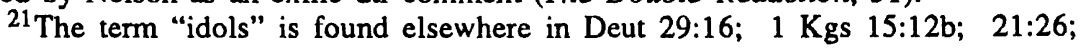
$2 \mathrm{Kgs} \mathrm{17:12;} \mathrm{23:24,} \mathrm{all} \mathrm{later} \mathrm{additions} \mathrm{to} \mathrm{the} \mathrm{history.}$ 
a later addition. ${ }^{22}$ It introduces a further accusation after the announcement of disaster in vv 12-14, and shifts the blame from Manasseh (v 11) to the people. The focus on the people associates this verse with the addition in $2 \mathrm{Kgs} 21: 8-9$ and the later nomistic stage of redaction. Onc may provisionally conclude therefore that the nomistic additions in $2 \mathrm{Kgs} 21: 8-9,15$ are later than the post-DTR redaction of $2 \mathrm{Kgs} 21: 2-7$ and the prophecy associated with it in vv 10-14. The significance of this will be explored further in the following chapter's comments on the later redaction history of DtrH.

The third section, $2 \mathrm{Kgs} 21: 16$, reports yet another crime by Manasseh, the shedding of innocent blood. $2 \mathrm{Kgs} 24: 4$ lists this crime, along with the rest of his sins (cf. v 3) as the reason for the exile. $2 \mathrm{Kgs} 21: 16$ is clearly in the spirit of the later redaction of $2 \mathrm{Kgs} \mathrm{21:2-7}$ and vv 10-14. Nevertheless it is doubtful whether one can attribute the verse to this redaction. The crime of shedding innocent blood occurs nowhere else in the historical books and finds its most extensive parallels in Jeremiah (cf. Jer 2:34; 7:6; 19:4; 22:3, 17; 26:15). ${ }^{23}$ Moreover $v 16 \mathrm{~b}$ appears to be a conflation of $v v 11$ (accusation against Manasseh of making Judah sin) and 15 (accusation against the people). This would suggest that it was appended after the nomistic reworking (cf. v $15)^{24}$

\section{KGS 21:19-26 (THE REIGN OF AMON)}

The basic judgment formula for Amon occurs in v 20.25 Verses 21-22 are later more polemical expansions of the formula. They provide no particular information about Amon's cultic abuses as did DTR's account of Manasseh. The statement "he walked in all the way in which his father walked" is pleonastic in comparison to the use of this metaphor in DTR's judgment formulas. ${ }^{26}$ The use of the term "idols" has already been noted as a mark of later redaction, as has also the use of the verb "to forsake" in v 22. Given the presence of "idols" in $2 \mathrm{Kgs} 21: 11$ and v 21, plus the verb pair "to serve" and "to worship" in $v 3 b \beta$ and $v 21$, one may with good reason attribute vv 21-22

${ }^{22}$ Dietrich (Prophetie und Geschichte, 33-34) assigns vv 10-14 to DtrP and v 15, along with v 16, to DirN. Würthwein (1.Kön. 17-2. Kön. 25, 440) assigns vv $14,15,16$ to diverse DtrN circles.

${ }^{23}$ It occurs also in Deut 19:10, judged to be a post-dtr addition by A. D. H. Mayes (Deuteronomy, 287-88). The hiphil form of the verb răbâ, noted earlier in $2 \mathrm{Kgs} 21: 6$, occurs also in $v 16$.

${ }^{24}$ Against Gray (I \& II Kings, 705) and Nelson (The Double Redaction, 67) who include the verse in DtrH. $2 \mathrm{Kgs} 21: 16$ also has the introductory wégam.

${ }^{25}$ Because Amon did evil like his father, DTR did not require a further affirmation that the promises to David were still intact. The statement in $2 \mathrm{Kgs}$ 21:7 sufficed also for Amon. $2 \mathrm{Kgs} \mathrm{21:7}$ thus functions in a similar manner to 2 Kgs 8:19, which covers Jehoram, Ahaziah and Ahaz.

${ }^{26} \mathrm{Cf} .1 \mathrm{Kgs} 3: 3 ; 15: 26,34 ; 16: 26 ; 2 \mathrm{Kgs} 22: 2$. None of these have the additional relative clause with saser. 
to the same redaction responsible for the expansions in $2 \mathrm{Kgs} 21: 2-7$ and the prophecy against Manasseh in vv 10-14. ${ }^{27}$

One can see from the examination of 2 Kings 21 how DTR established a parallel between Manassseh and Ahaz. This in turn enabled DTR to portray Josiah as another Hezekiah. As Hezekiah removed the high places after Ahaz had indulged in worshipping at them, so Josiah moved decisively to eliminate the threat to the exclusive centralized worship of Yahweh posed by Manasseh's program. But as will be seen, there is more to DTR's portrayal of Josiah than the parallel with Hezekiah. The discovery of the book of the law, the covenant in the temple, the definitive nature of the reform, and the celebration of Passover, all serve to mark the reign of Josiah as the beginning of a new era. It is more than the preservation of Judah from the Assyrians in the time of Hezekiah. Between Hezekiah and Josiah therefore one can observe another example what has been seen to bc a characteristic feature of DTR's work, namely continuity within a larger trajectory of change and development.

\section{KGS 22:1-23:30 (THE REIGN OF JOSIAH)}

DTR organized the account of Josiah around the same four-part pattern employed for David and Hezekiah. The pattern has even controlled the organization of the present text. There is first of all the critical event of the discovery of the book of the law in $2 \mathrm{Kgs} \mathrm{22:3-10.} \mathrm{Second,} \mathrm{as} \mathrm{a} \mathrm{result} \mathrm{of} \mathrm{this}$ discovery Josiah sends a delegation to consult the prophetess Huldah $(2 \mathrm{Kgs}$ 22:11-14). Huldah gives a prophecy in $2 \mathrm{Kgs} 22: 15-20$, which forms the third part of the pattern. The fourth part of the pattern is taken up with a description of Josiah's reform (2 Kgs 23:1-25). The effect of this four-part pattern is to portray Josiah as a model king like his predecessors David and Hezekiah. The judgment formula in $2 \mathrm{Kgs} 22: 2$ also contributes to this comparison. It states that Josiah "did what was right in the eyes of the Lord, and walked in all the way of David his father". ${ }^{28}$ The only other king compared to David in this way is Hezckiah (cf. $2 \mathrm{Kgs} \mathrm{18:3).}$

As with David and Hezekiah, the four-part pattern shows that Josiah was completely faithful to the prophet/king relationship. It also shows that he fulfilled the two other related criteria of DTR's model of kingship, namely complete fidelity to Yahweh and to the policy of centralized worship. The covenant ceremony in $2 \mathrm{Kgs}$ 23:1-3 testifies to Josiah's complete fidelity to Yahweh. The account of the reform (2 Kgs 23:4-20) and the celebration of Passover in the temple (2 Kgs 23:21-23) testify in their turn to his fidelity to the policy of centralized worship.

While the pattern itself is clearly recognizable the identification of the text of DtrH is another matter. Varying degrees of later redaction have been proposed for each part of the pattern. Each one will have to be examined in some

${ }^{27}$ The identification of $2 \mathrm{Kgs} 21: 21-22$ as a later addition is affirmed by Hentschel, 2 Könige, 104; Würthwein, 1. Kön. 17-2. Kön. 25, 444 (DtrN).

${ }^{28} \mathrm{It}$ is possible that $2 \mathrm{Kgs} 22: 2 \mathrm{~b} \beta$ is a later expansion of the formula. However Hentschel (2 Könige, 105) and Würthwein (1. Kön. 17-2. Kön. 25, $445)$ are incorrect in assigning all of $v 2 b$ to DtrN. 
detail therefore to determine as accurately as possible what is to be attributed to DTR, and what is to be attributed to later redaction.

The presence of the four-part pattern in 2 Kings 22-23 also raises the matter of sources. We have seen that DTR made extensive use of source material in the construction of the pattern for David and Hezekiah. Hence the possibility that a source or sources was used to construct the pattern for Josiah must also be considered. It may be helpful therefore to preface the more detailed examination of the text of 2 Kings 22-23 with some general comments on the question of source material.

The hypothesis which has dominated the investigation of sources in 2 Kings 22-23 was first proposed by Theodor Östreicher in 1923.29 He identified

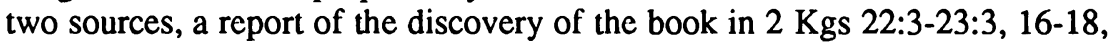
20-24 (Auffindungsbericht), and a report of Josiah's reform in $2 \mathrm{Kgs} 23: 4-14$, 15, 19 (Reformbericht). The identification of two sources led him to propose that Josiah's reform was independent of the book of the law. For Östreicher this correlated better with 2 Chronicles 34 where the reform is reported as having taken place prior to the finding of the book (cf. $2 \mathrm{Chr} 34: 3-18$ ).

Östreicher's report of the discovery of the book contains the four parts of the pattern: namely, the discovery (22:3-10); consultation of the prophet (22:11-13); prophecy (22:15-20); subsequent events (23:1-3, 16-18, 20-24). The structure and complexity of this text when compared with the report of the reform of $2 \mathrm{Kgs} 23: 4-14,15,19$ raises the question whether Östreicher's description of it as a report (Bericht) was quite accurate. ${ }^{30}$

N. Lohfink maintains Östreicher's basic distinction, but proposes that his Auffindungsbericht was in reality a special genre which he describes as a short historical narrative (Historische Kurzgeschichte). ${ }^{31}$ The text of this narrative,

${ }^{29}$ Theodor Östreicher, Das Deuteronomische Grundgesetz (BFCT 27/4; Gutersloh: Bertelsmann, 1923). Ötreicher's source analysis was not taken up explicitly by Noth, who proposed that DTR relied on an official record of the finding of the book, and on the "Books of the Chronicles" for the reform (The Deuteronomistic History, 73).

${ }^{30}$ In a recent study of 2 Kings 22 Dietrich has considerably pared down the amount of text identified as pre-dtr ("Josia und das Gesetzbuch [2 Reg. XXII]," VT 27 [1977] 13-35). His pre-dtr text is $2 \mathrm{Kgs} 22: 3,8,10,12,13^{*}, 14,15 \mathrm{aa}$ b, $16 \mathrm{a} a, 18 \mathrm{~b} \beta, 20 \mathrm{~b}$ (cf. pp. 18-27). Dietrich proposes that only the frame of Huldah's original oracle can be recovered. The oracle itself was replaced by later redaction (DtrP and DtrN).

${ }^{31}$ Lohfink, "Die Gattung der 'Historischen Kurzgeschichte' in den letzten Jahren von Juda und in der Zeit des Babylonischen Exils," ZAW 90 (1978) 31947, and "The Cult Reform of Josiah of Judah: 2 Kings 22-23 as a Source for the History of Israelite Religion," Ancient Israelite Religion: Essays in Honor of Frank More Cross (ed. P. D. Miller, Jr., P. D. Hanson, S. D. McBride; Philadelphia: Fortress, 1987) 459-75. A less detailed study but one which moves in the same direction as Lohfink's is that of Charles D. Isbell, "II Kings 22:3-23:24 and Jeremiah 36: A Stylistic Comparison," JSOT 8 (1978) 33-45. Isbell dates the Kings text in the Josianic era and holds that Jeremiah 36 was composed in the light of it to contrast Jehoiakim with the good king Josiah. Isbell sees a highly unified Kings text which supports the notion of a Josianic Dtr. He recognizes later editing only in the last part of $2 \mathrm{Kgs} 22: 20 \mathrm{a}$ (p. 42). 
which comprises $2 \mathrm{Kgs} 22: 3-20 ; 23: 1-3,21-23$, follows Östreicher's text quite closely. But Lohfink sces an organizing principle in the four initiatives of the king: Josiah sent (22:3); Josiah commanded (22:12); Josiah sent (23:1); Josiah commanded (23:21). ${ }^{32}$ According to Lohfink this short historical narrative about Josiah was later incorporated into DtrH.

Lohfink's perception of the four royal initiatives is helpful for making a suitable division of the material, but as a structural argument does not sufficiently draw out the importance of Huldah's prophecy in the story. Their function within the account can be more accurately seen once they are incorporated into the larger four-part pattern proposed here. Thus the dispatch of Shaphan the secretary to the temple in $2 \mathrm{Kgs} 22: 3$ leads to the discovery of the book (first part of pattern). The command in $2 \mathrm{Kgs} \mathrm{22:12}$ initiates the consultation of the prophetess (second part). ${ }^{33}$ Then comes the third part of the pattern, the prophecy of Huldah. The two commands in $2 \mathrm{Kgs} \mathrm{23:1} \mathrm{and} 21$ introduce important subsequent developments in the history. These subsequent developments demonstrate Josiah's complete fidelity to Yahweh (23:1-3) and his commitment to centralized worship (23:21-23 -in concert with the reform in 23:4-20). Along with fidelity to the prophet/king relationship, these constitute DTR's three criteria of model kingship. ${ }^{34}$

My own analysis indicates that it is unlikely there were any extensive sources available to DTR. It is possible there was a brief account of the finding of the book of the law, but it is difficult to maintain a clear distinction between source and redaction. Similarly, it is unlikely one can recover the text of a pre-dtr report of the reform. The best that can be said is DTR relied on official information about it or knew it first hand. ${ }^{35}$

The detailed exegesis of 2 Kings 22-23 will follow the division of the text provided by the four-part pattern; that is, $2 \mathrm{Kgs} 22: 3-10$ (discovery of the

${ }^{32}$ For the texts see Lohfink, "Kurzgeschichte," 342. He proposes there were similar short historical narratives about Jehoiakim (Jeremiah 26*; 36*) and Zedekiah (Jeremiah 37-38*; 40-43*).

${ }^{33}$ The division within the four-part pattern has been made at $2 \mathrm{Kgs} 22: 11$. The difference is not critical, since $v 11$ functions as a transition from the section dealing with the discovery to the section dealing with the prophetic consultation. Verse 12, in which the king dispatches the delegation, is the key verse of this section.

${ }^{34}$ In Rückblick im Zorn, 177, Lohfink allows the possibility that DTR-for Lohfink Josianic-may have composed this story prior to incorporating it into the history. This would bring his position closer to the one arrived at here.

${ }^{35}$ The position arrived at is in disagreement with the recent study by Spieckermann, who claims there was an extensive pre-dtr source that included the discovery of the book, the prophetic consultation and prophecy, the covenant ceremony, and the reform (Juda unter Assur, 423-29). The text (following his division within verses) is $2 \mathrm{Kgs} 22: 1,3-5,7-12,13 \mathrm{a} a * \beta b a, 14,15 \mathrm{a} a \mathrm{~b}, 16 \mathrm{a}$,

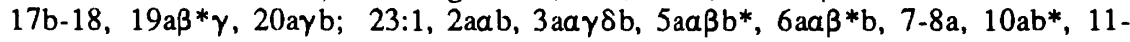
$12 \mathrm{aa \gamma}$ (nătas hammelek), 29-30. Aspects of his analysis will taken up in the following discussion. Dietrich considers it possible that a pre-dtr source dealing with the discovery of the book and Huldah's prophecy also contained a report of the reform. However he does not investigate the matter ("Josia und das Gesetzbuch," 32, n. 87). 
book), 22:11-14 (delegation to Huldah), 22:15-20 (Huldah's prophecy), 23:123 (subsequent events, comprising covenant ceremony in vv 1-3, reform in vv 4-20, and Passover celebration in vv 21-23). This will be followed by an examination of the rest of the reign of Josiah in $2 \mathrm{Kgs} 23: 24-30$, and the last four kings of Judah in $2 \mathrm{Kgs}$ 23:31-25:30.

\section{1)- 2 KGS 22:3-10 (DISCOVERY OF THE BOOK OF THE LAW)}

There are four key questions about this text which need to be considered in relation to the proposed conceptual plan and structure of DtrH. Each of them arises from a literary critical analysis of $2 \mathrm{Kgs} 22: 3-10$ in which vv 3 (omitting lêmōr), 8, 10 are identified as a report of the discovery of the book, and vv 4-7, 9 as a report about temple repairs. ${ }^{36}$ This division is prompted in part by the similarity between vv 4-7,9 and the narrative about the procedure set up by Jehoash in 2 Kgs 12:5-17 (RSV 12:4-16) for carrying out temple repairs. There is also no report of the execution of Josiah's command to Shaphan in vv 4-7, which is unusual in hebrew narrative style. The transition from vv 4-7 to $v 8$ looks abrupt, and $v 9$ appears to intrude between $v v 8$ and 10 , by returning to the topic of temple repairs.

An initial question which arises from this literary critical analysis is whether the two reports were part of $\mathrm{DtrH}$, or whether one or both were added subsequently. ${ }^{37}$ For the report of the discovery of the book in $2 \mathrm{Kgs} 22: 3^{*}, 8$, 10 the question of its inclusion in DtrH must be answered in the affirmative. Its omission would mean that there was no significant event to prompt the consultation of Huldah and her prophecy. There is nothing in the report of temple repairs to require the addition of the prophecy. ${ }^{38}$ The repairs are

${ }^{36}$ For a detailed discussion of this division see Dietrich ("Josia und das Gesetzbuch," 18-27). Dietrich regards the report of the discovery of the book as

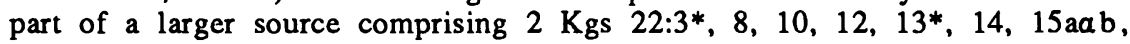
$16 \mathrm{aa}, 18 \mathrm{~b} \beta, 20 \mathrm{~b}$. A variation of this literary critical division is to include all of v 3 with the account of temple repairs (so Mayes, The Story of Israel, 130). In my judgment the division proposed by Dietrich is more satisfactory.

${ }^{37}$ C. Levin ("Joschija im deuteronomistischen Geschichtswerk," ZAW 96 [1984] 351-71) includes only $2 \mathrm{Kgs} 22: 1-2$; 23:8a, 25a (to melek) b, 28-30 in an exilic DtrH. An extended reform report (23:4-20) was added in the post-exilic period in conjunction with the report of temple repairs in 22:3-7, 9*. Huldah's original prophecy (cf. 22:12, 13 [to "people"], 15, 19a [to "Yahweh"], 20a [to "in peace"] b) was likewise inserted in the post-exilic period. The final redaction saw the incorporation of the discovery of the book, a revision of the prophecy and additonal material on the theme of obedience to the law in 23:1-3, 21-24, 25a*, 26-27. Mayes (The Story of Israel, 130) omits $2 \mathrm{Kgs} \mathrm{22:8,} 10$ and 22:1220 from DtrH, but retains the report of temple repairs in 22:3-7, 9 and the reform

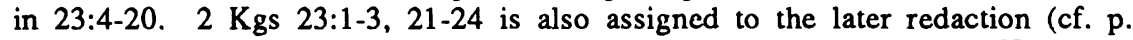
174 n. 63). Mayes's position here is a change from his earlier "King and covenant: a study of 2 Kings chs 22-23," Hermethena 125 (1978) 34-47, in which he included the discovery of the book and Huldah's prophecy (cf pp. 38 41).

${ }^{38}$ Against Mayes (The Story of Israel, 130). Levin's description of the growth of the text creates the same problem (see n. 37). According to Levin 
initiated by Josiah whereas the discovery of the book clearly is not. In the earlier examples of David and Hezekiah, it was a significant event in their reigns which prompted the prophetic consultation, not their own initiative. ${ }^{39}$ The deletion of $2 \mathrm{Kgs} \mathrm{22:3*}, 8,10$ would also create an awkward lacuna in the textual sequence. The remaining verses do not report an encounter between Shaphan and Hilkiah, which is supplied by $v 8$. One would expect such an encounter however, given the king's command in $\vee 3$ and the verb wayyābo' which commences $v 9$.

The reform of $2 \mathrm{Kgs} \mathrm{23:4-20}$ is also in a unique position in relation to other cultic reforms in DtrH, whether they be for or against the exclusive centralized worship of Yahweh. The other reports all follow immediately after the judgment formulas. Although the report of temple repairs in $2 \mathrm{Kgs} \mathrm{23:4-}$ 7,9 follows closely upon the judgment formula in $v 2$ it does not belong among the cultic reforms of the history. The report does not deal with the alternatives of fidelity or infidelity to Yahweh, temple or high places. ${ }^{40}$ It also describes the collection of funds and temple repairs as an already established practice (cf. 2 Kgs 12:5-17 [RSV 12:4-16]). The most reasonable explanation for the special location of the reform report is provided by the discovery of the book of the law. It supplied the motivating element for the reform, via the prophecy of Huldah.

The inclusion or omission of the report of temple repairs in $2 \mathrm{Kgs} \mathrm{22:4-7,}$ 9 is, strictly speaking, not essential for the conceptual plan and structure of DtrH. Given the validity of the literary critical division between vv 4-7, 9 and vv $3^{*}, 8,10$, the latter can stand on its own. Nevertheless there are some good reasons in favor of including $2 \mathrm{Kgs} 22: 4-7,9$ in the history. Its portrayal of Josiah's concern for the welfare of the temple fits nicely into the context of this section of DtrH. Also when one reads the report of the discovery of the book in the context of Josiah's concern for the temple it assumes the dimensions of a providential act. ${ }^{41}$ Josiah is the king who, as a

DtrH was concemed with cult centralization (Einheit) and not the exclusive worship of Yahweh (Reinheit). This became a concern of later redaction (p. 354). Hence his text of DtrH as $2 \mathrm{Kgs} 22: 1-2$; 23:8a, 25*, 28-30. However the reassessment of DtrH carried out so far rules out such a separation of concerns. See for example the analysis of Solomon's infidelity in 1 Kings 11, and DTR's redaction of the prophetic speeches and the judgment formulas, in particular the formula for Manasseh.

${ }^{39} 2$ Samuel 6 begins by reporting that David set out to bring the ark to Jerusalem, but his initiative was halted by Uzzah's death in vv 6-9. Only when it was reported that Yahweh blessed the house of Obed-Edom (v 12) did David set out again. The blessing was the divine signal that the ark could be brought into the city. After the entry of the ark David consulted Nathan. In the case of Hezekiah the consultation of Isaiah was a response to the Assyrian invasion.

${ }^{40}$ The other texts in DtrH which deal with the refurbishing or repair of the temple locate such reports after the judgment formula and any report of cultic

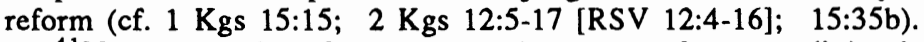

${ }^{41}$ Nelson speaks of "an appropriate aura of mystery" in the story of the discovery of the book (First and Second Kings, 255). The question of whether the book was actually discovered in the temple during repairs, or whether the 
result of the discovery of the book, acts decisively to remove the affront to Yahweh made by Manasseh when he set up the Asherah in the temple (2 Kgs 23:6, cf. 21:7). The report also portrays Josiah as exercising authority over the temple clergy. This fits in well with the rest of DTR's account of his reign, in particular the report of the reform (cf. $2 \mathrm{Kgs} 22: 12 ; 23: 4 ; 23: 8 \mathrm{a}$ may be included among these examples of Josiah's authority over the clergy). A third point in favor of its inclusion is that there is no satisfactory reason for attributing it to a later redactor.

A second question which arises from the literary critical division is the provenance of each report. Given that the reports were part of DtrH there is the possibility that they are the product of a source-redaction combination. However an examination of the literary evidence does not given any encouraging results in favor of such a view. With $2 \mathrm{Kgs} 22: 3^{*}, 8,10$ the only term or phrase that stands out and could indicate a pre-dtr provenance is the title of the book in $v 8$. It is possible this was the title for Deuteronomy prior to the dtr redaction. ${ }^{42}$ But the only other usage of this title occurs in dir passages (cf. Deut 28:61;29:20;30:10; 31:26; Josh 1:8; 8:34). It seems more reasonable therefore to accept that DTR coined the title. ${ }^{43}$

Moreover the literary critical division of itself does not necessarily mean that $2 \mathrm{Kgs} \mathrm{22:3-10} \mathrm{is} \mathrm{a} \mathrm{combination} \mathrm{of} \mathrm{source} \mathrm{(vv} \mathrm{3*,8,10)} \mathrm{and} \mathrm{redaction} \mathrm{(vv}$ 4-7, 9). It is after all the parallels with 2 Kings 12 which facilitate the division. Another possibility is that DTR composed the report of the book's discovery, and in order to provide a suitable setting for it drew on elements of the narrative in 2 Kings 12 . Admittedly there is the rather abrupt change between $2 \mathrm{Kgs} 22: 7$ and 22:8. One would expect some report of the execution of Josiah's command before $v 8 .{ }^{44}$ Nevertheless, given that $2 \mathrm{Kgs} \mathrm{22:4-7,9}$ was composed on the basis of 2 Kings 12 as a setting for the report of the discovery of the book, and that the main point was its discovery, DTR may

account given in 2 Kings 22 was a pious fraud need not concem us here. To endorse the words of Lohfink in "Zur neucren Diskussion über 2 Kön 22-23," 30; "In the end it is the text as text which needs to be understood and expounded".

${ }^{42}$ There is no need to defend the proposal that in the present text the title refers to Deuteronomy or an carlier version of it. This is generally accepted. See for example H. D. Preuss, Deuteronomium, 4-5, and Würthwein, 1. Kön. 17-2. Kön. 25, 447. Alternative proposals have not affected the mainstream position. Jack R. Lundbom ("The Lawbook of the Josianic Reform," CBQ 38 [1976] 293302) proposes Moses' song in Deuteronomy 32, while J. Maier ("Bemerkungen zur Fachsprache und Religionspolitik im Königreich Juda," Judaica 26 [1970] 89105) proposes a book from the priestly tradition. The names of the priest and secretary could have come equally from DTR or a source.

${ }^{43}$ Dietrich ("Josiah und das Gesetzbuch," 30-31) argues that the spartan style

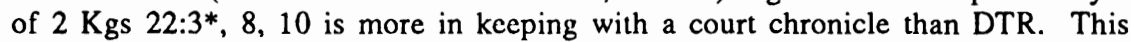
is difficult to assess, since the removal of material via literary critical analysis usually results in the remaining text having a simpler style. Dietrich also claims that the repetition of "the king" in vv 10 and 11 is stylistically awkward, showing the verse was inserted to prepare for DtrP's comment on Josiah in $v 19 \mathrm{a}$

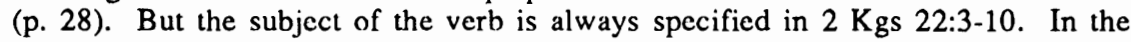
context therefore the repetition is not unusual.

${ }^{44}$ A point made by Dietrich, "Josia und das Gesetzbuch," 22. 
well have foregone reporting the execution of the king's command in order to move rapidly to the point.

A third question which arises from the literary critical division is the

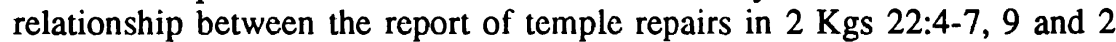
Kings 12. The preceding remarks were made on the understanding that DTR drew on aspects of 2 Kings 12 for the composition of $2 \mathrm{Kgs} \mathrm{22:3-10.45} \mathrm{It} \mathrm{has}$ recently been argued however that the account in 2 Kgs 12:5-17 (RSV 12:416) is dependent on $2 \mathrm{Kgs} \mathrm{22:3-10.46}$ This seems unlikely. The financial arrangements for the repair of the temple in $2 \mathrm{Kgs} 12: 5-17$ are central to the narrative. ${ }^{47}$ In $2 \mathrm{Kgs} 22: 3-10$ on the other hand these arrangements have been introduced to provide a suitable occasion for the providential discovery of the book of the law. Moreover a closer comparison of the two accounts shows that the author of $2 \mathrm{Kgs} \mathrm{22:4-7} \mathrm{summarized} \mathrm{the} \mathrm{more} \mathrm{extensive} \mathrm{account} \mathrm{in} 2$ Kings 12 by conflating the separate references to workmen in $2 \mathrm{Kgs} 12: 12 \mathrm{~b}-13$ and 15. The simple repetition of the verb nātan in $2 \mathrm{Kgs} \mathrm{22:4-6}$ also supports the notion of an author who was condensing material from 2 Kings 12 . As well as this there are some terms in 2 Kings 12 which do not appear in $2 \mathrm{Kgs}$ $22: 4-7.48$

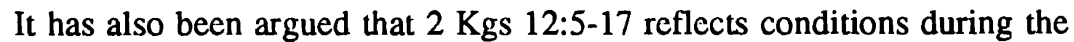
early period of the second temple and is therefore a post-exilic composition. The evidence for this rests principally on the following; the kesep haqqödasim (money of the holy things) in $\mathrm{v} 5$ with the accompanying clarification about the different types of donation, the term "high priest" in v 11, the list of cultic utensils in $\mathrm{v} 14$, and the description of offerings in $\mathrm{v} 17.49$

The phrase kesep haqqöašim is unique in the OT, which makes its provenance difficult to determine. Certainly it cannot simply be identified with the occurrence of haqqōdāsim alone in such later texts as Lev 21:22; Deut

${ }^{45}$ Following Dietrich (ibid., 22-25) but without subscribing to his view that 2

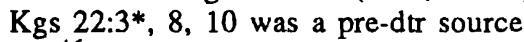

${ }^{46} \mathrm{Cf}$. Spieckermann (Juda unter Assur, 48-53, 179-83) and Levin ("Joschija im deuteronomistischen Geschichtswerk," 355, n. 14). Spieckermann develops a complicated picture of the growth of $2 \mathrm{Kgs} 12: 5-17$. The verses which parallel 2 Kgs 22:4-7, 9, namely $2 \mathrm{Kgs} 12: 5 \mathrm{a} \beta * \mathrm{~b}, 10,12-13,16$, are assigned to later dtr redaction. Levin simply makes the proposal, with the arguments to come in a future study. For the remainder of this discussion the MT versification of 2 Kings 12 will be followed.

${ }^{47}$ In relation to this there are some aspects of Spieckermann's literary critical

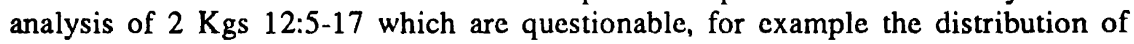
vv $10,13-14$ to the source and vv 11-12 to a late Dtr. The details of this cannot be investigated here.

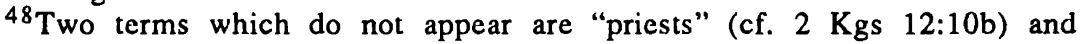
"stonecutters" (cf. 12:13a). Spieckermann argues that the infinitive clause in 2 $\mathrm{Kgs} \mathrm{12:13a \gamma}$ was compiled from the two separate phrases in $2 \mathrm{Kgs} 22: 5 \mathrm{~b} \beta, 6 \mathrm{~b} \beta$ (Juda unter Assur, 181-82). The texts offer little evidence for a decision either

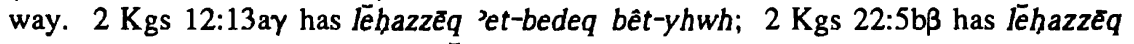
bedeq habbð̃yit, while 22:6bß has lehazzẽq 'et-habbðyit.

${ }^{49} \mathrm{Cf}$. Hoffmann, Reform und Reformen, 122-23; Würthwein, 1. Kön. 17-2. Kön. 25, 354-57. 
12:26; $1 \mathrm{Kgs} 15: 15 ; 2 \mathrm{Chr} 29: 33 ; 35: 13$; Neh 10:34. These texts have a more general reference whereas $2 \mathrm{Kgs} 12: 5$ looks to be a description of a particular type of offering. Its precise meaning may have been lost in later tradition. The various monctary contributions described in the latter part of 2 Kgs 12:5 reflect a later attempt to give specific content to a term which had become somewhat enigmatic. ${ }^{50}$

There seems little doubt that the use of the title "high priest" was a postexilic development. ${ }^{51}$ However the formulation of $2 \mathrm{Kgs} \mathrm{12:11} \mathrm{shows} \mathrm{that} \mathrm{it}$ has been inserted into the text. The singular form of the verb calah has only the king's secretary in mind. The phrase "and the high priest" has been inserted without changing the verb, even though it is clear the high priest is understood as going to the temple with the secretary.52 The insertion is therefore the work of a later editor who wished to cast Jehoiada as a post-exilic high priest. ${ }^{53}$ The addition of the title high priest in $2 \mathrm{Kgs} \mathrm{12:11} \mathrm{indicates}$ that the adjective gãdôl was also added to the title priest in $2 \mathrm{Kgs} 22: 4,8$; 23:4. ${ }^{54}$

The list of cultic utensils in $2 \mathrm{Kgs} \mathrm{12:14} \mathrm{cannot} \mathrm{be} \mathrm{used} \mathrm{either} \mathrm{as} \mathrm{evidence}$

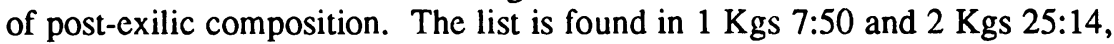
both of which were probably derived from source material or at least based on reliable information about the first tcmple..$^{55} 2 \mathrm{Kgs}$ 12:17 does appear to have Lev 5:16 in mind, but the verse has been appended by a later hand to regain some ground for the priests. According to vv 5-16 they had effectively lost control of temple finances as a result of the king's intervention. ${ }^{56}$

${ }^{50}$ Hoffmann (Reform und Reformen, 123) sees a relationship between these offerings and Exod 30:12-28 (P), but overlooks the evidence of later editing in 2 Kgs 12:5. Spieckermann (Juda unter Assur, 415) recognizes a post-dtr addition commencing after "house of the Lord" in $v 5 \mathrm{a}$.

${ }^{51}$ See J. Morgenstem, "A Chapter in the History of the High-Priesthood," AJSL 55 (1938) 1-24, 183-97, 360-77, especially p. 367. More recently see J. Bergman, H. Ringgren and W. Dommerhausen. "KOHEN kohēn," TWAT 4 (1984) 62-79, especially p. 75. J. Robinson (The Second Book of Kings, 209) defends the use of the title in the pre-exilic period.

${ }^{52}$ Against Hoffmann (Reform und Reformen, 120) who avoids the literary critical question by claiming the shift from pricst to high priest in $v 11$ is evidence of the fictional nature of the account.

${ }^{53}$ So Gray, I \& II Kings, 587; Jones, $I$ and 2 Kings II, 492; Spieckermann, Juda unter Assur, 180 , n. 49. The addition was probably by the same priestly editing evident in the elaborations in vv 5 and 17 (see below).

${ }^{54}$ If $2 \mathrm{Kgs} 12: 5-17$ and $2 \mathrm{Kings} 22-23$ had been composed in the post-exilic period with the aim of enhancing the authority of the high priest one would have expected a more consistent application of the title to Jehoiada and Hilkiah than is evident.

${ }^{55}$ Hoffmann (Reform und Reformen, 123, n. 101) cites Würthwein (1. Könige

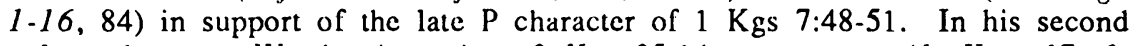
volume however Würthwein assigns $2 \mathrm{Kgs} 25: 14$ to a source (1. Kön. 17-2. Kön. 25, 477).

${ }^{56}$ Against Hoffmann (Reform und Reformen, 119) the priests are quite clearly

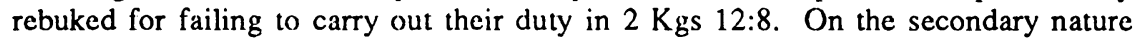
of v 17 cf. Gray, I \& II Kings, 585; Jones, $I$ and 2 Kings II, 494; 
$2 \mathrm{Kgs} 12: 5-16$ clearly asserts the royal prerogative to establish the financial arrangements for the upkeep of the temple. This is hardly in keeping with the post-exilic ascendancy of the temple priesthood. The parallel account in 2 Chronicles 24 is more likely a reflection of this later development. Here the good conduct and success of Jehoash is completely dependent on the presence of Jehoiada the priest (2 Chr 24:2). Jehoiada and the king appear to have equal authority in the distribution of funds ( $v 12)$. As soon as Jehoiada dies ( $v$ 15) the king is led astray by the advice of the princes, for which he receives a sharp rebuke from Zechariah son of Jehoiada ( $\mathrm{v} 20{ }^{57}$ It is reasonable to conclude therefore that $2 \mathrm{Kgs} 12: 5-17$ is a text of pre-exilic provenance. It is also reasonable to conclude that DTR either found the account already in place as a pre-dtr addition to the Southern Document, or added it to provide a suitable precedent for the report of Josiah's repairs to the temple..$^{58}$

Overall the analysis of $2 \mathrm{Kgs} 22: 3-10$ has uncovered no clear evidence of

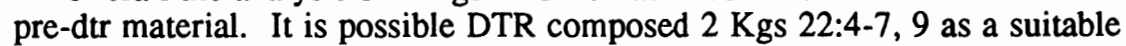
setting for a report to hand about the discovery of the book (vv $\left.3^{*}, 8,10\right)$. The more likely scenario however is that DTR composed the whole. The need to condense the more extensive account of temple repairs in $2 \mathrm{Kgs} \mathrm{12:5-17}$ (RSV 12:4-16) was probably responsible for a certain amount of abruptness in the sequence from $2 \mathrm{Kgs} 22: 7$ to 8 .

\section{2)- 2 KGS 22:11-14 (THE DELEGATION TO HULDAH)}

From an examination of these verses there is little that can be said for or against the notion of a pre-dtr source underlying the present text. ${ }^{59}$ What can be pointed out is that the text of $\mathrm{DtrH}$ was expanded by a later redactor in $\mathbf{v}$ $13 \mathrm{~b} .{ }^{60}$ This statement effectively provides an answer to Josiah's enquiry

Spieckermann, Juda unter Assur, 183, n. 56; Würthwein, 1. Kön. 17-2. Kön. $25,357$.

${ }^{57} \mathrm{Cf}$. the discussion of 2 Chronicles 24 by Frank Michaeli, Les livres des Chroniques, d'Esdras et de Néhémie (Commentaire de l'Ancien Testament, 16; Neuchâtel: Delachaux \& Niestlé, 1967) 207-9; and Rudolf Mosis, Untersuchungen zur Theologie des chronistischen Geschichtswerkes (Freiburger theologische Studien 92; Freiburg: Herder, 1973) 180-83.

${ }^{58}$ Against Spieckermann (Juda unter Assur, 48-53, 179-83) there is no evidence of dir reworking in the 2 Kings 12 account. A. F. Campbell $(O f$ Prophets and Kings, 193) omits $2 \mathrm{Kgs}$ 12:5-17 from the Southern Document. Jehoash's solicitude for the temple in vv 5-17 contrasts sharply with his readiness to strip it of its treasures in vv 18-19.

${ }^{59}$ Dietrich ("Josia und das Gesetzbuch," 25-27) includes $2 \mathrm{Kgs} \mathrm{22:12,13*,14}$ in a pre-dtr source. His case here depends principally on the said verses being a continuation of the pre-dtr account of the discovery of the book. The short form

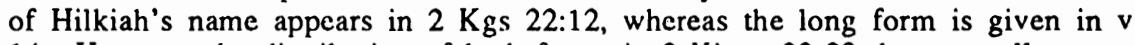
14. However the distribution of both forms in 2 Kings 22-23 does not allow any conclusions to be drawn in terms of source and redaction (cf. 22:4, 8a, 14; 23:4 [long form]; 22:8b, 10, 12 [short form]).

${ }^{60}$ Dietrich assigns v 13a (from "for me") to DtrP ("Josia und das Gesetzbuch," 26,28 ). While there is no compelling evidence to omit "for me" or the reference to the book which had been found, there is a case for omitting "and for the 
before it is given by Huldah. The kindling of Yahweh's wrath is referred to again in v 17b, a later addition to Huldah's prophecy. Furthermore, as will emerge in the course of the analysis, the discovery of the book as a sign of Yahweh's anger is not in accord with DTR's presentation of Josiah's reform. ${ }^{61}$

\section{3)- 2 KGS 22:15-20 (THE PROPHECY OF HULDAH)}

The prophecy of Huldah has two components, one an announcement of disaster for Jerusalem and its inhabitants (vv 15-17), the other a promise to Josiah (vv 18-20). It is generally recognized that the present text is the result of a complex process of redaction. ${ }^{62}$ The various stages in the growth of the text are difficult to unravel, nevertheless the analysis given here will show that three main stages can be recovered. We will begin with the first stage of the text's growth, the original oracle.

The original oracle can no longer be recovered in its entirety. Significant portions were deleted in favor of later dtr redaction. However its basic structure and an important element of the original promise can be recovered. It reads as follows: (v 15aab) "And she said to them, 'tell the man who sent you to me; (v 18b) thus says the Lord the God of Israel: regarding the words which you have heard ... (v 20aa) therefore, behold, I will gather you to your fathers"'.63

A critical verse for determining the provenance of Huldah's original oracle

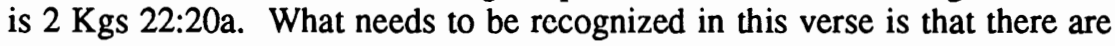

people". The later redaction of Huldah's prophecy shifted the focus from the king to the people (on this see below). BHS indicates the reference to all Judah is a gloss (also Jones, 1 and 2 Kings II, 612). This is possible, since Judah is included in the preceding reference to the people.

${ }^{61} 2 \mathrm{Kgs} 22: 13 \mathrm{~b}$ is recognized as a later addition by Dietrich, "Josia und das Gesetzbuch," 28-29 (DtrN); Hentschel, 2 Könige, 106; Würthwein, 1. Kön. 17-2. Kön. 25, $450(\mathrm{DtrN})$. Spieckermann (Juda unter Assur, 424) assigns a portion of $v 13 b$ to his source, the remainder to DtrN.

${ }^{62}$ Although there have been, and still are, those who defend the unity of the text. An earlier representative was Sanda, Die Bücher der Könige II, 360. More recently there is Hoffmann, Reform und Reformen, 170-87, and J. Van Seters, In Search of History, 318-19.

${ }^{63}$ There is a rather abrupt transition from $v 18 \mathrm{ba}$ to $\mathrm{v} 18 \mathrm{~b} \beta$ in the text. This would not be eased if one took $\vee 16 \mathrm{aa}$ as the original messenger formula. Furthermore it does not help to propose that $v 18 \mathrm{~b} \beta$ was appended later to $v$ $18 \mathrm{ba}$. One still has to explain the abruptness of the connection. E.W. Nicholson has proposed that an original preposition $c_{a l}$ or 'el was accidentally omitted through haplography after yisrás'el in v 18ba ("II Kings XXII 18-A Simple Restoration," Hermethena 97 [1963] 96-98). This is an attractive solution and provides a smooth transition. Dietrich (Prophetie und Geschichte, 56) includes $v 16 \mathrm{a} a$ in the original prophecy rather than $v 18 \mathrm{ba}$ because he regards the latter as a resumptive repetition, and because its fuller divine title is the one found in DtrP passages. On the first point, the analysis here leads to a reversal of the direction of dependence ( $v 16 \mathrm{a} a$ as the second messenger formula). On the second point Campbell has shown that the formula in $v 18 \mathrm{ba}$ had its origins in the pre-dtr Prophetic Record. It cannot therefore be claimed as characteristic of a later DtrP. 
three distinct elements in the promise to Josiah. The first is a prophecy concerning Josiah's death, "I will gather you to your fathers". The second is a prophecy concerning his burial, "you shall be gathered to your grave in peace". The third is a prophecy on the fall of Jerusalem, "your eyes shall not see all the evil which I will bring on this place". An examination of other texts in the OT where the verb 'asap is used in the sense of being gathered to one's people clearly shows that it always means the death of the person, not his or her burial. ${ }^{64}$ Furthermore, the reference is always to a peaceful death. ${ }^{65}$ Given this meaning, Huldah's promise that Yahweh would gather Josiah to his fathers must have been given before his death. It is difficult to accept that an author would have formulated such a promise in the light of Josiah's violent death in $2 \mathrm{Kgs} 23: 29-30.66$

The other two elements of Huldah's promise were added after the death of Josiah. When the history was undergoing later revision some reference to Josiah's death was required, but there was no way its actual circumstances could be accommodated within a prophecy of salvation. The best that could be done was to leave the first element in place and attempt to shift the emphasis from it by the addition of two positive statements which could be made about

${ }^{64} \mathrm{Cf}$. Gen $25: 8$ (burial in v 9), 17; $35: 29$ (burial in the following phrase); $49: 29,33$; Num $20: 24,26 ; 27: 13 ; 31: 2 ;$ Deut $32: 50$. All texts speak of being gathered to one's people. The reference to fathers in $2 \mathrm{Kgs} \mathrm{22:20 \textrm {aa }}$ is required because the promise is directed to a member of the Davidic dynasty.

${ }^{65} \mathrm{This}$ sense of the first element of the promise is overlooked by Dietrich, leading him to assign only $2 \mathrm{Kgs} 22: 15 \mathrm{aa}, 16 \mathrm{a} a, 18 \mathrm{~b} \beta$ to his pre-dtr source (Prophetie und Geschichte, 57-58; cf. also "Josia und das Gesetzbuch," 27). Hoffmann (Reform und Reformen, 182) notes the three elements of the promise but then ignores the first one in the remainder of his analysis. Others who fail to take due account of the first element are Hentschel, 2 Könige, 108; Mayes, The Story of Israel, 129-30; Rehm, 2 Könige, 219-20; Spieckermann, Juda unter Asur, 70; Van Seters, In Search of History, 318-19; Würthwein, 1. Kön. 17-2. Kön. 25, 451-52.

${ }^{66}$ B. Alfrink ("L'Expression ne'esap 'el-cammāyw," OTS 5 [1943] 118-31) argued that the author of $\vee 20 a a$ had to use 'assap instead of the more normal sakab (to sleep) because of the fact of Josiah's death (pp. 119-20). An oracle delivered before his death would have been formulated like Deut 31:16, using šakab. Alfrink overlooks both the fact that 'asap is used only with reference to a peaceful death, and that Deut 31:16 itself refers to Moses' peaceful death. As well the first person formulation of $v 20 \mathrm{aa}$ does not lend itself to the use of $s{ }^{a} k a b$ (also against Provan, Hezekiah, 149, n. 53). In favor of a Josian origin of the first element of the promise are: Burney, Noles, 355-56; Hugo Gressmann, "Josia und das Deuteronomium," ZAW 42 (1924) 313-37, cf. p. 319; R. Kittel, Die Bücher der Könige, 299; Isbell, "II Kings 22:3-23:24 and Jeremiah 36," 42; Jones, $I$ and 2 Kings II, 614; Lohfink, "Kurzgeschichte," 320, n. 8, 340, n. 53, and Rückblick im Zorn, 176-77; Nelson, The Double Redaction, 76-78; W. Nowack, "Dcuteronomium und Regum," Vom Alten Testament Karl Marti zum siebzigsten Geburtstag Gewidmet (BZAW 41; Giessen: Alfred Töpelmann, 1925) 221-32, cf. p. 228; John Priest, "Huldah's Oracle," VT 30 (1980) 366-68; M. Rose, "Bemerkungen zum historischen Fundament des Josia-Bildes in II Reg 22f.," $Z A W 89$ (1977) 50-63, cf. p. 55. 
his death. These are the second and third elements of the promise. The report in $2 \mathrm{Kgs} 23: 30$ that Josiah was buried peacefully in his own grave is in accord with these elements. ${ }^{67}$ The additional elements of the promise were also intended to show that Josiah's death was not part of the divinely ordained end of Judah.

The narrative of Josiah's encounter with Necho and his death in $2 \mathrm{Chr}$ 35:20-25 supports the position that there was an original element in Huldah's oracle which conflicted with the circumstances of his death. The Chronicler has Necho warn Josiah in $2 \mathrm{Chr} 35: 21$ that in opposing him he is effectively opposing God. In v 22 Josiah does not heed the warning, instead he presses on against Necho and is killed in battle in vv 23-24. The comment in v 22 that "he did not listen to the words of Necho from the mouth of God" is significant. In conjunction with Necho's warning it suggests that by disobeying Yahweh Josiah forfeited the promise of a peaceful death which Huldah had earlier given him (34:28). ${ }^{68}$

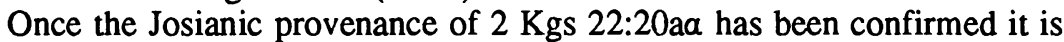
reasonable to expect that it was part of an oracle which was introduced by a messenger formula. The most likely one occurs in $v 18 \mathrm{ba} .{ }^{69}$ Two other points follow from the identification of the messenger formula and accompanying promise. The first is that the messenger formula and original oracle must have followed immediately on Huldah's response in $v 15 \mathrm{aab}$ to the men sent to consult her. The second is that, given the connection of the oracle with the preceding narrative, there is no reason to exclude $v 18 \mathrm{~b} \beta$ from it. This is clearly a reference to the contents of the book of the law which had been read to Josiah in $\mathrm{v} 10^{70}$

${ }^{67}$ Lohfink ("Kurzgeschichte," 340, n. 53 and Rückblick im Zorn, 176-77) proposes that the first element of the promise included the phrase "in peace", which was later appended to the second element. This is possible, but the analysis of the use of 'asap makes it unnecessary.

${ }^{68}$ For a discussion of the way the account in 2 Chronicles has expanded the version in 2 Kings see H. G. M. Williamson, "The Death of Josiah and the Continuing Development of the Deuteronomic History," VT 32 (1982) 242-48. He proposes $2 \mathrm{Chr}$ 35:20-25 was composed between the version in 2 Kings and the composition of Chronicles, drawing on aspects of the death of Ahab in 1 Kings 22. It was then incorporated by the Chronicler. Less useful but also on the difference between Chronicles and Kings is P. Hugger, "Der Tod des Königs Josia. Eine Passionsbetrachtung," BibLeb 14 (1973) 57-63. The death of Josiah was no doubt a grievous blow to Judah's hopes, and to the hopes of DTR. The account of his death in $2 \mathrm{Kgs} 23: 29-30$ is striking for its terseness and lack of detail: On this see Stanly Bruce Frost "The Death of Josiah: A Conspiracy of Silence," JBL 87 (1968) 369-82. In an earlier study A. C. Welch proposed that Josiah had been court martialled by Necho and executed ("The Death of Josiah," ZAW 43 [1925] 255-60).

${ }^{69}$ The remainder of this discussion will show that the other two formulas in 2 $\mathrm{Kgs} 22: 15 \mathrm{a} \beta$ and $16 \mathrm{a} a$ are better associated with the later redaction of Huldah's prophecy.

${ }^{70}$ Against Hoffmann (Reform und Reformen, 176) who claims that $v 18 \mathrm{~b} \beta$ refers to the content of the oracle in vv 16-17. 
As a final comment it may be said that the original oracle which has been recovered offers no clear evidence to decide the difficult issue of pre-dtr source or dtr composition. ${ }^{71}$ My preference, as with the report of the discovery of the

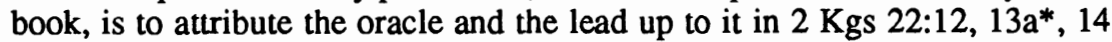
to DTR. One may presume that DTR drew on reliable information in order to compose it. This is all the more likely if Lohfink is correct in his suggestion that the dtr redaction was carried out by the Shaphan family, or under its patronage. ${ }^{72}$

The later redaction of the prophecy was carried out in two main stages. Initially there was the addition of $\mathrm{v} 19$ and the second and third promises in $\mathrm{v}$ $20 \mathrm{a}$. A subsequent redaction then created two oracles by adding the prophecy of disaster in vv 16-17. The creation of the two oracles necessitated the provision of a link between them, which is supplied by $\mathrm{v} 18 \mathrm{a}$. The provenance of the messenger formula in $v 15 \mathrm{a} \beta$ is difficult to determine, but it may well have been a later independent addition occasioned by the developing complexity of the text. By claiming all of $2 \mathrm{Kgs} 22: 15-20 \mathrm{a}$ as the word of "the Lord the God of Israel" this messenger formula sought to give the prophecy greater unity and authority. These additions have the situation of the Judean exile in mind and contain a number of terms which have been identified as later redaction in the course of the reassessment. ${ }^{73}$

The evidence in favor of distinguishing two layers of later redaction, in which $2 \mathrm{Kgs} 22: 16-17,18 \mathrm{a}$ is later than $22: 19,20 \mathrm{a} \beta$, emerges from the following considerations. ${ }^{74}$ First of all there is the different focus of $2 \mathrm{Kgs}$ 22:16-17 and 22:19. The former text is clearly directed against the people, who are to blame for the impending ruin of Jerusalem. The latter text is however addressed to the king, who is excused of any responsibility for the coming destruction. The two added promises in $2 \mathrm{Kgs} 22: 20 \mathrm{a} \beta$ of burial in

${ }^{71}$ The phrase "your fathers" in v 20aa supports a dtr composition to some extent, in that it refers to the Davidic dynasty. However there is no clear evidence against attributing it to Huldah.

${ }^{72}$ Lohfink, Rückblick im Zorn, 175.

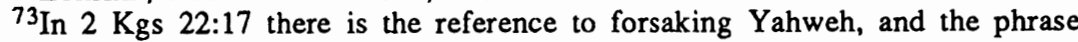
"other gods". There is also the way v 17 says that Yahweh's wrath will be kindled and not quenched. This statement is similar to ones in Jer 4:4; Jer 7:20. Association with the book of Jeremiah has been seen earlier as a mark of later redaction of DtrH. In addition the word pair "desolation and curse" in $2 \mathrm{Kgs}$ 22:19 finds its closest parallels in Jer 25:18; 42:18; 44:22; 49:13.

${ }^{74} 2 \mathrm{Kgs} 22: 18$ a need not be examined in any detail here. Granted that vv 16 17 are a later oracle inserted between the original introduction in $v 15 \mathrm{aab}$ and the messenger formula in $v 18 \mathrm{ba}$, it is reasonable to identify $v 18 \mathrm{a}$ as a literary seam from the same hand. It is a resumptive repetition of $v 15 \mathrm{~b}$. The fuller formulation of $v 18 \mathrm{a}$ was probably required after the inserted oracle in vv 16-17 which is directed against the people. Spieckermann (Judah unter Assur, 64-65, 424) assigns both $v 15 \mathrm{~b}$ and $v 18 \mathrm{a}$ to his source. In the light of the analysis carried out here and the different formulation of each verse this is unacceptable. Dietrich (Prophetie und Geschichte, 57-58) assigns $2 \mathrm{Kgs} 22: 15 \mathrm{aab}$ to a source, $v 18 \mathrm{aba}$ to DtrP. However the messenger formula in $v 15 \mathrm{a} \beta$ is best identified as a later independent addition which sought to give the complex prophecy greater unity and authority. 
peace and being spared the trauma of secing the destruction to come are best associated with $v$ 19. They function as Yahweh's recognition of Josiah's humble and penitential demeanor described in $v 19$.

One might be tempted to include $2 \mathrm{Kgs} 22: 16-17$ and $22: 19$ in the same redaction because the reference to the place and its inhabitants in $v 19$ appears to recall the announcement of disaster in $v 16$. What advises against this is that the said reference in $v 19$ cannot be separated from the statements about Josiah's pious demeanor which frame it. These do not refer to vv 16-17 but to Josiah's earlier reaction in $\mathrm{v} 11$ on hearing the contents of the book. Four aspects of Josiah's reaction are praised: his penitent heart, his humility, his rending of his clothes, and his weeping. 75 The third refers directly to $2 \mathrm{Kgs}$ 22:11. The remaining three draw in part on appropriate stories of other kings in order to enhance the quality of Josiah's reaction.76

A third point in favor of distinguishing different redactions is the way 2 $\mathrm{Kgs} 22: 16$ refers to the book the king has read, whereas 22:19 speaks of the words-of the book-which the king has heard. $2 \mathrm{Kgs} 22: 16$ suggests a redactor who paid less attention to the context than the one responsible for $v$ 19. The text of DtrH states in $2 \mathrm{Kgs} 22: 11$ that the king heard the words of the book. He did not read it as claimed by $v 16$. The formulation of $v 16$ also suggests that the redactor responsible attempted to enhance the status of the book of the law. In this verse the validity of all the words of the book is confirmed. In v 19 the sense is more of an interpretation of the status of the book. In response to the king's enquiry Huldah identifies the words of the book as the the word of Yahweh (cf. "how I spoke").

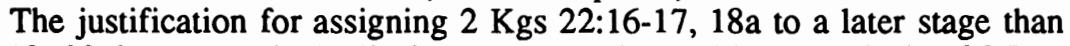
$22: 19,20 \mathrm{a} \beta$ comes principally from a comparison with the analysis of $2 \mathrm{Kgs}$ 21:1-16. The revision of DTR's account of Manasseh was observed to have taken place in two main stages. The earlier stage was identified in the expansions to $2 \mathrm{Kgs} 21: 2-7$ and in the prophecy of $21: 10-14$, the later nomistic stage in $2 \mathrm{Kgs} 21: 8-9$ and $21: 15$. In the light of this it is significant

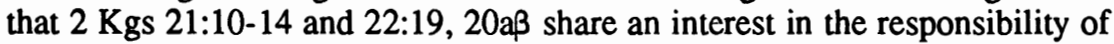
Davidic kings vis-à-vis the exile. $2 \mathrm{Kgs} 21: 10-14$ seeks to lay the blame for

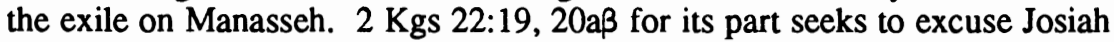
of any responsibility for the exile. The two promises in $v 20 \mathrm{a} \beta$ were intended

$752 \mathrm{Kgs} 22: 19 \mathrm{~b}$ implies that Josiah had also prayed to Yahweh. The verse is possibly a later addition. It is introduced by we gam and contains the phrase nérum yhwh, which is not found in any other dtr text. The phrase occurs in $1 \mathrm{Sam}$ 2:30; 2 Sam 23:1; 2 Kgs 9:26 and 19:33. Nevertheless it does maintain the focus on Josiah's piety. Dietrich (Prophetie und Geschichte, 58) assigns v 19b, along with v $17 \mathrm{a}$, to DtrN.

${ }^{76}$ Thus, humility (kana?) from the story of Ahab (1 Kgs 21:29) and weeping (baka) from the story of Hezekiah (2 Kgs 20:3). The notion of a penitent or meek heart (rak-leb) is not used elsewhere of a king's conduct. The corresponding verb is found in Deut 20:3 with the negative 'al. Mayes regards this as a late dir addition (Deuteronomy, 291-92). The adjective occurs in Deut 20:8; 28:54, 56; cf. also Isa 7:4 (with 'al) and Jer 51:46 (with pen). The terminology is discussed thoroughly by Hoffmann, Reform und Reformen, 177-80. 
to show that his death, although a violent one, was not part of the divinely ordained end of Judah. Both texts therefore could well be the work of a later redaction of DtrH which sought to excuse Josiah of any responsibility for the exile by laying the blame squarely on Manasseh. $2 \mathrm{Kgs} \mathrm{21:8-9,15}$ and 22:1617 on the other hand agree that the exile was the outcome of the sins of the people. This would locate these texts in the same stage of nomistic redaction, a stage which was nevertheless later than $2 \mathrm{Kgs} \mathrm{21:10-14;22:19,20aß.}$

One would expect that interest in the Davidic dynasty was maintained during the exilic and early post-exilic period while there was still some hope of a restoration of monarchical rule. The rehabilitation of the exiled king Jehoiachin described in $2 \mathrm{Kgs}$ 25:27-30 suggests just such an interest. One of the concerns in this interim period could have been to investigate the role of the Davidic kings in relation to the exile. Hence the reworking of DtrH in 2 Kgs 21:10-14 and 22:19, 20aß.77 After it had become clear that there was no chance of Judah regaining its monarchical rule the focus of ongoing dtr redaction shifted to the people, evident in the addition of $2 \mathrm{Kgs} 21: 8-9,15$ and 22:16-17, 18a.

\section{4)- 2 KGS 23:1-23:23 (DEVELOPMENTS FOLLOWING HULDAH'S PROPHECY)}

\section{a)- 2 Kgs 23:1-3 (The Covenant Ceremony)}

The analysis of Huldah's prophecy demonstrated that $2 \mathrm{Kgs} 22: 19$ has replaced the bulk of Huldah's original message to the king. The only element which survived was the promise of a peaceful death in $2 \mathrm{Kgs} 22: 20 \mathrm{aa}$. Given the way DTR organized the account of the reign of Josiah according to the four-part pattern one may presume that Huldah's original message contained a positive statement about the significance of the book, probably even a promise that the implementation of its program would bring Yahweh's favor on the king and people. Certainly, Josiah's commitment to "perform the words of

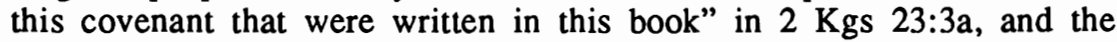
subsequent reform and Passover celebration, provide a fitting sequel to such a prophecy. In contrast there is considerable tension in the sequence of the present text. It is difficult to see why Josiah should initiate a covenant ceremony, reform and liturgical celebration, immediately after being informed that Judah and Jerusalem were doomed. The subsequent account does not report that Josiah acted in the hope that Yahweh's condemnation of Judah might be reversed.

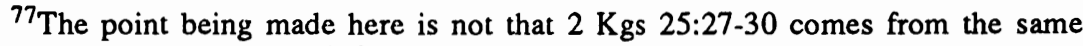
dtr hand responsible for $2 \mathrm{Kgs} 21: 10-14 ; 22: 19,20 \mathrm{a}$. Rather the report on Jehoiachin suggests that the fate of the Davidic dynasty was an important concern during the exile. Jones ( 1 and 2 Kings II, 648) thinks that Jehoiachin's rehabilitation would have led to hope of a restoration of the Davidic dynasty. G. von Rad had earlier commented on this passage "that a happening is mentioned which had the significance of an omen for the Deuteronomist, a fact from which Yahweh can start again, if it be his will" (Studies in Deuteronomy, 90). 
$2 \mathrm{Kgs}$ 23:1-3 has three parts to it; the assembly in response to the king's command ( $v 1$ ), the procession to the temple ( $v 2 \mathrm{a}$ ), and the covenant ceremony ( $v v 2 b-3$ ). As with 2 Kings 22 there is little evidence to support a pre-dtr text here. ${ }^{78}$ The language of the assembly and procession $(2 \mathrm{Kgs} 23: 1$ 2a) does not enable one to draw any conclusions as to provenance. These verses merely set the scene for the covenant ceremony in vv $2 b-3 .{ }^{79}$ The ceremony itself contains two elements which are part of DTR's theology. The first is the covenant undertaken by Josiah. ${ }^{80}$ This is an expression of his fidelity to Yahweh. The second is Josiah's commitment to establish (İehāqîm) the words that were written in the book. Within the context this surely refers to the reform which immediately follows. The effect of this connection is to emphasize that Josiah's reform was completely in accord with the requirements of the book.

${ }^{78}$ Spieckermann identifies $2 \mathrm{Kgs} 23: 1,2 \mathrm{aab}, 3 \mathrm{a}^{*}$ (omitting from laleket to nepes)b as part of a more extensive pre-dtr account of Josiah's reign (Juda unter Assur, 71-79, 425). The evidence in support of it is ambiguous. His assignation of $2 \mathrm{Kgs} \mathrm{23:1-2aa} \mathrm{to} \mathrm{the} \mathrm{source} \mathrm{is} \mathrm{based} \mathrm{on} \mathrm{the} \mathrm{position} \mathrm{that} \mathrm{"all} \mathrm{the} \mathrm{men} \mathrm{of}$ Judah and all the inhabitants of Jerusalem" is secondary in relation to the elders of $v 1$. He attributes the former to DtrH (exilic) and the latter to the source. The literary critical division is possible, but this hardly makes one dtr and the other pre-dtr. More evidence is required. Spieckermann claims that the DtrH addition has parallels in the dtr redaction of Jeremiah (p. 72, n. 88). But this still does not show how $v 1$ is pre-dtr. Similarly his proposal that the title "the book of the covenant", the covenant ceremony and the commitment to establish the words of the book ( $v v 2 b, 3 a^{*} b$ ) are integral to the narrative whereas the intervening material is not, does not make them pre-dtr. The literary critical distinction could equally well be between DTR and a later Dtr (in this case nomistic).

${ }^{79}$ While there may have been a tradition of covenant renewal ceremonies in Israel DTR presents this one as something unique. The covenant commitment undertaken by Josiah is with specific reference to establishing the words of the book which had just been found. This is done via the reform. For a discussion of the covenant renewal tradition see K. Baltzer, The Covenant Formulary, 51-62 and Lohfink, "Die Bundesurkunde des Königs Josias," Bib 44 (1963) 261-88, 461-98, cf. pp. 467-69. The book is described in $2 \mathrm{Kgs} \mathrm{23:2}$ and 21 as the book of the covenant whereas in 2 Kings 22 it is the book of the law. This could favor a pre-dtr title in 2 Kings 22 , and so a pre-dtr source. However DTR may have used the two titles to once again show continuity within a larger trajectory of development. The book discovered is a book of the law, but it results in a new commitment to Yahweh by the king and people. Within the context of this covenant commitment it functions as the normative guide for living out the covenant relationship.

${ }^{80}$ Against G. Fohrer ("Der Vertrag zwischen König und Volk in Israel," $Z A W$

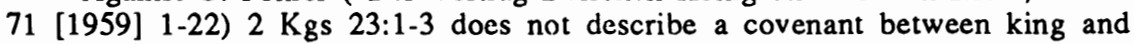
people (cf. pp. 13-15). This is pointed out by L. Perlitt, Bundestheologie im Alten Testament, 11, n. 6. Such a covenant is present in $2 \mathrm{Kgs} 11: 17 \mathrm{a}$ (with Fohrer, pp. 11-13), but in this text there are in effect two covenants; one between the king, the people, and Yahweh, and the other between the king and the people. 
The passage has undergone some later expansion. A fairly clear example is the mention of priests, prophets and people in $v 2 \mathrm{a}$. It is located after 'it $\hat{0}$ (with him) and was probably appended to give the procession added solemnity. ${ }^{81}$ The preceding mention of the men of Judah and the inhabitants of Jerusalem in $\vee 2$ a may also be an addition. ${ }^{82}$ Verse 1 refers only to elders. However $v 2 \mathrm{a}$ describes the procession to the temple, whereas $v 1$ deals with the initial assembly. It is possible then that $\mathrm{v} 2 \mathrm{a}$ was composed to give the impression of the men of Judah and the inhabitants of Jerusalem joining the king on his way to the temple. Finally, the phrase "to walk after the Lord and to keep his commandments and his testimonies and his statutes, with all his heart and all his soul" in $v 3 \mathrm{a}$ is somewhat superfluous in the context of DTR's presentation of Josiah as the model king. It too may therefore be an addition. ${ }^{83}$ However some caution is advisable. It is possible DTR was responsible for at least part of this phrase which emphasizes Josiah's complete commitment to Yahweh immediately prior to the reform. If this is the case then, on the basis of what has been observed earlier in the books of Kings, the expression "to keep his commandment and his testimonies and his statutes" could well have been added by the nomistic stage of redaction. The adoption of a fuller text here does not significantly alter the texture of DtrH.

\section{b)- 2 Kgs 23:4-20 (The Reform)}

The account of Josiah's reform divides easily into two main sections; the reform in Judah in vv 4-14, and the reform in Samaria in vv 15-20. After this initial division however things become considerably more difficult. Both sections of the account show evidence of literary complexity. In addition 2 Kgs 23:4-14 adverts to some cultic phenomena which are not mentioned elsewhere in the OT. These are: the vessels made for foreign deities, mentioned in $v 4$; the houses for the prostitutes and the hangings woven for Asherah in v 7; the horses dedicated to the sun and the chariots of the sun in $v$ 11; and the altars on the roof in $v 12$. As would be expected these features, as well as the obvious importance of the text as such, have generated considerable research.

A number of studies have proposed that the present text of the reform in Judah is a combination of source and redaction. ${ }^{84}$ Others would acknowledge

${ }^{81}$ So also Gray, I \& II Kings, 728, n. a; Hentschel, 2 Könige, 109; Jones, 1 and 2 Kings II, 614; Spieckermann, Juda unter Assur, 425; Wurthwein, 1. Kön. 17-2. Kön. 25, 452, n. 1 a.

${ }^{82} \mathrm{Cf}$. Spieckermann, Juda unter Assur, 72 (DtrH addition to source).

${ }^{83}$ Spieckermann (ibid.) assigns it to DtrN. Even if this phrase is omitted from DtrH the theme of Josiah's fidelity to Yahweh is still present in his undertaking of the covenant.

${ }^{84} \mathrm{Cf}$. (with source in brackets) Benzinger, Die Bücher der Könige, 192-94 (vv 6-7a, 8a, 9, 10-12), Joseph Coppens, "La réforme de Josias," ETL 4 (1928) 1-20 (vv 4aba , 6, 7, 8a, 9), Gressmann, "Josia und das Deuteronomium," 322 (vv 4 7, 11-12), Hentschel, 2 Könige, 109-10 (vv 6-7, 8a, 11, 12*), Helmut Hollenstein, "Literarkritische Erwägungen zum Bericht über die Reformmassnahmen Josias 2 Kön. XXIII 4ff.," VT 27 (1977) 321-36 (vv 4*, 11- 
the existence of some kind of source but are skeptical as to whether it can now be recovered. ${ }^{85}$ Some reject any notion of a source. ${ }^{86}$ In addition the text has been quarried for historical information about Judean religious practice during the Assyrian domination, and whether Deuteronomy was actually the norm for Josiah's reform. ${ }^{87}$

12*), Hölscher, "Könige," (vv 4aa, 6, 7*, 8b, 11, 12ba-E source), Jones, 1 and 2 Kings II, 616 (vv 11-12), Montgomery, Kings, 534 (vv 4*, 6, 7, 8b, 11, 12), Nelson, The Double Redaction, 79-82 (vv 6, 7, 8a, 10-13), Sanda, Die Bücher der Könige II, 360-63 (with reordering of verses-vv 6, 7, 11-12*, 13, 8b, 10, 5, 8a, 9), Spieckermann, Juda unter Assur, 425-27 (vv 5aaßb*, 6aa* $\beta^{*}$ b, 7, 8a, $10 \mathrm{ab}$, 11, 12aa* $\gamma$ (nătas hammelek only), Würthwein, "Die Josianische Reform und das Deuteronomium," ZTK 73 (1976) 395-423 (cf. p. 417-vv 4a, 11, 12aa). Würthwein reduces the source to vv 11-12aa in 1. Kön. 17-2. Kön. 25, 455. A. Jepsen attributes a reconstructed original order of the reform to a priestly redactor (RI), namely vv 4-7, 11-12, 8b, 8a, 9-10, 13-15 ("Die reform des Josia," Festschrift Friedrich Baumgärtel zum 70. Geburtstag [ed. L. Rost; Erlanger Forschungen, Reihe A., Geisteswissenschaften 10 . Erlangen: Universitätsbibliothek, 1959] 97-108, cf. pp. 99-100). This became the source for the dtr redaction (RII). See also Die Quellen des Königsbuches, 63 and Ubersicht (v $13 \mathrm{a}$ to RII).

${ }^{85}$ Burney (Notes, 355) spoke of a continuous narrative drawn from temple archives. For Gray ( I \& II Kings, 729) the report is "probably a telescoped account by the compiler resting ultimately on the Annals of Judah". Kittel (Die Bücher der Könige, 297, 300-302) does not appear to distinguish between source and redaction. Noth (The Deuteronomistic History, 66, 73, 80-81) regarded the report as dtr, but based on official annals. Rehm (2 Könige, 216) acknowledges the presence of official information but does not separate source from redaction. Rose ("Bemerkungen," 54) thinks that a pre-dtr account of 2 Kings 22-23 cannot be reconstructed.

${ }^{86} \mathrm{Cf}$. Hoffmann, Reform und Reformen, 264-70; Levin, "Joschija im deuteronomistischen Geschichtswerk," 371; Lohfink, Rückblick im Zorn, 178-79 (while not excluding the possibility that DTR made use of some report), cf. also "Zur neueren Diskussion über 2 Kön 22-23," 47, n. 99; Mayes, The Story of Israel, 130. In his earlier article ("King and Covenant," 43) Mayes accepted a "basic layer" which was redacted.

${ }^{87}$ On Judean religious practice see for example the studies by Cogan, Imperialism and Religion, 65-96; Matthias Delcor, "Les cultes étrangers en Israël au moment de la réforme de Josias d'après $2 \mathrm{R} 23$. Etude de religions sémitique comparées," Mélanges bibliques et orientaux en l'honneur de M. Henri Cazelles (AOAT 212; Neukirchen-Vluyn: Neukirchener Verlag, 1981) 91-123; McKay, Religion in Judah, 28-44; Spieckermann, Juda unter Assur, 79-120 and passim. On a rather different tack there is the study by W. E. Claburn, "The Fiscal Basis of Josiah's Reform," JBL 92 (1973) 11-22. The question of the historical relationship between the reform and Deuteronomy has generated an extensive bibliography. For a review and discussion see Preuss, Deuteronomium, 1-19. According to the conceptual plan of DtrH which I have proposed DTR certainly linked Josiah's reform with the deuteronomic code. Given that DTR wrote during the reign of Josiah there seems no reason to question the historicity of this link. 
The important issue for this reassessment is not so much the reconstruction of the history of Josiah's reform but rather the identification of the text of DtrH, and how it was composed. In the present text of $2 \mathrm{Kgs} \mathrm{23:4-}$ 14 one may discern a simple repeated pattern in which a report of cultic reform in the temple is followed by a report of cultic reform against the high places. The reports about the temple occur in $2 \mathrm{Kgs} 23: 4,6-7,11-12$. The reports about high places occur in $2 \mathrm{Kgs} \mathrm{23:5,} \mathrm{8-9} \mathrm{(10),} \mathrm{13-14.} \mathrm{The} \mathrm{pattern} \mathrm{is}$ repeated in an analogous fashion in $2 \mathrm{Kgs} 23: 15-20$, where an account of Josiah's activities at Bethel in vv 15-18 is followed by an account of his destruction of high places elsewhere in Samaria in vv 19-20.

However a closer inspection of $2 \mathrm{Kgs} \mathrm{23:4-14}$ indicates that the simple alternating pattern has been imposed on an earlier version of the reform which was arranged differently. ${ }^{88}$ The earlier structure was chiastic, with reports about Josiah's removal of foreign cults from the temple framing a report of his move against the high places in vv $8 \mathrm{a}, 9$. The verses which comprise it may be identified as follows.

a.- $2 \mathrm{Kgs} \mathrm{23:4aba,} \mathrm{5aab,} \mathrm{6-7} \mathrm{(exclusive} \mathrm{worship} \mathrm{of} \mathrm{Yahweh} \mathrm{in} \mathrm{the}$ temple)

b.- $2 \mathrm{Kgs} 23: 8 \mathrm{a}, 9$ (centralized worship in the temple)

a'.- 2 Kgs 23:11-12* (exclusive worship of Yahweh in the templeomitting the references to the kings of Judah). ${ }^{89}$

The central position of $2 \mathrm{Kgs} 23: 8 \mathrm{a}, 9$ in this structure is eminently appropriate within the context of DtrH. The issue of centralization versus the cult of the high places is one that pervades the whole of DTR's account of the monarchy from Solomon to Manasseh. ${ }^{90}$ Verse 9 does not disturb this structure. In point of fact it forms a small chiastic structure with the two elements of v 8a: a)- report about priests (v 8aa); b)- report about high places

${ }^{88}$ Hoffmann argues for a unified text from DTR (Reform und Reformen, 212 17). He notes that literary critics have assembled four main arguments against the unity of $2 \mathrm{Kgs} 23: 4-14$. These are 1)- lack of clear order or structure, 2)breaks in the sequence (eg. in vv 8-9), 3)-doublets (eg. vv 5, 8), 4)- the wéqátal form of the verb ( $v v 4 b \beta, 5,8 b, 10,14)$. He rejects each one of these (pp. 21217). Hoffmann's criticism of an uncritical use of no. 4 is timely. With n. 1 the literary critical analysis given here will show that DTR's structure can be recovered with reasonable accuracy. With respect to nn. 2 and 3, Hoffmann's dismissal of these literary critical criteria is too hasty, as the analysis will also show.

${ }^{89} \mathrm{~A}$ chiastic structure has been proposed by Lohfink for the present text (cf. "Zur neueren Diskussion über 2 Kön 22-23," 38, and "The Cult Reform of Josiah," 464-65). In my judgment however the chiastic structure is more clearly seen once the literary critical division is made. Later redaction blended the distinct elements of DTR's account in order to highlight the issue of the exclusive cult of Yahweh versus the cult of foreign gods.

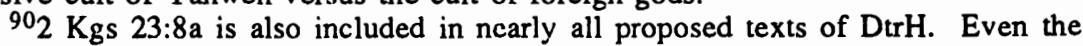
minimal text proposed by Levin includes $v 8 \mathrm{a}$ ("Joschija im deuteronomistischen Geschichtswerk," 371). 
(v 8aß); $a^{\prime}$ )- report about priests ( $v$ 9). ${ }^{91}$ This fits easily into the larger chiastic structure used for the reform report. Moreover the king's authority over the priests in vv $8 \mathrm{a}, 9$ matches that of $v 4 a .92$

The elements which frame vv $8 \mathrm{a}, 9$ are also appropriate for the way they enable centralized worship to be combined with DTR's other dominant concern, the exclusive worship of Yahweh. In a word, the recovered text describes the re-establishment of exclusive centralized worship of Yahweh. Some further considerations will provide confirmation that the text proposed was DTR's account of Josiah's reform. They will deal first of all with the verses omitted (vv $4 \mathrm{~b} \beta, 5 \mathrm{a} \beta \gamma, 8 \mathrm{~b}, 10,13-14)$ and then the question of how DTR composed the account.

The reference to Bethel in $2 \mathrm{Kgs} 23: 4 \mathrm{~b} \beta$ indicates this report item is most likely an attempt by a later editor to link the reforms in the north and south more closely. ${ }^{93}$ As will be secn in due course the description of Josiah's reform in the north in $2 \mathrm{Kgs} \mathrm{23:15-20}$ is itself a later addition. $2 \mathrm{Kgs} \mathrm{23:5aß \gamma}$ comprises the phrase "whom the kings of Judah had ordained to burn incense in the high places at the citics of Judah and round about Jerusalem". The

${ }^{91}$ Hoffmann (Reform und Reformen, 213) has observed the following concentric structure in vv 8-9: a)- report about priests (v 8aa); b)- report about high places ( $v 8 \mathrm{a} \beta)$; $\left.\mathrm{b}^{\prime}\right)$ - report about high places ( $\left.\left.v 8 \mathrm{~b}\right) ; \mathrm{a}^{\prime}\right)$ - report about priests ( $v 9)$. The structural observation is valid but it does not establish unity of authorship as Hoffmann would claim. This is shown by the way an equally neat structure can be found in vv $8 a$ and 9 . A literary critical examination of $v$ $8 \mathrm{~b}$ indicates it was inserted later (see below).

${ }^{92}$ Taken by itself $2 \mathrm{Kgs} 23: 9$ could be read as a report about the deposed priests of the high places taking the initiative. But in the context of the proposed text of DtrH, or of the present text, the verse is better read as a royal regulation. $2 \mathrm{Kgs} 23: 9$ has been linked with Deut 18:1-8, the law on the Levites: cf. Jones, $I$ and 2 Kings II, 619, M. Sekine, "Beobachtungen zu der josianischen Reform," VT 22 (1972) 361-68, Spieckermann, Juda unter Assur, 96-97. However the identification of the priests of $2 \mathrm{Kgs} \mathrm{23:9}$ as Levites is not accepted by Aelred Cody, A History of Old Testament Priesthood (AnBib 35; Rome: Biblical Institute, 1965) 134-35, Antonius H. J. Gunneweg, Leviten und Priester. Hauptlinien der Traditionsbildung und Geschichte des Israelitischjüdischen Kultpersonals (FRLANT 89; Göttingen: Vandenhoeck \& Ruprecht, 1965) 117-26, Johannes Lindblom, Erwägungen zur Herkunft der Josianische Tempelurkunde (Scripta Minora regiae societatis humaniorum litterarum Lundensis 1970-71: 3; Lund: Gleerup, 1971) 24-30. Gunneweg for example argues that the priests of the high places were not Levites and that is unlikely Josiah's reform permitted priests responsible for worship at the high places to function in

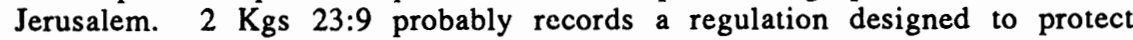
Jerusalem against cultic corruption by these priests (cf. also J. G. McConville, Law and Theology in Deuteronomy [JSOTSup 33; Sheffield: JSOT, 1985] 133).

${ }^{93}$ Graham S. Ogden ("The Northern Exient of Josiah's Reform," AusBR 26 [1978] 26-34) claims the reference to Bethel in $v 4 b \beta$ is part of a "primary tradition" (p. 29), and that vv 4-5 represent "the basic and ancient tradition" (p. 33). However he provides little evidence to back up these claims. His proposal that there were three traditions about Josiah's reform-2 Kgs 23:4-5, 6-15, and 2 Chr 34:4-7-is unlikely. 
weqatal form of the introductory verb has been taken as a sign that all of $2 \mathrm{Kgs}$ 23:5 is a later addition. ${ }^{94}$ Nevertheless there are reasonable grounds for retaining $v 5 a a b$ in $D t r H$, even though the structure of the reform report would still be intact with a text that proceeds directly from $v 4 b a$ to $v 6$.

The first thing to note is that the mention of high places in $2 \mathrm{Kgs} 23: 5 \mathrm{a} \beta \gamma$ disturbs an otherwise consistent pattern in 23:4-8a.95 In the reforms described

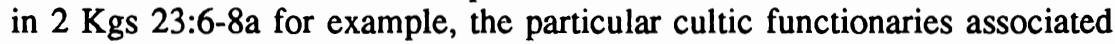
with each cultic abuse are mentioned. There are the women weavers associated with the cult of Asherah in vv 6-7.96 There are the priests associated with the high places in v $8 \mathrm{a}, 9$. With vv 4-5 however we find that a reform is carried out against the worship of foreign deities in the temple in $v 4$, but the idolatrous priests (hakkémãrim) and burners of incense (haméqattērim) in v 5 are associated with the high places and not with the temple. The discrepancy is removed if one eliminates the phrase in question. Both cultic functionaries are then located in the temple, and are part of the reform initiated in $v 4.97$

A second point is that $2 \mathrm{Kgs} 23: 5 \mathrm{a} \beta \gamma$ appears to have conflated elements which occur separately elsewhere in the reform, namely the high places in the cities of Judah (cf. v 8a), and in the environs of Jerusalem (cf. v 13). Two other observations may be made in connection with this point. One is that the present text of $v 5$ a effectively creates a doublet with $\mathrm{v} 8 \mathrm{a}$. Even though different terms are used for priests in each verse (hakkēmārîm in v 5a and hakkohannim in v 8a) their cultic activity in each is the same, namely the burning of incense. The other is that the rather complex construction of $v 5 \mathrm{a}$,

${ }^{94}$ See for example Hentschel, 2 Könige, 111. Other verses or phrases in the reform report which begin in this way are vv $4 b \beta, 8 b, 10,14,15 b \beta$.

${ }^{95}$ The relative clause "whom the kings of Judah had ordained" is best included in the later addition. There is no report in DtrH of Judean kings ordaining idolatrous priests. Also the polemical tone of this reference, and the similar ones in vv 11-12, is more in keeping with other additions to DtrH which exhibit a hostile attitude to the Davidic dynasty (cf. $1 \mathrm{Kgs} 11: 5,8 ; 15: 12 \mathrm{~b} ; 2 \mathrm{Kgs}$ $16: 3 \mathrm{~b})$. There is an awkward transition in the MT from the relative clause to the singular form of the verb wayequatter. The LXX and Targums read the plural, whereas LXX (Lucian), Vulgate and Peshitta have the piel infinitive. This indicates the difficulty was registered and an attempt made to smooth the sequence.

${ }^{96}$ One may include here the cult prostitutes as cultic functionaries associated with the worship of Asherah, even though the text only refers to the destruction of their houses.

${ }^{97}$ The close association between $2 \mathrm{Kgs} 23: 4$ and 23:5 without the addition is enhanced by the reference to Baal and the host of heaven in $v 4$ and $v 5 b$. This suggests that the reference to the sun, the moon and the constellations in $v 5 \mathrm{~b}$ may be a later addition. However Delcor notes that the mention of sun and moon in association with Baal is typical of Syrian inscriptions ("Les cultes étrangers," $100)$. Verse $5 \mathrm{~b}$ could reflect such usage. In any case the inclusion or omission of the triad does not significantly alter the texture of DtrH. 
due to the presence of the phrase in question, suggests that it was inserted into an already existing text. ${ }^{98}$

A third point is that one can offer a plausible reason for the insertion of the phrase about the high places in $v 5 a$. Without it $v 5$ clearly locates the idolatrous priests and the burners of incense in the temple. Given the importance of the Jerusalem temple and the ascendancy of the priesthood in the post-exilic period the notion that idolatrous priests once served in the temple precincts may have been found offensive. Hence a later editor drew on $v 8 \mathrm{a}$, and to a lesser extent on $v 13$, in order to modify $\vee 5$ and thereby locate them in the high places. ${ }^{99}$ It is more difficult to find an equally plausible explanation for the position that $\mathrm{v} 5$ as a whole was an addition.

An initial indication that $2 \mathrm{Kgs} 23: 8 \mathrm{~b}$ was a later addition to $v 8 \mathrm{a}$ is the use of the verb natas (to break down) to describe what Josiah did to the high places. Verse 8a on the other hand describes him as defiling (tames') the high places. A second indication is that although $\mathrm{v} 8 \mathrm{~b}$ is located within a series of reforms in which the cultic functionary associated with each cult is mentioned, it is lacking in this case. ${ }^{100} \mathrm{~A}$ third indication is that the reference to the city in $v 8 b$ follows awkwardly after $v 8 a$. A fourth indication is that $v 8 b$ is meant to supply information about high places near the city, presumably Jerusalem. ${ }^{101}$ This is not the concern of $v 8 \mathrm{a}$ which reports on the removal of high places around the country. ${ }^{102}$

With $2 \mathrm{Kgs}$ 23:10 an argument against its inclusion in DtrH is that it fits more readily into the present text's alternating pattern of report about the temple followed by report about high places than the structure of DTR's text. In addition to this it is the only verse in $2 \mathrm{Kgs}$ 23:4-14 which gives a reason for the elimination of the particular cult, namely "that no one might burn his son or his daughter as an offering to Molech". There is also the evidence that

${ }^{98} 2 \mathrm{Kgs} 23: 11$ and 12 are also complex verses, but they carry their complexity more easily by use of relative clauses.

${ }^{99}$ Spieckermann (Juda unter Assur, 425) identifies the description of the idolatrous priests' activities as an addition by DtrH to the source. However Spieckermann includes in the source the phrase "whom the kings of Judah had ordained".

${ }^{100}$ It has been proposed that the MT hassécarim (gates) should be read as haśsē̄rim (satyrs). Cf. Georg Hoffmann, "Kleinigkeiten," ZAW 2 (1882) 175, and Jones, 1 and 2 Kings II, 621. This is challenged by Barthélemy, Critique textuelle de l'Ancien Testament 1, 419 and N. H. Snaith. "The Meaning of šđrîm, "VT 25 (1975) 115-18.

${ }^{101} \mathrm{Y}$. Yadin proposes that $2 \mathrm{Kgs} 23: 8 \mathrm{~b}$ refers to the high place at Beer-sheba in v 8a ("Beer-shcba: The High Place Destroyed by King Josiah," BASOR 222 [1976] 5-17). This is possible but it still does not ease the awkward transition from $\vee 8 \mathrm{a}$ to $\vee 8 \mathrm{~b}$.

${ }^{102} 2 \mathrm{Kgs} 23: 8 \mathrm{~b}$ has long been regarded as a later addition to the verse. So Benzinger, Die Bücher der Könige, 193; Coppens, "La réforme," 9; Gressmann, "Josia und das Deuteronomium," 327-28; Hollenstein, "Literarkritische Erwägungen," 333-34; Rehm, 2 Könige, 216; Sanda, Die Bücher der Könige II, 363; Spieckermann, Juda unter Assur, 99-101; Würthwein, 1. Kön. 17-2. Kön. 25, 458-59. 
the other references to the practice of passing a child through fire in $2 \mathrm{Kgs}$ $16: 3 b ; 17: 17$ (31); $21: 6$ have been identified in the course of the reassessment as later additions to $\mathrm{DtrH} .{ }^{103}$

$2 \mathrm{Kgs} 23: 13$ refers to Solomon's construction of high places for foreign deities in $1 \mathrm{Kgs} \mathrm{11:7.} \mathrm{The} \mathrm{reference} \mathrm{is} \mathrm{however} \mathrm{not} \mathrm{accurate.} 1 \mathrm{Kgs} 11: 7$ speaks of high places for Chemosh and Molech whereas the gods referred to in $2 \mathrm{Kgs} \mathrm{23:13}$ are Ashtoreth, Chemosh, and Milcom. The first and third are found in $1 \mathrm{Kgs} \mathrm{11:5.} \mathrm{But} \mathrm{this} \mathrm{verse} \mathrm{does} \mathrm{not} \mathrm{report} \mathrm{the} \mathrm{construction} \mathrm{of} \mathrm{high}$ places. It is rather an accusation against Solomon for following the gods in question. The analysis of $1 \mathrm{Kgs}$ 11:1-8 also showed there were good grounds for regarding $\vee 5$ as a later polemical addition. Hence in $2 \mathrm{Kgs} \mathrm{23:13}$ we have a verse which has conflated $1 \mathrm{Kgs} 11: 5$ and 7 . This is a reasonbly clear indication that it is later than DtrH. ${ }^{104}$ It was added by a redactor who wanted to contrast the great reformer Josiah with Solomon, the first king to build high places to foreign gods. Given that $2 \mathrm{Kgs} 23: 13$ was not part of DTR's reform report it follows that $\mathrm{v} 14$ too is a later addition. It is clearly dependent on $v 13.105$ The similarity between the content of this verse and the stipulations in Deut 12:3 suggests a redactor who wanted to portray Josiah as a king who completely fulfilled the requirements of the law.

It is difficult to be sure whether the additions to DtrH came from the one hand. They all share a common interest in the elimination of high places which were devoted to the cult of foreign gods. $2 \mathrm{Kgs} 23: 10$ may be included in this, because in the structure of the present text it is associated with the material on high places in vv 8-9. Also the place called Topheth was located outside Jerusalem. There is some variation in the formulation of the additions which could point to different authorship. ${ }^{106}$ By the same token the variation

${ }^{103}$ The vocalization of Molech in $2 \mathrm{Kgs}$ 23:10 derives from the hebrew word shame (bסset) and is a polemical touch. This makes it difficult to identify the deity in question, although Ugaritic literature records the use of $m l k$ as a divine name in Canaan (Jones, 1 and 2 Kings II, 622). The polemical use of the vocalization of boset is also evident in the word Topheth. The polemical tone of this verse is not so clearly evident in DTR's text of the reform. It has been identified as a later addition by Coppens, "La réforme," 9; Gressmann, "Josia und das Deuteronomium," 327; Hentschel, 2 Könige, 111; Hollenstein, "Literarkritische Erwägungen," 334 ; Jones, 1 and 2 Kings II, 617; Montgomery, Kings, 534; Rehm, 2 Könige, 216; Sanda, Die Bücher der Könige II, 363; Würthwein, 1. Kön. 17-2. Kön. 25, 459. Coppens, Hentschel, Hollenstein and Jones employ the weqatal criterion.

${ }^{104}$ So also Hölscher, "Könige," 199; Jones, 1 and 2 Kings II, 617; Montgomery, Kings, 534; Würthwein, 1. Kön. 17-2. Kön. 25, 460 (DtrN).

${ }^{105}$ Cf. Benzinger, Die Bücher der Könige, 194; Coppens, "La réforme," 9 (dividing v 14a and $\mathrm{v}$ 14b [later gloss]); Hentschel, 2 Könige, 111; Hollenstein, "Literarkritische Erwägungen," 335; Hölscher, "Könige," 199; Jones, 1 and 2 Kings II, 617; Kittel, Die Bücher der Könige, 297; Montgomery, Kings, 534; Rehm, 2 Könige, 216; Würthwein, 1. Kön. 17-2. Kön. 25, 460. Hentschel, Hollenstein, and Jones employ the weqatal criterion.

${ }^{106}$ Thus $2 \mathrm{Kgs} 23: 8 \mathrm{~b}$ uses the verb natas (break down) to describe the elimination of high places. This occurs in DtrH in vv 7 and 12 . It also occurs in $v$ 
may have been occasioned by variation in the text of DtrH. For example, v 13 seems to follow the style of $v 12$, with the main verb coming after the detail of the reform. Verse 10 places the verb at the beginning. It may be wiser then to attribute the later revision of $2 \mathrm{Kgs} \mathrm{23:4-14}$ to the work of a school or stage of redaction rather than to any one redactor.

On the question of the composition of DTR's report of the reform a continuous pre-dtr source cannot in my judgment be recovered. The most that can be said is DTR may have used a portion of some report for the information contained in vv 11-12.

The chiastic structure of the report shows that it was carefully organized to highlight DTR's concern for exclusive centralized worship of Yahweh as well as to integrate it into the larger structure of $\mathrm{DtrH}$. This is clear from the central position occupied by vv $8 \mathrm{a}, 9$, the rcform of the high places. Josiah's removal of the high places ranks him with the other great defender of centralized worship, Hezekiah. It is also clear from the way the high point of the reform of the temple describes the removal of the Asherah with its associated cult prostitutes and attendant women (cf. $2 \mathrm{Kgs}$ 23:6-7). Within the larger sweep of DtrH this takes up $2 \mathrm{Kgs} \mathrm{21:7}$ which described Manasseh placing the Asherah in the temple. The way the report meshes with DTR's concerns therefore does not favor the hypothesis that it is of pre-dtr provenance.

The reform report does have a noticeably different style to the rest of 2 Kings 22-23. It is most noticeable in the repeated use of the verb without naming the king as subject. However this does not necessarily show that DTR took over an existing reform report. The same style is present in $2 \mathrm{Kgs}$ 21:1-2a, 3ba, 5, 7, which was composed by DTR. This gives two possibilities: either both texts were composed by DTR, or the report on Manasseh was composed in imitation of a pre-dtr report about Josiah's reform.

In relation to the question of style it is significant that the king is mentioned explicitly only in $2 \mathrm{Kgs} 23: 4 \mathrm{a}$ and $23: 12$, namely the beginning and end of the reform report. The first text contains the royal command which initiates the reform. As such it forms part of a sequence of royal directives (cf. $2 \mathrm{Kgs} 22: 3,12 ; 23: 1$ ) which mark important devclopments in DTR's account of Josiah's reign. Each one explicilly mentions the king. The location of 2 Kgs $23: 4$ is particularly significant since it follows close upon Josiah's undertaking in $\mathrm{v} 3 \mathrm{a}$ to establish the words of the book. From these observations one gains the unmistakable impression that $v 4$ is an integral part of DTR's composition. Granted this, the reference to the king in v 12 is more than likely the work of DTR as well. The sense is of an inclusion between 2 $\mathrm{Kgs} 23: 4 \mathrm{a}$ and 12 . This is supported by the way $2 \mathrm{Kgs} 23: 4,6$ and 12 all refer to the Kidron as the disposal site. ${ }^{107}$ These references could have been part of a source but, given the direction of the analysis so far, it seems more

15, a later addition (sec below). Verse 13 uses tămè’ (defile). This occurs in DtrH in $v 8 \mathrm{a}$.

${ }^{107} 2 \mathrm{Kgs} \mathrm{23:4}$ refers to the fields of Kidron (RSV) whereas vv 6 and 12 refer to the Kidron brook. There is however some difficulty with the meaning of sadémôt in $v 4$. For a discussion sec Jones, 1 and 2 Kings II, 617-18. 
reasonable to attribute them to DTR. They were located at appropriate points in the report, namely the beginning ( $v 4)$, the end ( $v 12)$, and for the removal of the Asherah (v 6).

A striking feature of $2 \mathrm{Kgs} \mathrm{23:4aba,5aab-8a,} 9$ is the information about priests and other cultic functionaries, such as the burners of incense in $v 5 b$, and the women weavers in $v 7 .{ }^{108}$ The information clearly illustrates the king's authority over such figures. It is therefore in harmony with the account

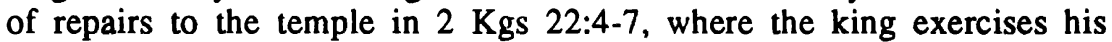
authority over the priest Hilkiah and other officials such as the keepers of the threshold. The instructions given by the king here were composed by DTR, based on $2 \mathrm{Kgs} 12: 5-17$ (RSV 12:4-16). It is more than likely then that 2 Kgs 23:4aba, 5aab-8a is also a composition by DTR, based on information to hand. A reform of the cult such as the one described here would necessarily require the king to exercise his authority over the clergy and other officials. ${ }^{109}$

There is also a certain amount of information about cults which is exclusive to the report; namely, the vessels made for foreign gods in $\mathrm{v} 4$, the prostitutes' houses in $v 7$, the horses and chariots in v 11, and the altars on the roof in $v 12$. The information in $v 4$ is located in a text which is best regarded as a dtr composition. This is favored by the introductory royal command, the

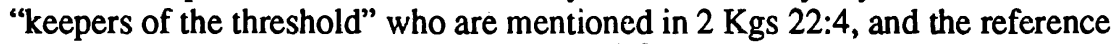
to Baal, Asherah, and the host of heaven. ${ }^{110}$ These elements are so much a part of DTR's presentation of 2 Kings 21-23 that it is difficult to attribute v 4 to another hand. The particular reference to vessels could well have derived from information which DTR had access to, given a Josianic date for the history. ${ }^{111}$ A similar explanation is applicable to the houses of the cult prostitutes in $2 \mathrm{Kgs} 23: 7$.

$2 \mathrm{Kgs}$ 23:11-12 offers perhaps the best evidence for the case that DTR made use of a source. ${ }^{112}$ The horses and the chariots of the sun in v 11, and

${ }^{108}$ The participle méqatterim was used in the Southern Document to describe the people burning incense on the high places. However it is only used here to describe those who burned incense to foreign deities. There is some difficulty in v 7 about what the women were weaving for Asherah. The term battim (MT) is somewhat obscure. For a discussion see Delcor ("Les cultes etrangers," 117-19), who proposes that it refers to a type of tunic.

${ }^{109}$ The hiphil form of the verb šabat to describe Josiah's removal of the idolatrous priests in $v 5 a$ is not used in this sense anywhere else. It could have been a technical term to describe a person's removal from office.

${ }^{110}$ The kohäne hammišneh in $2 \mathrm{Kgs} 23: 4$ is difficult to decipher. The RSV accepts the plural of the MT and renders it as "priests of the second order". However comparison with $2 \mathrm{Kgs} 25: 18$ and Jer 52:24 suggests the singular "the second priest" should be read. For a discussion see Spieckermann, Juda unter Assur, 79-80, n. 103.

${ }^{111}$ Hollenstein, who notes the use of the term hêkal to describe the temple, and the reference to vessels, nevertheless concludes that any Vorlage was thoroughly assimilated into DTR's introduction to the reform ("Literarkritische Erwägungen," 326-27).

${ }^{112}$ These verses have been identified as source material by Benzinger, Die Bücher der Könige, 192-94; Gressmann, "Josia und das Deuteronomium," 327 - 
the altars on the roof in v 12aa, are mentioned only here in DtrH. There is no

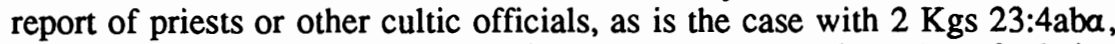
5aab-8a, 9. Verses 11-12 also contain a somewhat unusual number of relative clauses. The three which give information about the location of cult objects could possibly be part of a source. ${ }^{113}$ However this is not the case for the two relative clauses which refer to the kings of Judah. It is more than likely such general and polemical statements about the kings of Judah were later additions to DtrH. ${ }^{114}$

The description in $v 12$ of Josiah's demolition of the altars built by Manasseh argues against a source. Mention was first made of these by DTR in the report on Manasseh (cf. $2 \mathrm{Kgs} \mathrm{21:5).} \mathrm{It} \mathrm{is} \mathrm{possible} \mathrm{the} \mathrm{report} \mathrm{of} \mathrm{the}$ destruction of Manasseh's altars was added by DTR to an earlier report which dealt only with the removal of the horses, the burning of the chariots of the sun, and the demolition of the altars on the roof. ${ }^{115}$ Nevertheless the evidence in favor of this is rather limited. The fact that the horses, chariots and altars on the roof are mentioned only here, whereas Manasseh's altars are mentioned

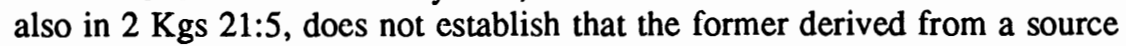
while the latter was part of a dtr polemic against Manasseh. The information about Manasseh's altars could be just as genuine as the other, with both of them deriving from a Josianic DTR. Also, although the information about Manasseh's altars can be removed from v 12, leaving a more concise report of the destruction of the altars on the roof, this does create a certain imbalance with $v 11$. This verse contains two items of information, the removal of the horses and the burning of the chariots of the sun. If one includes the report of Manasseh's altars in v 12 we have two matching items of information. The proposed source would also require the phrase natas hammelek to record the demolition of the altars on the roof. However this phrase, and its special position after the description of the altars, seems to have been formulated by

28; Hollenstein, "Literarkritische Erwägungen," 330; Jones, 1 and 2 Kings II, 616; Montgomery, Kings, 534; Nelson, The Double Redaction, 80-81; Sanda, Die Bücher der Könige II, 360-63.

${ }^{113}$ From a text critical point of view there is difficulty with the meaning of

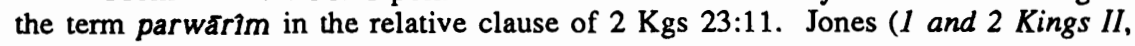
623) suggests the most probable connection is with parbar (temple precinct or forecourt). In v 12a the phrase căliyyat 'ăhăz (upper chamber of Ahaz) follows awkwardly after haggāg (the roof). One would expect a genitive construct here. It may be a later gloss which borrowed information from $2 \mathrm{Kgs} 20: 11$. The phrase wayyăros mišăm in $v 12 \mathrm{~b}$ does not make sense. It has been emended by Gray to "he beat them small on the spot" ( $I$ \& II Kings, 731, n. h).

${ }^{114} \mathrm{See}$ the earlier disccussion of $2 \mathrm{Kgs} 23: 5 \mathrm{a} \beta \gamma$.

${ }^{115}$ This is the proposal of Spieckermann. Juda unter Assur, 107-11, 426-27.

He includes vv 11, 12aa (to haggãg ) $\gamma$ (nãtas hammelek Only) in his source. The rest of $\mathrm{v} 12 \mathrm{a}$ is assigned to DtrH (except for the awkward phrase callyyat sahaza) and $12 \mathrm{~b}$ is assigned to a post-dtr stage. Spieckermann includes the relative clause referring to the kings of Judah in $\mathbf{v} 11$ in the source, but assigns the one in $\mathbf{v} 12$ to DtrH. For a similar interpretation see Hentschel, 2 Könige, 100-10, and Würthwein, 1. Kön. 17-2. Kön. 25, 453. 
DTR to create an inclusion with the other arm of the chiastic structure in $\mathbf{v}$ 4. 116

In short the case for a source in $2 \mathrm{Kgs} 23: 11-12$ is not at all clear. It may therefore be closer to the mark to propose that DTR relied on some official information about Josiah's removal of these cult objects. But, as with $2 \mathrm{Kgs}$ 23:4-8a*, one cannot recover the text of an official report about it.

The location of $2 \mathrm{Kgs} \mathrm{23:11-12} \mathrm{as} \mathrm{the} \mathrm{second} \mathrm{arm} \mathrm{of} \mathrm{the} \mathrm{chiastic} \mathrm{structure}$ suggests a certain hierarchy of importance in DTR's report of reforms to the temple. First in importance is the reform against foreign cults in the temple (vv 4aba, 5aab, 6-7). This reaches a climax with the elimination of the cult of Asherah. It was the decisive move against foreign cults, because Manasseh's installation of the Asherah in the temple in $2 \mathrm{Kgs} \mathrm{21:7}$ was for DTR the gravest affront to the status of the temple. The reform in $2 \mathrm{Kgs} 23: 11-12$ was not of the same order of importance for DTR. This is suggested not only by its structural positioning, but also by the location of the offending cult objects. Unlike those in $2 \mathrm{Kgs} 23: 4-7^{*}$ they were not located in the temple as such, but in its precincts. In v 11 the horses are located at the entrance to the temple. We may presume the chariots of the sun were also there. In v 12 one set of altars was on the roof, while Manasseh's altars were in the two courts.

With the reform report of $2 \mathrm{Kgs} \mathrm{23:15-20}$ an immediately noticeable feature is the shift from report in v 15 to a fuller narrative form in vv 16-20. This enables a convenient division to be made at this point. The provenance of $2 \mathrm{Kgs} 23: 15$ is somewhat obscured by the complexity of its formulation. In $v 15 \mathrm{a}$ there is an abrupt shift from the mention of the altar in Bethel to the high place. The difficulty created by this is reflected in the phrase immediately preceding the main verb nâtass. It emphasizes that both the altar and the high place were pulled down and appears to be a clarifying addition. In $v 15 \mathrm{~b}$ the burning of the high place is immediately followed by the awkward asyndetic phrase hedaq le ‘̄apar. The LXX has emended both phrases to read "and he broke up its stones and beat (them) to dust".

${ }^{116}$ There is as well the mention of the Kidron (cf. $2 \mathrm{Kgs} \mathrm{23:4,7).} \mathrm{The}$ provenance of the verbs used to describe Josiah's reform in $2 \mathrm{Kgs} \mathrm{23:11-12} \mathrm{is}$ difficult to decide. While there are a number of parallel occurrences in Deuteronomy, some of these may have been influenced by the terminology of the reform. An example is Deut 9:21, where the general reference to a brook suggests the description of the destruction of the calf is based on the specific reference to the Kidron brook in $2 \mathrm{Kgs} \mathrm{23:6,12.} \mathrm{On} \mathrm{balance} \mathrm{however} \mathrm{the}$ evidence does not argue against dtr composition in vv 11-12. Thus the verb to remove (sabat in the hiphil-v 11) occurs in DtrH only here and in $v 5$. The verb to burn (śárap-v 11) is used to describe the destruction of cult objects in Deut $7: 5,25 ; 9: 21 ; 12: 3 ; 1 \mathrm{Kgs} 15: 13 ; 2 \mathrm{Kgs} 23: 4,6,11,15,(16,20 \mathrm{a})$. A pre-

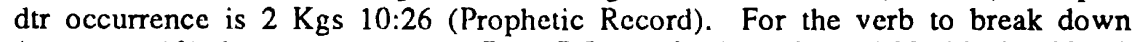
(nătaş_v 12) the occurrences are Deut 7:5; 12:3; Judg 2:2; 6:28, 30, 31, 32; 2 Kgs 11:18; 23:8, 12, 15. It occurs in the Prophetic Record in 2 Kgs 10:27. For the verb to cast-dust of something- (̌ălak-v 12b), the occurrences are Deut 9:21; 2 Kgs 23:6, 12. 
The complexity of the text has led to the explanation that $v 15$ originally did not refer to the high place. It would have read, following the LXX in $v$ 15b; "moreover the altar at Bethel he pulled down, and he broke up its stones and beat (them) to dust". ${ }^{117}$ This is a possible reconstruction. It is difficult to decide whether such a text was part of DtrH since its brevity does not furnish many clues. ${ }^{118}$ Two observations suggest however that it was not. The first is the introductory wegam. This term must always be used with due caution as a literary critical criterion. In this instance however its presence does indicate the verse was appended to DTR's reform report in 2 Kgs 23:4-12*. The second is that given the structure and extent of DTR's report of the reform in Judah it would be surprising to find it followed in DtrH by this single item. One would expect that if Josiah had sufficient power in the north to demolish the altar at Bethel he would not have stopped there. The present text of $2 \mathrm{Kgs}$ 23:15-20 supplies a more complete report to match the one in Judah, but further examination will show that it is a later addition.

The present text of $2 \mathrm{Kgs} \mathrm{23:15-accepting} \mathrm{the} \mathrm{LXX} \mathrm{emendations} \mathrm{in} \mathbf{v}$ $15 \mathrm{~b}$-is even more difficult to include in DtrH. The report that Jeroboam built a high place at Bethel is not confirmed by the corresponding report of his

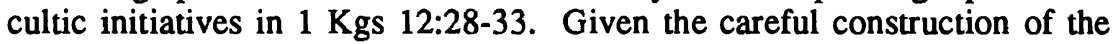
history it is unlikely that DTR would have made the claim in $2 \mathrm{Kgs} 23: 15$ if there were not some basis for it in 1 Kings 12 . The present text also mentions the destruction of the altar along with the high place. In DTR's report about high places in $2 \mathrm{Kgs} \mathrm{23:8a}$ there is no mention of altars. This occurs in vv 11-12. Thus what is treated separately in DtrH seems to have been conflated in v 15. Further, $2 \mathrm{Kgs} 23: 15$ uses the verb natas (pull down) to describe the destruction of the high place, in contrast to $v 8 \mathrm{a}$ which uses tames (defile). ${ }^{119}$ A final observation against including $2 \mathrm{Kgs} 23: 15$ is that nowhere in DtrH is there a reference to an Asherah in Bethel. ${ }^{120}$

${ }^{117}$ This is the reading proposed by Montgomery, Kings, 534, and Spieckermann, Juda unter Assur, 427. Würthwein (1. Kön. 17-2. Kön. 25, 453) includes the reference to Jeroboam. The elision of the reference to the altar in Bethel from an original verse is ruled out. This would leave the high place without any location. The LXX tradition attempted to conflate the two cultic structures by making high place qualify altar (see Barthélemy, Critique textuelle de l'ancien Testament 1,420 ).

${ }^{118}$ Wurthwein's inclusion of the reference to Jeroboam as the one who built the altar makes the proposed text even more difficult to include in DtrH. The

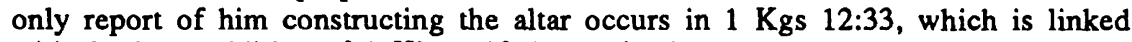
with the later addition of 1 Kings 13 (see below).

${ }^{119}$ Note that in $2 \mathrm{Kgs} 23: 8 \mathrm{a}, 13$ the verb tames is used to describe the end of the high places. In $v 8 \mathrm{~b}$ however the verb natas is used, as in $\mathbf{1 5}$. The expansions to $v 15$ could have been made therefore in conjunction with the addition of $v 8 b$.

${ }^{120}$ An Asherah in the capital Samaria is mentioned in $1 \mathrm{Kgs} \mathrm{16:33a} \mathrm{(DtrH),}$ and also in $2 \mathrm{Kgs} \mathrm{13:6} \mathrm{which} \mathrm{is} \mathrm{a} \mathrm{later} \mathrm{addition} \mathrm{to} \mathrm{the} \mathrm{history.} \mathrm{The} \mathrm{later}$ addition of the reference to the Asherah in $2 \mathrm{Kgs} \mathrm{23:15}$ is recognized by Jones, 1 and 2 Kings II, 624; Montgomery, Kings, 534; Würthwein, 1. Kön. 17-2. Kön. 25, 453, n. 1. 
$2 \mathrm{Kgs} 23: 16-20$ is clearly dependent on $\mathbf{v} 15$, since it presupposes Josiah is in Bethel. The statement in v 16 that Josiah defiled the altar at Bethel clashes with the information in $v 15$ that it had already been destroyed. The clash is particularly sharp if one sees $v 16$ following immediately after the proposed original version of $v 15$. This referred only to the destruction of the altar at Bethel. It is eased to some extent by the present text in which the destruction of the altar is followed by the high place and the Asherah ( $v 15 b)$. If the proposed original version of $\mathrm{v} 15$ is correct it would seem more likely that 2 Kgs 23:16-20 was appended after the verse had been expanded. ${ }^{121}$

Although $2 \mathrm{Kgs}$ 23:16-20 forms a prophecy-fulfillment schema with 1 Kings 13 there are two features which reveal its secondary nature in relation to DtrH. The first is the focus of this schema on the fate of an altar. This is quite different to the use of the schema by DTR, who consistently applied it to the interpretation of the fate of royal dynasties in Israel and Judah. Secondly, the fulfillment notices in vv 16 and 17 are different to DTR's characteristic formula "according to the word of the Lord which he spoke by his servant $X$ the prophet". ${ }^{122}$ The recognition of $2 \mathrm{Kgs} 23: 16-20$ as a later addition to the history means of course that $1 \mathrm{Kgs} \mathrm{13:1-32}$ was part of this addition.

It has been argued that $2 \mathrm{Kgs} 23: 16-18$ was originally a continuation of 1 Kgs 13:1-32, and that it was separated from this prophetic narrative and located in its present position to create the prophecy-fulfillment schema. Some of the original story was probably deleted in the process. ${ }^{123}$ The difficulty with this view is that although Josiah is an integral part of the narrative in $2 \mathrm{Kgs} \mathrm{23:16-}$ 18 , his presence in $1 \mathrm{Kgs} 13: 2$ is an addition. Indeed the whole oracle is probably a redactional replacement of an earlier one against Jeroboam. ${ }^{124}$ It makes better sense therefore to take $2 \mathrm{Kgs} \mathrm{23:16-18}$ as a composition by the redactor or stage of redaction responsible for the insertion of the prophetic narrative in 1 Kings 13 . This redactor or redaction was also responsible for the oracle in $1 \mathrm{Kgs} 13: 2$.

$2 \mathrm{Kgs} 23: 19-20 \mathrm{a}$ invites some special comment. It begins with the introductory wegam and uses a new term to describe the high places, namely

${ }^{121}$ Hoffmann's attempt to explain the literary critical problem of the link between $v 15$ and $v 16$ by claiming that "this sort of uneveness is typical of dtr cult-history writing" is unsatisfactory (Reform und Reformen, 261, n. 31).

${ }^{122} \mathrm{Cf}$. in particular $1 \mathrm{Kgs} 14: 18 ; 15: 29 ; 16: 12 ; 2 \mathrm{Kgs} \mathrm{17:23a}$. Also from DTR are $1 \mathrm{Kgs} 12: 15 ; 2 \mathrm{Kgs} 9: 36 ; 10: 10$.

${ }^{123} \mathrm{Cf}$. Jepsen, "Gottesmann und Prophet: Anmerkungen zum Kapitel 1. Könige 13," Probleme biblischer Theologie (ed. H. W. Wolff; Munich: Kaiser, 1971) 171-82, cf. p. 172. Also U. Simon, "1 Kings 13. A Prophetic Sign. Denial and Persistence," HUCA 47 (1976) 81-119, cf. pp. 84, 100.

${ }^{124}$ Thus Würthwein, "Die Erzählung von Gottesmann aus Juda in Bethel. Zur Komposition von 1 Kön 13," Wort und Geschichte. Festschrift für Karl Elliger zum 70. Geburtstag (AOAT 18; Neukirchen-Vluyn: Neukirchener Verlag, 1973) $181-89$, cf. p. 184 . The late insertion of Josiah's name is accepted by Dietrich, Prophetie und Geschichte, 117-18; Thomas B. Dozeman, "The Way of the Man of God from Judah: True and False Prophecy in the Pre-Deuteronomic Legend of 1 Kings 13," $C B Q 44$ (1982) 379-93, cf. p. 383; Gray, I \& II Kings, 318, 326; Noth, Könige, 292-93. 
batê-habbamôt (houses of the high places). This term has not occurred so far in the description of Josiah's reform. The evidence is not particularly strong, but it does suggest that these verses may have been appended to vv 16-18 in order to give a more complete picture of Josiah's reform in the north which would correspond to the one in the south. ${ }^{125}$ As the reform in the south encompassed both the central shrine (Jerusalem temple) and the high places throughout Judah, so the reform in the north encompassed the central shrine of Bethel (vv 15-18) and the high places throughout Samaria (vv 19-20a). The addition was incorporated into the prophecy-fulfillment schema in the

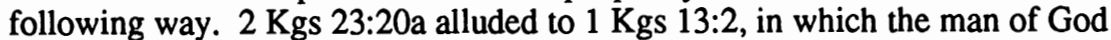
foretold that Josiah would sacrifice priests on the altar at Bethel. $2 \mathrm{Kgs}$ 23:19 alluded to $1 \mathrm{Kgs}$ 13:32, in which the prophet of Bethel forecast that the man of God's words "against the altar in Bethel, and against all the houses of the high places which are in the cities of Samaria" would come to pass. ${ }^{126}$

The recognition of $1 \mathrm{Kgs} 13: 1-32$ and $2 \mathrm{Kgs} 23: 16-20$ as later additions to DtrH permits some clarifying observations about the complex nature of $1 \mathrm{Kgs}$ 12:25-33. According to Campbell the text of the Prophetic Record comprised $1 \mathrm{Kgs} 12: 25,28 \mathrm{a}, 29 ; 13: 33 \mathrm{~b}-34$ (without wayyasob). The text of the Southern Document comprised $1 \mathrm{Kgs} 12: 26-27,28 \mathrm{~b}, 30 \mathrm{~b}, 31-32$. $1 \mathrm{Kgs}$

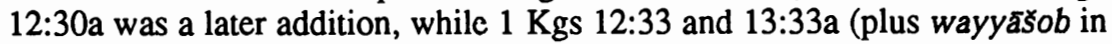
$v 33 \mathrm{~b}$ ) provided a literary seam for the insertion of $1 \mathrm{Kgs} 13: 1-32 .{ }^{127}$

The presence of the term "houses of the high places" in $1 \mathrm{Kgs} \mathrm{12:31}$ suggests however that this verse was a redactional comment associated with the later insertion of $1 \mathrm{Kgs}$ 13:1-32 rather than part of the Southern Document. ${ }^{28}$ This being so, v $32 \mathrm{~b}$ should also be included in this redaction. It links up with $v 31$ via the reference to the priests appointed by Jeroboam. The additional information that Jeroboam placed his priests in Bethel looks in turn to have been made with an eye to $v 33$ and the prophecy of the man of God in $1 \mathrm{Kgs}$ 13:2. This revision therefore gives the following distribution for $1 \mathrm{Kgs}$ 12:25-13:34: DtrH, made up of a combination of 12:25, 28a, 29, 13:33b-34 (Prophetic Record) and 12:26-27, 28b, 30b 32a (Southern Document); later redaction of DtrH in 12:31, 32b-33; 13:1-33a (plus wayyãsob in v 33b); probable independent addition in 12:30a.

${ }^{125}$ Nelson (The Double Redaction, 82-83) assigns $2 \mathrm{Kgs} 23: 19-20 \mathrm{a}$ to the exilic redactor, with vv 15-18 going to the Josianic historian. The secondary nature of vv 19-20a was noted earlier by Benzinger, Die Bücher der Könige, 194 and Kittel, Die Bücher der Könige, 303. $2 \mathrm{Kgs} 23: 20 \mathrm{~b}$ could follow equally well after $v 18$ as after $v 20$ a.

${ }^{126} \mathrm{It}$ is possible the reference to the houses of the high places in Samaria in $1 \mathrm{Kgs} 13: 32 \mathrm{~b}$ was added as part of this accommodation. It extends the horizon of the prophecy in 13:2, which refers only to Bethel.

${ }^{127}$ Campbell, Of Prophets and Kings, 89-90, 189. For Campbell $1 \mathrm{Kgs}$ 12:30a was probably added after the insertion of $1 \mathrm{Kgs} 13: 1-32$ (p. 189, n. 65).

${ }^{128}$ The MT of $1 \mathrm{Kgs} 12: 31$ has bet-bamót instead of batê-habbamót as in $1 \mathrm{Kgs}$ 13:32; $2 \mathrm{Kgs} \mathrm{23:19.} \mathrm{However} \mathrm{the} \mathrm{plural} \mathrm{bamôt} \mathrm{indicates} \mathrm{that} \mathrm{bet} \mathrm{should} \mathrm{also} \mathrm{be}$ plural. This is the case in the LXX and Vulgate. The term occurs also in $2 \mathrm{Kgs}$ $17: 29,32$, identified as a later addition to DtrH. 


\section{c)- 2 Kgs 23:21-23 (The Passover Celebration)}

There is no evidence of a pre-dtr source in $2 \mathrm{Kgs}$ 23:21-23.129 DTR's authorship of the pericope is shown by a number of linguistic features and by the way it forms an integral part of the conceptual plan and structure of the history. ${ }^{130}$ Thus the reference to the book of the covenant in $v 21$ is clearly dependent on the previous reference in $2 \mathrm{Kgs} 23: 1-3$, which was composed by DTR. There is also the reference to the time of the judges in $v 22$. The creation of a period of the judges was seen to be the work of DTR. ${ }^{131}$ In terms of the history's conceptual plan and structure $2 \mathrm{Kgs}$ 23:21-23 forges a link with the period of Israel under Moses and Joshua. The celebration of this particular Passover linked the people of Josiah's generation with the foundational period of Israel's history and its great events, namely the Exodus and conquest of the land. ${ }^{132}$ This is indicated by the nature of the Passover itself which was a celebration of the Exodus. It is also indicated by the way $v$ 22 states that no Passover like this (kappesah hazzeh) had been celebrated from the time of the judges or the monarchy.

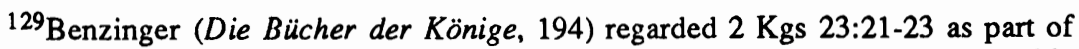
a source, but redacted. A similar position is held by Nelson, The Double Redaction, 83. Dtr composition is recognized by Gray, I \& II Kings, 728; Hentschel, 2 Könige, 113 (DtrN); Hölscher, "Könige," 198, 208; Jepsen, Die Quellen des Königsbuches, 26-28 and Übersicht (RII = DTR); Jones, 1 and 2 Kings II, 626; Peter Laaf, Die Pascha-Feier Israels. Eine literarkritische und überlieferungsgeschichtliche Studie (BBB 36; Bonn: Hanstein, 1970) 94, 13031; Mayes, The Story of Israel, 174, n. 63 (exilic Dtr); Noth, The Deuteronomistic History, 73; Rehm, 2 Könige, 216; Spieckermann, Juda unter Assur, 130-37, 428 (DtrN); Würthwein, "Die Josianische Reform" 408-9. In 1. Kön 17-2. Kön. 25, 454, 461, Würthwein assigns v 21 to DtrN, vv 22-23 being probably later.

${ }^{130}$ The dtr authorshp of the pericope does not make it a literary fiction. Given the Josianic provenance of DtrH there is no reason to deny such a feast was celebrated as part of the reform. Delcor suggests that Josiah instituted the feast to stop Phoenician inspired child sacrifice ("Réflexions sur la Paque de Josias d'après 2 Rois 23:21-23," Henoch 4 [1982] 205-19). The text of DtrH gives no evidence of this.

$1312 \mathrm{Kgs} \mathrm{23:22}$ lends support to my proposal that DTR organized the history into three periods; the period of Israel under Moses and Joshua, the period of Israel from the judges to the monarchy, and the period of Israel under the prophets and kings.

${ }^{132}$ Rose (Deuteronomist und Yahwist, 32-33) proposes that $2 \mathrm{Kgs} 23: 21-23$ recalls Josh 5:10-12, which for him is also a dtr composition. It is doubtful whether this link can be made. Admittedly both texts refer to "making" (๕đsâ) the Passover, but one may question whether this is sufficient to claim unity of authorship (the same verb is used in Exod 12:48; Num 9:2, 5-14; Deut 16:1; 2 Chr 30:1, 2, 5, 15, 18; 35:1, 16-19). Against Rose there is no mention of manna in DTR's review in Deuteronomy 1-3, as there is in Josh 5:12. As well 2 Kgs 23:22 does not refer to Joshua, as one would expect if the link were there, but to the judges. Noth (Überlieferungsgeschichtliche Studien, 183) identified Josh 5:10-12 as a later addition of a priestly nature. 
Note that $2 \mathrm{Kgs}$ 23:22 does not claim that Passover had never been celebrated since the time of the judges, rather that it had never been celebrated like this. The discovery of the book meant that it could now be done. The reference to the book is general but one may presume DTR had in mind the provisions for the celebration of the feast in Deut 16:1-8. $2 \mathrm{Kgs}$ 23:21-23 also celebrates the successful restoration of exclusive centralized worship of Yahweh, something which had been lost in the time of Solomon and only temporarily regained during the time of Hezekiah.

2 Kgs 23:23 states that the Passover was celebrated in the eighteenth year of Josiah's reign, the same date given in 22:3 for the discovery of the book. It is argued that this is evidence of later composition, because the date leaves an impossibly short time between discovery of the book and Passover for the implementation of the reform. The argument is however dependent on the theory that the Jewish year at the time began in the spring, a theory which is not at all assured. ${ }^{133}$ There are good grounds for accepting an autumnal new year throughout the period of the monarchy. This would mean there were about six months between the discovery of the book and Passover to implement the reform described in $2 \mathrm{Kgs} 23: 4 \mathrm{aba}$, 5aab-8a, 9, 11-12*.134 There is therefore no cause to assign $2 \mathrm{Kgs} 23: 21-23$ to a later dtr redaction.

\section{KGS 23:24-30}

The remainder of the account of Josiah's reign can be divided into four sections: v 24 (reform report), v 25 (judgment formula on Josiah), vv 26-27 (reaffirmation of Yahweh's wrath against Judah), vv 28-30 (death and burial of Josiah). $2 \mathrm{Kgs}$ 23:24 was appended by a later dtr redactor who wanted to include a number of items which were not part of DTR's reform report. The verse is located outside the reform report and is introduced by wegam. The practices listed are all mentioned elsewhere in secondary passages. ${ }^{135}$ Furthermore, in $2 \mathrm{Kgs}$ 23:3 Josiah pledged himself to establish (Iehaqqim) the words of the book of the covenant. Verse 24 speaks of him establishing (lehaqim) the words of the law. Within the context of the later redaction of

${ }^{133}$ The Passover was celebrated in the month of Abib (March-April, cf. Deut 16:1). Spieckermann (Juda unter Assur, 133), following J. Begrich, reckons that a chronology based on a spring new year would leave only fourteen days for the reform. Cf. also Würthwein, "Josianische Reform," 408.

${ }^{134}$ On the autumnal new year see S. deVries, "Calendar," IDB 1 (1962) 483 88, especially p. 484. See also V. Pavlovsky and E. Vogt, "Die Jahre der Konige von Juda und Israel," Bib 45 (1964) 321-47, especially p. 345; Gray, I \& II Kings, 744-45; and the comments by Lohfink, "Zur neueren Diskussion uber 2 Kon 22-23," 45, n. 91. Two further points are worth keeping in mind. One is that it is difficult for the modern reader to estimate the amount of time Josiah would have needed to implement a reform. The other is that it is quite likely the dismantling of foreign cults was under way before the discovery of the book (cf. Lohfink, "The Cult Reform of Josiah," 466).

135“Mediums" (2 Kgs 21:6), "wizards" (2 Kgs 21:6), “idols" (1 Kgs 15:12; 21:26; 2 Kgs 17:12; 21:11, 21), "teraphim" (Judg 17:5; 18:14, 17-18, 20); "abominations" (in the plural-Deut 29:16). 
DtrH this suggests the verse stemmed from the nomistic stage of redaction with its concern for obedience to the law. ${ }^{136}$ Finally, the dependence of $v 24$ on the already existing text of DtrH is indicated by the way it reverses its sequence. It begins by describing the reform carried out in Judah and Jerusalem (cf. $2 \mathrm{Kgs}$ 23:4-20), then refers to Josiah's commitment to the book (cf. 23:13 ), and ends by recalling the discovery of the book itself (cf. 22:3-10). ${ }^{137}$

$2 \mathrm{Kgs} 23: 25 \mathrm{a}$ has been identified by Cross and Nelson as the conclusion to the Josianic DtrH. ${ }^{138}$ Verse $25 \mathrm{~b}$, which compares Josiah with his less than illustrious successors, is from a later hand. Their proposal is attractive, but

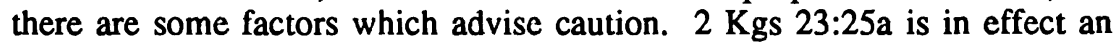
additional judgment formula to the one already given in $2 \mathrm{Kgs} 22: 2$. A second cautionary factor is the way v 25a describes Josiah as turning ( $s u b)$ to the Lord. This suggests repentance and conversion, and as such would align the verse more with $2 \mathrm{Kgs} 22: 19$. Moreover in other texts of DtrH which employ the metaphor of the heart the verb šub does not appear (1 Kgs 9:4; 11:4; $14: 8 \mathrm{~b} ; 15: 3 \mathrm{~b}$ ). On the other hand $2 \mathrm{Kgs} 23: 25 \mathrm{a}$ could be taken as an allusion to Josiah's gesture on hearing the law in $2 \mathrm{Kgs} 22: 11$.

In a word the evidence is somewhat ambiguous, but it does suggest there may be another text which would provide a more satisfactory conclusion to

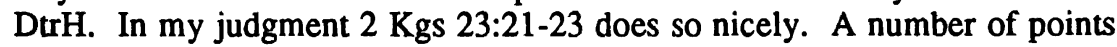
emerged in the preceding discussion of the passage which favor such a conclusion. First, it marks the successful restoration of the exclusive centralized worship of Yahweh. Secondly, the celebration of Passover forges a link with the period of Israel under Moses and Joshua (Exodus and conquest). Both of these points would have been important for a Josianic historian, one of whose principal aims was to promote the deuteronomic reform. In addition to recalling the beginning of DTR's history and its high point in the time of

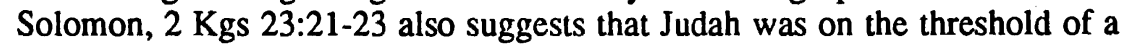
new era. If $2 \mathrm{Kgs} 23: 21-23$ was the conclusion to DtrH then $\vee 25$ was added by a later hand to ensure that Josiah was set apart from his evil successors. ${ }^{139}$ 13.

${ }^{136}$ The closest parallel to $2 \mathrm{Kgs} 23: 24$ in Deuteronomy occurs in Deut 18:10-

${ }^{137}$ The secondary nature of $2 \mathrm{Kgs} 23: 24$ has been identified by Hentschel, 2 Könige, 111; Hölscher, "Könige," 199, 208; Jones, 1 and 2 Kings II, 628; Mayes, The Story of Israel, 174, n. 63; Nelson, The Double Redaction, 83; Spieckermann, Juda unter Assur, 137, 38, 428; Würthwein, 1. Kön. 17-2. Kön. $25,454,461$.

${ }^{138}$ Cross, Canaanite Myth and Hebrew Epic, 287, n. 49; Nelson, The Double Redaction, 83-84. R. E. Friedman (The Exile and biblical Narrative, 7-8) identifies $2 \mathrm{Kgs} 23: 25$ as the conlusion. Cf. also Lohfink, Rückblick im Zorn, 177; Mayes, The Story of Israel, 131; Norman H. Snaith, "Introduction to and Exegesis of the First and Second Books of Kings," IB 3 (1955) 3-338, cf. p. 325; G. Vanoni, "Beobachtungen," 361.

${ }^{139}$ S. L. McKenzie (The Chronicler's Use of the Deuteronomistic History, 191) proposes $2 \mathrm{Kgs} 23: 21-23$ as the conclusion to DtrH. If $v 23$ is accepted as the conclusion there does not seem any reason to assign $v 25 \mathrm{a}$ and $v 25 \mathrm{~b}$ to different redactors. It seems unlikely that DTR intended to draw a parallel between Josiah and Joshua as Nelson supposes ("Josiah in the Book of Joshua," 
This was particularly necessary because he was the father, not only of his immediate successor Jehoahaz, but also of Jehoiakim and Zedekiah.

$2 \mathrm{Kgs}$ 23:26-27 reaffirms the condemnation of Manasseh given in $2 \mathrm{Kgs}$ 21:10-14. Although both texts address the same theme there is some difference between them in terminology and expression. ${ }^{140}$ Hence it is better to speak of a stage of redaction rather than a single redactor. This stage of later redaction saw Manasseh as the king responsible for the exile. The discussion of Huldah's prophecy argued that $2 \mathrm{Kgs} 22: 19,20 \mathrm{a} \beta$ was part of the same redaction as $2 \mathrm{Kgs} \mathrm{21:10-14}$. The relationship of these three texts may be illustrated in the following way. The combination of $2 \mathrm{Kgs} \mathrm{21:10-14}$ and 23:26-27 emphasize that Manasseh was responsible for the exile of Judah. 2 Kgs 22:19, 20aß is careful to point out however that Josiah's death was not part of the divinely ordained exile.

\section{KGS 23:31-25:30 (THE LAST FOUR KINGS OF JUDAH)}

The evident dtr passages in this block of material appended to DtrH are the judgment formulas in $2 \mathrm{Kgs} 23: 32,37 ; 24: 9,19$ and the comments in $2 \mathrm{Kgs}$ $24: 2-4,20 \mathrm{a}$. It is quite possible that the summary statement on Judah's exile in $2 \mathrm{Kgs} 25: 21 \mathrm{~b}$ is also dtr. $2 \mathrm{Kgs} 24: 13$ functions as the fulfillment notice for Isaiah's prophecy in $2 \mathrm{Kgs} \mathrm{20:12-19.141}$ It was pointed out in the analysis of the reign of Hezekiah that this prophecy, along with $2 \mathrm{Kgs}$ 18:14-16, was added as a frame around DTR's account of the Assyrian crisis. The narrative material from $2 \mathrm{Kgs} 23: 31$ to $25: 30$ is generally recognized as a compilation from a variety of sources.

The four judgment formulas in $2 \mathrm{Kgs} 23: 32,37 ; 24: 9,19$ are an important piece of evidence in favor of the hypothesis of a Josianic DtrH which was updated in the exile. Adherents of the hypothesis of an exilic DtrH have consistently overlooked their significance. This is particularly surprising in view of $\mathrm{H}$. Weippert's study in which she proposed that these last four formulas were composed by a different redactor to the others. ${ }^{142}$

531-40. The texts in the book of Joshua from which Nelson draws the parallel are later additions (cf. Josh 1:7-8; 8:30-35). As well DTR gives no evidence that Josiah recovered ancestral territory conquered by Joshua. One may accept however that later redaction portrayed these two figures as models of obedience to the law.

${ }^{140}$ The announcement of disaster in $v 27$ does not recall the imagery of $2 \mathrm{Kgs}$ 21:12-14. However it does repeat the parallel between Israel and Judah in 21:13. It also refers to the destruction of Jerusalem, described in 21:13 in the imagery of wiping a dish. Note the presence of the short form of the name formula in $\mathbf{v} 27$. This recalls $2 \mathrm{Kgs}$ 21:4. $2 \mathrm{Kgs}$ 21:7 (DTR) has the fuller form with "for ever".

${ }^{141}$ In fact there is good evidence for including $2 \mathrm{Kgs} 24: 14$. The two verses intrude between $v v 12$ and 15 , which belong together as a narrative about the imprisonment and exile of the royal family. For a succinct discussion see Nelson, The Double Redaction, 88.

${ }^{142} \mathrm{H}$. Weippert, "Die 'deuteronomistischen' Beurteilungen," 333-34. Her hypothesis of the independent authorship of the last four formulas has been confirmed by Nelson (The Double Redaction, 36-41), Mayes (The Story of Israel, 123) and Vanoni ("Beobachtungen," 359). None of the proponents of the Smend 
There are two features which distinguish these judgment formulas from the preceding ones. The first is their high degree of consistency. They are all identical except for some variation in their reference to predecessors. $2 \mathrm{Kgs}$ 23:32 and 37 contain a general reference to "his fathers", whereas $2 \mathrm{Kgs} \mathrm{24:9}$ has the singular "his father". $2 \mathrm{Kgs} 24: 19$ refers to Jehoiakim. However it is this variation which in turn forms the second distinguishing feature of the formulas. The general reference to "his fathers" in the first two formulas appears to have been dictated by two factors, namely the positive judgment formula for Josiah in $2 \mathrm{Kgs} 22: 2$ and the fact that both Jehoahaz and Jehoiakim were the sons of Josiah. Given DTR's enthusiastic assessment of Josiah the author of the negative judgment formulas for these two kings could hardly have written "according to all that his father (i.e., Josiah) had done". It is also highly unlikely that one author would have composed the formula for Josiah as well as the ones for Jehoahaz and Jehoiakim, thereby creating a tension in the text. The more acceptable explanation is that $2 \mathrm{Kgs} 23: 32$ and 37 are the work of a redactor who was adding to an already existing text.

The redactor responsible for the first two formulas was able to refer to the immediate predecessor in $2 \mathrm{Kgs} \mathrm{24:9}$ because Jehoiachin was the son of Jehoiakim and not of Josiah. The variation in the formula for Zedekiah in 2 Kgs 24:19 can be explained by a combination of historical facts and the redactor's desire to avoid a potential difficulty posed by these facts. First the historical facts. Zedekiah and Jehoahaz were brothers (their mother was Hamutal, cf. $2 \mathrm{Kgs} 23: 31 ; 24: 18$ ) and therefore Zedekiah was Jehoiachin's uncle ( $2 \mathrm{Kgs} 24: 17)$. This fact created a difficulty for the redactor. There was the same need to avoid any negative reference to Zedekiah's father Josiah, as in the formulas for Jehoahaz and Jehoiakim. But it appears the redactor in question also judged it unwise to repeat the general reference to "his fathers" from these earlier formulas. The increased textual distance between $2 \mathrm{Kgs}$ $24: 19$ and the account of Josiah's reign could lead a reader to mistakenly include Josiah among "his fathers". In order to avoid this the redactor opted for the reference to the evil Jehoiakim. ${ }^{143}$ In thcir own way therefore the

school have taken Weippert's work into account. Nor is Weippert's case examined by Hoffmann, Reform und Reformen, Van Seters, In Search of History, or B. Peckham, The Composition of the Deuteronomistic History. Provan (Hezekiah, 48-50) does consider Weippert's evidence and acknowledges the distinctive pattern in these formulas, but inclines against a particular redactor. His arguments are directed principally against a perceived inconsistency in Nelson. Why should Nelson claim the last four formulas for a particular redactor, when he includes an equally distinctive pattem (from $2 \mathrm{Kgs} 13: 10$ to 15:28) in DirH? This does not really dismantle Weippert's proposal. In any case Campbell's northern expansion now shows that this series of judgment formulas was the work of a particular author.

${ }^{143}$ The coronation of Zedekiah, son of Josiah, after Jehoiakim and his son Jehoiachin, seems to have created problems in Chronicles and the LXX about Zedekiah's parentage. The MT of 2 Chr 36:10 has "his brother" instead of "his uncle". The LXX (kaige) reads "his son". Nelson proposes that the exilic redactor originally wrote "his brother" in $2 \mathrm{Kgs} 24: 17$. This was adopted by Chronicles, but the MT was later changed to "his uncle" (The Double Redaction, 
variations contribute to the sense of a unified sequence in these four judgment formulas.

The other evident dtr passages are $2 \mathrm{Kgs} 24: 2-4$ and 24:20a. Verse 2, with its reference to "his servants the prophets" is the fulfillment notice for the prophecy against Manassseh in 2 Kgs 21:10-14.144 Verse 3 for its part appears to refer to $2 \mathrm{Kgs}$ 23:26-27. Both the introductory 'ak, and the use of the verb sur to refer to the removal of Judah from Yahweh's sight, occur in 2 Kgs 23:26-27.145 Granted that $2 \mathrm{Kgs} 21: 10-14$ and 23:26-27 stemmed from the same stage of later dtr redaction, one may also include $2 \mathrm{Kgs} 24: 2$ and 3 in this stage. Despite some variation in terminology these texts are united in their concern to explain the exile of Judah as the outcome of Manasseh's infidelity. $2 \mathrm{Kgs} 24: 4$ unmistakably recalls the similar statement in $2 \mathrm{Kgs}$ 21:16. The particular crime which Manasseh is accused of in these versesthe shedding of innocent blood-plus the location of $2 \mathrm{Kgs} 21: 16$ as an appendage to the account of Manasseh, point to them being independent of 2 Kgs $24: 2-3$. The location of $2 \mathrm{Kgs} 24: 4$ was probably prompted also by a desire to add some detail to the phrase "all that he had done" in v $3 .{ }^{146}$

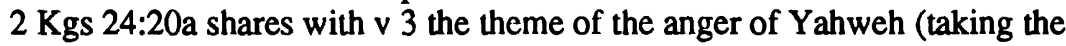
LXX reading instead of the MT), and the removal of Judah from his presence. However there is a recognizable shift from $2 \mathrm{Kgs} 24: 2-3$. Verse 20 does not state that the divine anger is directed against Manasseh or Zedekiah (v 19). The focus is rather on the inhabitants of Jerusalem and Judah. $2 \mathrm{Kgs} \mathrm{24:20 \textrm {a }}$ thus exhibits the same transfer of interest from king to people that has been observed in the later additions of $2 \mathrm{Kgs} 21: 8-9,15$ and 22:16-17.

As noted above it is generally agreed that the narrative material in $2 \mathrm{Kgs}$ 23:31-25:30 has been compiled from a number of sources. The details of this need not be gone into here. However a brief comment on the final chapter is in order. The major steps in the compilation of 2 Kings 25 can be clarified by comparative analysis with parallel passages in Jeremiah. Recent studies of

39). However this seems speculative and unnecessary. The text of Chronicles and the LXX betray later attempts to simplify the more complex line of descent in the MT.

${ }^{144}$ Cf. Cross, Canaanite Myth and Hebrew Epic, 286; Nelson, The Double Redaction, 88. It has been suggested that "Yahweh" as the subject in $\mathbf{v} 2$ is a gloss and that the original subject was Nebuchadnezzar of v 1 (cf. Gray, I \& II Kings, 757, n. a; Würthwein, 1. Kön. 17-2. Kön. 25, 468, n. 2). The present text is thought to create an awkward sequence with Yahweh sending the enemy against Judah in accord with the word of Yahweh. But if one sees the fullfillment notice as referring back to the phrase "to destroy it" this difficulty is alleviated and Yahweh may be retained as the subject (cf. the discussion in Barthelemy, Critique textuelle de l'ancien Testament 1, 421-22).

${ }_{145}$ The correlation is even clearer if one adopts the LXX (Lucian), Peshitta and Targum reading of 'ap (anger) instead of the MT p1 (mouth or command). The reference to Yahweh's anger would then recall $2 \mathrm{Kgs}$ 23:26. The MT reading can be taken however to recall 23:27. A point which does suggest the MT is a later revision is that it links $2 \mathrm{Kgs} 24: 3$ more closely with the preceding verse. For a discussion see Barthélemy, Critique textuelle de l'ancien Testament 1, 422.

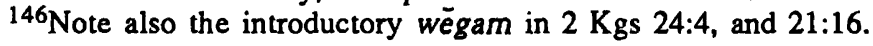


Jeremiah have proposed that the Gedaliah incident in $2 \mathrm{Kgs} 25: 22-26$ is dependent on the fuller version in Jer 40:7-41:18. ${ }^{147}$ However the reverse dependence is proposed between $2 \mathrm{Kgs} 25: 1-21$ and Jer 39:1-10.148 The implication to be drawn from this is that $2 \mathrm{Kgs} 25: 22-26$ was added subsequently to $25: 1-21$, on the basis of the Jeremiah account. The statement in v 21b "so Judah was taken into exile out of its land" was therefore once the conclusion to 2 Kings. It is likely that this terse remark came from the redactor responsible for the equally terse judgment formulas for the last four kings of Judah.

2 Kgs 25:27-30 deals with a different topic to vv 22-26 and its parallel in Jeremiah is located in Jer 53:31-34. It was therefore an independent addition. The relationship between it and $2 \mathrm{Kgs} 25: 22-26$ is difficult to determine, but if K.-F. Pohlmann's hypothesis of a late post-exlic date for the "gola" redaction in Jeremiah 37-44 is correct it would mean that $2 \mathrm{Kgs} 25: 22-26$ was later than $2 \mathrm{Kgs} 25: 27-30$. As was pointed out in the discussion of Huldah's prophecy, $2 \mathrm{Kgs}$ 25:27-30 shows an interest in the destiny of the Davidic dynasty. The report may have arisen around the same time as those later dtr passages which also show an interest in the dynasty and seek to blame Manasseh for the exile, while excusing Josiah (cf. 2 Kgs 21:10-14; 22:19, 20aß; 23:26-27; 24:2-3). This would have occurred after the work of the redactor responsible for the last four judgment formulas and $2 \mathrm{Kgs} 25: 21 \mathrm{~b}$, but prior to the nomistic redaction

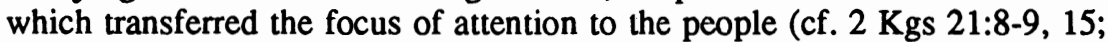
$22: 13 \mathrm{~b}, 16-17,18 \mathrm{a} ; 24: 20 \mathrm{a}$ ). The following chapter will explore in more detail the relationship between these different stages in the subsequent redaction of DtrH.

${ }^{147}$ Cf. the study by K.-F. Pohlmann, Studien zum Jeremiabuch: Ein Beitrag zur Frage nach der Entstehung des Jeremiabuches (FRLANT 118; Göttingen: Vandenhoeck \& Ruprecht, 1978) 110-11, and W. Thiel, Die deuteronomistische Redaktion von Jeremia 26-45 (WMANT 52; Neukirchen-Vluyn: Neukirchener Verlag, 1981) 54-55, n. 12. Cf. also Gray, I \& II Kings, 770; Jones, 1 and 2 Kings II, 630; Würthwein, 1. Kön. 17-2. Kön. 25, 479.

${ }^{48} \mathrm{Cf}$. Pohlmann, Studien zum Jeremiahbuch, 105; Thiel, Die deuteronomistische Redaktion von Jeremia 26-45, 54-55, n. 12. 


\section{THE SUBSEQUENT REDACTION OF THE DEUTERONOMISTIC HISTORY}

Three things are required in order to gain as clear an understanding as possible of the subsequent dtr redaction of DtrH. First, it is necessary that the structure, conceptual plan and text of the history be clearly established. It is only when this has been done that a clear perception of the course of later redaction can be gained. Second, one needs to be able to determine the relationship of later redaction to $\mathrm{DtrH}$, since it was no doubt carried out with a view to modifying the history in some way. Third, if there was more than one later redactor or redaction of $\mathrm{DtrH}$ then the relationship between them needs to be explained. One can expect that later redactors built on the work of their predecessors. In conjunction with this third point it is necessary to look for the sort of historical circumstances which gave rise to the different redactions of the history. This cannot always be done with complete satisfaction due to the limitations of our knowledge of Israelite history. Nevertheless such an investigation is required in order to construct as complete a picture as possible of the redaction history of DtrH.

The text, structure, and conceptual plan of DtrH has now been established, and the later additions to DtrH identified. The aim of this chapter is to examine how the later additions stand in relationship to the history, and how they stand in relationship to one another. It needs to be said at the outset that some of the later additions escape precise identification. Nevertheless the main lines of development in the subsequent redaction history of DtrH can be traced with reasonable certainty. The texts which are more difficult to identify do not significantly alter the overall picture. They are either isolated additions, or can be shown to have some thematic relationship to the main lines of later redaction, even if one is unable to be certain at what stage a particular text was added.

The examination reveals that the subsequent redaction history of DtrH took place in three main stages. The extent of the first stage is quite limited, and its uniformity points to the work of one person. The two subsequent stages of redaction were much more extensive, but the boundaries between each stage are at times difficult to determine precisely. There is a certain amount of variation within each stage which makes it difficult to speak of one redactor. It is for this reason that the broader description of a stage of redaction has been adopted. There is also some overlapping of terminology and theology between the two stages. This suggests the emergence of what one may call a dtr school, with a corresponding broadening of theological interest and vocabulary.

\section{THE FIRST STAGE OF SUBSEQUENT DTR REDACTION}

The first stage was a fairly straightforward account of the decline of Judah down to the exilc. It extended from $2 \mathrm{Kgs} 23: 28$ and ended at $2 \mathrm{Kgs} 25: 21$ 


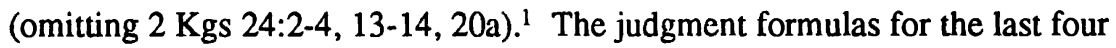
kings of Judah belong to this redaction ( $2 \mathrm{Kgs} 23: 32,37 ; 24: 9,19)$. Their uniformity is a good indication that they stem from the hand of one redactor. Their rather terse formulation suggests that this redactor did not intend to engage in any extended theological commentary on the reasons for Judah's fall. The primary aim seems to have been to bring the history up to date by recording the troubled reigns of the last four kings of Judah down to the exile. In order to do this the redactor adopted the regnal framework from DtrH and provided a brief assessment of each king in the judgment formulas. ${ }^{2}$ The early exilic period would be an appropriate date for the work of this redactor.

As can readily be seen, the initial stage of later redaction was quite limited. It did not attempt to account for the exile in terms of DTR's theological categories; that is, the explanation of the course of Israel's history in relation to the deuteronomic code and within a schema of prophecy and fulfillment. The reason for this may have been that the redactor encountered considerable difficulty at this point. In DTR's account of the reign of Josiah the deuteronomic code is thoroughly integrated into the four-part pattern. This tied it firmly to DTR's presentation of Josiah's reform as divinely favored and the dawn of a new era for Judah. Josiah's disastrous end and the subsequent decline and fall of the state threatened the authority of the deuteronomic code and indeed the whole of DTR's theological enterprise. Unless these events could be interpreted within DTR's theological categories in some way, the history would have become a grave embarrassment to its supporters.

\section{THE SECOND STAGE OF SUBSEQUENT DTR REDACTION}

The second stage of redaction saw the difficulty and undertook to retrieve the history by accounting for the exile and the death of Josiah in a way which could be accommodated to DTR's thcology. Its contribution can most clearly

1J. Gray (I \& II Kings, 753, 756) thinks that DTR completed the first edition of the history sometime between the revolt of Jehoiakim in 598 and the siege of Jerusalem under Jehoiachin from December 598 to March 597. He sees a break in the royal records at $2 \mathrm{Kgs} 24: 1$. The verse reports a revolt but the Babylonian reponse is first mentioned in $v 10$. This suggests two different authors. He also sees the use of Babylonian chronology in $v 12$ as supporting evidence. The problem with Gray's proposal is that it does not satisfactorily account for the judgment formulas for the last four kings. Also, he is obliged to admit there is no clear indication of where the first edition ended and the exilic continuation took up. The delay between the report of Jehoiakim's revolt and the Babylonian response need not indicate a break in the records. The use of Babylonian chronology does not support his position either. It could equally well have been reported at this stage by the exilic redactor to mark a significant turning point in

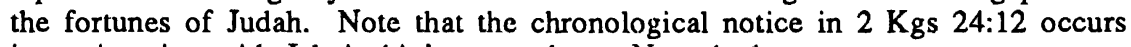
in conjunction with Jehoiachin's surrender to Necuchadnezzar.

${ }^{2}$ The normal death and burial notice, and the source citation, are missing for Jehoahaz, Jehoiachin, and Zedekiah. This is due to the fact they were deposed by the Babylonians. With Jehoiakim there is no report of the place of his burial as is customary with Davidic kings in DtrH, and occurs also for Josiah in $2 \mathrm{Kgs}$ $23: 30$. 
be seen in the following texts: the reworking of $2 \mathrm{Kgs} \mathrm{21:2-7} \mathrm{(vv} 2 b, 3 b \beta-4$, 6), the prophecy against Manasseh in 21:10-14, the reworking of Huldah's prophecy in $2 \mathrm{Kgs} 22: 19,20 \mathrm{a}$, the reaffirmation of Yahweh's wrath because of Manasseh in $2 \mathrm{Kgs} 23: 26-27$, and the fulfillment notice in $2 \mathrm{Kgs} \mathrm{24:2}$ (with v 3). As can be seen from these passages Manasseh was a key figure for the second stage of redaction. DTR's own negative portrayal of Manasseh was no doubt a contributing factor in fixing attention on him.

The second stage of redaction adopted three elements from DtrH. First of all, the accusation that Jeroboam made Israel sin was applied to Manasseh. This can be seen in $2 \mathrm{Kgs} \mathrm{21:11}$ where he is accused of having made Judah sin. Manasseh is the only Davidic king so accused. What is of course important about Jeroboam is that, according to DTR, it was his corruption of Israel which ultimately resulted in the northern exile (2 Kgs 17:21-23). In applying the same accusation to Manasseh, the second stage of redaction was able to provide a reason for the exile of Judah which was consistent with DTR's own criteria.

The second element adopted from DtrH was the model of the prophet/king relationship. This is evident in the way Manasseh is censured in $2 \mathrm{Kgs} \mathrm{21:10}$ "by all his servants the prophets" for the cultic abuses listed in $2 \mathrm{Kgs}$ 21:2-7. In conjunction with this the redaction remodelled DTR's report with the addition of vv $2 b, 3 b \beta-4,6$ in order to sharpen the condemnation of Manasseh. ${ }^{3}$ The additions to the account of Manasseh's son Amon in $2 \mathrm{Kgs}$ 21:21-22 were most likely part of this redaction.

The third element which the redaction adopted from DtrH was the prophecyfulfillment schema, evident in $2 \mathrm{Kgs} 21: 12-14$ and 24:2. The condemnation by all the prophets supplied the necessary authority to back up the redaction's accusation that Manasseh had corrupted Judah and was therefore responsible for the exile. The exile itself could then be accommodated within a prophecyfulfillment schema. In this way DTR's criteria for interpreting the course of Israel's history were able to be preserved.

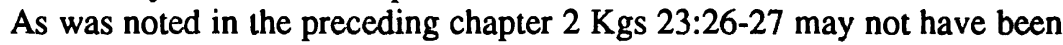
composed by the same hand responsible for $2 \mathrm{Kgs} 21: 10-14$ and 24:2. Nevertheless $2 \mathrm{Kgs}$ 23:26-27 does pursue the theme of Manasseh's guilt and seems to be a conscious summarizing of $2 \mathrm{Kgs} 21: 10-14$. It was probably added at the end of the account of Josiah's reform to reinforce the prophecy in 2 Kgs 21:10-14 that Yahweh would bring about the end of Judah because of the sins of Manasseh. $2 \mathrm{Kgs} 24: 3$ was added to $v 2$ to integrate $2 \mathrm{Kgs} \mathrm{23:26-27}$ into the prophecy-fulfillment schema. This is indicated by two things. First, the introductory $2 a k$ in $2 \mathrm{Kgs} 24: 3$ is designed to reinforce the preceding

\footnotetext{
${ }^{3}$ The details of this were given in the preceding chapter. Here we may note how the accusation of provoking Yahweh to anger ( $k \bar{x}^{c} a s$ in the hiphil) in $2 \mathrm{Kgs}$ 21:6 also borrows from DTR's judgment of Jeroboam and other northern kings. The accusation is not made against any other Davidic king. $1 \mathrm{Kgs} 11: 9$, which is probably a later addition, states that the Lord was very angry ('anap) with Solomon. For the way later redaction made use of DTR's work see also Vanoni, "Beobachtungen," 360-61.
} 
statement in $v 2$. Second, the reference to the removal of Judah from the sight of Yahweh occurs in $2 \mathrm{Kgs} 23: 27$ and 24:3.4

The other difficulty which this redaction had to contend with was the violent death of Josiah. This was in conflict with Huldah's promise that he would be gathered to his fathers ( $2 \mathrm{Kgs} 22: 20 \mathrm{aa})$. It also appeared to be in conflict with the deuteronomic notion that fidelity to Yahweh would be rewarded. However little could be done with Huldah's prophecy of a peaceful death for Josiah. There was no way a later redactor could incorporate its circumstances within a prophecy of salvation. It was therefore left intact.

Despite this difficulty the later redaction was able to do two things. First of all, it was able to make clear that Josiah's death was not part of the prophesied end of Judah. This is pointed out in the reworking of Huldah's prophecy in $2 \mathrm{Kgs} 22: 19,20 \mathrm{a}$. While $2 \mathrm{Kgs} 22: 19$ affirms that the people are to meet a violent fate, $v 20 \mathrm{a}$ separates Josiah from it by promising that he will be buried in peace. This promise could then be seen to be "fulfilled" by the report in $2 \mathrm{Kgs}$ 23:30 that Josiah was buried in his own tomb.

Secondly, the redaction was able to employ this separation between king and people in order to preserve the authority of the deuteronomic code. Thus the exile was interpreted in $2 \mathrm{Kgs} 22: 19$ as the working out of the deuteronomic requirement of retribution for sin. As pointed out in the preceding chapter the phrase "how I spoke" in v 19 refers to the book of the law which the king has heard. The death of Josiah before the exile was in its turn interpreted as a "reward" for his pious response to the law (cf. $2 \mathrm{Kgs} \mathrm{22:19).}$ Because he demonstrated such picty he was promised that he would be spared the trauma of the exile ( $v 20 \mathrm{a} \beta)$. The indirect reference to Josiah's untimely death in the phrase "your cycs shall not sce" was the only way the redaction could include it in the prophecy without implying that Yahweh had brought it about.

A number of other additions to DtrH which focus on the monarchy and employ the prophecy-fulfillment schema were probably also part of this stage

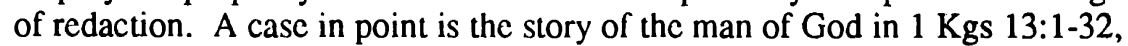
and its fulfillment in $2 \mathrm{Kgs} 23: 16-20$. As established in the preceding chapter $1 \mathrm{Kgs} 12: 31,32 \mathrm{~b}-33$ and 13:33a (plus wayyasob in $\vee 33 \mathrm{~b}$ ) were composed to facilitate the insertion of this story in DtrH. While the reworking of Huldah's prophecy in $2 \mathrm{Kgs} 22: 19,20 \mathrm{a} \beta$ did manage to accommodate the death of Josiah within a larger prophecy-fulfillment schema which also accounted for the exile, it did not embrace the reform at all. The insertion of 1 Kings 13 and $2 \mathrm{Kgs}$ 23:16-20 may well have been an attempt by the second stage of redaction to incorporate Josiah's reform within a prophecy-fulfillment schema. ${ }^{5}$ This

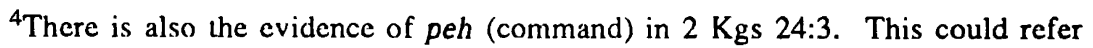
to the fulfillment of prophecy in $v 2$. However, if one adopts the LXX (Lucian) reading of ap (anger), it may refer to $2 \mathrm{Kgs} 23: 26$. $2 \mathrm{Kgs} 23: 27$ draws a parallel with the end of Isracl. This supports the proposal that Manasseh was cast by the redaction as a Judean "Jeroboam". The presence of the name formula in $v 27$ without "for ever" recalls $2 \mathrm{Kgs} 21: 4$.

${ }^{5}$ Robert L. Cohn has recently explored the literary function of 1 Kings 13 in its more immediate context of 1 Kings $12-14$ ("Literary Technique in the 
redaction borrowed from DTR's portrayal of Jeroboam for its indictment of Manasseh as the king responsible for the exile. The sharp contrast set up between Jeroboam and Josiah in 1 Kings 13 and $2 \mathrm{Kgs}$ 23:16-20 is in keeping with its concerns. ${ }^{6}$

The interest shown in Josiah's reform by this redaction suggests that it may also have been responsible for some, if not all, of the later additions to DTR's account of the reform in Judah. The texts identified in the analysis as additions are $2 \mathrm{Kgs} 23: 4 \mathrm{~b} \beta, 5 \mathrm{a} \beta \gamma, 8 \mathrm{~b}, 10,13-14$, and the references to the kings of Judah in vv 11-12. The effect of these additions was to transform DTR's chiastic structure into an alternating pattern in which a reform in the temple is followed by a reform of the high places. As noted in the analysis this pattern is discernible also in $2 \mathrm{Kgs} \mathrm{23:15-20.} \mathrm{It} \mathrm{is} \mathrm{reasonable} \mathrm{to} \mathrm{think}$ that the same redaction was responsible for creating this uniform pattern. However it is unlikely one can press the point to the extent of proposing that the additions all came from the one hand.?

A second prophecy-fulfillment schema which may have been added as part of this stage of later redaction is the one embracing the dynasty of Jehu in 2 $\mathrm{Kgs} 10: 30$ and 15:12. As with the preceding example this addition would be in keeping with a later revision of the history which extended the schema to cover areas which it was felt DTR had not adequately addressed.

Another case that merits consideration is the prophecy in $1 \mathrm{Kgs} 21: 19 \mathrm{~b}$ of a bloody death for king Ahab, with its fulfillment in $1 \mathrm{Kgs} 22: 38 \mathrm{~b}$. The narratives of the wars against Syria in $1 \mathrm{Kgs} 20: 1-43$ and 22:1-37 were judged to be part of this redaction. The violent death of Ahab told here is in conflict with the report in $1 \mathrm{Kgs} 22: 40$ of DtrH that he died peacefully. DTR's prophecy-fulfillment schema was directed against the northern dynasties rather than individual kings and so Ahab's peaceful death was not a problematic factor. One could imagine that this may have been regarded as somewhat

Jeroboam Narrative," ZAW 97 [1985] 23-35). He discerns a chiastic arrangement in the text: A)- Introductory exposition (11:26-28); $\mathrm{B}_{1}$ )- Prophecy of Ahijah (11:29-40); B2)- Fulfillment of prophecy (11:41-12:24); C)- Jeroboam's sin (12:25-33); D)- Man of God interlude (13:1-32); C')- Jeroboam's sin (13:33$34)$; $\left.\mathrm{B}_{1}{ }^{\prime}\right)$ - Prophecy of Ahijah (14:1-16); $\mathrm{B}_{2}{ }^{\prime}$ )- Fulfillment (in part) of prophecy $\left.(14: 17-18) ; \quad A^{\prime}\right)$ - Concluding exposition (14:19-20). 1 Kings 13 thus occupies the center of the structure. Cohn sees a parallel between the story of the man of God and Jeroboam. It is possible that the insertion of 1 Kings 13 was intended to draw the parallel suggested as well as supply the larger prophecy-fulfillment schema. The proposed structure is however not completely chiastic, as Cohn acknowledges (p. 25). If one removes the man of God story and attendant redaction ( $1 \mathrm{Kgs} 12: 31-32 \mathrm{~b}, 33 ; 13: 1-33 a)$ the arrangement of the narrative is more evidently sequential. This supports the proposal that the story is an insertion.

${ }^{6} 2 \mathrm{Kgs} 23: 15$ was in place before the addition of $2 \mathrm{Kgs} 23: 16-20$. The complex nature of the verse was discussed in the preceding chapter. Whether one opts for a shortened original form of the verse or the present text it would seem to be an addition to DtrH.

${ }^{7}$ For example, as observed in the analysis of Josiah's reform, the addition in $2 \mathrm{Kgs} 23: 5 \mathrm{a} \beta \gamma$ may reflect a concern by the post-exilic priesthood not to have the idolatrous priests associated with the temple, as they were in DtrH. 
unsatisfactory by later redaction. Ahab was the most notorious Israelite king in DtrH after Jeroboam. Hence Elijah's prophecy was revised by the addition of $1 \mathrm{Kgs} 21: 19 \mathrm{~b}$. The accompanying narratives in 1 Kings 20 and 22 then supplied a suitable account of the realization of the prophecy. ${ }^{8}$

What gives one pause however is the conclusion arrived at in the analysis that $1 \mathrm{Kgs} 21: 19 \mathrm{~b}$ could only have been added once $\mathrm{v} 20$-itself a later addition - was in place. The location of $1 \mathrm{Kgs} 21: 20$ in the prophecy suggests that it could have been part of the second stage of redaction. If so, then $1 \mathrm{Kgs}$ $21: 19 \mathrm{~b}$, with $1 \mathrm{Kgs} 20: 1-43$ and $22: 1-38 \mathrm{~b}$, could mark a subsequent development in this redaction's critique of Ahab. Alternatively it may reflect a later concern to show, via a prophecy-fulfillment schema, how Ahab came to a deservedly bad end.

The prophecy-fulfillment schema in $2 \mathrm{Kgs} 20: 12-19$ and 24:13-14 also invites some comment. Along with $2 \mathrm{Kgs} 18: 14-16$ the prophecy in 20:12-19 forms a negative frame around DTR's positive presentation of Hezekiah. ${ }^{9}$ What is significant about this addition is its negative attitude to the Davidic king. This strikes a chord with a number of other additions to the history which, when taken together, constitute a strain that is hostile to members of the Davidic dynasty. The first of these are the polemical additions to the account of Solomon in $1 \mathrm{Kgs} \mathrm{11:5,8.10}$ Next there is the negative reference

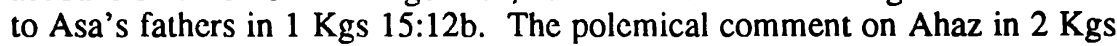
$16: 3 b$ (and $\vee 4 a b \beta$ ) also seems to reflect this more hostile attitude to the dynasty. It is interesting to observe that the abominable practices in $2 \mathrm{Kgs}$ $16: 3 \mathrm{~b}$ are also mentioned in the second stage's redaction of Manasseh, namely $2 \mathrm{Kgs} 21: 2 \mathrm{~b}$ and 11 . Finally there are the insertions referring to the kings of Judah in $2 \mathrm{Kgs} 23: 5,11,12$.

These additions may reflect a development within the second stage of redaction in which the decline and fall of Judah was traced beyond the evil Manasseh to the earlier Davidic kings. The effect of this was to give a picture of decline in the Davidic dynasty over a long period, culminating in the reign of Manasseh. $2 \mathrm{Kgs}$ 23:24-25 may have been part of this development within

${ }^{8} \mathrm{It}$ is widely recognized that the name of Ahab in $1 \mathrm{Kgs} 20: 2,13,14 ; 22: 20$ was added to these narratives as part of this redaction. Originally they referred to an anonymous king of Israel.

${ }^{9}$ Although it is not a prophetic text the analysis judged that $2 \mathrm{Kgs} 18: 14-16$ was added along with the prophecy and its fulfillment notice.

${ }^{10} 1 \mathrm{Kgs}$ 9:6-9 and 11:33 share this hostile attitude to the Davidic dynasty, but are formulated in the plural (following the MT for 11:33). This makes them sit rather awkwardly in their context. They may reflect a move within the second stage of redaction to a more general and at the same time sharper critique of the Davidic dynasty. They may also reflect a transition to the third stage of redaction which directed its attention to the people (see below). This is suggested by $1 \mathrm{Kgs} 9: 9$. It is possible that $1 \mathrm{Kgs} 11: 9-13$ was also added at the second stage. But the nomistic language in $v 11$ points more in the direction of the third stage of redaction. $1 \mathrm{Kgs} 9: 6-9 ; 11: 9-13$ and 11:33 show there was a certain amount of overlapping between the later stages of redaction. As noted in the analysis of $1 \mathrm{Kgs} 11: 29-39, \mathrm{v} 32$ was a later attempt to summarize what had become a complex prophecy. 
the second stage, reflecting a concern to exclude Josiah from this negative assessment of the dynasty. As v 25 states "before him there was no king like him". Nevertheless the focus on obedience to the law in both verses does create some overlap with the later nomistic redaction. ${ }^{11}$ Hence their provenance is somewhat uncertain.

There are four other examples where prophecies are applied to kings. There is Shemaiah's prophecy to Rehoboam in $1 \mathrm{Kgs} 12: 21-24$. There is the

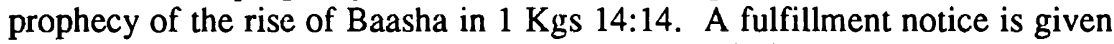
in $1 \mathrm{Kgs} \mathrm{16:34}$ in relation to Hiel of Bethel's building program at Jericho. There is also a fulfillment notice attached to Jeroboam II's recovery of territory

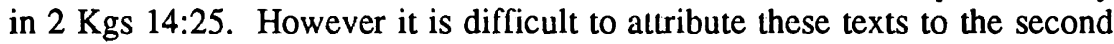
stage of redaction with any certainty.

The difficulty with $1 \mathrm{Kgs} 12: 21-24$ is that it appears to supply an apologia for Rehoboam's failure to regain the northern kingdom after the schism. The sense of the passage is that he refrained from doing so in obedience to the prophetic word of Shemaiah. This puts it at odds with the negative attitude to the Davidic dynasty in the texts just surveyed. It is therefore unlikely to have been part of the second stage of redaction.

The difficulty with the remaining three examples is that the schema is only partly represented. With the prophecy on Baasha there is no corresponding fulfillment notice. Admittedly the person responsible for its insertion was faced with a problem. The one place where such a notice could have been inserted, namcly the report of Baasha's assassination of Nadab in $1 \mathrm{Kgs}$ 15:29, was already occupied by DTR's fulfillment notice for Ahijah's prophecy. The third and fourth examples do not record the corresponding prophecy. The provenance of these examples must therefore be judged as uncertain.

A number of other additions to DTR's treatment of the northern kings are more likely candidates for inclusion in the second stage of redaction. They are $1 \mathrm{Kgs} 15: 30$; 16:7, 13, 19, 25b, 26b, 33b; 21:20, 25-26; 22:54b (RSV $22: 53 \mathrm{~b}) .{ }^{12}$ As with other texts identified with the redaction, all of these supply comments on the evil of the northern monarchy at points where there

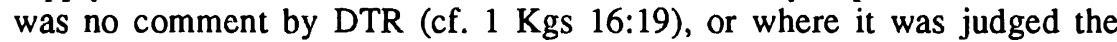
existing comment could do with some further elaboration (cf. $1 \mathrm{Kgs} 15: 30$; $16: 7,13,25 b, 26 b, 33 b ; 21: 20,25-26 ; 22: 54 b$ [RSV 22:53b]). In addition, except for $1 \mathrm{Kgs} 16: 19,25 \mathrm{~b}, 26 \mathrm{~b}$, they all have some association with the

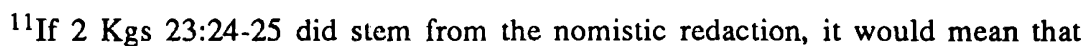
$2 \mathrm{Kgs} \mathrm{21:6a}$ was added to the reign of Manasseh by this redaction also. The list of accusations there seems to have been made with $2 \mathrm{Kgs} \mathrm{23:24} \mathrm{in} \mathrm{mind.} 2 \mathrm{Kgs}$ $21: 6 \mathrm{~b}$ could however be retained for the second stage. $1 \mathrm{Kgs}$ 15:5aba may reflect a similar concern to protect David from any association with the negative assessment of the dynasty, by emphasizing his fidelity.

${ }^{12}$ The analysis in chapter 6 pointed out that the comparison with Omri's predecessors in $1 \mathrm{Kgs} 16: 25 \mathrm{~b}$ and the accusation that he provoked Yahweh to anger in $v 26 \mathrm{~b}$ are additions. It is possible these were added at the same stage as the texts cited. The same accusation occurs also in $1 \mathrm{Kgs} 16: 13$. However they may also have been added to the formula by a later editor because Omri was the actual founder of the dynasty, not Ahab. The second stage of redaction seems to have been more concerned to develop DTR's anti-Ahab stance. 
prophecy-fulfillment schema. $1 \mathrm{Kgs} \mathrm{16:7}$ and 21:20 are prophetic texts. 1 Kgs 15:30 and 16:13 are appended to fulfillment notices. $1 \mathrm{Kgs} 16: 33 \mathrm{~b}$ was probably added to anticipate DTR's accusation against Ahab in Elijah's prophecy in 21:22. $1 \mathrm{Kgs} 21: 25-26$ for its part reinforces Elijah's condemnation of Ahab by briefly reviewing his evil ways for the reader. The connection is not so obvious with $1 \mathrm{Kgs} 22: 54 \mathrm{~b}$ (RSV 22:53b), but it may have been appended to the judgment formula for Ahaziah to bring it into line

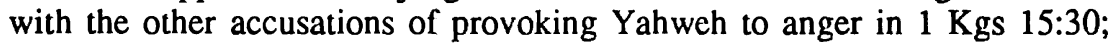
$16: 7,13,26 \mathrm{~b}, 33 \mathrm{~b}$.

A final passage which may be included in this consideration of the second stage of redaction is $1 \mathrm{Sam} 8: 7 \mathrm{aa}, 9-10$ (omit wécatâ in $v 9 \mathrm{a}$ ). This addition turns Samuel's diatribe in vv 11-17 against the sort of king desired by the people (cf. $v 5 b$ ) into a more gencral anti-monarchical statement by Yahweh against "the ways of the king who shall reign over them". This links it thematically with the other anti-monarchical texts surveyed. The analysis of 1 Samuel 8 established that the addition was made prior to vv $7 \mathrm{ab} \beta-8$, which betray a (later) anti-people attitude rather than an anti-monarchical one. Given that 1 Sam 8:7aa, 9-10* can be included in the second stage of dtr redaction it is significant that there is no evidence of its work before this point. This accords well with a redaction whose principal focus was the monarchy.

It is significant that although the second stage of redaction may be described as anti-monarchical it did not revoke the promise of an everlasting dynasty to David. This could have been due to a deep conviction about the validity of the dynastic promise in 2 Samuel 7 despite the way the redaction blamed the dynasty for the fall of Judah. It could also have been due to the uncertainty about the future of the dynasty which would have existed while

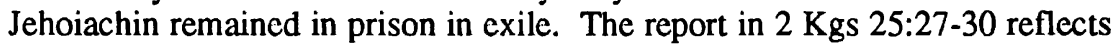
a genuine interest in the fate of the dynasty, but its tidings would not have resolved the uncertainty. Although Jehoiachin is given privileged treatment vv 29-30 indicate that he spent, or had to spend, the rest of his life in Babylon. It is tempting therefore to date the work of this second stage of redaction in the period of uncertainty created by the situation of Jehoiachin.

\section{Summary of the Second Stage of Redaction}

The results of this examination of the second stage of redaction may be summarized by listing the texts which can be identified with it in order of

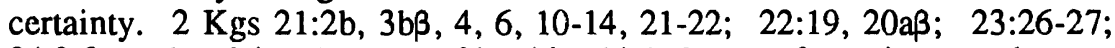
24:2-3 can be claimed as part of it with a high degree of certainty, as also can $1 \mathrm{Kgs} 12: 31,32 \mathrm{~b}-33 ; 13: 1-33 \mathrm{a}$ (with wayyāsob in $\mathrm{v} 33 \mathrm{~b}$ ) and $2 \mathrm{Kgs} 23:(15)$ 16-20. The prophecy-fulfillment schemas in $2 \mathrm{Kgs} 10: 30$ and 15:12, $2 \mathrm{Kgs}$ 20:12-19 (with 18:14-16) and 24:13-14 can be included with a reasonable degree of certainty. With these may be ranked $1 \mathrm{Kgs} 11: 5,8 ; 15: 12 \mathrm{~b} ; 2 \mathrm{Kgs}$ $16: 3 \mathrm{~b}(4 \mathrm{a} \beta \mathrm{b})$, the additions to Josiah's reform in $2 \mathrm{Kgs} 23:(4 \mathrm{~b} \beta, 5 \mathrm{a} \beta \gamma), 8 \mathrm{~b}$, $10,13-14$, as well as the phrases referring to the kings of Judah in $2 \mathrm{Kgs}$ $23: 11,12.13$ One may with some caution include also 1 Sam 8:7aa, 9-10 (omit wēatâ in v 9a); $1 \mathrm{Kgs} \mathrm{15:30;16:7,13,19,25b,26b,33b;21:20,} \mathrm{25-}$

${ }^{13}$ The other phrase referring to the kings of Judah appears in $2 \mathrm{Kgs} 23: 5 \mathrm{a} \beta$. 
26; 22:54 (RSV 22:53b). This less certain group of texts may have stemmed from the later activity of an emerging dtr school which continued the work of the second stage of redaction. It is in this sense that one may speak of their association with it. Finally there is a possibility that $1 \mathrm{Kgs} 21: 19 \mathrm{~b}$, with 20:1-43 and 22:1-38, may have been associated in some way with this stage of redaction. ${ }^{14} 1 \mathrm{Kgs}$ 9:6-9; 11:9-13, 33; 15:5aba; $2 \mathrm{Kgs} 23: 24-25$ are cases where there appears to be some overlap with the third stage of redaction. The provenance of $1 \mathrm{Kgs} 12: 21-24 ; 14: 14 ; 16: 34 ; 2 \mathrm{Kgs} 14: 25$ is uncertain.

\section{THE THIRD STAGE OF SUBSEQUENT DTR REDACTION}

The third identifiable stage of subsequent dtr redaction is the one which has been described throughout the analysis of the text as nomistic. ${ }^{15}$ This is a broadly conceived term to describe a redaction which was marked by three main characteristics; the use of nomistic language where appropriate; a shift of focus from the monarchy to the people; a different perception from DTR or the second stage of redaction of the role of the prophet. The review of DtrH carried out by this redaction was more extensive than the second stage. It was only after DTR's theology of history had been extended to cover the exile and the authority of the deuteronomic code had been preserved that such an extensive and reflective revision could be undertaken.

Nomistic language is most clearly evident in the following additions to DtrH: Deut 4:1-40; 30:1-20; Josh 1:7-9; 22:5; 23:1-16 (cf. v 6); Judg

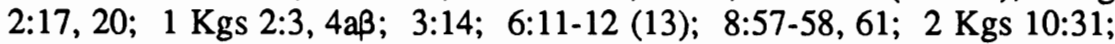
$17: 7-19 * ; 18: 6,12 ; 21: 8-9$ (with v 15); 22:13b, 16-17 (with v 18a). Some evidence of nomistic language was found in $1 \mathrm{Kgs} 11: 9-13 ; 18: 18 \mathrm{~b}$ and $2 \mathrm{Kgs}$ 23:24-25. Discrete nomistic phrases were also detected in Josh 7:11, 15, in 1 Kgs 9:4b; 11:33b $\beta 34 \mathrm{~b} \beta, 38 \mathrm{a} ; 14: 8 \mathrm{~b}$; and $2 \mathrm{Kgs} 23: 3 \mathrm{a}$. They look to have been added by this stage of redaction to give a nomistic touch to a number of texts in DtrH. This redaction was not however limited to using nomistic language and one cannot gain an accurate picture of its contribution by an exclusive application of the nomistic criterion. It had a considerably more flexible vocabulary. This is evident in particular in 1 Samuel 12 which, although it does not contain characteristic nomistic language, was found to be part of this stage of redaction.

The second characteristic of this stage of redaction is a marked shift in focus from the kings to the people. While the preceding list of texts shows

\footnotetext{
${ }^{14}$ For convenience the texts are listed here in order: 1 Sam 8:7aa, 9-10 (omit wécatá in $v$ 9a); $1 \mathrm{Kgs} 11: 5,8 ; 12: 31,32 \mathrm{~b}-33 ; 13: 1-33 \mathrm{a}$ (with wayyasob in $\mathrm{v}$ $33 \mathrm{~b})$; 15:12b, 30; 16:7, 13, 19, 25b, 26b, 33b; 20:1-43; 21:19b-20, 25-26; $22: 1-38 ; \quad 22: 54 \mathrm{~b}$ (RSV 22:53b); $2 \mathrm{Kgs} 10: 30 ; 15: 12 ; 16: 3 \mathrm{~b}(4 \mathrm{a} \beta \mathrm{b}) ; 18: 14-$ $16 ; 20: 12-19 ; 21: 2 b, 3 b \beta, 4,6,10-14,21-22 ; 22: 19,20 a \beta ; 23:(4 b \beta, 5 a \beta \gamma)$, $8 \mathrm{~b}, 10,11-12$ (i.e., the references to the kings of Judah), (15) 16-20, 26-27; 24:2-3, 13-14.

${ }^{15}$ The term is borrowed from the Smend school. It is used here to describe a stage of redaction rather than a particular redactor, as envisaged by the school. However in his later Entstehung und Geschichte Smend does speak of a nomistic "layer of redaction" (pp. 68, 115).
} 
there were some nomistic additions to passages dealing with kings, most of them seem designed to touch up existing dtr texts and none of them significantly alters the shape of DtrH. $1 \mathrm{Kgs} 6: 11-12$ is a more extensive nomistic comment directed to Solomon. However it only serves to anticipate and reinforce DTR's composition in $1 \mathrm{Kgs}$ 9:4-5. ${ }^{16}$ The same comment may be made of $1 \mathrm{Kgs} 11: 9-13$ in relation to Ahijah's prophecy in vv 31-39. The texts which do alter the shape of DtrH to a signficant degree are the dtr speeches addressed to the people in Deut 4:1-40; Deuteronomy 29-30; Joshua 23; 1 Samuel 12, and the der reflection on the fall of the north in $2 \mathrm{Kgs} \mathrm{17:7-}$ 19*. A number of differences between Deut 4:1-40 and Deuteronomy 29-30 were observed which cautions one against assigning them to the one hand. Likewise the analysis of Joshua 23; 1 Samuel 12 and 2 Kgs 17:7-19* suggested they were the work of highly sophisticated authors. Nevertheless the presence of nomistic language in particular in Deuteronomy 4; 30; Joshua 23 and $2 \mathrm{Kgs} \mathrm{17:7-19*}$, points firmly to their location in the nomistic stage of redaction.

An additional factor which supports the proposal that these passages stemmed from authors who belonged to a stage of redaction, or dtr school of thought, is the way they are located at strategic points in the structure of DtrH. This points to a well planned revision of the work of DTR. The effect of these strategically placed passages is to alter DtrH from being principally a story of Israel's leaders to a story of the people and their ultimate failure to obey the deuteronomic law, in particular the stipulations about the exclusive worship of Yahweh. Deuteronomy 4; 29-30 and Joshua 23 are located in the positive period of the conquest. Nevertheless their main aim is to stress the importance for the people of obedience to the law, and to warn of the dire consequences which would follow disobedience.

1 Samuel 12 in its turn assesses the critical transition to the period of the monarchy in the light of Israel's history so far. It recalls Israel's disobedience during the period of the judges and Yahweh's merciful forbearance (vv 9-11). ${ }^{17}$ The establishment of the monarchy is then interpreted as another example of this divine mercy in the face of further disobedience. 1 Sam 12:12 implies that the people's demand for a king was a rejection of Yahweh as their king. ${ }^{18}$ Certainly it was a great evil ( $v 17)$. The author goes on to make it abundantly clear that the successful outcome of the people's demand for a king does not excuse them from the demands of obedience. Indeed vv 14-15 and $\mathrm{v} 25$ indicate the establishment of the monarchy was a final merciful gesture by Yahweh. If this failed to elicit a satisfactory response then Israel and its king would be swept away.

${ }^{16} 1 \mathrm{Kgs} 6: 13$ is probably an addition to vv 11-12. Verse 14 may have been a literary seam accompanying the insertion of vv 11-12, since it duplicates $v 9 a$.

${ }^{17}$ As was seen in the exegetical discussion these verses may be linked up with .additions to Judg 2:11-19; 10:6b, 10-16, and 1 Sam 7:3-4. The accusation of forsaking Yahweh occurs in Judg 2:13; 10:6b, 10, 13; 1 Sam 12:10.

${ }^{18} 1$ Sam 12:12 shows similarity with 1 Sam $8: 7 \mathrm{a} \beta \mathrm{b} ; 10: 18-19$, although the theme of rejection is not as explicit as in these texts. 
$2 \mathrm{Kgs} \mathrm{17:7-19*}$ is located at a critical point in the period of the prophets and kings, namcly the northern exile. It looks back over Israel's history as one of hardened sin and continued disregard of Yahweh's warnings. Hence the destruction of the northern kingdom was fully justified. As was observed in the analysis of this passage the sins of which the north is accused were drawn as much from the story of Judah as from the northern kingdom. Hence the passage was no doubt intended as a comment on Judah as well. This was made quite explicit by the addition of a reference to Judah in $\mathrm{v} 13$ and by vv $18 \mathrm{~b}, 19$.

A number of other strategically less important additions to DtrH also pursue this theme of the people's disobedience to a merciful God and the consequences which flow from it. As well these additions share some of the linguistic features of the major passages. It is likely therefore that these stem from the same stage of redaction, and were designed to lend support to the argument of the major passages. The texts in question are the additions to Judg 2:11-3:6 in vv 12-13, 17, 20-21, 23a; 3:5-6;19 Judg 10:10-16;20 1 Sam $7: 3-4 ; 8: 7 a ß b$ (plus wēatâ in v 9a), 18;10:18-19; 1 Kgs 8:23* (plus 'ăšer in v 24a); 14:15; 14:22b, 24b; 2 Kgs $21: 8-9,15 ; 22: 13 b, 16-17,18 \mathrm{a}$; 24:20a.

A third characteristic of this stage of redaction is the way it changed the portrait of the prophet. Unlike DtrH prophets were no longer cast as figures who intervened to interpret the course of the Israel's history within a schema of prophecy and fulfillment. Instead they were seen by this redaction as essentially preachers of the law. Two of the major additions make this clear, namely 1 Sam 12:14-15, 23 and $2 \mathrm{Kgs} 17: 13 .{ }^{21}$ One can also see evidence of it in Judg 6:7-10. This text may therefore be included in the nomistic stage of redaction. The prophetic texts of $2 \mathrm{Kgs} 21: 15$ and 22:16-17 do not really change this picture. Even though these are additions to prophecies with a

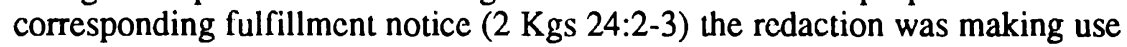
of a schema which had been constructed by the preceding stage of redaction.

\section{Summary of the Third Slage of Redaction}

We can sum up this survey of the third (nomistic) stage of redaction by listing the texts which can be confidently identified with it. Deut 4:1-40; 28:69-30:20 (RSV 29:1-30:20); Josh 1:7-9; 22:5; 23:1-16; Judg 2:12-13, 17, 20-21, 23a; 3:5-6; 6:7-10; 10:6b, 10-16; 1 Sam 7:3-4; 8:7aßb (plus wécatâ in v 9a), 18; 10:18-19; 12:1-25*; 1 Kgs 2:3,4aß; 3:14; 6:11-12, (13), 14; 8:23* (plus ’ăšer in v 24a), 57-58, 61; (11:9-13); 14:15; 14:22b, 23b, 24b; 18:18b; 2 Kgs 10:31; 17:7-19*; 18:6, 12; 21:8-9, 15; 22:13b,

${ }^{19}$ The discussion of Judg 2:11-3:6 found that Judg 2:22; 3:3-4 and 3:1-2 were independent later additions to the passage. Judg $2: 23 \mathrm{~b}$ is also a late appendage which clashes with $\vee 21$.

${ }^{20}$ In the discussion of Judg 10:6-16 a number of expansions in vv 6-9 were noted. Of these $v 6 \mathrm{~b}$ may stem from the nomistic redaction. The provenance of the expansions in $\vee 6 a$ and $v v 7-9$ is more uncertain.

${ }^{21}$ This feature is attributed by W. Dietrich to DtrN (Prophetie und Geschichte, 42 , n. 80). Judg 2:17 indicates the nomistic redaction also portrayed the judges as preachers of the law. As with the prophets the people did not listen to them. 
16-17, 18a; (23:24-25); 24:20a. As well as these one may include the nomistic phrases in Josh 7:11, 15; $1 \mathrm{Kgs} 9: 4 ; 11: 33 \mathrm{~b} \beta, 34 \mathrm{~b} \beta$, 38a; 14:8b; $2 \mathrm{Kgs} \mathrm{23:3a.22}$

Although it is an obvious addition to $1 \mathrm{Sam} 8: 7 \mathrm{a} \mathrm{b}, 1 \mathrm{Sam} 8: 8$ does share this redaction's concern about the people's apostasy. It may reflect a move by someone to locate the particular sin of Isracl's rejection of Yahweh's kingship more firmly within the nomistic redaction's understanding of Israel's history as one of repeated apostasy. Another addition which shares this redaction's focus on the people is 2 Sam 7:22-24. Its positive attitude to Israel may at first glance appear to be out of step with the critical tone of the nomistic redaction. Nevertheless the context requires the positive statement. It could therefore be the work of this redaction. ${ }^{23}$

\section{FURTHER DEVELOPMENTS}

The collection of seven prayers in $1 \mathrm{Kgs} 8: 31-51$, with the accompanying literary seam in vv $29 \mathrm{~b}-30$ and vv 52-54 (plus wayya'emod in v 55a), reflects the nomistic redaction's transfer of interest from the kings to the people. Nevertheless there are a couple of factors which suggest that the collection was inserted after the nomistic redaction. The first arises from $1 \mathrm{Kgs}$ 8:59-60 which was part of this insertion. The connection is clear from its reference to Solomon's supplication (cf. vv $30,33,38,45,47,49,52,54$ ), and its petition that Yahweh "maintain the cause of his servant, and the cause of his people Israel" (cf. 45, 49). What is significant in relation to the nomistic redaction however is that vv 59-60 are an insertion in vv 57-58,61. We have already seen that these verses are to be identified as part of the nomistic redaction. Hence $1 \mathrm{Kgs} 8: 59-60$, and therefore also 8:29b-54 (plus wayya emod in $v 55 a$ ), was a later addition to the text.

A second factor arises from the collection itself. The theme of the forgiveness of sins occurs in a number of the prayers, namely in $1 \mathrm{Kgs} 8: 34$, $36,39,50$. The verb used is sālah. This verb does not occur in any of the texts identified with the nomistic redaction. Moreover the nomistic redaction was dominated by the realization of Israel's disobedience and its consequences. The prayer for forgiveness and the emphasis on returning to Yahweh in vv 33, $35,47-48$ suggests a later stage when confidence in the restoration of Israel's relationship with Yahweh had replaced the nomistic redaction's tone of condemnation. ${ }^{24}$

22 Josh $11: 12 \mathrm{~b}, 15,20$ may have some association with this stage of redaction. Although the statements concern Joshua rather than the people, they do share the redaction's concern with obedience to the law.

${ }^{23} \mathrm{Cf}$. the sinilarities between 2 Sam 7:22-24 and Deut 4:7-8, 34-35.

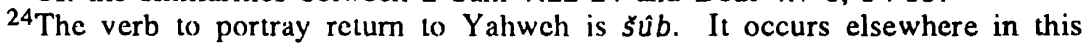
sense in Deut 4:30 and 30:2,8,10; 1 Sam 7:3; $2 \mathrm{Kgs} \mathrm{17:13.} \mathrm{Deut} \mathrm{4:29-31} \mathrm{and}$ 30:1-10 have been proposed as later additions to Deuteronomy 4 and 29-30 (cf. H. W. Wolff, "The Kerygma of the Deuteronomic Historical Work," 94-97). The difference between 1 Sam 7:3-4 and the prayers is that it has been inserted with the narrative sequence of the history in mind. The prayers on the other hand appear to address a number of typical situations, which do not have any direct 
The recognition that the collection of seven prayers was inserted in the wake of the nomistic redaction also provides a clue for dating this redaction. One gains the distinct impression that the seven prayers were collected together to meet the situation of the early post-exilic period. There is for example no evidence in the prayers that the temple was still in ruins. One can pray in it (cf.1 Kgs 8:31, 33) or towards it (cf. vv 35, 38, 44, 48). This indicates the early post-exilic period, after the construction of the second temple. The collection also contains prayers which address the situation both of those who were living in the land (cf. $1 \mathrm{Kgs} 8: 31-32,35-40$ ) and those who were still in exile (cf. vv 44-51). ${ }^{25}$ This also reflects the early post-exilic period when the people had regained some control of affairs in Judah but there were still many in exile. Finally, the collection is concerned to assure exiles that they have the same access to Yahweh as their brethren living in the land. The formula "toward this place (or housc)" is used for both groups (cf. vv 35, 38, 44, 48). It occurs also in the introduction in vv $29 \mathrm{~b}-30$. This would fit the early period of the second temple when those in Judah were anxious that their brethren living in the diaspora did not lose their allegiance to the Jerusalem temple.

In view of these considerations one may date the emergence of the nomistic redaction in the period between the completion of the second stage of redaction and the construction of the second temple, that is, from the late exilic to the early post-exilic period. Once it became fairly clear there was no hope of the Davidic dynasty being restored to the throne in the foreseeable future the dtr redaction of DtrH transferred its attention to the people and undertook an extensive revision of the history from this perspective. A cautionary note is however once again in order. As mentioned at the outset, the stages of redaction can be identified with reasonable certainty, but a precise demarcation of texts is difficult. There is a certain amount of overlapping which is indicative of the work of a developing dtr school.

Even though the subsequent redaction history of DtrH presented here is different to that of the Smend school, there is nevertheless a certain correlation between the three stages of redaction and the school's hypothesis of three exilic redactors; DtrH, DtrP, DtrN. The first stage of subsequent redaction was principally concerned to bring the history up to date (cf. DtrH). The second

relationship to the history. $2 \mathrm{Kgs} 17: 13$ uses the verb within the context of a review of Israel's history. Despite Yawheh's warning to return the people persisted in their sins. It therefore reflects the nomistic redaction's tone of condemnation. $2 \mathrm{Kgs}$ 23:25 describes Josiah as one who turned to the Lord. But it is not clear whether this is a statement about repentance-there is no accusation that Josiah sinned in 2 Kings $22-23$-or a way of emphasizing the quality of Josiah's fidelity to Yawheh.

${ }^{25} 1 \mathrm{Kgs}$ 8:33-34 refers to a defeat in battle, but after which the people can still come and pray in the temple ( $v 33 \mathrm{~b})$. It may therefore be of pre-exilic origin. Noth thought that the "land" in v 34 referred only to a portion of Israelite territory lost in a local conflict (Könige, 186). Würthwein accepts Noth's explanation of the sense of "land" but claims it reflects the situation of the second templc (1. Könige 1-16,98). $1 \mathrm{Kgs} 8: 44-45$ may also be of preexilic origin, but it now provides an introduction to vv 46-51, which clearly addresses the situation of exiles. 
stage made use of the prophecy-fulfillment schema in DtrH in order to interpret the exile in a way which was consistent with DTR's theology of history (cf. DtrP). A principal concern of the third stage of redaction was the people's disobedience to the deuteronomic law throughout the period of their occupation of the land (cf. DtrN). A further observation emerges from consideration of the work of the third stage of redaction. The nature and extent of the review carried out during this stage effectively produced a second edition of DtrH. I would identify this second edition with the DtrH of which M. Noth wrote. ${ }^{26}$

The notion of a dtr school may explain the provenance of a number of other additions to the history. These look to be dtr, but it is difficult to identify them with any of the three stages of redaction. There are the three passages in Deut 11:29-32; 27:1-26; Josh 8:30-35. Although these passages are clearly concerned with the proclamation of the law their common interest in Shechem (Mt. Ebal and Mt. Gerizim) sets them apart from the nomistic redaction. ${ }^{27}$ Next there are the later additions in Judg $2: 22,23 \mathrm{~b} ; 3: 1-$ 4. Three separate additions were identificd. The carliest was probably Judg $2: 22 ; 3: 3-4$, followed by $3: 1-2$. Judg $2: 23 \mathrm{~b}$ is an isolated addition. Judg $2: 22$ and 3:3-4 do contain nomistic language, which suggests some association with the nomistic redaction of Judg 2:11-3:6 (cf. Judg 2:12-13, 17, 20-21, 23a; 3:5-6) even though they were added after it. However the theme of Yahweh testing Israel is exclusive to this addition and to Judg 3:1-2. There is no clear evidence of dtr language in 3:1-2.

As well as these there are a number of texts in the books of Kings which may be classified as dtr but were unlikely to have been part of the second or third stage of redaction. $1 \mathrm{Kgs} 3: 2$ and $3 \mathrm{~b}$ attempt to counter the ideal picture of the early part of Solomon's reign by claiming that even then he and the people indulged in worship at the high places. There is therefore the same negative perception of Israel's history as the nomistic redaction. Nevertheless this redaction does not seem to have shown any particular interest in the high places. It is also difficult to be precise about the provenance of $1 \mathrm{Kgs} 8: 27$. It shares the general dtr antipathy toward any attempt to identify the temple as the dwelling place of the divinity. Beyond this there is little more that can be said.

Next there are the two texts which quote from Deuteronomy, namely $1 \mathrm{Kgs}$ 11:2a and $2 \mathrm{Kgs} 14: 6$. The focus on the law is in keeping with the nomistic redaction but the two examples are best judged as isolated insertions. There are

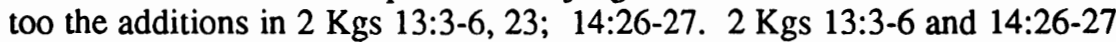
can be classified as dir in so far as they borrow clements from the period of the judges and apply it to Israclite kings. However this procedure is not discernible in any of the main stages of later redaction. The identification of 2 $\mathrm{Kgs} 13: 23$ is uncertain. Finally there is the material on the post-exilic situation in Samaria in $2 \mathrm{Kgs}$ 17:24-41. The analysis detected evidence that 2 Kgs 17:24-34a may stem from the post-exilic Judean priesthood which was

${ }^{26}$ According to F. M. Cross, the work of the exilic redactor (Dtr2) amounted to a second edition of DtrH (Canaanite Myth and Hebrew Epic, 287-89).

${ }^{27}$ They were identified as post-dtr by J. L'Hour, "L'Alliance de Sichem," 182. 
hostile to the priests of Samaria. $2 \mathrm{Kgs} \mathrm{17:34b-40} \mathrm{(41)} \mathrm{is} \mathrm{dependent} \mathrm{on} \mathrm{the}$ preceding passage, and so looks to be a later sermon against the north.

The notion of a dtr school also raises the question of the relationship between the subsequent redaction of $\mathrm{DtrH}$ and the dtr redaction of the Pentateuch and Jeremiah. This has generated considcrable activity in recent study. ${ }^{28}$ The topic is clearly too vast to engage here. However it is worth drawing attention to a number of passages identified in the analysis as additions to the history and which show some connection respectively with the Pentateuch and Jeremiah.

There are first of all a number of additions to Deuteronomy 1-3 and 31-34 which were found to have some association with the Pentateuch. ${ }^{29}$ Next there is the long section in Joshua 13-21 on the distribution of the land, and the story of the dispute over the altar at the frontier in Josh 22:7-34. Joshua 24 also seems to have connections with the Pentateuch. This is particularly evident in the long historical review in vv 2-13. ${ }^{30}$ What should be noted about these passages in relation to recent research on the Pentateuch is that they only supply evidence of the way later redaction sought to link DtrH more closely with the Pentatcuch. A major interest of this research is the way dtr language and thought influenced the composition of the Pentateuch. It was not the object of the study undertaken here to investigate this side of the relationship.

On the question of the relationship between the subsequent redaction of $\mathrm{DtrH}$ and the redaction of Jeremiah the passages cited here are only those to which attention was explicitly drawn during the course of analysis. There are no doubt other examples which could be added. A fairly clear connection with the book of Jeremiah can be seen in Deut 29:23-27 (RSV 29:24-28) and $1 \mathrm{Kgs}$ 9:6-9, which have a similar question and answer schema to Jer 22:8-9. The imaginative description of Yahweh's elimination of Israel in $1 \mathrm{Kgs} \mathrm{14:15} \mathrm{was}$ found to have echoes in the book of Jeremiah. Likewise the warning in $2 \mathrm{Kgs}$ 22:17 that Yahweh's anger would not be quenched, and the use of the word pair

${ }^{28}$ On the Pentateuch see the following studies. Frederick H. Cryer, "On the Relationship Between the Yahwistic and the Deuteronomistic Histories," BN 29 (1985) 48-74; R. Rendtorff, Das überlieferungsgeschichtliche Problem des Pentateuch (BZAW 147; Berlin: W. de Gruyter, 1977); M. Rose, Deuteronomist und Yahwist; Hans Heinrich Schmid, Der sogenannte Jahwist. Beobachtungen und Fragen zur Pentateuchforschung (Zürich: Theologischer Verlag, 1976). For a discussion of this literaturc sce Mayes, The Story of Israel, 139-49. On the dir redaction of Jeremiah there is the extensive study by W. Thiel, $D i e$ deuteronomistische Redaktion von Jeremia 1-24, and Die deuteronomistische Redaktion von Jeremia 26-45, as well as Robert P. Carroll's, From Chaos to Covenant. Uses of Prophecy in the Book of Jeremiah (London: SCM, 1981).

${ }^{29}$ The passages can only be listed here since it would unduly lengthen this study to reassemble the relevant evidence.

${ }^{30}$ Joshua 24 may have bcen associated with the other Shechem texts cited above, Deut 11:29-32; 27:1-26 and Josh 8:30-35. However some caution is advisable since Joshua's establishment of a covenant and statute conflicts with the other texts which understand that Joshua only proclaimed the Mosaic law. As noted in the discussion in chapter 4, it may be wiser to see it as an independent insertion. 
"desolation and curse" in 22:19, have parallels in Jeremiah. ${ }^{31}$ In addition to these there is the phrase "on every high hill and under every green tree" in 1

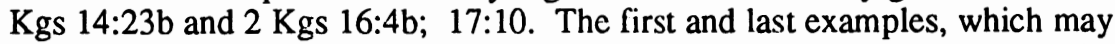
be assigned to the nomistic stage of redacton, are identical in wording to Jer $2: 20$. Finally it was noted that $2 \mathrm{Kgs} 21: 16$ and $24: 4$ find their closest parallels in Jer $2: 34 ; 7: 6 ; 19: 4 ; 22: 3,17 ; 26: 15 .^{32}$

To conclude this survey of later redaction a brief comment is in order on substantial blocks of material which were found to have been added to $\mathrm{DtrH}$, namely Judges $1 ; 13-21 ; 2$ Samuel $21-24$, and the Elisha cycle. The provenance of each of these is difficult to determine precisely, but it is generally agreed that they are of pre-exilic origin. They were probably added by editors who regarded them as preserving important traditions about the respective periods of Israel's history, namely the conquest, the judges, the reign of David and the period of the divided monarchy.

It is likely the insertion of Judges 1 took place before the history was broken up into separate books. This is indicated by the way the accompanying addition of Judg 2:6-9 was designed to incorporate Judges 1 into the overall story of the conquest and settlement, rather than the story of the judges. It is possible that Judges 17-21 was added along with Judges 1 as a frame around the material on the judges. This is suggested by the similarity of the two texts in Judg 1:1-2 and 20:18. In each case Isracl cnquires of Yahweh as to who should begin a battle, and in cach case Yahwch names Judah. One would expect that Judges 13-16 was in place by the time the frame was erected. Judg 2:1-5 was then added, presumably to condemn the coexistence of Israel with the inhabitants of the land as reported in Judges 1. 2 Samuel 21-24 is a heterogeneous collection of material inserted before the account of David's death. A similar phenomenon is observable in Deuteronomy 31-33 and in Joshua 13-21; 24, where material was added prior to the deaths of Moses and Joshua. The inclusion of 2 Samuel 21-24 may have been prompted by the way these additions had considerably enhanced the stories of the earlier great leaders of Israel. The Elisha material is varied and may have been incorporated in stages. The interest in this prophet was due not only to the number and variety of legends about him, but perhaps even more importantly, to his status as the successor of Elijah. ${ }^{33}$

${ }^{31}$ For $2 \mathrm{Kgs} 22: 17$ see Jer $4: 4 ; 7: 20 ; 17: 27$. For 2 Kgs 22:19 see Jer $25: 18 ; 42: 18 ; 44: 22 ; 49: 13$.

${ }^{32}$ As noted in chapter 7 , the addition of $2 \mathrm{Kgs} 25: 22-30$ was also associated with the redaction of the book of Jeremiah.

${ }^{33}$ The portrayal of Elisha as Elijah's successor is regarded as a later projection (cf. Jones, 1 and 2 Kings II, 381, and Würthwein, 1. Kön. 17-2. Kön. 25, 231$32,366)$. 


\section{CONCLUSION}

The reassessment has shown that DtrH was composed principally as a story of Israel's leaders, from Moses to DTR's contemporary Josiah. DTR constructed this history by organizing it into three distinct periods of leadership in Israel; the period of Israel under Moses and Joshua, the period of Israel from the judges to the monarchy, and the period of Israel under the prophets and kings. The story of Israel in each of these periods was composed with the aid of extensive sources. Key aspects of the theology of each of these sources were remolded to meet the requirements of DTR's own theological enterprise. The nature of DtrH as a combination of source and redaction shows that DTR was heir to a lively tradition of Israclite literary activity and thought. Nevertheless one may justifiably describe DtrH as a new and unique contribution to this tradition.

Within the period of Israel under Moses and Joshua DTR incorporated two major sources, the deutcronomic code and a pre-dtr account of the conquest of Cisjordan (West Jordan) territory under Joshua. Key elements of the deuteronomic code were employed by DTR as criteria to interpret the course of Israel's history. These were the requirement of complete fidelity to Yahweh and the requirement of centralized worship at the place which Yahweh would choose. In concert with these elements DTR also enhanced the authority of Moses as Israel's leader. For the deuteronomic code Moses was Israel's lawgiver. DTR added to this by portraying him as the one whom Yahweh had authorized to interpret the course of Isracl's history in accord with the code.

Thus, in the introduction to DtrH (Deutcronomy 1-3*) Moses interprets the failure of the exodus generation to conquer the land as punishment for their rebellion against Yahweh, who had established the deuteronomic covenant with them at Horeb. Moses' interpretation, made according to the deuteronomic schema of reward and retribution, is confirmed by the way the end of the exodus generation is framed by a schema of divine promise (Deut 1:35) and fulfillment (Deut 2:14). When Moses comes to proclaim that the emergent conquest generation is now the heir to the privileges and responsibilities contained in the code, its status as the normative program for Israel's life in the land has been secured. According to DTR the program was fully realized in the time of Solomon (1 Kgs 8:56). It was subsequently lost through Solomon's infidelity in the latter part of his reign (cf. $1 \mathrm{Kgs} 11: 1-7^{*}$ ). However the reform of Josiah had put Judah back on the road to recapturing the ideal enshrined in the code.

DTR incorporated the account of the conquest under the leadership of Joshua by portraying it as the completion of what Moses had begun in Transjordan with the emergent conquest generation (Deuteronomy 2-3*). Moses had assured this faithful gencration that Joshua would complete the task of conquest, and so it was. By drawing the conquest under Joshua within the 
compass of the Mosaic leadership DTR was able to give a strong sense of unity to the conquest theme, and to integrate it with the realization of the deuteronomic program. By the time of Joshua's death Israel had seen the completion of an important step in the realization of the deuteronomic program espoused by Moses (cf. Josh 21:43-45; 24:29-30). The full realization of the program in the time of Solomon was for DTR the fulfillment of all that Moses had said (1 Kgs 8:56).

For the period of Israel from the judges to the monarchy DTR made use of two major sources. The first was a document about the troubled times of the pre-monarchical period. This document was the product of successive deuteronomic redactions in northern Israel and Judah. The redactions portrayed Israel's history in the pre-monarchical period as a cycle of apostasy followed by divine deliverance. The outcome of this continued apostasy was Abimelech's attempt to establish a monarchy and its disastrous consequences (Judg 9:1-57). The second source was a late ninth century Prophetic Record, also from northern Israel, which began with the emergence of Samuel as a prophet and his anointing of Saul as king. This document then went on to record the story of Israel's monarchy from Saul to David and Solomon, and after the schism from Jeroboam through the northern dynasties to the reform of Jehu. Central to the theology of the Prophetic Record was the prophets' claim to have Yahweh's authority to designate kings and reject them for their transgressions.

What DTR did with the source which portrayed a cycle of Israelite apostasy followed by divine deliverance was to make it part of a larger linear sequence. This was accomplished by creating a two stage period of the judges of Israel. The first stage incorporated the source. Within the larger trajectory of DtrH the abortive attempt by Abimelech to become king served to raise the issue of monarchy. However Abimelech's failure and the return to the judges (Judg 10:1-5) implied that it could only be established in Yahweh's good time, and on his terms. The second stage then allowed DTR to present the successful establishment of the monarchy under the aegis of Samuel. It began like the first stage with a cycle of apostasy and deliverance, centered around the story of Jephthah. The Prophetic Record's account of the rise of Samuel in the face of the failed Elide priesthood was linked with this material to complete the second stage of the period of the judges. The success of Samuel as a leader heralded a resolution of the troubles of the judges period. The sense of an impending divine initiative in Israel's history was heightened by DTR's inclusion of the first part of the Ark Narrative at this point. The narrative reported the return of the ark to the land, and its lodging at Kiriath-jearim, after the disaster of the Philistine war. The second period of DtrH concluded with the transition to the monarchy.

DTR's understanding of the monarchy owed much to the Prophetic Record's claim that kings were under the authority of Yahweh's prophets. But DTR went beyond the scope of the Record to include the people under the umbrella of prophetic authority. The Record was concerned principally with the relationship between prophets and kings. DTR was however concerned with the larger issue of Israel's history in the land under different forms of leadership. The inclusion of the people was therefore an important component 
of DTR's presentation of the third period of the history, that of Israel under the prophets and kings.

DTR made use of three major sources to construct the period of Israel under the prophets and kings. There was first of all the Prophetic Record, which had already been employed for the emergence of the monarchy. The second source was a northern expansion of the Prophctic Record which had been composed shortly after the fall of the north. This document sought to complete the Record's story of the northern kings by providing a succinct account of the kings who ruled from Jehu to the northern exilc. According to the northern expansion it was Jeroboam's indiscriminate consecration of priests which corrupted the kingdom and led to its downfall. The third source was a parallel Southern Document which charted the course of the Davidic dynasty from the schism in the days of Rehoboam to Judah's deliverance from the Assyrian threat during the reign of Hezckiah. According to the Southern Document, the troubles experienced by Judah during this period were due principally to the failure of the Davidic kings to terminate the people's practice of worshipping on the high places. The high places were eventually removed by Hezekiah, who was rewarded with the successful resolution of the Assyrian crisis. As with the northern expansion, rcligious conduct was seen to have political repercussions.

DTR incorporated the Prophetic Record into the third pcriod of DtrH in the following manner. First, the Record's concern to show the prophetic guidance of Israel's history from the anointing of Saul to the anointing of Jehu was developed by DTR into a prophecy-fulfillment schema which embraced the whole of the third period of the history. In addition this schema was linked with the paradigmatic discourse of Moses by showing that the construction of the temple under Solomon was not only the fulfillment of Nathan's prophecy to David (1 Kgs 8:20), but also the fulfillment of what Moses himself had said (1 Kgs 8:56). Sccond, the prophetic speeches in the Record were redacted by DTR to portray the prophets as Mosaic like figures who interpreted the course of the monarchy according to the three deutcronomic criteria; fidelity to the exclusive worship of Yahweh, fidelity to centralized worship in the temple, and fidclity to the word of Yahwch's authorized lcaders, the prophets. In keeping with deuteronomic theology, kings who were judged by the prophets to be faithful according to these criteria were rewarded, kings who were judged unfaithful were punished. The prophecy-fulfillment schema served to verify the prophetic word in each case.

The northern expansion's focus on the transgression of Jeroboam was adopted by DTR, but with a signilicant shilt. In accord with the three criteria Jeroboam's sin was recast as onc of infidclity to the exclusive, centralized worship of Yahweh. He had also repudiated the word of Yahweh's prophet (Ahijah of Shiloh). Hence he had forfeited any reward of a lasting dynasty. The subsequent kings of northern Israel walked in the way of Jeroboam and completely corrupted the kingdom. So all of them stood under the condemnation of Ahijah and the subsequent prophets. The end of the northern kingdom could therefore be proclaimed as the fulfillment of the word of "all his servants the prophets" (2 Kgs 17:23a). By contrast, David had proved his fidelity to Yahwch and was rewarded with the promise of an enduring dynasty. 
The continuity of his dynasty despite the schism showed that not even the infidelity of Solomon could erase the promise, as the prophet Ahijah testified (1 Kgs 11:34, 36).

The principal issue of the Southern Document, centralized worship versus worship at the high places, was close to the concerns of DTR. This aspect of the Document could therefore be included in DtrH with a minimum of adjustment. There was a need however to integrate the Southern Document's presentation of the Davidic kings with the three deuteronomic criteria, and to demonstrate the validity of the schema of reward and retribution when applied to these kings. The Document's negative judgment of a number of the Davidic kings was handled in the same way as the infidelity of Solomon. That is, the continuity of the dynasty despite these infidelities was attributed to the reward gained by Yahweh's faithful servant David (cf. 1 Kgs 11:36; 15:4; 2 $\mathrm{Kgs} 8: 19$ ). The success of Hezekiah in the Assyrian crisis was integrated into the larger conceptual plan of the history by means of the same four-part pattern employed by DTR to portray David as the model king. At a critical point in his reign Hezekiah like David had turned to the prophet, in this case Isaiah. His fidelity to the prophet/king relationship was rewarded with a prophecy which was fulfilled in the withdrawal of the Assyrians.

There does not appear to be any source material in the account of Josiah. DTR probably composed it on the basis of information that was available. Two things in particular are significant about this account. On the one hand there is the parallel drawn between Josiah, Hezekiah and David by DTR's use of the four-part pattern. For DTR therefore Josiah was a model king like David and Hezekiah. On the other hand there are the unique events of the discovery of the book of the law, the king and people's commitment to the book in the covenant ceremony, the success of the reform, and the celebration of Passover. These unique events show that DTR believed the reign of Josiah was the beginning of a ncw era for Judah. The discovery of the book of the law and Judah's commitment to it created a situation which was analogous to the one at the time of Moses. Judah could begin to recapture the deuteronomic ideal which had been lost under Solomon.

Despite its new and unique contribution to Israelite literary activity and thought, DtrH was still of course a product of its time. DTR's whole theological enterprise, as well as the status of the book of Deuteronomy, was threatened by the historical events that followed the completion of the history. Josiah met a violent death and soon after Judah entered the throes of the exilic period. The analysis has shown however that $\mathrm{DtrH}$ was retrieved for posterity by subsequent redaction which sought to account for the disaster of the exile by adopting and reworking aspects of DTR's theology.

An initial but limited response was made by a redactor of the early exilic period who provided a fairly straightforward account of the fortunes of the last four kings of Judah, and borrowed the judgment formula from DtrH to make a brief theological assessment of each king. A second stage of redaction then confronted the problem of the exile morc directly by applying elements of DTR's critique of the northern kings to the Davidic dynasty. Manasseh was portrayed, like Jeroboam in DtrH, as a king who made the people (Judah) sin. The deuteronomic requirement of punishment for $\sin$ was then able to be 
identified with the exile of Judah. In keeping with DTR's theology this stage of redaction employed a prophecy-fulfillment schema to lend authority to the interpretation (2 Kgs 21:10-14; 24:2). DTR's version of Huldah's prophecy was also reworked to preserve Josiah from any blame for the exile of Judah (cf. $2 \mathrm{Kgs} 22: 19,20 \mathrm{a} \beta)$.

Once it had become clear there was no foreseeable hope of a restoration of the monarchy a third, nomistic stage of redaction transferred its attention to the people. This led to an extensive review of the whole history. The text of DtrH was used as a basis for pointing at appropriate points to the people's disobedience to the stipulations of the deuteronomic law. To lend authority to this revision the prophets were recast as Yahweh's authorized preachers of the law, rather than as figures who intervened with the kings to interpret the course of Israel's history, as in DtrH. The work of this redaction amounted to a second edition of DtrH, one which was more a history of the disobedience of Israel than of a history of Israel's leaders.

One can see from the work of these two later stages of redaction that a legacy of DTR's contribution was the emergence of a dtr school of literary activity and thought. By adopting and reworking aspects of DTR's theology this school was able to retrieve the history for posterity, despite the problems created by the violent death of Josiah and the disaster of the exile. Furthermore it was able to preserve the authority of the deuteronomic code beyond the reform of Josiah. As one would expect, the activity of this school gradually spread beyond the confines of DtrH. Its work can also be seen in the dtr redaction of the prophets-in particular Jeremiah-and the Pentateuch. 


\section{BIBLIOGRAPHY OF WORKS CITED}

Ackroyd, Peter R. Exile and Restoration. A Study of Hebrew Thought of the Sixth Century BC. London: SCM, 1968.

. The First Book of Samuel. The Cambridge Bible Commentary. Cambridge: University Press, 1971.

Alfrink, B. "L’Expression కăkab 'im 'ăbôtãyw." OTS 2 (1943) 106-118. "L'Expression ne’ěsap 'el-`ammāyw." OTS 5 (1948) 118-31.

Alt, Albrecht. "Judas Gaue unter Josia." In Kleine Schriften zur Geschichte des Volkes Israel, vol 2, 276-88. Munich: C. H. Beck'sche Verlagsbuchhandlung, 1953.

Andreasen, Niels-Erik A. "The Role of the Queen Mother in Israelite Society." CBQ 45 (1983) 179-94.

Auld, A. Graeme. Joshua, Moses and the Land. Tetrateuch-PentateuchHexateuch in a Generation since 1938. Edinburgh: T. \& T. Clark, 1980.

Baena, Gustavo. "El vocabulario de II Reyes 17, 7-23." EstBib 32 (1973) $357-84$.

"Caracter literario de II Reyes 17, 7-23." EstBib 33 (1974) 5-29.

Baltzer, Klaus. The Covenant Formulary in Old Testament, Jewish, and Early Christian Writings. Philadelphia: Fortress, 1971.

Barrick, W. Boyd. "On the Removal of the 'High Places' in 1-2 Kings." Bib 55 (1974) 257-59.

Barthélemy, Dominique. Critique textuelle de l'Ancien Testament. Vol 1, Josué, Juges, Ruth, Samuel, Rois, Chroniques, Esdras, Néhémie, Esther. OBO/1. Fribourg: Éditions Universitaires, 1982.

Begg, Christopher, T. "The Significance of the Numeruswechsel in Deuteronomy. The 'Pre-history' of the Question." ETL 55 (1979) 11624.

"The Literary Criticism of Deut 4,1-40. Contributions to a Continuing Discussion." ETL 66 (1980) 10-55.

"Unifying Factors in 2 Kings 1:2-17a." JSOT 32 (1985) 75-86.

"2 Kings 20:12-19 as an Element of the Deuteronomistic History." CBQ 48 (1986) 27-38.

. "The Function of Josh 7,1-8,29 in the Deutcronomistic History." Bib 67 (1986) 320-33.

Benzinger, Immanuel. Die Bücher der Könige. Kurzer Hand-Commentar zum Alten Testament 9. Freiburg-im-Breisgau: J. C. B. Mohr, 1899.

Bergman, J. Ringgren, H. Dommerhausen, W. "KOHEN köhęn." TWAT 4 (1984) 62-79. 
Bickert, Rainer. "Die Geschichte und das Handeln Jahwes: Zur Eigenart einer deuteronomistischen Offenbarungsauffassung in den Samuelbüchern." In Textgemäss: Aufsätze und Beiträge zur Hermeneutik des Alten Testaments. Festschrift E. Würth-wein, edited by A. H. J. Gunneweg and O. Kaiser, 9-27. Göttingen: Vandenhoeck \& Ruprecht, 1979.

. "Die List Joabs und der Sinneswandel Davids; Eine dtr bearbeitete Einschaltung in die Thronfolgeerzählung: 2 Sam xiv 2-22." In Studies in the Historical Books of the Old Testament, 30-51. VTSup 30. Leiden: Brill, 1979.

Bin-Nun, Shoshana R. "Formulas from Royal Records of Israel and of Judah." $V T 18$ (1968) 414-32.

Birch, Bruce C. "The Development of the Tradition on the Anointing of Saul in I Sam 9:1-10:16." JBL 80 (1971) 55-68.

. The Rise of the Israelite Monarchy: the Growth and Development of 1 Samuel 7-15. SBLDS 27. Missoula: Scholars, 1976.

Boecker, Hans Jochen. Die Beurteilung der Anfänge des Königtums in den deuteronomistischen Abschnitten des I. Samuelbuches. Ein Beitrag zum Problem des "deuteronomistischen Geschichtswerks". WMANT 31. Neukirchen-Vluyn: Neukirchener Verlag, 1969.

Bohlen, Reinhold. Der Fall Nabot: Form, Hintergrund und Werdegang einer alttestamentlichen Erzählung (1 Kön 21). Trierer Theologische Studien. Trier: Paulinus, 1978.

Boling, Robert G. Judges. A New Translation with Introduction and Commentary. AB 6a. Garden City: Doubleday, 1975.

Boling, Robert G. and Wright, G. Ernest. Joshua. A New Translation with Introduction and Commentary. AB 6. Garden City: Doubleday, 1982.

Braulik, Georg. "Spuren einer Neubearbeitung des deuteronomistischen Geschichtswerkes in I Kön 8:52-53, 59-60." Bib 52 (1971) 20-33. . Die Mittel deuteronomischer Rhetorik. Erhoben aus Deuteronomium 4, 1-40. AnBib 68. Rome: Biblical Institute, 1978.

"Literarkritik und archăologische Stratigraphie. Zur S. Mittmann's Analyse von Deuteronomium 4, 1-40." Bib 59 (1978) 35183.

"Zur deuteronomistischen Konzeption von Freiheit und Frieden." Congress Volume Salamanca VTSup 36 (1985) 29-39.

Brekelmans, C. H. W. "Die sogenannten deuteronomistischen Elemente in Genesis bis Numeri. Ein Beitrag zur Vorgeschichte des Deuteronomiums." Volume du Congrès Genève 1965, VTSup 15 (1966) 90-96.

"Solomon at Gibeon." In Von Kanaan bis Kerala. Festschrift für Prof. Mag. Dr. Dr. J. P. M. van der Ploeg O.P., 53-59. AOAT 211. Neukirchen: Neukirchener Verlag, 1982.

Briend, Jacques. "Jéroboam II, saveur d'Israel." Mélanges bibliques et orientaux en l'honneur de M. Henri Cazelles, 41-49. AOAT 212. Neukirchen: Neukirchener Verlag, 1981. 
Brueggemann, Walter. "The Kerygma of the Deuteronomistic Historian." Int 22 (1968) 387-402.

Buis, Pierre. Le Deutéronome. VS; Ancien Testament 4. Paris: Beauchesne, 1969.

Burney, C. F. Notes on the Hebrew Text of the Book of Kings. Oxford: Clarendon Press, 1903.

Busink, Th. A. Der Tempel von Jerusalem, von Salomo bis Herodes. Eine archäologisch-historische Studie unter Berücksichtigung des westsemitischen Tempelbaus. 2 vols. Leiden: Brill, 1970.

Campbell, Antony F. The Ark Narrative (1 Sam 4-6; 2 Sam 6): A Formcritical and Traditio-historical Study. SBLDS 16. Missoula: Scholars, 1975.

"Yahweh and the Ark: A Case Study in Narrative." JBL 98 (1979) 31-43.

. Of Prophets and Kings. A Late Ninth-Century Document (1 Samuel 1-2 Kings 10). CBQMS 17. Washington: The Catholic Biblical Association of America, 1986.

Carlson, R. A. David, the chosen King: A Traditio-Historical Approach to the Second Book of Samuel. Stockholm: Almqvist \& Wiksell, 1964.

Carroll, Robert P. From Chaos to Covenant. Uses of Prophecy in the Book of Jeremiah. London: SCM, 1981.

Cazelles, Henri. "Passages in the Singular within Discourses in the Plural of Dt 1-4." CBQ 29 (1967) 207-19.

Childs, Brevard S. Isaiah and the Assyrian Crisis. SBT 3. London: SCM, 1967.

Claburn, W. E. “The Fiscal Basis of Josiah's Reform.” JBL 92 (1973) 11-22.

Clements, Ronald, E. "The Deuteronomic Interpretation of the Founding of the Monarchy in 1 Sam VIII." VT 24 (1974) 398-410.

Isaiah and the Deliverance of Jerusalem. JSOTSup 13. Sheffield: JSOT, 1980.

Clifford, Richard. Deuteronomy. Old Testament Message. Wilmington: M. Glazier, 1982.

Cody, Aelred. A History of Old Testament Priesthood. AnBib 35. Rome: Biblical Institute, 1965.

Cogan, Mordechai. "Israel in Exile-The View of a Josianic Historian." JBL 97 (1978) 40-44.

Cogan, Morton. Imperialism and Religion: Assyria, Judah and Israel in the Eighth and Seventh Centuries B. C. E. SBLMS 19. Missoula: Scholars, 1974.

Cohn, Robert L. "Literary Technique in the Jeroboam Narrative." ZAW 97 (1985) 23-35.

. "Convention and Creativity in the Book of Kings: The Case of the Dying Monarch." CBQ 47 (1985) 603-16.

Conroy, Charles. Absalom Absalom! Narrative and Language in 2 Sam 1320. AnBib 81. Rome: Biblical Institute, 1978.

Coppens, Joseph. "La réforme de Josias." ETL 4 (1928) 1-20. 
Cornill, Carl Heinrich. Einleitung in die kanonischen Bücher des Alten Testaments. Tübingen: J. C. B. Mohr-Paul Siebeck, 1908.

Cortese, Enzo. "Lo schema deuteronomistico per i re di Giuda e d'Israele." Bib 56 (1975) 37-52.

Cross, Frank Moore. "The Structure of the Deuteronomic History." In Perspectives in Jewish Learning, 9-24. Annual of the College of Jewish Studies, 3. Chicago, 1968.

. Canaanite Myth and Hebrew Epic. Cambridge: Harvard University, 1973.

Crüsemann, Frank. Der Widerstand gegen das Königtum. Die antiköniglichen Texte des Alten Testamentes und der Kampf um den frühen Israelitischen Staat. WMANT 49. Neukirchen-Vluyn: Neukirchener Verlag, 1978.

Cryer, Frederick H. "On the Relationship Between the Yahwistic and the Deuteronomistic Histories." BN 29 (1985) 48-74.

Debus, Jörg. Die Sünde Jerobeams. FRLANT 93. Göttingen: Vandenhoeck \& Ruprecht, 1967.

Delcor, Matthias. "Les cultes étrangers en Israël au moment de la réforme de Josias d'après $2 \mathrm{R} 23$. Étude de religions sémitique comparées." In Mélanges bibliques et orientaux en l'honneur de M. Henri Cazelles, 91-123. AOAT 212. Neukirchen-Vluyn: Neukirchener Verlag, 1981.

. "Réflexions sur la Paque de Josias d'après 2 Rois 23:21-23." Henoch 4 (1982) 205-19.

Delekat, Lienhard. "Tendenz und Theologie der David-Solomon-Erzählung." In Das ferne und nahe Wort, 26-36. BZAW 105. Berlin: de Gruyter, 1967.

DeVries, Simon J. "Calendar." IDB 1 (1962) 483-88.

. 1 Kings. Word Biblical Commentary 12. Waco: Word Books, 1985.

Dietrich, Walter. Prophetie und Geschichte. FRLANT 108. Göttingen: Vandenhoeck \& Ruprecht, 1972.

" "David in Überlieferung und Geschichte." VF 22 (1977) 44-64. "Josia und das Gesetzbuch (2 Reg. XXII)." VT 27 (1977) 13-35.

Dhorme, Paul. Les livres de Samuel. EBib. Paris: Gabalda, 1910.

Dozeman, Thomas B. "The Way of the Man of God from Judah: True and False Prophecy in the Pre-Deuteronomic Legend of 1 Kings 13." $C B Q 44$ (1982) 379-93.

Driver, Samuel R. Notes on the Hebrew Text and the Topography of the Books of Samuel, with an Introduction on Hebrew Palaeography and the ancient Versions and Facsimiles of Inscriptions and Maps. 2d ed. rev. and enl. Oxford: Clarendon, 1913.

Dumbrell, W. J. "'In those days there was no king in Israel; every man did what was right in his own eyes.' The Purpose of the Book of Judges Reconsidered." JSOT 25 (1983) 23-33.

Edelman, Diana. "Saul's rescue of Jabesh-Gilead (1Sam 11:1-11): Sorting Story from History." ZAW 96 (1984) 195-209. 
Eissfeldt, Otto. Die Komposition der Samuelisbücher. Leipzig: Heinrichs, 1931.

The Old Testament. An Introduction. Oxford: Blackwell, 1965.

Engnell, Ivan. "The Pentateuch." In Critical Essays on The Old Testament, 50-67. London: SPCK, 1970.

Eslinger, Lyle M. Kingship of God in Crisis. A close Reading of 1 Samuel 1-12. Bible and Literature Series, 10. Sheffield: Almond JSOT, 1985.

Flanagan, J. W. "Court History or Succession Document? A Study of 2 Samuel 9-20 and 1 Kings 1-2." JBL 91 (1972) 172-81.

Floss, Johannes Peter. Yahwe Dienen-Göttern Dienen. Terminologische, literarische und semantische Untersuchung einer theologischen Aussage zum Gottesverhältnis im Alten Testament. BBB 45. Bonn: Peter Hanstein, 1975.

Fohrer, Georg. "Der Vertrag zwischen König und Volk in Israel." ZAW 71 (1959) 1-22.

- Introduction to the Old Testament. London: SPCK, 1968.

Foresti, Fabrizio. The Rejection of Saul in the Perspective of The Deuteronomistic School. A Study of $1 \mathrm{Sm} 15$ and Related Texts. Studia Theologica-Teresianum 5. Rome: Edizioni del Teresianum, 1984.

Fretheim, Terence E. Deuteronomic History. Interpreting Biblical Texts. Nashville: Abingdon Press, 1983.

Fricke, Klaus Dietrich. Das zweite Buch von den Königen. Die Botschaft des Alten Testaments, 12/2. Stuttgart: Calwer, 1972.

Friedman, Richard Elliott. The Exile and Biblical Narrative. The Formation of the Deuteronomistic and Priestly Works. HSM 22. Chico: Scholars, 1981.

"From Egypt to Egypt: Dtr1 and Dtr2." In Traditions in Transformation: Turning Points in Biblical Faith, ed. B. Halpern and J. D. Levenson, 167-92. Winona Lake: Eisenbrauns, 1981.

Fritz, Volkmar. "Die Deutungen des Konnigtums Sauls in den Überlieferungen von seiner Entstehung I Sam 9-11." ZAW 88 (1976) 346-62.

. "Abimelech und Sichem in JDC. IX." VT 32 (1982) 129-44.

Frost, Stanley Bruce. "The Death of Josiah: A Conspiracy of Silence." JBL 87 (1968) 369-82.

Fuss, Werner. Die deuteronomistische Pentateuchredaktion in Exodus 3-17. BZAW 126. Berlin: W. de Gruyter, 1972.

Gamper, Arnold. "Die heilsgeschichtliche Bedeutung des Salomonischen Tempelweihgebets." ZKT 85 (1963) 55-61.

Garbini, Giovanni. “'Narrativa della successione' o 'storia dei re'?” Henoch 1 (1979) 19-41.

"Le fonti citate nel 'Libro dei Re' a proposito degli 'Atti di Salomone', degli 'Annali dei re di Giuda' e degli 'Annali dei re d'Israele'." Henoch 3 (1981) 26-46.

García López, Felix. "Le roi d'Israël: Dt 17,14-20." In Das Deuteronomium: Entstehung, Gestalt und Botschaft, edited by $\mathrm{N}$. Lohfink, 277-97. BETL 68. Leuven: University Press, 1985. 
Gerbrandt, Gerald Eddie. Kingship According to the Deuteronomistic History. SBLDS 87. Atlanta: Scholars, 1986.

Gese, Hartmut. "Die ältere Simsonüberlieferung (Richter c. 14-15)." ZTK 82 (1985) 261-80.

Giblin, Charles H. "Structural Patterns in Joshua 24,1-25." CBQ 26 (1964) 50-69.

Gooding, D. W. "Ahab According to the Septuagint." ZAW 76 (1964) 26979.

. "The Septuagint's Rival Versions of Jeroboam's Rise to Power." VT 17 (1967) 173-89.

Gordon, R. P. "The Second Septuagint Account of Jeroboam: History or Midrash?" VT 25 (1975) 368-93.

Görg, Manfred. Gott-König Reden in Israel und Ägypten. BWANT 105. Stuttgart: W. Kohlhammer, 1975.

. "Ein 'Machtzeichen' Davids 1 Könige XI:36." VT 35 (1985) 36367.

Gray, John. Joshua, Judges and Ruth. NCB. Rev ed. London: Oliphants, 1977. I \& II Kings. OTL. 3d ed. London: SCM, 1980.

Green, Alberto R. "Regnal Formulas in the Hebrew and Greek Texts of the Books of Kings." JNES 42 (1983) 167-80.

Gressmann, Hugo. "Josia und das Deuteronomium." ZAW 42 (1924) 313-37. Gunn, David M. The Story of King David. Genre and Interpretation. JSOTSup 6. Sheffield: JSOT Press, 1978.

Gunneweg, Antonius H. J. Leviten und Priester. Hauptlinien der Traditionsbildung und Geschichte des israelitisch-jüdischen Kultpersonals. FRLANT 89. Gơttingen: Vandenhoeck \& Ruprecht, 1965.

Halpern, Baruch. "The Centralization Formula in Deuteronomy." VT 31 (1981) 20-38.

. The Constitution of the Monarchy in Israel. HSM 25. Chico: Scholars, 1981.

Hamlin, E. John. Joshua. Inheriting the Land. International Theological Commentary. Grand Rapids: Eerdmans, 1983.

Hanson, Paul D. "The Song of Heshbon and David's Nir." HTR 61 (1968) 304-16.

Hentschel, Georg. Die Elijaerzählungen: Zum Verhältnis von historischem Geschehen und geschichtlicher Aufsätze. Erfurter Theologische Studien 33. Leipzig: St. Benno, 1977.

1 Könige. Die Neue Echter Bibel Altes Testament 10. Würzburg: Echter, 1984.

2 Könige. Die Neue Echter Bibel Altes Testament 11. Würzburg: Echter, 1985.

Hertzberg, Hans Wilhelm. I \& II Samuel. OTL. London: SCM, 1964.

Hobbs, T. R. 2 Kings. Word Biblical Commentary 13. Waco: Word Books, 1985.

Hoffmann, Georg. "Kleinigkeiten." ZAW 2 (1882) 175.

Hoffmann, Hans-Detlef. Reform und Reformen. ATANT 66. Zürich: Theologischer Verlag, 1980. 
Holladay, William L. "On Every High Hill and Under Every Green Tree." VT 11 (1961) 170-76.

Hollenstein, Helmut. "Literarkritische Erwägungen zum Bericht über die Reformmassnahmen Josias 2 Kön. XXIII 4ff." VT 27 (1977) 32136.

Hölscher, Gustav. "Das Buch der Könige, seine Quellen und seine Redaktion." In Eucharisterion: Studien zur Religion und Literatur des Alten und Neuen Testaments. Hermann Gunkel zum 60. Geburtstag, edited by H. Schmidt, 158-213. FRLANT 36/1. Göttingen: Vandenhoeck \& Ruprecht, 1923.

Hoppe, Leslie J. "The Meaning of Deuteronomy." BTB 10 (1980) 111-17.

L'Hour, Jean. "L'Alliance de Sichem." RB 69 (1962) 5-36, 161-84, 350-68.

Hugger, P. "Der Tod des Königs Josia. Eine Passionsbetrachtung." BibLeb 14 (1973) 57-63.

Hylander, Ivar. Der literarische Samuel-Saul-Komplex (I. Sam 1-15) traditionsgeschichtlich untersucht. Uppsala: Almqvist \& Wiksell, 1932.

Ihromi. "Die Königinmutter und der 'amm ha'arez im Reich Juda." VT 24 (1974) 421-29.

Isbell, Charles D. "II Kings 22:3-23:24 and Jeremiah 36: A Stylistic Comparison." JSOT 8 (1978) 33-45.

Janssen, Enno. Juda in der Exilszeit. FRLANT 69. Göttingen: Vandenhoeck \& Ruprecht, 1956.

Jaroš, Karl. Sichem. OBO 11. Göttingen: Vandenhoeck \& Ruprecht, 1976.

Jenni, Ernst. "Zwei Jahrzehnte Forschung an der Büchern Josua bis Könige." TRu 27 (1961) 1-32, 97-146.

Jepsen, Alfred. Die Quellen des Königsbuches. 2d ed.; Halle: Niemeyer, 1956.

. "Die reform des Josia." In Festschrift Friedrich Baumgärtel zum 70. Geburtstag, edited by Leonhard Rost, 97-108. Erlanger Forschungen, Reihe A, Geisteswissenschaften 10. Erlangen: Universitätsbibliothek, 1959.

. "Ahab's Busse. Ein kleiner Beitrag zur Methode literarhistorischer Einordnung." In Archäologie und Altes Testament. Festschrift für $K$. Galling, edited by A. Kuschke and E. Kutsch, 145-55. Tübingen: J. C. B. Mohr, 1970.

. "Gottesmann und Prophet: Anmerkungen zum Kapitel 1. Könige 13." Probleme biblischer Theologie, edited by H. W. Wolff, 17182. Munich: Kaiser, 1971.

Jones, Gwilym H. 1 and 2 Kings. 2 vols. NCB. Grand Rapids: Eerdmans, 1984.

Jüngling, Hans-Winfried. Richter 19-Ein Plädoyer für das Königtum. AnBib 84. Rome: Biblical Institute, 1981.

Kaiser, Otto. Isaiah 13-39. OTL. London: SCM, 1974.

Kearney, Peter J. "The Role of the Gibeonites in the Deuteronomic History." $C B Q 35$ (1973) 1-19.

Kenik, Helen. Design for Kingship. The Deuteronomistic Narrative Technique in 1 Kings 3:4-15. SBLDS 69. Chico: Scholars, 1983. 
Kittel, Rudolf. Die Bücher der Könige. HKAT 1/5. Göttingen: Vandenhoeck \& Ruprecht, 1900.

Klein, Ralph W. 1 Samuel. Word Biblical Commentary 10. Waco: Word Books, 1983.

Kline, Meredith G. Treaty of the Great King. The Covenant Structure of Deuteronomy. Grand Rapids: Eerdmans, 1963.

Kloppenborg, John S. "Joshua 22: The Priestly Editing of an Ancient Tradition." Bib 62 (1981) 347-71.

Knierim, Rolf P. "The Messianic Concept in The First Book of Samuel." Jesus and the Historian: Written in Honour of Ernest Cadman Colwell, edited by F. T. Trotter, 20-51. Philadelphia: Westminster, 1968.

Koch, Klaus. "Sühne und Sündenvergebung um die Wende von der exilischen zur nachexilischen Zeit." EvT 26 (1966) 127-39.

Köppel, Urs. Das deuteronomistische Geschichtswerk und seine Quellen. Die Absicht der deuteronomistischen Geschichtsdarstellung aufgrund des Vergleichs zwischen Num 21,21-35 und Dtn 2, 26-3,3. Europaische Hochschulschriften Reihe 23, Bd. 122. Bern-Frankfurt-am-Main: P. Lang, 1979.

Kraus, Hans-Joachim. "Gesetz und Geschichte. Zum Geschichtsbild des Deuteronomisten." EvT 11 (1951-52) 415-28.

Kreuzer, Siegfried. "Zur Bedeutung und Etymologie von hištahāwăh/yšthwy." VT 35 (1985) 39-60.

Kuhl, C. "Die 'Wiederaufnahme'-ein literarkritisches Prinzip?" ZAW 64 (1952) 1-11.

Laaf, Peter. Die Pascha-Feier Israels. Eine literarkritische und überlieferungsgeschichtliche Studie. BBB 36. Bonn: Hanstein, 1970.

Labuschagne, C. S. "Some Remarks on The Prayer of David in II Sam. 7." In Studies on the Books of Samuel, 28-35. Papers read at 3rd Meeting of Die O. T. Werkgemeenskap in Suid-Afrika, University of Stellenbosch, 1960.

Lance, H. Darrell. "The Royal Stamps and the Kingdom of Josiah." HTR 64 (1971) 315-32.

Langlamet, F. "Les récits de l'institution de la royauté (I Sam., vii-xii). De Wellhausen aux travaux récents." $R B 77$ (1970) 161-200.

. "Pour ou contre Salomon? La rédaction prosalomienne de I Rois, I-II." RB 83 (1976) 321-79, 481-529.

Langohr, Guy. "Redaction et composition du livre de Sophonie." Mus 89 (1976) 51-73.

- "Le livre de Sophonie et la critique d'authenticité." ETL 52 (1976) 1-27.

Lemaire, André. "Vers L'histoire de la Rédaction des Livres des Rois." ZAW 98 (1986) 221-36.

Levenson, Jon D. "From Temple to Synagogue: 1 Kings 8." Traditions in Transformation: Turning Points in Biblical Faith, edited by B. Halpern and J. D. Levenson, 121-66. Winona Lake: Eisenbrauns, 1981.

. "Who Inserted The Book of The Torah?" HTR 68 (1975) 203-33. 
Levin, Christoph. Der Sturz der Königin Atalja. Ein Kapitel zur Geschichte Judas im 9. Jahrhundert v. Chr. SBS 105. Stuttgart: Verlag Katholischen Bibelwerk, 1982.

. "Joschija im deuteronomistischen Geschichtswerk." ZAW 96 (1984) 351-71.

Lindblom, Johannes. Erwägungen zur Herkunft der Josianische Tempelurkunde. Scripta Minora regiae societatis humaniorum litterarum Lundensis 1970-71:3. Lund: Gleerup, 1971.

Lipinski, E. "Le Récit de 1 Rois XII 1-19 à la Lumière de l'Ancien Usage de l'Hébreu et de Nouveaux Textes de Mari." VT 24 (1974) 430-37.

Liver, J. "The Book of the Acts of Solomon." Bib 48 (1967) 75-101.

Lohfink, Norbert. "Darstellungskunst und Theologie in Dt 1,6-3,29." Bib 42 (1960) 105-34.

. "Die deuteronomistische Darstellung des Übergangs der Führung Israels von Moses auf Josue. Eine Beitrag zur alttestamentlichen Theologie des Amtes." Scholastik 37 (1962) 32-44.

. "Der Bundesschluss im Land Moab." BZ 6 (1962) 32-56.

. "Die Bundesurkunde des Königs Josias." Bib 44 (1963) 261-88, 461-98.

Höre Israel! Auslegung von Texten aus dem Buch

Deuteronomium. Die Welt der Bibel. Düsseldorf: Patmos, 1965.

. "Die Gattung der 'Historischen Kurzgeschichte' in den letzten Jahren von Juda und in der Zeit des Babylonischen Exils." ZAW 90 (1978) 319-47.

"Kerygmata des Deuteronomistischen Geschichtswerks." In Die Botschaft und die Boten. Festschrift $H$. W. Wolff, edited by J. Jeremias \& L. Perlitt, 87-100. Neukirchen-Vluyn: Neukirchener Verlag, 1981.

. "Die Bedeutungen von hebr. Jrš qal und hif.," BZ 27 (1981) 14-33. "Zur deuteronomischen Zentralisationsformel." Bib 65 (1984) 297-329.

. Rückblick im Zorn auf den Staat. Vorlesungen zu ausgewählten Schlüsseltexten der Bücher Samuel und Könige. Frankfurt-am-Main: Hochschule Sankt Georgen, 1984.

"Zur neueren Diskussion über 2 Kön 22-23." In Das Deuteronomium: Entstehung, Gestalt und Botschaft, edited by $\mathrm{N}$. Lohfink, 24-48. BETL 68. Leuven: University Press, 1985.

. "The Cult Reform of Josiah of Judah: 2 Kings 22-23 as a Source for the History of Israelite Religion." In Ancient Israelite Religion: Essays in Honor of Frank More Cross, edited by P. D. Miller, Jr., P. D. Hanson, S. D. McBride, 459-75. Philadelphia: Fortress, 1987.

Long, Burke O. 1 Kings with an Introduction to Historical Literature. The Forms of the Old Testament Literature 9. Grand Rapids: Eerdmans, 1984.

Loretz, O. "Der Torso eines Kanaanaisch-israelitischen Tempelweihspruches in I Kg 8, 12-13." UF 6 (1974) 478-80. 
Lundbom, Jack R. "The Lawbook of the Josianic Reform." $C B Q 38$ (1976) 293-302.

MacDonald, John. "The Structure of II Kings XVII." Glascow University Oriental Society Transactions 23 (1969-1970) 29-41.

Maier, J. "Bemerkungen zur Fachsprache und Religionspolitik im Königreich Juda." Judaica 26 (1970) 89-105.

Mauchline, John. 1 and 2 Samuel. NCB. London: Oliphants, 1971.

Mayes, A. D. H. "King and covenant: a study of 2 Kings chs 22-23." Hermethena 125 (1978) 34-47.

" "The Rise of the Israelite Monarchy." ZAW 90 (1978) 1-19.

. Deuteronomy. NCB. Grand Rapids: Eerdmans, 1981.

. The Story of Israel between Settlement and Exile. A Redactional Study of the Deuteronomistic History. London: SCM, 1983.

McCarter, P. Kyle. I Samuel. AB 8. Garden City: Doubleday, 1980.

-II Samuel. AB 9. Garden City: Doubleday, 1984.

McCarthy, Denis, J. "II Samuel 7 and the Structure of the Deuteronomic History." JBL 84 (1965) 131-38.

. "The Inauguration of Monarchy in Israel. A Form-Critical Study of I Samuel 8-12*." Int 27 (1973) 401-12.

. "2 Kings 13:4-6." Bib 54 (1973) 409-10.

. "The Wrath of Yahweh and the Structural Unity of the Deuteronomistic History." In Essays in Old Testament Ethics, edited by J. L. Crenshaw and J. T. Willis, 97-110. New York: Ktav, 1974.

. Treaty and Covenant. A Study in Form in the Ancient Oriental Documents and in the Old Testament. AnBib 21A. Rome: Biblical Institute, 1978.

McConville, J. G. Law and Theology in Deuteronomy. JSOTSup 33. Sheffield: JSOT, 1985.

McKay, John. Religion in Judah under the Assyrians. 732-609 BC. SBT 26. London: SCM, 1973.

McKenzie, Steven L. The Chronicler's Use of the Deuteronomistic History. HSM 33. Atlanta: Scholars, 1984.

. "The Prophetic History and the Redaction of Kings." Biblical and Other Studies in Memory of S. D. Goitein. Hebrew Annual Review 9 (1985) 203-20.

Mendelsohn, I. "Samuel's Denunciation of Kingship in the Light of Akkadian Documents from Ugarit." BASOR 143 (1956) 17-22.

Mettinger, Tryggve N. D. King and Messiah. The Civil and Sacral Legitimation of the Israelite Kings. ConBOT 8. Lund: Gleerup, 1976.

Meyer, Rudolf "Auffallender Erzählungsstil in einem angeblichen Auszug aus der 'Chronik der Könige von Juda'." In Festschrift Friedrich Baumgärtel zum 70. Geburtstag, edited by Leonhard Rost, 114-23. Erlanger Forschungen, Reihe A, Geisteswissenschaften 10. Erlangen: Universitätsbibliothek, 1959.

Michaeli, Frank. Les livres des Chroniques, d'Esdras et de Néhémie. Commentaire de l'Ancien Testament 16. Neuchâtel: Delachaux \& Niestlé, 1967.

Miller, J. Maxwell. "The Fall of the House of Ahab." VT 17 (1967) 307-24. 
Miller, Patrick D. and Roberts, J. M. The Hand of the Lord: A Reassessment of the "Ark Narrative" of 1 Samuel. The Johns Hopkins Near Eastern Studies. Baltimore: Johns Hopkins, 1977.

Minette de Tillesse, G. 'Sections 'tu' et sections 'vous' dans le Deutéronome." VT 12 (1962) 29-87.

Mittmann, Siegfried. Deuteronomium 1:1-6:3 literarkritisch und traditionsgeschichtlich untersucht. BZAW 139. Berlin: de Gruyter, 1975.

Mölle, Herbert. Der sogenannte Landtag zu Sichem. FB 42. Würzburg: Echter, 1980.

Montgomery, James A. and Gehman, Henry Snyder. A Critical Exegetical Commentary on the Books of Kings. ICC. Edinburgh: T. \& T. Clark, 1951.

Moran, W. L. "The End of the Unholy War and the Anti-Exodus." Bib 44 (1963) 333-42.

Morgenstern, J. "A Chapter in the History of the High-Priesthood." AJSL 55 (1938) 1-24, 183-97, 360-77.

Mosis, Rudolf. Untersuchungen zur Theologie des chronistischen Geschichtswerkes. Freiburger theologische Studien 92. Freiburg: Herder, 1973.

Mullen, E. Theodore. "Judges 1:1-3:36: The Deuteronomistic Reintroduction of the Book of Judges." HTR 77 (1984) 33-54.

Nelson, Richard D. "Dynastic Oracle in Dtr: A Worskshop in Recent Trends." In Society of Biblical Literature 1976 Seminar Papers, edited by G. MacRae, 1-14. Montana: Scholars Press, 1976.

. The Double Redaction of the Deuteronomistic History. JSOTSup 18. Sheffield: JSOT, 1981.

. "Josiah in the Book of Joshua." JBL 100 (1981) 531-40.

. First and Second Kings. Interpretation. Atlanta: John Knox, 1987.

Nicholson, E. W. "II Kings XXII 18-A Simple Restoration." Hermethena 97 (1963) 96-98.

. Preaching to the Exiles. Oxford: Blackwell, 1970.

Noth, Martin. Das Buch Josua. HAT 7. Tübingen: J. C. B. Mohr, 1953. Überlieferungsgeschichtliche Studien: Die sammelnden und bearbeitenden Geschichtswerke im Alten Testament. Darmstadt: Wissenschaftliche Buchgesellschaft, 1963.

"David and Israel in II Samuel VII." In The Laws in the Pentateuch and Other Essays, 250-59. Edinburgh: Oliver \& Boyd, 1966.

. Könige I. 1-16. BKAT 9/1. Neukirchen-Vluyn: Neukirchener Verlag, 1968.

A History of Pentateuchal Traditions. Englewood Cliffs: Prentice-Hall, 1972.

. The Deuteronomistic History . JSOTSup 15. Sheffield: JSOT, 1981. 
Nowack, W. "Deuteronomium und Regum." In Vom Alten Testament Karl Marti zum siebzigsten Geburtstag Gewidmet, 221-32. BZAW 41. Giesen: Alfred Töpelmann, 1925.

Nübel, H. -U. Davids Aufstieg in der Frühe israelitischer Geschichtsschreibung. Bonn: Rheinische Friedrich-Wilhelms-Universität, 1959.

O'Doherty, Eamon. “The Literary Problem of Judges 1,1-3,6." $C B Q 18$ (1956) 1-7.

Ogden, Graham S. "The Northern Extent of Josiah's Reform." AusBR 26 (1978) 26-34.

Östreicher, Theodor. Das Deuteronomische Grundgesetz. BFCT 27/4. Gütersloh: Bertelsmann, 1923.

Pavlovsky, V. and Vogt E. "Die Jahre der Könige von Juda und Israel." Bib 45 (1964) 321-47.

Peckham, Brian. "The Composition of Deuteronomy 9:1-10:11." In Word and Spirit. Essays in Honor of David Michael Stanley S.J. on his 60th Birthday, 3-59. Regis College Press, 1975.

. "The Composition of Deuteronomy 5-11. In The Word of the Lord Shall Go Forth. Essays in Honor of David Noel Freedman in Celebration of His Sixtieth Birthday, edited by C. L. Meyers and M. O'Connor, 217-40. Winona Lake: Eisenbrauns, 1983.

- "The Composition of Joshua 3-4." CBQ 46 (1984) 413-31. 209.

. The Composition of the Deuteronomistic History. HSM 35. Atlanta: Scholars, 1985.

Perlitt, Lothar. Bundestheologie im Alten Testament. WMANT 36. Neukirchen-Vluyn: Neukirchener Verlag, 1969.

. "Deuteronomium 1-3 im Streit der Exegetischen Methoden." Das Deuteronomium: Entstehung, Gestalt und Botschaft, edited by N. Lohfink, 149-63. BETL 68. Leuven: University Press, 1985.

Plein, Ina. "Erwägungen zur Überlieferung von I Reg 11:26-14:20." ZAW 78 (1966) 8-24.

Plöger, Otto. "Reden und Gebete im deuteronomischen und chronistischen Geschichtswerk." In Festschrift für Günter Dehm zum 75. Geburtstag, edited by W. Schneemelcher, 35-49. Neukirchen: Verlag der Buchhandlung des Erziehungsvereins, 1957.

Pohlmann, K.-F. Studien zum Jeremiabuch: Ein Beitrag zur Frage nach der Entstehung des Jeremiabuches . FRLANT 118. Göttingen: Vandenhoeck \& Ruprecht, 1978.

Polzin, Robert. Moses and the Deuteronomist. A Literary Study of the Deuteronomic History. New York: Seabury, 1980.

Priest, John. "Huldah's Oracle." VT 30 (1980) 366-68.

Preuss, Horst Dietrich. Deuteronomium. Erträge der Forschung 164. Darmstadt: Wissenschaftliche Buchgesellschaft, 1982.

Provan, Ian W. Hezekiah and the Books of Kings. A Contribution to the Debate about the Composition of the Deuteronomistic History. BZAW 172. Berlin: de Gruyter, 1988. 
Purvis, J. The Samaritan Pentateuch and the Origin of the Samaritan Sect. Cambridge: Harvard University Press, 1968.

Rad, Gerhard von. Studies in Deuteronomy. SBT 9. London: SCM, 1953. . Old Testament Theology. 2 vols. Edinburgh: Oliver and Boyd, $1962-65$.

. Deuteronomy. OTL. London: SCM, 1966.

"The Early History of the Form-Category of I Corinthians xiii. 47." In The Problem of the Hexateuch and Other Essays, 310-17. London: SCM, 1984.

. "The Promised Land and Yahweh's Land in the Hexateuch." In The Problem of the Hexateuch and Other Essays, 79-83. London: SCM, 1984.

Radjawane, Arnold Nicolaas. "Das deuteronomistische Geschichtswerk." TRu 38 (1974) 177-216.

Rehm, Martin. Das erste Buch der Könige: ein Kommentar. Würzburg: Echter, 1979.

. Das zweite Buch der Könige: ein Kommentar. Würzburg: Echter, 1982.

Rendtorff, Rolf. Das überlieferungsgeschichtliche Problem des Pentateuch. BZAW 147. Berlin: de Gruyter, 1977.

. Das Alte Testament. Eine Einleitung. Neukirchen-Vluyn: Neukirchener Verlag, 1983.

Richter, Wolfgang. Traditionsgschichtliche Untersuchungen zum Richterbuch. BBB 18. Bonn: Hanstein, 1963.

. Die Bearbeitung des "Retterbuches" in der deuteronomischen Epoche. BBB 21. Bonn: Hanstein, 1964.

"Die Überlieferungen um Jephtah. Ri 10,17-12,6." Bib 47 (1966) 485-556.

Robinson, J. The First Book of Kings. The Cambridge Bible Commentary. Cambridge: University Press, 1972.

. The Second Book of Kings. The Cambridge Bible Commentary. Cambridge: University Press, 1976.

Rose, Martin. Der Ausschliesslichkeitsanspruch Yahwes. Deuteronomische Schultheologie und die Volksfrömmigkeit in der späten Königszeit. BWANT 106. Stuttgart: W. Kohlhammer, 1975.

"Bemerkungen zum historischen Fundament des Josia-Bildes in II Reg 22f." ZAW 89 (1977) 50-63.

. Deuteronomist und Yahwist. Untersuchungen zu den Berührungspunkten beider Literaturwerke. ATANT 67. Zürich: Theologischer Verlag, 1981.

Rosenbaum, Jonathan. "Hezekiah's Reform and the Deuteronomistic Tradition." HTR 72 (1979) 23-44.

Rösel, Hartmut N. "Die Überleitungen vom Josua- ins Richterbuch." VT 30 (1980) 342-50.

Rost, Leonhard. The Succession to The Throne of David. Historic Texts and Interpreters in Biblical Scholarship 1. Sheffield: The Almond Press, 1982. 
Roth, Wolfgang. "The Deuteronomic Rest-Theology: A Redaction-critical Study." BR 21 (1976) 5-14.

Sanda, Albert. Die Bücher der Könige. EHAT 9. 2 vols. Münster: Aschendorffsche Verlagsbuchhandlung, 1911-12.

Sauer, Georg. "Die chronologischen Angaben in den Büchern Deut. bis 2. Kön." TZ 24 (1968) 1-14.

Scharbert, Josef. "Zefania und die Reform des Joschija." in Künder des Wortes. Beiträge zur Theologie der Propheten, edited by L. Perlitt, P. Weimar, E. Zenger, 237-53. Würzburg: Echter, 1982.

Schicklberger, Franz. Die Ladeerzählung des ersten Samuel-Buches. Eine literaturwissenschaftliche und theologiegeschichtliche Untersuchung. FB 7. Würzburg: Echter, 1973.

Schmid, Hans Heinrich. Der sogenannte Jahwist. Beobachtungen und Fragen zur Pentateuchforschung. Zürich: Theologischer Verlag, 1976.

Schmidt, Ludwig. "Deuteronomistisches Geschichtswerk." In Altes Testament, 101-14. Neukirchener Arbeitsbücher. Neukirchen-Vluyn: Neukirchener, 1983.

Schmitt, Hans-Christoph. Elisa. Traditionsgeschichtliche Untersuchungen zur vorklassischen nordisraelitischen Prophetie. Gütersloh: Mohn, 1972.

Schmoldt, Hans. "Elijas Botschaft an Ahab. Überlegungen zum Werdegang von 1 Kön 21." BN 28 (1985) 39-51.

Schulte, Hannelis. Die Entstehung der Geschichtsschreibung im Alten Israel. BZAW 128. Berlin: de Gruyter, 1972.

Schüpphaus, Joachim. Richter- und Prophetengeschichten als Glieder der Geschichtsdarstellung der Richter- und Königszeit. Bonn: Rheinische Friedrich-Wilhelms-Universität, 1967.

Scott, R. B. Y. "Solomon and the Beginnings of Wisdom in Israel." VTSup 3 (1955) 262-79.

Seebass, Horst. "Zur Königserhebung Jerobeams I." VT 17 (1967) 324-33.

. "Tradition und Interpretation bei Jehu ben Chanani und Ahia von Silo." VT 25 (1975) 175-90.

. "Zur Teilung der Herrschaft Salomos nach 1 Reg 11:29-39." ZAW 88 (1976) 363-76.

. David, Saul und das Wesen des biblischen Glaubens. NeukirchenVluyn: Neukirchener Verlag, 1980.

Sekine, M. "Beobachtungen zu der josianischen Reform." VT 22 (1972) 36168.

Seitz, Gottfried. Redaktionsgeschichtliche Studien zum Deuteronomium. BWANT 93. Stuttgart: W. Kohlhammer, 1971.

Shea, W. H. "Sennacherib's Second Palestinian Campaign." JBL104 (1985) 401-18.

Simon, U. "1 Kings 13. A Prophetic Sign. Denial and Peristence." HUCA 47 (1976) 81-119.

Skweres, D. E. "Das Motiv der Strafgrunderfragung in biblischen und neuassyrischen Texten." BZ 14 (1970) 181-97. 
Smend, Rudolf. "Das Gesetz und die Volker: Ein Beitrag zur deuteronomistischen Redaktionsgeschichte." In Probleme biblischer Theologie, edited by H. W. Wolff, 494-509. Munich: Kaiser, 1971.

. Die Enstehung des Alten Testaments. Stuttgart: W. Kohlhammer, 1978.

Snaith, Norman H. "Introduction to and Exegesis of the First and Second Books of Kings." IB 3 (1955) 3-338.

. "The Meaning of StYrim." VT 25 (1975) 115-18.

Soggin, J. Alberto. "Der Entstehungsort des Deuteronomistischen Geschichtswerkes. Ein Beitrag zur Geschichte desselben." TLZ 100 (1975) 3-8. . "Deuteronomistische Geschichtsauslegung wăhrend des babylonischen Exils." In Oikonomia: Oscar Cullmann zum 65. Geburtstag gewidmet, edited by Felix Christ, 11-17. Hamburg-Bergstedt: Reich, 1967.

. Judges. A Commentary. OTL. London: SCM, 1981.

Spieckermann, Hubert. Juda unter Assur in der Sargonidenzeit. FRLANT

129. Göttingen: Vandenhoeck \& Ruprecht, 1982.

Stade, Bernhard. "Anmerkungen zu 2 Kö. 10-14." ZAW 5 (1885) 275-97.

. "Anmerkungen zu 2 Ko. 15-21." ZAW 6 (1886) 156-89.

Stahl, Rainer. "Aspekte der Geschichte deuteronomistischer Theologie. Zur

Traditionsgeschichte der Terminologie und zur Redaktionsgeschichte der Redekompositionen." Ph.D. diss., Jena, 1982.

Steck, Odil Hannes. Israel und das gewaltsame Geschick der Propheten. Untersuchungen zur Überlieferung des deuteronomistischen Geschichtsbildes im Alten Testament, spät Judentum und Urchristentum. WMANT 23. Neukirchen-Vluyn: Neukirchener Verlag, 1967.

Überlieferung und Zeitgeschichte in den Elia-Erzählungen. WMANT 26. Neukirchen-Vluyn: Neukirchener Verlag, 1968.

Stoebe, Hans Joachim. Das erste Buch Samuelis. KAT 8/1. Gütersloh: Mohn, 1973.

Talmon, Shemaryahu. "The Textual Study of the Bible-A New Outlook." In Qumran and the History of the Biblical Text, edited by F. M. Cross and S. Talmon, 321-400. Cambridge: Harvard University, 1975.

Thiel, Winfried. Die deuteronomistische Redaktion von Jeremia 1-25. WMANT 41. Neukirchen-Vluyn: Neukirchener Verlag, 1973.

. Die deuteronomistische Redaktion von Jeremia 26-45. WMANT 52. Neukirchen-Vluyn: Neukirchener Verlag, 1981.

Timm, Hermann. "Die Ladeerzählung (1. Sam. 4-6; 2. Sam. 6) und das Kerygma des deuteronomistischen Geschichtswerks." EvT 26 (1966) 509-26.

Timm, Stefan. Die Dynastie Omri: Quellen und Untersuchungen zur Geschichte Israels im 9. Jahrhundert vor Christus. FRLANT 124. Göttingen: Vandenhoeck \& Ruprecht, 1982.

Trebolle Barrera, Julio C. "Jeroboán y la Asamblea de Siquén (1 Rey. 12, 23a; LXX 11, 43; 12, 24d. f. p.)." EstBib 38 (1979-1980) 189-220. 
Salomón y Jeroboán. Historia de la recensión y redacción de 1 Reyes, 2-12, 14. Instituto Español Bíblico y Arqueológico de Jerusalén. Jerusalén-Valencia: Casa de Santiago, 1980.

"Testamento y muerte de David. Estudio de historia de la Recensión y Redacción de I Rey., II." RB 87 (1980) 87-103.

. "La coronación de Joás (2 Re 11). Texto, narración e historia." EstBib 41 (1983) 5-16.

. Jehú y Joás. Texto y composición literaria de 2 Reyes 9-11. Institución San Jerónimo 17. Valencia: Edilva, 1984.

Trible, Phyllis. Texts of Terror. Literary-Feminist Readings of Biblical Narratives. Overtures to Biblical Theology. Philadelphia: Fortress, 1984.

Tsevat, Matitiahu. "The House of David in Nathan's Prophecy." Bib 46 (1965) 353-56.

Van Den Born, A. "Zum Tempelweihspruch (I Kgs viii 12f)." OTS 14 (1965) 235-44.

Vannoy, Robert J. Covenant Renewal at Gilgal. A Study of 1 Samuel 11:1412:25. New Jersey: Mack, 1978.

Vanoni, Gottfried. "Der Geist und der Buchstabe: Überlegungen zum Verhältnis der Testamente und Beobachtungen zu Dtn 30, 1-10." $B N$ 14 (1981) 65-98.

. Literarkritik und Grammatik. Untersuchung der Wiederholungen und Spannungen in 1 Kön 11-12. Arbeiten zu Text und Sprache im Alten Testament 21. St. Ottilien: EOS Verlag, 1984.

. "Beobachtungen zur deuteronomistischen Terminologie in 2 Kön 23,25-25,30." In Das Deuteronomium: Entstehung, Gestalt und Botschaft, edited by N. Lohfink, 357-62. BETL 68. Leuven: University Press, 1985.

Van Seters, John. "Histories and Historians of the Ancient Near East: The Israelites." Or 50 (1981) 137-85.

. In Search of History: Historiography in the Ancient World and the Origins of Biblical Historiography. New Haven: Yale University, 1983.

"Joshua 24 and the Problem of Tradition in the Old Testament," in In the Shelter of Elyon. Essays on Ancient Palestinian Life and Literature in Honor of G.W. Ahlström, edited by W. Boyd Barrick and John R. Spencer, 139-58. JSOTSup 31; Sheffield: JSOT, 1984.

Vaux, Roland de. Les Livres des Rois. SBJ. Paris: Cerf, 1958.

Veijola, Timo. Die ewige Dynastie. David und die Entstehung seiner Dynastie nach der deuteronomistschen Darstellung. Annales Academiae Scientiarum Fennicae, B 193. Helsinki: Suomalainen Tiedeakatemia, 1975.

. Das Königtum in der Beurteilung der deuteronomistischen Historiographie. Eine redaktionsgeschichtliche Untersuchung. Annales Academiae Scientiarum Fennicae, B 198. Helsinki: Suomalainen Tiedeakatemia, 1977. 
Viviano, Pauline A. "2 Kings 17: A Rhetorical and Form-Critical Analysis." $C B Q 49$ (1987) 548-59.

Wallace, H. N. "The Oracles Against the Israelite Dynasties in 1 and 2 Kings." Bib 67 (1986) 21-40.

Weimar, Peter. Untersuchungen zur Redaktionsgeschichte des Pentateuch. BZAW 146. Berlin: Gruyter, 1977.

Weinfeld. Moshe. "The Period of the Conquest and of the Judges as Seen by the Earlier and the Later Sources." VT 17 (1967) 93-113.

. Deuteronomy and the Deuteronomic School. Oxford: Clarendon Press, 1972.

"The Worship of Molech and of the Queen of Heaven and its Background." UF 4 (1972) 133-54.

Weippert, Helga. "Die 'deuteronomistischen' Beurteilungen der Könige von Israel und Juda und das Problem der Redaktion der Königsbücher." Bib 53 (1972) 301-39.

"Der Ort, den Jahwe erwählen wird, um dort seinen Namen wohnen zu lassen." BZ 24 (1980) 76-94.

"Die Ätiologie des Nordreiches und seines Königshauses (1 Reg 11:29-40)." ZAW 95 (1983) 344-75.

. "Das deuteronomistische Geschichtswerk. Sein Ziel und Ende in der neueren Forschung." TRu 50 (1985) 213-49.

Weiser, Artur. Introduction to the Old Testament. The Canon, the Apocrypha and Pseudepigrapha. London: Darton, Longman \& Todd, 1961.

. Samuel: seine geschichtliche Aufgabe und religiöse Bedeutung. Traditions-geschichtliche Untersuchungen zu 1. Samuel 7-12. FRLANT 81. Göttingen: Vandenhoeck \& Ruprecht, 1962.

Welch, A. C. "The Death of Josiah." ZAW 43 (1925) 255-60.

Wellhausen, Julius. Die Composition des Hexateuchs und der historischen Bücher des Alten Testaments. 4th ed. Berlin: de Gruyter, 1963.

Welten, Peter. Die Königs-Stempel. Ein Beitrag zur Militärpolitik Judas unter Hiskia und Josia. Abhandlungen des Deutschen PalästinaVereins 1. Wiesbaden: Harrassowitz, 1969.

Wenham, Gordon J. "The Deuteronomic Theology of the Book of Joshua." JBL 90 (1971) 140-48.

Whitelam, Keith W. "The Defense of David." JSOT 29 (1984) 61-87.

Williamson, H. G. M. "The Death of Josiah and the Continuing Development of the Deuteronomic History." VT 32 (1982) 242-48.

Wolff, Hans Walter. "The Kerygma of the Deuteronomic Historical Work." In The Vitality of Old Testament Traditions, edited by $\mathrm{W}$. Brueggemann \& H. W. Wolff, 83-100. 2d ed. Atlanta: J. Knox, 1982.

Würthwein, Ernst. "Die Erzăhlung von Gottesmann aus Juda in Bethel. Zur Komposition von 1 Kön 13." In Wort und Geschichte. Festschrift für Karl Elliger zum 70. Geburtstag, 181-89. AOAT 18. Neukirchen-Vluyn: Neukirchener Verlag, 1973.

. Die Erzählung von der Thronfolge Davids-theologische oder politische Geschichtsschreibung?. Theologische Studien 115. Zürich: Theologischer Verlag, 1974. 
"Die Josianische Reform und das Deuteronomium." ZTK 73 (1976) 395-423.

Die Bücher der Könige. 1. Könige 1-16. ATD 11/1. Göttingen: Vandenhoeck \& Ruprecht, 1977.

Die Bücher der Könige. 1. Kön. 17-2. Kön. 25. ATD 11/2. Göttingen: Vandenhoeck \& Ruprecht, 1984.

Yadin, Y. "Beer-sheba: The High Place Destroyed by King Josiah." BASOR 222 (1976) 5-17.

Zimmerli, Walther. Ezekiel 1. A Commentary on the Book of the Prophet Ezekiel, Chapters 1-24. Hermeneia. Philadelphia: Fortress, 1979. . Ezekiel 2. A Commentary on the Book of the Prophet Ezekiel, Chapters 25-48. Hermeneia. Philadelphia: Fortress, 1983. 


\section{SELECTIVE INDEX OF BIBLICAL REFERENCES}

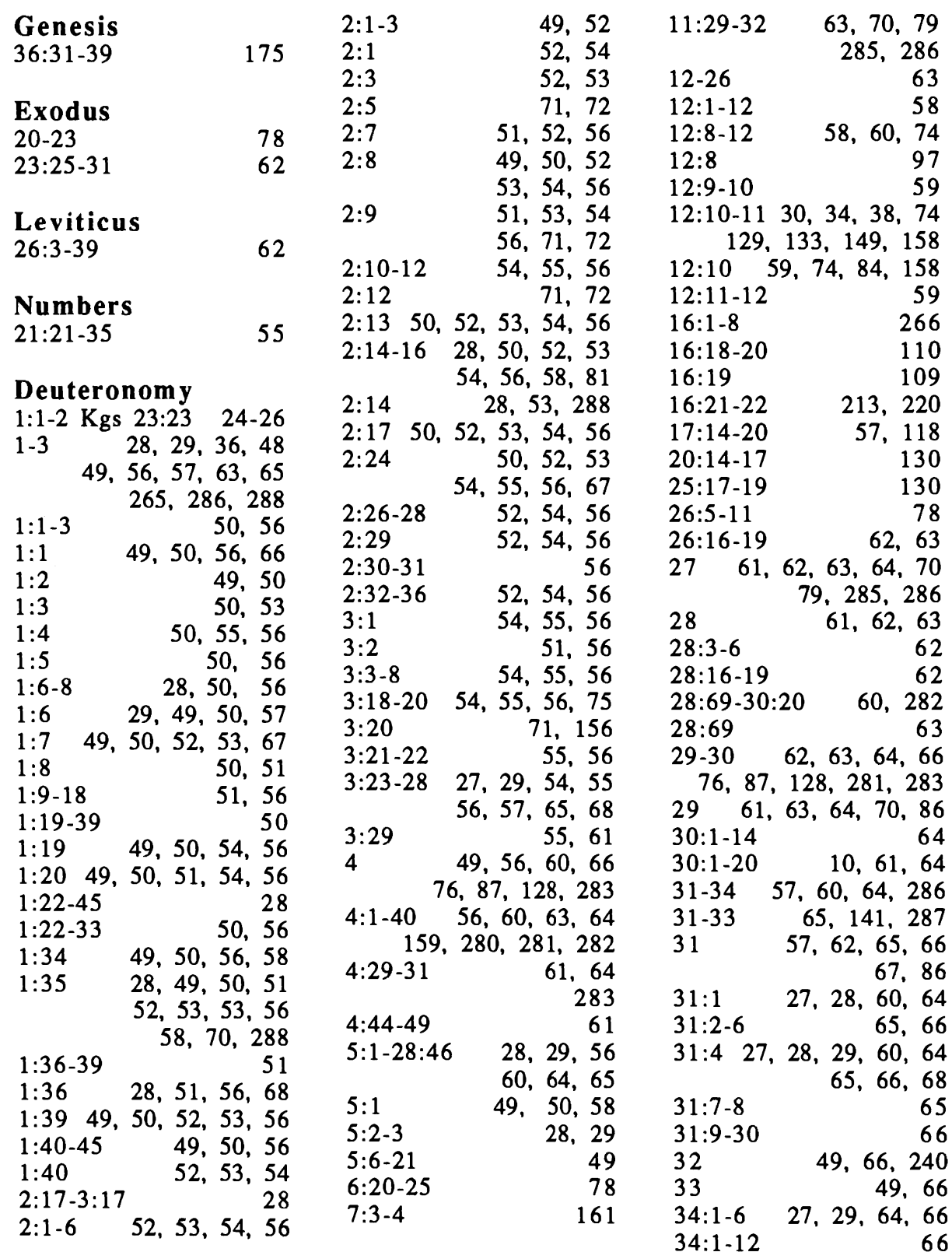


Joshua

$1: 1-6: 25$

$1: 1-6$

$1: 2-6$

$1: 7-9$

$1: 10-11$

$1: 12-18$

2-11

$3: 5$

5:10-12

$7-8$

7

$7: 11 \quad 70,77,280,283$

$7: 13$

$7: 15 \quad 70,77,280,283$

$8: 30-35 \quad 63,68,70,79$

$268,285,286$

9

9:24-25

$10: 25$

$11: 12$

$11: 15-20$

$68,75,76,84$

$70,71,283$

$11: 15 \quad 68,70,71,283$

$11: 20 \quad 68,70,71,283$

$11: 23 \quad 18,67,68,71$

$72,73,74,76,84$

$12 \quad 29,67,71,72$

13-21 51, 72, 73 286,287

13:1-7 $10,72,73,74$

$13: 1 \quad 72,73,74$

$13: 7 \quad 72,73,74$

14:6-15 $\quad 51,68$

15-19 73, 74

20:1-21:42 74

21:1-42

$21: 43-45$

$30,59,59$

$74,75,76,82,289$

$21: 43$

$21: 44$

67,74

134,158

22:1-4

$22: 4$

$22: 5$

158

$75,131,192$ $221,280,282$

22:7-34 75, 76, 286

23:1-Judg 2:10 67

$2348,64,72$

$75,76,77,79,80$

$81,86,87,122,128$

$134,280,281,282$

23:15-16
93

$23: 16 \quad 70,77,79,162$ $190,205,209,213$

$2470,78,79,80$ $81,86,128,286,287$ 24:2-13 78, 79, 286 $24: 25 \quad 78,118$

24:29-31 27, 31, 75, 80 $81,82,83$

24:29-30 29, 30, 80

81,259
$24.31 \quad 30,31,80,81$

$24: 31 \quad 30,31,80,81$

Judges

1:1-2:10

$1: 1:-2: 5$

75

$1: 1-36$

$1: 16-36$

2:1-5

2:6-10

$82,98,287$

$2: 10 \quad 27,30,31,80$

$81,82,83$

2:11-3:6 82,88, 92

$93,282,282$

2:11-19 81, 82, 83, 87 $90,92,95,281$

$2: 1182,83,84,85,92$

2:12-13 84, 85, 86 $213,282,285$

$2: 1475,82,83,84,85$ $86,89,205,208$

$2: 15 \quad 82,83,84$

$86,89,92$

$2: 16 \quad 31,83,84$

$89,90,91,206,208$ $2: 17 \quad 86,87,126$ $131,190,212,213$ $280,282,285$

2:20-3:6

$2: 20-23$

86

87,282

285

3:1-6

$3: 1-2$

285

3:3-4

$87,282,285$

3:7-1 Sam 7:17 82

3:7-10:5

3:7-9:57

6:7-10

$82,88,91$

91,108

90,94

6:10

$88,91,93$

115,282

$87,110,212$
9:1-57

31,289

10:1-5 31, 84, 88, 89 $91,93,94,289$

10:1 88, 91, 91, 106 10:6-1 Sam 7:17 82, 88

10:6-16 88, 89, 90 123,282

$\begin{array}{lr}10: 6-9 & 88,282 \\ 10: 6 & 32,83,85,86\end{array}$ $91,92,93,113$ $281,282,282$

$\begin{array}{lr}10: 7-9 & 92,282 \\ 10: 7 & 83,84,92,205\end{array}$

$10: 8 \quad 92,94,95,96$

$10: 984,91,92,93,95$

10:10-16 70, 88, 92 93,282

10:10 84, 85, 86 $92,93,124,281$

$10: 11 \quad 92$

10:17-13:1 32, 93

11:1-12:6 84

12:7-15 84, 88, 89, 91

$13-21 \quad 94,287$

13:1 83, 84, 93, 94 $95,96,108$

13:2-16:31 88, 94, 96

$15: 20 \quad 94,96$

16:31 94, 96

17-21 88, 93, 97-98

287

\section{Samuel}

1:1-2 Kgs 10:28 14, 101 1-7

$32,98,101$

$1: 1-7: 17$

93, 107

$1: 1-4: 1$

105

$1: 1-2: 36$

32

1:1-2:34

1

2:27-36

2:35-36

$3: 1-4: 1$

3:20-4:1

21,104

106,107

88,107

32

4-7; 2 Samuel $6 \quad 107$

$7-12 \quad 99,100$

$7 \quad 100,105,106$ 108,120

7:3-4 100,106, 124 $124,281,282,283$ 7:5-12 100 


$\begin{array}{lrr}7: 5-6 & 105,106,108 \\ 7: 6-12 & & 106 \\ 7: 6 & 32,105,106 \\ 7: 13-17 & & 105 \\ 7: 15-17 & 100,106,109 \\ & & 110 \\ 8: 1-12: 25 & 82\end{array}$

8-11 27, 34, 98, 108 $899,100,109,110$ $113,114,115,116$ $117,120,122,279$

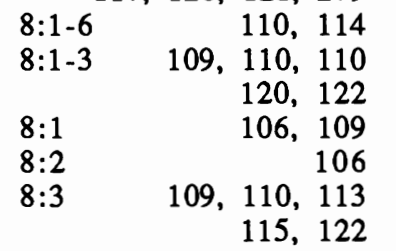
$8: 4-5 \quad 110,112,113$ $8: 5 \quad 33,110,111$ $113,114,118,279$

$8: 6110,111,113,127$

$8: 7 \quad 99,111,112,116$ $121,125,279,280$ 281,282

$8: 8 \quad 85,86,100,110$ $112,124,125$ 190,213 $8: 9$ 111,112 $115,121,282$ 8:11-17 33, 34, 99, 100 $110,111,112,113$ $114,115,122,279$ $8: 18110,113,126,282$ $8: 19-22106,110,111$ $114,120,121$

9:1-10:27 110,131

9:1-10:16 98-99, 100 $102,103,104,105$ $109,115,117,120$ $130,131,165$

10:17-27 99, 100 $109,115,117$

10:18-19 89, 100

$115,116,281,282$ $10: 20-27 \quad 32,33,114$ $115,116,117,120$ $10: 2533,34,106,114$ $115,117,118,119$ $10: 26-27117,118,119$ $1199,100,110,111$ $115,117,118,120$
11:1-11 33, 104, 105 $109,111,118,119$ 120

11:12-13 34, 109, 111 $117,118,119$ 120,148

11:14-15 109, 118, 119 120,121

$11: 1434,105,110,120$ $11: 15 \quad 34,88,104$ $105,110,120,121$

$1248,86,92,99,100$ $109,121,122,125$ $126,127,128,134$ $157-158,209,211$ $213,280,281,282$

12:1-5 100,121, 122 $122,124,127,128$ 128

12:6-15

12:7-12

$12: 7$

$12: 8$

121,123

$12: 9$

$123,123,127$

$123,124,125$

$12: 10-11 \quad 123,124$

$12: 12 \quad 112,121,124$

$125,126,281$

12:13-15 125,126

12:16-19 121, 122

$125,126,127$

$12: 19-25 \quad 122$

$12: 20-25121,125,127$

$12: 23 \quad 106,121,122$ 128,282

$12: 24 \quad 106,121,122$ 127

$12: 25$

13-14

$13: 1$

13:7-15

13:13-14

$14: 52$

15

15:2-3

$15: 17-35$

$15: 28$

121,122

$127,212,281$

130,131

100,121

35,130

131

105,130

$35,101,102$

$105,129,130$

16-2 Samuel 5131,132

$16: 1-13 \quad 102,130,133$

28:17-19

$28: 17$

\section{Samuel}

2-5 132

$35,36,107,108$ $135,136,137,153$ 154,239

7

$36,38,102,129$ $131-34,138,139$

$147,153,154$ 167,279

7:1-17 134, 165

$7: 1 \quad 59,60,74,75,76$ $84,102,132-34$ $135,137,154,158$

$7: 2-5$

$7: 2-3$

$7: 2$ 102,133

$7: 2$

$7: 3-4$

7:4-17

$7: 4-7$

$7: 8-10$ 135

$36,135,136$ 137, 154 133 135 132-34 133-34

$7: 1159,74,75,76,84$ $132,133,134,135$ $137,138,158$

7:12-13 137

$7: 12$ 133,147

$7: 13-16$ 139

$7: 13$

$133,134,135$

$136,137,145$ 149,154

7:14-15 39, 133

$7: 16$ 132

133, 138

7:18-29 138

7:22-24 138, 158, 283

8-1 Kings $2 \quad 135$

$8: 15 \quad 119,139,148$

9-1 Kings $2 \quad 139$

9-20 13, 140,141

$11-12 \quad 36,139,140$

$12: 7-10 \quad 102,103$

$12: 13 \quad 37,140$

21-24 141, 287

\section{Kings}

$1-2 \quad 35,139,140,141$ $1: 48 \quad 137,148$ $1: 49-53 \quad 142$ $2: 1 \quad 139,141,142$ 143

2:2-4 141, 155 $2: 2$
$141,142,155$ 168,230 
$\begin{array}{lrr}2: 3 & 109,131,141 \\ & 155,280,282 \\ 2: 4 & 141,142,151 \\ & 155,156,159,168 \\ & 230,280,282 \\ 2: 5-11 & & 141 \\ 2: 5-9 & 142 \\ 2: 10 & 139,141,201 \\ 2: 11 & 142,182 \\ 2: 12 & 139,141,142 \\ 2: 13-46 & 141,142 \\ 3: 1-10: 29 & & 143 \\ 3: 1 & 143,144,145 \\ 3: 2-3 & 144,145 \\ 3: 2 & 145,146,285 \\ 3: 3 & 145,146,162 \\ & 234,285 \\ 3: 4-5: 26 & & 162 \\ 3: 4-15 & 144,145-48\end{array}$

3:4-15 144, 145-48

$149,150,160$

$3: 14 \quad 131,147,280$

282

5:9-14 144, 148, 160

5:15-26 144, 145

$148,150,160$

$5: 17 \quad 75,76,84,137$

149

$5: 18 \quad 59,60,74,129$

$6: 1-8: 56 \quad 134,149,158$

$6: 194,95,96,144$ $150,151,181$

6:11-12 151, 280, 281

282

$6: 13151,280,281,282$

$6: 14$

8

$8: 1-13$ 151,282

$8: 1-11 \quad 108,151,152$

153

$8: 12-13 \quad 151,152,153$

155

8:14-26 153,154, 156

8:15-21 136, 151, 153

$8: 15$

$8: 16-19$

$8: 16$

$8: 17-18$

$8: 18$

$8: 19$ $\begin{array}{lr}8: 20 & 107,137,155 \\ 8: 22-30 & 151,153,154 \\ 8: 22 & 153,154,158 \\ 8: 23 & 153,154,282 \\ 8: 24-26 & 155,156,159 \\ 8: 24 & 153,154,155 \\ & 188,282 \\ 8: 25-26 & 153,154,156\end{array}$

$8: 2536,148,151,155$

$156,159,168$

188,230

$8: 26$

155

$8: 27 \quad 153,154,285$

8:28-29 153, 154

$155,156,159$

$8: 28154,156,157,158$

$8: 29-53 \quad 157,159,209$

8:29-30 156, 157, 283

$\begin{array}{lr}8: 29 & 155,156 \\ & 157,158 \\ 8: 30-43 & 154,155 \\ 8: 30 & 156,156,157 \\ & 158,283 \\ 8: 31-53 & 151,153,156 \\ & 157,158,283 \\ 8: 52-53 & 157 \\ & 159 \\ 8: 52 & 157,158,283 \\ 8: 54-61 & 151,153 \\ 8: 54 & 158,283 \\ 8: 55-56 & 153,158 \\ 8: 55 & 158,283 \\ 8: 56 & 27,37,58,60\end{array}$

$74,75,129,134$

$158,288,289,290$

8:57-58 280,282, 283

$8: 57 \quad 159$

$8: 58 \quad 109,131,159$

8:59-60 155, 157

159,283

$8: 61 \quad 131,154,159$

$280,282,283$

$8: 62-66 \quad 151,152,153$

$9: 1-9 \quad 159,160$

9:1-5 38, 155,159

168,169

$9: 3 \quad 156,158,159$

9:4-9

$9: 4-5$
159,230

160

$155,156,159$
$9: 4 \quad 36,109,148,159$

$167,188,220,230$

$267,277,280,283$

$9: 5 \quad 151,155,159$ 160,168

9:6-9 138, 159, 160 $169,216,225,286$

9:8-9 160

$9: 9 \quad 85,86,190,277$

$9: 10-10: 29 \quad 144,160$

9:15-24 143, 144, 160

$11: 1-13 \quad 160,161$

$11: 1-8 \quad 159,160,167$ 169,257

$11: 1-7 \quad 38,160-62,288$

$11: 1 \quad 86,146,161,162$

$11: 2 \quad 110,146,161$

$162,209,285$

$11: 3 \quad 110,161,162$

$11: 4 \quad 146,161,162$

$188,189,217,267$

$11: 5 \quad 86,161,162,169$

$216,220,225,257$

$277,279,280$

$11: 6 \quad 161,162$

$11: 7 \quad 161,162,257$

$11: 8 \quad 42,86,161$

$255,277,279,280$

11:9-13 160,162-63

$277,280,281,282$

$11: 29-39$

35,37

$38-39,41,160,162$

$163,164,277$

$11: 29-31 \quad 102,163,164$

$11: 31-39 \quad 102,165-66$ 281

$11: 31 \quad 102,103,163$ 169

$11: 32 \quad 163,164,167$ $169,171,230,277$

$11: 3385,86,109,163$

$166,169,170,216$

$220,225,277$ 280,283

$11: 34-36 \quad 167,169$

$11: 34 \quad 38,131,148$

$154,163,164,166$

$167,169,170,189$ $280,283,291$

$11: 35 \quad 38,42,163,164$

$166,167,168,171$

$11: 36 \quad 38,39,42,154$

$156,159,163,164$ 
$166,167,168,169$

$215,216,218,226$ 230,291

$11: 37 \quad 102,163,164$ $11: 38 \quad 38,39,102,131$ $148,163,164,166$ $167,168,169,170$ $188,189,280,283$ $11: 39$ 102,163

12 $166,169,170$ $58,101,143$ $143,171-73,262$ $12: 1538,107,171,263$ $12: 20 \quad 71,166,171$ 172,173 12:21-24 166, 171 $173,279,280$ $12: 25-13: 34 \quad 186,264$ $12: 25-33 \quad 39,264,276$ $12: 25-32 \quad 168,189$ $12: 25-31 \quad 186$ $12: 25 \quad 143,186,264$ 12:26-27 186, 187, 264 $12: 28 \quad 179,186,186$ 188,264

$12: 29 \quad 176,186,264$ $12: 30 \quad 186,187,264$ 12:31-32 264, 276 $12: 31 \quad 186,187,264$ $275,279,280$

12:32-33 264, 275 279,280

$\begin{array}{lr}12: 32 & 186,264 \\ 12: 33 & 186,262,264\end{array}$ 275,276

$13187,262,263,275$

13:1-33 186, 264, 276

$\begin{array}{lr}13: 2 & 279,280 \\ 13: 32 & 263,264 \\ 13: 33-34 & 176,186 \\ & 187,264,276 \\ 14: 1-16 & 187,192 \\ 14: 7-13 & 39,168 \\ 14: 7-11 & \\ 14: 8 & 102\end{array}$

$14: 8-9 \quad 102,187,190$ 191

$14: 8 \quad 131,163,188$ $189,190,267$ 280, 283

14:9-13

$14: 9$

55, 103, 188 $189,190,191,192$ $196,197,213,229$

$14: 10-13 \quad 188,189$

$14: 10-11$

193

$14: 10$

103

$14: 13$ 190

$14: 14$

190, 192 $193,278,280$

$14: 15-16 \quad 178$

$14: 15 \quad 189,190,191$ 209, 213, 282, 286

$14: 16$

$14: 17-18$

$14: 18 \quad 107,173,187$

$188,200,201$

205,263

$14: 21 \quad 154,179,214$ 230

$14: 22$

176, 178

$213,214,282$ 214, 219 220,282

$14: 23 \quad 41,176,177$ $210,213,214$ $219,282,287$

$14: 25 \quad 224,278$

$14: 26$

$14: 27-28$

$14: 31$

15:3-5

$15: 3$ 217, $220,1728,267$

15:41, 220, 228, 267

$15: 4 \quad 215,220,226$ 230,291

$15: 5 \quad 145,215,278$

$15: 7$

$15: 8$

15:11-12

15:11

15:12

$214,216,217$

$220,225,233,255$

$266,277,279,280$

$15: 13$

216,217

220,261

$15: 14$

$41,176,177$

$178,216,217,220$

$15: 15 \quad 183,216,217$

239, 242

15:16-21

$15: 18$

$15: 23$
$15: 24$ 201

$15: 26$

$40,178,187$ $191,192,234$

15:29-30 187

$15: 29 \quad 107,173,188$ $200,201,205$ 208, 263

$15: 30 \quad 189,192,194$ $197,278,279,280$

$15: 34 \quad 40,178,191$ $192,193,234$

$16: 1-4 \quad 40,103,190$ $192-93,204$ $16: 6 \quad 40,201,202$ $16: 7 \quad 189,192,193$ $194,278,279,280$ $16: 12 \quad 107,173,192$ $193,200,201$ 205,263

$16: 13$ 178,189 $192,194,195$ 197, 278, 279, 280 $16: 15 \quad 40,194$ $16: 19 \quad 40,178,194$ $278,279,280$

$16: 25-26 \quad 40,178,195$ $16: 25 \quad 195,278,278$ 279,280 $16: 26 \quad 189,194,197$ $234,278,279,280$ $16: 27$

$16: 28-29$ 184

$16: 28$

181

$16: 30-33 \quad 40,178,195$ $16: 30 \quad 195,196,213$ $16: 31-32 \quad 195$ $16: 31 \quad 195,196,200$ $16: 32-33 \quad 229$ $16: 32 \quad 187,195,196$ $16: 33 \quad 189,196,213$ $278,279,280$ $16: 34 \quad 68,278,280$ $20 \quad 201,202,277$ 20:1-43 276, 277, 280 $\begin{array}{ll}21: 17-24 & 280 \\ & 102\end{array}$ 165,194 21:17-19 102, 198, 201 21:19-24 201 $21: 19 \quad 102,201,202$ $203,276,277,280$ $21: 20 \quad 102,201,202$ 277, 278, 279 


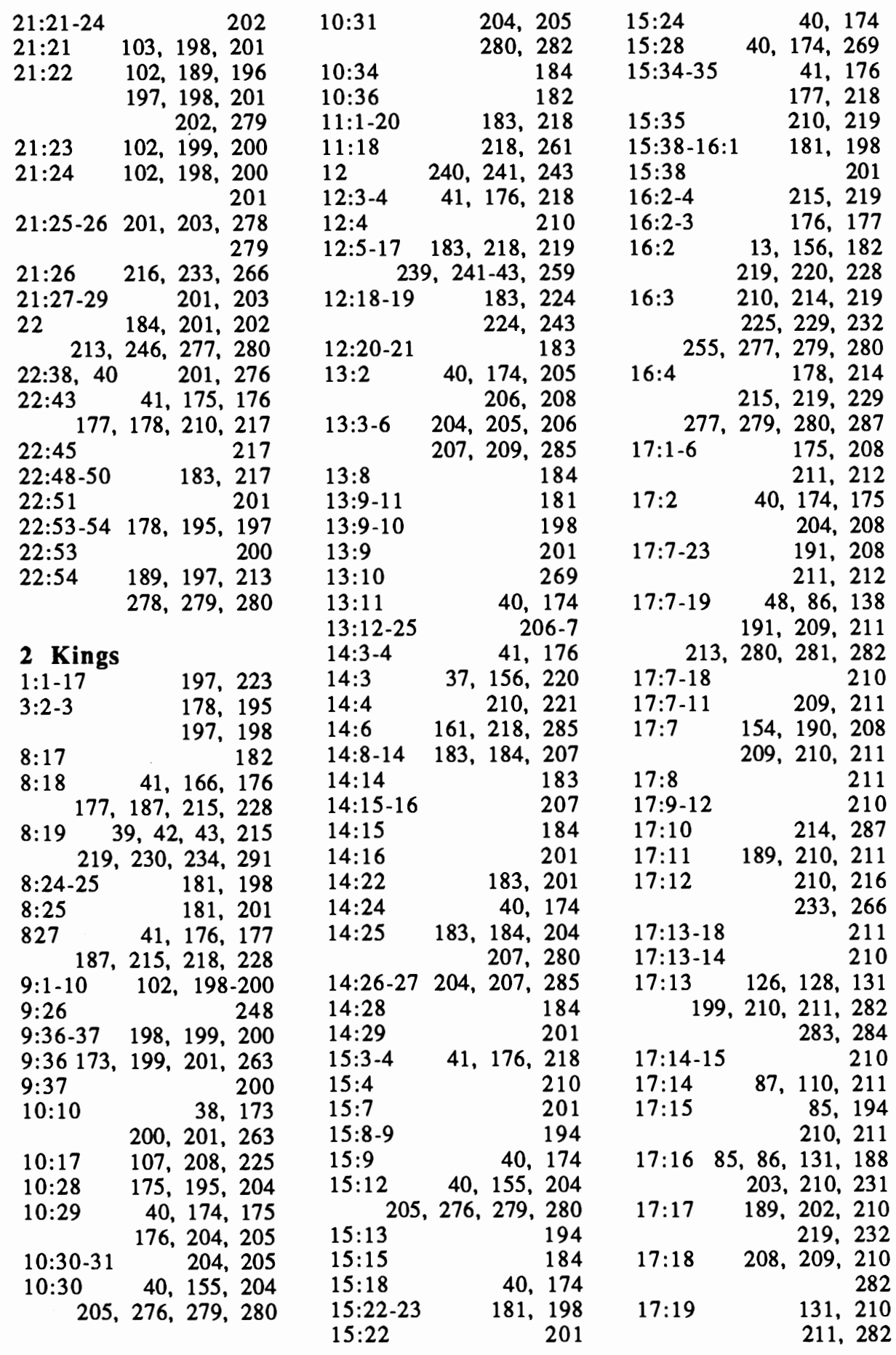




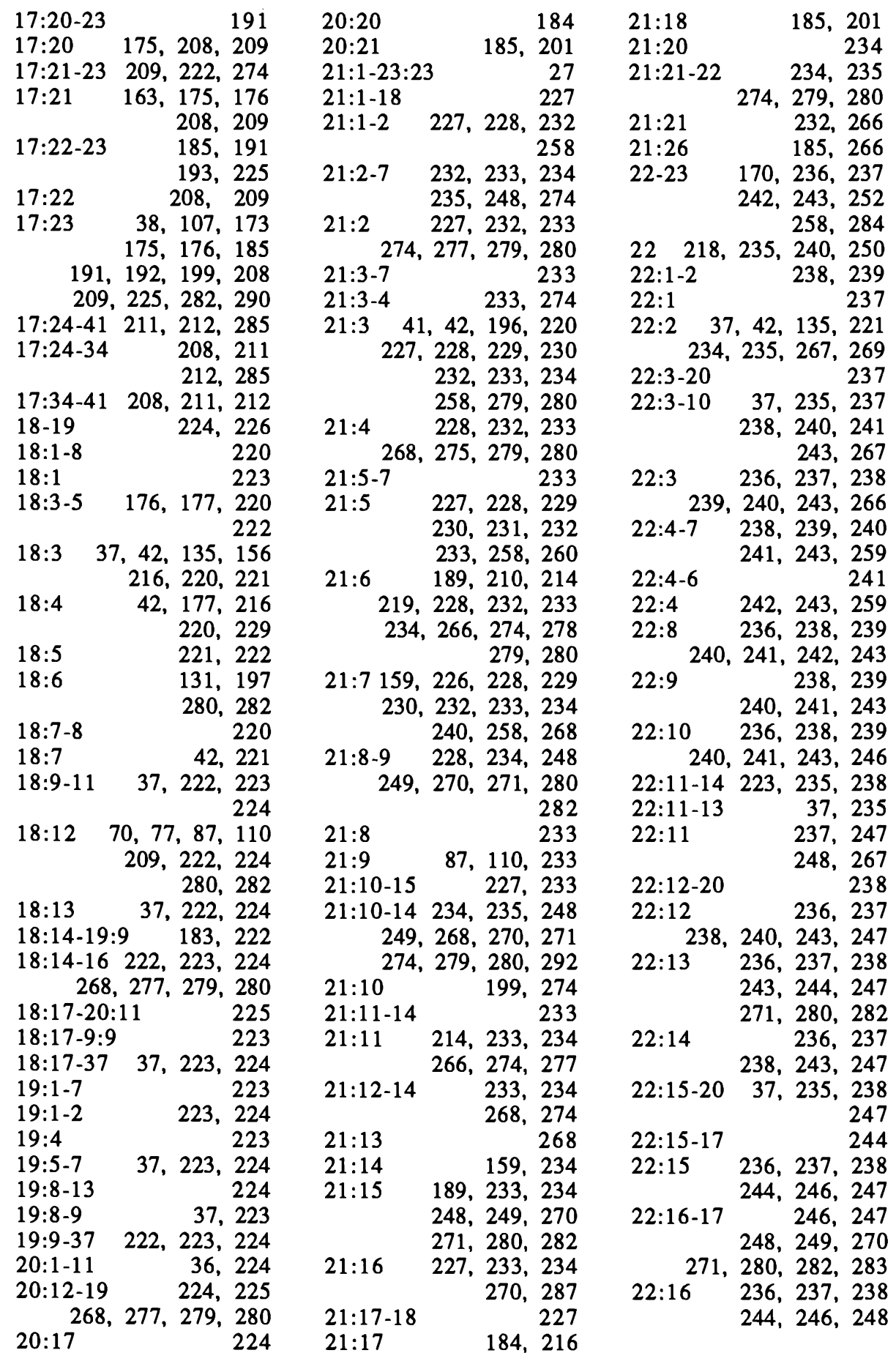


$22: 1785,86,189,190$ $244,247,286,287$ 22:18-20 244 $22: 18 \quad 236,238,244$ 246, 247, 248, 271 $280,282,283$ $22: 19 \quad 203,237,238$ $240,247,248,249$ $267,268,271,274$ $275,279,280$ 287,292

$22: 20 \quad 236,237,238$ $244,245,246,247$ $248,249,268,271$ $275,279,280,292$ 23:1-25 235 23:1-23 37,238 23:1-3 $43,218,235$ $236,237,238$ $250,265,267$

23:1-2 250 23:1 237, 250 251,258

$\begin{array}{lr}23: 2-3 & 250 \\ 23: 2 & 237,250,251\end{array}$

$23: 3 \quad 237,249,250$ $251,266,280,283$ 23:4-20 237, 238 239,267

23:4-14 236, 251, 252 $253,256,258$

23:4-12 43,262

23:4-8 255,261

23:4-5 230, 254, 255 $23: 4 \quad 230,231,240$ $242,243,251,253$ $254,255,258,259$ $260,261,266,270$ 279,280

23:5-8 259, 260, 266 $23: 5 \quad 230,231,237$

$253,254,255,256$ $259,261,276$ $277,279,280$

$23: 6-8$

$23: 6-7 \quad 255,258,261$ $23: 6 \quad 230,237,240$ $255,258,259,261$ 23:7-8 237, 238 $23: 7 \quad 251,257,258$ 259, 261

23:8-9 253, 254, 257
$23: 8 \quad 238,239,240$ $253,254,255,256$ $257,258,262,276$ 279,280 $23: 9 \quad 57,253,254$ $254,255,259,266$ $23: 10 \quad 210,214,219$ $232,237,253,254$ $255,256,257$ $276,279,280$

23:11-12 237, 253 $255,258,259,260$ $261,262,266,280$

$23: 11 \quad 251,256,260$ $261,277,279$

$23: 12 \quad 229,231,251$ $256,257,258$ 259, 260, 261, 277 23:13-14 253, 254, 276 $23: 13 \quad 161,255,256$ $257,258,262,279$ $23: 14 \quad 253,255,257$ 23:15-20 186, 187, 253 $254,261,262,276$ 23:15-18 253, 264 $23: 15 \quad 236,255,258$ $261,262,263,276$ 279,280

23:16-20 263, 264, 275 $276,279,280$

23:16-18 236, 263

23:16-17 187

23:16 261, 263

$23: 17 \quad 263$

23:18 264

23:19-20 253, 263, 264

$23: 19 \quad 189,232$ 236,264

23:20-24 236, 238

23:21-23 43, 235, 237 238, 265, 266, 267

23:21

23:22-23

237,265

$23: 22$

$23: 23$

265,266

265, 267

23:24-25:30 129, 227

23:24-30

23:24-25

$23: 24 \quad 228,232,233$ 277,278 280,283

$266,267,278$

$23: 25 \quad 238,239,266$ $267,277,278,284$
23:26-27 266, 268, 270 $271,274,279,280$

$23: 26 \quad 70,189,205$ 270,275

$23: 27 \quad 209,268,270$ 275

23:28-30 239, 266 $23: 28 \quad 272$

23:29-30 237, 245, 246 $23: 30 \quad 185,246,273$ 275

23:31-25:30 238, 270 $23: 31 \quad 194,269$ $23: 32 \quad 268,269,273$ $23: 37 \quad 268,269,273$ 24:1 273 24:2-4 268, 270, 273 $24: 2 \quad 199,270$

274, 275, 292 209,270

$\begin{array}{rr}24: 4 & 158,275 \\ & 270,287\end{array}$ 270,287 $24: 6 \quad 185,201$ $24: 8 \quad 194$ $24: 9 \quad 268,269,273$ $24: 10 \quad 273$ $24: 12 \quad 268,273$

24:13-14 273, 277, 279 280

$24: 13 \quad 225,268$

$24: 14,15 \quad 268$ $24: 17,18 \quad 269$

$24: 19 \quad 268,269,270$ 273

24:20 270, 271

273, 282, 283

$25: 21 \quad 268,271,272$

25:22-30 287

25:22-26 271

25:27-30249, 271, 279

Jeremiah

2:20

214, 219

4:4

6:10

7:6

7:20

9:21

$11: 7$

$16: 4$

$17: 23$
247, 287 211

234, 287

247, 287 200 211 200 211 


$\begin{array}{lrll}17: 27 & 287 & 24: 2,12,20 & 243 \\ 19: 4 & 234,287 & 34: 3-18 & 236 \\ 19: 8 & 160 & 34: 3 & 188 \\ 19: 13 & 232 & 34: 28 & 246 \\ 19: 15 & 211 & 35: 20-25 & 246 \\ 22: 3,7 & 234,287 & 36: 10 & 269 \\ 22: 8-9 & 160,286 & & \\ 22: 17 & 234 & & \\ 24: 9 & 160 & & \\ 25: 3 & 200 & & \\ 25: 18 & 247,287 & & \\ 26: 15 & 234,287 & & \\ 33: 14-26 & 107 & \\ 39: 1-10 & 271 & \\ 40-43 & 237 & \\ 40: 7-41: 18 & 271 & \\ 42: 18 & 247,287 & \\ 42: 19 & 211 & \\ 42: 22 & 247 & \\ 44: 22 & 287 & \\ 49: 13 & 247,287 & \\ 49: 17 & 160 & \\ 50: 13 & 160 & \\ 53: 31-34 & 271 & \\ & & \\ \text { Ezekiel } & & \\ 34: 24 & 170 & \\ 38: 7,13 & 152 & \\ 40: 17,28 & 231 & \\ 43: 9 & 151 & \\ \text { Hosea } & & \\ 4: 13 & 214 & \\ 13: 2 & 188 & \\ 13: 10 & 110 & \\ \text { M } & & \end{array}$

\section{Zephaniah}

Psalms

78:58

135:11

136:19-20

\section{Nehemiah}

9:6, 17, 22, $26 \quad 211$

$9: 29,30,34 \quad 211$

\section{Chronicles}

$\begin{array}{ll}4: 9 & 231 \\ 15: 16 & 217 \\ 20: 5 & 231\end{array}$


Bd. 1 OTTO RICKENBACHER: Weisheitsperikopen bei Ben Sira. X-214-15* Seiten. 1973. Vergriffen.

Bd. 2 FRANZ SCHNIDER: Jesus der Prophet. 298 Seiten. 1973. Vergriffen.

Bd. 3 PAUL ZINGG: Das Wacbsen der Kirche. Beiträge zur Frage der lukanischen Redaktion und Theologie. 345 Seiten. 1974. Vergriffen.

Bd. 4 KARL JAROS: Die Stellung des Elobisten zur kanaanäischen Religion. 294 Seiten, 12 Abbildungen. 1982. 2. verbesserte und überarbeitete Auflage.

Bd. 5 OTHMAR KEEL: Wirkmächtige Siegeszeichen im Alten Testament. Ikonographische Studien zu Jos 8, 18-26; Ex 17, 8-13; 2 Kön 13, 14-19 und 1 Kön 22, 11. 232 Seiten, 78 Abbildungen. 1974. Vergriffen.

Bd. 6 VITUS HUONDER: Israel Sobn Gottes. Zur Deutung eines alttestamentlichen Themas in der jüdischen Exegese des Mittelalters. 231 Seiten. 1975.

Bd. 7 RAINER SCHMITT: Exodus und Passa. Ibr Zusammenbang im Alten Testament. 124 Seiten. 1982. 2. neubearbeitete Auflage.

Bd. 8 ADRIAN SCHENKER: Hexaplarische Psalmenbrucbstücke. Die hexaplarischen Psalmenfragmente der Handschriften Vaticanus graecus 752 und Canonicianus graecus 62. Einleitung, Ausgabe, Erläuterung. XXVIII-446 Seiten. 1975.

Bd. 9 BEAT ZUBER: Vier Studien zu den Ursprüngen Israels. Die Sinaifrage und Probleme der Volks- und Traditionsbildung. 152 Seiten. 1976. Vergriffen.

Bd. 10 EDUARDO ARENS: The $\mathrm{H} \Lambda \Theta O N$-Sayings in the Synoptic Tradition. A Historico-critical Investigation. 370 Seiten. 1976.

Bd. 11 KARL JAROS: Sichem. Eine archäologische und religionsgeschichtliche Studie, mit besonderer Berücksichtigung von Jos 24. 280 Seiten, 193 Abbildungen. 1976.

Bd. 11a KARL JAROŠ/BRIGITTE DECKERT: Studien zur Sicbem-Area. 81 Seiten, 23 Abbildungen. 1977.

Bd. 12 WALTER BÜHLMANN: Vom recbten Reden und Scbweigen. Studien zu Proverbien 10-31. 371 Seiten. 1976.

Bd. 13 IVO MEYER: Jeremia und die falschen Propheten. 155 Seiten. 1977. Vergriffen.

Bd. 14 OTHMAR KEEL: Vögel als Boten. Studien zu Ps 68, 12-14, Gen 8, 6-12, Koh 10, 20 und dem Aussenden von Botenvögeln in Ägypten. - Mit einem Beitrag von Urs Winter zu Ps 56, 1 und zur Ikonographie der Göttin mit der Taube. 164 Seiten, 44 Abbildungen. 1977.

Bd. 15 MARIE-LOUISE GUBLER: Die frübesten Deutungen des Todes Jesu. Eine motivgeschichtliche Darstellung aufgrund der neueren exegetischen Forschung. XVI-424 Seiten. 1977. Vergriffen.

Bd. 16 JEAN ZUMSTEIN: La condition du croyant dans l'Evangile selon Mattbieu. 467 pages. 1977. Epuisé.

Bd. 17 FRANZ SCHNIDER: Die verlorenen Söbne. Strukturanalytische und historisch-kritische Untersuchungen zu Lk 15. 105 Seiten. 1977.

Bd. 18 HEINRICH VALENTIN: Aaron. Eine Studie zur vor-priesterschriftlichen Aaron-Überlieferung. VIII-441 Seiten. 1978. 
Bd. 19 MASSÉO CALOZ: Etude sur la LXX origénienne du Psautier. Les relations entre les leçons des Psaumes du Manuscrit Coislin 44, les Fragments des Hexaples et le texte du Psautier Gallican. 480 pages. 1978.

Bd. 20 RAPHAEL GIVEON: The Impact of Egypt on Canaan. Iconographical and Related Studies. 156 Seiten, 73 Abbildungen. 1978.

Bd. 21 DOMINIQUE BARTHÉLEMY: Etudes d'bistoire du texte de l'Ancien Testament. XXV419 pages. 1978. Vergriffen.

Bd. 22/1 CESLAS SPICQ: Notes de Lexicograpbie néo-testamentaire. Tome I: p. 1-524. 1978. Epuisé.

Bd. 22/2 CESLAS SPICQ : Notes de Lexicograpbie né-testamentaire. Tome II: p. 525-980. 1978. Epuisé.

Bd. 22/3 CESLAS SPICQ: Notes de Lexicograpbie néo-testamentaire. Supplément. 698 pages. 1982.

Bd. 23 BRIAN M. NOLAN: The Royal Son of God. The Christology of Matthew 1-2 in the Setting of the Gospel. 282 Seiten. 1979.

Bd. 24 KLAUS KIESOW: Exodustexte im Jesajabuch. Literarkritische und motivgeschichtliche Analysen. 221 Seiten. 1979. Vergriffen.

Bd. 25/1 MICHAEL LATTKE: Die Oden Salomos in ibrer Bedeutung für Neues Testament und Gnosis. Band I. Ausführliche Handschriftenbeschreibung. Edition mit deutscher Parallel-İ̈bersetzung. Hermeneutischer Anhang zur gnostischen Interpretation der Oden Salomos in der Pistis Sophia. XI-237 Seiten. 1979.

Bd. 25/1a MICHAEL LATTKE: Die Oden Salomos in ibrer Bedeutung für Neues Testament und Gnosis. Band Ia. Der syrische Text der Edition in Estrangela Faksimile des griechischen Papyrus Bodmer XI. 68 Seiten. 1980.

Bd. 25/2 MICHAEL LATTKE: Die Oden Salomos in ibrer Bedeutung für Neues Testament und Gnosis. Band II. Vollständige Wortkonkordanz zur handschriftlichen, griechischen, koptischen, lateinischen und syrischen Überlieferung der Oden Salomos. Mit einem Faksimile des Kodex N. XVI-201 Seiten. 1979.

Bd. 25/3 MICHAEL LATTKE: Die Oden Salomos in ibrer Bedeutung für Neues Testament und Gnosis. Band III. XXXIV-478 Seiten. 1986.

Bd. 26 MAX KÜCHLER: Frübjüdische Weisheitstraditionen. Zum Fortgang weisheitlichen Denkens im Bereich des frühjüdischen Jahweglaubens. 703 Seiten. 1979. Vergriffen.

Bd. 27 JOSEF M. OESCH: Petucba und Setuma. Untersuchungen zu einer überlieferten Gliederung im hebräischen Text des Alten Testaments. XX-392-37* Seiten. 1979.

Bd. 28 ERIK HORNUNG/OTHMAR KEEL (Herausgeber): Studien zu altägyptischen Lebenslebren. 394 Seiten. 1979.

Bd. 29 HERMANN ALEXANDER SCHLÖGL: Der Gott Tatenen. Nach Texten und Bildern des Neuen Reiches. 216 Seiten, 14 Abbildungen. 1980.

Bd. 30 JOHANN JAKOB STAMM : Beiträge zur Hebräischen und Altorientalischen Namenkunde. XVI264 Seiten. 1980.

Bd. 31 HELMUT UTZSCHNEIDER: Hosea - Prophet vor dem Ende. Zum Verhältnis von Geschichte und Institution in der alttestamentlichen Prophetie. 260 Seiten. 1980.

Bd. 32 PETER WEIMAR: Die Berufung des Mose. Literaturwissenschaftliche Analyse von Exodus 2, 23-5, 5. 402 Seiten. 1980. 
Bd. 33 OTHMAR KEEL: Das Böcklein in der Milch seiner Mutter und Venvandtes. Im Lichte eines altorientalischen Bildmotivs. 163 Seiten, 141 Abbildungen. 1980.

Bd. 34 PIERRE AUFFRET: Hymnes d'Egypte et d'Israël. Etudes de structures littéraires. 316 pages, 1 illustration. 1981.

Bd. 35 ARIE VAN DER KOOIJ : Die alten Textzeugen des Jesajabucbes. Ein Beitrag zur Textgeschichte des Alten Testaments. 388 Seiten. 1981.

Bd. 36 CARMEL McCARTHY: The Tiqqune Sopberim and Other Theological Corrections in the Masoretic Text of the Old Testament. 280 Seiten. 1981.

Bd. 37 BARBARA L. BEGELSBACHER-FISCHER: Untersucbungen zur Göttervelt des Alten Reiches im Spiegel der Privatgräber der IV. und V. Dynastie. 336 Seiten. 1981.

Bd. 38 MÉLANGES DOMINIQUE BARTHÉLEMY. Etudes bibliques offertes à l'occasion de son $60^{*}$ anniversaire. Edités par Pierre Casetti, Othmar Keel et Adrian Schenker. 724 pages, 31 illustrations. 1981.

Bd. 39 ANDRÉ LEMAIRE: Les écoles et la formation de la Bible dans l'ancien Israël. 142 pages, 14 illustrations. 1981.

Bd. 40 JOSEPH HENNINGER: Arabica Sacra. Aufsätze zur Religionsgeschichte Arabiens und seiner Randgebiete. Contributions à l'histoire religieuse de l'Arabie et de ses régions limitrophes. 347 Seiten. 1981.

Bd. 41 DANIEL VON ALLMEN: La famille de Dieu. La symbolique familiale dans le paulinisme. LXVII-330 pages, 27 planches. 1981.

Bd. 42 ADRIAN SCHENKER: Der Mäcbtige im Scbmelzofen des Mitleids. Eine Interpretation von 2 Sam 24. 92 Seiten. 1982.

Bd. 43 PAUL DESELAERS: Das Buch Tobit. Studien zu seiner Entstehung, Komposition und Theologie. 532 Seiten + Übersetzung 16 Seiten. 1982.

Bd. 44 PIERRE CASETTI: Gibt es ein Leben vor dem Tod? Eine Auslegung von Psalm 49. 315 Seiten. 1982.

Bd. 45 FRANK-LOTHAR HOSSFELD: Der Dekalog. Seine späten Fassungen, die originale Komposition und seine Vorstufen. 308 Seiten. 1982. Vergriffen.

Bd. 46 ERIK HORNUNG: Der ägyptische Mythos von der Himmelskub. Eine Ätiologie des Unvollkommenen. Unter Mitarbeit von Andreas Brodbeck, Hermann Schlögl und Elisabeth Staehelin und mit einem Beitrag von Gerhard Fecht. XII-129 Seiten, 10 Abbildungen. 1982.

Bd. 47 PIERRE CHERIX: Le Concept de Notre Grande Puissance (CG VI, 4). Texte, remarques philologiques, traduction et notes. XIV-95 pages. 1982.

Bd. 48 JAN ASSMANN/WALTER BURKERT/FRITZ STOLZ: Funktionen und Leistungen des Mythos. Drei altorientalische Beispiele. 118 Seiten, 17 Abbildungen. 1982. Vergriffen.

Bd. 49 PIERRE AUFFRET: La sagesse a bâti sa maison. Etudes de structures littéraires dans l'Ancien Testament et spécialement dans les psaumes. 580 pages. 1982.

Bd. 50/1 DOMINIQUE BARTHÉLEMY: Critique textuelle de l'Ancien Testament. 1. Josué, Juges, Ruth, Samuel, Rois, Chroniques, Esdras, Néhémie, Esther. Rapport final du Comité pour l'analyse textuelle de l'Ancien Testament hébreu institué par l'Alliance Biblique Universelle, établi en coopération avec Alexander $R$. Hulst $t$, Norbert Lohfink, William D. McHardy, H. Peter Rüger, coéditeur, James A. Sanders, coéditeur. 812 pages. 1982. 
Bd. 50/2 DOMINIQUE BARTHÉLEMY: Critique textuelle de l'Ancien Testament. 2. Isaïe, Jérémie, Lamentations. Rapport final du Comité pour l'analyse textuelle de l'Ancien Testament hébreu institué par l'Alliance Biblique Universelle, établi en coopération avec Alexander R. Hulst $\dagger$, Norbert Lohfink, William D. McHardy, H. Peter Rüger, coéditeur, James A. Sanders, coéditeur. 1112 pages. 1986.

Bd. 51 JAN ASSMANN: Re und Amun. Die Krise des polytheistischen Weltbilds im Ägypten der 18.-20. Dynastie. XII-309 Seiten. 1983.

Bd. 52 MIRIAM LICHTHEIM: Late Egyptian Wisdom Literature in the International Context. A Study of Demotic Instructions. X-240 Seiten. 1983.

Bd. 53 URS WINTER: Frau und Göttin. Exegetische und ikonographische Studien zum weiblichen Gottesbild im Alten Israel und in dessen Umwelt. XVIII-928 Seiten, 520 Abbildungen. 1987. 2. Auflage. Mit einem Nachwort zur 2. Auflage.

Bd. 54 PAUL MAIBERGER: Topographische und bistorische Untersucbungen zum Sinaiproblem. Worauf beruht die Identifizierung des Gabal Musā mit dem Sinai? 189 Seiten, 13 Tafeln. 1984.

Bd. 55 PETER FREI/KLAUS KOCH: Reicbsidee und Reichsonganisation im Perserreicb. 119 Seiten, 17 Abbildungen. 1984. Vergriffen.

Bd. 56 HANS-PETER MÜLLER: Vergleich und Metapher im Hobenlied. 59 Seiten. 1984.

Bd. 57 STEPHEN PISANO: Additions or Omissions in the Books of Samuel. The Significant Pluses and Minuses in the Massoretic, LXX and Qumran Texts. XIV-295 Seiten. 1984.

Bd. 58 ODO CAMPONOVO: Königtum, Königsherrschaft und Reich Gottes in den Frübjüdischen Schriften. XVI-492 Seiten. 1984.

Bd. 59 JAMES KARL HOFFMEIER: Sacred in the Vocabulary of Ancient Egypt. The Term DSR, with Special Reference to Dynasties I-XX. XXIV-281 Seiten, 24 Figures. 1985.

Bd. 60 CHRISTIAN HERRMANN: Formen für ägyptische Fayencen. Katalog der Sammlung des Biblischen Instituts der Universität Freiburg Schweiz und einer Privatsammlung. XXVIII-199 Seiten. 1985.

Bd. 61 HELMUT ENGEL: Die Susanna-Erzäblung. Einleitung, Übersetzung und Kommentar zum Septuaginta-Text und zur Theodition-Bearbeitung. 205 Seiten + Anhang 11 Seiten. 1985.

Bd. 62 ERNST KUTSCH: Die chronologischen Daten des Ezechielbuches. 82 Seiten. 1985.

Bd. 63 MANFRED HUTTER: Altorientalische Vorstellungen von der Untervelt. Literar- und religionsgeschichtliche Überlegungen zu «Nergal und Ereškigal». VIII-187 Seiten. 1985.

Bd. 64 HELGA WEIPPERT/KLAUS SEYBOLD/MANFRED WEIPPERT: Beiträge zur prophetischen Bildsprache in Israel und Assyrien. IX-93 Seiten. 1985.

Bd. 65 ABDEL-AZIZ FAHMY SADEK: Contribution à l'étude de l'Amdouat. Les variantes tardives du Livre de l'Amdouat dans les papyrus du Musée du Caire. XVI-400 pages, 175 illustrations. 1985.

Bd. 66 HANS-PETER STÄHLI: Solare Elemente im Jabweglauben des Alten Testamentes. X-60 Seiten. 1985.

Bd. 67 OTHMAR KEEL / SILVIA SCHROER: Studien zu den Stempelsiegeln aus Palästina/Israel. Band I. 115 Seiten, 103 Abbildungen. 1985.

Bd. 68 WALTER BEYERLIN: Weisheitliche Vergewisserung mit Bezug auf den Zionskult. Studien zum 125. Psalm. 96 Seiten. 1985. 
Bd. 69 RAPHAEL VENTURA: Living in a City of the Dead. A Selection of Topographical and Administrative Terms in the Documents of the Theban Necropolis. XII-232 Seiten. 1986.

Bd. 70 CLEMENS LOCHER: Die Ebre einer Frau in Israel. Exegetische und rechtsvergleichende Studien zu Dtn 22, 13-21. XVIII-464 Seiten. 1986.

Bd. 71 HANS-PETER MATHYS: Liebe deinen Näcbsten wie dicb selbst. Untersuchungen zum alttestamentlichen Gebot der Nächstenliebe (Lev 19, 18). XIV-196 Seiten. 1986.

Bd. 72 FRIEDRICH ABITZ: Ramses III. in den Gräbern seiner Söbne. 156 Seiten, 31 Abbildungen. 1986.

Bd. 73 DOMINIQUE BARTHÉLEMY/DAVID W. GOODING/JOHAN LUST/EMANUEL TOV: The Story of David and Goliath. 160 Seiten. 1986.

Bd. 74 SILVIA SCHROER: In Israel gab es Bilder. Nachrichten von darstellender Kunst im Alten Testament. XVI-553 Seiten, 146 Abbildungen. 1987.

Bd. 75 ALAN R. SCHULMAN: Ceremonial Execution and Public Rewards. Some Historical Scenes on New Kingdom Private Stelae. 296 Seiten. 41 Abbildungen. 1987.

Bd. 76 JOŽE KRAŠOVEC: La justice (Ṣdq) de Dieu dans la Bible bébraïque et l'interprétation juive et chrétienne. 456 pages. 1988.

Bd. 77 HELMUT UTZSCHNEIDER: Das Heiligtum und das Gesetz. Studien zur Bedeutung der sinaitischen Heiligtumstexte (Ez 25-40; Lev 8-9). XIV-326 Seiten. 1988.

Bd. 78 BERNARD GOSSE: Isaie 13,1-14,23. Dans la tradition littéraire du livre d'Isaïe et dans la tradition des oracles contre les nations. 308 pages. 1988.

Bd. 79 INKE W. SCHUMACHER: Der Gott Sopdu - Der Herr der Fremdländer. XVI-364 Seiten, 6 Abbildungen. 1988.

Bd. 80 HELLMUT BRUNNER: Das börende Herz. Kleine Schriften zur Religions- und Geistesgeschichte Ägyptens. Herausgegeben von Wolfgang Röllig. 449 Seiten, 55 Abbildungen. 1988.

Bd. 81 WALTER BEYERLIN: Bleilot, Brecheisen oder was sonst? Revision einer Amos-Vision. 68 Seiten. 1988.

Bd. 82 MANFRED HUTTER: Bebexung, Entsübnung und Heilung. Das Ritual der Tunnawiya für ein Königspaar aus mittelhethitischer Zeit (KBo XXI 1 - KUB IX 34 - KBo XXI 6). 186 Seiten. 1988.

Bd. 83 RAPHAEL GIVEON: Scarabs from Recent Excavations in Israel. 114 Seiten, 9 Tafeln. 1988.

Bd. 84 MIRIAM LICHTHEIM : Ancient Egyptian Autobiographies chiefly of the Middle Kingdom. A Study and an Anthology. 200 Seiten, 10 Seiten Abbildungen. 1988.

Bd. 85 ECKART OTTO: Rechtsgeschicbte der Redaktionen im Kodex Ešnunna und im "Bundesbuch». Eine redaktionsgeschichtliche und rechtsvergleichende Studie zu altbabylonischen und altisraelitischen Rechtsüberlieferungen. 220 Seiten. 1989.

Bd. 86 ANDRZEJ NIWIŃSKI: Studies on the Illustrated Theban Funerary Papyri of the 11th and 10th Centuries B.C. 488 Seiten, 80 Seiten Tafeln. 1989.

Bd. 87 URSULA SEIDL: Die babylonischen Kudurru-Reliefs. Symbole mesopotamischer Gottheiten. 236 Seiten, 33 Tafeln und 2 Tabellen. 1989.

Bd. 88 OTHMAR KEEL/HILDI KEEL-LEU/SILVIA SCHROER : Studien zu den Stempelsiegeln aus Palästina/Israel. Band II. 364 Seiten, 652 Abbildungen. 1989.

Bd. 89 FRIEDRICH ABITZ: Baugeschicbte und Dekoration des Grabes Ramses' VI. 202 Seiten. 1989. 
Bd. 90 JOSEPH HENNINGER SVD: Arabica varia. Aufsätze zur Kulturgeschichte Arabiens und seiner Randgebiete. Contributions à l'histoire culturelle de l'Arabie et de ses régions limitrophes. 504 Seiten. 1989.

Bd. 91 GEORG FISCHER: Jabwe unser Gott. Sprache, Aufbau und Erzähltechnik in der Berufung des Mose (Ex 3-4). 276 Seiten. 1989.

Bd. 92 MARK A. O'BRIEN: The Deuteronomistic History Hypothesis: A Reassessment. 340 Seiten. 1989. 